Historic, archived document

Do not assume content reflects current scientific knowledge, policies, or practices. 



\section{BOLGIANO'S of BALTIMORE "BIE IPROP" \\ SEEDS for 1923}

Tested and Frusted Oven a Century

Bolgiano's

"Glorida

Special"

Tomato

BOLGIANO'S

"THREE DAINTIES"

FOR 25ఢं POSTPAID

ONE LARGE $10 \AA$ PKT.OF

EACH OF THESE 3

CHOICE DELICIOUS

VEGETABLES FOR

$25 \%$ POSTPAID

Bolgiano's famous Stock Big Boston Lettuce

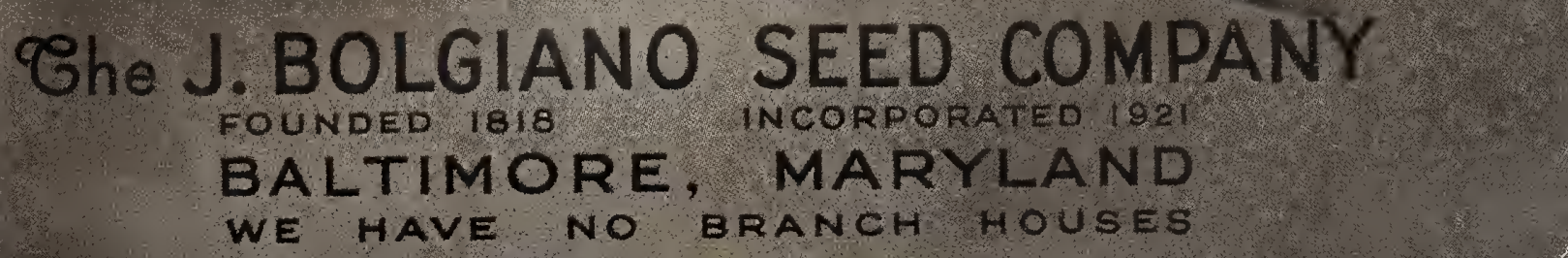




\section{BOLGIANO'S "SUPREME"}

Vegertable Garden Collection

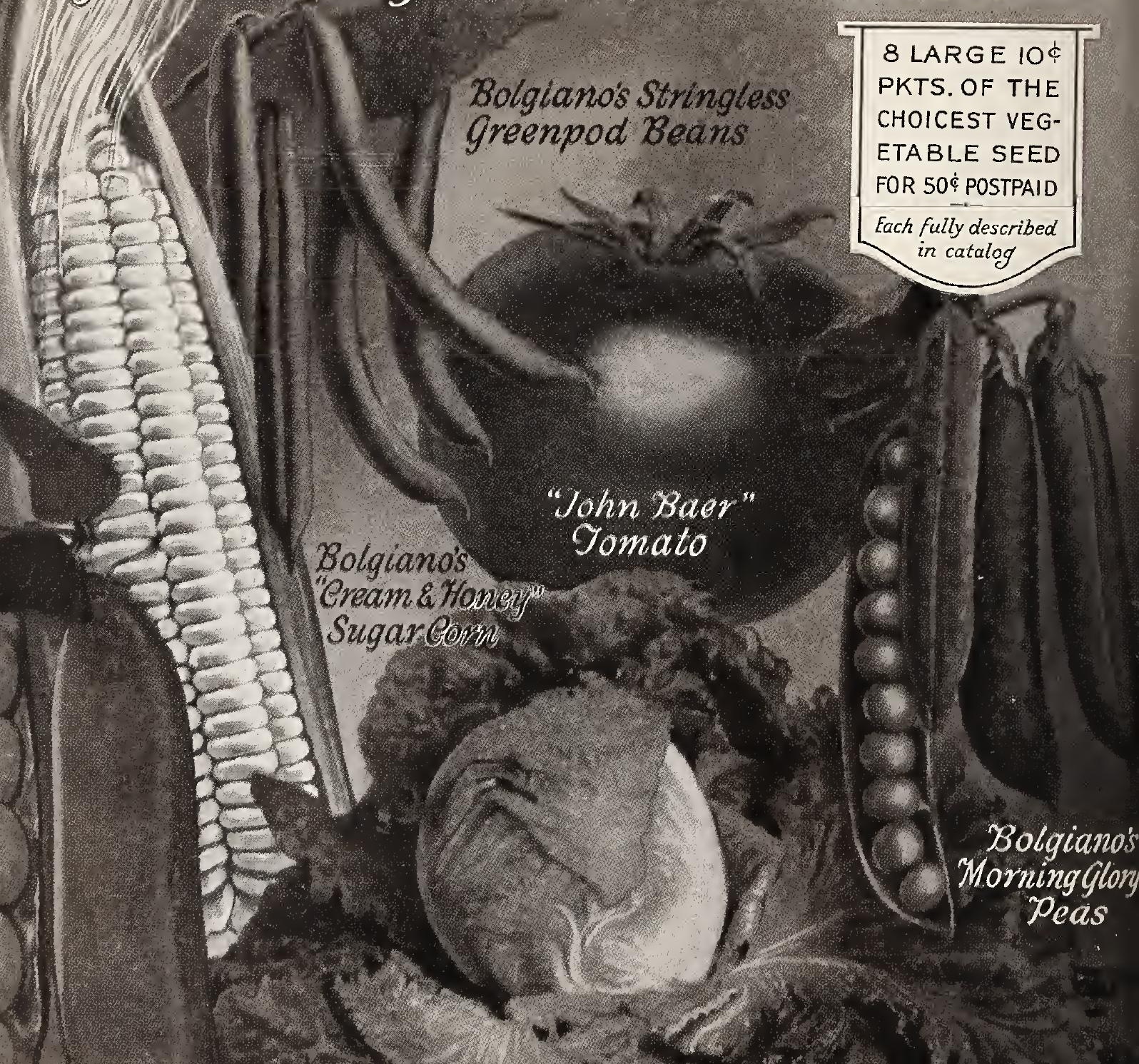

Balgiano's "timeralditsle" Pole Limas
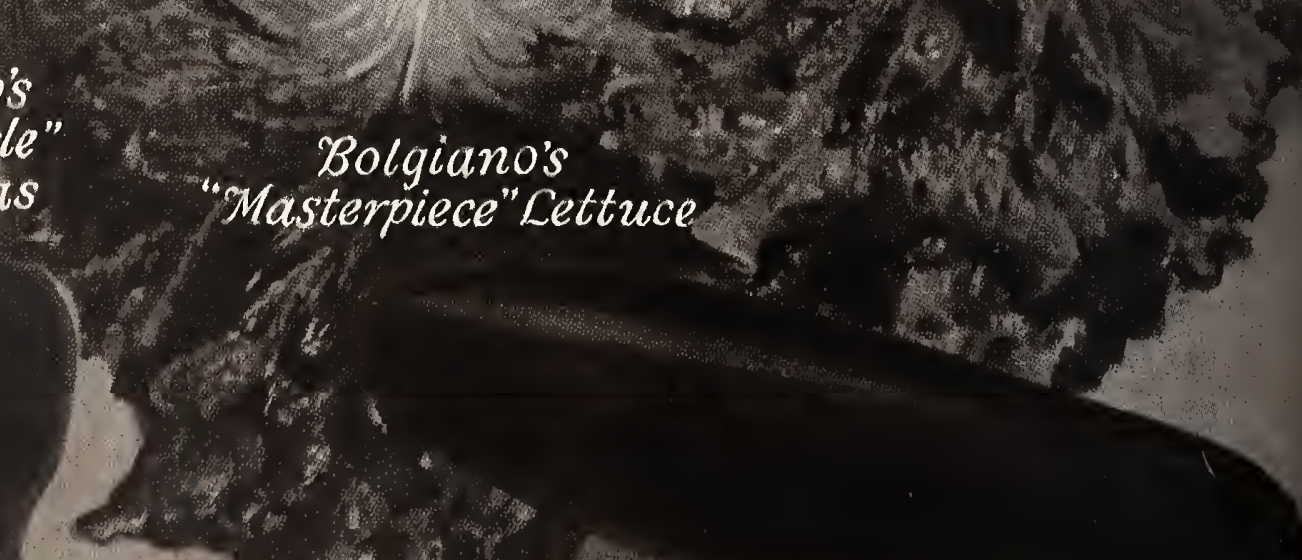


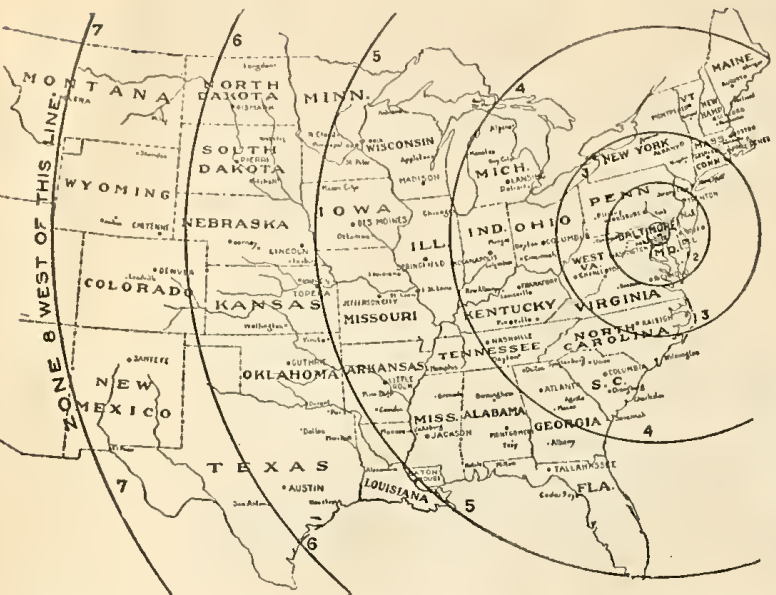

SIZE OF PARCEL THAT CAN BE SENT BY PARCEL POST

Size of package that can be sent by Parcel Post cannot be over $8 \pm$ The in length and girth combined.

The rate of postage on mailable parcels of seeds, cuttings, bulbs, root and plants, weighing $8 \mathrm{oz}$. or less, shall be $1 \mathrm{c}$ for each $2 \mathrm{oz}$. or fraction thereof, regardless of distance, and on those weighing nore than $8 \mathrm{oz}$ the vound rates shown in table shall apply.

\section{WEIGHTS BY PARCEL POST}

Parcels up to $70 \mathrm{lbs}$. can be sent by Parcel Post in the locai, 1st, 2nd and $3 \mathrm{rd}$ zones, and up to $50 \mathrm{lbs}$. in all other zones.

To points further than the 2nd zone, on weight of over $10 \mathrm{lbs}$, the charge by freight or express is usually more economical.

\section{Rate Table}

Local Rate, Baltimore and Suburbs orly. First Each Addi-

irst Zone, within 50 miles of Baltimore City.... $5 \mathrm{c} \quad 1 \mathrm{c}$ Second Zone, within 150 miles of Baltimore Cit: $5 \mathrm{c}$ 1c Fourth Zone, within 600 miles of Baltimore City.. $7 \mathrm{c}$ 4c Fifth Zone, within 1,000 miles of Baltimore City.. 8c $8 \mathrm{c}$ $\begin{array}{lrr}\text { Sixth Zone, within 1,400 miles of Baltimore City. } & 9 \mathrm{c} & 8 \mathrm{c} \\ \text { Seventh Zone, within } 1,800 \text { niles of Baltimore City } & 11 \mathrm{c} & 10 \mathrm{c}\end{array}$ Eighth Zone, all over 1,800 miles from Baltimore. 12c $12 \mathrm{c}$

WE WILL PAY WAR TAX ON PARCEL POST PACKAGES

As a courtesy to our customers and as an appreciation of their United States Parcel Post Map Showing Zones from Baltimore, Md, ordered from us.

On most of the articles listed in this Catalogue, we have given the mailing weight. By referring to the Parcel Post Map above, you ean easily see in what zone you are located, and from Rate Table, you can easily determine the amount of postage required.

United States Food Administration License, No, G 06237 INDEX

For General Information, Ordering, Remitting, Shipping, Parcel Post Rates, etc., see Page 1 and above. Directions for Cultivating Vegetables, see Heading of Each Item, Pages 9 to 37.

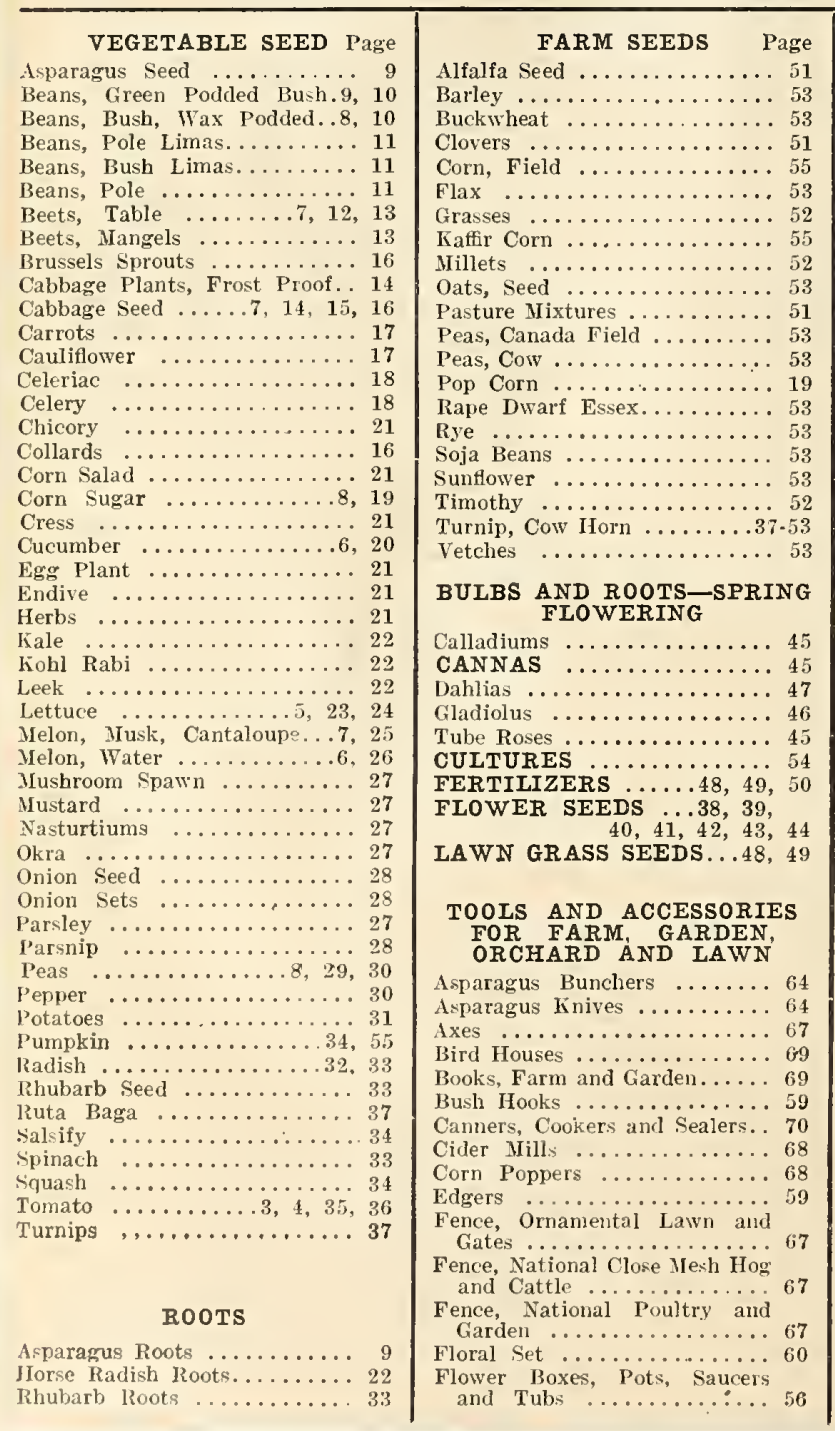

Flower Guard

Forks, Manure

$\ldots \ldots \ldots \ldots+59$

Fountains ....

Garden Tools, Iron Age and Planet Jr. ..........60, 61 Garden Tools, Pull Easy...... 59 Grass Catchers ............ 58

Hardware Cloth ..........6 67 Hoes $\ldots \ldots \ldots \ldots \ldots \ldots \ldots . \ldots \ldots, 59$ Hose and Hose Sundries..... 58 Hose Reels ............. 59 Hot Bed Sash and Sundries... 57 Insecticides ........64, 65,66 Labels, Pot and Tree....... 57 Lawn Mowers $\ldots \ldots \ldots \ldots \ldots$. 58

Lawn Mower Compound...... 58

Lawn Rollers $\ldots \ldots \ldots \ldots \ldots \ldots$
Machine Oil $\ldots \ldots \ldots \ldots \ldots$
48

Mattocks

Plow

Potato Hooks ............ 59

Rakes, Lawn and Garden...60, 61

Rat Trap and Exterminators. . 68

Scrapers, Poultry House...... 59

Scythes and Snaths......... 59

Scythe Stones

Seeders

Shears $\ldots, \ldots \ldots \ldots \ldots .57,58$

Shovels $\ldots \ldots \ldots \ldots \ldots \ldots \ldots \ldots$
Sickles $\ldots \ldots \ldots \ldots \ldots \ldots \ldots$

Spades $\ldots \ldots \ldots \ldots \ldots \ldots \ldots .59$

Sprayers ..........62, 63, 64

Sprinklers $\ldots \ldots \ldots \ldots 56,58,59$

Stakes, Plant $\ldots \ldots \ldots \ldots \ldots \ldots .57$

Traps, Sparrow ......... 69

Trellis Wire .............. 57

Trowels ................. 57

Watering Pots $\ldots \ldots \ldots \ldots \ldots, 56$

Weeders $\ldots \ldots \ldots \ldots \ldots 57,59,60$

Wheel Barrows ........... 57

Wire, Barbed Hog and Cattle. 67

Wire Stretchers ...........6 67

Wrench Jar ...,.,.,.,., 70

\section{POULTRY SUPPLIES}

Baby Chicks ..........74, 75

Books, Poultry ........... 96

Brooders $\ldots \ldots \ldots \ldots \ldots$. $1,82-94$

Buckets, Feed and Water.... 85

Cans, Storage ........... 85

Caponizing Sets $\ldots \ldots \ldots \ldots 77$

Carbola ................. 95

Chick Boxes .............. 79
Fage

Corn shellers .............. 95

Egg and Butter Crates...78, 79

Eggs for Hatching........... 75

Egg Scales ............. 93

Egg Testers ............ 79

Feed, Poultry, Chick and Pig-

eon $\ldots .72,73,74,75,89,91$

Fountains and Heater's....86,

Gape Worm Extractor....... 88,78

Incubators $\ldots \ldots \ldots \ldots \ldots \ldots 80$

Incubator Hygrometers ..... 8

Incubator Parts ............ 8

Incubator Thermometers ..... 88

Judges Sticks ........... 78

Leg Bands

Live Stock Dept.......... 76

Mills, Grinding Feed and

Grist $\ldots \ldots \ldots \ldots \ldots \ldots, 8,8$

Nest Eggs . . . . . . . . 9

Oat and Grain Sprouters..... 93

Poultry Houses

Poultry Killing Knives ........ 78

Poultry Narkers .......... 78

Poultry Remedies and Tonics,

Conkeys Colored Insert on

page $88 \ldots \ldots .89,90,91,92$

Roofing ...............

Roupe Syringe $\ldots \ldots \ldots \ldots \ldots 78$

Scrapers and Cleaners ........ 88

Sheeting, Water Proof........ 95

shipping Coops ........... 79

Water Glass . . . . . . . . . 89

Wire Nests ............. 94

Wire, Poultry and Pigeon.... 9.

ANIMAL REGULATOR ..90, 91 BEE KEEPERS SUPPLIES. 71

BIRD TONICS $\triangle N D$

BOOKs ............92, 96

DOG AND CAT FOODS AND

REMEDIES .......... 9

FISH FOOD

PIGEON FEEDS, REMEDIES AND SUPPLIES, BOOKS, ETC. $. .73,89,93,96$

RABBIT SUPPLIES AND

BOOKS $\ldots \ldots \ldots \ldots 78,95,96$

TURKEY TONICS AND

FOODS ..........89, 99 


\section{"To The "Bolgiano" Tomato}

INTRODUCED BY BOLGIANO OF BALTIMORE IN 1920

The Most Wonderful Yielder Ever Known

Two Weeks Earlier than the Earliana. Stands Long Distance Shipping. First Fruit as Good as the Prime of the Season. A Solid Mass of Red, Meaty Flesh, Skin Tough, Flesh Tender and Sweet

The recommendations we have received far exceed those received from any of our other liew creations. Nature with her wonderful activities, helped by our expert selections has produced this wonder of the tomato family. This tomato fills every need of the grower, whether it be for canning, the market, or for home consumption.

The Bolgiano Tomato is very smooth and its heary potato-leaf foliage protects it from Sun scald and blister. 'The Bolgiano Tomato is a most wonderful producer, blossoming continuously throughout the Season. It has produced large returns from a single acre when adjoining fields have been almost barren.

Deep red in color, very solid, free from watery seed cavities, a solid mass of meaty flesh. No tough green core. No green streaks radiating from the stem end. Fruit picked ripe has remained fit for table use for two weeks.

The flesh is sweet and tender while the skin is very tough wlich makes it an exceptionally good long distance shipper, remaining solid and as fresh as if just pulled from the vine.

Plants set out on the twentieth of May have produced ripe fruit by the first of July.

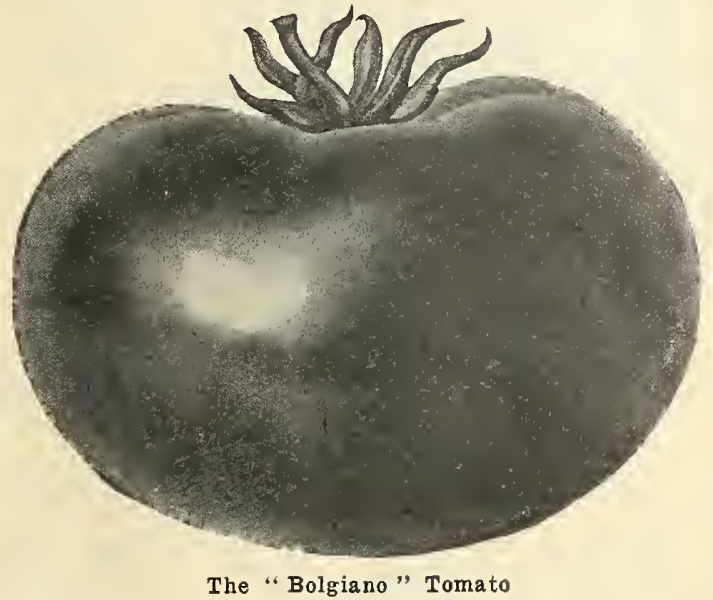

It is the best yielder on the market stall and it can be grown successfully in any part of the United States. The Bolgiano Tomato introduced by us in 1920 is acknowledged to be a most wonderful variety and we would like all of our friends to give it a trial.

Pkts. 5c and 10c. 1/2 Oz. 50c. Oz. 90c. 2 Ozs. $\$ 1.50$. $1 / 1$ Lb. $\$ 2.75$. 1/2 Lb. $\$ 5.15$. Lb. $\$ 10.00$. Postpaid.

\section{"Bolgiano's "Florida Special" Tomato}

\section{Introduced By Us Twelve Years Ago Primarily for Florida on Account of Its Blight Resisting and Excellent Shipping Qualities. Now Used In All Other Tomato Growing Sections with Marked Success}

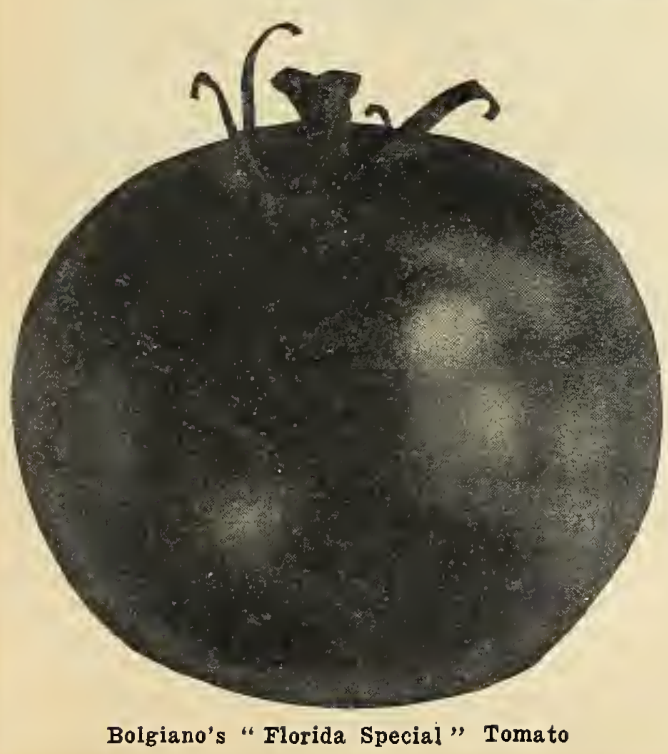

Bolgiauo's "Florida Special" Tomato was developed especially to fill a long felt need for a tomato that would resist blight and at the same time have the necessary qualities of a good shipper; these two rital points are among the many that make this tomato so popular to-day with our Florida friends.

Bolgiano's "Florida Special" while especially well adapted for Florida has been used in other tomato growing sections with the same high degree of success. Its color is red, large size, fine flavored, firm and very prolific and as early as the Earliana, a most excellent slipper, standing the long distance shipment from Florida to the Northern markets remarkably well. It is very solid and excellent for slicing.

If you grow tomatoes, no matter where you are located in the United States, it will pay you to give this variety a trial. Pkts. 5c and 10e. 1/2 Oz. 25e. Oz. 40c. 2 Ozs. 70c. 1/4 Lb. $\$ 1.30$. 1/2 Lb. $\$ 2.40$. Lb. $\$ 4.50$. Postpaid. 


\section{"John Baer" Tomato The Earliest of the Earlies}

INTRODUCED BY BOLGIANO OF BALTIMORE IN 1914

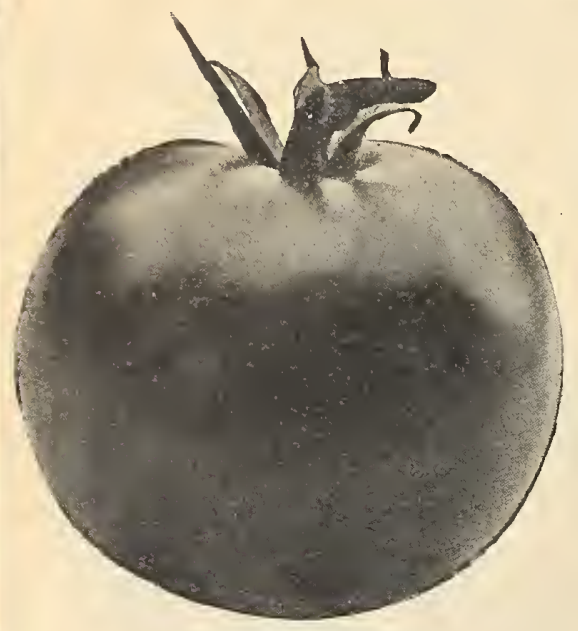

"John Baer" Tomato

Bolgiano's Perfect Type

We Are the Sole Distributors of Originators' Stock

The Best Extremely Early Tomato on Earth

"John Baer" Tomato produces the most perfect High Crown Tomatoes ever grown, entirely free from core. "John Baer" Tomato produces an enor"mous crop of tomatoes, 100 fruit or over to eacli plant. Every "John Baer" Tomato ripens evenly right up to the stem. No eripples, no scalds, no blight, no cracked, no wrinkled, no one-sided, uneven, scarred fruit. When dead ripe "John Baer" will not burst. "John Baer"' has a wonderful glistening brilliant, bright red color. "John Baer" has a mild, deìiciously sweet flavor. "John Baer" Tomato is almost seedless. A marvelous stem setter, often ten fruit in first eluster, solid and meaty. "John Baer" Tomato is the most perfect shipping tomato ever grown-24 fruit exaetly fill a six carrier basket. As a paeking tomato, "John Baer" is a milaele-they all pack fancy, no seconds and all pack whole.

Pkts. 5e and 10c. $1 / 2$ Oz. 30c. 1 Oz. 50e. 1/4 Lb. $\$ 1.40 . \quad 1 / 2$ Lb. $\$ 2.65$. Lb. $\$ 5.00$. Postpaid.

\section{${ }^{2 \pi}$ Bolgiano's \\ "Greater Baltimore" Tomato}

INTRODUCED BY BOLGIANO OF BALTIMORE IN 1905

\section{The World's Greatest Canning Tomato}

The Best Second Early and Main Crop Tomato. Ranks First in Yield and Quality. Its Extremely Heavy Weight, Due to Its Firmness and Great Meatiness, Makes It a Wonderful Canning Tomato. It Ripens Evenly to the Stem and is Entirely Free from Ridges, Cracks and Blight. Smooth, Well-Formed. Fruits in Large Clusters at Every Second Joint. Joints Are Short and Sturdy. Brilliant Red Color. Vigorous, Compact, Healthy Vines. Just Doubles the Yield of Many of the Best Cropping Tomatoes You Have Ever Grown.

One man raised 17.000 plants from one-fourth pound of "Greater Baltimore" Tomato Seed. "Vigorous grower, strong, healthy plants. Fruit uniform in shape and size, large, very regular, smooth, shapely, fleshy, very meaty, ripens well and evenly. Beautiful bright red color, fruit very handsome, dozens weighing 30 ounces, and several exceeding 32 ounces." Seed planted side by side with Stone has outyielded that variety four to one. Used almost exclusively by the principal eanners of the United States and Canada.

Pkts. 5e and 10c. 1/2 Oz. 25c. Oz. 40e. $20 \%$ s. 70c. 1/2 Lb. \$1.30. 1/2 Lh. $\$ 2.40$. Th. \$4.50. Postpaid.

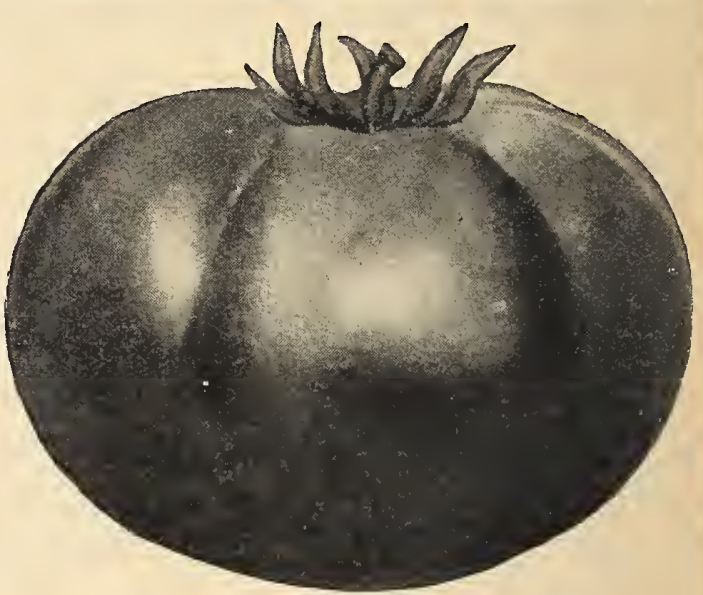

Greater Baltimore Tomato

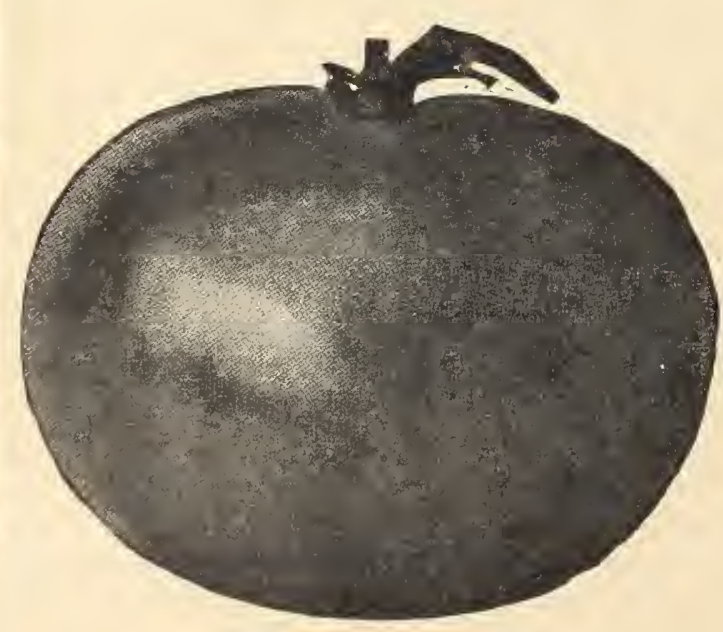

"My Maryland" Tomato

\section{" "My Maryland" Tomato} INTRODUCED BY BOLGIANO OF BALTIMORE IN 1911

\section{A Marvelous Double Yielder}

\section{A Wonderful Second Early Main Crop Tomato}

The vast possibilities of this Tomato are astonishing. We believed in Greater Baltimore Tomato the limit of produetiveness had been reaehed, but "My Maryland" so far outyields any other 'Tomato ever grown that its remarkable produetiveness is amazing. People have driven miles to see a field of "My Maryland" Tomatoes, and they all marveled at the prodigious abundance of the erop it had produced. The fields were literally covered with the finest well-shaped, perfeetly formed, solid, smooth, bright red, uniform fruit, all free from roughness and cracks, much larger than any ever seen before. It was ealled then and there "A Winner," and it well deserved the title. The Tomatoes are much larger and far heavier than the Greater Baltimore.

Plt. 10c. 1/2 Oz. 30c. Oz. 50c. 2 Ozs. 80c. 1/4 Lb. $\$ 1.40$. $1 / 2$ I.b. $\$ 2.65$. Lb. $\$ 5.00$. Postpaid. 


\section{"Bolgiano's "Sure Summer Header" Lettuce}

INTRODUCED BY BOLGIANO OF BALTIMORE IN 1922

\section{One of the Best Summer Heading Lettuces}

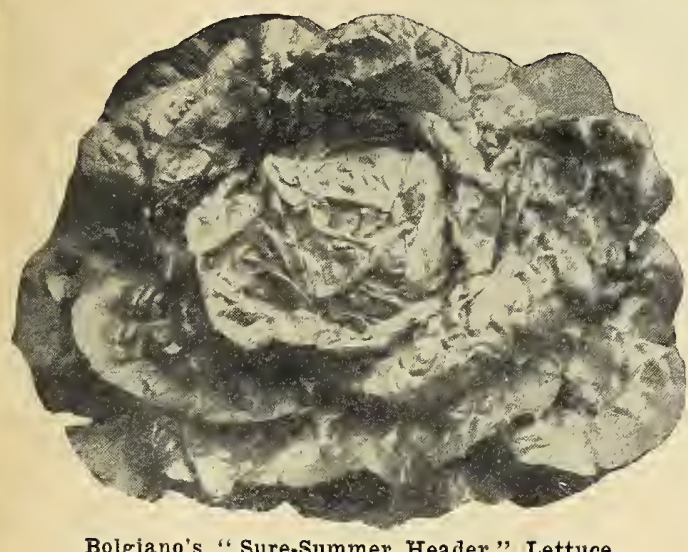

This is the best Nid-Summer Variety, resisting heat and drought and remains in a heading condition longer than any other. It is a sure header in the hottest, driest weather and proves a big success under conditions when all others fail. The heads are a good size. very solid, a fresh green color. Loose leaves can all be used as they are brittle and tender. This strain is a lig improvement over all other Sunmer varieties. Pkts. $5 e$ and 10e Oz. $15.1 / 4 \mathrm{Lb}$. 45e. $1 / 2$ Lb. 80e. Lb. $\$ 1.50$. Postpaid.

Read What a Market Gardener of Long Experience Says

Ir. J. F. Langenfelder, of Baltimore Collnty, IId., saus : "Bolgiano's Sure Summer Header Lettuce is all that you claim it to be. During July of this year I had a small patch of this lettuce planted along side of another variety. Both kinds were planted same time and under identical conditions. Every head of the Sure Summer Header was cut and marketed at $\$ 1.00$ per box, while the other lettucc all went to seed and not one incarl fit to market. In my lifetime experience as a market gardener, it is the only lettuce I luave ever been able to realize a good profit from during the summer months. I highly recommend it to my fellow gardeners."

\section{"Bolgiano's "Masterpiece" Lettuce}

INTRODUCED BY BOLGIANO OF BALTIMORE IN 1920

\section{Sure Header, Very Solid, Beautifully Blanched, Crisp as Ice, Mild, Tender, Delicious Flavor.} A Very Profitable Lettuce to Grow

A sure header, very solid, beautifully blanched, erisp as ice, with a mild tender, sweet, delicious flavor. No niatter how hot or how long it remains in the garden, it will keep erisp, tender and sweet. No bitterness. It will not go to seed quickly. Heads grow to the size of 24 inches around and 12 inches from tip to tip of leaf. Can be grown in open ground after danger of frost is over, all during Summer and early Fall. Nerer spots or turns dark in any part.

This Lettuce will please the most critical market gardeners. It is equally well suited for the home garden, nearby markets, or longdistance shipping. It does well in any section of the country, and Lettuce growers throughout the United States will find it a very profitable variety to grow.

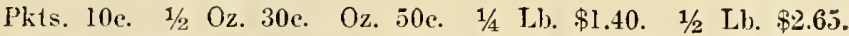
Lb. $\$ 500$. Postpaid.
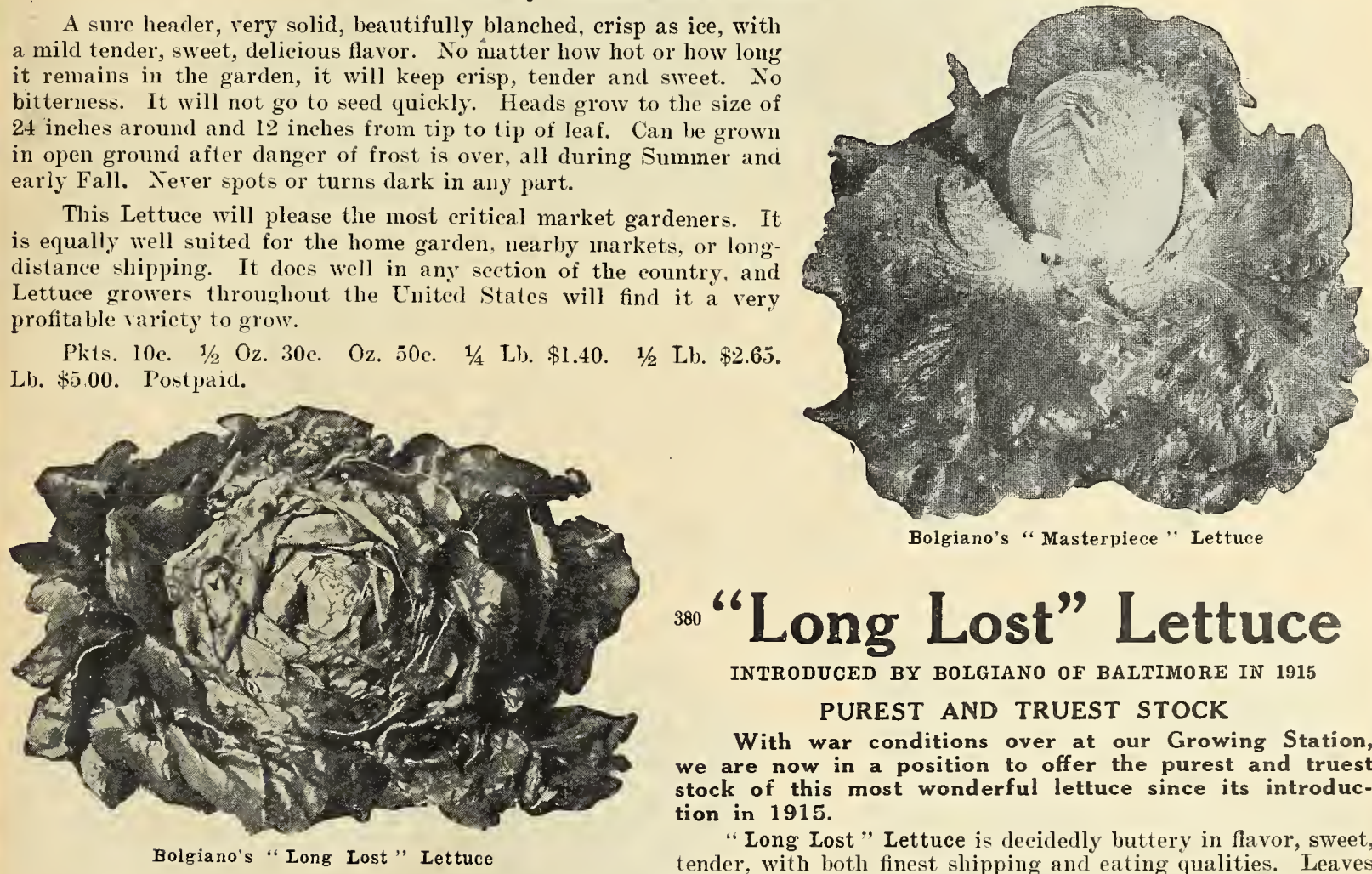

INTRODUCED BY BOLGIANO OF BALTIMORE IN 1915

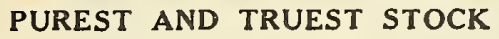

With war conditions over at our Growing Station, we are now in a position to offer the purest and truest stock of this most wonderful lettuce since its introduction in 1915.

"Long Lost" Lettuce is decidedly buttery in flavor, sweet, tender, with both finest shipping and eating qualities. Leaves are of much sulstance and not easily torn.

"Long Lost" Lettuce is of a solid, bright, attractive green. It is never spotted or brownish in any part.

As a splendid shipper "Long Lost" Lettuce far" surpasses every other Lettuce, including the Big Boston. It is a wonderful shipper and those growers who realize it first and quickly grasp this remarkable opportunity, are the ones who will profit far beyond their highest hopes.

"Long Lost" Lettuce produces large, extremely solid, compact, cabbage heads. It is a reliable, sure header and is very hardy. It will Winter over better than Big Boston Lettuce. It stands the cold.

"Long Lost" Lettuce will keep remarkably weli. It is distinetly a market gardeners' and Southern shippers' Lettuee. Heads are large, compact, glohular in shape, very firm, well defined and beautifully blanched.

Pkt. 10c. $1 / 2$ Oz. 30c. Oz. 50c. 2 Ozs. 80c. 1/4 Lb. \$1.40. 1/2 Lb. \$2.65. Lb. \$5.00 Postpaid. 


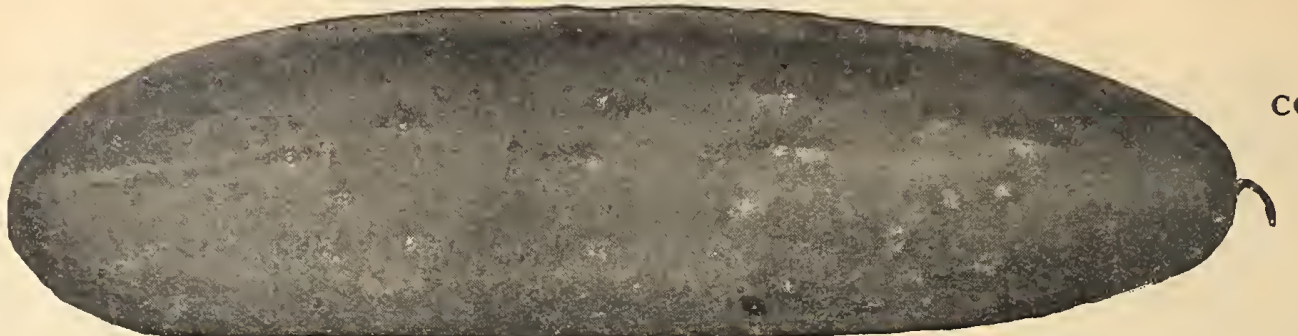

The vines are of strong, vigorous growth with healthy foliage, mildew-proof, and maintains their luxuriance and set the extra long fruit alundantly from the earliest to the latent season. The Cucumbers are uniformly smooth and regular in form-in fact, it is the most perfect Cucumber that you have ever seen. No missliapen fruits or culls. The skin is thin and tender. An attractive rich glossy deep green in color, which it carries to the very tips. It never turns yellow, even when fully ripe. The flesh is firm, fine grained and tender, sparkling white, of the most delightful and refreshing flavor. It is entirely free of the bitter taste so often noticed in other varieties. The flesh is thick, the fruit being two to three inches in diameter, with very few seeds. It is ideal for slicing. The quality is superb. Bolgiano's New "Crystal Springs" Cueumber is the Earliest, Heaviest Yielding, Long Green White Spine Cucumber ever known, under all conditions of culture, whether under glass or in the open ground. It is the ideal Cucumber for either shipping, market ol home use. Pkts. 5c and 10c. Oz. 20c. 1/4 Lb. 60c. 1/2 Lb. \$1.10. Lb. \$2.00. Postpaicl.

\section{"Bolgiano's "Early Fortune" White Spine Cucumber INTRODUCED BY BOLGIANO OF BALTIMORE IN 1900}

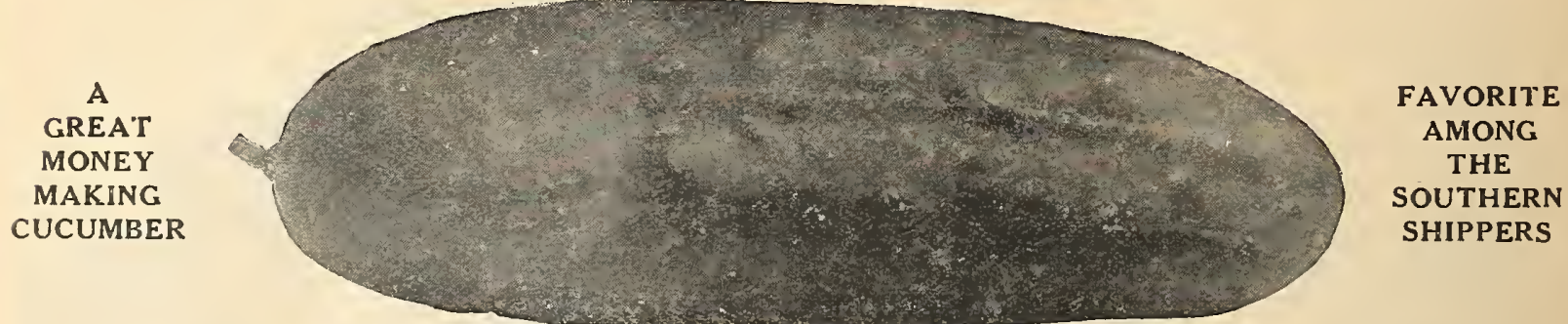

Bolgiano's Early Fortune White Spine Cucumbers All Pack Fancy

Early Fortune Always Brirgs the Highest Prices. You Can Always Depend on Early Fortune

In color, Early Fortune is a rich, attractive deep green. This inviting color it retains during a much longer period of growth than any other variety; it is so regular in form. one so much like the other, growers marvel at the purity and trueness of our stock-in fact, in seleeting our stock seed these Cucumbers are so perfect it is almost impossible to sav which is best.

The quality is superb, flavor delicate, refreshing and delightful, entirely free from any bitterness; being finegrained, the flesh compact it is exceedingly crisp and brittle, making it an ideal slicing Cucumber.

As a shipping Cucumber. "Early Fortune" cannot be surpassed, as it holds up in color and quality longer and better than any other variety.

Phts. 5c and loc. Oz. 15c. 1/4 Jh, 45c. 1/2 Jh. 80c. Lb, \$1.50. Postpaid.

\section{"General Pershing" Watermelon}

INTRODUCED BY BOLGIANO OF BALTIMORE IN 1919

More Prolific Than Watson, Sweeter Than Kleckley Sweet. Will Stand Long Distance Shipping Better Than Any Other Melon.

"General Pershing" Watermelon is a distinct and very raluable melon. The produetiveness is won. derful, producing more marketable melons under the same conditions than any other melon. It is the best to stand dry weather and produces no culls. The rines resist insects that attack them. It is a long melon, well filled out at both ends. The eating quality is unequalled. The sparkling red flesh is as sweet as honey and fairly melts in your mouth. It is entirely free from hard centers and stringiness, yet the flesh is very firm and compact. The size is uniformly large, ranging from 35 to 50 pounds each. Color of rind a light pea green. Ripens mucl, earlier

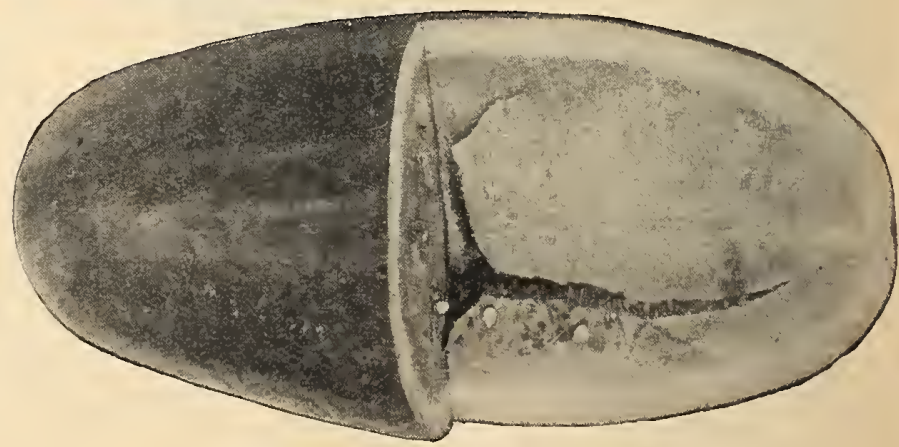

"General Pershing " Watermelon

than the Tom Watson, and will keep in good condition for a long time after picking. Will stand long-distance shipping bettel than any other melon. The rind will not sunburn and will keep in good condition for several days in the sun after hecoming ripe, while all dark rind melons will blister on the top, which makes them unsalable.

Pkts. 5c and 10c. Oz, 15c. 1/4 Lb. 45c. 1/2 Lb. 80c. Lb. \$1.50. Postpaid. 


\section{"Bo Bolgiano's \\ "Unsurpassed" Cantaloupe}

INTRODUCED BY BOLGIANO OF BALTIMORE IN 1920

The Best Cantaloupe Ever Grown

FAIRIY MELTS IN YOUR MOUTH

Tender, Delicious, Sweet Flavored, Salmon

Colored Meat

Vigorous Grower, Blight Resister, Enormous Producer, Splendid Shipper, Solid Netted, No Culls, Handsome Appearance

SATISFIES THE MOST CRITICAL TRADE

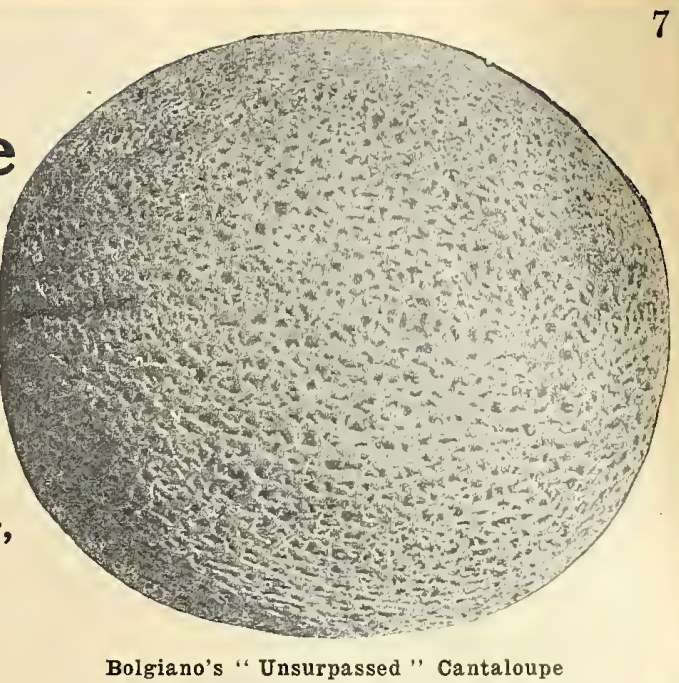

The meat is salmon color, delicious, sweet flavor, perfectly tender and not stringy or tough. It fairly melts in your mouth. The vines are of a vigorous growth, one of the best blight resisters, producing large crops of even size melons, absolutely no culls, solid netted which gives it a beautiful appearance. It is just the kind of Cantaloupe that the shippers and market gardeners should grow, as it sells in any market at a high price. No one purchasing this melon would ever huy any other kind. It is without exception the greatest money maker for the market gardeners, and it will please the most critical huyer and will stand long-distance shipping successfully.

The home gardener will make no mistakc in planting this Cantaloupe, and when once used, he will plant nothing else.

Pkts. 5c and 10c. Oz. 20c. 2 Ozs. 35c. 1/4 Lb. 60c. 1/2 Lb. \$1.10, Lb. \$2.00. Postpaid.

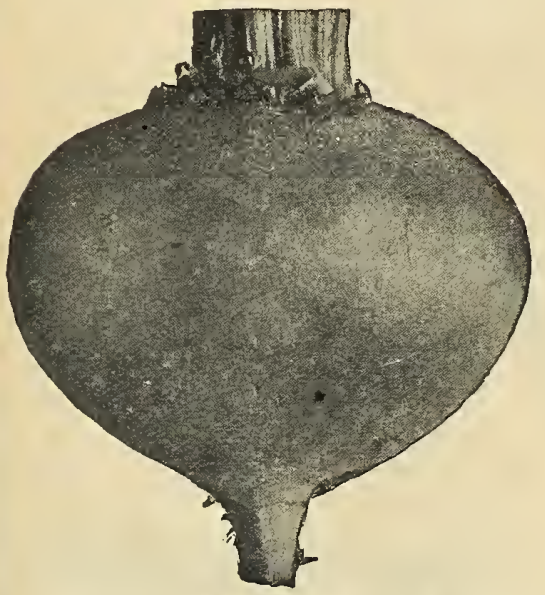

Bolgiano's New Early Spring Beet
"Br Bolgiano's

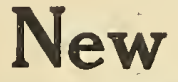

\section{"Early Spring" Beet}

INTRODUCED BY BOLGIANO OF BALTIMORE IN 1916

The First Beet in Market, Where it Commands Fancy Prices

Bolgiano's New "Early Spring" Beet has now been given a trial by all the leading market gardeners. They have been wild in their praise of its wonderfully good qualities. It was the first Beet in market, where it commanded the fancy prices. Most perfect in shape and beautiful deep red color. It is much earlier maturing than Crosby's Egyptian and is of a much finer grain. Has a very small tap root, also top not being quite as large as Crosby's Egyptian. Even in maturing, that is, all the Beets can be pulled one week after you start in pulling. Can be sown under grass and transplanted outdoors or sown in the open field and will mature much earlier than Crosby's Egyptian. Bolgiano's New "Early Spring" Beet is the result of years of reselecting and improving, resulting in, we belierc, the earliest and best Beet on the market. It will pay you liandsomely to give it a trial.

Pkts. 5c and 10c. Oz. 15c. 2 Ozs. 25c. 1/4 Lb. 45c. 1/2 Lb. 80c. Lb. $\$ 1.50$. Postpaid.

Bt Bolgiano's New

\section{"Square-Deal" Cabbage}

INTRODUCED BY BOLGIANO OF BALTIMORE IN 1910

It is absolutely a "Square Deal," as we have seen ten-acre fields without a single irregular head. The uniform heads are of excellent size for shipping, larger than the "New Leader" and yet not so large as to he unwieldly. The color is a fine fresh green and is retained during long slipments. The heads are solid and compact with very few outer leaves. For a fine Solid, Tender, Uniform, Early Flat Cabbage. Bolgiano's New "Square Deal" Cabbage challenges the world. The demand for a fine Cablage of this eharaetc $x$ led us by the nost rigid and eareful selection. to mature this Cabbage. which we are confident will give all our friends and customers a "Square Deal" every time.

Pkts. 5c and 10c. 1/2 Oz. 15c. Oz. 25c. 2 Ozs, 40c. 1/1 Ll. 65c $1 / 2$ L.b. $\$ 1.20$. Lb. $\$ 2.25$. Postpaid.

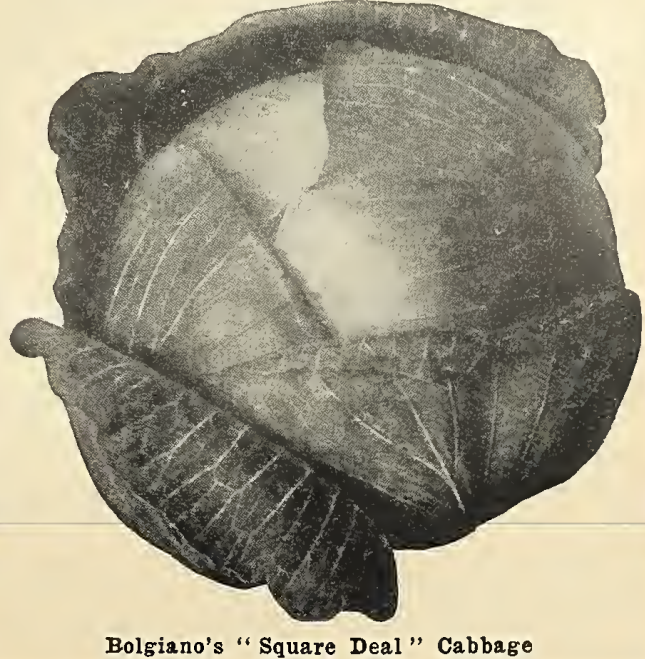




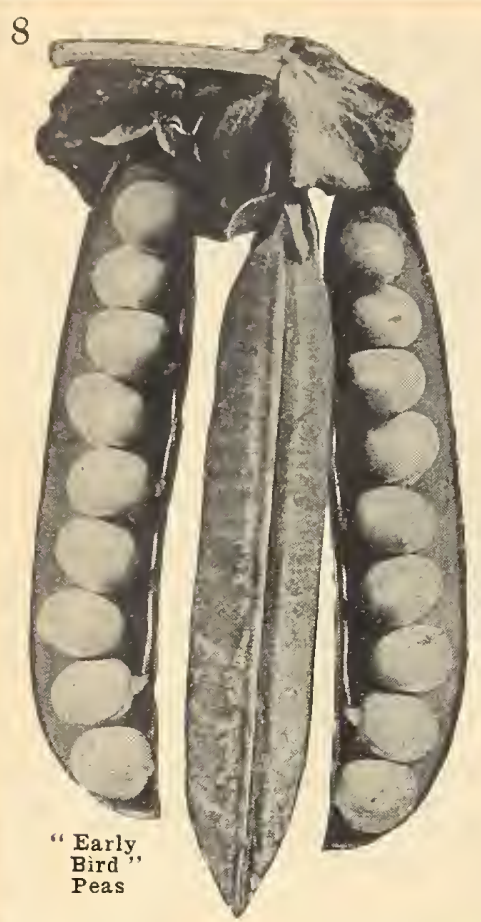

\section{Bolgiano's "Early Bird" Pea}

INTRODUCED BY BOLGIANO OF BALTIMORE IN 1917

A Wonderful New Early Semi-Wrinkled Dwarf Pea Extremely Early, Very Hardy, Mammoth Podded Vines 2 to $2 \frac{1}{2}$ Feet High

1048. Bolgiano's "Early Bird" Peas are unsurpassed for their extreme earliness, superb quality and musual prodnctiveness.

The dwarf, vigorons vines measure 2 to $2 \frac{1}{2}$ feet and carry enormous crops of large, long. beautiful, deep-green pods.

The handsome pods measure 4 to $4 \frac{1}{2}$ inclies long and are filled with 9 to 10 slightly indented, round, blue marrow Peas.

The Peas are large in size and of the most luscions flavor.

Bolgiano's “Early Bird" Peas ean he sown as soon as the ground can be worked, for they do not rot in the ground like fully wrinkled varieties.

Bolgiano's " Early Bird" Peas ean be pulled as early as the Extra Early Alaskas, with pods double the size.

A robust grower and a very heary eropper.

As a Pea for the home garden it is unsurpassed.

Pht. 10c. $1 / 2$ Lb. 25c. Lb. 40c. 2 Lbs. 75e. 10 Lbs. $\$ 3.50 .25$ Lbs. $\$ 8.00$. 100 Lbs. $\$ 30.00$.

\section{${ }^{1220}$ Bolgiano's Extra Early "Harvester" Sugar Corn}

INTRODUCED BY BOLGIANO OF BALTIMORE IN 1920

First Delicious White Sugar Corn on the Market. Earlier, Sweeter than the Golden Bantam. Rapid Grower. Medium Height, Enormous Yielder

This is the best Extra Early White Sugar Corn that has ever been placed on the market. For many years the home gardeners have been auxions to obtain a white Corn that would be as early and as sweet as the "Golden Bantain." Bolgiano's "Extra Early Harvester" Sugar Corn has been thoroughly tested and tried with all the other extra early varieties. It is several days earlier than the "Golden Bantam," sweeter flavor, pure white in color. We tested this Corn in the northern part of Maine where the seasons are very short and where often Corn does not grow to maturity. "Bolgiano's

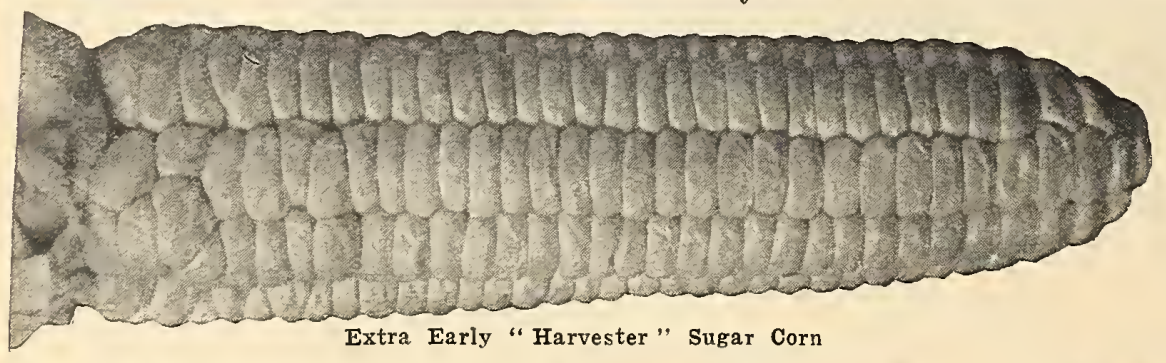
"Extra Early Harvester" Sugar Corll has won honors in this seetion, always maturing. It can be planted early in the Spring, just as soon as the ground begins to show warmth. It is a rapid grower, nedium in heiglit. This is a superior variety for the home garlener and is a profitable extra early Corn for market gardeners. Lb. 24 e. 2 Lbs. 48 c. 10 Lbs. $\$ 2.10$. 25 Lbs. $\$ 5.00$. 100 Lbs. $\$ 18.00$.

\section{8

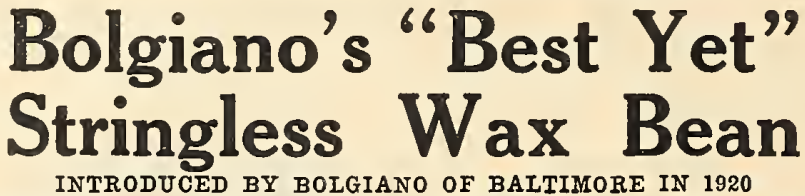

Beautiful Lemon Yellow Wax Pods Without Rust, Rot or Blight. Absolutely Stringless

Of all the Wax Beans Bolgiano's "Best Yet" Strungless Wax Beans me the finest that have ever been introduced. The plant is of an ereet bushy habit, reaching 18 to 20 inches high, thus proteeting the fleshy pods from wet soils during rainy seasons. Pods 6 to 7 inches long, rich lemon vellow in color, brittle, absolutely stringless, without fiber.

Market gardeners will be delighted with Bolgiano's " Best Yet" String less Wax Beans beeause they are a wonderful yielder, the lushes are heavy larlen with pods free from rust, rot or blight. This makes them very desirable for both market and camning trade. Its tenderness and delicious flavor has attraeted not only the market gardeners but the home gardeners as well. They retain their flavor when eanned, and one would believe they were eating Beans fresh from the vines. Fou could readily afford to place your entire aereage in Bolgiano's New Stringless Wax Beans. Market gardeners who grow a erop of these wonderful Beans will be the big money makers.

Wide-awake home gardeners will be the first to enjoy the most delicious stringless wax Bean ever created.

Pkt. 10e. 1/2 Lb. 20e. J.b. 35e. 2 Lbs. 60. 10 Lbs. \$2.75. 25 Lbs. \$6.25. ] 00 J.bs. $\$ 23.00$.

2.

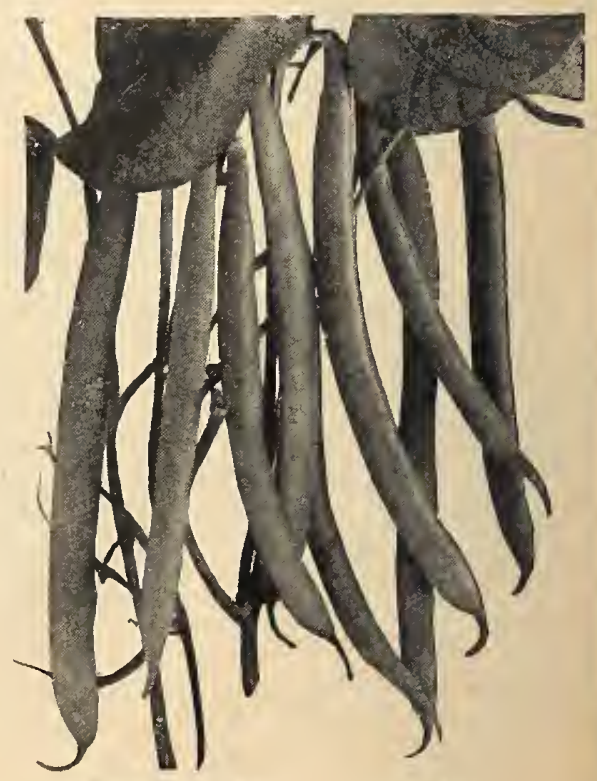

Bolgiano's "Best Yet" Wax Beans 


\section{Bolgiano's \\ “Big Krop" Vegetable Seeds for 1923}

\section{We Pay Postage on Pkts., Ozs., 1/4 Lbs. and Pounds of All Vegetable Seeds-Except Beans, Peas and Sugar Corn-On These the Postage Extra and Must Be Included in Remittance-See Parcel Post Table on Page 2}

\section{Asparagus Seed}

1. New Palmetto. Is very early, large yielder, and very regular and even in growtl. Average bunches contain 15 shoots, measuring $13 \frac{1}{2}$ inches ill eircumference; weighs 2 pounds. It is equally well adapted for all sections. Its quality is unequaled. Pkt. 5c. $\mathrm{Oz}$. 10c. $1 / 4 \mathrm{Lb} .20 \mathrm{c}$. Lb. 60e. 5 Lbs. at $55 \mathrm{c}$.

2. Conover Colossal. A well-known variety. Pkt. 5e. Oz. 10e. 1/4 Lb. 20e. I.h. 60e. $5 \mathrm{~J}$ bs. at $55 \mathrm{c} \mathrm{Lb}$.

526. Columbian Mammoth White. Pkt. 5c. Oz. 10c. 1/4 Lb. 20c. Lb. 60e. 5 Lbs. at $55 \mathrm{c} \mathrm{Lb}$.

582. Barr's Mammoth. Pkt. 5e. Oz. 10c. 1/4 Lb. 20c. Lb. 60e. 5 Lbs. at 55e Lh.

583. Argentine Giant. Pkt. 5e. Oz. 10c. 1/4 Lb. 20c. Lb. 60e. 5 Lbs. at $55 \mathrm{c} \mathrm{Lb.}$

\section{Asparagus Roots}

Directions. Select a good sandy loam, plow the ground as deep as possible, dig out 12 inclies deep, put in a layer of 4 inches of good, strong stable manure, and press down; then fill in with good, rich, black loam to the top of the bed; sow on the top of the bed $100 \mathrm{lbs}$. of Kainit to 1000 square feet of bed; incorporate this thoroughly to depth of 3 inches. After leveling bed off even, stretch a line the lengtl of bed 9 inches from the edge, and with a spade cut a furrow 8 inches deep, set a row of plants along the trench 9 inches apart, with the crowns of the ronts 2 inches below the surface, then cover up, make even and plant other rows 9 inches apart. $\$ 9.00$.

Palmetto Fine Healthy Roots. (Doz. roots 35c, postpaid.) 100 for $\$ 1.50 .1000$ for

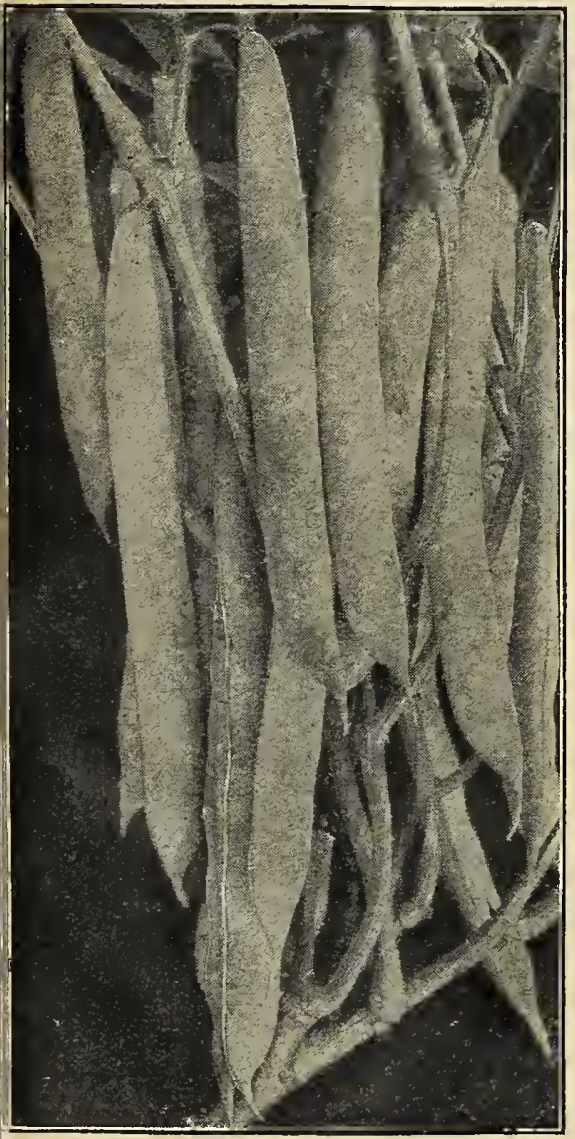

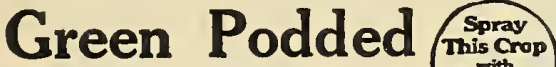 Bush Beans}

KRUP BOHNEN-Haricots Nains-Frigolis

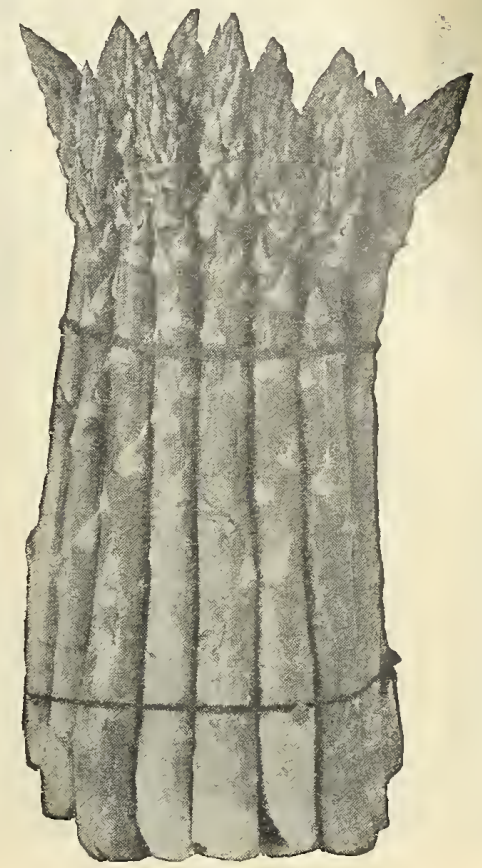

Asparagus

We Pay Postage on $5 c$ and $10 \mathrm{c}$ Pkts. only. Larger Quantities Postage Extra and must be included with remittance. Larger Quantities Postage Extro

Beans by Weight

1 pint 15 Pounds equals about 1 peck

2 Pounds equals about 1 quart 60 Pounds equals about 1 bushel

Seed Beans Weight by Parcel Post Including Packing: Pint, 2 lbs. Qts., 3 lbs, 4 Qts., 9 lbs. Pk., 17 lbs. 2 lbs. to 100 feet of drill, $120 \mathrm{lbs}$, to the acre

Cuture. Beans are somewhat tender, but it often pays to take some risk. Plant in warm, loam soil at the beginning of settled, warm weather in Spring, and at intervals for succession until August Rows may be made 2 feet apart, and the Beans planted not more than 2 inches deep and several inches apart in the drills, or 3 or 4 Beans in hills 6 to 8 inches apart. Cultivate and hoe frequently, always, however, when the vines are perfectly dry. In hoeing draw the soll up toriards the rows or plants. For String Beans, gather the pods clean as fit for use. The plants will remain all the longer in bearing.

1134. "Home, Sweet Home," Bolgiano's New Bean. A most dclicious addition for the home garden. Pkt. 10c. Lb. 24c. 2 Lbs. $48 c .10$ Llos. $\$ 2.10 . \quad 25$ Ibs. $\$ 5.00$. 100 Lbs. $\$ 18.00$.

1008. New Giant Stringless Valentine. This is a great improvement on the oldtime popular favorite Valentine Bean. The pods are fully one-third longer, averaging 5 to 6 inches in length; absolutely stringless, very crisp, round, full and flesly It is enormously productive, its handsome pods being ready for market a few days earlier than old Valentine. We confidently recommend it either for the lome garden or as a profitable variety to grow for maiket. Pkt. 10c. 1h. $26 \mathrm{c} .2 \mathrm{Lbs} 52 \mathrm{c}$. 10 Lbs. \$2.30. 25 Lbs. \$5.50. 100 Lbs. $\$ 20.00$.

1009. Burpee's New Stringless Green Pod Beans. Crisp, tender, luscious flavor Handsome light green pods, are ready to market. TITO IVEKKS EARLTER than the Red Valentine. Pods are full, fleshy and produced in great abundance, remaining green on vines in an edible condition longer than any other Bean known. Pkt. 10c. Lb. 26c. 2 Lbs. 52 c. 10 Lbs. $\$ 2.30 .25$ Lbs. $\$ 5.50 .100$ Lbs. $\$ 20.00$.

1003. Extra Early Refugee Round Green Pod. Has pods of a beautiful, attractive, light green color, round, tender and of a luscious flavor. Pkt. 10c. Lb. $24 \mathrm{c}$ 2 Lbs. $48 \mathrm{c} .10 \mathrm{Lbs}$. $\$ 2.10$. $25 \mathrm{Lbs}$. $\$ 5.00$. $100 \mathrm{Lbs} . \$ 18.00$.

1013. Black Valentine Beans. Matures early, producing long, round, straight, tender pods of blight resisting qualities. Pkt. $10 \mathrm{c}$. Lb. 28c. 2 Lbs. $56 \mathrm{c} .10 \mathrm{Lbs}$. $\$ 2.50 .25 \mathrm{Lbs} . \$ 6.00 .100 \mathrm{Lbs} . \$ 22.00$.

1004. Late Refugee or 1,000 to 1. Exceedingly productive; for medium and late use. The young pods are tender and of fine flavor; the color is a silver green. Pods are round and slim. Pkt. 10e. Lb. 21e. 2 Lbs. 42c. 10 Lbs. $\$ 1.80,25$ Lhs 


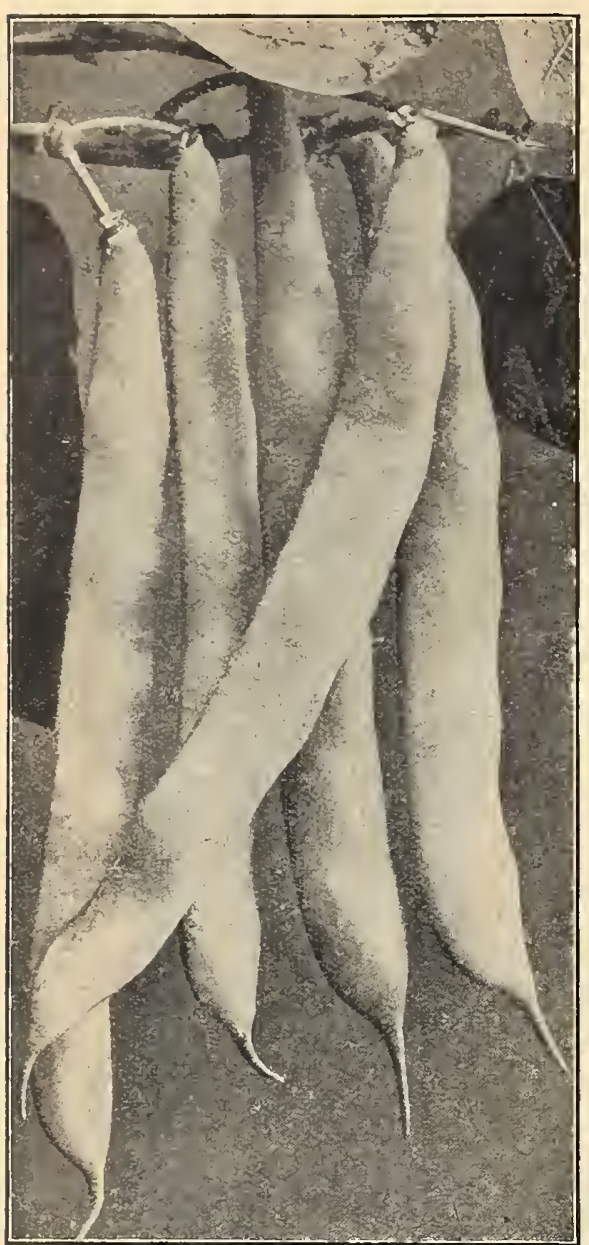

Bolgiano's New Pearl Wax Beans

\section{Green Podded Bush Beans-Cont'd}

1002. New Emerald Beauty Bean. The Emerald Beauty is a flat, green podded Bush Bean, a prolific and continuous bearer. It is absolntely stringless, very tenrler and delicious flavor. The plant is of remarkably handsome and thrifty growtl. The rich, green pods are of immense size, thick, broad, extra long; uniform shape, solicl, meaty and of high quality. Market that will accept a flat podded Bean will soon appreciate the sumpassing qualitics of the Emerald Beauty. Pkt. 10c. Jb. 25c. : Lbs. 50c. 10 Lbs. $\$ 2.20$. 25 Lbs. $\$ 5.25$. 100 Lbs. $\$ 19.00$.

1001. Bolgiano's New Early "May Queen" Beans. Pkt. 10c. Ll). 29c. 2 l.s. 58c. $10 \mathrm{Lbs}$. \$2.60. $25 \mathrm{Lbs}$. \$6.25. $100 \mathrm{Lbs}$ \$23.00.

1006. Hopkins' Earliest Red Valentine Beans. Are one of the earliest and most prolific round green podded Beans. Comes into bearing earlier than the old stock of Valentines, is a wonderful producer and,a perfect shipper. It will remain in a perferet condition for nearly two weeks after picking. Pkt. 10c. Lb. 26c, 2 Lbs. 52c. $10 \mathrm{Lb}$. $\$ 2.30$. 25 Lbs. $\$ 5.50$. 100 Lbs. $\$ 20.00$

1007. Bolgiano's Earliest Red Valentine Beans. This superior Bean has beru carefully built up to satisfy a most critical market gardener"s trade. Under farorable conditions it is ready for picking in 3.5 days from planting. Canners use them because they are always tender and have beautiful round green pods. Pkt. 10c. Ll. $26 \mathrm{c} .2 \mathrm{Lbs} .52 \mathrm{c}$. $10 \mathrm{~J}$ J.s. $\$ 2.30$. $25 \mathrm{Lbs} . \$ 5.50$. $100 \mathrm{Lbs}$. $\$ 20.00$.

1010. Dwarf Horticultural or Cherry Bean. A crop of these Beans has never failed to pay. This is a broad, long, flat, meaty Bean, very productive, delicious flavor. It also makes a good dried Berin for Winter. Pkt. 10c. Lb. 24c. 2 Lbs. 4si. 10 Lbs. $\$ 2.10$. 25 L hs. $\$ 5.00$. 100 Lbs. $\$ 18.00$.

1011 Henderson's Bountiful Beans. A prolific and continuous licarer. The first in Spring. the last in Fall. Stringless, delicious flavor. Jkt. 10c. Li). 2.5r. 2 Lbs. 50c. 10 Lbs. $\$ 2.20$. 25 Lbs. $\$ 5.25$. 100 Lbs. $\$ 19.00$.

1015. Longfellow Green Podded Bush Beans. Long, round, green pods, ex ceedingly prolific, always solid. Remarkably early. Pkt. 10c. Lb. 26c. 2 Lbs. 5) 2 . 10 Lls. $\$ 2.30$. $25 \mathrm{Ll}$ s. $\$ 5.50$. $100 \mathrm{Lbs}$. $\$ 20.00$.

1017. Extra Long Yellow, Six Weeks. Pods flat and green; a leading marlie sort. Pkt. 10c. Lb. $24 \mathrm{c} .2 \mathrm{Lbs} .48 \mathrm{c} .10 \mathrm{Lbs}, \$ 2.10$. 25 Lbs. $\$ 5.00$. $100 \mathrm{Lbs}$. $\$ 18.00$.

1300. Tennessee Green Pod. Prolific, but a tender variety. Foliage dari green, leaves large and crumpled, somewhat earlier than Hodson Green Pod. Pols. 5 to $5^{1 / 2}$ inches long, flat, irregular in shape, light green and of good quality. Pkt. Ilk. Lb. 24 c. 2 Lbs. $48 \mathrm{c} .10 \mathrm{Jbs}$. $\$ 2.10$. $25 \mathrm{Lbs} . \$ 5.00 .100 \mathrm{Lbs} . \$ 18.00$.

1301. Full Measure. Heavy light green foliage. Very prolific. Pods $51 / 2$ to 6 inches long, stringless, round, slightly curved, very good quality. Pkt. 10c. Lb. 31 i". 2 Lbs. 62e. 10 Lbs. $\$ 2.80$. 25 Lbs. $\$ 6.75$. 100 Lbs. $\$ 25.00$.

1184. White Navy or Pea Beans. Pkt. 10c. Lb. 23c. 2 Lbs. 46c. 10 Llss. $\$ 2.00$. 25 Lis. $\$ 4.75$. 100 Lbs. $\$ 17.00$.

\section{He supply Pkts. of} ull Beaus at $5 c$ and
$10 \mathrm{c}$ each, postpaid

\section{Wax Pod Bush Beans}

Parcel Post Rates. see Page 2

Bolgiano's “Best Yet" Stringless Wax Beans. (Specialty, see page S.) Beautiful, lemon-yellow wax pods, without lust or blight. Absolutely stringless. A wonderful yielder. Pkt. 10c. 1/2 Lb. 20c. Lb. 35c. 2 Lbs. $60 \mathrm{c}$. 10 Lbs. \$2.75. 2.) Lls. $\$ 6.25$. 100 Lbs. $\$ 23.00$.

1031. New Pearl Wax Beans. A distinct, enormously prolific and prodigious growing Bush Wax Bean. Every grower should try it. It will soon become a popular and lucrative variety to grow. Will not rust in the wettest kind of weather. Plit. 10c. Lb. 24 c. 2 Lbs. 48c. 10 Lbs. \$2.10. 25 Lbs. \$5.00. 100 Lbs. \$1\$.00.

i183L "Truckers' Reward," Bolgiano's New Flat Wax Bean. One of the most valuable and important Bean introductions in many years. Unequaled as an enormous, beautiful crop producer and money maker. Pkt. 10c. Lb. 26c. 2 Lbs. 52c. 10 L.bs. $\$ 2.30 .25 \mathrm{Ll}$. $\$ 5.50$. $100 \mathrm{Lbs}$. $\$ 20.00$.

1079. New Hodson Wax Beans. A very sturdy grower. prolific; frec from rust and blight. Vigorous plants are loadel with long, handsome, straight pods, averaging 7 inches in length; color of a clean, light yellow. When picked young they are itringless. Pkt. 10c. Lb. 24c. 2 Lbs. 4 c. $10 \mathrm{Lbs} . \$ 2.10$. $25 \mathrm{Lbs} . \$ 5.00 .100 \mathrm{Lbs} . \$ 18.00$.

1021. Round Podded Kidney Wax Bean. (Brittle Wax.) This handsome waxpodded Bean is an inproved Wardwell's Kidney Wax, besides having that popular variety's lusuriant growth, it is entirely stringless. The pods are long, straight and extremely handsome. It is an exceedingly heavy bearer, and is fully as early in maturing as the Wardwell's Kidney $\mathrm{F}^{\circ} \mathrm{x}$, and is of excellent quality. Pkt. $10 \mathrm{c}$. Ll. 26e. 2 Lbs, 52c. 10 Lbs. $\$ 2.30 .25$ Lbs. $\$ 5.50 .100$ Lbs. $\$ 20.00$.

1024. New California Rust-Proof Dwarf Wax. One of the handsomest and most productive flat podded Wax Beans ever grown. The vines are of vigorous growtl, leaves dark green, hardy and yield enormous quantities of large, handsome, flat, meaty pods, bome wall up from the ground and has not shown any disposition to rust no matter where grown. It is from eiglrt to ten days earlier than the Valentine. Plkt. 10c. Lb. 2te. 2 Lbs. 48c. 10 Llk. \$2.10. 25 Lbs. $\$ 5.00$. 100 Lbs. $\$ 18.00$

1019. Currie's Rust-Proof Wax Beans. Is the earliest to mature of either the Green or Wax Beans. It is ready for market in 25 days from date of planting. Its beautiful, pure golden, long, flat pods of extra fine quality are borne in aljundince and attract the admirtion of both the planter and the consumer. Entirely free from rust and blight. Plit. 5e and 10c. Lb. 24 '. 2 Lbs. $48 \mathrm{c}$. $10 \mathrm{Lbc}, \$ 2.10$. 25 Lbs. $\$ 5.00$. $100 \mathrm{Lbs}$ \$ $\$ 1 \$ .00$.

1022. New Davis Kidney Wax. The King of Flat Tiax Beans. A beautiful form, handsome long pods, attractive color, luscious flavor, prolific yielder, rust-proof, excellent shipper, making this Grand Bean a perfect success. Pkts. 5e and $10 \mathrm{c}$. IH. 2.5c. 2 Lbs. $50 \mathrm{c}$. 10 Lbs. $\$ 2.20$. 25 Lbs. $\$ 5.25$. 100 Lbs. $\$ 19.00$. 1020. Wardwell's Kidney Wax. Early, long, flat, pure wax pods. is hardy, botl pors and plants are robust and healthy and it is a heavy
del. It i.s a remarkablo shipuer. l'kt. 10c. Lb. 24 e. 2 Lbs. $48 \mathrm{e} .10$

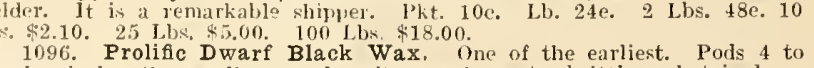

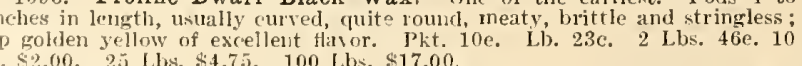
25 Lbs. $\$ 4.75,100$ Lb. $\$ 17.00$
Sure Crop Stringless Wax Beans. Vines are tall, rather aderl with delicious, rich rellow beans, six to seven inches long. at all stages of growth. The kind that sell whell other varieties
lkkt. $10 \mathrm{c}$ Lb. $24 \mathrm{c}$. 2 Lb. $18 \mathrm{e} .10 \mathrm{Lbs} \$ 2.10 .25 \mathrm{Lbs}, \$ 5.00$.

1026. Golden Wax Improved. Early, vigorous and a botintiful yiefler of heautiful tender pods. The vine grows $1 \frac{1 / 2}{1}$ feet high, hoiding the porls well off the ground. The pods are shapely, flat and large. Plit. 100 Lb. $23 \mathrm{c} .2 \mathrm{Lbs} .46 \mathrm{c} .10 \mathrm{Lbs} . \$ 2.00$. $25 \mathrm{Lbs} . \$ 4.75 .100 \mathrm{Lbs} . \$ 17.00$ 1283. Brittle Wax. Pods round, tender, stringless. Very prolific.
Pkt. 10e. Lb. $26 \mathrm{e}$. 2 Lbs. 52e. 10 Lbs. $\$ 2.30$. 25 Lbs. $\$ 5.50 .100$ L.ls.. Plit. 10

1219. Pencil Pod Black Wax Beans. Plants of true bush growth, fifteen inches high, extremely productive; magnifieent straight pods six to seven inches long, light golden rellow in color, beautifully round, meaty ani deeply saddle-backed; forsh brittle, solid and entirely stringless: fine anrl mild fluvol. Pkt, 10c. Lb. $25 \mathrm{c} .2 \mathrm{Lbs} .50 \mathrm{c}, 10 \mathrm{Lbs} \$ 2.20 .25 \mathrm{Lbs} \$ 5.25$. $100 \mathrm{Lb} \leqslant \$ 19.00$. 


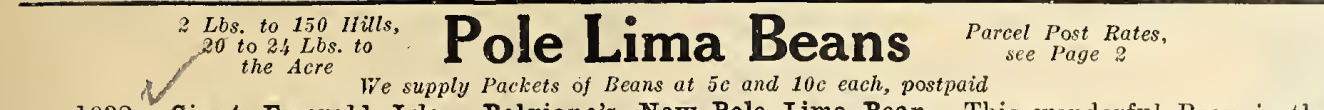

1032. Giant Emerald Isle. Bolgiano's New Pole Lima Bean. This wonderful Bean is the largest podded and the heaviest cropper of all Limas. It grows green, dries green, stays green. Pkt. 10e. Lb. 27c. 2 Lbs. 54c. 10 Lbs. $\$ 2.40$. 25 Lbs. $\$ 5.75$. 100 Lbs. $\$ 21.00$.

1040. Early Leviathan Pole Lima Bean. This sort is at least one week earlier than any large Pole Lima yet offered. Earliness is often obtained at a sacrifice of other features, but in this variety we claim superiority, not only in this respect, but in size of bean pod and enormous productiveness. Pkt. 10c. Jb. 24c. 2 Lbs. 48c. 10 Lbs. $\$ 2.10 .25$ Lbs. $\$ 5.00 .100$ Jbs. $\$ 18.00$. 1041. Dreer's Irnproved Pole or Challenger Lima. Outyield any Lime Bean ever offered. Each pod contains from 2 to 6 delicious Beans, so compactly placed that they make indentations in each other. Pods are produced on the vines in great clusters. The yield is continuous and abundant. Lb. 30c. 2 Lbs. 60c. 10 Lbs. $\$ 2.70 .25$ Lbs. $\$ 6.50 .100$ Lbs. $\$ 24.00$.

1223. Henderson Ideal Pole Limas. Very early, wonderfully productive. Lb. 25c. 2 Lbs. 50c. 10 Lbs. $\$ 2.20$. 25 Llis. $\$ 5.25$. 100 Lbs. $\$ 19.00$.

1042. Seibert's Early Lima. Pods long, easily opened. The green Beans large, handsome, lelicious. Lb. 24c. 2 Lbs. 48 c. 10 Lbs. $\$ 2.10$. 25 Ĺbs. $\$ 5.00 .100$ Lbs. $\$ 18.00$.

1043. Jersey Extra Early Lima. Is 10 days to 2 weeks earlier than any other Pole Lima, except the Leviathan.- The beans are exceptionally tender and delicious. Lb. 24c. 2 Lbs. 48c. 10 Lbs. $\$ 2.10$. 25 Lbs. $\$ 5.00$. $100 \mathrm{Lbs}$. $\$ 18.00$.

1044. Carolina or Sieva Beans. Very early and productive. Lb. 23c. 2 Lbs. 46 c. 10 Lbs. $\$ 2.00$. 25 Lbs. $\$ 4.75$. 100 Lbs. $\$ 17.00$.

1046. Ford's Mammoth Extra Large Lima. Pods are large in size, unsurpassed in quality and productiveness Lb. $24 \mathrm{c} .2 \mathrm{Lbs} .48 \mathrm{c}$. $10 \mathrm{Lbs} . \$ 2.10 .25 \mathrm{Lbs}$ \$5.00. $100 \mathrm{Lbs}$. $\$ 18.00$.

1047. King of Garden Lima Beans. Outrivals all other Pole Limas. Its vine las a luxurious growth, which abounds with enormous pods, often 5 to 8 inches long, and filled with 5 or 6 perfect Beans to a pod. Lb. 240 . 2 Lbs. 48 e. 10 Lbs. $\$ 2.10$. 25 Lbs. $\$ 5.00$. 100 Lbs. $\$ 18.00$.

1224. Carpenteria Pole Limas. One of the longest podded and heaviest croppers of all Limas.

Pkt. 10c. Lb. 25c. 2 Lbs. 50e. 10 Lhs. $\$ 2.20$. 25 Lbs. $\$ 5.25 .100$ Lbs. $\$ 19.00$.

1045. Extra Large Limas. Large white Bean; very tender, equally good in Winter if soaked 10 hours before cooking. Lb. 24c. 2 Lbs. $48 \mathrm{c}$. 10 Llss. $\$ 2.10$. 25 Lbs. $\$ 5.00$. 100 Lbs. $\$ 18.00$.

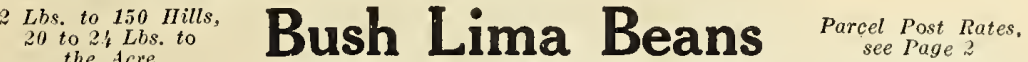 \\ We Supply Packets of Lima Beans at jc and $10 \mathrm{c}$ each}

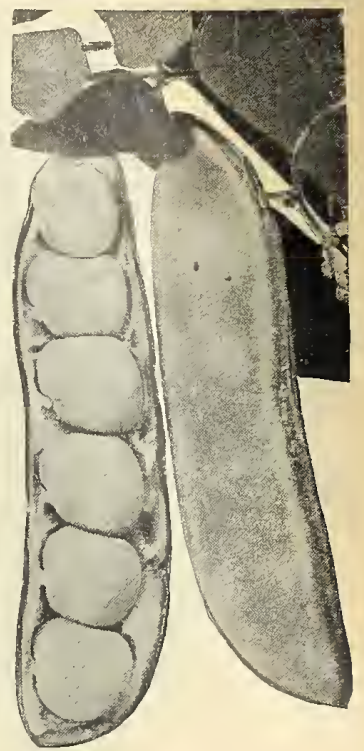

Bolgiano's Giant “ Emerald

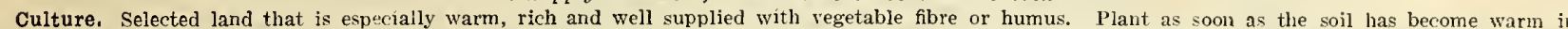

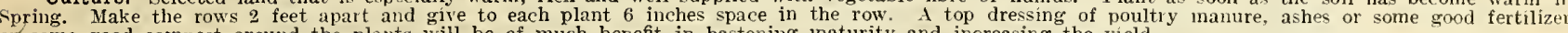
or some good compost around the plants will be of much benefit in hastening inaturity and increasing the yield.

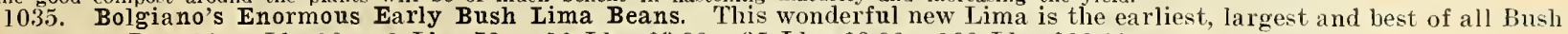
Lima Beans. Pkt. 10c. Jl. 36e. 2 Lbs. 72 e. 10 Lbs. $\$ 3.30 .25$ Lbs. $\$ 8.00 .100$ Lbs. $\$ 30.00$

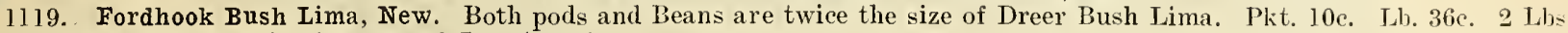
72c. 10 Lbs. $\$ 3.30$. 25 Llis. $\$ 8.00$. 100 Lbs. $\$ 30.00$.

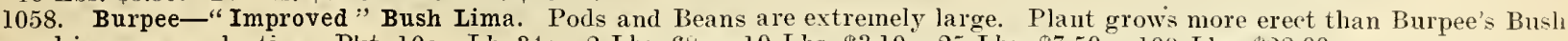
Lima and is more productive. Pkt. 10c. Lb. 34c. 2 Lbs. 66e. 10 Lbs. $\$ 3.10 .25$ Lbs. $\$ 7.50$. 100 Lbs. $\$ 28.00$.

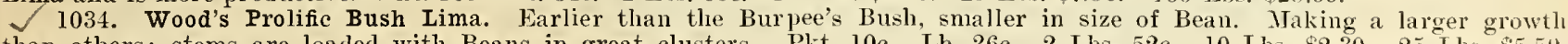

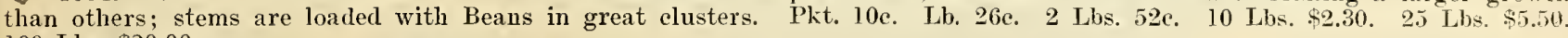
100 Lbs. $\$ 20.00$.

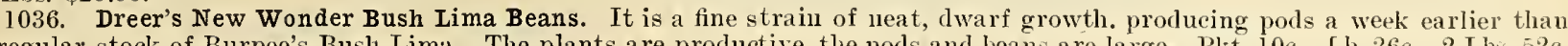

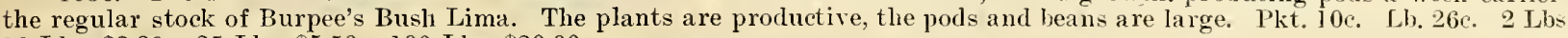

10 Lbs. $\$ 2.30$. 25 Lbs. $\$ 5.50 . \quad 100$ Llss. $\$ 20.00$.

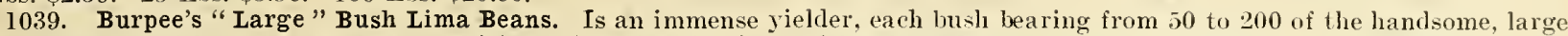

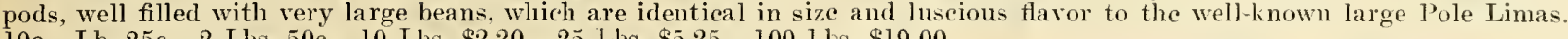

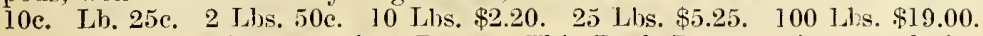

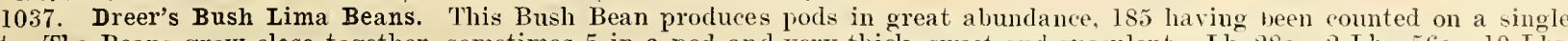

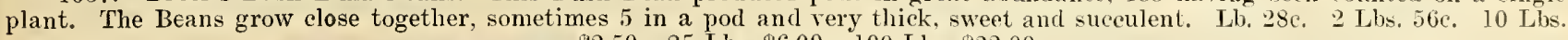

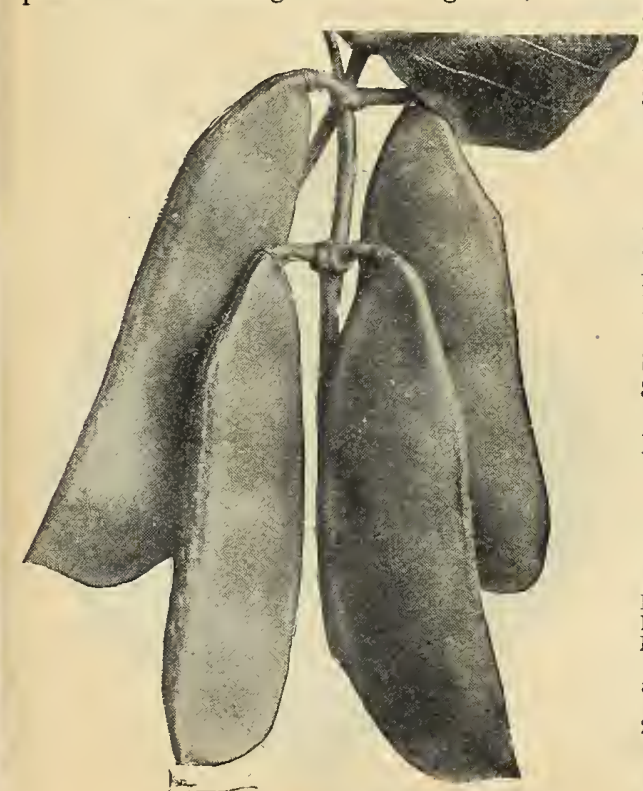

1038. Henderson's Dwarf Bush Lima Beans. Producing Beans of smaller size, is very productive and decidedly delicious. Ib. 26e. 2 Lbs, 52e. $10 \mathrm{Lbs}$. $\$ 2.30 .25$ Lbs. $\$ 5.50 . \quad 100$ Lbs. $\$ 20.00$.

\section{Lbs tuls 150 Pole or Running Beans}

\section{Lazy Wife or White Pole Cherry Beans. Pods are prod} abundance and measure $41 / 2$ to 6 inches in length; broad, thick, very fleshy,
entirely stringless. Retaining their rich, tender and stringless qualities until nearly ripe. Pods contain 6 to 8 round, white beans which make excellent Shell Beans. Lb. 23c. 2 Lbs. 46c. 10 Lbs. $\$ 2.00$. 25 Lbs. $\$ 4.75 .100$ Lbs. $\$ 17.00$.

1025. Point Market Prolific Pole Beans. A very productive and delicious Stringless Pole Bean. Pkt. 10c. Lb. 22e. 2 Lbs. $44 \mathrm{c}, 10 \mathrm{Lbs} . \$ 1.90 .25 \mathrm{Llss}$. $\$ 4.50$. 100 Jus. $\$ 16.00$.

1028. White Creaseback or Best of All. The best eariy Stringless Green Podded Pole Bean. Pkt. 10c. Lb. 22c. 2 Lbs. 44c. 10 Lbs. $\$ 1.90 .25$ Lbs. $\$ 4.50$. 100 Lbs. $\$ 16.00$.

1030. Old Homestead. (Improved Kentucky Wonder.) Enormously productive; stringless. Lb. $26 \mathrm{c} .2 \mathrm{Lbs} .52 \mathrm{c} . \quad 10 \mathrm{Lbs} . \$ 2.30$. $25 \mathrm{Lbs} . \$ 5.50 .100$ Lbs. $\$ 20.00$

1220. Horticultural Pole, Cranberry or Wren's Egg. This is the popular Pole Cherry Bean, growing for either snapshots or dry shell Beans, especially adapted for short seasons and cool locations. Productive; pods four to five inches in length, one-half incl broad, thick and teshy Pkt. $10 \mathrm{c}$. Lb $21 \mathrm{c}$. 2 Lbs. 42c. 10 Lbs. $\$ 1.80$. 25 Lbs. $\$ 4.25 .100$ Lbs. $\$ 15.00$.

1258. Red Speckled, Cut Short, or Corn Hill. An old variety, very popular for planting mong Corn. Pht 10c. Lb. 21c. 2 Lbs. 42c. 10 Lbs. $\$ 1.80$. 25 Lbs. $\$ 425$. 100 Lbs. $\$ 15.00$ 1259. Dutch Caseknife. Early, Iong, green, flat pods, white seed. Pkt. 10c. Lb. 21c. 2 Lbs. $42 \mathrm{c}$. 10 Lbs. $\$ 1.80$. 25 Lbs. $\$ 4.25$. 100 Lbs. $\$ 15.00$.

Kentucky Wonder Wax. It is similar in habit of growth to "Kentucky Wonder Green Pod," and bears as early, or when about as high as the average bush bean. Pods are beautiful golden-yellow, and so fleshy that often the thickness surpasses the width; make delicious eating. Burpee's Bush Lima Beans golden-yellow, and so fleshy that often the thickness surpasses the widt ; make del
Pkt. 10c. Lb. 28c. 2 Lbs. 56c. 10 Lbs. \$2.50. 25 Lbs, 86.00 . 100 I.b. $\$ 22.00$. 


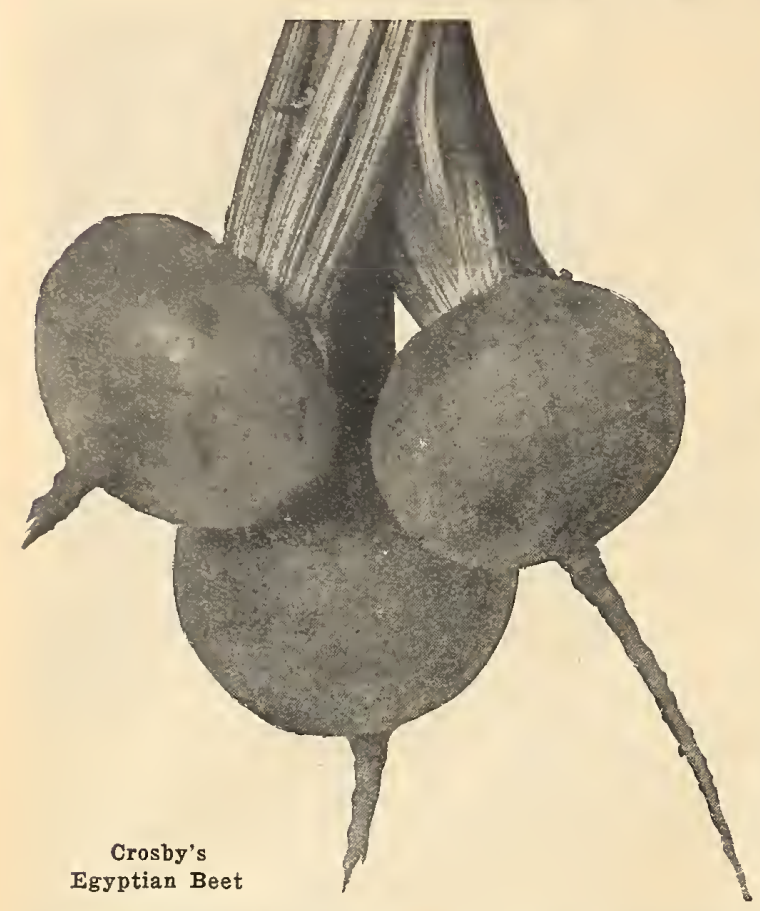

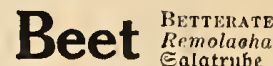

We Pay Postage on Pkts., Ozs., 34 Lbs, and Lbs.

Culture. Fibrous loam, well drained and well enriched, will raise good Beet crop. For early table Beets, have dirills 16 to 20 inches apart, and sow the seed about 1 incl deep, as early as the ground can be put in good sliape, or seed may be sow under glass 4 weeks sooner and the young seedlings transplanted to open ground, to give an extra early crop.

Give thorough and clean cultivation, and thin the plants to stand 3 to 4 inches apart in the row.

For succession, sow at intervals to middle of July. For earliest sowings, a light dressing of nitrate of soda, say 100 pounds per acre, will sometimes work wonders.

377. Bolgiano's New Early Spring Beet. New introduction. (Specialty, see page 7.) First Beet in market. Most perfect shape and color. Earlier maturing than Crosby's Egyptian and of much finer grain. Has very small tap root and small top. All coming into maturity at same time. Well adapted for forcing. Pkt. 10e. Oz. 15c. 2 Ozs. 25c. 1/4 Lb. $45 \bar{c}$. $1 / 2$ Lb. 80 c. Lb. $\$ 1.50$.

295. "Bonfire," Bolgiano's New Early Beet. A splendid new ra. riety, especially adapted for market gardeners; being suited for forcing under glass and for open ground culture. For home garden this Beet will be found desirable, as it retains its freshness and high quality without becoming tougl. Pkts. 5c and 10c. Oz. 10c. 2 Ozs. 15c. 1/4 Lb. 25c. $1 / 2$ Lb. 45c. Lb. 85e.

18. Bolgiano's Deep Blood Beauty Beet. The most popular market gardeners' Beet ever introduced, Pkts. 5c and 10c. Oz. 10c. I/4 Lb. 25c. $1 / 2$ Lb. 40 c. Lb. $75 \mathrm{c}$.

12. American Beauty Beet. The skin and flesh of "American Beauty" Beet are both a deep rich blood erimson color. It matures just after the Eclipse, has a most beautiful form. being a little deeper than round, medium in size, generally about three inches in diameter, has a remarkable surface and a small tap root. Pkts. 5c and 10c. Oz. 10c. 1/4 Lb. 25c. Lb. $75 \mathrm{c}$.

115. Early Model Beet. This is a fine selection of blood-red Beet, extremely smooth and of symmetrical growth, rich color and desirable shape. It makes a rapid growtl and matures very early. The shape is nearly round, and color of flesh blood red. Pkt. 5e. Oz. 10e. 1/4 Lb. 25e. Lb. 85e.

3. Early 0x-Blood. 6 Reasons Why We Introduce This New Beet. 1. It is extra dark blood color from end of its tap root to top of its short graceful leaves. 2. Early as the Crosby Egyptian. 3. Almost globe shape. 4. Small amount of even foliage of deep ox-blood color. 5. Beets are very smooth and free from side rootlets. 6 . Flesh fine grained, sweet and of ox-blood color. Pkts. 5e and 10c. Oz. 10c. 1/4 Lb. 20c. Lb. 65e.

4. Extra Early Eclipse. Remarkable for its very rapid growth, the perfection of its form-which is globular-of its beautiful crimson flesh, and for its dwarf foliage. Roots are bright glossy red. Pkt. 5c. Oz. 10c. 1/4 Lb. 20c. Lb. 65c.

5. Crosby's Improved Extra Early Egyptian Beet. An improvement on Extra Early Egyptian, being as early, but of more desirable shape, color and quality. It is very sweet and tender ; a most valuable sort for early market, as it is ready before any other Beet of equal quality. Pkt. 5c. Oz. 10. 1/4 Lb. 20c. 1/2 Lb. 35c. Lb. 65̃.

6. "New Crimson Globe" Beet. This is one of the best Bunching Beets yet introduced. A handsome variety of medium size, almost globe shape, and entirely free from rootlets; a grand second early or main crop sort. Very handsome in shape. The foliage is small and of a rich bronze purple. Flesh is a rich blood red, slightly zoned or ringed. Never stringy. Pkt. 5c. Oz. 10c. $1 / 4$ Lb. 20e. 1/2 Lb. 35̄e. Lb. 65̃e.

7. Detroit Dark Red Beet. A splendid Beet of a dark red color, for home or market. By far the best for canning, on account of its beauty. Small, upright tops and perfectly small roots. Flesh zoned witl lighter and darker hands; tender and sweet. Pkt. 5c. Oz. 10c. 1/4 Lb. 20c. 1/2 Lb. 35c. 'Lb. 65c.

11. Extra Early Dark Red Flat Egyptian Beet. The Egyptian Beet is one of the most popular varieties anong market gardeners for forcing purposes. It will bear close planting in the valuable space under glass or in a warm garden in early Spring. It is turnip-shaped, and when young is crisp and tender. In color it is dark red. To gardeners having a preference for Egyptian we offer the best straill of seed now on the market. Pkt. 5c. Oz. 10c. 1/4 Lb. 20c. 1/2 Lb. 35c. Lb. 65c.

20. Early Blood Turnip Beet. New Improved. It is early, smooth, does not grow overlarge, has few root:. It does not become stringy, matures a medium size, deep crimson Beet of rlecided uniform type. Pkt. 5c. Oz. 10c. 1/4 Lb. 20c. 1/2 Lb. 35c. Lb. $65 \mathrm{c}$.

21. Edmand's Blood Turnip Beet. A handsome, clean, turnip-shaped blood Beet. Skin and flesh are of deep blood red, sweet and tender in quality and unsurpassed for solidity and keeping purposes. The roots grow regular and are of right marketable size. Tops are small, allowing them to be grown close together. They mature early and give every satisfaction as a bunching sort. Pkt. 5c. Oz. 10c. 1/4 Lb. 20c. 1/2 Lb. 35̄c. Lb. 65e.

10. Early Large Egyptian. None better for an early general crop than the early Egyptian; handsome shape and loes not erack open. This erop commands a good market all the season. Pkt. 5c. Oz. 10c. 1/4 Jb. 20c. 1/2 Lb. 35c. Lb. 65.

13. Lentz Extra Early Beet. Color a deep, blood red, tender and sweet at all stages of its growth. Has small top and can be used six weeks from sowing. Very productive, splendid keeper and slipper. Pkt. 5c. Oz. 10c. 1/4 Lb. 20c. 1/2 Lb. 35c. Lb. $60 \mathrm{c}$.

358. Nutting's Early Gem Beet. Extremely early, light colored top, flesh beautifully zoned light red. Very popular as a Florida Shipping Beet. Pkt. 5c. Oz. 10c. $1 / 4$ Lb. 20c. 1/2 L.b. 35e. 1.h. 65c.

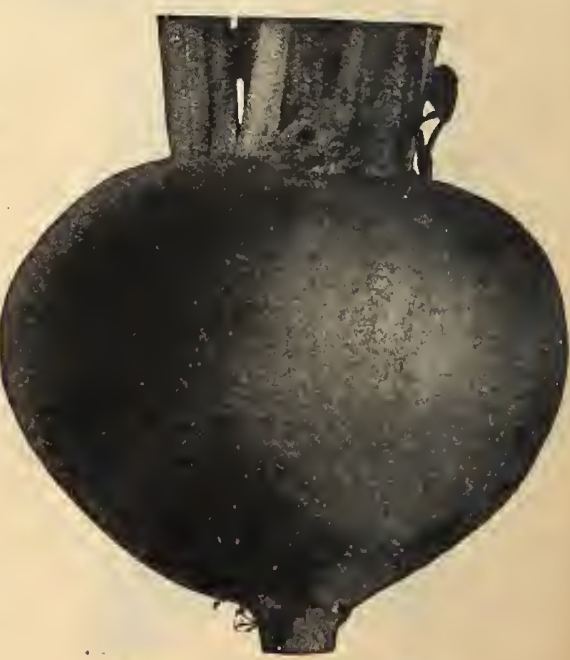




\section{Beets-Continued}

\section{We Pay Postage on Pkts., Ozs., 14 Lbs. and Lbs.}

571. Half Long Dark Blood. This is rapidly becoming a very popular sort and will probably produce more bushels from a given area than any other sort, as it does not occupy so much space in the rows as the turnip-shaped varicties. Pkt. 5e. Oz. 10c. $1 / 4$ Lb. 20c. Lb. 65 c.

15. Long Smooth Blood Beet. An old time favorite in the South. Has long, smooth, blood-red roots, going well down into the soil, enabling it to resist drought and heat. Flesh very tender and sweet. Pkt. 5c. Oz. 10c. 1/4 Lb. 20c. Lb. $65 \mathrm{c}$.

165. Lucullus. The New Swiss Chard or Spinach Beet, but can be served both as Asparagus and as Spinach. Delicious. Pkts. 5e and 10c. Oz. 10c. $1 / 4$ Lb. 25c. 1/2 Lb. 40c. Lb. $75 \mathrm{c}$.

341. Swiss Chard or Silver Beet. Grown exclusively for the foliage, which cooked makis most delicious greens. Pkt. 5e Oz. 10c. $1 / 4$ Lb. 25c. $1 / 2$ Lb. 40c. Lb. 75 c.

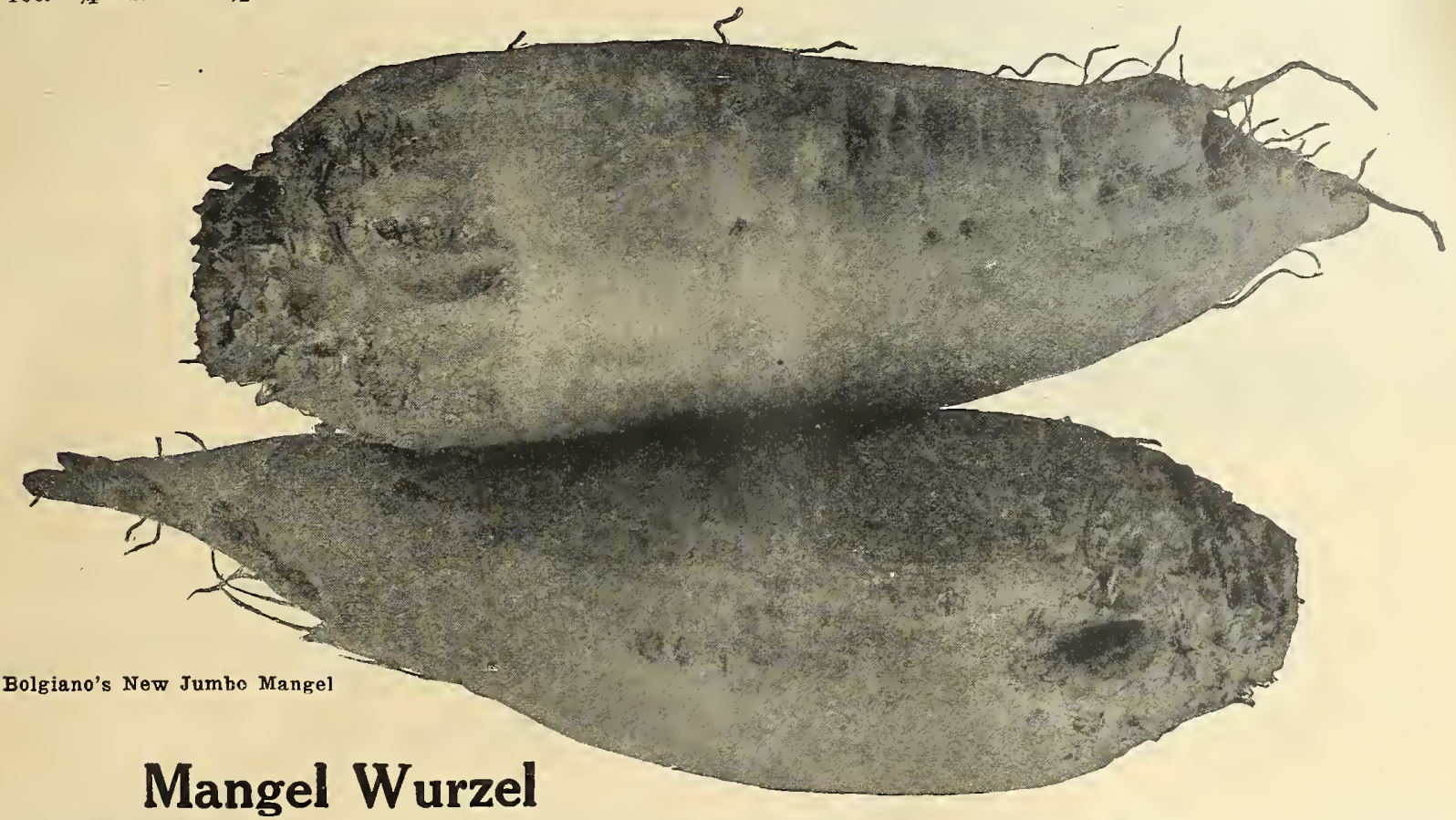

Culture. Sow 5 pounds to the acre in April or June, in rows 3 feet apart, and thin to 9 inches in the row. Cultivate frequently with horse tools and you will have an abundant crop of roots for Winter use.

1217. Bolgiano's Sludstrup. This wonderful Mangel has repeatedly been awarded first prize as containing the largest percentagc of dry matter. 'Root is smooth, 14 inches long, rich orange color, flesh pure white. About one-half of the root grows above the ground. Pkt. 5c. Oz. 10c. 1/4 Lb. 15c. 1/2 Lb. 25c. Lb. 35c. 5 Lbs. at 30c Lb.

1151. New Jumbo Mangel. It is a milk producer of the highest quality and at the same time keeps the cattle over Winter in prime condition. It will outyield any other Mangel two to one. It is easy to grow, producing immense roots in great quantities, thus yielding a most profitable crop. Plkts. $5 \mathrm{c}$ and $10 \mathrm{c} .0 \mathrm{z}$. 10c. 1/4 Lb. 15e. 1/2 Lb. 25e. Lb. 45e. 5 Lbs. at 40c. Lb.

1152. Gate Post Mangel. Immense size. Among the Yellow Mangel it stands supreme. The milk it produces when fed to cows is of the richest character. If you want the best Yellow Mangel you ever grew, buy Bolgiano's Gate Post Mangel. Pkts. 5c and 10c. Oz. 10c. 1/4 Lb. 15c. Lb. 35c. 5 Lbs. at $30 \mathrm{c} \mathrm{Lb}$.

1153. Giant Mammoth Long Red Mangel. The roots are very large, uniformly straight and well formed. Color deep red, roots solid. tops small. Produces an immense bulk and tonnage. Pkts. 5c and 10c. Oz. 10c. 1/4 Lb. 15c. Lb. 45e. 5 Lbs. at $40 \mathrm{c} \mathrm{Lb}$.

1154. Improved Golden Tankard Mangel. It combines apparently all the fine points possible to condense into a Mangel The color is a deep, rich yellow. The flesh is firm and solid. On account of its shape enormous crops are grown, and it is easily lifted from the ground. Pkts. 5e and 10e. Oz. $10 \mathrm{c}$. $1 / 4 \mathrm{Lb} .15 \mathrm{c}$. Lb. 35c. 5 Lbs. at $30 \mathrm{e} \mathrm{Lb}$
359. Golden Giant Intermediate. Root intermediate be tween the long and the globe-shaped. Flesh white, firm and sweet. much liked by cattle. Pkts. $5 \mathrm{c}$ and $10 \mathrm{c}$. Oz. 10e. 1/4 Lb. 15c. Lb. 35c. 5 I.bs, at $30 \mathrm{c} \mathrm{Lb}$

\section{Sugar Beets}

\section{For Stock Feeding}

Culture. Sow and cultivate same as Mangel, except that they slrould be thinned out 6 to 8 inches in the row.

115.. Giant Feeding Sugar Beet or Half Sugar Mangel. This magnificent Sugar Beet, whilc giving nearly as large a vield of easily grown and harvested roots as a crop of Mangels, supplies a food of very much higher nutritive value, the roots for feeding purposes being really more valuable, pound for pound, than those of the very best strains of Sugar Beet, and the yicld under equally favorable conditions being more than double. The roots grow partly out of the ground, and because of this and their shape, the crop can be harvested and stored at less expense than any other root crop. Every farmer should try it. Pkts. 5e and 10c. Oz. 10c. 1/4 Lb. 15e. Lb. 35e. 5 Lbs. at $30 \mathrm{c} \mathrm{Lb}$

1204. Klein-Wanzle Bener Elite. It may be distinguished by its brighter color and its lighter colored leaves, which are beautifully undulating, and scalloped around the edges; while not as a rule equal to the Vilmorin in saccharine richness, it is considerably more productive. Pkts. $5 \mathrm{e}$ and $10 \mathrm{c}$. Oz. 10c. $1 / 4$ Lb. 15c. Lb. $35 \mathrm{c}$. 5 Lbs, at $30 \mathrm{c} \mathrm{Lb.}$

360. Lane's Improved Sugar. An American variety and the best stock-feeding Beet known. It is not so sweet as the French Sugar Beets grown especially for sugar making, but the roots are longer and finer grained; very sweet. Pkts. 5c and 10c. Oz. 10c. 1/4 Lb. 15c. Lb. 35c. 5 Lbs. at 30c Lb. 


\section{Bolgiano's Frost-Proof Cabbage Plants}

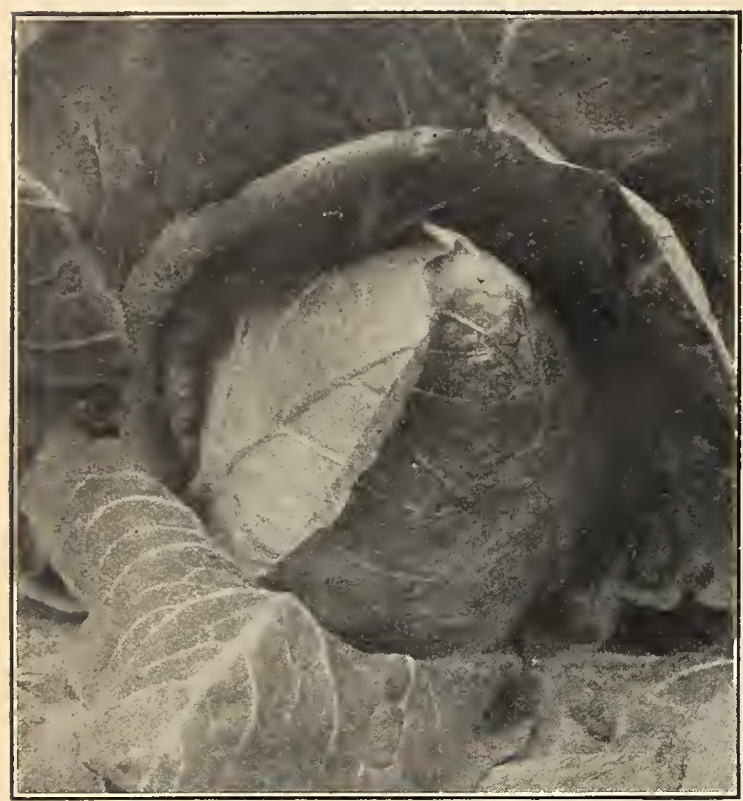

The Charleston or Large Wakefield Cabbage

\section{Will Mature Heads Two To Three Weeks Earlier Than Your Home Grown Plants and Double Your Profits}

There are a number of islands along the Sea Coast of South Carolina, where the soil and climatic conditions are just suited for growing tough, hardy cabbage plants during the Winter and early Spring. The plants make a slow but stearly growth, until at eight to ten weeks of age they are very tough and hardy, the buds are purple and the outer leaves a reddish brown. When in this condition they ean be shipped to territory farther north and be planted in the open ground a month to six weeks earlier than the home-grown lot hed or cold frame plants. The FROST PROOF CABBAGE PLANTS will stand a temperature of 20 degrees above zero witlout injury. The land freezing, or the plants being covered with ice, sleet or snow after they are planted will not injure them. The roots grow from the time they are planted, and just as soon as Spring weather starts, the establisherl root growtl assimilates the fertilizer in the soil, the plants grow very fast, maturing headed cabbage two to three weeks sooner than you can mature them from hot loed and cold frame plants.

TO GET THE ADVANTAGE OF THESE FROST-PROOF CABBAGE PLANTS THEY MUST BE PLANTED A MONTH OR SIX WEEKS EARLIER THAN YOU WOULD PLANT HOME-GROIVN PLANTS.

WE FILL ORDERS FROM DECEMBER IST to MAY 1st.

The plants when received will be somewhat wilted and have a hard stunted appearance, which will be disappointing to persons who have never used these plants before. Regardless of appearance, they will produce the crop results.

VARIETIES: EARLY JERSEY WAKEFIELD, CHARLESTON LARGE TYPE WAKEFIELD, SUCCESSION AND EARLY FLAT DU'TCH.

Prices by Parcel Yost, Postage Paid. In lots of $100,200,300$ or 400 plants at 50 e per 100 plants; 500 plants for $\$ 1.60 ; 1000$ or more at $\$ 5.00$ per 1000 plants.

Orders are filled by the 100 , not 250 or 350 . These prices are for even quantities of one variety to package; if you order 200 of one variety and 300 of another variety you would pay at the 100 rate.

PRICES BY EXPRESS, buyer paying express charges. In lots of 1000 to 3000 plants at $\$ 2.00$ per 1000 ; 5000 or more at $\$ 1.50$ per 1000 . Plants packed for express shipment, 1000 or 2000 plants of a variety to package, they weigh about 25 pounds per tlousand plants, packed for shipment.

Oreler Early to prevent delay. We ship direct from growing Station. Plants eannot be pulled when beds are wet. Send your order two or three weeks before you expect to set the plants so you will get them in time.

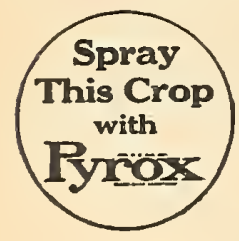

\section{Cabbage Seed}

This Crop

with

French

Chou Poma

liopFKоHL, KRAU't

\section{Italian}

Cavolo Cappecio
Spanish

Cot, REPELTO

We Pay Postage on Pkts., Ozs., 1/4 Lbs. and Lbs. of All Cabbage Seed

\section{Culture}

Early Cabbage requires a rich, warm, loam soil. well drained, and the soil for the ate Cabbage should be heavier and more retentive of moisture and not so rich as for early crops, as the heads are liable to burst.

To have Cabbage real early, sow seed in hotbed in February, or still better, Winter over the crops in a cold irame. For this purpose the seed is sown from the tenth to the twentieth of September. From four or five weeks from the time of sowing they will lie fit to transplant into the cold frames. It is very important that the plants be set down to the first leaves so that the stem is all under the ground, otherwise the stem oulis split by the action of the frost.

These early Cabbage plants are set out in March or April. in rows two feet apart is inches between the plants. The early crop matures in June. For sccond early 作 and Iugust. Late Cabbage for Fall and Winter use. sow seed in May to June. The plants are set in July, at a distance of three feet between the rows and two feet between the plants. This crop matures in October. Cabbage should not be planted two years in
succession in the same spot of the garden. One ounce of seed will produce 3000 plants.

\section{Extra Early Varieties}

30. Early Jersey Wakefield Cabbage. Bolgiano's Selected Stock. True Type. The most popular early Cabbage with market gardeners all over the country. It is grown in vast quantities for shipment to Nortlern cities. Unequaled for size, solidity, earliness, uniformity and trueness, is the universal verdict of Cabbage growers. Our Stock of Wakefield is the earliest in cultivation. Every Cabbage grower should use our Wakefield. Our seed is orlered by large Cabbage growers long in advance of the time of sowing seed in order to secure our fine stock, which lias never failed to produce satisfactory crops. Our seed is used in all the States where early Calubage is grown. Pkts. 5c and 10c. 1/2 Oz. 15c.

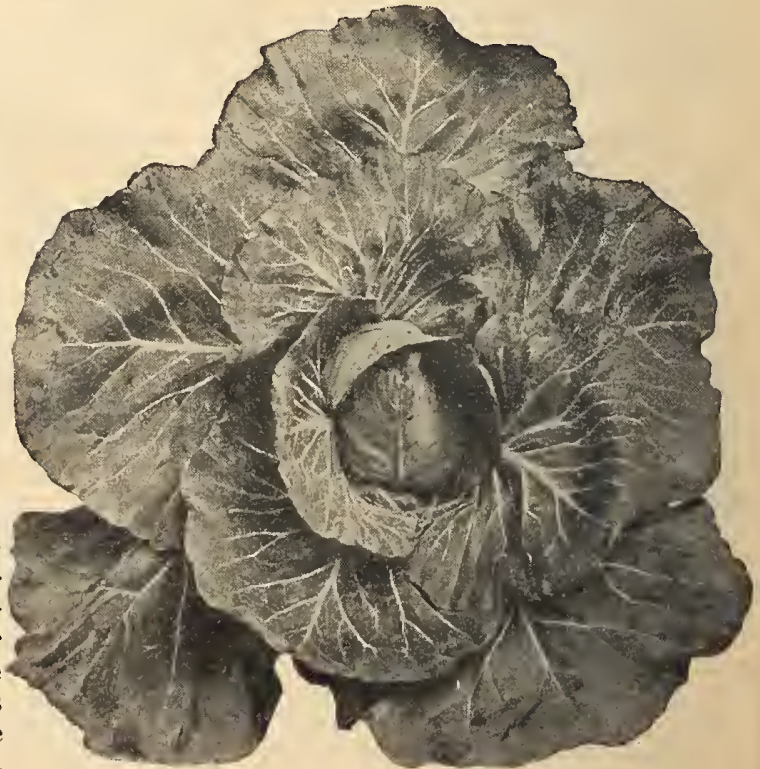




\section{Extra Early Cabbage-Cont'd}

25. "Big Winner" Wakefield. No other Cabbage of which we have knowledge has aroused such enthusiasm among Cabbage growers as has our "Big Winner" Wakefield. It has the same general cliaracteristics of other Wakefield Cabbages, the heads being conical with a rounded or blunt point. It is, however, far superior to other strains of Wakefield Cabbage, being nearly double the size and better quality, and at the same time is fully as early. It has few outer leaves, permitting close planting, so that more heads can be grown to the acre than with other sorts. Large Pkts. $5 \mathrm{c}$ and $10 \mathrm{c} .1 / 2 \mathrm{Oz} .15 \mathrm{c}$. Oz. 25̄c. 2 Ozs. 40c. 1/4 Lb. 65e. Lb. $\$ 2.25$.

26. New Leader. As early as the Wakefield, yields 12,000 heads, one-third more per acre than any other extra early Cabbage. The outer leaves are so few and so small that they can be planted very close. The heads are compact and solid from the time a head is formed and keeps so until thoroughly matured, thus enabling extremely early cutting of small, hard leads, or later when the Wakefield comes in, of large, thoroughly matured, solid, round, flat heads. Pkts. 5c and $10 \mathrm{c}$. $1 / 2$ Oz. 15c. Oz. 25̃. 2 Ozs. 40c. 1/4 Lb. 65c. 1/2 Lb. $\$ 1.20$. Lb. $\$ 2.25$.

27. Extra Early Express. This, the earliest of all Cabbage, has produced marketable heads in 80 days from the sowing of the seed. It can be planted close and yields large, early, paying crops. Pkts. 5c and 10c. $1 / 2$ Oz. 15c. Oz. 25c. 2 Ozs. 45c. $1 / 4$ Lb. 75 c. $1 / 2$ Lb. $\$ 1.35$. Lb. $\$ 2.50$.

28. Extra Early Jersey Wakefield. American Grown. An excellent, early sort. Heads formed like a Wakefield, but ten days earlier; habit vigorous, short stem and most profitable to grow. Pkts. 5c and 10c. Oz. 25c. 2 Oz. 45c. 1/4 Lb. 75 c. Lb. $\$ 2.50$.

373. Enkhuizen Glory. Is a valuable, early variety. It produces fine, marketable heads and is a splendid sort for the private garden and market gardener who grows for high-class trade. The heads are very solid with but few outer leaves and of such compact growth to permit close planting. The quality is excellent. Pkts. 5c and 10c. 1/2 Oz. 15c. Oz. 20c. 2 Ozs. 35c. $1 / 4$ Lb. 60c. 1/2 Lb. $\$ 1.10$. Lb. $\$ 2.00$.

29. Extra Early Pilot Cabbage. American Grown. Three wecks earlier than the Jerser Wakefield. Pkts. 5c and $10 \mathrm{c}$. Oz. 25c. $1 / 4$ Lb. 65c. Lb. $\$ 2.25$.

32. The Charleston, or Large Wakefield. The Best Large, Early Cabbage. This Cabhage lias ereated a sensation with the Cabbage growers all over the country on account of the decided advantage it has over all other sorts. It can be the FIRST, variety SENT TO MARKET, and on account of its handsome appearance will invariably bring the tip-top prices. If, how-

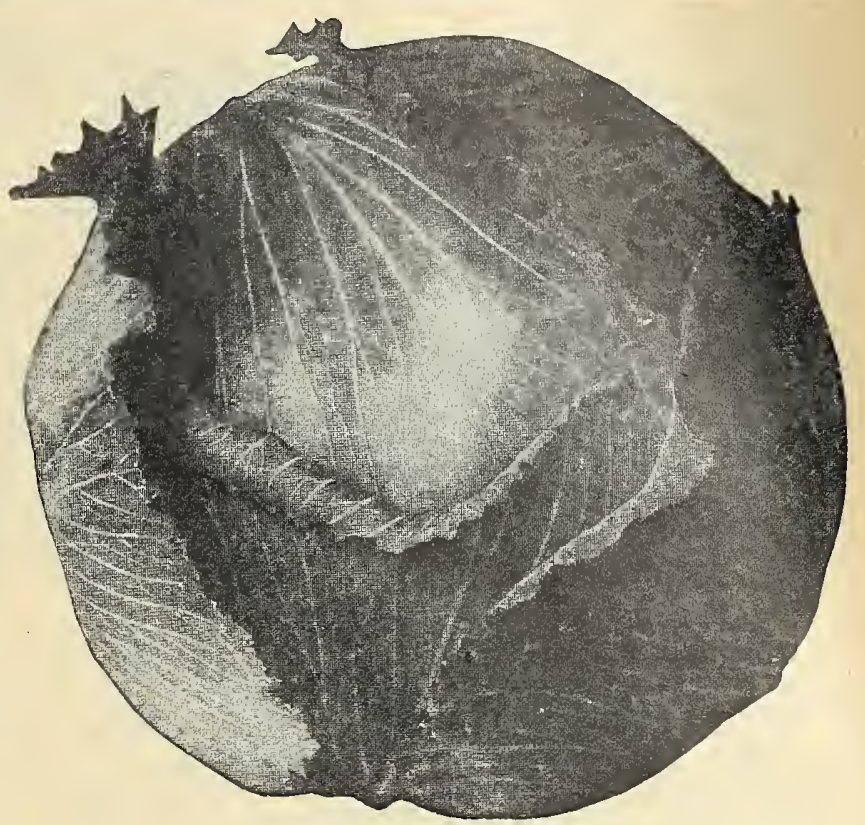

Stein's Early Flat Dutch

ever, the early market prices are low, it can be safely left standing in the field to mature, to an extra large, compact, solid, magnificent Cabbage, which las never failed to attract the admiration of the most skilled gardeners, and always brings better prices than any other sort harvested at the same time. Our stock is thoroughly reliable. Pkts. 5c and $10 \mathrm{c} . \mathrm{Oz} .20 \mathrm{c}$. $1 / 4$ Lb. 60c. Lb. $\$ 2.00$.

\section{Stein's Early Flat Dutch}

Unquestionably the best early cabbage in the world. Unexcelled for early spring planting, producing medium-sized heads that are unbeatable for home use or shipping purposes. No garden is complete without some of this splendid strain planted in it. Pkts. 5c and 10c. Oz. 25c. 1/4 Lb. 65c. Lb. $\$ 2.25$.

33. Eariy Large York. 'This is a very raluable, early variety and follows the Express and Jersey Wakefield in heading. The heads are round, heart-shaped and firm. Its dwalf growth will permit them being planted closely together. Plsts. $5 \mathrm{c}$ and $10 \mathrm{c}$. Oz. 20c. 1/4 Lb. 60e. 1/2 Lb. $\$ 1.10$. Lb. $\$ 2.00$.

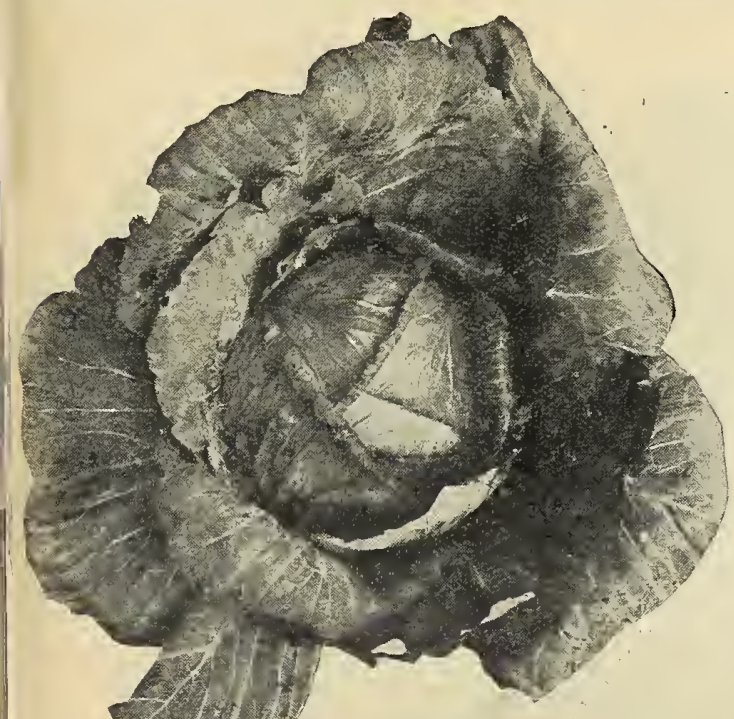

Henderson's Early Summer Cabbage

34. Early Winnigstadt-The Prussian Prize Stock. The popularity of Winnigstadt Cabbage in all sections of the world is proverbial but there is a great difference in the quality of the stocks. Some will produce heads of twice the size of others; the finest is grown in Northern Prussia. It is from this section that our famous stock was introduced a few years ago. It has become very popular with our msirket gardeners. Pkts. 5c and 10c. $0 \mathrm{z} .20 \mathrm{c}$. 1/4 Lb. 60c. 1/2 Lb. $\$ 1.10$. Lb. $\$ 2.00$.

\section{Second Early Varieties}

154. Bolgiano's Early "Square Deal" Cabbage. The Best on Earth. (Specialty, see page 7.) The heads are solid and compact with very few outer leaves. For a fine, solid, tender, uniform, early, flat Cabbage, Bolgiano's "New Square Deal" Cabbage challenges the world The demand for a Cabbage of this character led us, by the most rigid and careful selection during the past five years, to mature this Cabbage, which we are confident will give all our friends and customers a "Square Deal "every time. Pkts. 5c and 10c. 1/2 Oz. 15c. Oz. 25c. 2 Ozs: 40c. $1 / 4$ Lb. 65c. 1/2 Lb. $\$ 1.20$. Lb. $\$ 2.25$.

35. Bolgiano's "New Early" Cabbage. It forms solid, compact, round, flat heads, the leaves growing close to the head, thus allowing more Cabbage to be grown to the acre than any other sort. Its earliness (a week before other early, flat varieties) is one of its best marketable features. Pkts. 5c and $10 \mathrm{c}$. Oz, 25c. 1/4 Lb. 65c. Lb. $\$ 2.25$.

38. Henderson's Early Summer Cabbage. In size, form, solidity and earliness this is truly a model Cabbage. It heads just after our Jersey Wakefield. Pkts. כૅ and 10c. Oz. 20c. 1/4 Lls. 60c. Lb. $\$ 2.00$. 


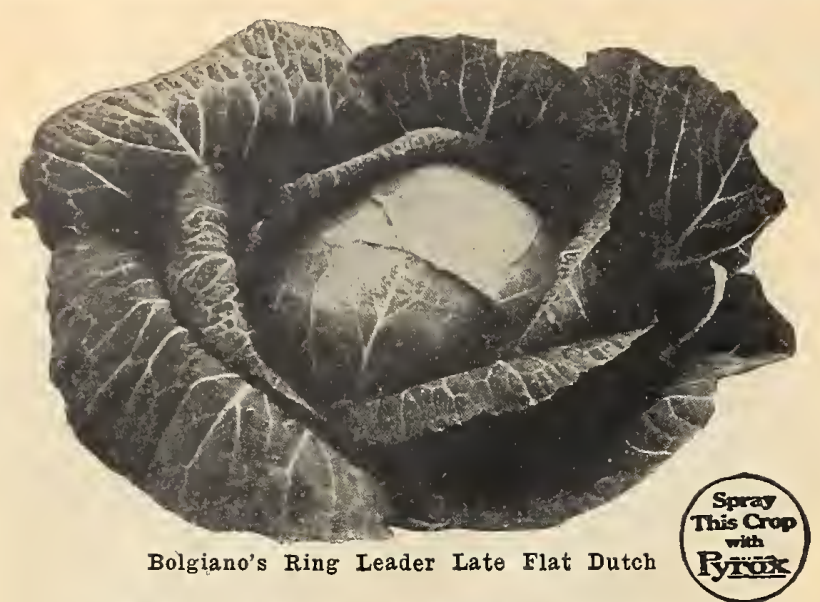

Second Early Varieties-Cont'd

36. Florida Header Cabbage. In color, shape and size the heads are most uniform. Pkts. 5e and 10c. Oz, 20c. $1 / 4$ Lb. 60c. Lb. $\$ 2.00$.

37. All Head Early Cabbage. For uniformity, reliability of heading, size, earliness and quality it is very superior. Its heads grow compact and free from spreading leaves. Pkts. 5c and $10 \mathrm{c} .0 z .20 .1 / 4$ Lb. 60c. Lb. $\$ 2.00$.

148. Brunswick, Fottler's Cabbage. In this vicinity the Brunswick is considered second to none by the market gardeners. Plants are very short stemmed. Pkts. 5c and 10c. Oz. 20c. $1 / 4$ Lb. 60c. Lb. $\$ 2.00$.

39. Iong Island, Early, Flat Dutch Cabbage. The heads are large and solid and mature very early-just after the select Jersey Wakefield. In every respect it is a Cabbage worthy of cultivation. Pkts. 5c and 10c. Oz. 20c. 1/4 Lb. 60c. Lb. $\$ 2.00$.

40. Early, Short Stem, Drumhead Cabbage Seed. It is ready for marketing 2 or 3 weeks earlier than the late Drumliead, forms large, solid, rounded heads. Pkts. 5c and 10c. $\mathrm{Oz}$. 20c. $1 /$ Lb. 60c. 1/2 Lb. $\$ 1.10$. Lb. $\$ 2.00$.

41. Henderson's Early Succession Cabbage. A wonderful Cabbage for solidity, productiveness and fine, large heads. Pkts. 5c and 10. Oz. 20c. 1/4 Lb. 60c. Lb. $\$ 2.00$.

42. Sure Head Cabbage. (Pedigree Stock.) True American grown. Produces large, round, flattened heads that are all head. Pkts. 5c and 10c. Oz. 20c. 1/4 Lb. 60c. Lb. $\$ 2.00$.

542. Solid South. This is one of the purest and truest Cabbages ever bred. Produces very large, shapely, solid heads. An excellent shipper. Pkts. $5 \mathrm{c}$ and $10 \mathrm{c} .1 / 2 \mathrm{Oz} .15 \mathrm{c} . \mathrm{Oz} .20 \mathrm{c}$ $1 / 4$ Lb. 60c. $1 / 2$ Lb. $\$ 1.00$. Lb. $\$ 2.00$.

53. BOLGIANO'S PERFECTION DRUMHEAD SAVOX CABBAGE. Surpasses all varieties of Savoy Cabbage for uniformity of heads, beauty of curl and superior keeping qualities. Pkts. $5 \mathrm{c}$ and $10 \mathrm{c}$. Oz. 25c. 1/4 Lb. 65. Lb. $\$ 2.25$.

49. Mammoth Red Dutch. Is the largest Red Cabbagc, and heads very solid and is deep red in color to the very center. Pkts. 5c and 10c. 1/2 Oz. 15c. Oz. 25c. 2 Ozs. 40c. 1/4 Lb. 65 c. $1 / 2$ Lb. $\$ 1.20$. Lb. $\$ 2.25$.

374. All Seasons. An "all-season" variety, equally good for Fall and Winter as for Summer use. The heads are large, solid, round, flattened on top and of the best quality. Pkts. 5e and 10c. Oz. 20c. 1/4 Lb. $60 \mathrm{c}$. Lb. $\$ 2.00$.

266. "Copenhagen Market," New Early Danish Cabbage. As early as Charleston Wakefield. This new Cabbage is very heavy and solid, makes a fine, large, globe-shaped head with well-developed outside leaves. Pkts. 5e and 10c. 1/2 Oz. 15c. Oz. 25c. 2 Ozs. 40 c. 1/4 Lb. 65 c. Lb. $\$ 2.25$.

\section{Late or Winter Cabbage}

43. Bolgiano's Extra Large, Late, Flat Dutch; Market Gardener's Choicest Stock. Can be planted later than the oldtime varieties and matures more quickly into a liandsome, EXTRA LARGE, solid; uniform Cabbage of perfect kceping qualities. Extra Flat Dutch. Pkts. 5e and 10c. Oz. 20c. 1/4 Lb. 60c. 1/2 Jb. $\$ 1.10$. Lb. $\$ 2.10$.

50. Louisville Drumhead. (Best of all Drumhead Cabbage.) There is no Cahlage of the Drumhead type whicl can he compared witl this beautiful representative in shape, color, firmness and excellent table qualities. Drought has little effect upon it on account of the low habit of growth. Pkts. 5c and 10 c. Oz. 20 c. $1 / 4$ Lh. $60 \mathrm{c} .1 / 2$ Lb. $\$ 1.10$. Lb. $\$ 2.00$
Late or Winter Varieties-Cont'd

96. Bolgiano's "Ringleader" Large, Late, Flat Dutch Cabbage. Will always produce heads of enormous size and of the very finest quality. Pkts. 5c and 10c. 1/2 Oz. 15c. Oz. 20c. 2 Ozs. 35c. $1 / 4$ Lb. 60 c. $1 / 2$ Lb. $\$ 1.10$. Lb. $\$ 2.00$.

372. Pe-Tsai Chinese or Celery Cabbage. Improved Chin. ese Cabbage. This vegetable is new to the public although old to the Horticulturists. Plant in July. Sow in drills 16 to 20 inches apart and the scedlings thinned two or three times. Pkts. 5c and 10c. Oz. 25c. 2 Ozs. 45c. 1/4 Lb. 75c. 1/2 Lb. $\$ 1.35$. Lb. $\$ 2.50$.

45. The Lupton Cabbage. Is a splendid late sort, heading after the second early sorts, and sooner than the Late Flat Dutch. It is particularly uniform in shape and size. Pkts. $5 \mathrm{c}$ and 10c. Oz. 20c. $1 / 4$ Lb. 60c. Lb. $\$ 2.00$.

46. Premium Flat Dutch. It has long been the favorite sort for cole-slaw and sanerkraut. It matures just before severe frost and keeps perfectly over Winter. Pkts. $5 \mathrm{c}$ and $10 \mathrm{c}$ Oz. 20c. 1/4 Lb. 60c. Lb. $\$ 2.00$.

47. Iarge, Late, Drumhead Cabbage. This splendid Cabbage produces enormous lieads. Its good keeping quality makcs it a first-class sort to carry over Winter. Pkts. 5c and $10 \mathrm{c}$ Oz. 20c. $1 / 4$ Lb. 60c. $1 / 2$ Lb. $\$ 1.10$. Lb. $\$ 2.00$.

44. Boss Flat Dutch Cabbage. The leads are large, hard, thick and flat, the leaves lapping across the center. Pkts. 5c and 10c. Oz. 20c. $1 / 4$ Lb. 60c. 1/2 Lb. $\$ 1.10$. Lb. $\$ 2.00$.

52. Henderson's Autumn King Cabbage. It is often from 3 to $3 \frac{1}{2}$ feet in circumference, and weighs from 25 to 30 pounds each. Interior crisp. Pkts. 5c and 10c. Oz. 20c. 1/4 Lb. 60c. $1 / 2$ Lb. $\$ 1.10$. Lb. $\$ 2.00$.

48. Danish Ball Head Cabbage. This is the most excel lent Cabbage, is rery solid and outweighs any other Caboage of equal size. The head is round witl flattened top. Pkts. $5 \mathrm{c}$ and $10 \mathrm{c}$. Oz. $20 \mathrm{c}$. $1 / 4$ Lb. $60 \mathrm{c}$. Lb. $\$ 2.00$.

\section{Brussels Sprouts}

Culture, Sow in May, in the same manner as Cauliflower, and trans plant in July, 1 foot apart in row very best Winter vegetable that can be grown. It is as hardy as the common Curled Greens. When cooked through such sprouts melt in the mouth like the tenderest Cauliflower, and are equally as good.

22. Bolgiano's Matchless, Long Island, Improved Brassels Sprouts. Pkts. 5c and 10c. Oz. 25c. 2 Ozs. 40c. 1/4 Lb. 65c. $1 / 2$ Lb. $\$ 1.20$. Lb. $\$ 2.25$.

355. Paris, Half Dwarf, Brussels Sprouts. Pkts. 5c and 10c. Oz. 25c. $1 / 4$ Lb. 65c. $1 / 2$ Lb. $\$ 1.20$. Lb. $\$ 2.25$.

\section{Collards}

23. Georgia Southern, or Creole. Forms a large, loose, open head or a mass of leaves on a tall stem. Freezing does not injure, but rather improves their quality, Sow thick in drils, in rich ground, transplanting when 4 inches high, or sow in drills where the plants are to remain and thin to or 3 feet apart in the row when of proper size. In the South sow from January to May, and August to October. Pkts. 5c. Oz. 10c. 1/4 Lb. $20 \mathrm{c}$. January to May, and

590. Torth Carolina Short Stem. A decided improvement, and has proved very popular wherever grown. Has short stem, large spreading leaves, very hardy, withstanding drought in summer and cold in winter. Its flavor and cooking qualities are the very best. Pkt. $5 \mathrm{c} .0 \mathrm{Oz}, 10 \mathrm{c}$ $1 / 4$ Lb. 20c. Lb. 50 c.

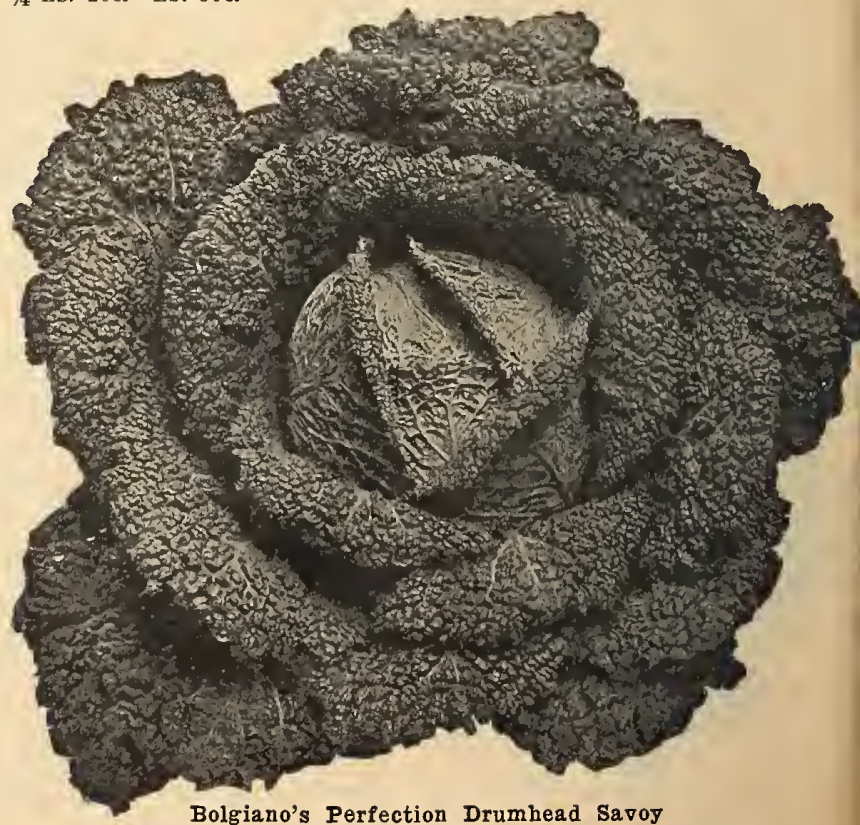




\section{Cauliflower}

We Pay Postage on Pkts., Ozs., 1/4 Lbs. and Lbs.

\author{
French
CHOU-FLEU \\ Italian
}

Cavolo Flore

\author{
German \\ BLUMEN KOH \\ Spanish \\ COLIFLOR
}

\section{Culture}

The soil and culture requirements of Cauliflower and Cabbage are similar. Seed may be sown and handled in the same way as described in the Cahhage culture. It is hest to plan your planting to have no Cauliffower maturing in the hot summer months, as the cool weather of late Spring and early Fall is best adapted for the growing of perfect heads.

\section{New Century Cauliflower}

\section{The Best in the World}

1. It heads when others fail. 2. Large, perfect heads, measure from 12 to 14 inches in diameter. 3 . The beautiful white heads are compact, deep and solid. 4. Heads will outweigh those of any other strain. 5 . It is the earliest of all Cauliflower. 6. One-third more can he planted on the same space than can be done with other varieties can he planted on the same space thact habit. 7 . It is the Most Carefully hecause of its close growing, compact habit. 7 . It is the Most Carefilly ing the care and attention which is ahsolutely necessary for the growing of this Special Stock. We cannot sell it for less than: Pkts. 10c, $15 \mathrm{c}$ and 25 c. $1 / 2$ Oz. $\$ 1.25 .1 \mathrm{Oz}$. $\$ 2.25$. 1/4 Lb. $\$ 7.50 .1 / 2$ Lb. $\$ 14.00$ Per Lb. $\$ 25.00$.

59. Erfurt Extra Early Dwarf, Extra Selected First Quality. Pkts. $10 \mathrm{c}$ and $25 \mathrm{c}$. $1 / 2 \mathrm{Oz} .75 \mathrm{c}$. Oz. $\$ 1.502$ Ozs. $\$ 2.90$. 1/4 Lh. $\$ 5.50 .1 / 2$ Lb. $\$ 10.50$. Lb. $\$ 20.00$.

105. Danish Giant or New Dry Weather Cauliflower. Will produce splendid crops in very dry locations. Pkts. $10 \mathrm{c}, 15 \mathrm{c}$ an

\section{One ounce will sow 100 feet of drill, 3 or 4 pounds for \\ Carrots}

Culture. Carrots do best in warm, deep, rather light and fairly fertile soil that is well supplied with humus, or on strong loam, having heen in clover and broken the year before. For earliest crop, sow seed of the early, short-rooted sorts in April or May, in drills a foot apart and thin to 2 inches. For main crop, sow in May or June or for succession even in July, using the long rooted varieties. The rows for these may he 16 to 20 inches apart, and the plants thinned to 2,3 or even 4 inches.

60. Scarlet Beauty Carrot. 1. A handsome and prolific Carrot. 2. Rich deep scarlet in color. 3. In length, between long and half-orange. 4. Very straight roots. 5. Very little foliage for size of roots. 6. Delicious flavor. 7. Heavy yielder. 8. Uniform in size. 9. Often $21 \frac{1}{2}$ to 3 inches
at the top and 10 to 12 inches long. Pkts. $5 \mathrm{c}$ and $10 \mathrm{c}$. Oz. 15c. 2 Ozs. $25 \mathrm{c}$. $1 / 4 \mathrm{Lb}$. $35 \mathrm{c}$. $1 / 2$ Lb. $60 \mathrm{c}$. Lb. $\$ 1.10$.

64. Pride of the Market Carrot. Has led all Half-Long Carrots for 10 years. Pkts. 5c and 10c. Oz. 15c. 2 Ozs. 25c. 1/4 Lh. 40c. 1/2 Lh. 70c. Lb. $\$ 1.25$.

62. Improved Long Orange Carrot. Uniformly a deep orange color, rrowing a long, smooth, symmetrical Carrot Remarkahle for the absence of the detractive side roots and divisions at the point. Tremendous yielder and of a rich sweet flavor: vill retain its delicious flavor all Winter. Pkts. and of a rich, sweet flavor : will retain its delicious flavor all

63. Early Ox-Heart Carrot. So very early, so shapely, so tender, and of such a fine, bright, scarlet color. Not only is extreme earliness a charactcristic of our Ox-Heart Carrot, but its exceptionally fine quality, being almost entirely without core. Pkt. $5 \mathrm{c}$. Oz. 10c. 2 Ozs. $15 \mathrm{c}$. 1/1 Lh. 30c. $1 / 2 \mathrm{Lb}$. 50c. Lb. $90 \mathrm{c}$.

14. Early Sunbeam. Bolgiano's New, Extremely Early Carrot. This bcautiful, delicious, exceptionally early forcing Carrot conies at the time of the year when new vegetables are most appreciated and enjoycd. Be sure to plant some. Pkts. 5c and 10c. Oz. 15c. 2 Ozs. 25c. 1/4 Lb. $35 \mathrm{c} .1 / 2$ Lh. 60c. Lh. \$1 10.

61. Half-Long Orange Carrot. The skin is clear, bright in color and the flesh is close in texture, of very fine grain, with very small core. For bunching the handsome appearance is a marked advantage. Pkts. 50 and 10c. Oz. 15c. 2 Ozs. $25 \mathrm{c} .1 / 4 \mathrm{Lb}$. $30 \mathrm{c}$. $1 / 2 \mathrm{Lb}$. $55 \mathrm{c} . \quad \mathrm{Lb}, \$ 1.00$.

91. New King Carrot. The greatest Carrot introduced in the last 10 years. Pkts. $5 \mathrm{c}$ and $10 \mathrm{c}$. Oz. 15c. 2 Ozs. 25c. 1/1 Lb. 35. $1 / 2$ Lh. $60 \mathrm{c}$ Lh. \$1.10.

65. St. Valery, Iong Red. Color. orange-red. Roots large and handsome, intermediate in shape hetween Danvers and Long Orange. Pkt 5c. Oz. $10 \mathrm{c}$. $1 / 4$ Lh. $25 \mathrm{c}$. 1/3 Lb. $45 \mathrm{c}$. Lh. $85 \mathrm{c}$.

66. Early Scarlet Horn. A very popular sort; quick growing deep orange in color: hlunt rooted: six to eight inches in lengtl. Pkts. $5 \mathrm{c}$ and 10c. Oz. 15c. i L Lb. 30c. 1/2 Lh. 55c. Lb. $\$ 1.00$

67. Danvers Half Long. One of the heaviest croppers, roots dark orange color; eight to ten inches in dength, thick and ending in a somewhat abrupt point. Pkts. 5c and 10c. Oz, $25 \mathrm{c}$. 1/4 Lh. 30c. $1 / 2 \mathrm{Lb}$. 55c. Lb. $\$ 1.00$.

68. Chantenay or Model. Early. scarlet color, stump rooted, broad, thick shoulder, heary cropper. Pkts $5 \mathrm{c}$ and 10c. Oz. 15c. 1/4 Lh. 35c. $1 / 2$ Lh. 60c. Lb. $\$ 1.10$.

69. Nantes, Half Long, Stump Rooted. Roots 8 or 10 inches in length, thick shoulder, dcep orange aud good cropper. Pkt. 5c. Oz. 10c. $1 / 4$ Lb. 30c. $1 / 2$ Lb. 50c. Lb. $90 \mathrm{c}$

570 . James' Intermediate Scarlet. Roots similar in shape and size to Danver Pointed: color, scarlet: nearly coreless. Pkt. 5c. Oz. 10c. $1 / 4$ Lh. $25 \mathrm{c}$. $1 / 2$ Lh. $40 \mathrm{c}$. Lh. $75 \mathrm{c}$.

361. Large, White Belgian Carrot. Produces large roots four inches in diameter at the top and 10 inches in length It has a white skin
and tlesh. These Carrots are grown for teeding stock during Winter: they keep stock in fine condition. Pkt. 5c. Oz. 10c. 1/4 Lb. 15c. 1/2 Lh. 25c Lb. $45 \mathrm{c}$.

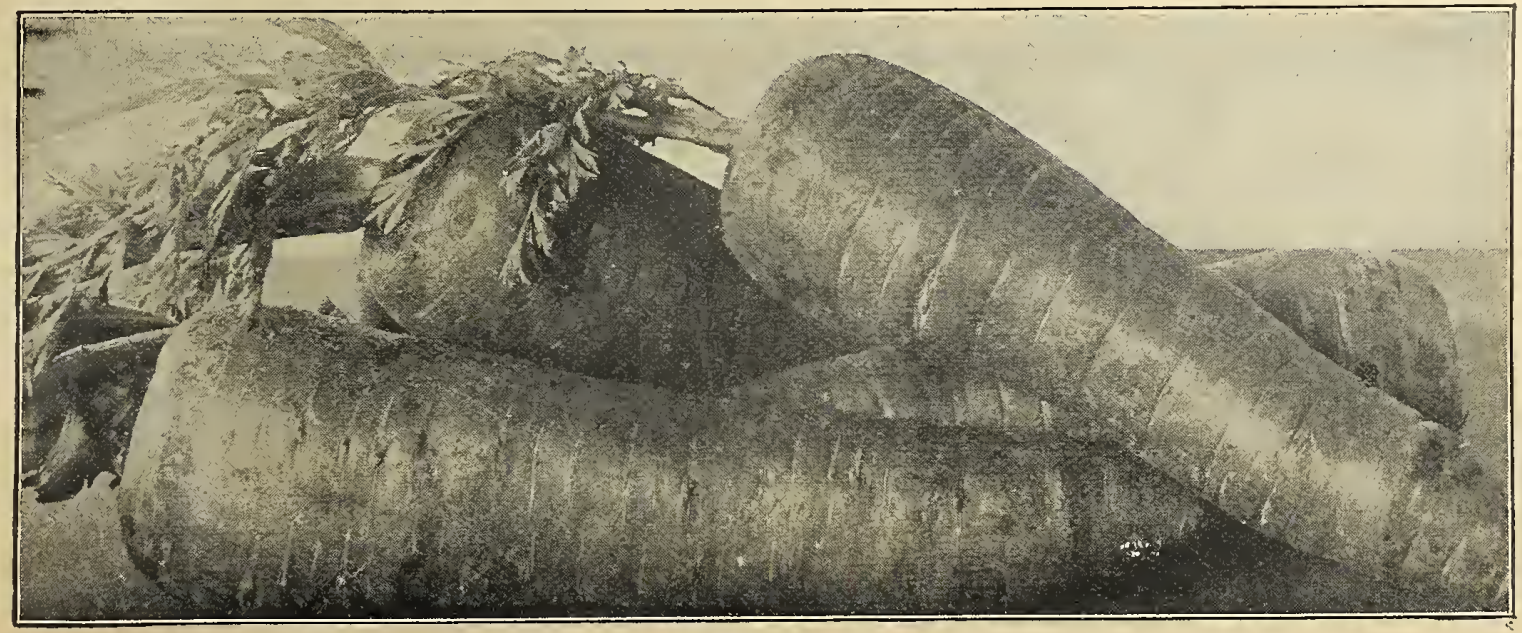




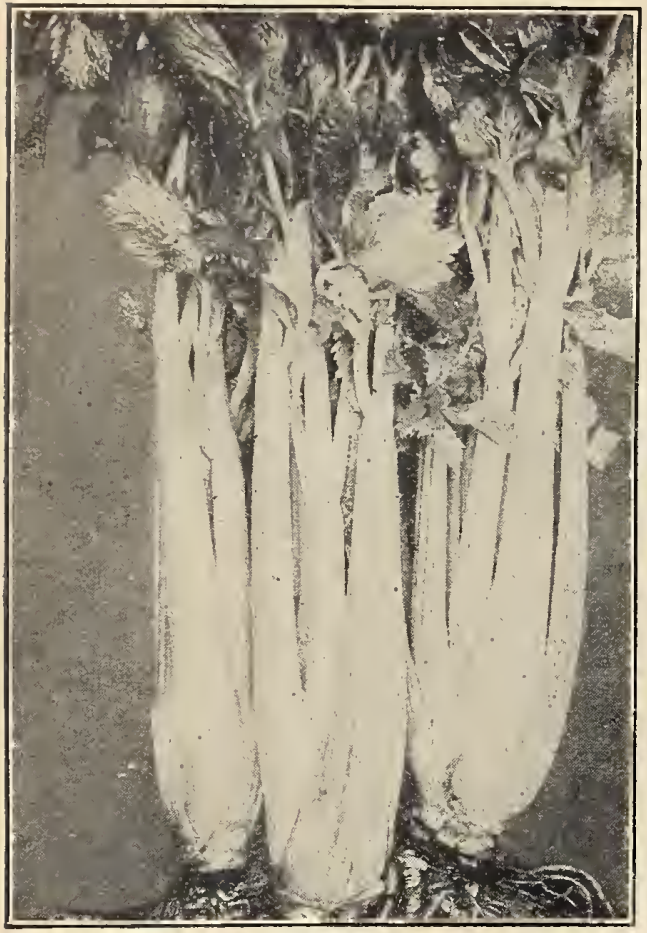

Bolgiano's Golden Self Blanching

\section{CELERY}

We Pay Postage on Pkts., Ozs., 1/4 Lbs. and Lbs.

Culture. One ounce will produce about twenty-five hundred plants and sow about two hundred feet of row. Sow the last of March or early in April, in an open border, in rich, mellow ground in shallow drills, watering freely in dry weather. By rolling or pressing in the seed, the result will be more satisfactory than when only cosered. Cut the tops off once or twice before planting ont, to make them stocky. When the plants are 5 or 6 inches high, transplant the dwart varieties 3 feet and the taller sort 4 feet between the rows; plant 6 inches apart in the row cultivite well and when large enough, blanch by earthing up. The first operation is that of "handling," generally done by the begiming of September. After the soil has been him up with the hoe, it is drawn around each plant by hand to keep the leaves firm in upright position and prevent spreading. Whon plants have become "set" in an upright position and the Celery is winted for early use, they shonld be "banked." This is done by throwing the soil up as close to the plants as possible with a plow and finishing it with a spade, tecting it is by covering the tops of the banks with waterproof felt paper.

\section{Bolgiano's French Golden Self-Blanching Celery}

Won the Blue Ribbon at the South Florida Fair, Held at Tampa

Bolgiano's French Grown Golden Self-Blanching Celery is of the most Superb Quaity. Its erispness and tenderness and its delight fully rich, mutty, appetizing flavor makes it the leading variety in any marliet. The stalks are large, solid and a beautiful, rich. golden yellow, entirely free from stringiness. It is an excellent keeper, stands shipment better than any other sort and brings the highest market prices. It is a vigorous dwarf grower, eompact in growth and self blanching to a very remarkable degree; even the ribs become a handsome, fresh, clean, yellow color, with a heart that is large and solid and of a beautiful, rich, golden yellow color. It is quite early and easy to cultivate. In the home garden it produees golden yellow stalks very earl, which are crisp, tender and nutty in flavor. It will keep in gool condition until Christmas or New Years. Our stock of this most wonderful Celery eannot be surpassed. It is grown especially for us by the originator in France. While it would pay you handsomely to plant your entire acreage in this stock of Celery, you cannot afford not $t o$ give it a trial. Stock is limited, and we ask you to let us have your orler at once in order for you to be sure of securing this most valuable Oz. 35e. 1/4 Lb. $\$ 1.10$. 1/2 Lb. $\$ 2.00$. Lb. $\$ 3.75$.

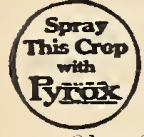

stock. Ple $5 c$ and $10 \mathrm{c} .1 / 2 \mathrm{z}, 20 \mathrm{c}$

\section{Bolgiano's "New Victory" Celery}

81. Our French Grown "New Victory" Celery is the Best Winier Celery on lituth. It has a great amount of heart, is lieavier, stouter and thieker than many of its rivals. It is the most economical Celery ret introluced, every particle being solid, erisp and of a delieions flavor. Its beautiful, large, golden heart and compaet growth make an ornament hard to surpass. It is a remarkable keeper, maintaining its firmness as late as Mar. Critieal market gardeners pronounce it to be the finest quality, liest keeper and most salable Celery they have ever raised. It is rearly for market by December. Pkts. 5c and 10c. Oz. 20c. 2 Ozs. 35e. 1/4 Ll. 60c. 1/2 Lb. \$1.10. Lb. \$2.10.

45.5. BOLGIANO'S "EASY BLANCHING" CELERY. Excels all other varieties in earliness, in quick blanching. in flavor and in tenderness. Every stalk solid, does not get pethy. Pkts. 5c and $10 \mathrm{c}$. 1/2 Oz. $20 \mathrm{c}$ Oz. 35c. 1/4 Lb. $\$ 1.15$. 1/2 Lb: $\$ 2.15$. Lb. $\$ 4.00$.

73. Giant Pascal Celery. This is a large, solid, excellent sort. It blanches very quickly to a beautiful yellowish-white color, is rery solid and crisp, and a fine nutty flavor. Stalks grow broad and thick. Pkis. $5 \mathrm{c}$ and 10c. Oz. 20c. 2 Ozs. 35e. 1/4 Lb. 60c. 1/2 Lb. \$1.10. Jb. \$2.10.

72. Perfected White Plume Celery. Is the most extensively used on account of its extreme earliness. Its stalks and portions of its inner leaves and heart are white naturally, by simply tying the plant together, or by drawing the soil firmly against the plant. Pkts. 5e and $\mathrm{J} 0 \mathrm{e}$. Oz. 15c. 2 Ozs. 25c. 1/4 Lb. 45e. 1/2 Lb. 75c. Lb. \$1.35.

75. New Winter Queen Celery. (Pedigree Stock.) A gool keeper and beautiful in appearance. Ribs perfectly solid, crisp and of a relicious, nutty flavor. Plet. 5c and 10c. Oz. 20c. 1/4 Lh. 60c. 1/2 Lb. $\$ 1.10$. Lb. $\$ 2.10$

74. Dwarf Golden Heart Celery. Is erisp, solid, liandsome and most excellent flavor, with a heautiful Golden Heart. Pkts, 5c and loc. Oz. 20c. 1/4 Lb. 50c. Lb. \$1.60.

78. Giant Golden Heart Celery. A gardener found in his Dwarf Golden ITeart a few plants of larger growth. A careful selection made for many years resnlted in the Golden Giant Ileart, which excels for larger size, solidity and keeping quality. Plit. 10c. O\%. 20c. 20\%. 30c. $1 / 4$ Lb. $50 \mathrm{c}$. 1/2 Lb. 90c. Jh. $\$ 1.60$.

Celery seed for Flavoring (Soup Celery). I'kt. 5c. O\%. 10c. 1/4 Lb.

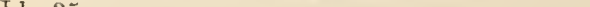

\section{Celeriac, or Turnip-Rooted Celery}

Giant French Celeriac. There is not a single item of interest in the grow: There is whout most thoroughly investignating and there is something of vilue to our customers. To prove our watchful(hench Celeriac. Many thought the Celeriac ing better and are rewardol for our pains by being able to offer this

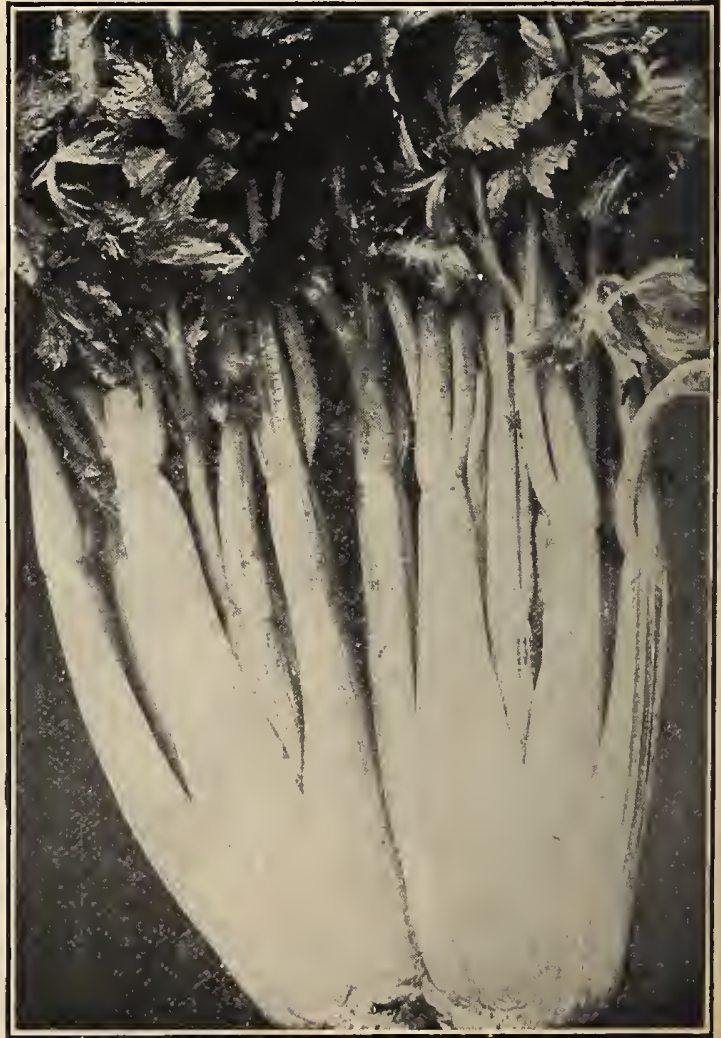




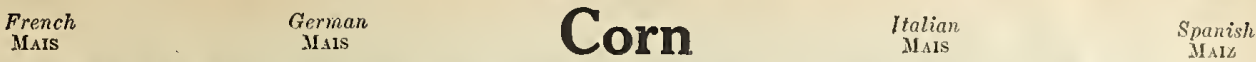

We Pay Postage on 5c and 10c Pkgs. of Corn Only, on Larger Quantities, Postage Extra and Must Be Included With Remittance-Parcel Post Charges-See Page 2

Culture. Seed of the sweetest varieties is liable to rot if planted in wet or cold ground. Yet if we have an earl spring, it may pay

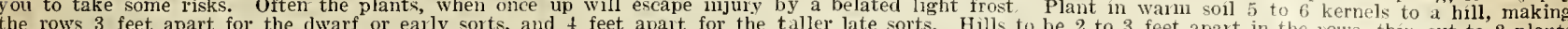

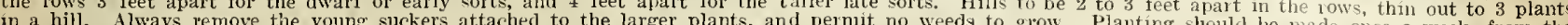

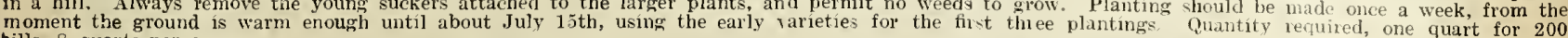
hills, 8 quarts per acre.

\section{These varieties are not Sugar Corns. They are hardier and can be planted earlier. Make excel- lent roasting ears.}

1222. Truckers' Favorite. Not a Sugar Corn, inut used largely in Baltimore and the South as a table Corn. Lb. ISc. 2 Lbs. 36e. 10 Lbs. $\$ 1.50 .25$ Lbs. $\$ 3.50 .100$ Lbs. $\$ 12.00$.

1049. 65-Day White Cob Corn. This Extremely Early Corn looks like Snow IThite Evergreen Corn, but is ready fer the market in 60 to 65 days from planting. Lb. 18c. 2 Lbs. 36e. 10 Lbs. $\$ 1.50$. 25 Lbs. $\$ 3.50 .100$ Lbs, $\$ 12.00$.

1052. Adams Extra Early. A splendid early raricty, largely grown for early market. Lb. 18c. 2 Lbs. 36e. $10 \mathrm{Lbs}$. $\$ 1.50$. 25 Lbs. $\$ 3.50$. $100 \mathrm{Lbs} . \$ 12.00$.

1053. Second Early Adams'. Ears are larger and later than Adams' Extra Early. Lb. $18 \mathrm{c} .2$ Lbs. 36e. $10 \mathrm{Lbs}, \$ 1.50$. 25 Lbs. $\$ 3.50 .100$ Lbs. $\$ 12.00$.

\section{Sweet or Sugar \\ Extra Early}

1290. Bolgiano's Extra Earily Harvester Sugar Corn. New 1920 Creation. (Specialty, see page 8.) The best extra early white Sugar Corn that has ever been placed on the market. Earlier tlian the Golden Bantan, much sweeter, larger ears and very prolific. Jb. $24 \mathrm{c} .2 \mathrm{Lbs} .48 \mathrm{c} .10 \mathrm{Lbs}$. $\$ 2.10 .25 \mathrm{Lbs} . \$ 5.00 .100 \mathrm{Lbs} . \$ 18.00$.

1136. California Golden Country Gentleman Corn. This is a wonderful combination of the " Crean and Honey" Sugai Corn and the well-known "Country Gentleman" Sugar Corn. Could you possibly think of anything more delicious than the good points of these two Coms combined into one? Lb, 22a 2 Lbs. 44c. 10 Lbs. $\$ 1.90$. 25 Lbs, $\$ 4.50 .100$ Lbs. $\$ 16.00$

1182. Bolgiano's New "Cream and Honey" Sweet Corn. Ex tremely early, most delicious flavor, exceptionally fine quality. Should bo tried by every wide-awake market gardener and in home garden, where the "best" of everything is enjoyed. Lb. $4 \mathrm{c}$, 2 Lbs, $48 \mathrm{c}$. 10 Lbs. $\$ 2.10$ 25 Lbs. $\$ 5.00100 \mathrm{Lbs}$. $\$ 18.00$.

1256. Howling Mob. Superb long ears of sweetest quality. Stalk are of strong, vigorous growth, $4^{1 / 2}$ to 5 feet in height, abundant foliage, and generally produces 2 fine ears to a talk. Lb. $22 \mathrm{c}$. 2 Lbs. $44 \mathrm{c} .10 \mathrm{Lb}$. $\$ 1.90 \quad 25$ Lbs. $\$ 4.50$. $100 \mathrm{Lb}$. $\$ 16,00$.

1005. Early "Butter-Nut", Sugar Corn. New Variety, follows "Cream and Honey" Sugar Com by four to seren days. Ears 7 fo 9 mches long, with 14 rows of good size "Butter-Nut" pearly white grains. Stalks grow about 5 feet high and produce 2 fine ears. Lb. $23 \mathrm{c}$. 2 Lbs. $46 \mathrm{c}$ $\$ 2.00$ 2.5 Lbs. $\$ 4.75 .100$ Lbs. $\$ 17.00$

1057. Mammoth White Cory Sweet Corn. Produces ears 7 to 8 inches long: 12-rowed whiteProduces ears 7 to 8 inches long: 12-rowed, Mhiteextra quality. Lb. 23c. 2 Lbs. $46 \mathrm{c}$. Whe Lbs. $\$ 200$. 25 Lbs. $\$ 4.75$. 100 Lbs. $\$ 17.00^{\prime}$ 1112 Golden B a n a m Corn. This very early, yellow grained Sweet Corn, when in best condition for the table, is remarkably sweet and tender. The stock we offer has been improved by and therefore will be and therefore will be perior to much that is offered. Lb. $23 \mathrm{C}$. $\begin{array}{lrrr}\text { Lbs. } & 46 c . & 10 & \text { Lbs. } \\ \$ 2.00 & 25 & \text { Lbs } & \$ 4.75\end{array}$ $\$ 2.00$. 25 Lbs,
100 Lbs, $\$ 17.00$. $\$ 1200$.

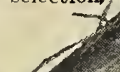
.
1 qt. is about $2 \mathrm{lbs}$.

21 qts. is about $5 \mathrm{lbs}$.

10 lbs. is abcut 2.3 peck.

Order 50 lbs. at peck.

1050. Gillespie's First Early Patapsco Neck Corn. The very First Good size Corn that can be brought to market. It is so hardy that it can readily be planted ns soon as the ground is in good working order, and will, from the day of its germination, hurry forward to meet the carly demand for fresin Corn, which is always rery keen and canses this delicious, attractive and superior Corn to bring profitable prices. Lb. Ise 2 Lbs. 36c. 10 Lbs. $\$ 1.50$. 25 Lbs. $\$ 3.50$. 100 Lbs. $\$ 12.00$

1051. Double XX Extra Early Adams' Sweet Corn. Two weeks earlier than Extra Early Adams', large ears completely filied with 10 to 14 straight rows of snow white deep grains. Lb. 18e. 2 Lhs. 36e. $10 \mathrm{Lbs}$ \$1.50. $25 \mathrm{~J}$ Ls. $\$ 3.50 .100 \mathrm{Lbs}$

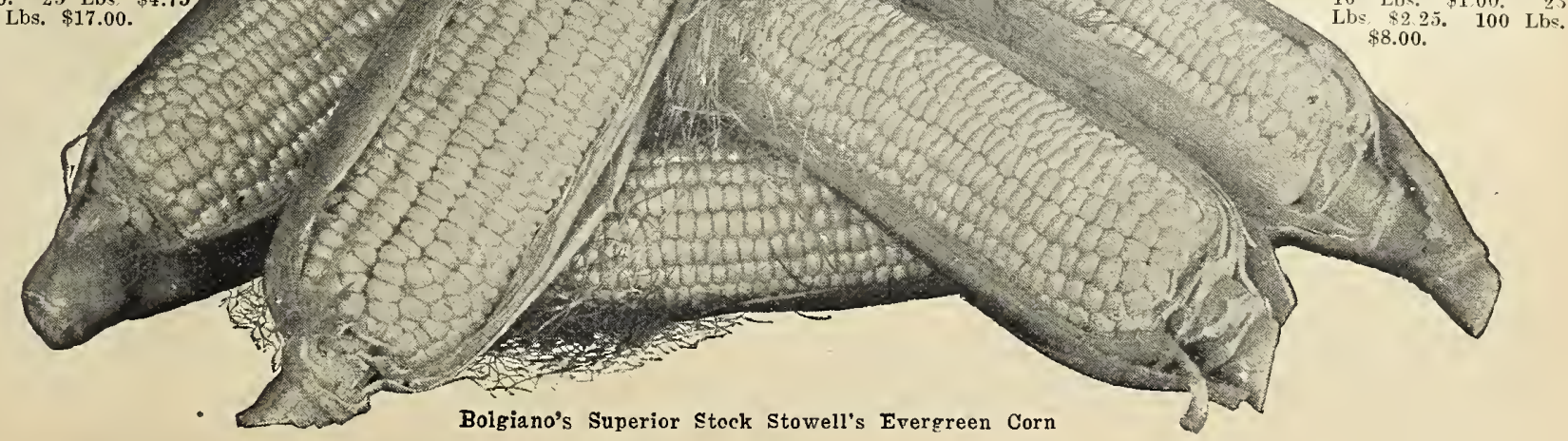

\section{General Crop}

1066. Snow White Evergreen, Lb. 21c. 2 Lbs +2c, 10 Lbs, $\$ 1.80$ 25 Lbs. $\$ 4.25 .100 \mathrm{~J}$. $15 . \$ 15.00$

\section{Second Early}

1302. Early Crosby. A high quality, second early, very popular in Eastern sections, cspecially New England. Ears swcet and tender. Pkt. I0e $\$ 1.90$. 25 Lbs. $\$ 4.50 .100 \mathrm{Lb}$. $\$ 16.00$.

1060. Extra Early Evergreen. Ears like Evergreen-very large, with about 18 irregular rows and a rery long gran of the very best quality stowell's in this respect. Lb. 22c. 2 Lbs. 4 c. 10 Lbs, $\$ 190$. t.j0. 100 I bs $\$ 1600$

1061. Early Mammoth Sugar.

Market Cardeners' favorite. Two j Lbs $\$ 1$ arlier than the Late Mammoth. Lb. 22c. 2 Lbs, 44c. 10 Lbs. $\$ 1.90$ 1067 Stowell's Evergreen. The truest strain of the leader of all Coms is in our possession. It lemain Jonger" in a first-class marketable condition than
other vaniety, "Lb. 21c 2 Lbs. 42c 10 Lbs. $\$ 1.80$. Late Crop 1065 . Country Gentleman Sugar Corn. Lb. $21 \mathrm{c}$
$2 \mathrm{Lbs}$ t2. $10 \mathrm{Lbs}$. 1.80 . 25 Lbs. $\$ 425.2100 \mathrm{Lbs}$ 1062 Large Late Mammoth Sugar. Lb, 21c
Lbs, $42 \mathrm{c}, \quad 10$ Lbs $\$ 1.80$. 25 Lbs. $\$ 4.25 . \quad 100$ Lbs 1063. Black Mexican. Lb. 22c. 2 Lbs. 4 c. 10 Lbs $\$ 1,90,25 \mathrm{Lbs} . \$ 450$.
Lbs. $\$ 1600$. Plus Ultra. Lb. 21c. or 2 Lbe $42 \mathrm{c}, 70$ Lbs $\$ 180.25 \mathrm{Lbs}$

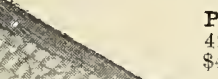
Rice Pop Corn for
Popping or Seed.
Lb. 15c

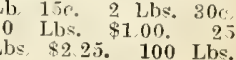




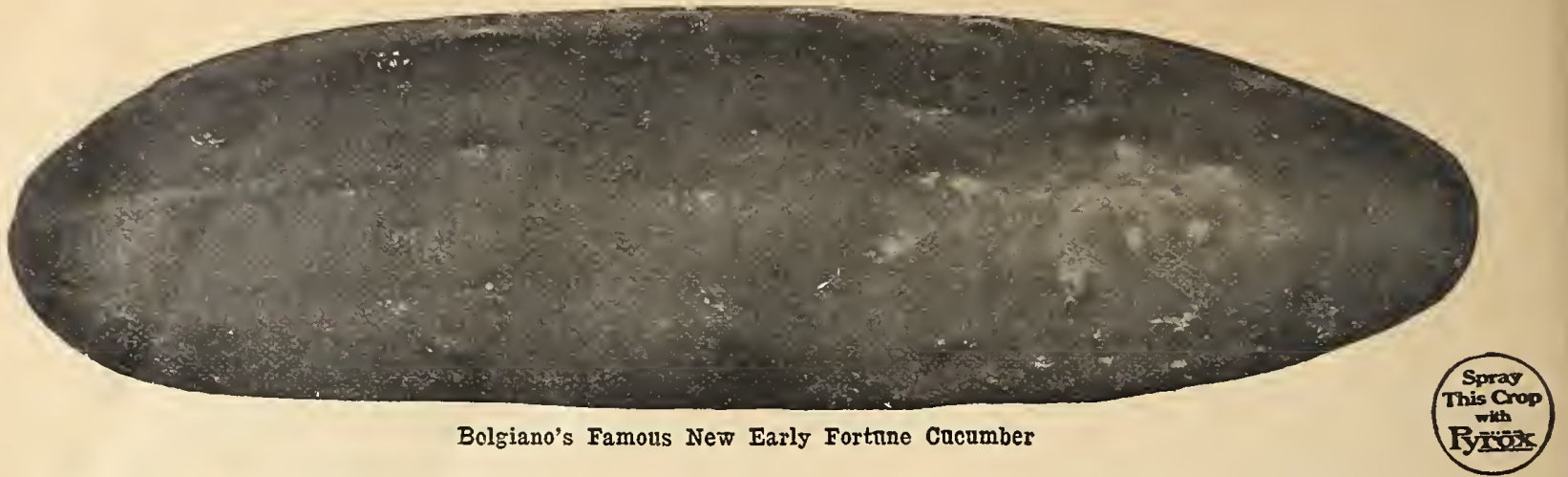

We Pay Postage on Pkts., Ozs., 14 Lbs. and Lbs.
Cucumber

Concomble Eurfe
One ounce will plant fifty hills,
two pounds u'ill plant one acre

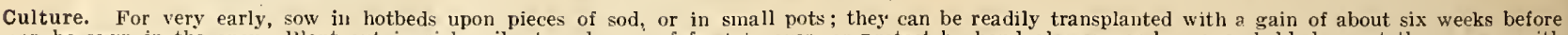

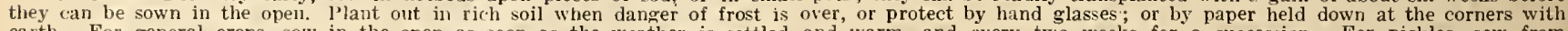

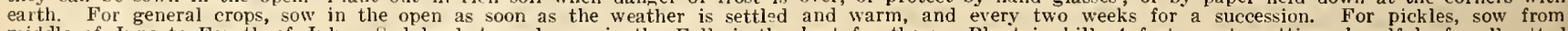

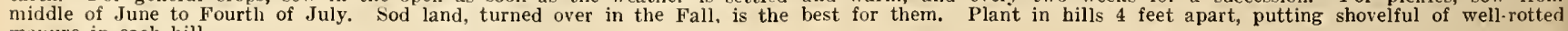
manure in each hill.

394. Bolgiano's New "Crystal Springs" Cucumber. New 1918 introduction. (Specialty, see page 6.) Extra early, heaviest yielding, continuous bearer. Attractive rich, glossy, deep green color. Deep green to the very tips. Mildew-proof, never turns yellow. Perfect in shape, color and size. No missliapen fruits or culls. Flesh firm, fine grained and tender. The quality is supcrl. Most refreshing and delightful flavor. Entirely free from bitterness. Very few seeds. Fine for slicing. The ideal Cucumber for either shipping, market or home use. Pkt. 10c. Oz. 20c. 2 Ozs. 35e. 1/4 Lh. 60c. 1/2. Lb. $\$ 1.10$. Lb. $\$ 2.00$.

84. Bolgiano's Early Fortune Cucumber. Full blooded, as pretty as a picture, and extremely early, wonderfully productive. a model in shape, of the most inviting and attractive deep green color. Without a doubt the finest in the world. (See page 6.) Pkts. 5c and 10c. Oz. 15c. 1/4 Lb. 45c. 1/2 Lb. S0c. Lb. \$1.50. Postpaid.

17. Bolgiano's "Prosperity" White Spine Cucumber. New introduction. This wonderful new Cucumber will immediately jump into utmost favor with shippers, market gardeners and private gardeners. It absolutely has no equal; it will bring prosperity to you quick. Pkts. 5c. and 10c. Oz. $15 \mathrm{c}$. 2 Ozs. 25e. 1/4 Lb. 45 c. $1 / 2$ Lb. S0e. Lb. $\$ 1.50$.

135. New Klondike. Very dark green, 6 or 7 inches long and two inches thick, remains crisp a long time. It is a grand market sort. Pkts. 5e and 10e. Oz. 15e. 2 Ozs. 25e. $1 / 4$ Lb. 30c. $1 / 2$ Lb. 55c. Lb. $\$ 1.00$.

398. Early Green Cluster Cucumber. This is an extra early pickling or frame variety, being the earliest Cucumber of practical use. Fruit is set in clusters of two or three and are used for either pickles or for extra early slicers. They will produce fruits 10 days earlier than the earliest slicing varieties. Pkt. 5c. Oz. 10c. 1/4 Lb. 20c. 1/2 Lb. 35e. Lb. 65 c.

88. New Extra Long White Spine Cucumber, or Fordbook Samous. Skin very deep green; firm and usually crisp. The plant is a to 17 inches), sinooth, slim and uniforn. Pkts. 5c and 10c. Oz. 10c. 2 to 17 inches) sinooth, slim and uniform.

86. Improved Extra Early Wbite Spine Cucumber. We have a very uniform dark green strain. Vines are exceptionally rugged and productive and fruit holds color well after harvesting. Pkts. $5 \mathrm{c}$ and $10 \mathrm{c} . \mathrm{Oz}$. 10c. 2 Ozs. 15c. 1/1 Lb. 30c. 1/2 Lb. $50 \mathrm{c}$. Lb. $90 \mathrm{c}$

93. Bolgiano's New Prolific Pickling. Bears fruit from the time it frst starts until frost. Vines are strong and vigorous, rielding immense

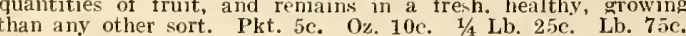

236. Boston Pickling. Fruit short, smooth and pointed at each end : light green, a great vielder; one of the best for pickling. Pkt 5c. Oz. 10c Lb. $20 \mathrm{c}$, g reat

208. Chicago or Westerfield Pickling Cucumber. Fine for Mar. tardeners. Medium length, pointed at each end. large spine. deep green, ry prolific. A fine pickling variety. Pkt. 5c. Oz. 10c. 1/4 Lb. 20c. Lb. 65 c. Tborburn's Everbearing. A short, early pickling variety on a ine, which stands hard pickling well. The chief characteristic of ariety is the rough pimplc spines, completely covering the pickle and g what is known as a gherkin pickle. These pickles are exceedingly 15c. $1 / 2$ Lb. 20c. 1/\% Lh. 35c. Lb. 65c. Improved Long Green Cucumber. If you have to make one do for everything. this is the one to use. It is used for an early

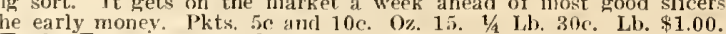
Early Frame, or Early Short Green. Desirable for producing medium size and fine quality. 1'kt. Jc. Oz. 10c. 1/4 Lb. $25 \mathrm{c}$.
19. Henderson's Perfection White Spine Cucumber. This Cucumber is very inuch the same type as the Early Forture. This sort has great quantities of extra fancy dark green fruit, which always sells well in all markets. Pkts. 5c and 10c. Oz. 15c. 2 Ozs. 25c. 1/4 Lb. 30c. 1/2 Lb. 55e. Lb. $\$ 1.00$.

85. Arlington White Spine Cucumber. For many years the standard slicing and market variety. Very prolific, and of dark green color. Pkts. 5c and 10c. Oz. 15c. 2 Ozs. 25c. 1/4 Lb. 30c. 1/2 Lb. 55e. Lb. $\$ 1.00$.

90. Evergreen, or Long White Spine Cucumber. The best extra long table and market Cucumber. Fruit grows 8 to 10 inclies long, holding diameter well from end to end. Heavy producers of extra fancy dark green fruits of good quality. Pkts. 5e and 10c. Oz. 15e. 1/4 Lb. 30c. Lb. $\$ 1.00$.

340. Fordhook Pickling. A very prolific pickling. Pkts. 5c and 10c. Oz. 10c. 2 Ozs. 15e. $1 / 4$ Lb. 20c. $1 / 2$ Lb. 35c. Lb. $65 \mathrm{c}$

92. New Excelsior Long Green Cucumber. It is a model for size, form and beauty. Deep green color, and an abundant cropper. For table use and pickles. This sort runs so uniform that the Cucumbers look as if they had all been selected. Pkts. $5 \mathrm{c}$ and $10 \mathrm{c}$. Oz. 15c. $1 / 4$ Lb. 30c. Lb. $\$ 1.00$.

95. Inproved Jersey Pickle. It is medium in length, very shapely, prolific and holds its color. Pkt. 5c. Oz. 10c. 1/4 Lb. 20c. Lib. $65 \mathrm{c}$.

544. Davis Perfect Cucumber. This variety is noted for producing the only Cucumbers of quality enabling them to sell in competition with hothouse grown stock. Very slender, almost seerlless, cylindrical and tapering at the ends. It nuch resembles the expensive English forcing varieties and is superseding them in the markets. Pkts. 5c and 10c. Oz. 15c. 2 Ozs. 25c. $1 / 4$ Lb. 30c. $1 / 2$ Lb. 55e. Lb. $\$ 1.00$.

518. West Indian Gberkin. This is the only genuine Gherkin. It is small, oval and covered with spines; color light green. Pkts, 5c and 10c. Oz. $15 \mathrm{c}$. $1 / \mathrm{s}$ Lb. $30 \mathrm{c}$. $1 / 2$ Lb. $55 \mathrm{c}$. Lb. $\$ 1.00$.

517. Japanese Climbing Cucumber. Used as a beautiful vine and also for its fruit. Pkts. $5 \mathrm{c}$ and 10c. Oz. 15c. 1/4 Lb, 30c. Lb. $\$ 1.00$

342. Tbe New Lemon Cucumber. It has a thin skin, is crisp, tender and sweet. Can be used sliced, whole or as pickles. Pkts. $5 \mathrm{c}$ and $10 \mathrm{c}$ Oz. 15c. 2 Ozs, 25 c, $1 / 4$ Lb. $300.1 / 2$ Lb. 55c. Lb. $\$ 1.00$.

384. Cool and Crisp. This is the earliest and one of the most prolific pickling Cucumbers. The Cucunibers are of a dark color, straight, long, even and slim. They are very tender and crisp. Pkt. 5c. Oz, 10c. 1/4 Lb. 25c. Lb. $75 \mathrm{c}$.

454. Pittsburg b Famous Pickling Cucumber. Tbis stock has been bred to order by one of the most cxpert plant breeders for a concern who use; thousands of acres vearly and know just what is wanted in pickling Cucumbers. The vines are exceptionally robust: fruit scts close in and are very uniform. Pkts. 5c and 10c. Oz. 10c. 2 Ozs. 15c. 1/4 Lb. $25 \mathrm{c}$. 1/2 Lb. $40 \mathrm{c}$. Lb. $75 \mathrm{c}$.

587. Snow's Fancy Pickling. This type is shorter when ripe than the Chicago Pickle and is broad at the stem end, tapering slightly to the tip. The small pickles, although quite similar to the Chicago Pickle, have an additional value where blight prevails. The fruit being smaller, the blight does not sap the strength of the vine to the detriment of a crop. Pkts. $5 \mathrm{c}$ and $10 \mathrm{c}$. O\%. $10 \mathrm{c}$. 2 Ozs. $15 \mathrm{c}$. $1 / 4 \mathrm{Lb}, 25 \mathrm{c}$. $1 / 2 \mathrm{Lb} .40 \mathrm{c}$. Lb. $75 \mathrm{c}$

591. Earliest of All, A fair size, dark green White Spine. The earliest of good guality we have tried, of especial value in localities wher blight prevents the maturing of the late and longer sorts; also of value in the south for first crop. Pkts. $5 \mathrm{c}$ and $10 \mathrm{c}$. Oz. $10 \mathrm{c} .1 / 1 \mathrm{Lb} .25 \mathrm{c}$. Lb. $75 \mathrm{c}$ 
1 Ounce will sow 20 square feet,
6 pounds will sow an acre We Pay Postage on Pkts., Ozs., 1/4 Lbs, and Lbs.

Culture. Sow during August or early in September, in drill $1 / 4$ inch deep and 6 inches apart. If the weather is dry when the seed is sown, tread it lightly to insure germination. Keep down weeds with hoe. Just before the Winter, cover thinly with straw or leaves.

24. Large German Corn Salad. Used as a salad and for garnishing. Pkt. 5e. Oz. 10c. 1/4 Lb. 25c. Lb. $75 \mathrm{c}$.

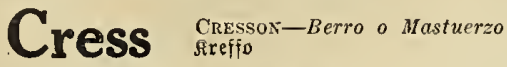

Culture. Sow curled or pepper grass thickly, in shallow drills, every 2 weeks. It should be cut often and will continue to grow. It is useful for salad and for garnishing.

520. True Water Cress. Should be sown in damp soil; or if a stream of water can be utilized, they would be much finer. They will thrive well in damp hotbeds. Rightly managed, their culture is very profitable. To obtain early salad it is a good plan to sow with Water Cress Seed a strip 4 inches wide on the upper margin of the hotbed, inside the frame, where it is always cool. Pkts. 5c and 10c. Oz. 50c. 2 Ozs. 80c. 1/4 Lb. $\$ 1.40$. Lb. $\$ 5.00$.

521. Fine Curled or Pepper Grass. Pkt. 5c. Oz. 10c. $1 / 4 \mathrm{Lb}$. 20c. Lb. $50 \mathrm{c}$.

\section{Oz. will produce
500 Plants AUBERGNe Berengena Cerpflanze}

Culture. Sow in hotbeds very early in Spring and transplant when 2 inches high into a second bed or into small pots. If this is not done, thin to 4 inches apart. Do not plant out until weather is perfectly settled and warm. Cool nights or wet weather will check them. Keep some back in frames for a second planting, in case of weather changing unexpectedly. Set out plants 3 feet by 2 .

100. Bolgiano's Black Beauty Egg Plant. The earliest and best of all large fruited Egg Plants. Pkts. 5c and $10 \mathrm{e}$. $1 / 2$ Oz. 25c. Oz. 40c. 2 Ozs. 75 c. 1/4 Lb. $\$ 1.30$. 1/2 Lb. $\$ 2.40$. Lb. $\$ 4.60$.

99. The Florida High Bush Egg Plant. Holds the fruit well off the ground, resists drought and wet weather. Fine purple color, very productive. Plits. 5c and 10c. $1 / 2 \mathrm{Oz} .20 \mathrm{c}$. Oz. 30c. 2 Ozs. 55c. $1 / 4$ Lb. $\$ 1.00$. 1/2 Lb. $\$ 1.90$. Lb. $\$ 3.60$.

103. Bolgiano's Improved Large Purple Egg Plant. Perfect stock of improved Large Purple Egg Plant-purer, truer, better than lias ever been offered before. It has a handsome shape, a fine, dark, purple color, beautiful form, large size. and is uniform, making it attractive for shipping and market use. Pkts. $5 \mathrm{c}$ and $10 \mathrm{c}$. 1/2 Oz. 20c. Oz. 35c. 2 Ozs. 65c. 1/4 Lb. $\$ 1.15$. $1 / 2$ Lb. $\$ 2.15$. Lb. $\$ 4.10$.

101. New York Improved Egg Plant. (Spineless.) A vigorous grower; fruit large, fine, free from thorns, and produce until frost; skin of a rich purple, flesh white and of a rich flavor. We can highly recommend this Egg Plant. Pkts. $5 \mathrm{c}$ and $10 \mathrm{c}$. $1 / 2$ Oz. $20 \mathrm{c}$. Oz. 35e. 2 Ozs. 65c. 1/4 Lb. \$1.15. $1 / 2$ Lb. $\$ 2.15$. Lb. $\$ 4.10$.

556. New Jersey Improved Large Smooth Egg Plant. Pkts. 5c and 10c. 1/2 Oz. 20c. Oz. 35c. 2 Ozs. 65c. 1/4 Lb. $\$ 1.15$. $1 / 2$ Lb. $\$ 2.15$. Lb. $\$ 4.10$.

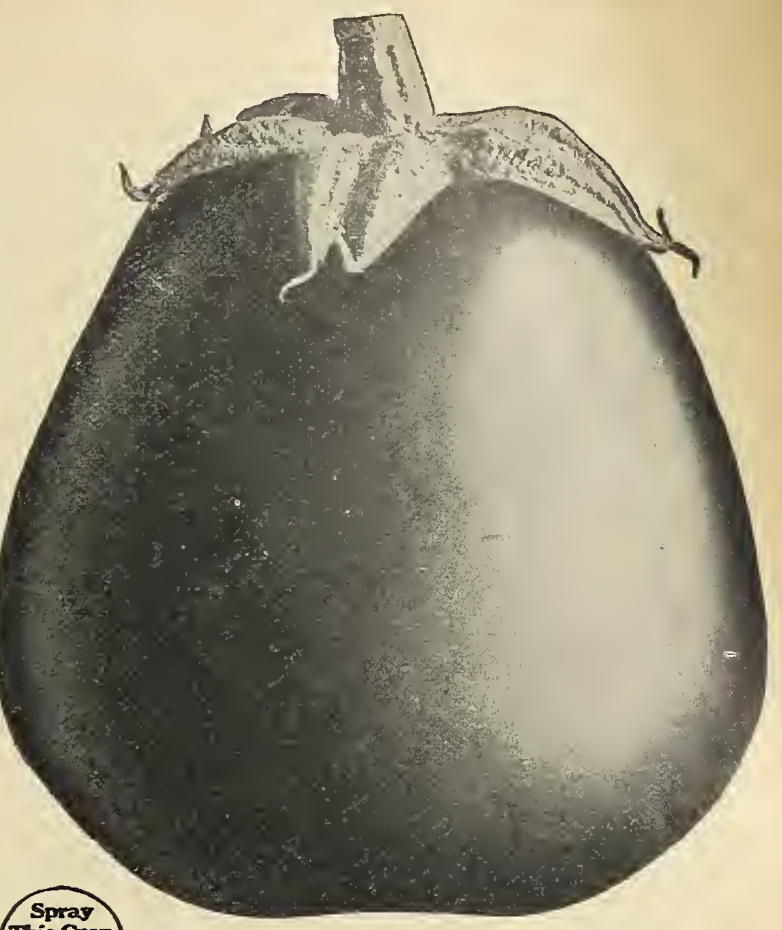

This Crop

New York Improved Purple Egg Plant

104. New Orleans Egg Plant. Large, dark, purple or New Orleans Market. They are good shippers. Pkts. 5e and 10c. $1 / 2$ Oz. 20c. Oz. 30c. 2 Ozs. 55c. 1/4 Lb. $\$ 1.00$. $1 / 2$ Lb. $\$ 1.90$. Lb. $\$ 3.60$.

\section{$10 z$ to 150 feet $\begin{gathered}\text { tow } \\ \text { of row }\end{gathered}$}

We Pay Postage on Pkts., Ozs., 1/4 Lbs. and Lbs.

106. Bolgiano's New Self-Blanching Endive. A perfect self-blanching curled Endive, beautiful and graceful in shape, most attractive, perfect color, shading from a large, rich golden heart to the outer leaf of emerald green. Pkt. 5c. Oz. 15c. 2 Ozs. 25c. 1/4 Lb. 30c. 1/2 Lb. 55c. Lb. $\$ 1.00$.

107. Green Curled Endive. Much better than the common varieties. An attractive and ornamental vegetable. Pkt. 5c. Oz. 10c. $1 / 4$ Lb. $25 \mathrm{c}$. $1 / 2$ Lb. 45 c. Lb. $85 \mathrm{c}$.

452. Broad-Leaved Batavian. The leaves are large and broad, having the edges slightly cut. It can be blanched, but is more generally used to cook like Spinach, or as flavoring for soups, stews, etc. Called "Fiscarolle" in the Soutl. Pkt. 5c. Oz. 10c. 1/4 Lb. 25e. Lb. 75 c.

\section{Chicory}

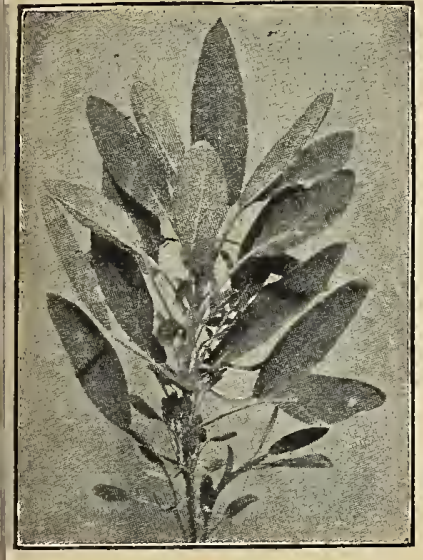

Sage

404. Witloof or French Endive. Witloof is used principally as a winter salad. The seed should be sown in the open ground not later than June. The roots are lifted in the fall, and stored in soil in a cool place until wanted for forcing. They are then trimmed of side roots and the tails cut off to have an even length of 6 inches. A box 14 inches high is filled with 2 inches of soil at the bottom and the roots packed upright in rows with a thin layer of soil between each row. The crowns of the roots are covered loosely with 6 inches of sand or light earth. After watering thoroughly, the box is placed near the heater of the cellar and kept moderately moist until the sprouts push through. Pkt. 15c. Oz. 25c. 1/4 Lb. 75c. Lb. \$2.50. Postpaid.

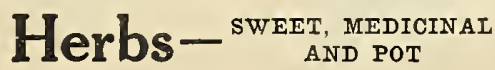

\begin{tabular}{|c|c|c|c|c|c|c|c|c|}
\hline Basil Sweet & $\begin{array}{l}\text { Pkt. } \\
10 \mathrm{c}\end{array}$ & $\begin{array}{l}\mathrm{Oz.} \\
15 \mathrm{c}\end{array}$ & $\begin{array}{c}1 / 4 \mathrm{Lb} . \\
40 \mathrm{c}\end{array}$ & Lb. & Martynia & $\begin{array}{l}\text { Pkt. } \\
10 \mathrm{c}\end{array}$ & $\begin{array}{l}\text { Oz. } \\
30 \mathrm{c}\end{array}$ & $\begin{array}{l}1 / 4 \mathrm{Lb} . \\
\$ 1.00\end{array}$ \\
\hline Caraway .. & $5 c$ & $10 \mathrm{c}$ & $20 \mathrm{c}$ & & Rosemary & $10 \mathrm{e}$ & $65 \mathrm{c}$ & 2.00 \\
\hline Chives. & $10 \mathrm{c}$ & $5 \tilde{5} \mathrm{c}$ & 1.65 & & Sage ........... & $10 c$ & $40 \mathrm{c}$ & 1.30 \\
\hline Coriander & $5 c$ & $10 \mathrm{c}$ & $20 c$ & $50 c$ & Summer Savory. & $10 e$ & $25 \mathrm{c}$ & $60 \mathrm{c}$ \\
\hline Dill Mammoth & $5 c$ & $10 \mathrm{e}$ & $15 \mathrm{c}$ & $40 c$ & Thyme $\ldots \ldots$ & $10 \mathrm{c}$ & $50 \mathrm{c}$ & 1.40 \\
\hline Fennel Sweet .... & $10 c$ & $15 \mathrm{c}$ & $45 \mathrm{c}$ & $\$ 1.40$ & Horehound & $10 \mathrm{c}$ & $30 \mathrm{c}$ & $95 \mathrm{c}$ \\
\hline Marjoram Sweet & $10 c$ & $20 \mathrm{c}$ & $60 \mathrm{c}$ & 2.00 & Lavender. & $10 \mathrm{c}$ & $25 \mathrm{c}$ & $\mathrm{soc}$ \\
\hline
\end{tabular}

Lb. 


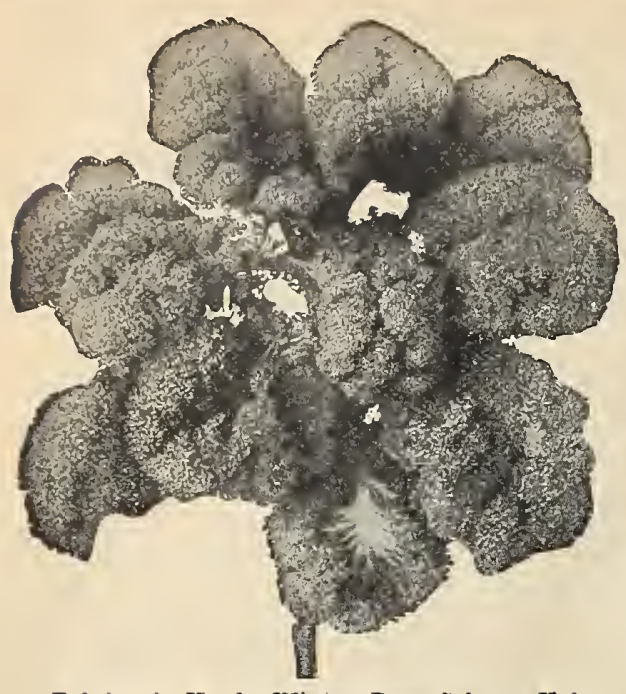

Bolgiano's Fardy Winter Bore Cole or Kale

\section{Horse Radish Roots}

By mail Postpaid Doz. 30c, Express not paid 50 for $60 \mathrm{c}, 100$ for $\$ 1.00$, 300 for $\$ 2.75,500$ for $\$ 4.25,1000$ for $\$ 8.00$

This is a hardy plant, thriving best in a cool, moist spot. The small sets or roots are planted each spring to furnish large, straight, smooth roots for use the following season. The roots can he left in the garden until needed for use and, when grated, make an appetizing relish for all meat dishes.

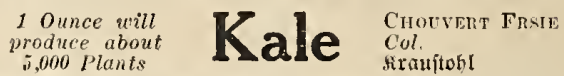

We Pay Postage on Pkts., Ozs., 1/4 Lbs, and Lbs.

Culture. The Kales are more hardy than Cabbage, make excellent greens for Winter and Spring nee, and are improved by frost. Sow from May to Jume, and cultivate the same as Cabbage. For early Spring use sow in September, and protect during Winter. Some of the varieties are so hardy that the green leares may he dug out from under the snow in Winter and he used for greens.

113. Bore Cole or Kale. Hardy Winter Spargel Kohl. The most salable, delicious and tender of all Winter Kales. About Baltimore it is sown in May, and transplanted like Cabbage to stand over Winter. It is taller than the extra dwarf rarieties, and when the leaves are stripper or fall off new tender leaves quickly grow out. Then they are again stripped off and used for marketing. It will stand the coldest Minter. Besides being a delicious regetahle, it has always been an exceptionally profitable crop, bringing money during the Winter montis when most all regetables are searce. Pkts. 5c and i0c. $1 / 2 \mathrm{Oz}$. 15e. Oz. 25e. 2 Ozs. 45c. $1 / 4$ Lb. 75 c. $1 / 2$ Lb. $\$ 1.35$. Lb. $\$ 2.50$.

112. Extra Dwarf Green Curled Scotch, or Norfolk Kale. One of the best Kales for Spring rowing in the North; the principal sort grown South for Northern markets; hardy, and will remain over Winter where temperature does not go below zero. Tery dwarf and spreading, rarely exceeding 18 inches in height. Jueaves are a bright green color, beautifully eurled and procluced in abundance. Pkt. 5e. Oz. 10c. 1/4 Lb. 20c. 1/2 Lb. 30c. Lb. 50c.

108. New Imperial, Very Curly, Long Standing Kale. Beautifully curled and erimpled sort; strong, rigorous habit, perfectly hardy, bright green color; very attractive in appearance; superior to all late sorts; will stand longer without shooting to seed than any other variety. Pkt. 5c. Oz. 10c. 1/4 Lb. 20c. 1/2 Lb. 30c. Lb. 50c.

351. Spring or Smooth Kale. A hardy, quick growing, smooth leaved variety. The best for Spring sowing, but largely sown in the Fall, making greens earlier than the Winter rarieties. Pkt. 5e. 1/4 Jb. 10c. 1/2 Lb. 15c. J.b. 20c.

109. Curled German Kale. Hardy; stands the frost of our sererest Winters; grows rapidly, dwarf habit, beautifully eurled. Pkt. 5c. Oz. 10c. 1/4 Lb. 15c. 1/2 Lb. 25c. Lb. 45c.

110. Siberian Curled Kale. The green leaves are very large and comparatively plain in the center, but heavily curled on the edige. It is a fast grower, extremely hardy and will stand longer in the Spring without bolting than any other variety. Pkt. 5e Oz. 10e. 1/4 Ll. 15e. 1/2 Lb. 25e. Lh. $45 \mathrm{e}$.

512. New American, Extra Curled, Long Standing Kale. Of a beautiful green color. Plit, 5c. Oz. 10c. 1/4 Lb. 15c. 1/2 Lb. 25e. Lb. $45 \mathrm{e}$.

\section{Kohl-Rabi Colinabo \\ We Pay Postage on Pkts., Ozs., 1/4 Lbs. and Lbs. \\ 152 "Best-of-All" Kohl-Rabi}

Combines the qualities of the finest varieties. Romnd like an apple, fine. smooth skin. Leaves rery few, stand erect, enabling grower to plant closer and helps him in bunching. Flesh is unsurpassed in tenderness and flavor. "Best of All" Kohl-Rabi will not run to seed in frosty weatler. Equally valuable for foreing or open ground culture. Pkts. 5c and 10c. Oz. 15e. 1/4 Lb. 40c. Lb. \$1.25.

117. Earliest White Vienna. The standard well known variety most largely used: fine stock. Pkts, 5e and 10c. Oz. 15e, 2 Ozs. 25c. 1/4 Lb. 30c. Lb. $\$ 1.00$.

343. Purple Kohl-Rabi. Very much appreciated by the best truekers. Pkts. 5c and 10c. Oz. 15e. 1/4 Lb, 30c. Lb. \$1.00.

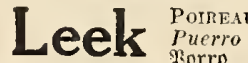

We Pay Postage on Pkts., Ozs., 14 Lbs. and Lbs.

culture. Sow early in April in drills 1 foot apart and 1 incli deep. When plants are 6 to $S$ incles high transplant in a deep, rich soil in rows 12 inches apart and 6 inches in the rows, as

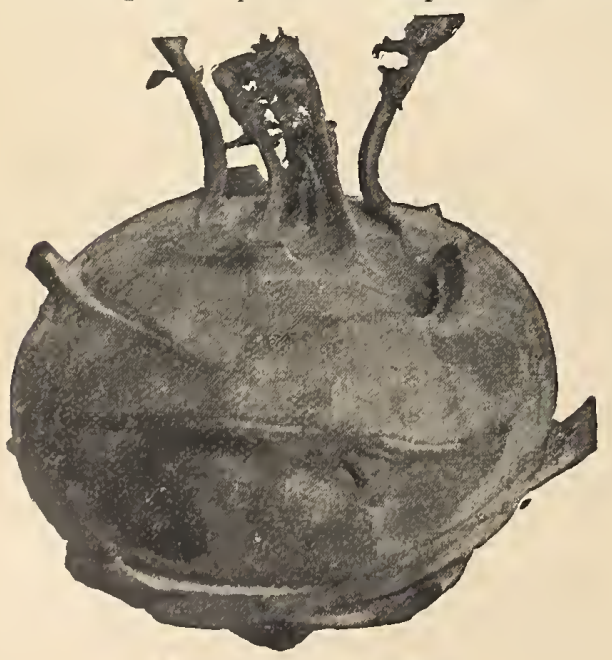
deep as possible, so that the neck may he covererl and blanched; iraw the earth to them as they grow,

\section{Bolgiano's Famous Mammoth King Leek}

114. This stock we have by years of selection built up until it has become to those who use it a pleasure to grow and a profit too. It has a handsome form, is rery miid, agreeable in flavor, grows to doulle the size of ordinary varieties, is pure white, has attractive, dark-colored leaves, is stout in habit and hardy. The edible part is 8 to 15 inches long ancl 3 to 5 inches in diameter. It is without execption the largest and best Leek ever placed in the hands of the grower. Plit. 5e and $10 \mathrm{c}$. Oz. 20c. 2 Ozs. 30c. 1/4 Lh, 50c. 1/2 Lb. 95e. Lh. $\$ 1.75$.

546. Monstrous Carenton or Scotch Champion. Very large, hardy and productive; popular for market. Plkt. 5c and 10c. Oz. 20c. $20 \mathrm{Oz} .30 \mathrm{c}$. $1 / 4$ Lb. 50c. 1/2 Jb. 95e. Lb. \$1.75.

116. Extra Large American Flag or Broad London. Distinct and dark-colored leaves; stout in labit and hardy. Pkt. 5c and 10c. Oz. 20c.

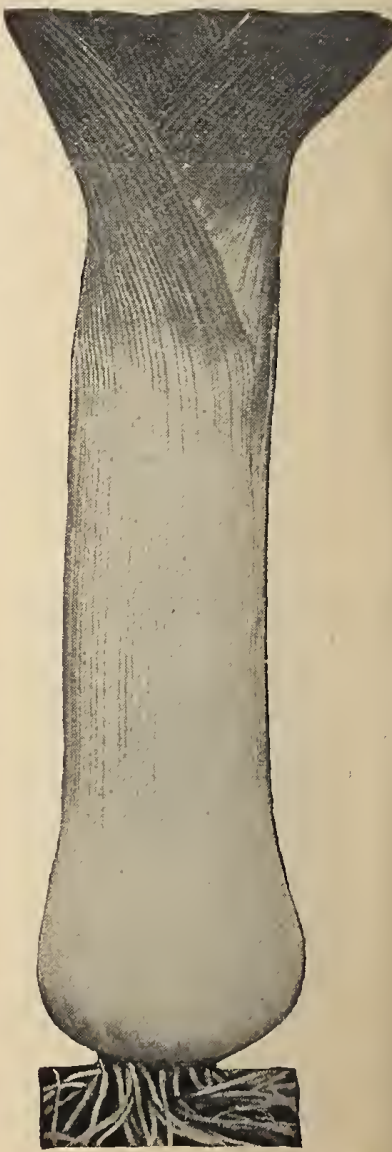

Bolgiano's Mammoth King Leek 
Lettuce $\begin{array}{ll}\text { Laspos } \\ \text { Lechuga } \\ \text { Salat }\end{array} \quad \begin{aligned} & 10 z \text { to } 3,000 \text { Plants } \\ & 2 \text { Lbs. to the Acre }\end{aligned}$

We Pay Postage on Pkts., Ozs., 14 Lbs. and Lbs.

Culture. For early Summer use, sow in hotbeds in March, sowing every two weeks for succession. Transplant the young plants to rows 2 feet apart and 8 to 12 inches a part in the row. For Winter use, sow in August, transplant to frames; and for this purpose the early heading plant to rrames; and for this purpose the early heading varieties, such as the Millionaire Lettuce, are best adapted.
The Cos varieties require to be tied up for a few days in order to properly blanch them.

\section{Earliest Varieties}

415. Bolgiano's "Masterpiece" Lettuce. New 1920 Creation. (Specialty, see page 5.) Șure header, very solid, beautifully blanehed, crisp as ice; mild, tender, sweet, delicious flavor. It is equally well suited for the home garden, near-by markets or long-distance shipping. Does well in any section of the country. A very profitable Lettuce to grow. Pkts, $10 \mathrm{c}$ and 25e. $1 / 2 \mathrm{Oz}$. 30e. Oz. 50c. $1 / 4$ Lb. $\$ 1.40$. 1/2 Lb. $\$ 2.65$. Lb. $\$ 5.00$.

380. “Long Lost" Lettuce. (Specialty, see page 5.) Produces large, extremely solid, compact cabbage heads. It is a reliable sure header and is very liardy. It stands the cold. It will Winter over better than Big Boston Lettuce. "Long Lost" Lettuce has both shipping and eatiug qualities, decidedly buttery in flavor, sweet and tender. Of a solid, bright, attractive green, never spotted or brownisli iu any part. As a shipper, "Long Lost" Lettuce far surpasses every otlier Lettuee, including the Big Boston. Supply very limited. Pkts. $10 \mathrm{c}$ and $25 \mathrm{c}$. 1/2 Oz. 30c. Oz. 50c. 2 Ozs. 80c. $1 / 4$ Lb. $\$ 1.40$. 1/2 Lb. $\$ 2.65$. Lb. $\$ 5.00$.

352. May King. A handsome, light green heading variety of medium size and excellent quality. Outdoors the leads mature exceptionally early, attaining a size suitable for use before other sorts, and often the edges of the outer leaves have a brownish tinge. The plant is very compact for so large a head. It is very satisfactory also for forcing under glass. Pkts. 5c and 10c. Oz. 15e. 2 Ozs. 25c. 1/4 Lb. 30e. 1/2 Lb. 55c. Lb. \$1.00.

480. Bolgiano's "Sure Summer Header" Lettuce. (Specialty, see page 5.) This is the best Mid-Sumner Variety, resisting heat and drought and remains in a heading condition longer than any other. It is a sure header in the hottest, driest weather and proves a big suceess under conditions when all others fail. The heads are a good size, vcry solirl, a fresh green eolor. Loose leaves can all be used as they are brittle and tender. This strain is a big improvement over all other Summer varieties. Pkts. 5c and 10c. Oz. $15 \mathrm{c}$. 1/4 Lb. 45c. $1 / 2 \mathrm{Lb}$. 80c. Lb. $\$ 1.50$.

122. Improved White Loaf Lettuce. After the most careful cultivation and roguing, we have established the truest and most uniform straiu of improved White Loaf Lettuce. It is planted largely in the Fall and allowed to remain in the open ground all Winter. In the earliest Spring it quickly forms most delicious, large light colored Lettuce heads. As a frame Lettuce it has 110 equal; often 18 heads have brought $\$ 2.50$ wholesale. If planted in early Spring, it quickly forms heads and can be brought to market long before other Lettuce. Pkts. 5e and $10 \mathrm{c}$. Oz. 10c. 2 Ozs. 15e. $1 / 4$ Lb. 25e. 1/2 Lb. 40e. Lb.75e.

156. Big Boston Lettuce. Bolgiano's Famous Stock. Big Boston Lettuce is the most valuable Lettuce in cultivation; it excellent qualities have made it the most popular and most extensively used Lettuce in the world. It can be grown in the open grouid for Summer or Fall, in frame for Spring or forced cool in grcenhouses for Winter use, producing under each eondition, grand, large, buttery, yellow heads, filled with sweet, crisp, tender, beautifully blanched leaves. Stands long without going to seed; has few outer leaves and makes a large, attraetive plant. Big Boston Lettuce is specially adapted to cool, open ground culture. Our stock of this fanous Lettuce is the finest in the World. Pkts. 5e and 10c. Oz. 15c. $2 \mathrm{rzs} .25 \mathrm{c}$. 1/4 Lh. 45c. 1/2 Lb. 80e. Lb. $\$ 1.50$.

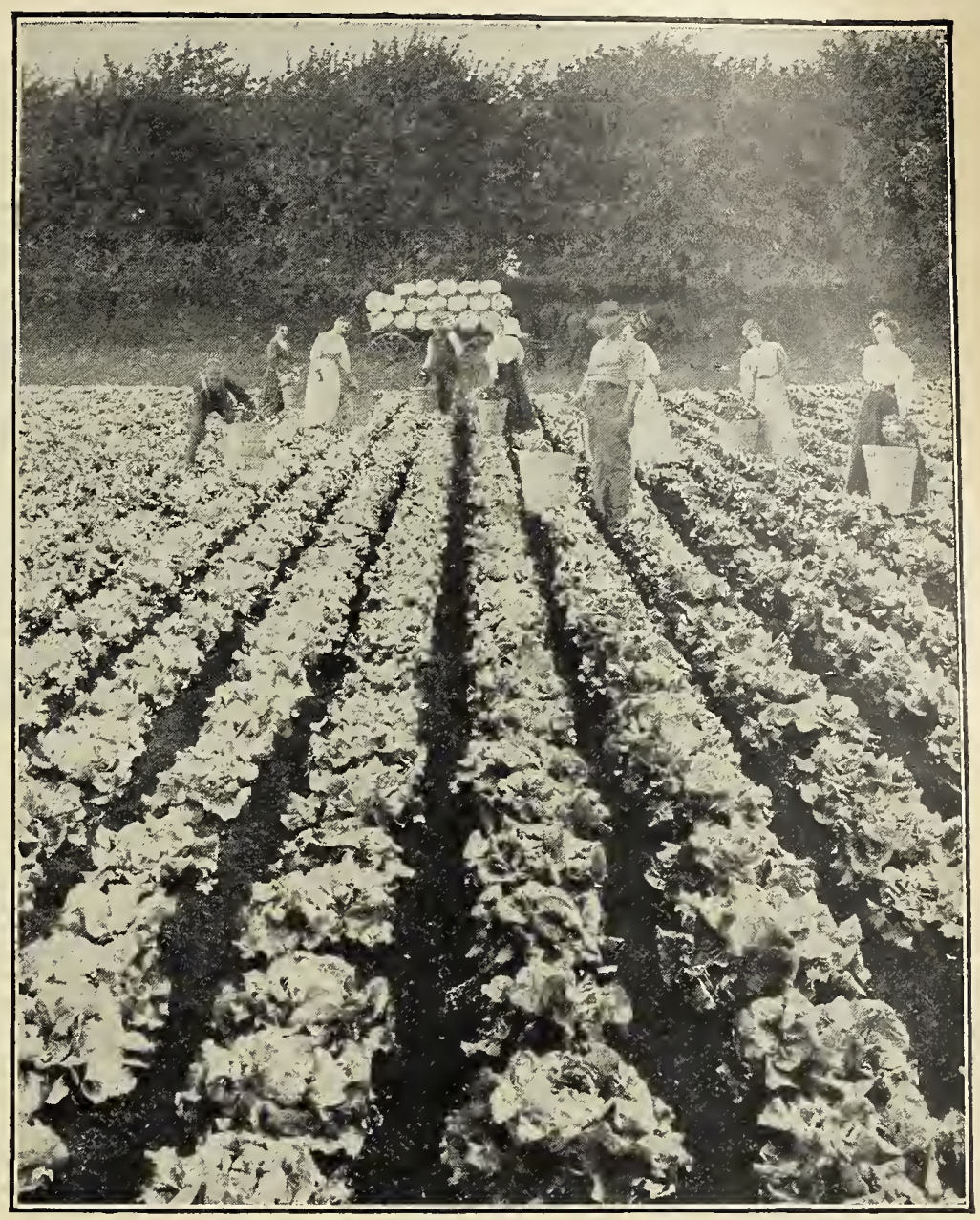

A Field of Bolgiano's Famous Big Boston Lettuce

425. New York or Wonderful Lettuce. A decidedly crisp variety; strictly cabhage head. Very large. Extremely slow to shoot to seed. Hardy, well blanched; sweet, delicious flavor Pkts. 5c and 10c. 1/2 Oz. 15c. Oz. 25c. 2 Ozs. 45e. 1/4 Lb. $75 c$ $1 / 2$ L... $\$ 1.35$. Lb. $\$ 2.50$.

137. Black Seeded Tennis Ball or Boston Market. One of the very best for either forcing or early outdoor planting l'lants good size, leaves are of good substance and of attractice, lark green color. Heads are solid. crisp and tender. Pkt. 5c. Oz. 15e. 2 Ozs. 25e. 1/4 Lb. 40e. Ib. \$1.25.

\section{5. "Unrivaled" Lettuce.}

Boston Lettuee, etc. It can be sown almost the whole year around; it resistthe Summer heat. is crisp and solid.
2 Ozs. 25e. 1/4 Lb. 30c. Lh. $\$ 1.00$.

150. Millionaire Lettuce. Tinquestionably the Farliest and far hetter than any other extremely early large heading Lettuce. A Lettuce fit for a king. Pkts. 5c and 10c. Oz. 15c.
2 Ozs. 25c. 1/4 Lh. 30c. 1/2 Lb. 55c. Lb. $\$ 1.00$.

\section{Burpee's Wayahead Lettuce.} combination of earliness, nirm heading character, handsome appearance and fine quality. Both in cold-frames early in the Spring and in the open ground in Spring, Summer and early Fall months, it has proven to be one of the earliest and surest heading of all early Lettuces. The outer leaves are a light green, with the inner head firmly blanched to a rich, buttery rellow. Retrins its good quality throughont the season and stands longer witlout going to seed than many other early varieties. Plts. 5e and 10c. Oz. 15e. 1/4 Ll, 30c. 1/2 Lb. 5.je. Lb. $\$ 1.00$. 


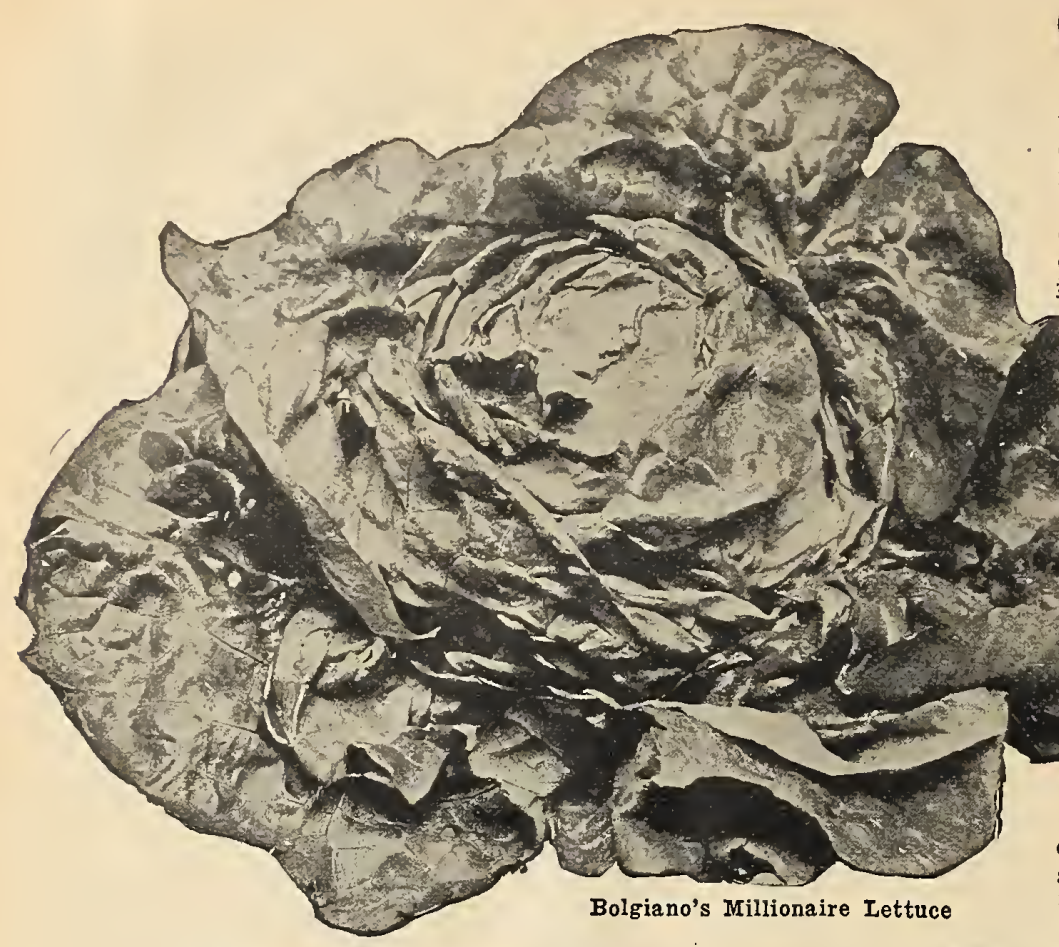

\section{Cos or "Celery" Lettuce}

The Lettuce called Salad Romaine is of distinct, upright growth, and esteemed for its fresh crispness and mild flavor during the Summer and in warm climate.

339. Eelipse or "Express" Cos. The most dwarf and earliest of all. The plants grow stifly erect, only six or seven inches in height. The interior leaves are almost pure white, very crisp, and mild in flavor, even in hot weather. Pkts. 5e and 10c. Oz. 10c. 2 Ozs. 15e. $1 / 4$ Lb. 30c. $1 / 2$ Lb. 50c. Lb. $95 \mathrm{c}$.

123. Paris Self-Folding or Trianon White Cos. Grows to a very large size, producing long-pointed, compact bunches. The inner leaves blanch readily and are of fine flavor. Pkts. $5 \mathrm{c}$ and $10 \mathrm{c}$. Oz. $10 \mathrm{c}$. 2 Ozs. 15c. 1/4 Lb. 30c. $1 / 2$ Lb. $50 \mathrm{c}$. Lb. $95 \mathrm{c}$.

\section{Heading Lettuce}

120. "Lucky Stroke." Bolgiano's New Lettuee. The largest and most suceessful Lettuce growers are wild over this new early Summer Lettuce. It is simply perfect. Plts. 5e and 10e. Oz. 15c. 2 Ozs. 25e. $1 / 4$ Lb. 40c. 1/2 Lb. 70c. Lb. $\$ 1.25$.

133. California Cream Butter Lettuce. Outside leaves are a medium green eolor, inside is folded a solid head of rich, creamy color. The largest growers considering it one of the best in eultivation. Pkts. 5c and 10c. Oz. 10c. 1/4 Lb. 25c. $1 / 2$ Lb. 40e. Lb. $75 \mathrm{c}$.

215. Burpee's Butterhead Lettuce. A fine, large, hardheaded variety, solid, rich and buttery. Always well blanehed and tender. Pkts. 5e and 10c. Oz. 10c. 1/4 Lb. 25c. 1/2 Lb. 40c. Lb. $75 \mathrm{e}$.

124. Bolgiano's Celebrated Big Head Lettuce. Its beautiful form and color attract the attention of expert growers. It forms a compact head; has no core, but a tender, golden heart. As a shipper it is unexcelled, eommands the very best priees; demand always exceeds the supply. It resists the eold, withstands the Summer heat, always has a crisp, mild flavor, when open it hecomes a table ornament; in fact, in this sort the trucker has found a perfect Lettuce. Pkt. 5c. Oz. 10e. 1/4 Lb. 25c. Lb. $75 \mathrm{c}$.

348. Tait's Imperial Cabbage Iettuce. Sone of the most successful growers in the vieinity of Norfolk prefer it to any other sort. The leaves are thick, crisp and stiff, and carry well in shipment. Color bright grcen, and holds well after eutting. As an open air Lettuee it is unexcelled for enduranee of extreme cold and yield per acre. Pkts. 5e and $10 \mathrm{c}$. Oz. $15 \mathrm{c}$. 1/4 Lb. 30c. 1/2 Lb. 55e. L\}. $\$ 1.00$.

Pkt. Oz. 1/1 Lb. Lb.

134. Mammoth Black

Seeded Butter 5c 10c 25c 75e

153. Baltimore Cab-

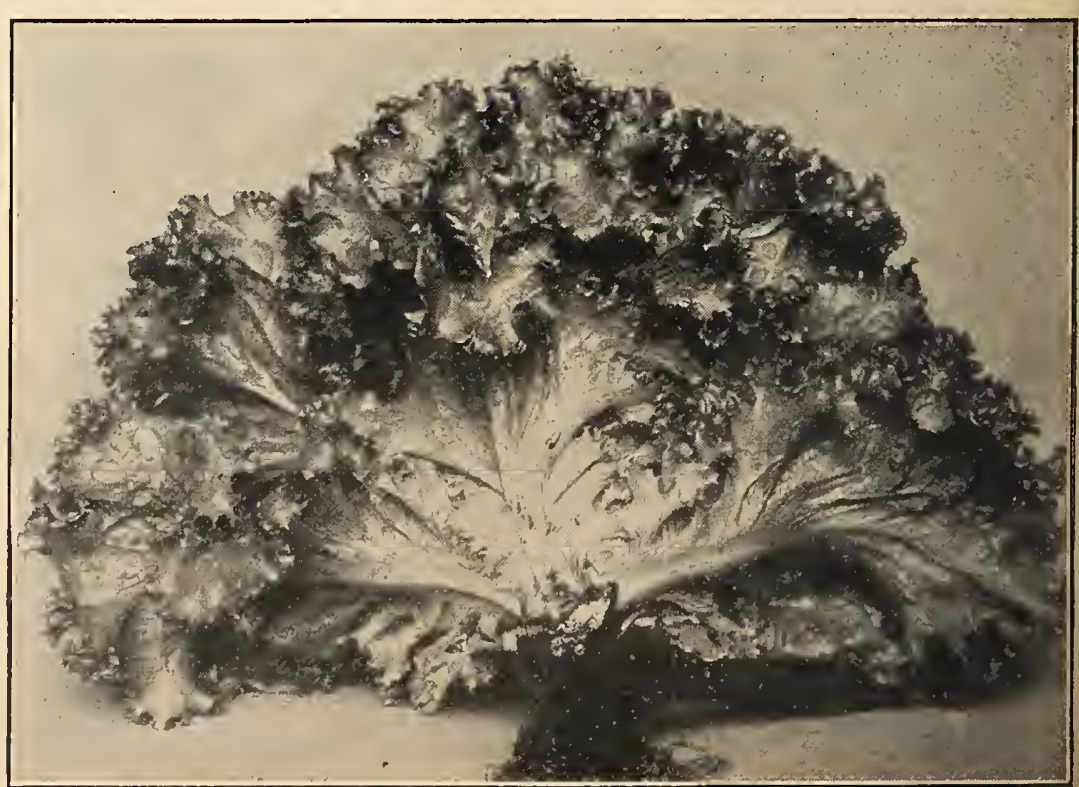

350. "Iceberg" Lettuce. The heads are large, erisp, solid and tender. Pkts. 5e and 10c. $\mathrm{O} z$. 10e. 1/4 Lb. 30c. $1 / 2$ Lb. 50c. Lb. 90c.

145. Hanson. Grows to large size and is uniformly sure heading. Heads very solid and beautifully blanched; crisp, mild and tender. One of the finest varieties to grow for market during the Summer months. Pkts. $5 \mathrm{c}$ and $10 \mathrm{c} . \mathrm{Oz} .10 \mathrm{e}$. $1 / 4$ Lb. 30c. $1 / 2$ Lb. 50c. Lb. $90 \mathrm{c}$.

147. Black-Seeded Simpson. Very large, finely fringed. Pkt. 5c. Oz. 10c. 1/4 Lb. 25c. 1/2 Lb. 40c. Lb. $75 \mathrm{c}$.

345. Early-Prize Head. (Brown Cabbage.) Large, loose lieads, tinged with brown. Pkt. 5c. Oz. 10c. 1/4 Lb. 20c. Lb. $65 \mathrm{c}$.

WE WILL GLADLY MAIL A COPY OF THIS CATALOG TO YOUR FRIEND OR NEIGHBOR IF HE IS INTERESTED. TO YOUR FRIEND OR NEIGHBOR
PLEASE LET US HAVE HIS NAME. 


\section{Muskmelons}

\section{(Cantaloupe)}

$\begin{array}{lll}\text { French } & \text { German } & \text { ltalian } \\ \text { MELoN } & \text { MeLONE } & \text { PofoNe }\end{array}$

Spanish

We Pay Postage on Pkts., Ozs., $1 / 4$ Lbs. and Lbs. Culture. A sandy loam to which plenty of well rotted manure has been added will be found ideal. Plant early in May, when the ground has become warm, in hills 6 feet apart each "ray ; 12 to 15 sceds to the hill ; cover half inch deep. To prevent damage by insects, spray with Pyrox. Thin out few plants after they show good growth and when all danger of insects is over thin out to 3 to 4 plants to the hill. For an early crop sow seed in berry boxes placed in hotbeds and transplant outhills; two-thirds pound for an acre.

\section{Green Fleshed Varieties}

16. "Junior" Rocky Ford. Two weeks earlier, a little larger, twice as productive as Rocky Ford. More thoroughly and deeply netted. Rust and blight proof. Packs in crates better and carries better than any other melon. Most deliciously sweet and spicy. The attractive, green flesh is thick, smooth and firm. Plkts. $5 \mathrm{c}$ and 1

450. Honey Dew. The new Mfelon. Average size 6 inches in diameter and 7 to 8 inches in length. Weight averages 8 to 10 pounds. The skin is smooth and the rind though thin is very tough. Will keep until Christmas. Creamy yellow when ripe. Flesh an emerald green. Can be eaten to the extreme rind. Is a good shipper. Pkts. 5c and 10c. Oz. 15c. 2 Ozs. 25c. Lb. 30c. $1 / 2$ Lb. 55c. Lb. $\$ 1.00$.

207. Watters' Improved Solid Net Rocky Ford Cantaloupe. This is the earliest strain of Rocky Ford Cantaloupes. The meat is light green, spicy and sweet. The heavy gray netting is clo

Oz. $10 \mathrm{c}$. $1 / 4 \mathrm{Lb} .25 \mathrm{c}$. 1/9 Lb. 40c. Lh. $75 \mathrm{c}$. ith large growers and shippers; somewhat larger than the Rocky Ford or Netted Gem. We offer the original stock, which is very fine. Pkt. 5c. Oz. 10c. 2 Ozs. $15 \mathrm{c}$. $1 / 1$ Lb. $25 \mathrm{c}$. 1/2 Lb. $45 \mathrm{c}$. Lb. $85 \mathrm{c}$

157. Thoroughbred "Rocky Ford" "Cantaloupe. Thoroughbred Stock. Bolgiano's Trustworthy Stock. The finest in the world. Meat light green changing rery slightly toward gold near the center. Very spicy and
sweet; abundant yielder, having produced 300 standard crates from one acre; it is an excellent shipper. Pkt. 5c. Oz. 10c. 1/4 Lh. 20c. 1/2 Lb. 35c. Lb. $65 \mathrm{c}$.

471. 10-25 Cantaloupe. A reselection of the Pollack Salnion Tint No. 25 strain of Rocky Ford, which in the last few seasons has hecome the most popular strain of the Rocky Ford Cantaloupe among market growers. Salmon flesh, tender, sweet flavored, without strings or toughness. Excellent shipper. Good seller.

\section{Baltimore Nutmeg Cantaloupe}

\section{The Original Stock. Finest on Earth.}

170. Is delicious in flavor, attractive in form and color, and unexcelled as a shipper Our seed of Baltimore Nutmeg Cantaloupe is produced under a bracing, clear and invigorating climate. This insures a parent stock of the finest flavor. We recommend this melon, and firmly helieve the cash balance of every trucker will he materially increased if he grows our superior stock of Nutmeg Cantaloupe. Pkts. $5 \mathrm{c}$ and 10c. Oz. 10c. 1/4 Lb. 25c. 1/2 Lb. 40c. Lb. $75 \mathrm{c}$.

160. Extra Early Hackensack. Will weigh from 10 to 12 pounds, Lb. 75c. Netted Gem. Fetra early, weight 1 to $1^{1 / 4}$ pounds, fine. Pkt. $5 \mathrm{c}$ 161. Netted Ge. 1/2 Lb. 40c. Lb. $75 \mathrm{c}$

166. Anne Arundel. Large, green fleshed, deeply netted. Pkts. 5 and 10c. Oz. 10c. 1/4 Lb. $25 \mathrm{c}$. 1/2 Lb. 40c. Lb. $75 \mathrm{c}$

401. Delicious Gold-Lined Rocky Ford Cantaloupe. This strain of Eden Gem type is the result of several years selection by one of the nost progressive farmers of Rocky Ford, Colo. Shape is ideal, no rihs, and it is heavily netted over the entire nielon. The melon is thick meated, fine grained and sweet ; color, green, with a gold margin next to the seed cavity. Pkts. 5c and 10c. Oz. $15 \mathrm{c}$. 1/4 Lb. 30c. 1/2 Lb. 55c. Lb. $\$ 1.00$.

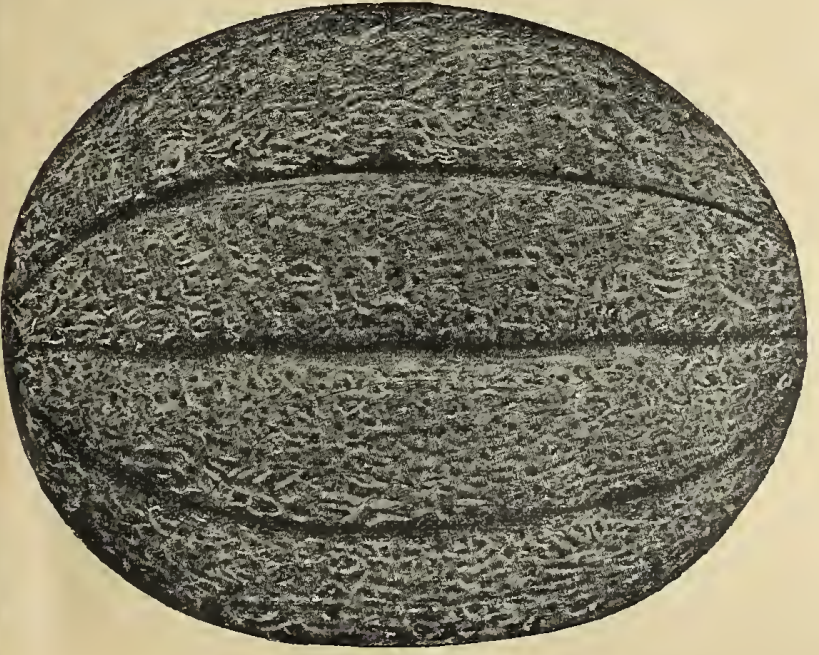

"Junior" Rocky Ford Cantaloupe
167. Eden Gem or Netted Rock Rocky Ford Cantaloupe. This magnificent new Jiuskmelon is a selection of the old Rocky Ford, which completely surpasses in lusciousness, yield heary ; good

$10 \mathrm{c}$. Oz. $15 \mathrm{c} . \mathrm{L} / \mathrm{Lb} .30 \mathrm{c} .1 / \mathrm{Lb}$. 55c. Lb. $\$ 1.00$.
334 . Pollock Rocky Ford Gantaloupe. A rust resisting melon, with netting over the blossom end; not a long nielon, but rather inclined to be short, with the finest shipping and eating qualities. The selection from time to time have reduced the size; now they crate nicely. Pkts. 5c and
$10 \mathrm{c}$. Oz. 10c. $1 / 4 \mathrm{Lb} .25 \mathrm{c} .1 / 2 \mathrm{Lb}$. $40 \mathrm{c}$. Lb. $75 \mathrm{c}$.

492. Bottomley Cantaloupe. A great blight resister. A few days later than the Knight. Slightly smaller than the Knight. Uniform size,
about 7 inches from stem to blossom end. Beautifully netted with deep green ribs, giving it a most attractive appearance. Thick meated, very crisp and fine flavor. Handsome greenish color shading to a frosty salmon next to seed cavity. Small seed cavity. Shape oval, slightly more pointed next to seed cavity. Small seed cavity. Shape oval, slightlv more pointed and firmness longer than any other melon. A great favorite wherever grown. Pkts. 5c and $10 \mathrm{c}$. $\mathrm{z}, 15 \mathrm{c}$ 1/4 Lb. $40 \mathrm{c}$ Lb. $\$ 1.2$.

168. Improved Jenny Lind. The Jenny Lind is the earliest small medium sized melon known. 1t is very uniform in size, well netted and with thick meat. Sinall seed cavity. Pkts. $5 \mathrm{c}$ and $10 \mathrm{c}$. Oz. 10c. 1/4 Lb. $25 \mathrm{c}$.

333. Acme or Baltimore. Popular, large, fine flavored. Pkts. 5c and 10c. Oz. 10c. $1 / 4$ Lb. 25̄c. 1/2 Lb. 40c. Lb. 7

\section{Orange Fleshed Varieties}

51. Melting Gold Rocky Ford Cantaloupe. Simply the most delicious Cantaloupe that was erer eaten. The sweet, luseious flesh is as
yellow as melting gold. It is the hest eating Cantaloupe in the world and a splendid, profitable shipper. Pkts. $5 \mathrm{c}$ and 10c. Oz. 15c. 2 Ozs. $25 \mathrm{c}$. 574. Salmon Fleshed Eden Gem. Outward appearance is identical with the Eden Gem, but a trifie more uniform in size; it is the best long distance shipping Rocky Ford strain, with a new delicious flavor and color
of flesh. One of the closest netted of all melons. It is unequaled in hardiness, prolificness and disease resistance. It originated with Professor Blum. ness, prolificness and disease resistance. It originated with Professor Blum. if cut at the right stage. Supply of seed rery limited. Pkts. $5 \mathrm{c}$ and 10c. Oz. 15c. 1/1 Lb. 30c. 1/2 Lb. 25c. Lb; \$1.00. (Specialty, see page 7.) The best Cantaloupe ever grown, fairly melts in ous grower, blight resister, enormous producer, splendid shipper, solid Pkts. $5 \mathrm{c}$ and 10c. Oz. 20c. 2 Ozs. $35 \mathrm{c} .1 / 4$ Lb. $60 \mathrm{c} .1 / 2 \mathrm{Lb} . \$ 1.10$ Lb. $\$ 2.00$.

548. Burrell's Gem. The fruit is of good size, handsome appearance deep, orange-salmor colored flesh; sweet, tender. Pkt. 5c. Oz. 10c. 1/4 Lb. 20c. $1 / 2 \mathrm{Lb}$. 35c. Lh. $65 \mathrm{c}$. The melons are about the size of Netted Gem. The fesh is of a beautiful salmon color, and is peculiarly crystalline in appearance, the flavor is sweet and luscious beyond description. Pkt. $5 \mathrm{c}$ Oz. $10 \mathrm{c}$. 1/4 Lb. $20 \mathrm{c}$. Lb. $65 \mathrm{c}$. Flesh. This melon is identical with the Green Fleshed Honey Dew only that the flosh is a heautiful salmon instead Lb. $\$ 1.00$

528. Banana. The deep, golden flesh is of equisite flavor. It looks and smells like a banana. command prices from $50 \mathrm{c}$ and $\$ 1.00$ for a single specimen. Pkts. $5 \mathrm{c}$ and $10 \mathrm{c}$.

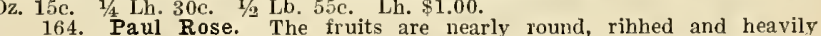
netted. The flesh is thick, of rich, deep orange color, and ripens close to the rind, with small seed cavity. It is an excellent shipper. Pkts. 5c and 10c. Oz. 10c. 1/4 Lh. 20c. ${ }^{1 / 2}$ Lb. 30c. Lb. 50c.
162. Orange-Flesh Osage. The fruits are larger than those of the Emerald Gem; nearly round in form, but having the same distinct dark green skin with lighter bands hetween the ribs, and thick, firm, orange flesh of fine quality. Pkts. 5c and 10c. Oz. 10c. 1/4 Lb. 20c. 1/2 Lb. 30c.

353. Extra Early Osage Gem. Round, well netted, thick, deep salmon-colored flesh, small seed carity, delicious flavor. Plit. 5c. Oz. 10c. $1 / 4$ Lb. 20c. Lb. $50 \mathrm{c}$. 


\section{Watermelon}

French

German

Italian Spanish

Melon dead Wasser-Jéloxe Meloxedieda saxda

Culture. Require a rich, though sandy roil for perfect development, and thrive best in warm latitudes, such as the Souther or Southwestern States, althougl in a warm sandy soil in a more northern latitude fine crops are often oltained. Cultivate and treat exactly as for Mnskmelons, except that the hills should be eight to ten feet apart. 1 ounce seed to 30 hills ; 4 to 5 pounds for an acre.

172. I n d i a $\mathbf{n}$ C hi ef, Bolgiano's Wonderful New Watermelon. Large, oblong, dark-green melon, with a thick netting all over it. The rind is thin but tough. The flesh is a bright attractive red. The flavor is delicious, sweet and satisfying. Very productive. A perfect slipper. Pkts. 5e and 10e. Oz, 15e. 1/4 Lb. 30c. 1/2 Lb. 55c. Lh. $\$ 1.00$.

\section{TOM WATSON}

\section{KLECKLEY'S}

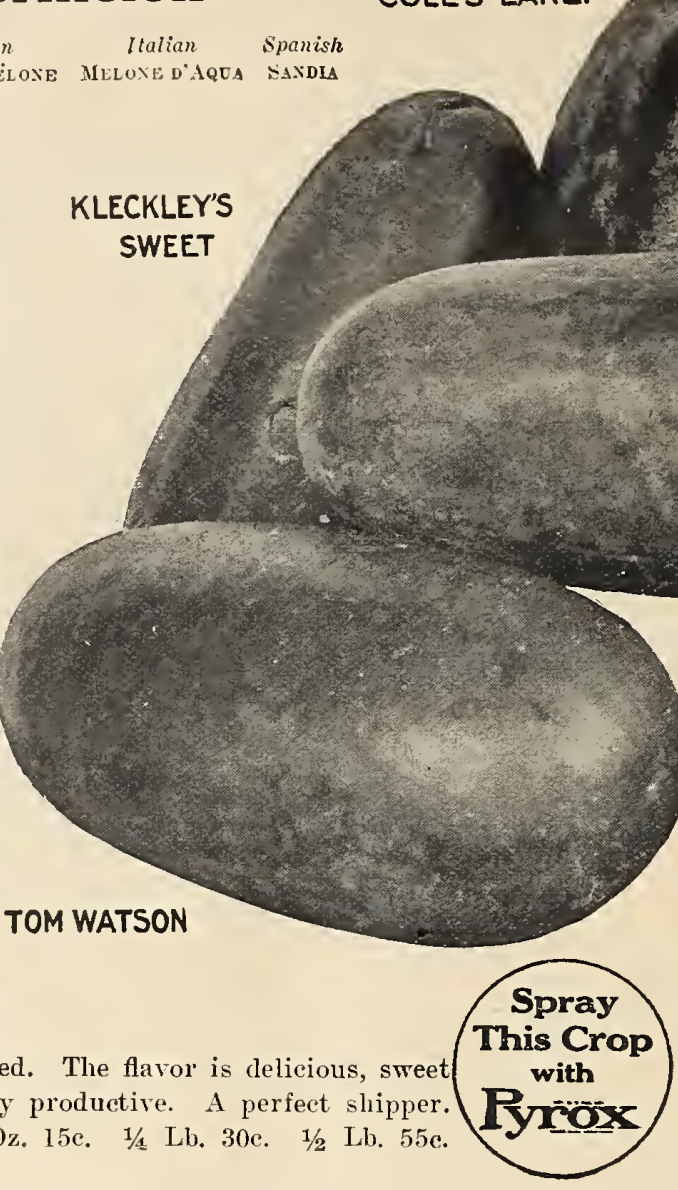

COLE'S EARLY

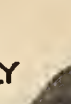

$\infty$
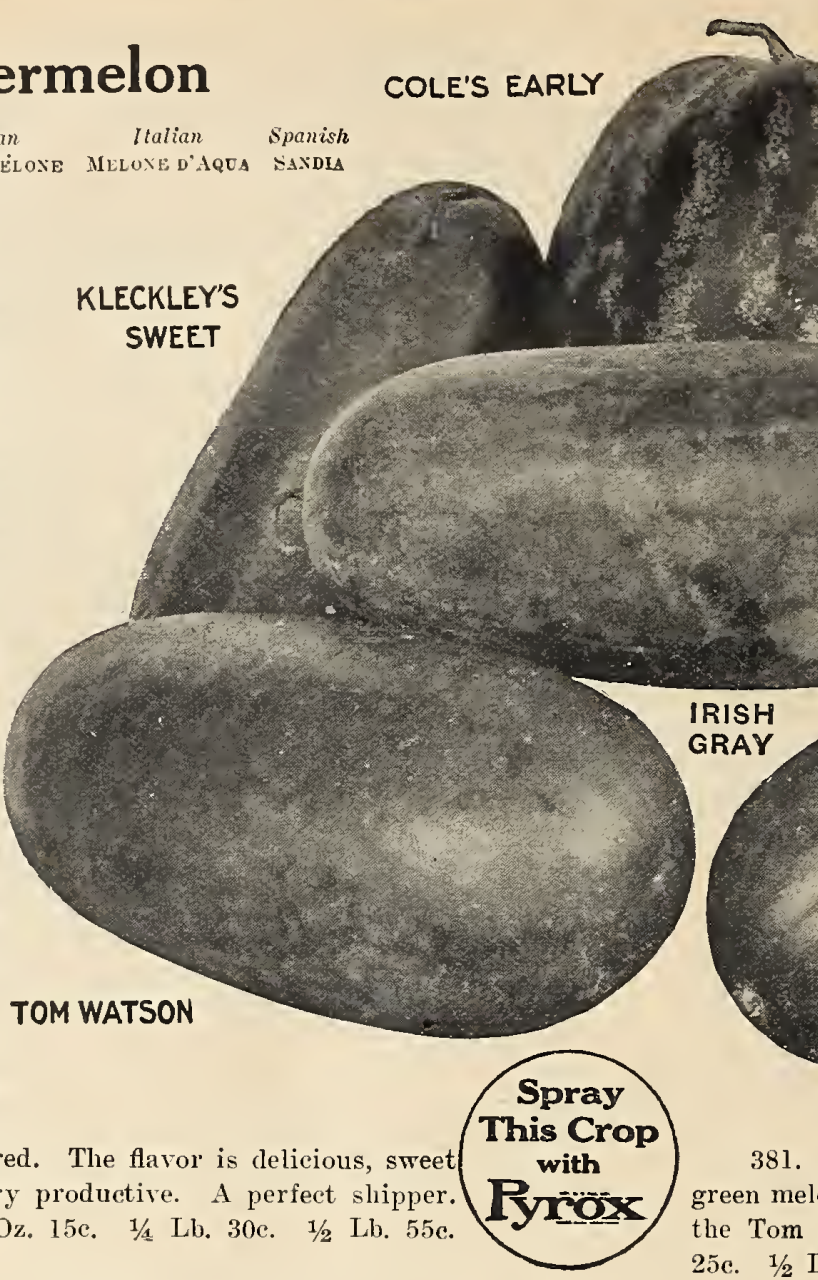

We Pay Postage on

Pkts., Ozs., 1/4 Lbs. and Lbs.

17l. Bolgiano's Cold Mountain Spring Watermelon. The ideal melon for Southern shippers, prolifie, uniformly, good -ize, tough rind, flesh red and delicious. Pkts. 5e and $10 \mathrm{c}$. Oz. 15e. $1 / 4$ Lb. 30e. 1/2 Lb. 5.5e. Lb. $\$ 1.00$.

405. "General Pershing" Watermelon. (Specialty, see page 6.) I wonderful producer. No culls. Stands dry weather. Disease resistant. Eating qualities unequalled. The sparkling red flesh is as sweet as honey. Size uniformly large, langing from 35 to 50 pounds. Color a light pea green. Will not sumburn. Ripens earlier than Tom Watson. Will keep in good condition for a long time after picking. Will stand longdistance shipping better than any other melon. Plits. 5c and 10c. Oz. 15e. $1 / 4$ Lb. $45 \mathrm{c}$. 1/2 Lb. 80c. Lb. $\$ 1.50$.

176. Florida Favorite. An oblong melon, with dark green kin faintly striped with lighter green, deep red flesh of excellent flavor. One of the best table sorts. Not a good shipper. Ripening 80 days. Pkt, 5e. Oz. 10e. 1/4 Lb. 25e. Lb. $75 \mathrm{c}$.

245. Tom Watson Watermelon. A large, oblong melon, dark green rind. Rind is thin but tough. Flesh deep red, tender, firm and sweet. Plkt. 5c. Oz. 10c. 1/4 Lb. $25 \mathrm{c}$. 1/2 Lb. 40c. Lh. $75 \mathrm{c}$.

406. Irish Gray Watermelon. The size is uniform and large. Color of rind gray. Ripens earlier than Tom Watson and will keep in good condition for a long time after picking. Very prolific and a good shipper. A fine market sort. Pkt. 5c. (1\%. $10 \mathrm{c} .1 / 4 \mathrm{Lb}, 25 \mathrm{e} .1 / 2 \mathrm{~L}, \mathrm{~b}, 45 \mathrm{c}$. Lb. $85 \mathrm{c}$.

192. Kleckley's Sweet. Oblong, dark green. Pkt. 5e. Oz. 10c. 1/1 Lb. 25c. 1/2 Lb. 40c. Lb. 75 c.

181. Alabama Sweet. Good size, very uniform, long, dark green skin, red flesh. Pkt. 5e. Oz. 10e. 1/4 Lb. $25 \mathrm{c}$. Lb. $75 \mathrm{c}$.

178. Georgia Rattlesnake or Striped Gypsy. Shape oblong, of light green color and beautifully mottled and striped with a light shade; flesh searlet, rind thin, very solid, and both sweet and delicious. Pkt. 5c. Oz. 10c. 1/4 Lb. 25c. 1/2 Lb. 40e. Lb. 75 e.

217. Peerless or Ice Cream Watermelon. Very early and one of the best; form oval, rind mottled light green, flesh firm and sugary. Pkt. 5e. Oz. 10c. 1/4 Lb. 25c. Lb. $75 \mathrm{c}$.

31. Halbert Honey. Average 18 to 20 inches long, bluntly rmoled at both ends. Skin dark green. Flesh a beautiful, rich crimson, sweet and luscious, ripens to the rind. Pkt. 5c. Oz. 10e. 1/4 Th. $25 \mathrm{c}$. Th, 75 c.

173. Coles Early. Strictly a home inarket melon, almost round in shape. Rind light green, striped with broad bands of dark green. Flesh bright red, crisp and delicate texture. Ripening 80 days. Pkt. 5c. Oz. 10c. 1/4 Lb. 25c. Lb. $75 \mathrm{c}$. 


\section{Try Mustard cooked like Spinach-it is delicious
Cne ounce will sou 100 feet of drill}

203. Southern Giant Curled. The true curled leaf variety. sweet flavored, pungent and suceulent; used for early salad. Pkt. 5c. Oz. 10c. 1/4 Lb. 15c. 1/2 Lb. 25c. Lb. $45 \mathrm{c}$.

204. Ostrich Plume Mustard or Fordhook Fancy. Desirable and ornamental. It is distinct from any other variety. The plants are of vigorous growth, and the beautiful dark green, pungent leaves curve outwardly like a fine ostrich plume. The edges are as thoroughly curled and laciniated as the best double curled Parsley, making the leaves equally desirable for garnishing. So attractive is the habit of growth and the feathery effect of the finely fringed leaves that this plant is quite worthy of a place in the garden as an ormamental border plant. Pkt. 5c. Oz. 10c. 1/4 Lb. 15c. 1/2 Lb. 25c. Lb. $45 \mathrm{c}$.

Chinese Broad Leaf. The leaves are twice the size of the ordinary Mhite Mustard, while the flavor is sweet and pungent. Pkt. 5c. Oz. 10c. 1/4 Lb. 15c. Lb. 45c.

\section{Mushroom Spawn}

Culture. Mushrooms may be grown in cellars, under benches in greenhouses, or in sheds wherever the temperature of 50 degrees can be kept up during the Winter. The beds should be made from November to February, according to the time the Mushrooms are wanted, and it requires about 2 months for them to begin bearing. Secure fresh horse dung. free from straw and litter and mix an equal bulk of loam from an old pasture with it. Keep this under cover, taking care to turn it every day to prevent it from heating, until the pile is large enough to make a bed of the required size. Three or four feet wide, eight inches deep and any length desired are the proper proportions for a bed, but this may be varied. Prepare the mixture of loam and manure, making the bed in layers and pounding down each with the back of a spade. Leave this to heat through for a few days, and as soon as the heat subsides to 90 degrees make holes in the bed about a foot apart each way, into which put pieces of spawn 2 or 3 inches in diameter; fill up the holes with compost, and at the expiration of a week or 10 days the spawn will have thoroughly diffused itself through the bed. Spread laver of soil over the heap to the depth of 2 inches, and cover with 3 or 4 inches of hay, straw or litter. Examine bed often to see that it does not get dry. Take special care. however, when water is given that it be at a temperature of 100 . One brick to a bed 6 feet square.

American Pure Mushroom Spawn. Bricks 25c each; 10 Bricks at 221/2c; 25 Bricks at $20 \mathrm{c} ; 50$ to 100 Bricks at $18 \mathrm{c}$.

\section{Nasturtium}

Nasturtium of all varieties are useful for furnishing tender seed-pods which make delicious pickles. The seeds for pickling should be gathered while green and with a portion of the stem attached. Pick them over and place in a jar until filled; then cover them with eider vinegar that has been brought to the boil and is still warm, to keep for Winter use. Lb. 60c.

Dwarf Mixed. Pkts. 5e and 10c. Oz. 10c. $1 / 4$ Lb. $20 \mathrm{c}$. Lb. $50 \mathrm{c}$.

Tall Mixed. Pkt. 5c. Oz. 10e. 2 Ozs. 15c. 1/1 Lb. 15̄e.

\section{We Pay Postage on Pkts., OKre, Or Gumbo 10 . to to. Feet of Drill
Ozs., 14 Lbs. to Acre}

198. Perkin's Mrammoth Long-Podded Okra. Pods shoot out from the stalk within three inches of the ground and the whole plant is covered with them to its extreme height. Pods are an intense green color, 9 to 10 inches long, iery slim and do not get hard. Pkt. 5c. Oz. 10c. 1/4 Lb. 20c. Lb. 50c.

201. Bolgiano's Imperial Dwarf Short-Podded Okra. It has a dwarf, shapely, dense pod, of an attractive pea-green color. The flavor is exceptionally rich. Pkt. 5c. Oz. 10c. 1/4 Lb. 20c. Lb. $50 \mathrm{c}$.

199. Dwarf Green Prolific Density Okra or Gumbo. Its green pods impart fine flavor and consistency to soups and stew's, besides being palatable when stewed and served as a dish of Asparagus. Pkt. 5c. Oz. 10c. 1/4 Lb. 20c. Lb. 50c.

200. White Velvet 0kra. The pods of this distinct and beautiful new Okra are much longer, perfectly smooth, never prickly. Plt. 5c. Oz. 10c. 1/4 Lb. 20c. Lb. 50c.

202. Lady Finger 0kra. The plants produce long, tender pods of fine, round form. white and smooth. Pkt. 5e. Oz. $10 \mathrm{c}$. $1 / \frac{1}{t}$ Lb. 20c. Lb. 50c.

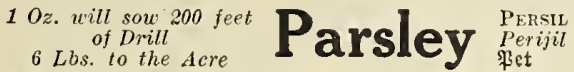

221. Bolgiano's New Green Mountain Triple Parsley. Pkt. 5c. Oz. 10c. 2 Ozs. 15c. 1/4 Lb. 25c. 1/2 Lb. 40c. Lb. $75 \mathrm{c}$

222. Market Gardeners' Best Triple Curled Parsley. Very handsome; plants are of a robust and free growth and it is

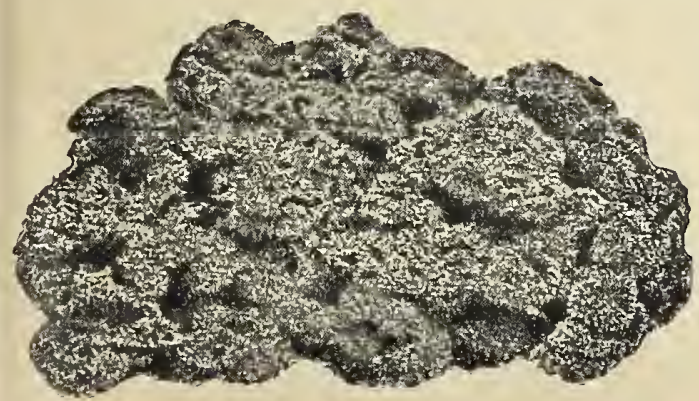

Green Mountain Triple Curled Parsley
223. Extra Dark Champion Moss curled Parsley. The large, moss, curled leaves are of a rich, dark green color and very productive. Pkt. 5c. Oz. 10c. 1/4 Lb. 20c. $1 / 2$ Lb, 35c. Lb. 60c.

541. Fine Double Curled Parsley. Pkt. 5c. Oz. 10c. 1/4 Lb. 20c. 1/2 Lb. 35c. Lb. $60 \mathrm{c}$.

540. Extra Curled Dwarf or Emerald. Pkt. 5c. Oz. 10c. 1/4 Lb. 20c. 1/2 Lb. 35c. Lb. $60 \mathrm{c}$.

224. Plain or Single Parsley. Plt. 5c. Oz. 10c. $1 / 4$ Lb. 20c. $1 / 2$ Lb. 35c. Lb. 55c.

Hamburg Rooted. Pkt. 5c. Oz. 10c. $1 / 4$ Lb. 15 c. $1 / 2$ Lb. 25 c. Lb. $45 \mathrm{c}$.

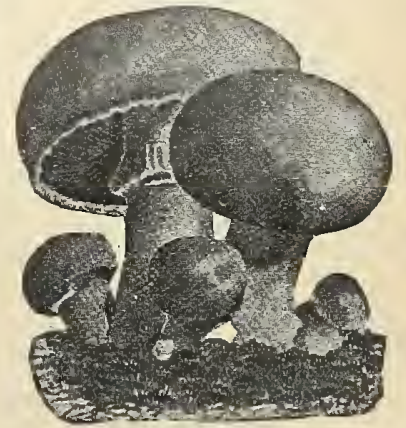

Mushrooms 


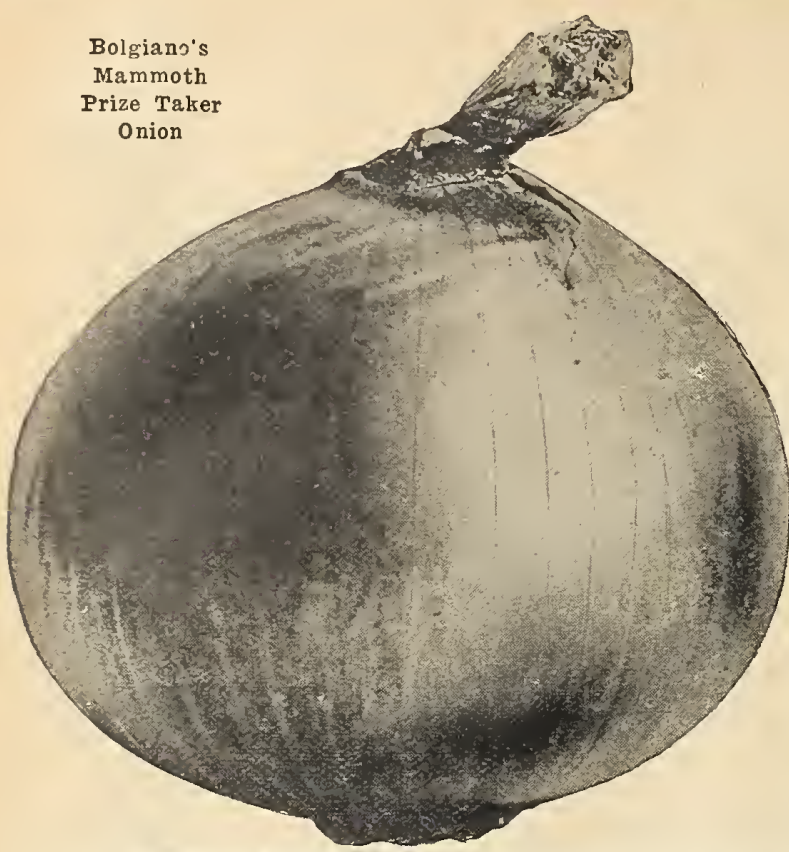

213. Mammoth Silver King. Bulbs of attractive form, flattened, but thick through; average diameter 5 to 7 inches; single bulbs often weigh 2 to 3 pounds; skin is a clear, silvery white: flesh snow white, sweet and tender.

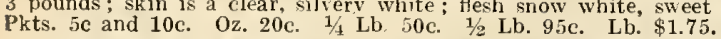

210. Extra Early Pearl, White Queen, or Barletta Onion. Enormous size; grows full-size roots from seeds the first season; skin pure white, waxy color. flesh snowy wbite, delicate and tender. Often grows 6 inches in diameter and weights 3 pounds; valued as a very early sort Pkts. 5c and 10c. Oz. $25 \mathrm{c} .2$ Ozs. $40 \mathrm{c}$. $1 / 4$ Lb. $65 \mathrm{c} .1 / 2 \mathrm{Lb}$. $\$ 1.20$. Lb. $\$ 2.25$.

511. Large White Portugal. The standard, large, flat variety. Plits. 5c and 10c. Oz. $25 \mathrm{c}$. $1 / 4$ Lb. $75 \mathrm{c}$. $1 / 2 \mathrm{Lb}$. $\$ 1.35$. Lb. $\$ 2.50$.

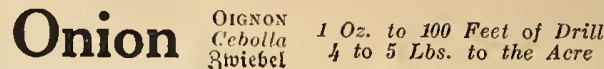

We Pay Postage on Pkts., Ozs., 14 Lbs. and Lbs.

By sowing seed of the Spanish type, such as tbe Prizetaker, Southport Globes, Pearl or Queen and Berınuda Onions, under glass in January, February or even March, and transplanting in April to open ground 3 to a inches apart in the rows, bulbs of inmense size may be produced.

214. White Silver Skin Onion, Tbis superior stock is almost exclusively used for growing sets, whicb is the strongest proof tbat it is the best froin whicb to giow large wbite onions. Its delicate, mild flavor, stately form, laroe, handsom size, pure white color, make it a most wonderful variety for the table, the most profitable for market and shipping. Plants are of an extremely thin neck and sure to ripen early. Bulbs perfect in form, quite thick through, fine grained, crisp and preserve their silvery white skin preserve their silvery white skin. Pkts. 5c and 10c. Oz. 25c. 2 Ozs. 45c. 1/4 Lb.

205. Mammoth Prizetaker Onion. True American Seed. 12 to 18 inches in circunference, bright straw color, flesh white. Pkts. 5c and $10 \mathrm{e}$ Lb. 50c. $1 / 2$ Lb. $95 \mathrm{c}$. LD. $\$ 1.75$.

$344^{1} / 2$. Southport White Globe. A large, globe-shape Onion; firm, fine grained, of mild flavor; keeps well. This is one of tbe bandsomest Onions grown, of beautiful shape, clear white skin, and commands the highest market price. Plkt. ce and 10c. Oz. 20c. 2 Ozs. 30c. $1 / 4$ Lb. 55c. $1 / 2$ Lb. $\$ 1.05$. Lb. $\$ 1.85$.

575. Southport Large Yellow Globe. Produces bulbs more perfectly globe shaped and larger than Globe Danvers, but later in ripening; excellent keeper easily grown from seed the first year, has a beautiful, pale, straw colored skin heavy cropper, large size. Pkts. 5c and 10c. Oz. 20c. 2 Ozs. 30c. $1 / 4 \mathrm{Lb} .55 \mathrm{c}$ Lb. $\$ 1.05$. Lb. $\$ 1.85$.

576. Southport Large Red Globe Onion, Produces large, handsome, globeshaped bulbs from tbe seed the first season; are excellent keepers; bave glossy purplisb skin; mature little later tban Red Wetbersfields. Fine grained, mild an nder. Pkts. 5c and 10c. Oz. 20c. 1//4 Lb. 55c. 1/2 Lb. $\$ 1.05$. Lb. $\$ 1.85$. sets. Skin a bright attractive straw color. Full-sized Onions are flattened mild flavor, excellent keepers and sbippers. Very productive. Pkts. $5 c$ and 10c. Oz. 20c. 2 Ozs. 30c. 1/4 Lb. 50c. 1/2 Lb. 95c. Lb. $\$ 1.75$.

206. Yellow Globe Danvers Onion. Bolgiano's True Stock, Handsome form, very thick bulb, small neck; very early, enormous cropper : keep perfectly, of large size, solid and heavy; safest, surest keeper. Pkts. $5 c$

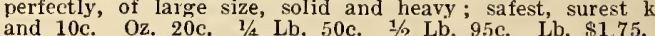

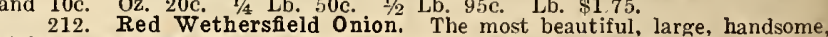
globe-shaped red Onion. Perfect form, skin deep, polished red; flesl purplish white; fine grained; produces enormous Onions. Pkts. 5c and $10 \mathrm{c}$ Oz. 20c. 2 Ozs. $30 \mathrm{c}$. 1/4 Lb. 50c. $1 / 2$ Lb. 95 c. Lb. $\$ 1.75$.

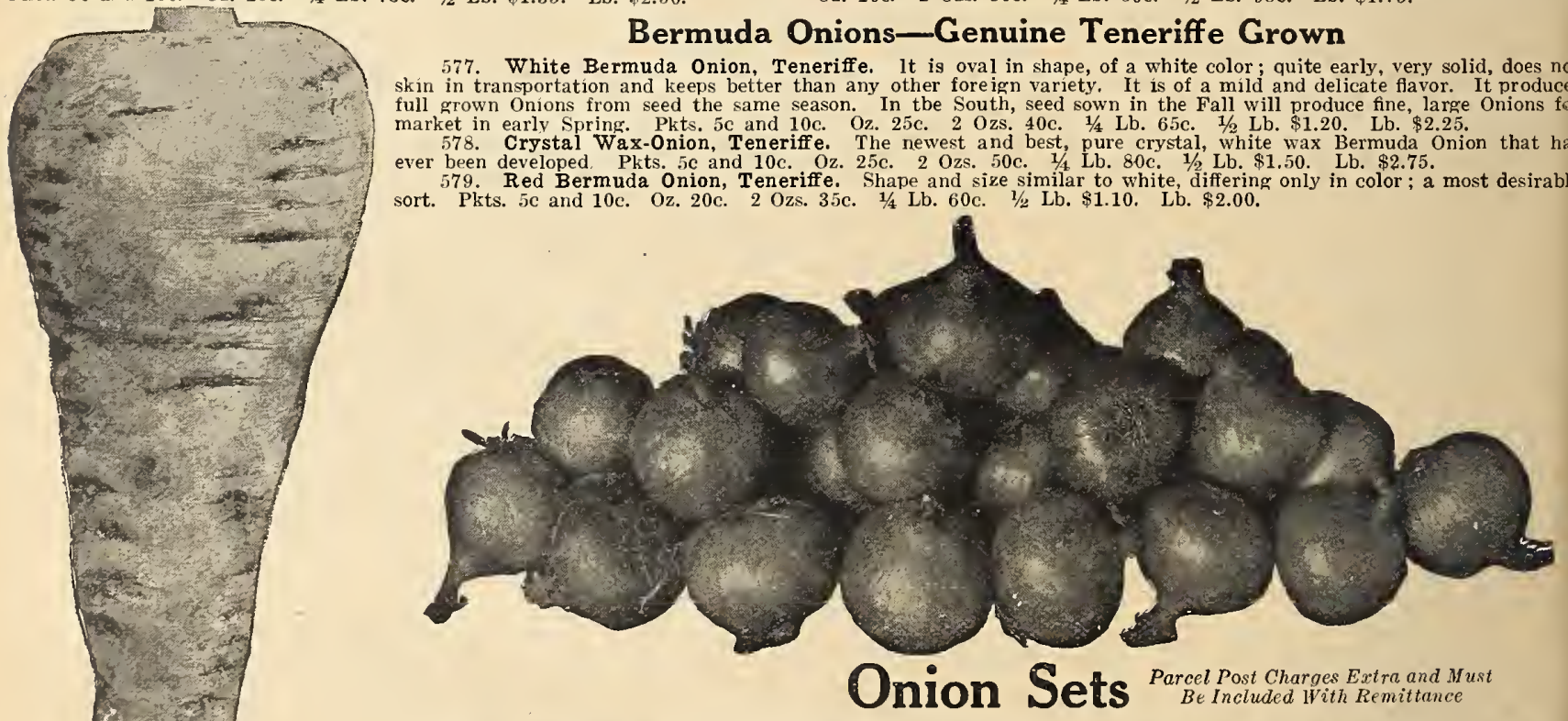

Prices given below are those ruling when this catalog goes to press an

Bv mail, add $10 \mathrm{c}$ per quart. Plant in drills 12 inches apart, and 4 inches in the rows. Must have high culture White Silver Skin Onion Sets. Grown from our choice strain of White Silver Skin or Portugal Onion Seed. Pt. 15c. Qt. 25c. 1/2 Pk. 70c. Pk. \$1.15. Bu. $\$ 4.00$.

Large Red wethersfield. Choicest recleaned. Grown from seed of our celebrated strain of Red Wethersfield Onion. Pt. 15e. Qt. 25c. 1/2 Pk. 65c. Pk. $\$ 1.00$. Bu. $\$ 3.50$

Yellow Danver Onion Sets, Choice recleaned. Grown from our choice strain of Yellow Strasburg or Dutch Onion Seed. They will produce handsome, wcll ripened bulbs of large size quite early in the Summer. Pt. 15c. Qt 25c. $1 / 2$ Pk. 65c. Pk. $\$ 1.00$. Bu. $\$ 3.50$.

Japanese Onion Sets. Finest keepers and big producers. Pt. 25c. Qt. 40c. 1/2 Pk. 75c. Pk. $\$ 1.35$. Bu. $\$ 5.00$.

One Ounce to 100 Feet of Drill
5 to 6 Pounds for the Acre aISMID $\begin{aligned} & \text { Panirija } \\ & \text { Paftifent We Pay Postage on Pkts., }\end{aligned}$

219. Bolgiano's Hollow Hub Parsnip. The very best of all Parsnips, it is unequalled. Pkt. 5c. Oz. 15c Hub metrically to a single tap root. Are easily gathered; heavy croppers; roots run uniformly smootl, with fine-grained flesh, and good quality. Pkt. $5 \mathrm{c}$. Oz. $15 \mathrm{c}$. 1/1 Lb. $45 \mathrm{c}$. $1 / 2 \mathrm{Lb}$. $70 \mathrm{c}$. Lb. $\$ 1.35$.

ITollow. Guernsey. (Improved Ifalf Long.) A greatly improved strain. The roots do not grow as long as the the flesh is fine prained and of most excellent quality. Pkt $5 \mathrm{c}$. A heavy cropper. The roots are very smooth 
1 pint is about 1 pound.

Garden Peas By Weight

1 quart is about 2 pounds.

1 peck is about 15 pounds. WEIGHT BY PARCEL POST INCLUDING PACKING

WEIGHT BY PARCEL POST INCLUDING PACKING
Pint 2 lbs., Qt. 3 lbs., 4 qts. 9 lbs., pk. 17 lbs. Parcel post table-See Page 2. We pay postage on $5 c$ and 10 c pkgs. only. Larger quantities, postage extra and must be included in remittance.

One guart will plant about 100 feet of drill. One and one-half to two buskels for an acre.

Those Marked with a Star (*) are wrinkled marrows, and unless otherwise stated should be sown thicker than the round Peas, and not until the ground has become warm, as they are more liable to rot. They are the finest flavored of all Peas.

\section{Extra Early Dwarf Varieties}

1048. “EARLY BIRD” Bolgiano's New Early Large Pod Pea. (Specialty, see page 8.) A very early, hardy, large podded, 2 to $2 \frac{1}{2}$-foot Pea. Can be pulled as early as Pilot with pods double the size. A robust grower, heavy cropper, 9 to 10 peas in a pod. Can be sown with safety as soon as the ground can be worked. Pkt. 10c. $1 / 2 \mathrm{Lb}$. 25c. Lb. 40 c. 2 Lbs. 75 c. $10 \mathrm{Lbs}$. $\$ 3.50$. 25 Lbs. $\$ 8.00$. $100 \mathrm{Lbs} . \$ 30.00$. 1218 * "100 Per Cent Profit" Peas. Earlier, dwarfer, morc prolific, more delicious than either the Gradus or the Thomas Laxton Pea. It is a wonder. Try it. Lb. 31c. 2 Lbs, 62c. 10 Lbs. $\$ 2.80$. 25 Lbs. \$6.75. 100 Lbs. $\$ 25.00$.

1261. Iittle Marvel Peas. Divarf, even growth, 15 in. high. Heavily set witl fine pods and frequently borne in pairs. Ready for table fully as early as American Wonder. Lb. 26c. 2 Lbs. 52c. 10 Lbs. $\$ 2.30$. 25 Lbs. $\$ 5.50$. 100 Lbs. $\$ 20.00$.

1081. * American Wonder. It is of dwarf and robust habit, 10 to 15 inches high, and produces a profusion of good sized and well-filled pods of finest flavor. Pkt. 10c. Lb. 23c. 2 Lbs. $46 \mathrm{c} .10 \mathrm{Lbs} . \$ 2.00$. 25 Lbs. $\$ 4.75,100$ Lbs. $\$ 17.00$.

1084. * Extra Early Premium Gem. Early, large, well-filled, straight pods. Height 1 foot. Pkt. 10c. Lb. 22c. 2 Lbs. $44 \mathrm{c} .10 \mathrm{Lb}$. $\$ 1.90$. 25 Lbs. $\$ 4.50$. 100 Lbs. $\$ 16.00$.

1196. * MeLeon's Little Gem. Very early, prolific; delicious flavor. Height 1 1/4 feet. Pkt. 10c. Lb. 22c. 2 Lbs. 44c. 10 Lbs. $\$ 1.90$. 25 Lbs. $\$ 4.50$. 100 Lbs. $\$ 16.00$.

1080. * Nott's Excelsior Pea. The very best, short vine, wrinkled, extra early Pea. Vines are more vigorous and taller than the American Wonder, and the pods are one-third larger, containing often 6 to 8 large Peas very close together, and for sweetness and quality has no equal. Height 1 foot. Pkt. 10c. Lb. 23c. 2 Lbs. 46c. 10 Lbs. $\$ 2.00$. 25 Lbs. $\$ 4.75$. 100 Lbs. $\$ 17.00$.

1203. * Sutton's Excelsior. As early as American Wonder, with much larger pods and more prolific. Height 1 foot. Pkt. 10c. Lb. 24c. 2 Lbs. 48c. 10 Lbs. $\$ 2.10$. 25 Lbs. $\$ 5.00$. 100 Lbs. $\$ 18.00$.

Laxtonian Peas. Pkt. 10c. Lb. 26c. 2 Lbs. 52c. 10 Lbs. \$2.30. 25 Lbs. $\$ 5.50 .100$ Lbs. $\$ 20.00$.
L

\section{Extra Early Várieties}

1295. Bolgiano's "Morning Glory" Pea. New 1920 creation. The earliest of all lound seeded varieties. Pkt. 10c. $1 / 2$ Lb. 20c. Lb. 35c. 2 Lbs. 65c. $10 \mathrm{Lbs}$. \$3.00. 25 Lbs, $\$ 6.75$. 100 Lbs. $\$ 25.00$.

1289. Pilot Peas. As early as the best selected, small, smooth sceded extra earlies. Pods and Peas are nearly as large as those of the Gradus and produced three days earlier. Pkt. 10c. Lb. 26c. 2 Lbs. 52c. 10 Lbs. $\$ 2.30 .25$ Lbs. $\$ 5.50 .100$ Lbb. $\$ 20.00$.

1087. New Long Podded Alaska Pea. We recommend this new Pea as the greatest money making Pea that has been introduced since we first put out the Wonder Worker Pea. Be sure to give it a trial. Height $2 \frac{1}{2}$ feet. Pkt. 10c. Lb. 24c. 2 Lbs. $48 \mathrm{c}$. $10 \mathrm{Lbs} . \$ 2.10$. 25 Lbs. $\$ 5.00$. $100 \mathrm{Lbs}, \$ 18.00$.

1029. The Hustlers. Bolgiano's new, extremely early, handsome green podded Peas. Height $2 \frac{1}{2}$ feet. Pkt. 10c. Lb. 26c. 2 Lbs. 52c. 10 Lbs. $\$ 2.30$. 25 Lbs. $\$ 5.50$. 100 Lbs. $\$ 20.00$.

1088. New Extremely Early Prolific Bolgiano's "GO0D IUCK" Peas. Crop very short this year. Height $2 \frac{1}{2}$ feet. Pkt. 10c. Lb. 24c. 2 Lbs. 48c. 10 Lbs. \$2.10. 25 Lbs. $\$ 5.10$. 100 Lbs. $\$ 18.00$.

1071. Bolgiano's Extra Early Alaska Peas. By careful selection and thorough roguing we have a fine stock that is unequaled. Height $2 \frac{1}{2}$ feet. Pkt. 10c. Lb. 23c. 2 Lbs. 46c. 10 Lbs. $\$ 2.00$. 25 Lbs. \$4.75. 100 Lbs. $\$ 17.00$.

1070. Bolgiano's Extra Early Triumph Peas. Our standard market garden extra early Pea. Height $2 \frac{1}{2}$ feet. Pkt. 10c. Lb. 22c. 2 Lbs. 44 c. 10 Lbs. $\$ 1.90$. 25 Lbs. $\$ 4.50$. 100 Lbs. $\$ 16.00$.

1201. Pedigree Extra Early. Also known as "The New Early Pea." Extremely early, wonderfully productive and exceptionally uniform stock. Height $2 \frac{1}{2}$ feet. Pkt. 10c. Lb. 22c. 2 Lbs. 44 c. 10 Lbs. \$1.90. 25 Lbs. \$4.50. 100 Lbs. $\$ 16.00$.

1016. Ameer Peas. An exceptionally profitable Early Pea. Green seed. Height $21 / 2$ feet. Pkt. 10c. Lb. $24 \mathrm{c}$. 2 Lbs. $4 \mathrm{Sc}$ 10 Lbs. $\$ 2.10$. 25 Lbs. $\$ 5.00$. 100 Lbs. $\$ 1 \$ .00$.

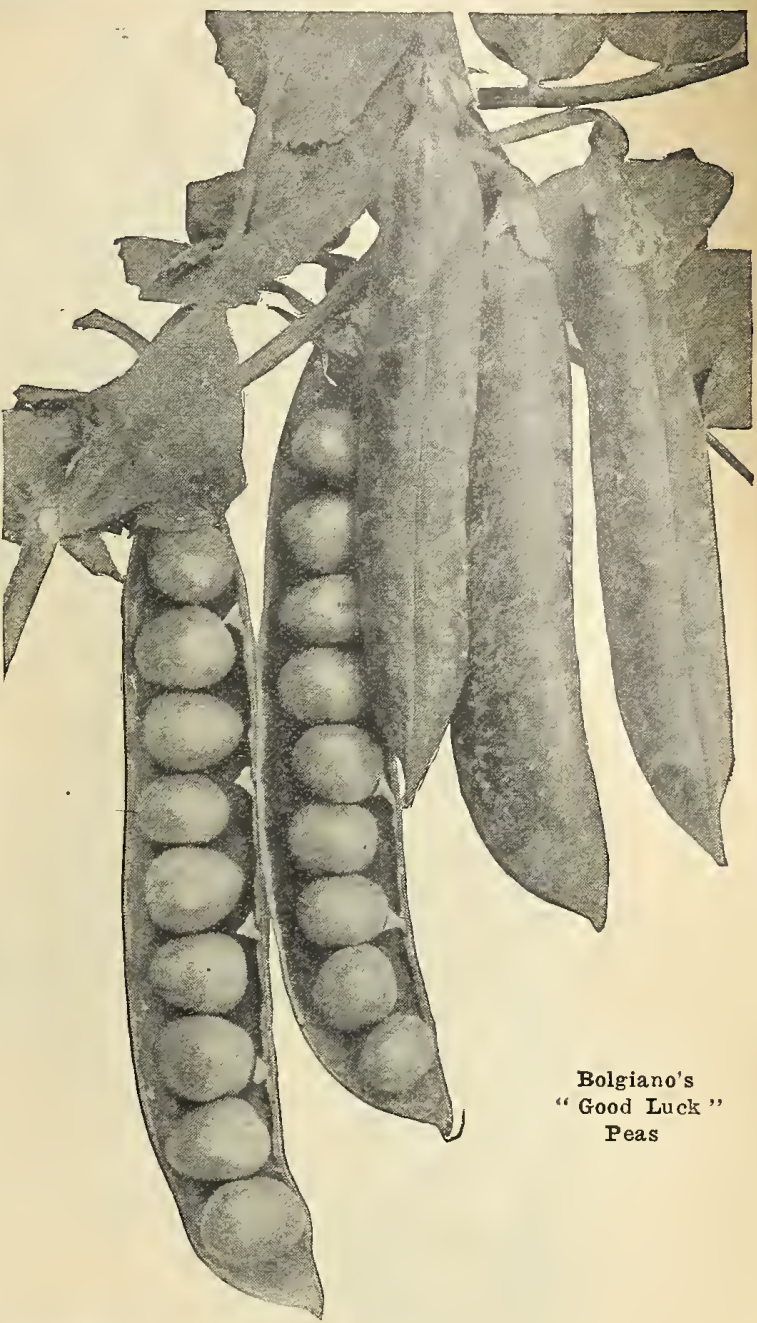

1082. Bolgiano's Extra Early Nonpareil Peas. Entire crop can be had at one picking. The beautiful green pods retain color and fresimess longer than other sorts. Heiglit $2 \frac{1}{2}$ feet. Pkt. 10c. Lb. 23c. 2 Lbs. 46c. 10 Lbs. \$2.00. 25 Lbs. \$4.75. $100 \mathrm{Lbs}$. $\$ 17.00$.

1260. Bountiful Peas. Bears an abundance of beautiful, green pods, crowded with delicious Peas. Extremely early Height $2 \frac{1}{2}$ feet. Pkt. 10c. Lb. 24c. 2 Lbs. 48 c. 10 Lbs. $\$ 2.10$. 25 Lbs. $\$ 5.00$. 100 Lbs. $\$ 18.00$.

1202. Prolific Early Market. Not quite so early as the Pedigree, but the most productive of all the Extra Early Peas. Beautiful large pods, fine quality, one of the best Peas ever introduced. Hcight $2 \frac{1}{2}$ feet. Pkt. 10c. Lb. 23c. 2 Lbs. $46 \mathrm{c}$. $10 \mathrm{Lbs}$. $\$ 2.00$. $25 \mathrm{Lbs} . \$ 4.75 .100$ Lbs. $\$ 17.00$.

1073. Extra Early Morning Star Peas. Many of our largest customers use this Pea, and it gives satisfaction. Height $2 \frac{1}{2}$ feet. Pkt. 10c. Lb. 22c. 2 Lbs, 44c. 10 Lbs. $\$ 1.90 .25$ Lbs. $\$ 4.50$. 100 Lbs. $\$ 16.00$

1074. First and Best. First-class selecied strain of extra early earlies. Height $2 \frac{1}{2}$ feet. Pkt. 10c. Lb. 22c. 2 Lbs. 4 4c. $10 \mathrm{Lbs}, \$ 1.90$. 1200 . Philadelphia Extra Early. Resembles the First and Best. Height $2 \frac{1}{2}$ feet. Pkt. 10c. Lb. $22 \mathrm{c} .2$ Lbs. $44 \mathrm{c} .210$ Lbs. $\$ 1.90 .25$ bs $\$ 4.500100$.

1075. Rural New Yorker. Fine sbape; prolific, extra early. Pkt. 10c. Lb. 22 c. 2 Lbs. 44 c. 10 Lbs. $\$ 1.90$. 25 Lbs. $\$ 1.50$. 100 Lbs. $\$ 16.00$.

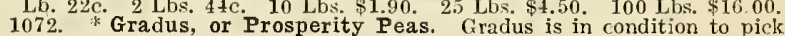
about 4 days after our Early Triumph. The pods are laroe, well filled with deep green Peas of the finest quality. Height 3 feet. Pkt. 10c. Lb. 26 c. 2 Lbs. 52 c. 10 Lbs. $\$ 2.30$. 25 Lbs. $\$ 5.50 .100$ Lbs. $\$ 20.00$

1077. * Improved Sugar Marrowfat Pea. Luxurious growth and abundant, large and handsome pods. Height 3 feet. Plit. $10 \mathrm{c} . \mathrm{Lb} .22 \mathrm{c}$. 2 Lbs. 4 tc. 10 Lbs. $\$ 1.90$. 25 Lbs. $\$ 4.50$. 100 Lbs. $\$ 16.00$.

1078. * Thomas Laxton. A cross between Gradus and one of the extra early sorts. It ripens within a day or two of the earliest round rarieties. Height 1 foot. Pkt. 10c. Lb. 26c. 2 Lbs. 52c. 10 Lbs. $\$ 2.30$.

25 Lbs. $\$ 5.50 .100$ Lbs. $\$ 20.00 .0$ Worker Pea. Earliest Extra Early Wrinkled Pea. Most profitable for growers. Pkt. 10c. Lb. 28c. 2 Lbs. 56c. 10 Lbs 50.25 Lbs $\$ 6.00,100$ Lbs Peas Cortinued on Next Page 


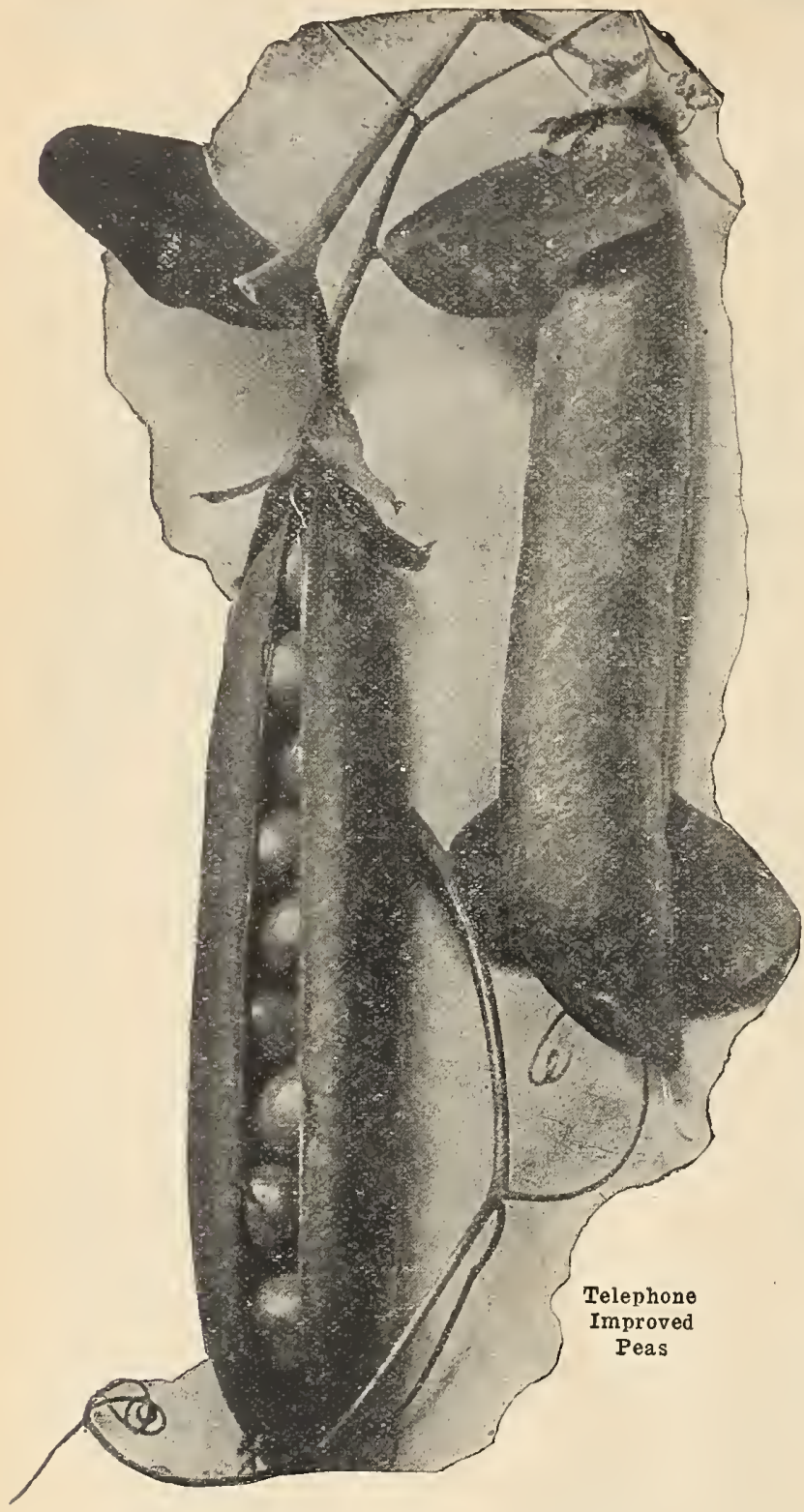

\section{Second Early and General Crop Varieties}

1277. "Bolgiano's "New Victory" Pea. New 1920 creation. Beautiful dark green pods $51 / 2$ to 6 inches long, filled full of deli cious large Peas. Pkt. 10e. Lb. 3lc. 2 Lbs. 62c. 10 Lbs. $\$ 2.80$. 25 Lbs. \$6.75. 100 Lbs. $\$ 25.00$

1089. * Bolgiano's "CRACKER JACK" Pea. Height 21/ feet. Pkt. 10c. Lb. 24c. 2 Lbs. 48 c. 10 Lbs. $\$ 2.10 .25$ Lbs. $\$ 5.00$. 100 Lbs. $\$ 18.00$.

1231. * Horsford's Market Gardeners' Pea. One of the largest yielding second early Peas in cultivation. Only 2 feet high. The pods are bolne in parrs. Pkt. 10c. Lb. 22c. 2 Lbs, 44c. 10 Lbs. \$1.90. 25 Lbs. $\$ 4.50$ 100 Lbs. $\$ 16.00$

1090. * Dwarf Giant Podded Prolific Green Marrow Pea. Bears enormous, handsome pods 7 to 8 inches in length, filled with large deep green Peas; requires no support. Height 2 feet. Pkt. 10c. Lb. 24c. 2 Lbs, $48 \mathrm{c}$. $10 \mathrm{Lbs} \$ 210,25 \mathrm{Lbs} \$ 5.00,100 \mathrm{Lbs} \$ 18,00$

$1092 \%$ Shropshire Hero. Very productive ; fine flavor ; long pods. Height $21 / 2$ feet. Pkt. 10c. Lb. $26 \mathrm{c}, 2$ Lbs. $52 \mathrm{c}, 10$ Lbs. $\$ 2.30 .25$ Lbs. $\$ 5.50$ 100 Lbs. $\$ 20.00$

1093. Champion of England. A well-knowi, standard variety. Hejght 5 feet. Pkt. 10c. L.b. 23c. 2 Lbs. 46c. 10 Lbs. $\$ 2.00$. 25 Lbs. $\$ 4.75 .100$ Lb. $\$ 17.00$.

1218 $\frac{1}{2}$. Alderman. (Admiral Dewey.) Extra large, dark green pods, on order of Duke of Albany. Very fine. Height 4 feet. Pkt. 10c. Lb. 26c 2 Lbs. 52 c. 10 Lbs. $\$ 2.30$. 25 Lbs. $\$ 5.50 .100$ Lbs. $\$ 20.00$.

108.0. * Telephone Improved. Robust habit. A single vine produces 18 to 30 unusually long well-filled pods of larger size, containing 10 to 12 Peas, often forming a double row, of fine flavor. Height 5 feet Pkt. 10c. Lb. 26c 2 Lbs, 52c 10 Lbs $\$ 2.30$, 25 Lbs $\$ 5.50$. 100 Lbs $\$ 20.00$

1301 . Market Surprise, A little later than the Pedigree. Prolific vielder. Beautiful lioht oreen color. Pods about three inches long containing from seven to eight peas of most dolicious flavor Excellent for market and shipping. Lb. to eight Peas of most delicious flavor. Excellent for market and shippi

1302. Potlatch Peas. An excellent market garden Pea bearing an abundance of large pods filled full of delicious beautiful green Peas. Lb. 23c. 2 Lbs. 46c. 10 Lbs. $\$ 2.00$. 25 Lbs. $\$ 4.75 .100 \mathrm{Lbs}$. $\$ 17.00$

1102. * Everbearing. A long time in bearing. Peas large, pods long. $1 \frac{1}{2}$ feet high. Pkt. $10 \mathrm{c}$. Lb. $22 \mathrm{c} .2$ Lbs. $44 \mathrm{c} .10 \mathrm{Lbs}$. $\$ 1.90 .25 \mathrm{Lbs} . \$ 4.50$ 100 Lbs. $\$ 16.00$.

1086. * Daisy, or Dwarf Telephone, Plants stout, self-supporting, heavy cropper. Height $1 \frac{112}{2}$ feet. Pkt. 10c. Lb. 28c. 2 Lbs. 56c. -10 Lbs. $\$ 2.50$ 25 Lbs. $\$ 6.00$. 100 Lbs. $\$ 22.00$

1094 * Dwarf Champion. A dwarf growing Champion of England. Height 2 feet. Pkt. 10c. Lb. 24 c. 2 Lbs. $48 \mathrm{c} .10$ Lbs. $\$ 2.10 .25$ Lbs, $\$ 5.00$ 100 L $\$ 1800$

100 Lbs. \$18.00. Juno. 2 feet high. Large pods filled with large dark green Peas of delicious flavor. Pkt. $10 \mathrm{c}$ Lb. $24 \mathrm{c} .2 \mathrm{Lbs} .48 \mathrm{c} .10 \mathrm{Lbs} . \$ 2.10 .25 \mathrm{Lbs}$ $\$ 5.00$. 100 Lbs. $\$ 18.00$

1100. * Duke of Albany. 4 feet higb. Dark green pods, prolific. Pkt. 10c. Lb. $26 \mathrm{c} .2$ Lbs. $52 \mathrm{c} .10$ Lbs. $\$ 2.30 .25$ Lbs. $\$ 5.50 .100$ Lbs. $\$ 20.00$ 1303. Edible Podded Mammoth Melting Sugar. The vines reach height of about 4 feet. The pods are borne in great profusion. They should be gathered when the seeds are just beginning to form. They are broken in pieces the same as string beans and make a delicious dish. Pkt. 10c. Lb. 31c 2 Lbs. $62 \mathrm{c} .10$ Lbs. $\$ 2.80$. 25 Lbs. $\$ 6.75$. 100 Lbs. $\$ 25.00$.

1199. Dwarf Gray Sugar. Grow 18 inches high and produce a heavy crop of small flat pods. The pods are gathered, broken and cooked like string crept. 10c Lb, 28c 2 Lbs. $56 \mathrm{c}, 10 \mathrm{Lbs}$ \$2.50. $25 \mathrm{Lbs}$. $\$ 6.00$. 100 Lbs. $\$ 22.00$.

56c. 1110. * Stratagem, Very large pods. Peas of finest quality. Height $1^{1 / 2}$ feet. Pkt. $10 \mathrm{c} .4$ Lb. $23 \mathrm{c}$. 2 Lbs. $46 \mathrm{c} .10$ Lbs. $\$ 2,00,25$ Lbs. $\$ 4.75$. 100 Lbs. $\$ 17.00$

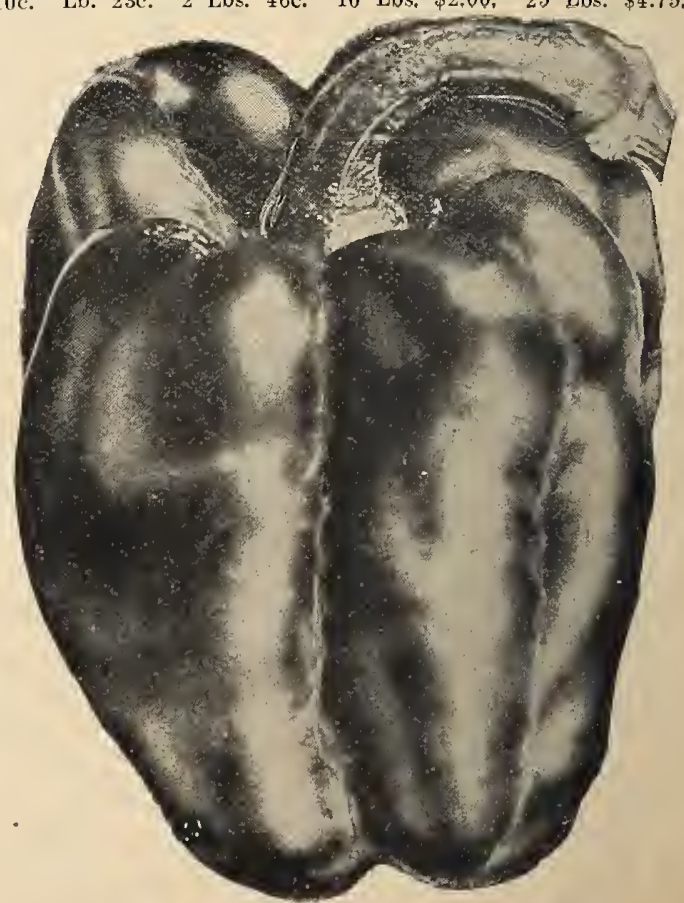

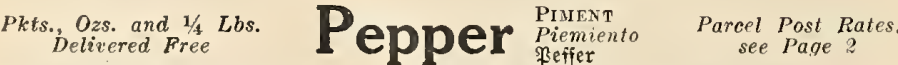

Culture. Sow in hotbeds in March, and when the soil has become warm, set in rows 2 feet apart and 18 inches in the row ; hoo frequently; the plants may also be forwarded in small pot

163. Scarlet Mammoth, Bolgiano's New Early Pepper. Much carlier and more prolific than the Chinese Giant, Plits. 5e and 10c. 1/2 Oz. 20c. Oz. 35c. $1 / 4$ Lb. $\$ 1.10$. 1/2 Lb. $\$ 2.00$. Lb. $\$ 3.75$.

226. Chinese Giant. Pkts. 5r and 10c. 1/2 Oz. 20c. Oz. 35c. 1/4 Lb. $\$ 1.10$. $1 / 2$ Lb. $\$ 2.00$. Lb. $\$ 3.75$

396. World Beater. Pkts. 5c and 10c. 1/2 Oz. 20c. Oz. 35c. 2 Ozs. 60c. $1 / 4$ Lb. $\$ 1.10$. 1/2 Lb. $\$ 2.00$. Lb. $\$ 3.75$.

233. New Neapolitan. Pkts. 5c and 10c. 1/2 Oz. 15e. Oz. 30c. 2

Ozs. 55c. 1/4 Lb. 85c. 1/2 Lb. $\$ 1.60$. Lb. $\$ 3.00$.

227. Ruby King Peppers. Extra Selected Stock. Recognized as one of the best Red-Peppers for market or family use. Pkts. 5e and 10e. 1/2

Oz. 15c. Oz. 30c. 1/4 Jh. 85c. 1/2 Lb. $\$ 1.60$. Lb. $\$ 3.00$.

562. Sweet Bull Nose. Pkts. $5 \mathrm{c}$ and 10c. Oz. 30c. 1// Lb. 85c. Lb. $\$ 3.00$.

Sweet Mountain. Flesh very thick and mild. Pkts. 5c and 10c. Oz. 30c.

$1 / 1$ Lb. $85 \mathrm{c}$. Lb. $\$ 3.00$

560. True Red Chili. Not as long or thick as Cheyenne. Pkts. $5 \mathrm{c}$ and 10c

Lb. $\$ 1.00$ Lb. $\$ 3.50$

561 . Long Red Cheyenne, For pickling. Pkts. 5c and 10c. 0z. 30c. 1; Lb.

563. Red Cherry. Pkts. 5c and 10c. Oz. 30c. 1/4 Lb. $\$ 1.00$. Lb. $\$ 3.50$

485. Pimento Pepper. Pkts. 5c and $10 \%$ o\% 30c. 1/4 Lb. 85e Lb. $\$ 3.00$

Bolgiano's Selected Ruby King Pepper 


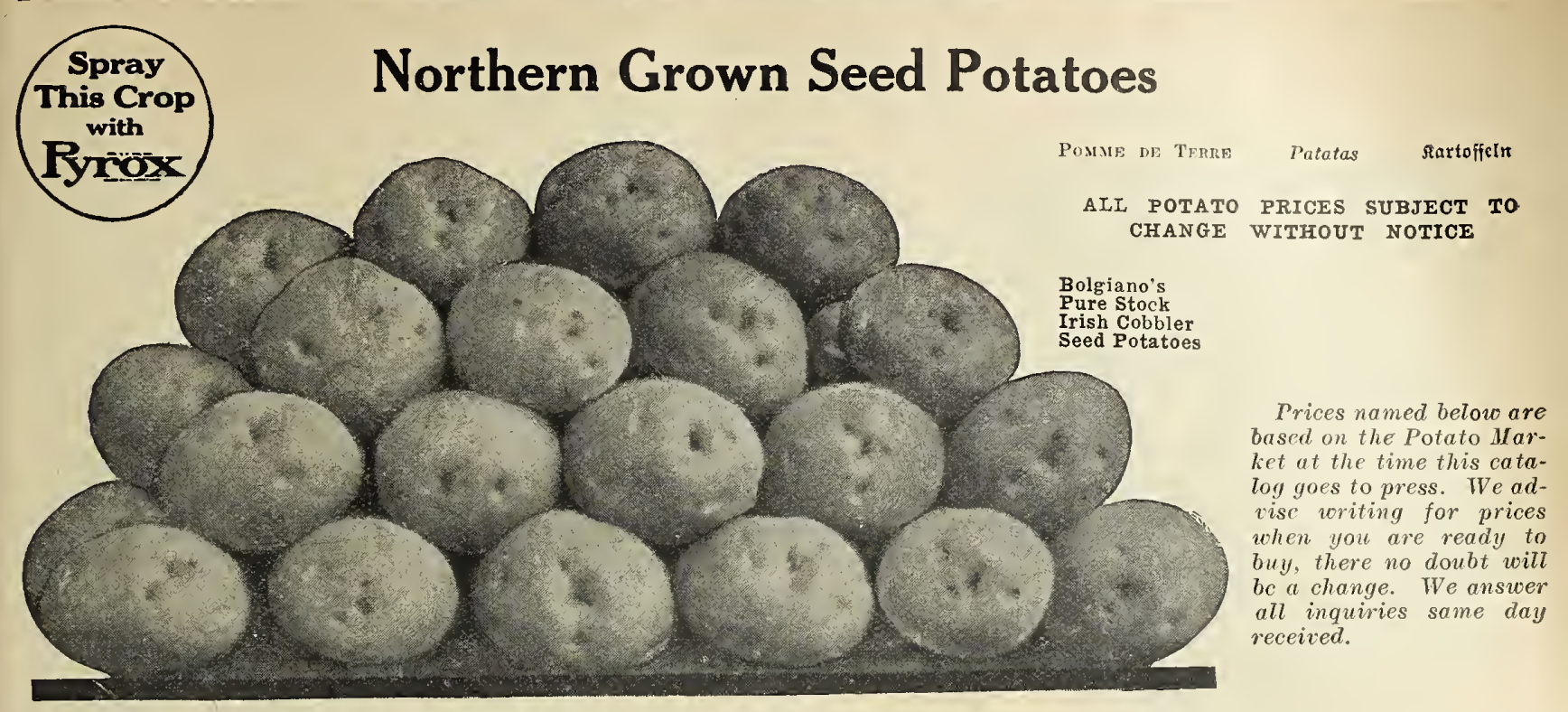

Culture. Any good, well drained, fibrous loam will produce Potatoes under right climatic conditions. Open furrows 3 feet apart and 3 to 4 inches deep. Apply the fertilizer, and run the furrower or small plow again in the furrow to mix the fertilizer with the soil and leare a mellow seed-
bed. Then plant good-sized pieces, each containing not less than 2 or 3 eyes, 15 inches apait in the furrows for early Potatoes, and 18 inches apart for late ones. Cultivate often. Spray with Bordeaux Arsenate of Lead Mixture as a protection from fiea beetle, Potato beetle and blight. 8 to 10 busbels will plant an acre.

Trust Buster. Bolgiano's Wonderful, New, Prodigious Yielding, Early Seed Potatoes. Pk. \$1.00. 1/2 Bu. \$1.75. Bu. $\$ 3.25$. Bbl. sack $\$ 7.50$.

Plucky Baltimore. The best and earliest Potato on earth. Without equal. Pk. \$1.00. 1/2 Bu. \$1.75. Bu. \$325. Bbl. sack $\$ 7.50$.

Gray's Mortgage Lifter Seed Potato. An enormous yielder, second early Potato with no culls. Pk. $\$ 1.00$, 1/2 Bu. $\$ 1.75$. Bu. \$3.25. Bbl. sack $\$ 7.50$.

Red Bliss Triumph or Improved Red Bermuda. One of the earliest varieties grown. Its great productiveness, landsome color and resistance to diseasc make it most popular. Pk. $\$ 1.00$. 1/2 Bu. $\$ 1.85$. Bu. $\$ 3.35$. Bbl. sack $\$ 8.00$.

Ensign Bagley or White Rose. An excellent cropper, smooth, not susceptíble to disease. Pt.. 90c. $1 / 2$ Bu. $\$ 1.60$. Bu. $\$ 3.00$. Bbl. sack $\$ 7.00$.

Early Round Six Weeks, Ready for table in six weeks. Pk. 90c. $1 / 2$ Bu. $\$ 1.60$. Bu. $\$ 3.00$. Bbl. sack $\$ 7.00$.

Sir Walter Raleigh. Big cropper, flesh white, superior quality, fine grained Pk. 90c. $1 / 2 \mathrm{Bu}, \$ 1.60$. Bu $\$ 3.00$, Bbl. sack $\$ 7,00$.

Green Mountain. $\Lambda$ very popular main ctop Potato. Pk. 90c. 1/2 Bu. $\$ 160$. Bu. $\$ 3.00$. Bbl. sack $\$ 7.00$.
Bolgiano's Famous Prosperity Potato. Yields fine crops of even, fine. mooth, large Potatoes under the most unfavorable circumstances. Flesh is as white as snow and cooks dry and mealy. Pk. $\$ 1.00$. 1/2 Bu. $\$ 175$. Bu. $\$ 3.25$. Bbl. sack $\$ 7.50$.

Carmon No. 3. Most successful of the Carmon's; heavy yielder. Pk. 90c. $1 / 2$ Bu. $\$ 1.60$. Bu. $\$ 3.00$. Bbl. sack $\$ 7.00$.

Maine Houlton Early Rose. The genuine Early Rose still remains the standard early variety. $\mathrm{Pk}$. 90c. $1 / 2 \mathrm{Bu} . \$ 1.60$. Bu. $\$ 3.00$. Bbl. sack $\$ 7.00$.

Irish Cobbler. It is a vigorous grower, ripens uniformly, and a good keeper. Pk. 90c. $1 / 2$ Bu. $\$ 1.60$. Bu. $\$ 3.00$. Bbl. sack $\$ 7.00$.

Rural New Yorker. Second ealy, large, smootl, white, wide as long, very productive. Pk. $90 \mathrm{c} .1 / 2$ Bu. $\$ 1.60$. Bu. $\$ 3.00$. Bbl. sack $\$ 7.00$

Early Ohio. One of the standard early varieties. Full week earlier than the Early Rose; shape oblong; quality diy, mealy. Pk. 90c. $1 / 2 \mathrm{Bu}$ $\$ 1.60$. Bu. $\$ 3.00$. Bbl. sack $\$ 7.00$.

American Giants. One of the most popular of the new heavy yielding Potatoes. Pk. 90c. $1 / 2$ Bu. $\$ 160$. Bu. $\$ 3.00$. Bbl. sack $\$ 7.00$.

McCormack Potatoes. A very late, heavy yielding Potato, about the best of all Winter keepers. Pk. 90c. $1 / 2$ Bu. $\$ 1.60$. Bu. $\$ 3.00 . \quad B b l$ sack $\$ 7.00$.

Burbank. An old standard popular on account of its fine eating quality Pk. 90c. 1/2 Bu. \$1.60. Bu. \$3.00. Bbl. sack $\$ 7.00$.

Spalding No. 4, Extra Early Rose XX. Earliest Rose Potato in the world, good cropper, fine appearance. Pk. 90c. $1 / 2 \mathrm{Bu} . \$ 1.60$. Bu. $\$ 3.00$ Bbl. sack $\$ 7.00$. 
Radish

We Pay Postage on Pkts., Ozs., 14 Lbs. and Lbs.

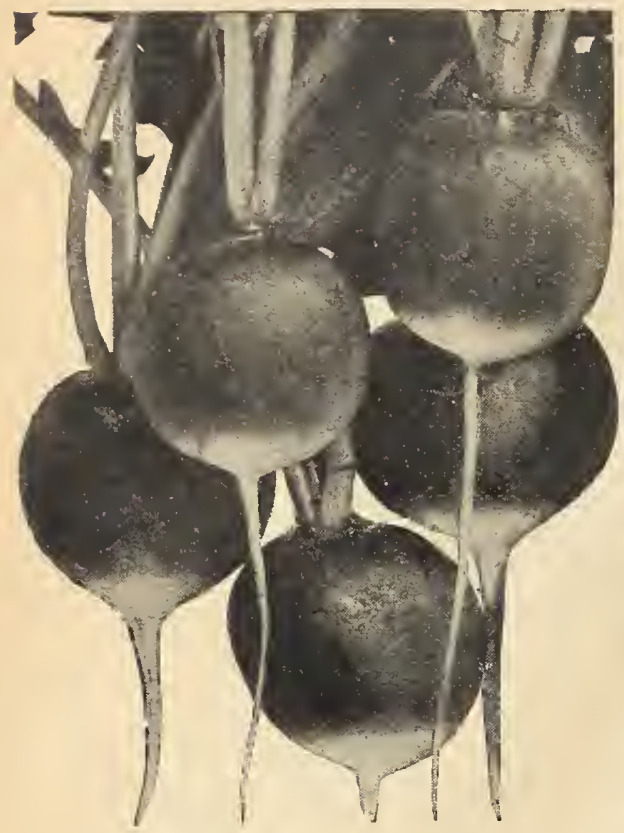

Tip Top White Tip Radish

Ozs, to 100 Feet of Drill

Culture. Sow as soon as the ground is dry in the Spring, in rows 8 to 12 inches apart, every week or 10 days for succession, up to the middle of June, after which they are little used, unless a cool northern spot can lse found where the ground is sladed during part of the day. They should be sown in light, rich soil, as a crisp Radish cannot be produced in heavy soils. Sow also in early Fall for late crops and Winter use. Sow 8 to 12 pounds to the acre. Radishes should be eaten when quite small; it is a mistake to let them grow too long and too large. This applies, particularly to Ruby King and small turnip-shaped sorts.

\section{Extra Early Round Varieties}

9. Tip Top White Tip. The beautiful New Extremely Early Radish. Pkts. 5c and 10c. Oz. 10c. 1/4 Lb. 25c. 1/2 Lb. 45c. Lb. 85e.

258. Strawberry Radish. This is the extremely early round Radish that attracted so much attention when we first introduced it by sample packages to our Market Garden customers. Pkts. 5c and 10c. Oz. 10c. 1/4 Lb. 30c. 1/2 Lb. 50c. Lb. $90 \mathrm{c}$.

230. Ruby King, Bolgiano's Extra Early Radish. The best of all brilliant red Radishes. Pkts. 5c and 10c. Oz. 15c. 1/4 Lb. 30c. 1/2 Lb. 55c. Lb. $\$ 1.00$.

238. Bolgiano's Round Scarlet Globe Radish. Rich, scarlet color, faultless shape, matures in 20 days. Pkts. 5c and 10c. Oz. 10c. 1/4 Lb. 25c. 1/2 Lb. $45 \mathrm{c}$, Lb. $85 \mathrm{c}$.

241. Vick's Scarlet Globe Radish. A leader among bright, round, red Radishes. Quick maturing, extremely attractive, short tops, solid and fine flavor. Pkts. 5c and 10c. Oz. 10c. 1/4 Lb. 25c. Lb. 85c.

232. Lexington Market Money Maker. The best early, round, white, turnip Radish. Pkts. 5c and 10c. Oz. 10c. 1/4 Lb. 25c. Lb. $75 \mathrm{c}$.

240. Crimson Giant Globe Radish. Originator's Stock Seed. This is an entirely new variety, suitable for forcing or early outdoor planting. Pkts. 5c and 10c. Oz. 10c. 1/4 Lb. 20c. 1/2 Lb. 35c. Lb. 65 a.

231. Felton's Model or Philadelphia White Box Radish. Handsome and early, with fewer short leaves, lience can be sown thickly in the row. Pkts. 5c and 10c. Oz. 10c. $1 / 4$ Lb. 20c. $1 / 2$ Lb. 35c. Lb. 65 c.

509. Prussian Globe Radish. It is a GLOBE shape of a crimson color, short top and will stand forcing. Pkts, 5e and 10c. Oz. 10c. 1/4 Lb. 25c. 1/2 Lb. 40c. Lb. $75 \mathrm{c}$.

248. Bolgiano's Solid Crimson King. Double the size of the ordinary early turnip-shaped Radishes. this one often measuring 6 to 7 inches in circumference; the shape varies between round and oval; adapted for either open ground or forcing. Pkts, 5c and 10c. Oz. 10c. 1/4 Lb. 25c. 1/2 Lb. 40c. Lb. $75 \mathrm{c}$.

\section{Early Long Varieties}

255. Improved Early Long Scarlet Short Top. The finest strain of the most popular Radish. The long, slender, handsome red roots are most attractive. They are ready in about 25 days. Crisp, brittle and of choicest quality. Length 5 to 6 inches. Pkts. 5c and 10c. Oz. 10c. $1 / 4$ Lb. 20c. $1 / 2$ Lb. 35e. Lb. $60 \mathrm{c}$.

250. Bolgiano's New Long Red Glass Radish. Plits, 5c and 10c. Oz. 10a. 1/4 Lb. 20c. 1/2 Lb. 35c. Lb. 65e.

252. Cincinnati Market. A strain of the Long Scarlet, growing to slightly larger size, fully as early and darker in coloring. Pkts, 5c and 10e. Oz. 10c. 1/4 Lb. 20c. 1/2 Lb. 35e. Lb. $60 \mathrm{c}$.

537. Woods' Early Frame. This is an extra early strain of the Long Scarlet Short Top, largely used for growing under glass. Pkts. 5c and $10 \mathrm{c}$. Oz. 10c. 1/4 Jb. 20c. 1/2 Lb. 35c. Lb. 60c.

249. White Pearl Forcing. Bolgiano's Extra Early Long Radish. Sweet, crisp flavor, very popular and profitable. Pkts. 5c and l0c. Oz. 10c. 1/4 Lb. 20c. $1 / 2$ Lb. 35c. Lb. $60 \mathrm{c}$.

257. New White Icicle Radish. Introduced from Europe, is one of the finest and longest of the very early, pure white varietics. Pkts. 5c and $10 \mathrm{c}$. Oz. 10c. 1/4 Lh. 20c, 1/2 Lb. 35c. Lb. 60c.

253. Lady Finger or White Vienna. Long white, very early, attractive. Pkts. $5 \mathrm{c}$ and $10 \mathrm{c} . \mathrm{Oz}$ 10c. $1 / 1 / 1$ Lb. 20 c. $1 / 2$ Lb. 35c. Lb. 60c.

557. Half Long Deep Scarlet. Tery popular in the New Orlcans Market. The radislies are of slightly larger diameter and most brilliant scarlet coloring. Flesh purest white, erisp, juicy. Pkts. 5c and 10c. Oz. I0e. 1/4 JA). 20e. 1/2 Jh. 35e. Lb. 60e.
239. Scarlet Turnip White Tip Radish. Round, bright scarlet, attractive, white tip, matures in 25 days. Pkts. $5 \mathrm{c}$ and 10c. Oz. 10c. $1 / 4$ Lb. 25c. $1 / 2$ Lb. 40c. Lb. 75 e.

538. Rosy Gem. Everybody wants this pretty, crisp tasty little French Radish, so showy with its brilliant cardina red, contrasted with its immaculate white. Pkts. $5 \mathrm{c}$ and $10 \mathrm{c}$. Oz. 10c. $1 / 4$ Lb. 25c. Lb. $75 \mathrm{c}$.

500. Early Snowball. Forcing White Turnip Radish. Earliest, round, white, solid. Pkts. $5 \mathrm{c}$ and $10 \mathrm{c} .0 \mathrm{Oz} .10 \mathrm{c} .1 / 4 \mathrm{Lb}$. 20c. Lb. $65 \mathrm{c}$.

235. French Breakfast Radish. Quick growth, mild, tender, good for forcing. Pkts. 5c and 10c. Oz. 10c. $1 / 4 \mathrm{Lb}$. 20c. Lb. $65 \mathrm{c}$.

246. Tait's Favorite Forcing Extra Early Radish. For forcing under glass. It is also largely used for field culture. Perfect both in shape and color, the skin being a bright, trans parent red, and many bunches may be put in a single package. P'kts. 5c and 10c. Oz. 10c. 1/4 Lb. 20c. Lb. 65c.

370. New Sparkler White Tip Red Radish. Pkts. 5c and 10c. Oz. 10c. $1 / 4$ Lb. $25 \mathrm{c}$. $1 / 2$ Lb. $40 \mathrm{c}$. Lb. $75 \mathrm{c}$.
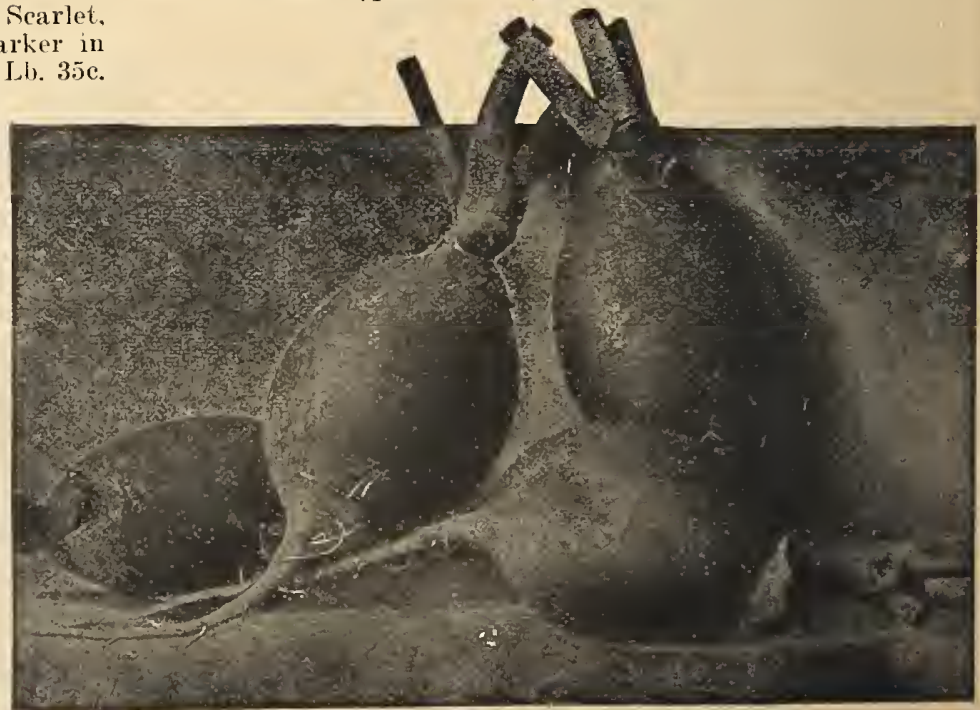

Ruby King Radish 


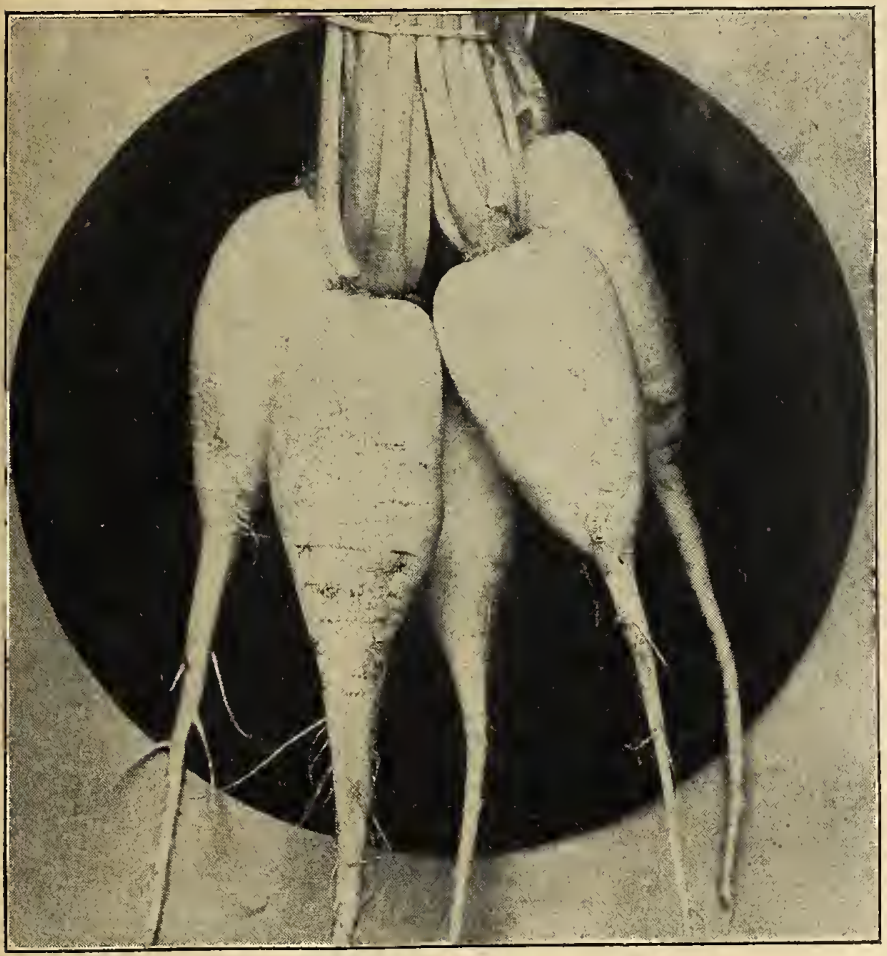

New White Strasburg Radish

\section{Radish}

\section{Summer and Autumn Varieties}

254. New White Strasburg Radish. The most popular Summer Radish; of oblong shape, tapering to a point. Skin and flesh arc pure white, almost transparent; very tender. of a delightful pungent state. Pkts. $5 \mathrm{c}$, and $10 \mathrm{c} . \mathrm{Oz} .10 \mathrm{c}$. $1 / 4$ Lb. 25c. $1 / 2$ Lb. 40 c. Lb. 75 c.

243. Large White Globe Summer. Deliciously mild and sweet. Pkts. 5c and $10 \mathrm{c}$. Oz. 10c. 1/4 Lb. 20c. Lb. 60c.

244. Giant White Stuttgart. An immense white summer radish. Pkts. 5c and 10c. Oz. 10c, $1 / 4 \mathrm{Lb}, 20 \mathrm{c}, 1 / 2 \mathrm{Lb}$. 35c. Lb. $60 \mathrm{c}$

247. Chartier or Shepherd. Long, crimson, tipped with white. Pkts. 5c and 10c. Oz. 10c. $1 / 1 / 4$ Lb. 20c. Lb. 60c.

\section{Winter Varieties}

256. New Short White Chinese Winter or Celestial Radish. The best of all Winter Radishes. Pkts. 5e and $10 \mathrm{e}$ Oz. 10c. $1 / 4$ Lb. 20c. $1 / 2$ Lb. 30c. Lb. $50 \mathrm{c}$.

242. Chinese Rose Winter. Pkts, $5 \mathrm{c}$ and $10 \mathrm{c}$. Oz. $10 \mathrm{c}$ $1 / 4$ Lb. 20c. $1 / 2$ Lb. 30c. Lb. 50c.

259. Round White Spanish Winter. Pkts. $5 \mathrm{c}$ and $10 \mathrm{c}$ Oz. 10c. $1 / 4$ Lb. 20c. $1 / 2$ Lb. 30c. Lb. 50c.

261. Long White Spanish Winter. Pkts. 5e and $10 \mathrm{c}$ Oz. 10c. $1 / 4$ Lb. 20c. $1 / 2$ Lb. 30c. Lb. 50c.

260. New Winter Radish 0saka. Pkts. 5c and $10 \mathrm{c}$ Oz. 10c. 1/4 Lb. 20c. 1/2 Lb. 30c. Lb. 50c.

263. Long Black Spanish Winter. Pkts. 5c and $10 \mathrm{c}$. Oz. 10c. $1 / 4$ Lb. 20c. $1 / 2$ Lb. 30c. Lb. 50c.

\section{Rhubarb or Pie Plant}

The seed should be sown in a shallow drill, using 1 ounce to 150 feet of row. When well started, thin to stand 10 to 12 inches apart. The stalks should not be gathered until the plants have lad a full season's growth.

Myatt's Victoria. The most popular variety; comes quite true from seed. Pkts. 5c and 10c. Oz. 15c. 1/4 Lb. 45c. L.l, $\$ 1.50$. Postpaid.
Rhubarb Roots. Roots listed below, if planted in good soil in the spring, will make a strong growtl and yield stalks for market the following spring.

2-Year-0ld, Extra Large Fine Roots. $25 \mathrm{c}$ each. 3 for $65 \mathrm{c}$. Postpaid. By express, not prepaid: Doz. $\$ 2.00$. 100 roots, $\$ 15.00$.

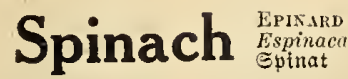

1104. Curled Leaf Savoy or Bloomsdale, Imported. We grow many thousands of pounds of both the American and linported seed each year. We believe our private stock is the choicest it is possible to produce. 'We solicit your orders. Pkt. 5c. Oz. 10c. $1 / 4$ Lb. 15c. 1/2 Lb. 25c. Lb. 35c. 10 Lbs. at $30 \mathrm{c} \mathrm{Lb}$.

1105. Curled Leaf Savoy or Bloomsdale. American Grown. Large curled and wrinkled leaves, tender, finest flavor. Pkt. $5 \mathrm{c}$. Oz. $10 \mathrm{c}$. 1/4 Lb. $15 \mathrm{c}$. Lb. 40c. 10 Lbs. at $35 \mathrm{c} \mathrm{Lb}$.

1000. Long Season Spinach. This new variety is especially adapted for Summer sowing, as it remains in perfect condition a long time, before going to seed. Pkt. 5c. Oz. 10c. 1/4 Lb. 15c. 1/2 Lb. $25 \mathrm{c}$. Lb. $35 \mathrm{c}$.

1108. Long Standing, Thick-Leaved Spinach. Leaves are large, thick, fleshy, and erumpled, fully equal to the Savoy Leaf. Pkt. 5e. Oz. 10c. 1/4 Lb. 15c. $1 / 2$ Lb. $25 \mathrm{c}$. Lb. $35 \mathrm{c}$.

1109. Monstrous or Viroflay. A valuable variety; has large, round, thick leaves. Pkt. 5c. Oz. 10e. $1 / 4$ Lb. 15c. $1 / 2$ Lb. $25 \mathrm{c}$. Lb. $35 \mathrm{c}$.

1232. New Triumph Spinach. This excellent new Spinach is nearly double the size of the Victoria and has all of its good qualities. Very profitable for market gardeners and shippers. Pkt. 5c. Oz. $10 \mathrm{c}$. $1 / 4$ Lb. $15 \mathrm{c}$. 1/2 Lb. 25c. Lb. 40c.

1262. New Zealand Spinach. This variety endures heat and drought; excellent for Summer use. Pkt. 5c. Oz. 10c. 1/4 Lb. 20c. 1/2 Lb. 35c. Lb. 60c.
1106. New Improved Curled Long Standing. The very best for Spring. Pkt. 5c. Oz. 10c. $1 / 4$ Lb. 15c. $1 / 2$ Lb. 25c. Lb. 35c.

1107. New Victoria Spinach. The foliage is heavy, the broad, dark green leares are of the finest quality. Pkt. 5c. $\mathrm{Oz}$. 10c. $1 / 4$ Lb. 15 c. $1 / 2$ Lb. 25 c. Lb. 35 c.

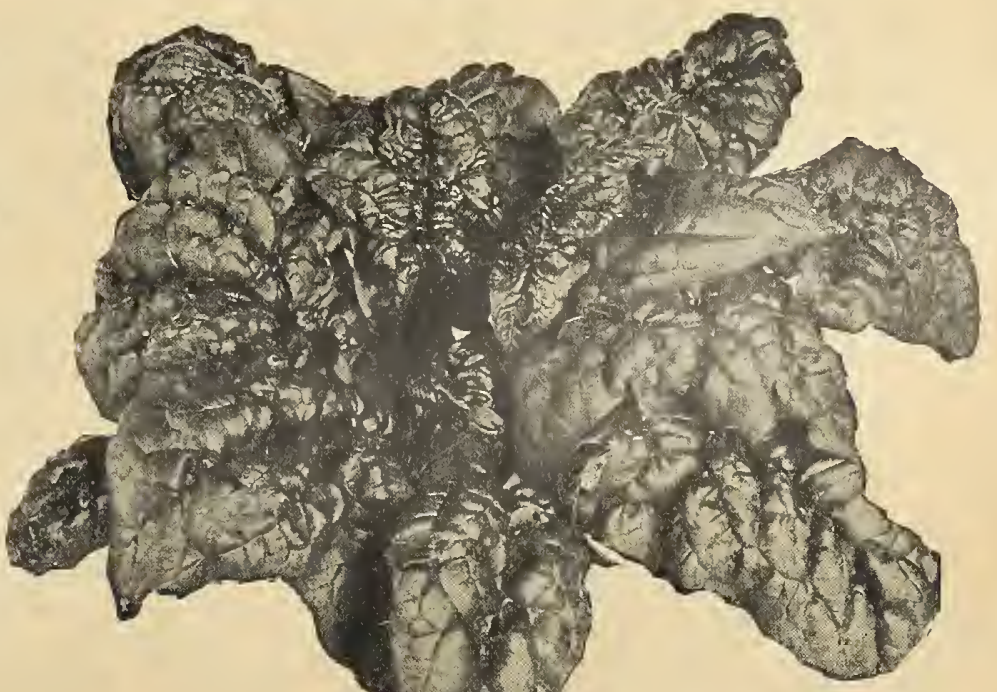

Curled Leaf Savoy or Bloomsdale Spinach 


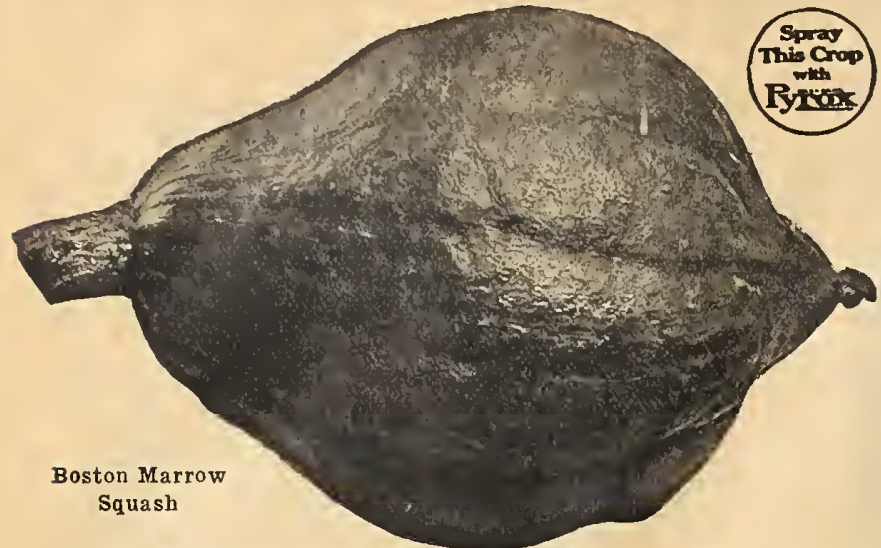

331. Bolgiano's Extra Early Dawn Squash. The earliest and finest white Bush Squash. Pkts. 5c and 10c. Oz. 10c. $1 / 4$ Lb. 30c. $1 / 2$ Lb. 50c. Lb. 90c.

501. New Extra Early Jersey White Bush. An extra early strain of the White Busl. Pkts. 5c and 10c. Oz. 10c. $1 / 4$ Lb. 25c. Lb. $75 \mathrm{c}$.

304. Mammoth or Giant Summcr Crookneck Squash. Double the size of the ordinary Crookneck and very warty; fine for market. Pkt. 5c, Oz, 10c. $1 / 4$ Lb. 25c. $1 / 2$ Lb. 40c. Lb. $75 \mathrm{c}$.

\section{Running Varieties}

272. Early Prolific Orange Marrow. A very early, prolific Boston Marrow of most delicate flavor and uniform type. suitable for Fall or Winter. Pkt. 5c. Oz. 10c. 1/4 Lb. 25c. $1 / 2$ Lb. 40e. Lb. $75 \mathrm{c}$.

273. Boston Marrow. Oval, bright orange, flesli yellow. Our stock is exceptionally fine. Pkt. 5c. Oz. 10c. 1/4 Lb. 25c. $1 / 2$ Lb. 40 c. Lb. $75 \mathrm{c}$.

\section{Pumpkins}

Culture. May be planted middle of Spring among Indian Corn or in field or garden, in hills 8 to 10 feet apart each way, 4 seeds in a hill: in other respects are cultivated in same manner as Melons and Cucumbers: avoid planting near other vines, 2 Lbs. to acre.

274. Improved Winter Crookneck or Cushaw. Mottled green and white; flesll is yellow, solid, fine grained and sweet; excellent for pies. Pkts. $5 \mathrm{c}$ and $10 \mathrm{c}$. Oz. $10 \mathrm{c}$. $1 / 4 \mathrm{Lb} .30 \mathrm{c}$. $1 / 2$ Lb. 50 c. Lb. 90 c.

136. Small Sugar Pumpkin. Small orange colored, sweet. Pkt. 5c. Oz. 10c. $1 / 4$ Lb. 25c. Lb. 75 c.

10581/2. Kentucky Large Field. Flat, fine for Pumpkin pies, Winter, etc. Pkt. 5c. Oz. $10 \mathrm{c}$. $1 / 4$ Lb. 20 c. Lb. 50 c.

225. Sweet Potato Pumpkin. Finest variety for table. Pkt. 5c. Oz. 10c. 1/4 Lb. 20c. Lb. $60 \mathrm{c}$.

365. Winter Luxury. A superior pie Pumpkin, small but enormously productive and an excellent keeper; shape slightly oval, about 10 inches in diameter, color golden-russet, finely netted; flesli deep golden, sweet and tender. Pkt. 5c. Oz. 10c. $1 / 4$ Lb, 25c. $1 / 2$ Lb, 40 c. Lb. 70 c.

\section{Potiron} $50 \mathrm{c}$. $1 / 2$ Lb. 40c. Lb. 70c. 35c. Lb. 60c.

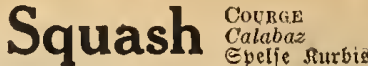

We Pay Postage on Pkts., Ozs., 14 Lbs. and Lbs.

1 Os. Bush Varieties for 40 Hills; Large Seeded Varieties, 15 Hills; 2 to :3 Lbs. Bush; 3 to $4 \mathrm{Lbs}$. Large Seeded per Acre

Culture. Sow in hills in the same manner and at the same time as Cucumbers and Melons, the bush varieties 3 to 4 feet apart, and the ruming kinds from 6 to 9 feet apart.

\section{Bush Varieties}

329. Fordhook Bush. Early, sweet and dry, ohlong. bright yellow, one of the handsomest and best keeping llinter varieties, also a good Summer sort. Pkt. 5c. Oz. 10c. $20 \mathrm{gm}$. 15c. $1 / 4$ Lb. $25 \mathrm{c}$. Ll. $75 \mathrm{c}$

269. Golden Summer Crookneck Squash. Of dwarf, bushy habit, very productive; skin yellow; flesh greenishyellow color, dry and agreeable flavor. Pkt. 5c. Oz. 10c. 1/4 Lb. 25c. 1/2 Ĺb. 40c. Ll). 75c.

265. Extra White Bush Scalloped or Patty Pan Squash. Good size, uniform, a heary cropper, and early. The skin is white and the flesh fine grained and tender. Pkt. 5c, Oz. 10c. $1 / 4$ Lb. $25 \mathrm{c}$. Lb. $75 \mathrm{c}$.

2671/2. Mammoth White Bush Scalloped. Frequently 12 to 14 inches in diameter. Pkt. 5c. Oz, 10c. 1/4 Lb. 25c. Lb. $75 \mathrm{c}$.

585. Cocozelle Bush. Of compact bush growth, with dark green foliage; the fruits are oblong, 12 inches or more in length, and 4 to 5 inches in diameter. Skin dark green, with stripes of a still deeper sliade. Pkt. 10c. Oz. 15c. 1/4 Lb. 30c. Lb. $\$ 1.00$
80. The True Hubbard Squash. Vines of strong running growtlı; fruits large, olive sliape, with dark green skin, very rich flesh. An excellent keeper and of splendid quality. Our strain is extra fine. Pkt. 5c. Oz. 10c. 1/4 Lb. 30c. Lb. 95c.

330. Chicago Warted Hubbard. A superior strain of luammoth size witlı skin heavily warted. Pkt. 5c. Oz. 10c. $1 / 4$ Lb. 25c. $1 / 2$ Lb. 40 c. Lb, 75 c.

(3robe אillrbis

102. King of the Mammoth or True Potiron. The Great Prize Pumpkin growing the largest of all, from 100 to 200 pounds in weiglit, bright yellow, tender, excellent. Pkt. 50. Oz. 10c. 2 Ozs. 15c. $1 / 4$ Lb. 20c. Lb. 60c.

364. Golden Oblong Pumpkin. Produces oblong, bright orange colored fruits of good size, with rich colored flesh Pkt. 5c. Oz. 10c. 1/4 Lb. 25c. Lb. 75c.

1069. Connecticut Field or Large Yellow Pumpkin. Excellent for stock feeding. Pkt. 5c. Oz. 10c. 1/4 Lb. 20c. Lh.

402. New England Pie or Sugar Pumpkin. A small, round sort; very sweet, fine grained and of the best quality, Pkt. 5c. Oz. 10c. 1/4 Lb. 25e.

403. Japanese Pie Pumpkin. A large, crookneck sort. Skin green, striped yellow; flesh yellow and of fine quality. Pkts. $5 \mathrm{c}$ and 10c. Oz. 10c. $1 / 4$ Lb. 25c. $1 / 2$ Lb. 40 c. Lb. 75 c.

89. - Large Cheese Pumpkin. Forms fiat like a cheese; a sure cropper and extensively grown for eannillg. Pkt. 5c. Oz. 10c. 1/4 Lb. 20c. 1/2 Lb.

\title{
Salsify or Oyster Plant
}

\author{
1 Oz. to 100 Feet of Drill. \\ 10 to 12 Lhs. in Drills for an Acre \\ 25 to 35 Lbs. Broadcast for an Aere.
}

Parcel Post Rates, see Page 2

Culture. Sow as early as the ground can be worked in the Spring in drills 12 inches apart, 1 inch deep, and thin the Spring, in drills 12 inches apart, 1 inch deep, and thin Cultivate the same as Carrots and Parsnips. Sow 8 to 10 pounds to the acre. One ounce to 50 feet of drill.

275. Bolgiano's New "Great Giant" Salsify. The largest, purest and best Salsify to grow. Pkt. Oz. 15c. $1 / 4$ Lb. 45e. Th. $\$ 1.50$
276. Sandwich Mammoth White Salsify. Superior in quality, pure white color, very meaty and fine flavor. Our stock unusually good, grows so large and sliapely. Pkts, 5c and $10 \mathrm{c}$. Oz. $15 \mathrm{c}$. $1 / 4$ Lb. 40 c. $1 / 2$ Lb. 70 c. Lb. $\$ 1.25$.

504. Large White. Pkts, 5c and 10c. $\mathrm{Oz}$. 15c. $1 / 4$ Lb. 40 c. $1 / 2$ Lb. 70 c. Lb. $\$ 1.25$

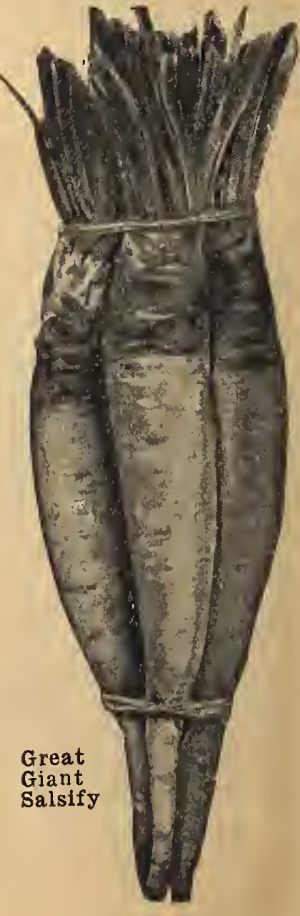




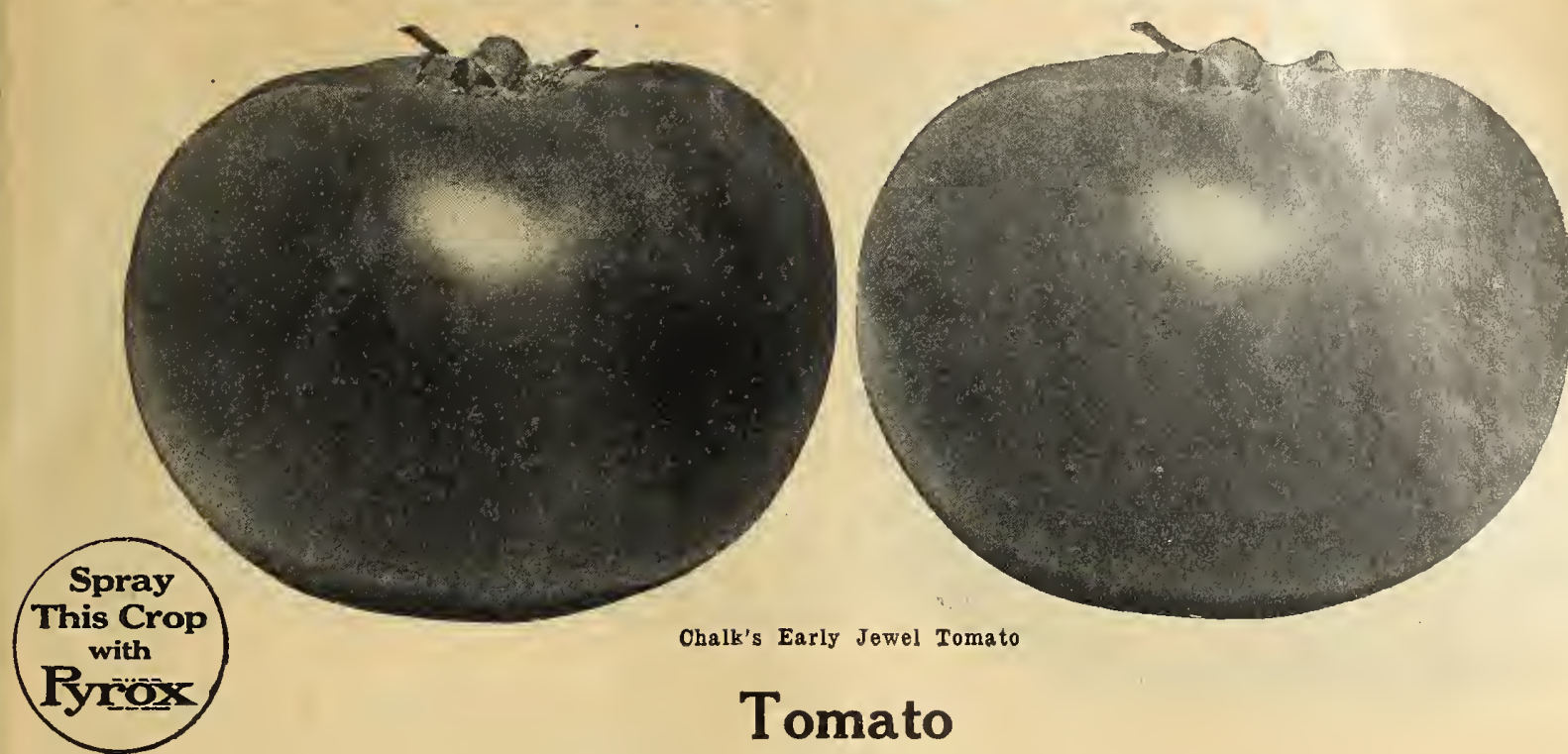

We Pay Postage on Pkts., Ozs., 14 Lbs. and Lbs.

French
PoMme D'AMOU:

German

Italian

Pomo D'Ono

Spanish

Tomate

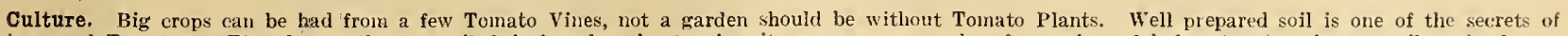

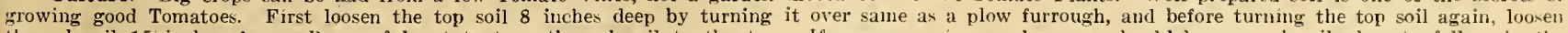

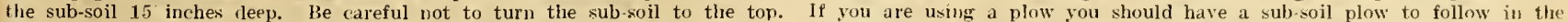

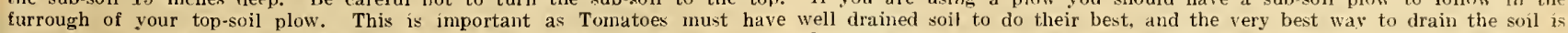

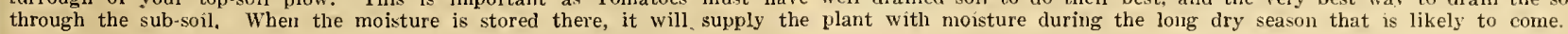

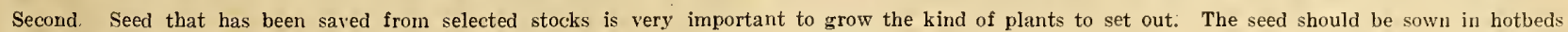

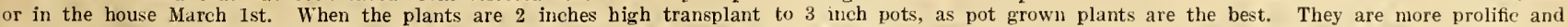

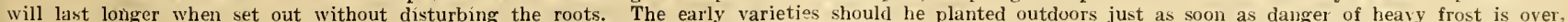

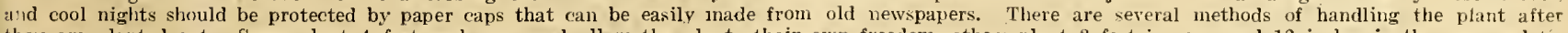

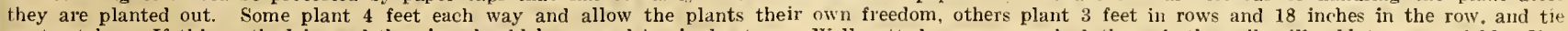

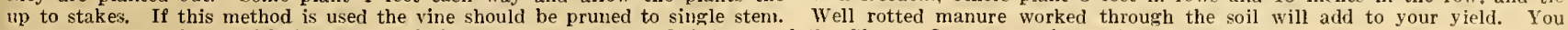
camnot get the soil too rich for such varieties as the John Baer, Bolgiano and the Glory. One ounce of seed to 3,000 plants.

\section{Red Tomatoes}

460. The "Bolgiano" Tomato. New 1920 Creation. (Spe(cialty,' see page 3.) The most wonderful yielder ever known. Two weeks earlier than the Eurliana. First fruit as good as the prime of the season. A solid mass of red, meaty flesh. Skin tough, flesh tender and sweet. Stands long-distance slipping perfectly. Pkts. $10 \mathrm{c}$ and $25 \mathrm{c} .1 / 2 \mathrm{Oz} .50 \mathrm{c}$. Oz. 90c. 1/4 Lb. $\$ 2.75$. 1/2 Lb. \$5.15. Lb. $\$ 10.00$. Postpaid.

407. "Victory" Tomato. New 1920 Creation. Early, full of vim, new life and health, free from wilt, blight, disease, jerfect sliape, high crown fruit, entirely free from core, firm, solid and meaty, beautiful brilliant red color, perfectly smootl and even, mild, refreshing, lelicious flavor. A marvelous yielder. Pkts. $10 \mathrm{c}$ and $25 \mathrm{c} .1 / 2 \mathrm{Oz} .30 .0 \mathrm{Oz} .50 \mathrm{c} .1 / 4 \mathrm{Lb} . \$ 1.40$ $1 / 2$ Lb. $\$ 2.65$. Lb. $\$ 5.00$. Postpaid.

378. Bolgiano's "Glory" Tomato. Outyields and outsells any. Tomato on the market. The yield of "Glory" Tomato is marvelous. Produces at every joint large clusters of good size, smooth, firm, beautifully shaped fruits, uniform in shape, color and size. At times the vines are so full that they can laardy hold all the fruit that they produce. They ripen evenly and color up well. Keep vigorous and green until frost and are then full of fruit. Pkts. $10 \mathrm{c}$ and $25 \mathrm{c} .1 / 2 \mathrm{Oz} .30 \mathrm{c} . \mathrm{Oz} .50 \mathrm{c}$. 1/4 Lb. $\$ 1.40$. 1/2 Lb. $\$ 2.65$. Lb. $\$ 5.00$. Postpaid.

234. "John Baer" Tomato. (Specialty, see page 4.) "John Baer" Tomato produces perfect, solid, high crown, beau tiful, brilliant red shipping Tomatoes. It is the earliest of the Earlies. Plts. Se thi $10 \mathrm{e}, 1 / 2 \mathrm{Oz}^{3}, 30 \mathrm{c} .0 \mathrm{Oz} .50 \mathrm{c}, 2 \mathrm{Ozs} .80 \mathrm{c}$. $1 / 4$ Lb. $\$ 1.40$. 1/2 Lib. $\$ 2.65$. Ll). $\$ 5.00$. Postpaid.

420. "Baltimore Baer" Tomato. Beautifully shaped, perfect, high crown, free from core, firm, solid and heavy. A very heary yielder. Early, free from wilt and blight. Pkts. $5 \mathrm{c}$ and $10 \mathrm{c}$. $1 / 2$ Oz. $25 \mathrm{c}$. Oz. $40 \mathrm{c}, 2$ Ozs. 70c. $1 / 4 \mathrm{Lb} . \$ 1.30$. $1 / 2$ Lb. $\$ 2.40$. Lb, $\$ 4.50$.

\section{Red Tomatoes}

310. "Prosperity." The Wonder Among New Early Tomatoes. The earliest of all Tomatoes, a brilliant red, an enormous vielder. Grown and developed from single plant, selections covering a period of five years, filled full of strong. sturdy, healthy, new blood. Pkts. $5 \mathrm{c}$ and $10 \mathrm{c}, 1 / 2 \mathrm{Oz} .30 \mathrm{c} .0 \%$. 50c. 2 Ozs. 80c. 1/4 Lb. $\$ 1.40$, 1/2 Lb. \$2.65. Lb. \$5, 00.

277. I. X. I., Bolgiano's Extremely Early Tomato. Earl iest, largest most prolific. Pkts. $5 \mathrm{c}$ and $10 \mathrm{c}, 1 / 2 \mathrm{Oz} .25 \mathrm{c} . \mathrm{Oz}$. 40c. 2 Ozs. 70 c. $1 / 4$ Lb. $\$ 1.30$. 1/2 Lb. $\$ 2.40$. Lb. $\$ 4.50$.

77. Maryland, My Maryland. A wonderful "Double Yielding" Tomato, entirely distinct, never before has there been a regetable so remarkable. It is simply startling in it. immense productiveness. (Specialty, see page 4.) Pkts. 5c and 10c. $1 / 2$ Oz. 30c.' 1 Oz. 50c. 2 Ozs 80c. 1/4 Lb. \$1.40. 1/2 Ll. $\$ 2.65$. Lb. $\$ 5.00$.

279. Bolgiano's "Greater Baltimore" Tomato. Selecter Stock Seerl. Makes a fine crop when all others fail. (Specialty, see page 4.) Pkts. 5e and 10c. 1/2 Oz. 25e. Oz. 40e. 20 ors. 70c. $1 / 4$ Lb. $\$ 1.30$. 1/2 Lb. $\$ 2.40$. Lb. $\$ 4.50$.

311. Florida Special Tomato. (Specialty, see page 3. Farly, prolific, blight proof. Plts. 5c and 10c. $1 / 2$ Oz. $25 \mathrm{c}$. Oz. 40c. 2 Ozs. $70 \mathrm{c}$. 1/4 Lb. $\$ 1.30$. 1/2 Lb. $\$ 2.40$. Lb. $\$ 4.50$.

287. Chalk's Early Jewel. Very fine new sort; large, solid, smooth, bright red; similar to the Stone, but early. Pkt.. 5c and 10c. $1 / 2$ Oz. 25c. Oz. 40c. 2 Ozs. $70 \mathrm{c} .1 / 4 \mathrm{Lb} . \$ 1.30$. $1 / 2$ Lb. $\$ 2.40$. Lb. $\$ 4.50$.

286. Sparks' Earliana Tomato. It is remarkable for its earliness, very large size, handsome shape and bright red color. Its solidity and fine qualities are equal to the best medium and late sorts. Pkts. 5e and 10c. 1/2 Oz. 20c. Oz. 35e. 2 Ozs. 65e. $1 / 4$ Lb. $\$ 1.15$. $1 / 2$ Lb. $\$ 2.15$. Lb. $\$ 4.00$.

284. Bolgiano's Great B. B. Tomato. Used successfully: for early and late crops. Pkts. 5c and $10 \mathrm{c}$. $1 / 2 \mathrm{Oz} .15 \mathrm{c}$. Oz. $25 \dot{\mathrm{c}}$. $1 / 4$ Lb. 75 c. $1 / 2$ Lb. $\$ 1.35$. Lb. $\$ 2.50$. 


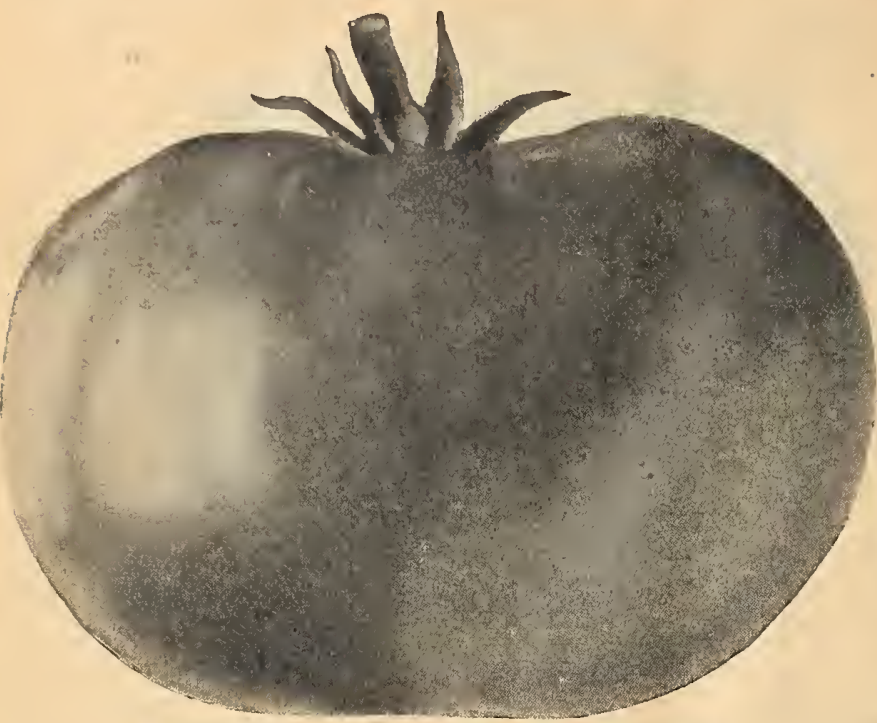

Tomato-Continued

We Pay Postage on Pkts., Ozs., 1/4 Lbs. and Lbs.

\section{Red Tomatoes}

572. New Red Rock Tomato. One of the finest, large, solid, smooth Tomatoes, of very fine, red color. A heary producer and an excellent slipper. Pkts. 5e and 10e, 1/2 Oz. 20c. Oz. 35c. 2 Ozs. 60c. 1/4 Lb. $\$ 1.10$. 1/2 Lb. $\$ 2.00$. Lb. $\$ 3.75$.

332. Bonny Best Early Tomato. This is a very early and very popular variety, quite as early as the best strains of Earliana Tomato; it is a vigorous grower, enormously prolifie, with splendid foliage and of an intense velvety glowing scarlet color; ripens evenly all over and up to the stem. Pkts. $5 c$ and 10c. $1 / 2 \mathrm{Oz}$. 25. Oz. 40e, 2 Ozs. 70c. 1/4 Lb. $\$ 1.30 .1 / 2 \mathrm{Lb}$. $\$ 2.40$. Lb. \$4.50.

307. New Stone Tomato, Selected Stock. We have the truest, purest, cleanest stock, free from rust and blight, of this most valuable Tomato. Pkts. $5 \mathrm{c}$ and 10e. $1 / 2 \mathrm{Oz} .15 \mathrm{c} . \mathrm{Oz} .25 \mathrm{c}$. 2 Ozs. 40c. 1/4 Lb. 65c. 1/2. Lb. \$1.20. Lb. \$2.25.

379. New Stone Tomato. Special. Saved from the finest cluster's of the Earliest Stem Set Fruit only. Pkts. $5 \mathrm{c}$ and $10 \mathrm{c}$. $1 / 2$ Oz. 15c. Oz. 25c. 2 Ozs. 45 c. $1 / 4$ Lb. 75 c. $1 / 2$ Lb. $\$ 1.35$. Lb. $\$ 2.50$.

302. Kelly Red, or Wade Temato. This splendid Red Tomato originated in Anne Arundel County, Md., and through its superior qualities it has become the Tomato most largely used in tbat section. It is large, neaty, an abundant yielder, and withstands unfavorable conditions remark ably well. pkts. $5 \mathrm{c}$ and $10 \mathrm{c}$. $1 / 2 \mathrm{Oz}$. 20c. Oz. $35 \mathrm{c}$. $20 \mathrm{zz}$. $65 \mathrm{c}$. $1 / 4 \mathrm{Lb}$. $\$ 1.15$. 1/2 Lb. $\$ 2.15$. Lb. $\$ 4.00$.

288. King of the Earlies Tomato. Large and productive. Very early, Phts. 5c and 10c. 1/2 Oz. 20c. Oz. 35c. 1/4 Lb. $\$ 1.15$. Lb. $\$ 4.00$

法 with beautiful fruit of largest size and solidity. First-class shipper. Plit. $5 \mathrm{c}$ and $10 \mathrm{c} .1 / 2 \mathrm{Oz}$. $15 \mathrm{c} .0 \mathrm{Oz} .25 \mathrm{c} .2 \mathrm{Ozs} .40 \mathrm{c} .1 / 4 \mathrm{Lb}$. 6.5. Lb. $\$ 2.25$.

524. Maul's Success Tomato. Large, red, main erop. Pkts. $5 \mathrm{c}$ and 10c. $1 / 20 z .15 \mathrm{c}$. Oz. $25 \mathrm{c}$. $20 z \mathrm{~s}$. $40 \mathrm{c}$. $1 /$ Lb. $65 \mathrm{c}$. Lb. $\$ 2.25$.

312. Livingston's Paragon. Briglit, red, round; very productive. Pkts. 5c and 10c. Oz, $25 \mathrm{c}$ 1// Lb. $65 \mathrm{c}$. Lb. $\$ 2.25$.

308. Livingston's Favorite. Large, Smooth, productive and a good hipper. Pkts. 5c and 10c. Oz. 25c. 1/4 Lb. 65c. Lb. $\$ 2.25$.

397. The Wisdom Tomato. Perfectly smooth, deep red, mediun early. Uniform. Pkts. 5c and 10c. 1/2 Oz. $25 \mathrm{c} .0 \mathrm{z} .40 \mathrm{c} .2 \mathrm{Ozs} .70 \mathrm{c}$. $1 / 4$ Lb. $\$ 1.30$. $1 / 2$ Lb. $\$ 2.40$. Lb. $\$ 4.50$.

309. Perfection. Early, regular and productive, reddish scarlet. Pkts. 5c and 10c. 1/2 Oz. 15c. Oz. 25c. 2 Ozs. $40 \mathrm{c}$. 1/4 Lb. 65c. 1/2 Lb. $\$ 1.20$. Lb. $\$ 2.20$

1.20. Lb. Ten Ton Tomato. One of the heaviest yielding red Tomatoes. Pkts. $5 \mathrm{c}$ and 10c. Oz. $25 \mathrm{c}$. 1/4 Lb. $65 \mathrm{c}$. Lb. $\$ 2.25$.

300. Trophy. Very large, solid, extra selected; free from rougbnes of the old strains. Pkts. 5c and 10c. Oz. 25c. 1/4 Lb. 75c. Lb. $\$ 2.50$.

298. Brinton's Best. As a second early and late cropper it is favorite with canners and truckers. Pkts. $5 \mathrm{c}$ and $10 \mathrm{c} .1 / 2 \mathrm{Oz} .15 \mathrm{c}$. Oz. $25 \mathrm{c}$. 2 Ozs. 40c. $1 / 4$ Lb. $65 \mathrm{c}$. $1 / 2$ Lb. $\$ 1.20$. Lb. $\$ 2.25$.

$2851 \%$. World's Fair. One of the heavier, solid fruited, large Tomaof good quality. Pkts. 5c and 10c. Oz. 25c. 1/4 Lb. 65c. Lb. $\$ 2.25$.

502. Ponderosa. Very large, heavy, smooth Tomato; very fine for home garden. Pkts. $5 \mathrm{c}$ and $10 \mathrm{c}$. 1/2 0z. 20c. Oz. 35c. 1/4 Lb. $\$ 1.40$ Lb. $\$ 3.75$.

296. Dwarf Stone Tomato. Double size of Dwarf Champion, the Largest Fruited Upright Growing Variety in existence. Color same as Stone Tomato. Pkts. $5 \mathrm{c}$ and $10 \mathrm{c} .1 / 2 \mathrm{Oz} .15 \mathrm{c} . \quad 0 \mathrm{z} .25 \mathrm{c} .2 \mathrm{Ozs} .40 \mathrm{c} .1 / 4 \mathrm{Lb} .65 \mathrm{c}$

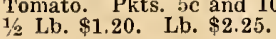

268. June Pink Tomato. This is the Pink Earliana Tomato. and where a Pink Tomato is in demand, this will be the earliest and most profitable to grow. Pkts. 5e and 10c. 1/2 Oz. 25c. Oz. 40c. 2 Ozs. 70c. 3/4 Lb. $\$ 1.30$. Lb. $\$ 4.50$.

369. Extra Selected Stock June Pink Tomato. Pkts. 5c and $10 \mathrm{c}$. $1 / 2$ Oz. 30e. O\%. 50e. 2 Ozs. S0e. 1/4 Lb. $\$ 1.40$. $1 / 2$ Lb. $\$ 2.65$. Lb. $\$ 5.00$.

291. Improved Acme. Very early, of medium size; perfectly smooth, very solid and a great bearer. Crimson color witli a pinkish cast. Plits. 5e and 10c. Oz. 25e. 1/4 Lb. 65e. $1 / 2$ Lb. $\$ 1.20$. L.b. $\$ 2.25$.

303. Crimson Cushion. Very large, bright searlet, fine flavor. Pkts. 5e and 10e. 1/2 Oz. 20c. Oz. 35e. 1/4 Lb. \$1.15. $1 / 2$ Lb. $\$ 2.15$. Lb, $\$ 4.00$.

\section{Yellow Tomatoes}

Golden Eagle Tomato. Leader of all Yellow Tomatoes. Color 382. Golden Eagle Tomato. Leader of all Yellow Tomatos. Color It is very attractive. Pkts. $\bar{c} \mathrm{c}$ and $10 \mathrm{c}, 1 / 2 \mathrm{Oz}, 20 \mathrm{c}$. Oz. 35c. $20 \mathrm{zs}$. $65 \mathrm{c}$ $1 / 4$ is very aftractise. Pkts. $\bar{x}$ and $10 \mathrm{c}$

383. Yellow Pear-Shaped. $\$$ pretty little Tomato, which is used largely for picking and preserving purposes; very prolific. Pkts. 5e and $10 \mathrm{c}$ $1 / 20 z$ 20c. Oz. 35c. 1/4 Lb. $\$ 1.15$. 1/2 Lb. $\$ 2.15$. Lb. $\$ 4.00$.

385. Yellow Plum-Shaped. Little larger than the Pear. Shaped; deep ellow color, very popular for preserving. Pkts. 5c and 10c. 1/2 0z. $20 \mathrm{c}$ Oz. $35 \mathrm{c} .2$ Ozs. $65 \mathrm{c}$. $1 / 4$ Lb. $\$ 1.15$. 1/2 Lb. $\$ 2.15$. Lb. $\$ 4.00$

386. Golden Queen Tomato. Large, smooth and good, a great show Tomato at the County Fairs Pkts, $5 \mathrm{c}$ and $10 \mathrm{c}$. $1 / 20 z$. 20c. $0 z .35 \mathrm{c}$ Ozs. 60c. $1 / 4$ Lb. $\$ 1.10$. $1 / 2$ Lb. $\$ 2.00$. Lb. $\$ 3.75$.

Ozs. 60c. 1/4 Lb. $\$ 1.10$. 1/2 Lb. $\$ 2.00$. Lb. $\$ 3.75$. Red Cherry Tomato. Attractiv

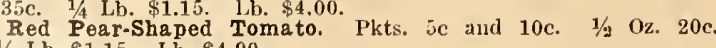

Lb. $\$ 1.15$. Lb. $\$ 4.0$

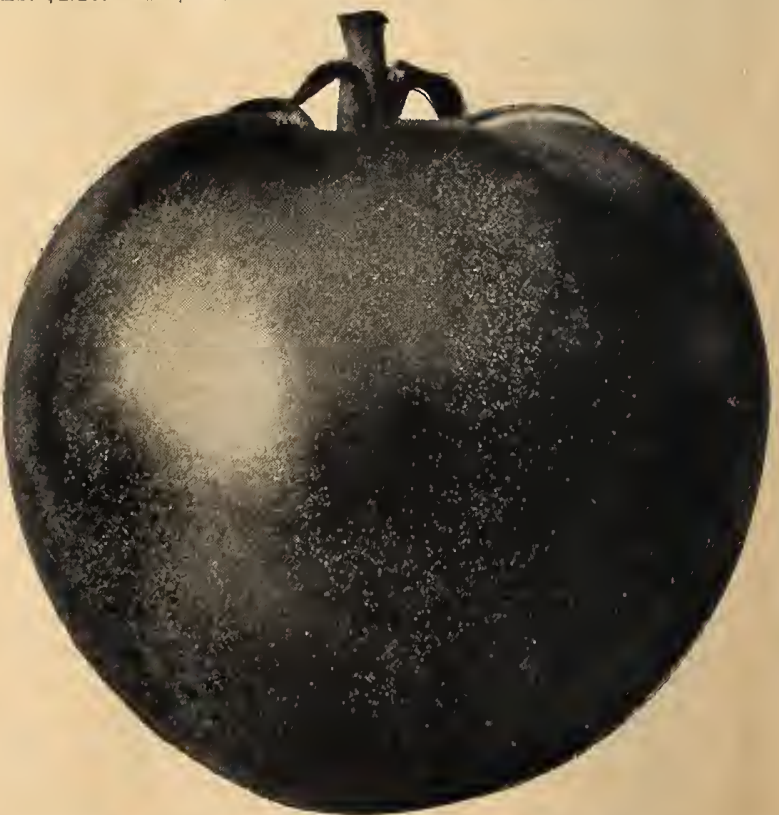




\section{Bolgiano's Dependable Flower Seeds for 1923 Selected Strains - Superior Quality Packets 10c Each, 3 Packets 25c}

Plain Culture Directions Printed on Each of Our Flower Seed Packets

We Pay Postage on Pkts., Ozs., 14 Lbs. and Lbs.

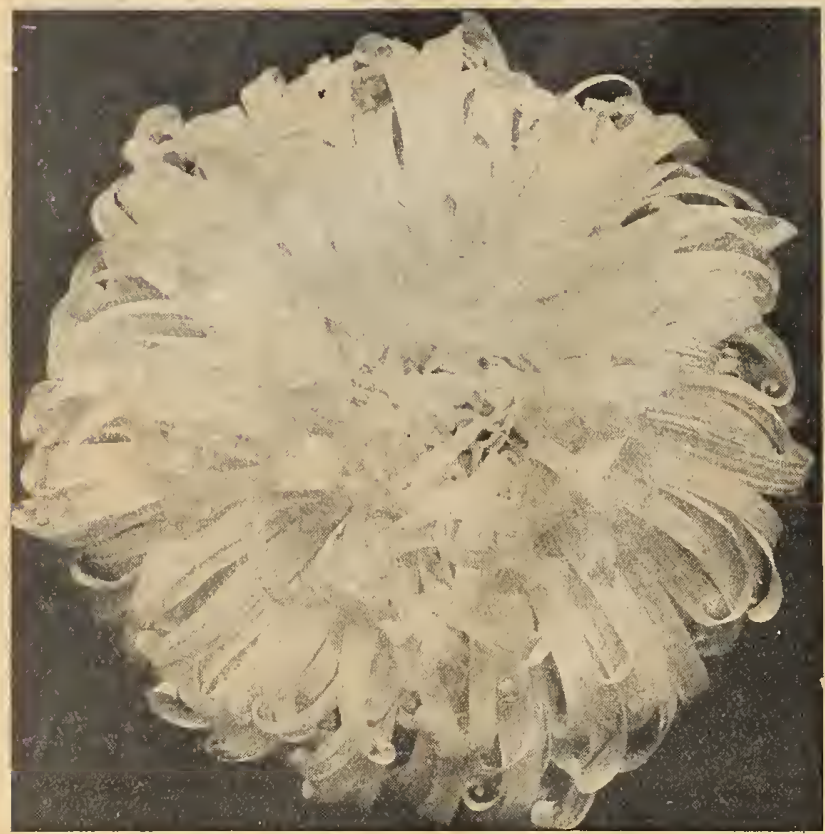

Crego's Giant Comet Asters

\section{Crego's Giant Comet Asters}

We consider this the finest and largest of all Comet Asters, bearing immense fluffy flowers five inches and over in diameter, resembling choice Japanese Chrysanthemuns, and when cut they keep in good condition longer than any other type. The delightîl flowers are borne in abundance from August until the end of September. We offer the following separate colors: 1. Giant White-Pure White. 2. Giant Pink-Delicate Shell Pink. 3. Giant Crimson-A Beautiful Crimson. 4. Giant LavenderDeep Lavender. 5. Giant Rose-Rich Deep Rose. 6. Giant Purple-

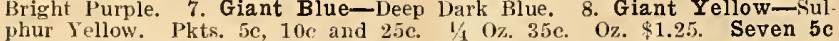
pkts., including all colors, for 25c. 9. Crego's Mixed. Pkts. 5c, 10c

Truffant's Peony Flowered Perfection Aster. For mid-season flowering we recommend these beautiful Asters; they are stiffly erect or upright in growth, averaging 2 feet, produce fine, large double flowers.

10. Snow white. Pkts. 5c, $10 \mathrm{c}$ and $25 \mathrm{c} .1 / 40 z .45 \mathrm{c} .0 \%$. $\$ 1.50$.

11. Darkest Blue. Pkts. 5c, $10 \mathrm{c}$ and $25 \mathrm{c}, 1 / \mathrm{O} \mathrm{Oz} 45 \mathrm{c}$. $0 z \$ 1.50$

12. Glowing Dark Crimson. Pkts. $5 \mathrm{c}, 10 \mathrm{c}$ and $25 \mathrm{c}, 1 / 4 \mathrm{O} \%$

Oz. $\$ 1.50$ Light Red. Pkts. 5e, 10c and 25c. 1/4 Oz. $45 \mathrm{c}$. Oz. $\$ 1.50$.

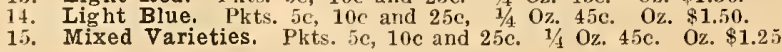

\section{Bolgiano's Giant Comet Asters}

These are earliest to produce fine, large, Chrysanthemum-like flowers the plaut Wbite Extra Fine. have fire, long stems.

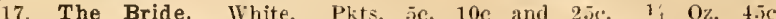

18. Ligbt Yellow. Pkts, 5c, 10c and 25c. 1/4 Oz, 45e. Oz. \$1.50.

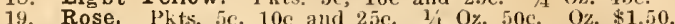

20. Light Blue, Pkts, 5c, $10 \mathrm{c}$ and $25 \mathrm{c} .1 / \mathrm{L} \mathrm{Oz} .45 \mathrm{c}, 0 \% \$ 1.50$

21. Azure Blue. Pkts. $5 \mathrm{c}, 100$ and $25 \mathrm{c} .1 / 40 z .45 \mathrm{c} .0 \% \$ 1.50$ 22. Dark Violets. Pkts, 5c, $10 \mathrm{c}$ and $25 \mathrm{c} .1 / \mathrm{O} \%$. $45 \mathrm{c}$. $0 \% \$ 1.50$ Mixed, l'kts. 5c, 10c and 2.5c. 1/ 0\%. 35c. Oz. $\$ 1.25$

Bolgiano's Giant Stock of Semples, Branching Asters. These grow 2 to 3 feet high and branch very freely, the flowers being of the and length of stem. Whe largest supply of $\Lambda$ sters.

Lavender. Azure Blue. Pkts. 5c, 10c and $25 \mathrm{c} .1 / 1 \mathrm{Oz} .30 \mathrm{c}$

Shell Pink. Pkts. 5c and 10c. 1/4 Oz. 30c. Oz. $\$ 1.00$. Flesh Pink. Pkts. $5 \mathrm{c}$ and 10c. 1/1 Oz. 30c. Oz. $\$ 1.00$ Crimson. Pkts. 5c and 10c. 1/4 0z. 30c. Oz. $\$ 1.00$.

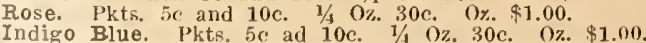
Purple. Pkts. 5e and 10c. 1/1 0z. 30e. Oz. $\$ 1.00$.
34. Purple. Phts. 5c, 10c and 25c. 1/4 Oz. 35ci 0z, $\$ 1.25$

35. White, Pkts. 5c, $10 \mathrm{c}$ and $25 \mathrm{c}$. 1/4. $0 \mathrm{z}$. $35 \mathrm{c}$. $\mathrm{Oz}$. $\$ 1.25$

36. Pink. Pkts. 5c, $10 \mathrm{c}$ and 25c. 1/4 0z. 35c. 0z $\$ 1.25$.

37. Crimson. Pkts. 5c, $10 \mathrm{c}$ and $25 \mathrm{c}$. 1/4 Oz. $35 \mathrm{c}$. Oz. $\$ 1.25$

38. Aster, European Quilled. Rose-pink flower with quilled renters. Various colored petals in gorgeous mixture. Pkts. $5 \mathrm{c}$ and $10 \mathrm{c}$ Oz. $30 \mathrm{c}$. Oz. $\$ 1.00$.

39. Abutilon. Flowèring Maple Elegant flowering peremial slimb: of strong grosth and easy cultivations "free flowering with various colore beautiful drocking flowers Considered indispensable for flowering indoor: during tbe Winter, and Spring months and useful for bedding out in the Summer:- Pkts. 5c, 10c and $25 \mathrm{c}$.

40. Acroclinium. A pretty annual "Everlasting," growing about 15 inches high, bearing iovely white or rosy-pink flowers, whicb, when cut in the bud state, can be dried and used in Winter bouquets. A nice thing to orow in $a$ mixed border aside from its use as an everlasting. Double mixed. Pkts. $5 \mathrm{c}$ and $10 \mathrm{c}$. Oz. $20 \mathrm{c}$

41. Amaranthus. Candatus, Love Lies Bleeding. Rapid growing annual" with long, drooping crimson flowering spikes, 3 to 5 inches high. Pkts. 5c and 10c, $1 / 20 \mathrm{z}, 15 \mathrm{c}$. $02.25 \mathrm{c}$

42. Amaranthus. Tri-color. Joseph's Coat. Showy annual foliage plant for gardens; leaves red, yellow, green, etc. ; 3 feet. Pkts. $5 \mathrm{c}$ and $10 \mathrm{c}$ $1 / 2$ Oz. 1 s. $0 z$. $50 \mathrm{c}$

43. Ageratum. Dwarf llixed. One of the best Summer-blooming plants. They are rapid growers and constant bloomers. During the hot dry Summer months their bright flowers are produced in the oreates profusion of charming blue or white flowers. Pkts. $5 \mathrm{c}$ and $10 \mathrm{c}$ $0 \mathrm{c}, 0 \mathrm{z}, \mathrm{c}$

44. Agrostemma. Rose of Heaven. Coronaria. An attractive-free flowering, hardy perennial of easy culture, producing glowing crimson flowers like a single pink and silver-white foliage; blooms the first season fine for cutting; 2 feet. Pkts. $5 \mathrm{c}$ and 10c. 1/2 Oz. 15c. 0z. $25 \mathrm{c}$.

45. Alyssum, Sweet. Little Gem. A beautiful white variety of Sweet Alyssum, especially adapted to edging borders and rock work. The plats grow about 6 inches, produce hundreds of flowers and form a masx or bloom 15 to 18 inches in diameter. Hardy annual Pkts. $5 c$ and $10 r .0 \%$ 50c. 4 Ozs. $\$ 1.50$.

46. Alyssum. Saxitale. Flowers golden-yellow; desirable for rock ork. Showy in masses. Hardy perennial. Pkts. $5 \mathrm{c}, 10 \mathrm{c}$ and $25 \mathrm{c} .0 \mathrm{Oz}, 45 \mathrm{c}$

47. Anchusa. Italica Dropmore.. One of the best hardy perennials. and becoming more popular each season, grows 3 to 5 feet high, and bear in abundance fiowers of the richest gentian-blue during May and June. Pkts. 5c and 10c. 1/1 Oz. 25c. Oz. 90c.

48. Anemone. St. Brigid. Windflower. A very pleasing perennial, producing large, Irish Poppy flowers; few plants compare with them in beauty; fine for bouquets. Sow outdoors in spring, keeping shaded till the plants appear. Pkts. 5c, $10 \mathrm{c}$ and $25 \mathrm{c} .1 / 4 \mathrm{Oz} .50 \mathrm{c}$.

49. Antirrhinum. Snap Dragon. Beautiful spikes of gaily colore flowers. They are one of the best cut flowers which can be grown from seed. While for beds or borders they are a pleasure, being in flower al the time if placed in a sunny position. Tall mixed. Pkts. 5c and $10 \mathrm{c}$ $1 / 4$ Oz. 25c. Oz. 75 c.

50. Tom Thumb-Dwarf Mixed. Pkts. 5c, $10 \mathrm{c}$ and 25c. 1/2 0z. 50c

51. Asparagus. Sprengeri, Enterald Feather. One of the best plant to grow in suspended baskets, window boxes, bases, etc., for tbe greenhouse in Winter and outdoors in the Summer. Pkts. $5 \mathrm{c}, 10 \mathrm{c}$ and $25 \mathrm{c}, 1 / 4 \mathrm{z}$. $35 \mathrm{c}$ $0 \% \$ 1.25$.

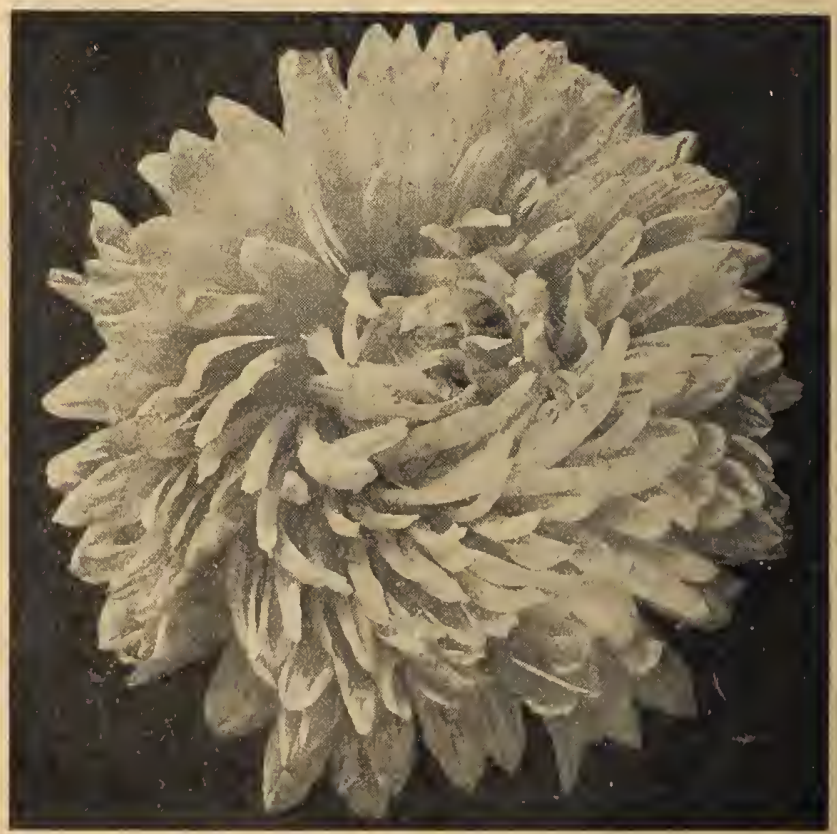

Bolgiano's Giant Comet Asters 


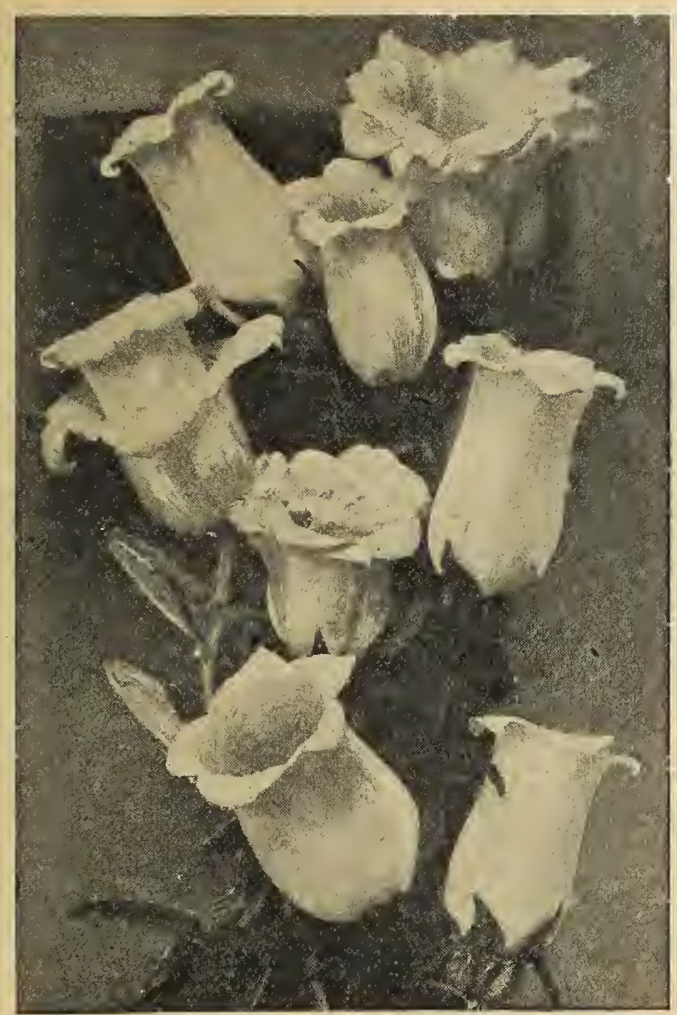

Canterbury Bells

91. Cypress Vine.' Mixed. For training on treitises the Cypress Vine cannot be excelled. It has a profusion of scarlet and white star-shaped blossoms, and its finely cut foliage is particularly adapted to ornamental work, Pkts, $5 \mathrm{c}, 10 \mathrm{c}$ and $25.0 \mathrm{Oz}$. $35 \mathrm{c}$.
52 . Balloon Vine. Love in a Puff. A rapid growing, annual cliniber, succeeds best in light soil and warm situation; flowers white, seed vessels look like miniature balloons. Pkts. $5 \mathrm{c}$ and 10c. Oz. $20 \mathrm{c}$.

53. Balsam, or Lady Slipper. These are very beautiful for borders; the plants nake perfect little bushes with flowers that are double; the colors are very pretty and pleasing. Pkts. 5c and 10c. 1/4 Oz. 15c. Oz. 50c. most excellent foliage vine. Pkts. $5 \mathrm{c}$ and 10e.

Producing showy, golden-yellow flowers, fragrant at night, above its gray and downy, thistle-like foliage, which is exceedingly brilliant in the sunshine. Pkts. $5 \mathrm{c}$ and $10 \mathrm{c}$. $1 / 20 \mathrm{z} .20 \mathrm{c} .0 \mathrm{z} .35 \mathrm{c}$. 56 . Begonia. Tuherous Rooted. The plants are of robust, compact habits, dark
green foliage, and brilliant double cinnabar-scarlet flowers. Single splendid mixed. Pkts. 5c, 10e and 25c. Bellis Perennis. Double Daisy. A large growing, Spring flowering plant, a companion to the Pansy and Forget-Me-Not. Pkts. 5c and 10c. 1/8 Oz. 25e. 1/1 Oz. 40c. $0 \% \$ 1 . \tilde{0}$

58. Brachycome. Swan River Daisy. Free-flowering, dwarf-growing annuals: suit-
able for edgings, small beds or pot culture; 9 inches. Pkts. $5 \mathrm{c}, 10 \mathrm{c}$ and $25 \mathrm{c}$. 1/2 $0 \mathrm{z}$. $30 \mathrm{c}$.

59. Calendula. Pot Marigold. A perpetual bloomer: the flowers are oriental in color and exhibit every shade of yellow from ivory to deepest orange. Makes good cut 60. Calliopsis. Showy garden annual, 1 to 2 feet high; producing profusely large flowers of brilliant shades, ranging from canary to orange-red and maroon. All the choice sorts mixed. Pkts. 5c and 10c. 1/2 Oz. 15c. Oz. 25c. growtl, rich color and profuse bloom. Has large bell-shaped flowers, are effective in varigrowtl, rich color and profuse bloom. Fas large bell-shaped flowers, are effective in vari-
ous colors. Height two to four feet. Finest mixed-all colors of the cup and saucer type.

Pkts. $5 \mathrm{c}$ and $10 \mathrm{c} .1 / 2 \mathrm{Oz} .20 \mathrm{c}$. Oz. 35c.
62 Candytuft. White. The finest of all the white varieties, being a complete mass of pure white fiowers, in bloom throughout the season. Grows 12 inches high. Pkts. $5 \mathrm{C}$ and 10c. 1/2 Oz. 15c. Oz. $25 \mathrm{c}$.

63. Candytuft. Mixed. Most excellent mixture, rose, crimson, white purple, etc. 13ushy plauts 12 inches high growing large umbels of flowers. Pkts. $5 \mathrm{c}$ and $10 \mathrm{c} .1 / 2 \mathrm{Oz}$.

15c. Oz. 2oc. 15 feet high. It will cover trellis work in the most graceful manner, producing hundreds of its pretty fringed bright yellow flowers, which resemble a canary bird with expanded wings Pkts $5 \mathrm{c}$ and $10 \mathrm{c}$ 1\% Oz. $15 \mathrm{c}$. Oz. $25 \mathrm{c}$

wings. Pkts. $5 \mathrm{c}$ and $10 \mathrm{c}$. $1 / 2 \mathrm{Oz}$. $15 \mathrm{c}$. Oz. in lukewarm water for 24 hours before sowing. Pkts. $5 \mathrm{c}$ and $10 \mathrm{c}$. Oz. $25 \mathrm{c}$

66. Cardinal Climber. (Ipomoea cardinalis.) The vines attain a height of 20 to 30 f et. The teaves are deeply laciniated, resembling those of a fine japanese maple. The piants bear countless numbers of sniall, glowing scarlet flowers. Pkts. 5c, 10c and 25c.
67 . Carnation. Marguerite. The plants of this wonderfully fine strain may be made to bloom in 12 weeks. The flowers are large, double, very fragrant and appear in very

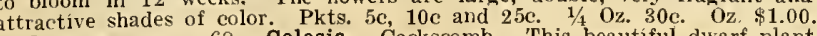

attractive shades of color. Celosia. Cockscomb. This beautiful dwarf plant has dark green

75. Chrysanthemum. Perennial. (Japonicuin fl. Pleno. Japanese Mixed.) Hardy plants for permanent borders and gardens, compact bushe
$1 / 2$ to 2 feet, splendid cut flowers, has long stems. Pkts. 5c, 10c and $25 \mathrm{c}$. $1 / 2$, to 2 feet, splendid cut flowers, has long stems. Pkts. 5c, $10 \mathrm{c}$ and $25 \mathrm{c}$.
76 . Cineraria. Hybrid Grandiflora. Choicest mixed for the window ox. Conservatory; large flowers from 2 to 3 inches across, various color: borne in profusion in the Spring. Pkts. $10 \mathrm{c}, 25 \mathrm{c}$ and $50 \mathrm{c}$

77. Clematis. Paniculata. Well-known hardy perennial climber, fine for covering arbors, verandas, etc., as they cling to alnost any object. Glossy green foliage and white star-shaped flowers

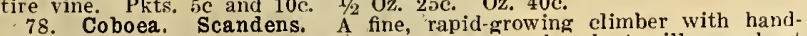
78. Coboea, Scandens. A fine, rapid-growing climber with hand30 'feet in season. Pkts. 5e, $10 \mathrm{c}$ and $25 \mathrm{c} .1 / 2 \mathrm{Oz} .35 \mathrm{c}$. Oz. $60 \mathrm{c}$

\section{Coix Lachrymae (Job's Tears)}

A strong, broad leaved ornamental grass, with large shining, pearly seeds; annual; 2 to 3 feet. Seed is frequently used as an old fashioned remedy for sore throat, goiter and teething babies. It is strung on a linen string and worn around the neck. Pkts. 5c. Oz. 10c. 1/4 Lb. 15c. Lb. 50c.
80 . Coleus. The showy plants are grown for their brilliant foliage, which forms the bases of the ribbon beds of foliage plants in the parks and lawns. The colors range from light to dark red leaves, are very finely marbled and spotted. Pkts. 10c, 25c and 50c.

81. Convolvulus Minor, or Dwarf Morning Glory. Fine bushy plants, colors. Pkts. 5c and 10c. Oz. 15c. 1/4 Lb. 35c. 1/2 Lb. 50c. Lb. $90 \mathrm{c}$.

82. Coreopsis. Lancelota Grandiflora. Harvest Moon. One of the finest, hardiest garden plants grown, forming bushes 2 to 3 feet high bearing quantities of long" stemmed, large, single, yellow flower's throughout the

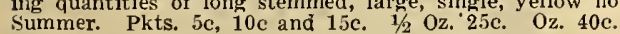

\section{Cosmos}

One of our finest Fall flowers. A vigorous, tall-growing annual. It is most effective when planted in masses or along back-ground borders against evergreen or fences. We offer only the choice large flowering strains. Sow seeds outdoors early in May, but to get early flowering plants,
in March or April and transplant outdoors when large enough.

83. Cosmos. Mamnoth. A very effective Autumn flowering plant, hardy and rapid growing, forming bush-like plants 5 to 8 feet high and covered with large, single, Dahlia-like flowers. Pkts. 5c and 10c. Oz. 20c. $1 / 1$ Lb. 50c. $1 / 2$ Lb. 90c. Lb. $\$ 1.50$.

\section{Bolgiano's Extra Early Giant Flowering Cosmos}

The earliest strain of Cosmos in cultivation which has been placed in a class by itself. Plants grow about 4 feet high, are bushy and branch freely and begin to bloom in July with Giant Blossoms, measuring 4 to 5 inches across, and continue until frost. The largest and most beautiful of all cosnos. From seed sown in the open ground this strain will bloon in 60 days.
Pkts. $1 / 2 \mathrm{Oz}, 1 \mathrm{Oz}$ Pkts. 1/2 0z. $1 \mathrm{Oz}$. $\begin{array}{lllllllll}\text { Crimson } \ldots 5 \mathrm{c} & 10 \mathrm{c} & 25 \mathrm{c} & 45 \mathrm{c} & 86 . \text { Pure White } .5 \mathrm{c} & 10 \mathrm{c} & 25 \mathrm{c} & 45 \mathrm{c} \\ \text { Pink } & .5 \mathrm{c} & 10 \mathrm{c} & 25 \mathrm{c} & 45 \mathrm{c} & 87 \text {. Mixed } \ldots . .5 \mathrm{c} & 10 \mathrm{c} & 20 \mathrm{c} & 35 \mathrm{c}\end{array}$

88. Cyclamen. Persicum. Giant double flowers, finest mixed colors. 88. Cyclamen.

89. Cypress Vine. Scarlet. Very deep scarlet flowers. Pkts. 5e, and $25 \mathrm{c}$. Oz. $30 \mathrm{c}$

90. Cypress Vine. White. Clear paper white flowers. Pkts. 5c, 10c and 25c. Oz. $30 \mathrm{c}$. leaves and forms immense coxcom

69. Cont newest sort, 2 or 3 feet higl with large flowers 3 to 4 inches across, varieties of colors and shades, large fragrant flowers, excellent for cutting. Pkts. 5e and $10 \mathrm{c}$. $1 / 2 \mathrm{Oz}$. 25c. fragrant flowers, excellent for cutting. Pkts, 5e and $10 \mathrm{c} .1 / 2 \mathrm{Oz} .25 \mathrm{c}$.
$\mathrm{Oz} .40 \mathrm{c}$. 70 . Centaurea. Corn-flower. or Bachelor's Button. Showy, hardy,
border plants about 2 feet high and bearing freely during the Summer, border plants about 2 feet high and bearing freely during the Summer, corm-flower-like heads of bloom. Pkts. $5 \mathrm{c}$ and 10c. 1/2 Oz. 15c. Oz. 25c.
71 . Centaurea. Candidissina. Dusty Miller. White foliage used for bedding, edging, vases, etc. Pkts. $5 \mathrm{c}, 10 \mathrm{c}$ and $25 \mathrm{c}$. 72. Chrysanthemum. Single and double mixed. Most gorgeous and

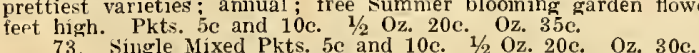
74. Double Mixed Pkts, 5e and 10c. $1 / 2$ Oz. 20c. Oz. 30c.

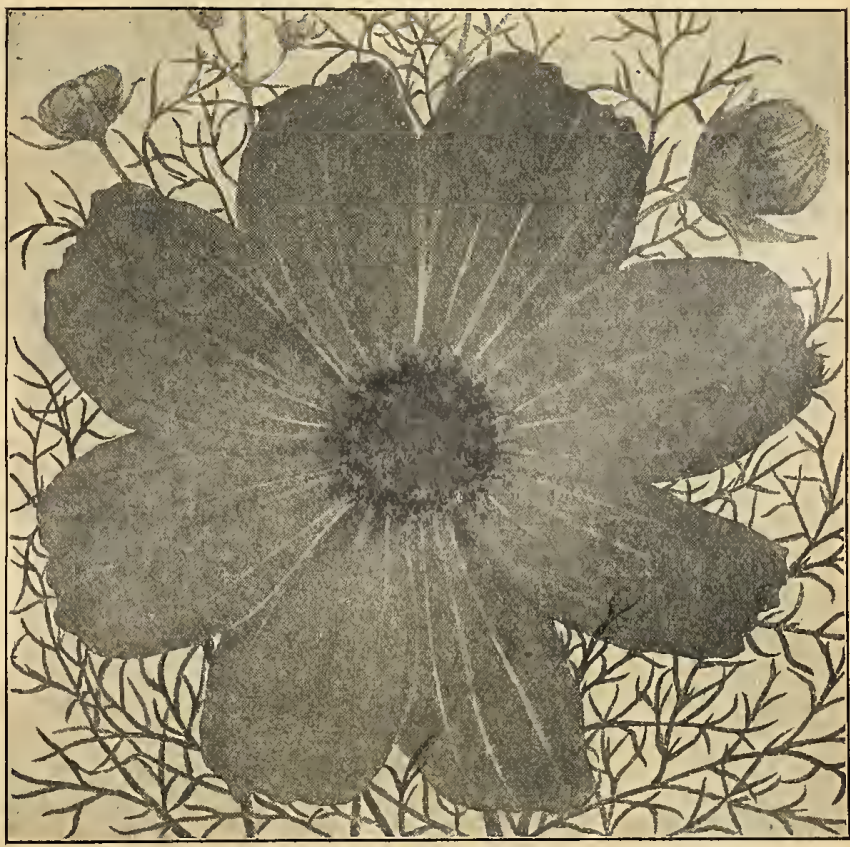

Bolgiano's Extra Early Giant Flowering Cosmos 


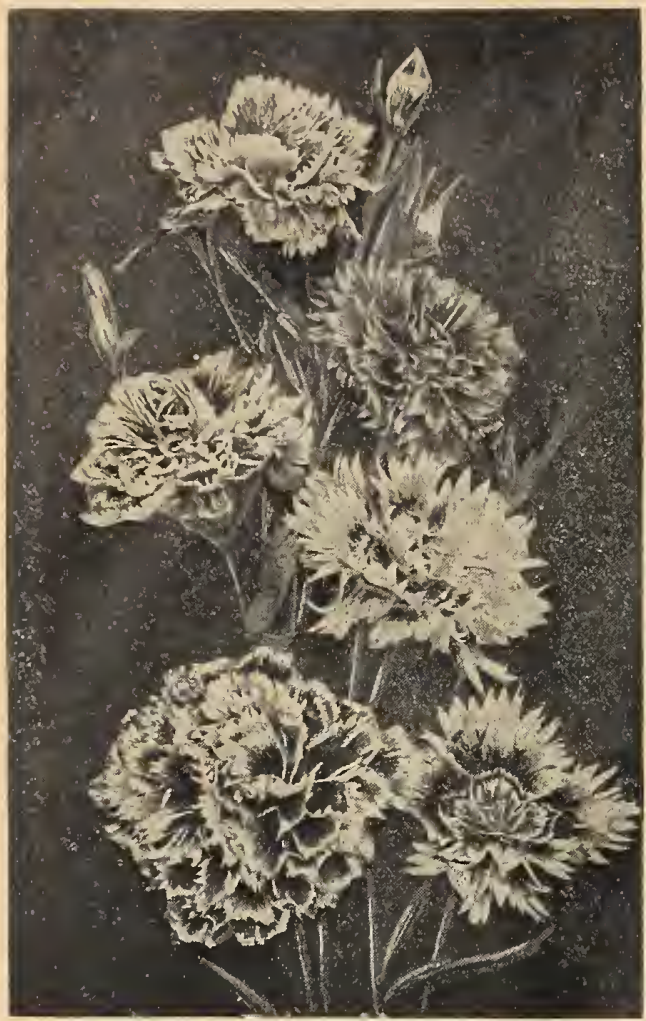

Dianthus, Hardy Garden or Grass Pinks

92. Dahlia. Extremely large flowers. Double mixed. Although perennial these will Hower the first season if sown early. $t$ to 6 feet. Pkts. $5 \mathrm{c}, 10 \mathrm{c}$ and $25 \mathrm{c}$. $1 / 40 \mathrm{Oz}$. $40 \mathrm{c}$. Oz. $\$ 1 . \overline{5} 0$.

93. DeIphinium. Hardy perennial Larkspur, Double and single hybrid. Finest niixed colors. Among our best plants for mixed borders, producing spikes of flowers. Pkts. $5 \mathrm{c}, 10 \mathrm{c}$ and $25 \mathrm{c} .1 / 40 \mathrm{z} .30 \mathrm{c}$. Oz. $\$ 1.00$.

94. Dianthus. Double annual. China Pinks. They form bushy dwarf plants about 1 foot high, producing freely all summer long. flowers of most brilliant colors. One of our most effective garden plants. Plits. $5 \mathrm{c}, 10 \mathrm{c}$ and $25 \mathrm{c}$. $\mathrm{Oz}$. 60c.

95. Dianthus. Hardy porennial Pinks. Pheasant's Eye Pink. Bush plants of large 96. Dianthus fashioned pinks of dwarf, sturdy growth, with large, double fringed fragrant flowers of various fashioned pinks of dwart, sturdy growth,

97. Digitalis. Fox Glove. Finest mixed colors. Hardy perennial of easy culture, producing long spikes of tubular flowers of various colors. 3 to 5 feet. Pkts. $5 \mathrm{c}$ and $10 \mathrm{c}$. $1 / 2$ Oz. 25c. Oz. 40c.

98. Eschscoltzia. California Poppy. Mixed Popular garden annuals of easy culture. Forming bushy plants about 1 foot high, bearing large saucer-shape tlowers. Pkts. 5c and 10c. Oz. $15 \mathrm{c}$

99. Euphorbia. Variegata. Snow on the Mountain. Strong-growing annuals, suitable for beds of tall-growing plants or mixed borders; the tlowers are inconspicuous; the foliage, howerer, is exceedingly ornamental. Attractive foliage; veined and margined with white: 2 feet. Pkts. $5 \mathrm{c}$ and $10 \mathrm{c}$. $0 \mathrm{z}$. $25 \mathrm{c}$.

100. Gaillardia. Grandiflora. Mexican Blanket Flower. Hardy porennial. Large, gay colored, double flowers. Useful for cutting. The colors brilliant golden-yellow, crimson, orangc, amaranth and claret. Pkts. 5c and 10c. 1/ Oz. 15c. Oz. 25c.

101. Geraniums. Scarlet or Zonale. Well known plant for garden or plot culture. Flowering from seed the first season if sown early. Brilliant scarlet flowers. Pkts. 5c, $10 \mathrm{c}$ and $25 \mathrm{c}$

102. Godetia. Satin Flower. A most attractive bushy little annual plant with bright flowers opening in the morning and closing at evening; very effective in gardens; not serviceable as a cut flower; height, 15 inches. Choice mixed. Pkts. 5c and 10c. 1/2 0z. 30c. 0z. 50o.

\section{Gourds}

Annual climbers, Rapid growers. Twenty to twenty-five feet high, bearing ornamental fruit in most peculiar shapes. Very suitable for covering arbors, fences and trellises.

103. Apple Shaped. Pkts. $5 \mathrm{c}$ and 10c. Oz. 25c.

104. Bottle. Pkts. 5c and 10c. Oz. 25c.

105. Calabash or Pipe Gourd. Pkts. 5c and 10c. 0z. $25 \mathrm{c}$.

106. Dipper. Used by the natives in tropical countries as dippers. Pkts. 5c and 10c.

Oz. 25c. Dish-Rag. Pkts. 5c and 10c. Oz. $25 \mathrm{c}$

108. Hercules Club. Long white. Phts. $5 \mathrm{c}$ and 10c. Oz. $25 \mathrm{c}$

109. Mock Orange. Pkts. 5c and 10c. Oz. 25c.

110. Pear Shaped. Pkts. $5 \mathrm{c}$ and $10 \mathrm{c}$. Oz. $25 \mathrm{c}$

111. Sugar Trough. Uscd as water holders. Pkts. 5c and 10c. Oz. 25c.

112. Jixed from named varieties. Pkts. $5 \mathrm{c}$ and 10c. Oz. 20c.

113. Gypsophila. ? feet. Elegans Grandiflora Alba. Angel's Breath. Graceful plants of light fairy-like growtli. Much in demand for cutting and combining with other flowers for bouquets and vases. This is an inproved, large-flowering, pure white, of free, easy growth. Pkts. 5c and 10c. Oz. 20c.

114. Helichrysum. Straw Flower. Large flower, double, finest mixed colors. Annual. 1 to 2 feet high. Double everlasting Howers, in shades of yellow, white, red, dark blue, etc. Pkts, 5c, $10 \mathrm{c}$ and $25 \mathrm{c} .1 / 2 \mathrm{Oz}, 30 \mathrm{c}$. $0 \mathrm{z}, 50 \mathrm{c}$.

115. Heliotrope. Dark blue and white. The well-known fragrant flowering plants. 1 to 2 feet high. For pots and gardens. Pkts. $5 \mathrm{c}, 10 \mathrm{c}$ and $25 \mathrm{c}$. $1 / 80 \mathrm{z}, 35 \mathrm{c} .1 / 40 z .60 \mathrm{c}$. $07 . \$ 2.00$.

116. Hibiscus. Hardy variety. Marsh Mellow. A very vigorous plant of easiest culture, growing about 2 feet high, with bandsome, cream-colored single tlowers. Hardy annual. Pkts. 5c, 10c and $25 \mathrm{c}, 1 / 2$ Oz. 35c. Oz. $60 \mathrm{c}$.

\section{Hollyhock}

Hollyhocks are perennials, but we suggest sowing seed every year in January indoors and grown in pots until tbey can be set outdoors. These plants will blossom the same season and give larger flowers, but smaller plants. Sowings can also be made from June to August. When plants are large enough transplant to a cool, 1 ich soil, planting at least a toot apart. They should be supplied with plenty of water throughout the season. Four to eight feet high.

117. Hollyhock. Double Superb. Mixed. Favorite hardy plants, with immense flowers on spikes from 4 to 6 inches high. Bolgiano's strain of Double Hollyhocks are famous for beauty and coloring. Pkts. 5c, 10c and 25c. 1/4 Oz. 30c. Oz. \$1.00.

118. Hollyhock. Single mixed. Pkts. 5c, 10c and 25c. 1/2 0z. 35c. 0z. 60c.

119. Hollyhock. Single and Double Mixcd. Pkts. 5c and 10c. 1/2 0z. 25c. Oz. 45c.

120. Kochia Trichophylla. An old-fasbioned popular annual, sometimes known as Belvidere, Mock Cypress, Mexican Fire Plant, etc. It is easily grown from seed-forming oval bushes 2 to $21 / 2$ feet high, densely clothed with small feathery light-green foliage, deepening in color as the Summer advances until the whole plane assumes a fiery-crimson hue. Pkts. 5c and 10c. 0z. 20c.

121. Kudzu Vine. A twining vine of remarkably rapid growth, attaining a Iength of 40 to 50 feet in one season. Hardy. Foliage large and lobed; purple pea-shaped flowers in clusters, borne late in the season. A fine vine for arbors, verandas, etc. Easily grown from seed. Pkts. 5c, 10c and $25 \mathrm{c}$, Oz. $50 \mathrm{c}$.

\section{Lobelia}

These are very useful plants for hanging baskets, window boxes, edging or pot culture. They bloom continually from June until November.

122. Crystal Palace Compacta. The very best belding variety; rich dark blue: 4 inches

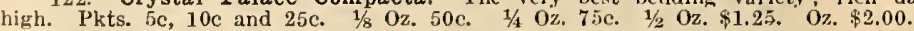

123. Gracilis. Trailing habit; suitable for hanging baskets, vases, etc.; dark blue. Pkts. 5c and $10 \mathrm{c} .1 / 40 \mathrm{Oz}, 25 \mathrm{c} .0 \mathrm{z}, 75 \mathrm{c}$.

124. Lantana. Finest mixed colors. Tender perennial. Flowering continuously: 2 to 3 feet. $10 \mathrm{c}$ and $25 \mathrm{c}, 0 \mathrm{z} .35 \mathrm{c}$

Larkspur. Double Dwarf German Rocket. Beautiful spikes of doublc flowers in many ades, ranging from pure whitc to deep rich pink. Hardy annuals. 1 foot high. Pkts. 5c and $10 \mathrm{c}$.

Lathyrus. Latifolius. Hardy Everlasting Peas. These climb 6 to 8 feet bigh when trained on a trellis; the flowers are borne in large clusters and very closely resemble Sweet Peas. They are peculiarly adapted to rough places, to scramble over rocks and bushes; splendid cnt flowers. Mixed 127. Lupin. A very conspicuous plant with spikes of pea-shaped blossoms. Growing 3 feet tall.

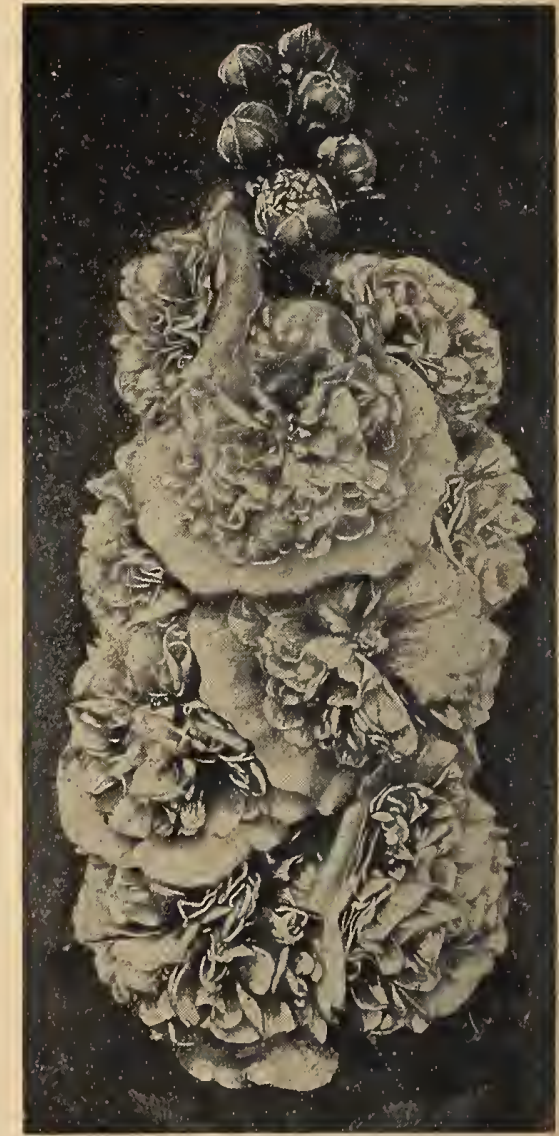

Hollyhock, Bolgiano's Superb Double Strain 


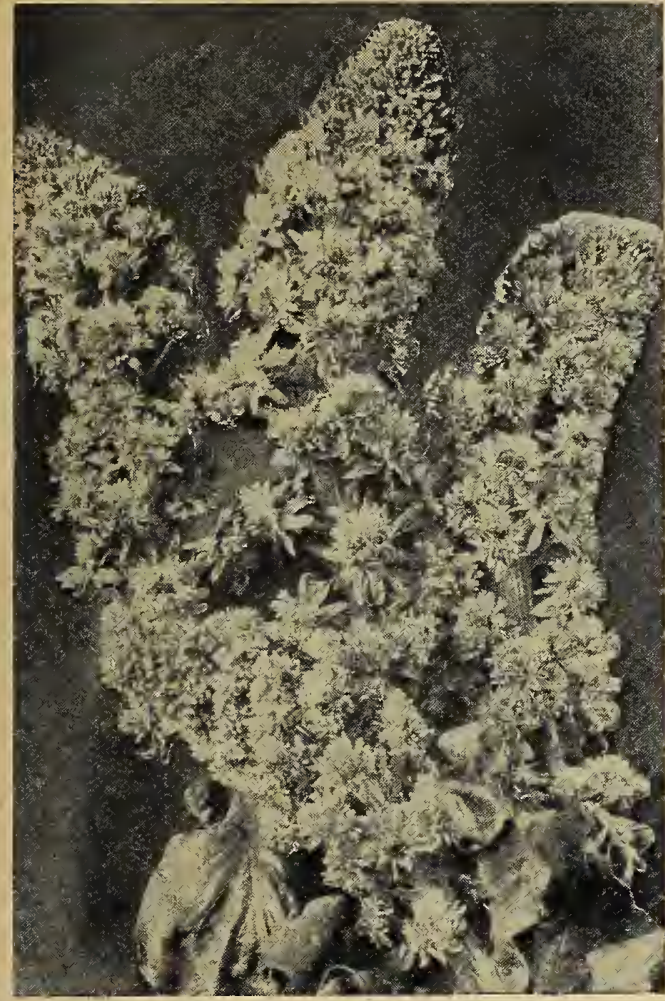

Mignonette Mammoth Flowering

Marigold (Tagetes)

Marigolds afford a wealth of color that is simply invaluable. The African varieties produce large self-colored blossoms on tall plants; the French are smaller, but the colors prod very interesting.

128. Double Tall African Mixed. Large double flowers. Pkts. 5c and 10c. 1/2 129. Double Dwarf African Mixed. Immense golden yellow flowers. Compact dwarf habit, forming dense bushes. Pkts. $5 \mathrm{c}$ and $10 \mathrm{c} .1 / 2 \mathrm{Oz} .25 \mathrm{c}$. Oz. $40 \mathrm{c}$. double fiowers. Pkts. $5 \mathrm{c}$ and $10 \mathrm{c}$. $1 / 2 \mathrm{Oz}$. 25c. Oz. $40 \mathrm{c}$.
Double Dwarf French Mixed. Low bushes covered with small flowers. Pkts. 131. Double Dwarf French Mixed, Low bushes covered with small flowers. Pkts.

132. Marvel of Peru. Four o'Clocks. Large and beautiful old-fashioned plants of spreading habits. Produce brilliant colored flowers that open about 4 o'clock in the afternoon. Pkts. $5 \mathrm{c}$ and 10c. Oz. 20c. 1/4 Lb. 60c. Lb. $\$ 2.00$. flowers being a dull purplish lilac. Pkts. $5 \mathrm{c}$ and $10 \mathrm{c}$. 134. Mignonette. Mammoth Flowering. It is the best Mignonette for all purposes, either outside or inside. Ever blooming, flowers lasting until late in Fall. Pkts. 5c and 10c. Oz. 20c. 1/4 Lb. 50c. those of other sorts. The spikes are very dense. Its foliage is crinkled while its odor is delicious. Pkts. $5 \mathrm{c}$ and $10 \mathrm{c}$. $1 / 2$ Oz. 25c. Oz. $45 \mathrm{c}$

136. Memosa. Sensitive Plant. Curious and interesting spikes, white flowers, the leaves close or droop when touched or shaken. 1 foot high. Pkts. $5 \mathrm{c}$ and $10 \mathrm{c}$. $1 / 2 \mathrm{Oz}$. $25 \mathrm{c}$. Oz. $40 \mathrm{c}$. Morning Glory Javanese. (1pomea Grandiflora Superba.) A handsome showy climber of easy culture and suitable for covering windows, trellises, old stumps, etc. The flowers are most brilliant in the morning and run through many shades, from white to dark flowers are most briliant in the morning and run through many shades, from white to dark
blue, red and striped. Hardy annual. 30 to 50 feet high. Pkts. 5c and 10c. 0z. 15c. blue, red and striped.

138. Morning Glory. Imperial Japanese. Frilled and fancy. Even more beautiful than the Superba. You should certainly try this beautiful and wonderful Morning Glory. Pkts. 5c and 10c. Oz. 20c. 1/4 Lb. 60c. Lb. $\$ 2.00$.

139. Moon Flower. Ipomea Grandiflora Alba. One of the most virgorous of all Summer climbers, and will grow 30 to 40 feet in a season, and be covered with saucerLb. $\$ 1.75$. Lb. $\$ 5.00$.

140. Myosotis Alpertris. Forget-Me-Not. Popular perennials, flowering first season from early Spring-sown seeds. Pkts. 5c and $10 \mathrm{c}$ 1/2 Oz. 25c. Oz. $40 \mathrm{c}$

141. Nemophila. Love Grove. Hixed. Free-flowering annual, of dwarf, compact habit, with a profusion of cup-shaped flowers; thrives best in a cool, shady situation; 1 foot. Pkts. 5c and 10c. Oz. 20c. 142 . Nicotiana. Affinis. Splendid pure white flowers on long terminal tubes
it is so fragrant that a small bed will perfume the surrounding atmosphere. Pkts. $5 \mathrm{c}$ and

10c. $1 / 2 \mathrm{Oz} 15 \mathrm{c} . \mathrm{Oz}$. $25 \mathrm{c}$. Nigella. Love in the Mist or Devil in the Bush. Damacena. Free-flowering plant with finely cut foliage. Curious loking flowers and seed pods; blue and white mixed; growth 1 foot. Pkts. 5c and 10c. Oz. 20c.

144. Oenothera. Evening Primrose. Mixed. $1 / 2$ to 2 feet. Neat plants, with large, saucer-shaped flowers, white or golden yellow; open at dusk; emit a delightful perfume. Pkts. 5c and 10c. Oz. 20c.

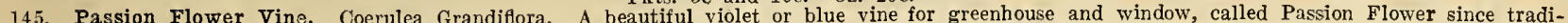
tion: see represented in its flowers the symbols of the Christian Faith. Pkts. 5c, 10c and 25c. 1/4 Oz. $30 \mathrm{c}$. Oz. $\$ 1.00$.

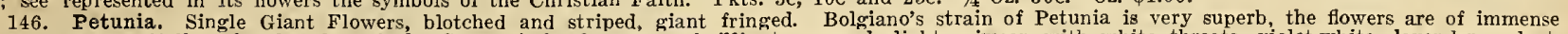

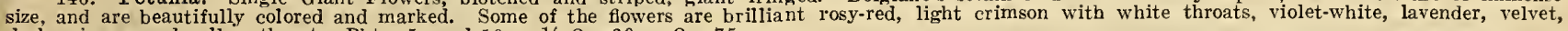
dark crimson and yellow throat. Pkts. $5 \mathrm{c}$ and $10 \mathrm{c}$. 1/4 0z. 20c. 0z. $75 \mathrm{c}$

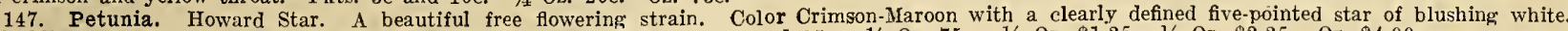
For bedding, baskets, vases, etc., this is exceptionally fine. Pkts. 5c, $10 \mathrm{c}$ and $25 \mathrm{c} .1 / \mathrm{sz} .75 \mathrm{c}$. $1 / 4 \mathrm{Oz}$. $\$ 1.25$. $1 / 2 \mathrm{Oz}$. $\$ 2.25$. $0 \mathrm{z}$. $\$ 4.00$.

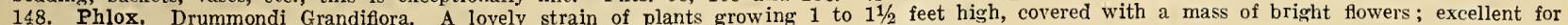
pot plants and for bedding. Choice Mixed. Pkts. 5c, $10 \mathrm{c}$ and $25 \mathrm{c}$. $1 / 1 \mathrm{Oz}$. $40 \mathrm{c}$. $0 \mathrm{z}$. $\$ 1.50$.

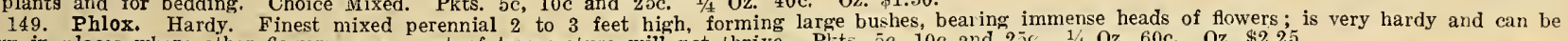
grown in places where other flowers on account of temperature will not thrive. Pkts. $5 \mathrm{c}, 10 \mathrm{c}$ and $25 \mathrm{c}$. $1 / \pm \mathrm{Oz}$. $60 \mathrm{c}$. $\mathrm{Oz}$. $\$ 2.25$.

\section{Poppy}

\section{(Papaver)}

A magnificent group of hardy anmuals and hardy perennials which should be in everybody's garden who wish a beautiful display of color in all shades from Spring until frost. The seed of the annual varieties should be sown where they are to blossom, as they do not like transplanting; thin out when large enough. Best results are to be had from a sandy loam.

150. Bolgiano's Fairy Maid Mixture. This is a beautiful mixture of all that is best in annual Poppies. The colors are simply gorgeous, both in single and double varieties. Pkts. 5c and 10c. Oz. 25c. 1/4 Lb. $75 \mathrm{c}$.

\section{SINGLE ANNUAI VARIETIES}

151. Bolgiano's Choice Shirley Mixture. This strain is especially grown for us and great care is taken with the colors, which range through apple blossom, deep pinks, old rose, crimson, terra cotta, white to the deepest red. Several sowings should be made
during the Summer. One and one-half feet high. Pkts. 5c and 10c. Oz. 30c during the $\$ 1 / 4$ Lb. $\$ 1.00$.

152. Miss Sherwood. Large flowers of satiny white, the upper half shading to a silky chamois rose; a combination of rare delicacy. Two feet high. Pkts. $5 \mathrm{c}$ and $10 \mathrm{c}$. Oz. 20c. $1 / 4$ Lb. $50 \mathrm{c}$.

153. Umbrosum (Caucasian Poppy). Dark crimson with a black blotch on the lower part of each petal. One and one-half feet high. Pkts. 5c and 10c. Oz. $30 \mathrm{c}$. $1 / 4$ Lb. $\$ 1.00$.

\section{DOUBLE ANNUAL VARIETIES}

154. American Flag. Beautiful variety. Flowers very large and double; snow white, bordered witl scarlet. Pkts. 5c and 10c. Oz. 20c. 1/4 Lb. $75 \mathrm{c}$.

155. Carnation Flowered Mixed. A very fine mixture with large, double fringed flowers. Pkts. 5c and 10c. Oz. 20c. 1/4 Lb. $75 \mathrm{c}$.

156. Paeony Flowered Mixture. Immense, showy, double flowers; very similar to a double Paeony. Pkts. 5c and 10c. Oz. 20c. 1/4 Lb. $75 \mathrm{c}$.

\section{PERENNIAL VARIETIES}

157. Alpinum Mixed. An exquisite small Poppy. Excellent for sunny borders or rock work. It resembles Nudicaule, but is dwarfer. One foot high. Pkts. 10c and $25 \mathrm{c}$.

158. Hardy Giant. Iceland and Oriental. Hardy perennials 2 to 3 feet high, producing flowers 4 to 6 inches across. Our splendid mixture contains salmon, fiery-scarlet, rose-lilac and copper color, white, golden-tinged crimson. Pkts. 5e and 10c. $1 / 4 \mathrm{Oz}$. 35c. Oz. \$1.25.

159. Iceland Poppy. While this is a hardy perennial, it flowers the first year from eed, blooming almost as quickly as the annual sorts. Finest Mixed all colors. Pkts. 5c, $10 \mathrm{c}$ and $25 \mathrm{c}$.

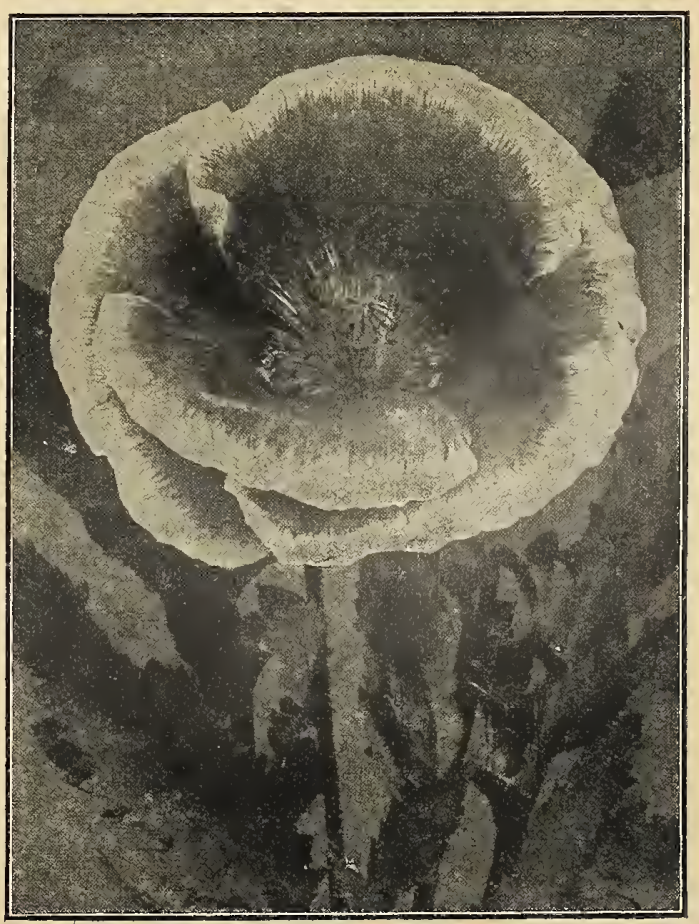

Bolgiano's Shirley Poppies 


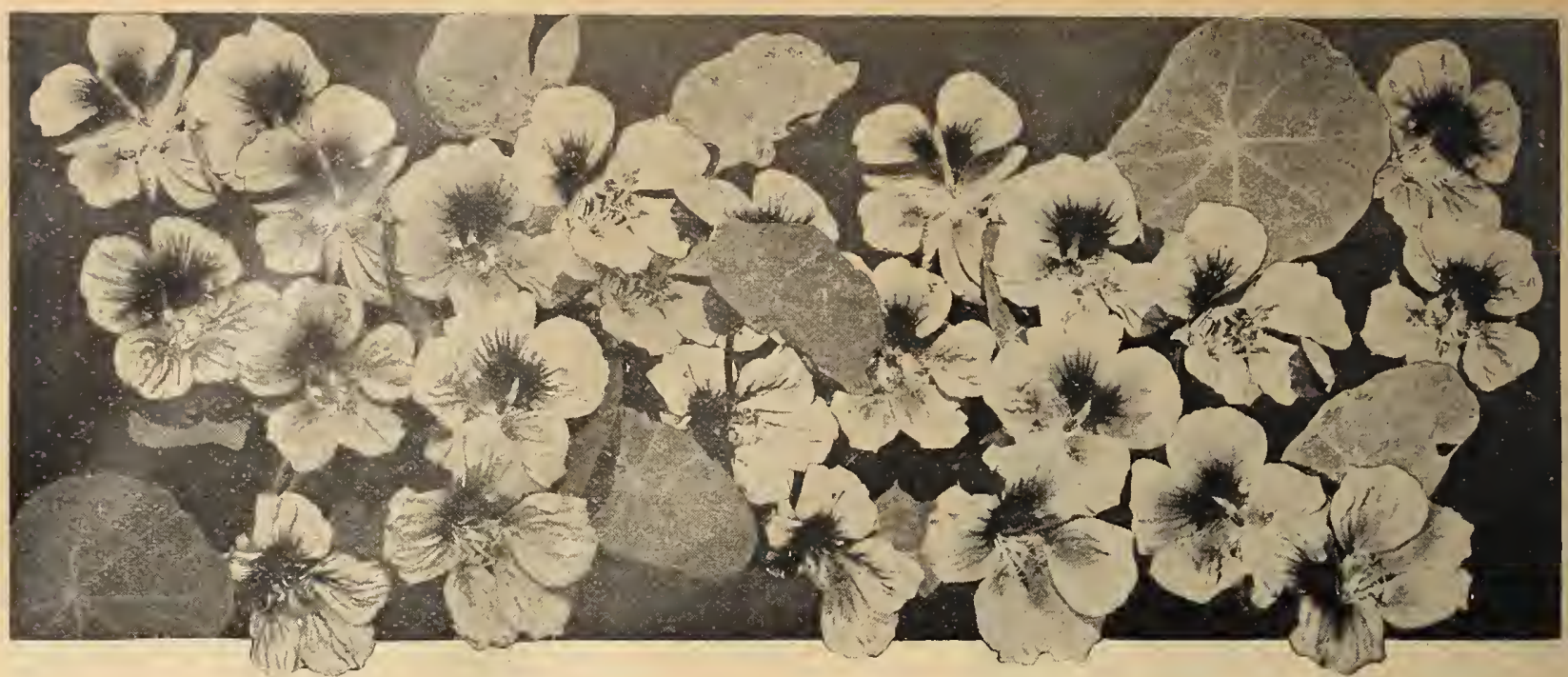

Bolgiano's Giant Flowering Nasturtiums

\author{
We Pay Postage on Pkts., Ozs., 14 Lbs. and Lbs.
}

The Nasturtium comes rext to the Sweet Pea in popularity. The Dwarf Varieties are excellent for bedding and edging. The Climbing Varieties for covering stone walls, rubbish heaps, or trailing on trellises to shade porches or verandas.

\section{Bolgiano's Dwarf Giant Flowering}

Pkts. $\quad$ oz. $1 / 4$ Lb. $1 \mathrm{Lb}$.

160. Beauty. Yellow spotted scarlet. 5c and $10 \mathrm{c} \quad 15 \mathrm{c} \quad 50 \mathrm{c} \quad \$ 1.50$

161. Cloth of Gold. Scarlet with yel-

low foliage

162. Express of India. Deep crimson,
leaved. extra fine................. $10 \mathrm{c}$ and $15 \mathrm{c}$ 50 $\quad 1.50$

163. French Chameleon, Giant flowered

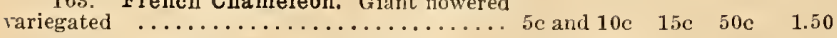

164. King of Tom Thumbs. Bright

scarlet. dark leaved ...................... 5e and $10 \mathrm{c} \quad 15 \mathrm{c} \quad 50 \mathrm{c} \quad 1.50$

165. King Theodore, The grandest dwarf Nasturtiums ever introduced. The large flowers are a beautiful dark maroon; these are set off and made conspicuous by their dark

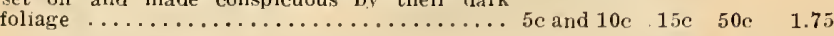

166. Pearl Amber. White flowers... 5e and $10 \mathrm{c} \quad 15 \mathrm{c} \quad 50 \mathrm{c} \quad 1.75$

167. Prince Henry, Pale yellow, spot-

168. Queen of Tom Thumbs. Giant

crimsoll, variegated green and white foliage.. 5c and $10 \mathrm{c} \quad 15 \mathrm{c} \quad 50 \mathrm{c} \quad 1.50$

169. Rose. Soft carmine rose..... 5c and $10 \mathrm{c} \quad 20 \mathrm{c} \quad 60 \mathrm{c} \quad 2.00$

170. Ruby King. Giant red flowers.. 5c and $10 \mathrm{c} \quad 20 \mathrm{c} \quad 60 \mathrm{c} \quad 2.00$

171. Spotted King or Lady Bird. Golden vellow spotted cardinal red, calyx and spur ruby ....................... $5 \mathrm{c}$. $15 \mathrm{c} \quad 50 \mathrm{c} \quad 1.50$

172. Nasturtium Dwarf or Tom Thumb. fiant flowering; most gorgeous mixture of colors; improved type of bushy garder1 annual. 1 foot. Pkts. $5 \mathrm{c}$ and $10 \mathrm{c}$. Oz. 10c. 1/4 Lb. $20 \mathrm{c}$. Lb. $60 \mathrm{c}$.

173. Lobb's Medium High Nasturtium. Grandest mixture of 30 arieties. This mixture of Nasturtiums will grow from 6 to 10 feet high, vhile the tall Nasturtium will grow more than 15 feet high. To produce best results, you should select the Dwarf for bedding, tbe Lobb's for low

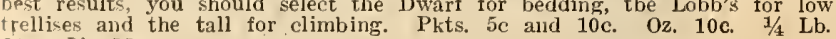
20c. Lb. $55 \mathrm{c}$.

174. Tall or Climbing Varieties, Giant flowering, gorgeous mixannual climber. " to 10 feet high, producing large flowers, flowering in light dry soil. Pkts. 5c and 10c. 0\%. 10c. 1/4 Lb. 15c. Lb. 50c.

Portulaca. Mexican Rose. There are few flowers that make a dazzling display of colors in the bright sunshine as a bed of PortuThey are in bloom from the first of July until killed by frost, grow-
to 8 inches higl. Single mixed. Pkts. $5 \mathrm{c}, 10 \mathrm{c}$ and $25 \mathrm{c}$. 1/2 0z. $40 \mathrm{c}$.

176. Portulaca, Double Rose Flowered Mixed. A large percentage wers will come perfectly double, of the most brilliant scarlet, yellow. Pkts, 5c, $10 \mathrm{c}$ and $25 \mathrm{c}$. 1/4 Oz. 50c. Oz. $\$ 2.00$.
177. Ricinus. Castor Oil Beans and other varieties. Garden amulual of luxuriant yrowth, with large palni-like leaves; extremely attractive on account of their sub-tropical effect. Our wonderful mixture contains varieties fronl 6 to 12 feet high. Some with immense leaves, green, brown or purple, other purplish leaves and stem, some with foliage, also maroon or purple, other purplish leaves and stem, some with foliage, also maroon
and black stems. Pkts. 5c and 10c. Oz. $15 \mathrm{c}$. 1/4 Lb. 40c. 1/2 Lb. 60c. Lb. $\$ 1.00$.

\section{Ricinus Separate Varieties:}

178. Gibsoni. Deep red foliage.

179. Sanguineus, Obermamni. Blood-red stalks and fruit.

180. Zanzbariensis. Inmense size. Coppery-bronze, changing to dark green with reddish ribs.

80c. Any of the above: Pkts. 5c and 10c. Oz. $15 \mathrm{c}$. 1/4 Lb. 50c. 1/2 Lb.

181. Salpiglossis. One of the most attractive annuals and should be in every garden. The blossoms are tube-shaped much like a Petunia but rivaling the latter in the beautiful colors displayed. Each flower is veined with a glint of gold. Mixed all colors. Pkts. 5c, 10 c and $25 \mathrm{c}$. 1/4 Oz. $35 \mathrm{c}$. Oz. $\$ 1.00$.

182. Salvia Splendens. Grandiflora. Among the most brilliantly colored of garden flowers, and extremely useful for bedding, hedging or border. It is like a blaze of flaming scarlet; is intensely brilliant. A single plant will carry as many as two hundred spikes of tlowers. Pkts. 5c. $10 \mathrm{c}$ and $25 \mathrm{c} .1 / 80 \mathrm{z} .35 \mathrm{c}$. $1 / 4 \mathrm{Oz} .60 \mathrm{c}$. Oz. $\$ 2.00$.

183. Salvia. Dwarf Bonfire, or Little Lord Fauntleroy. This is one of the finest of the scarlet sages, growing in a bush, 2 feet high. Its spikes of flowers of brilliant color stand clear above the dark foliage and com pletely cover the plant. It attracts immediate attention in the garden. Pkts. 5c, 10c and 25c. 1/8 Oz. 40c. 1/4 Oz. 75c. Oz. $\$ 2.50$.

184. Scabiosa. Large flowered double. Mourning Bride. These beautiful flowers of many bright colors are useful for cutting. They are gracefully borne on long, slender stems. Pkts. $5 \mathrm{c}$ and $10 \mathrm{c} .1 / 2 \mathrm{Oz} .20 \mathrm{c}$. Oz. $30 \mathrm{c}$.

185. Scarlet Runner Vine. Annual. 15 feet. This bean produces a rapid growing vine and makes clusters of showy scarlet bloons. Pkts. 5e and $10 \mathrm{c}$. $1 / 4 \mathrm{Lb} .15 \mathrm{c}$. $1 / 2 \mathrm{Lb}$. $25 \mathrm{c}$. Lb. $40 \mathrm{c}$.

186. Schizanthus. Butterfly Flower. One of our finest hardy annuals, bearing a profusion of pretty butterfly-like flowers of variou colors, closely resembling some species of Orchids: also desirable for Winter blooming in pots. All colors, nixed. Pkts. 5c. 10c and $25 \mathrm{c}$. $1 / 2$ Oz. $50 \mathrm{c}$.

187. Shasta Daisy. A large flowering single white, hardy daisy has long been considered one of our finest hardy perennials for permanent has long been considered one of our finest hardy perennials for pertsanent 2 to $2 \frac{1}{2}$ feet in height. Pkts. $5 \mathrm{c}, 10 \mathrm{c}$ and $25 \mathrm{c}$. $1 / 2 \mathrm{Oz}$. $40 \mathrm{c}$. Oz. $75 \mathrm{c}$.

188. Smilax. Myrsiphyllum Aspargoides. In many respects the Smilax is the nost uscful and graceful climber which adorns the greenhouse or conservatory. For bouquets and floral decorations it is indispensable. Pkts. 5e, $10 \mathrm{c}$ and $25 \mathrm{c}$. $1 / 2$ Oz. $30 \mathrm{c}$. Oz. $50 \mathrm{c}$.

189. Statice. Sea Lavender. Splendid hardy perennials, either for the border or rockery, producing all Summer panicles of minute flowers which can be dried and used for Winter bouquets. Mixed varieties. Plkts. $5 \mathrm{c}, 10 \mathrm{c}$ and $25 \mathrm{c}$. $1 / 2 \mathrm{Oz}$. $35 \mathrm{c}$. Oz, $65 \mathrm{c}$. 
We Pay Postage on Pkts., Ozs., 1/4 Lbs. and Lbs.

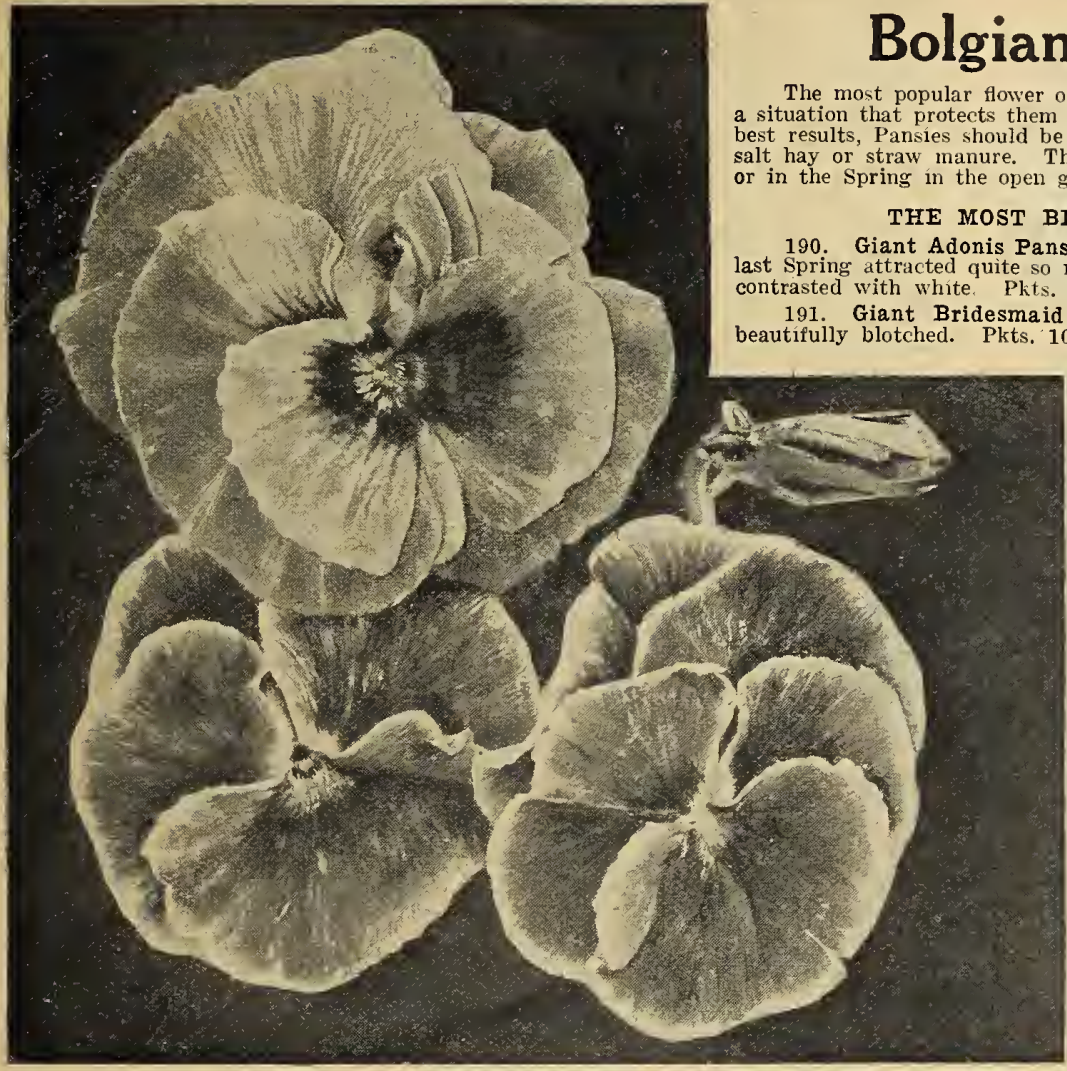

Bolgiano's Giant Show Pansies

\section{Bolgiano's Giant Pansies}

The most popular flower of the garden. They delight in a cool, rich, moist soil and
situation that protects them from the cutting winds as well as the bright sun. To get a situation that protects them from tbe cutting winds as well as the bright sun. To get
best results, Pansies should be sown in July or August and protected with a cold frame, salt hay or straw manure. The seed may also be sown indoors in January or February,

THE MOST BEAUTIFUL PANSIES IN THE WORLD

190. Giant Adonis Pansy. None among the thousand of Pansy plants that we sold $10 \mathrm{c}$ and $25 \mathrm{c}$ as this beauty; it is a beautiful light blue Pz. $10 \mathrm{c}$ and 25c. 1/8 $0 \%$. 50c. 1/4 Oz. 90 $0 \mathrm{c} . \$ 3.00$.

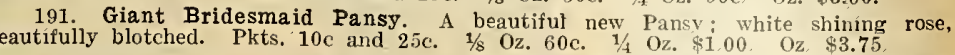
192 Emperor william. Blue with violet eve.
A new ideal beauty. Looks like velvet. Pkts. 10c
and $25 \mathrm{c} .1 / 8 \mathrm{Oz} 50 \mathrm{c}$. 1/4 Oz, 90c. Oz $\$ 3.00$.
193. Giant Golden Yellow With Large Black 193 Giant Golden Yellow With Large Black
Eyes. One of the most effective Pansies that is Eyes. One of the most effective Pansies that is
grown, a veritable niass of molten gold. Pkts. $10 \mathrm{c}$ and
$25 \mathrm{c} 1 / 8 \mathrm{Oz} .50 \mathrm{c} 1 / 4 \mathrm{Oz} 90 \mathrm{c}$

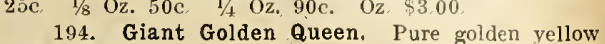
and five-spotted. Pkts. $10 \mathrm{c}$ and $25 \mathrm{c} .11 / 80 \mathrm{z}, 60 \mathrm{c}, 1 / 4$ Oz. $\$ 1.00$. Oz. $\$ 3.50$

195. Triumph of the Giant. Most wonderfully beautiful, in immense size. Pkts. $10 \mathrm{c}$ and

$\$ 1.25, \quad 1 / 4$ Oz. $\$ 2.00 \quad$ Oz. $\$ 7.00$

196. Giant Lord Beaconfield. a Pansy that arrests the attention immediately wonderful combination and its beauty, P

197. Giant Ruffled "Masterpiece" Imperial. A new class of blotched, heavily ruffled Pansies with large blooms, mostly undulated or curled; many fine,
rich colors. Very popular. Pkts. $10 \mathrm{c}$ and $25 \mathrm{c} 1 / 8 \mathrm{Oz}$ $\$ 1.00$. 1/: Oz. $\$ 1.75$, Oz $\$ 6.00$.

198. Mme. Perret. A new and beautiful strain, originated with a French specialist; flowers of large size, borne very freely in great diversity of colors;
especially rich in red and wine sbades. Pkts. 10: and $25 \mathrm{c} .1 / 8 \mathrm{Oz} .50 \mathrm{c}, 1 / 4 \mathrm{Oz} 90 \mathrm{c}$. $\mathrm{Oz} . \$ 3.00$.

199. Snow Queen, A magnificent pure white, of large size and heavy texture. Pkts. $10 \mathrm{c}$ and $25 \mathrm{c}$. $1 / 80 z .35 \mathrm{c}, 1 / 40 z .60 \mathrm{c}$, Oz. $\$ 2.25$.

200. Superb Mixture of the Odier, Cassier and Bugnot Strains. This is one of the most beauti. ful and most costly mixture of Pansies in the world. Oz. $\$ 6.00$.

203. Stocks. Bolgiano's Giant Perfection Double Stocks. A mag. nificent strain, $2 \frac{1}{2}$ feet high, with long, well-filled spikes of very large nifcent stram, $21 / 2$ feet high, with long, well-filled spikes of very large
flowers. This well-known annual is sometimes grown in pots, but usually flower. This well-known annual is sometimes grown in pots, but usually
used for garden decorations. Pkts. $5 \mathrm{c}, 10 \mathrm{c}$ and $25 \mathrm{c}$. 1/2 Oz, 60c. 0z. $\$ 2.00$.

204. Sunflower, Single thousand flowered, Single Cut and Come Again, Double Cut and Come Again. Double Globes of Gold, in grandest mixture. This is a branching pyramidal plant, bearing hundreds of yellow flowers The Cut and Come Agains are from 3 to 4 feet high, and of a Doubie Cut and Come Again are extremely attractive. The Double Globes of Gold grow 3 to $3 \frac{1}{2}$ feet high and bear double golden flowers.

205. Single and Double Mixed. Pkts. 5c and 10c 1/2 Oz. 15c. Oz. 20c.

206. Tall Sunflower. Pkts. 5c and 10c. 1/2 Oz. 15c. Oz 20c.

Sweet William. For many years the Sweet William has been es. teemed as one of the finest of our hardy garden plants, being of easy
culture and thriving in any good garden soil and lasting for years. The culture and thriving in any good garden soil and lasting for years. The plants grow about 1 foot high and form fine clumps. Our perfection strains
produce heads of fragrant flowers, including blood crimson, salmon, pink, white, cerise, etc. Many have large white eyes, and all being sweet scented.

207. Single mixed. Pkts. 5c, $10 \mathrm{c}$ and 25c. 1/2 Oz. 30c. Oz. 50c.

208. Double mixed. Pkts. 5c, $10 \mathrm{c}$ and $25 \mathrm{c}$. 1/2 Oz. 30c. Oz. $50 \mathrm{c}$

209. Thunbergia. Black-eyed Susan. Beautiful, rapid-growing annual climbers, preferring a warm, sunny situation; used extensively in hanging baskets, vases, low fences, etc.; very pretty flowers in buff, white, orange, etc., with dark eyes; mixed colors; 4 feet. Pkts. $5 \mathrm{c}$ and $10 \mathrm{c}$. $1 / 4$ Oz. $15 \mathrm{c}$. Oz. $50 \mathrm{c}$.

210. Tritoma. Red Hot Poker Plant. Showy plants either for bedding, vases or pot culture. A most striking ornamental Autumn plant; valuable for shrubberies, flower borders or beds; large spikes of orangescarlet flowers; 3 to 4 feet. Pkts. $5 \mathrm{c}$ and $10 \mathrm{c} 1 / 4 \mathrm{Oz} .20 \mathrm{c}$. $0 \mathrm{z} .75 \mathrm{c}$

211. Verbena, Mammoth. This Verbena produces mamnificent flowers in wide range of colors. The blooms are frequently larger than a silver in wide range of colors. The blooms are frequently larger than a silver
quarter. The colors are rich and varied, embracing all the bright shades. quarter. The colors are rich and varied, embracing all the
Pkts. 5c, $10 \mathrm{c}$ and $15 \mathrm{c}$. 1/4 Oz. 20c. $1 / 2 \mathrm{Oz}$. $40 \mathrm{c}$. Oz. $75 \mathrm{c}$.

212. Verbena. Bushy or dwarf. These are free flowering hardy annuals of low spreading growth. Single plants in rich soil will cover a space 3 to 4 feet in diameter and furnish a profusion of flowers. If the flowers are kept cut the plants bloom much more freely. Pkts. $5 \mathrm{c}, 10 \mathrm{c}$ and $15 \mathrm{c}, \quad 1 / 4$ Oz. 20c. $1 / 2$ Oz. $40 \mathrm{c}$. Oz. $75 \mathrm{c}$

213. Wallflower. German. Finest Mixed. An old favorite garden flower. The large, massive spikes of the Wallflower are very conspicuous in the beds and borders and are very useful in making bouquets. Height about $1 \frac{1}{2}$ feet. Pkts. 5c, $10 \mathrm{c}$ and $15 \mathrm{c}$. 1/4 Oz. 20c. Oz. $75 \mathrm{c}$.
201. Trimardeau Parisian Large Stained, Very beautiful improved strain of Trimardeau Pansies, mostly white ground and finely blotched varieties. Pkts. 10c and 25c. 1/8 Oz. 50c. 1/2 Oz. 90c. Oz. $\$ 3.00$.

202 Bolgiano's Finest Mixed Giant Pansies. This mixture, full of startling beauties, is so well known that a description is hardly necessary; if you want a perfect dream of beauty, try this mixture. Pkts $10 \mathrm{c}$ and $25 \mathrm{c} .1 / 8 \mathrm{Oz} .35 \mathrm{c}$. 1/4 Oz. $60 \mathrm{c}$. Oz. $\$ 2.2$.

214. Wild Cucumber. Quickest grower of all climbers. Thickly dotted with pretty, white, fragrant flowers followed by ornamental seed pods Pkts. 5c and 10c. Oz. 15c. $20 z \mathrm{~s}, 25 \mathrm{c}$

215. Xeranthemum. Everlasting or Immortelle. Annum. One of the prettiest and most satisfactory of the everlasting, bearing bright rose. purple and white flowers, which are not only showy in the garden, but useful for dried flowers in Winter bouquets. Grows about 3 feet high and can be sown in the open ground early in May, growing in any sunny position, remaining in bloom fron early Sunmer till frost. Mixed colors. Pkts. $10 \mathrm{c}$ and $25.0 \mathrm{z} .50 \mathrm{c}$.

216. Zinnias. Tall Mammoth Mixed The garden annuals are greatly improved; the plants form handsome bushes 2 feet in height, with $35 \mathrm{c}$. $0 \mathrm{z}$. $60 \mathrm{c}$.

217. Zinnias. Dwarf Mixed. Thick branching little plants about 1 foot high : they fairly bristle with tiny, short-stemmed double flowers like a large daisy in size. They may be used with success in pots as well as for
groups and edgings. Pkts. $5 \mathrm{c}, 10 \mathrm{c}$ and $25 \mathrm{c}$. 1/2 0z. $40 \mathrm{c}$. Oz. $75 \mathrm{c}$.

218. Dwarf Double White. Pkts. $5 \mathrm{c}, 10 \mathrm{c}$ and $25 \mathrm{c} .1 / 2 \mathrm{Oz}, 40 \mathrm{c} . \mathrm{Oz} .75 \mathrm{c}$.

219. Dwarf Canary Yellow, Pkts. $5 \mathrm{c}, 10 \mathrm{c}$ and $25 \mathrm{c}, 1 / 2 \mathrm{Oz} .40 \mathrm{c} . \mathrm{Oz} .75 \mathrm{c}$.

220. Dwarf Double Scarlet. Pkts. $5 \mathrm{c}, 10 \mathrm{c}$ and $25 \mathrm{c} .1 / 2 \mathrm{Oz} .40 \mathrm{c} .0 \mathrm{z} .75 \mathrm{c}$. 221. Dwarf Salmon Rose. Pkts. $5 \mathrm{c}, 10 \mathrm{c}$ and $25 \mathrm{c}$. 1/2 Oz.60c. Oz, $\$ 1.00$.

\section{Bolgiano's Wild Flower Garden or Children's Flower Garden Mixture}

This is a mixture which will give great pleasure to all who try it for waste corners and patches, and with a little or no care will procure a pleasing effect in places that would otherwise be nothing but a collection of unsightly weeds. This mixture is ideal for the Children's Garden. Why not put aside a little patch of ground for every one of your children; show them how to spade and rake the bed smoothly, then early in May sow the seeds broadcast over the bed, and cover about one-half inch with fine sifted soil? Make the children a present of a package of seed and a watering pot sond teach them to water when necessary Do not thin out the plants and and teach them to water when necessary, bo not thin out the plants and

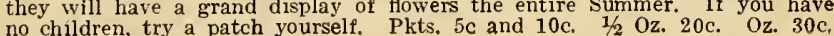
no children, try a patch your
$1 / 4$ Lb. $\$ 1.00$. Lb. $\$ 3.00$. 
We Pall Postuge on Plts., Ozs., 1/4 Lbs. and Pounds

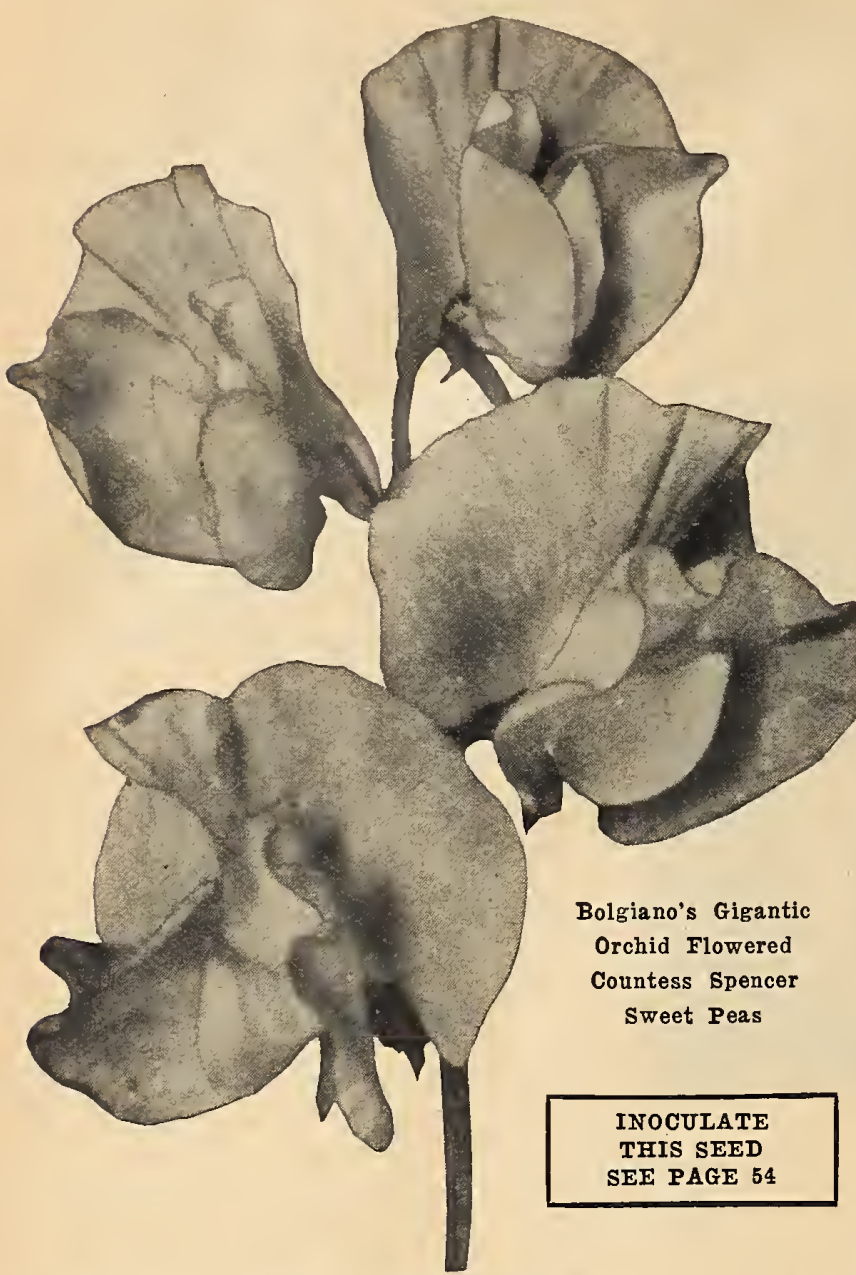

247. Mrs, Routzahn Spencer. The heautiful coloring is buff on apricot ground flushed with pink deepening toward the edges. Cliarming as

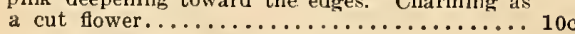

248. Mrs, Walter Wright Spencer, A beautiful shade of deep mauve; very artistic..... 10c

249. Primrose Spencer. The finest primrose yellow, with very large wavy flowers....... 10c

250. Rainbow Spencer. Ivory streaked rose. I handsome sort.................. 10c

251. Rosabelle. A very large bright waved rose. $10 \mathrm{c}$ 252. Royal Purple. The color of this charming variety is a fine royal purple and beautifully waved. It is absolutely distinct....... 10c

253. Ruby Spencer. Rich, dark red. Tbe flowers are enormous and borne three and four to a stem........................ $10 \mathrm{c}$

254. Senator Spencer. The color is a varving combination of deep scarlet and chocolate striped and flaked on a ground of light helio-

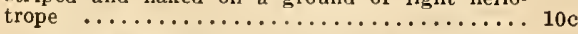

255. The President. The intensely rich and dazzling orange-scarlet color of the flower equals in brilliance the Oriental Poppy. Both for exhibition and garden decoration. "The President" is the most striking and valuable addition to Sweet Peas that has been offered in recent years ........................ 10 c $40 \mathrm{c} \quad 1.15 \quad 4.00$

256. Wedgewood. Flowers of good size and a fine shade of Wedgewood hlue; wings well waved; very free flowering; considered by

ariety yet introduced.................. 10c

57. White Spencer. A pure wavy white of normous size and splendid substance.......10

Oz. 1/4 Lb. $1 \mathrm{Lb}$

\section{Bolgiano's Superb Collections Sweet Peas}

8 Pkts. choice Spencer varieties in all the most beautiful shades for $\$ 1.00$

choice Spencer varieties in all the most beautiful sbades for

\section{Sweet Peas}

\section{Bolgiano's Giant Orchid or Spencer Flowering Varieties}

We recommend the following methods of planting: Sow seeds indoors in January or February in boxes or pots. If in pots put 4 to 6 seeds in a 3-inch pot, grow in a cool temperature. Plant outside ahout the middle of April. If the ground for same has been well prepared and enriched, they will need nothing but watering in dry weather: except when in blossom when watering of liquid manure will be very beneficial. Keep the flowers well cut if you desire to prolong the flowering season.

\section{Bolgiano's Giant Orchid or Spencer Flowering Mixture}

This wonderful mixture contains only the choicest and finest Spencer types. The colors are grown separately, then mixed in equal proportions to insure a well halanced range of colors. Pkts. 10c. Oz. 20c. 1/4 Lb. 60c. Lb. $\$ 2.00$.

\section{Bolgiano's Choice Mixture of Grandiflora Varieties}

This mixture is made up of the best distinct varieties of Grandifloras and has a vast range of color and profusion of bloom. Pkts. 5c. Oz. 10c. $1 / 4$ Lh. 25c. $1 / 2$ Lh. 40 c. Lb. 75 c.

225. America Spencer. Striped brilliant carPkt. $\quad 0 z . \quad 1 / 4$ Lh. $1 \mathrm{Lb}$. mine red on white.......

226. Apple Blossom Spencer. Immense waved and crinkled flowers of crimson rase color with creamy blusb wings .................... 10 $10 \mathrm{c} 30 \mathrm{c} \quad 1.00 \quad 3.50$ 227. Asta Ohn. Lavender tinted mauve; very fine $\ldots \ldots \ldots \ldots \ldots \ldots \ldots \ldots \ldots \ldots \ldots .10 \mathrm{c} \quad 30 \mathrm{c} \quad 1.00 \quad 3.50$

228. Aurora Spencer. Brilliant orange rosestriped and flaked on a cream white, the most attractive of the striped Spencers.......... 10

229. Blanche Ferry Spencer. Pink and white. These beautiful colors in the large, wavy standard and wings are a welcome addition.... $10 \mathrm{c} \quad 30 \mathrm{c} \quad 1.00 \quad 3.50$

230. Constance Hinton. A beautiful white Spencer of enormous size. Young flowers usually tinted a trifle pink but they soon turn pure white $\ldots \ldots \ldots \ldots \ldots \ldots \ldots \ldots \ldots \ldots, 10$

231. Countess Spencer. The coloring is a soft rose pink, which deepens at the outer edges and becomes still richer or more heavily suffused in cool weather................ $10 \mathrm{c}$

232. Dobbies Cream. We consider this the very best deep cream or primrose colored variety; nicely waved.................. 10

233. Fiery Cross. Has all the appearances of live fire, the color being a scorching fire-red, or scarlet, without any shading and which scintillates and glitters in bright sunshine, thus adding a glowing fire like sheen, which radiates ing a glowing fire like sheen, which radiates over the flower. It can be grown in all soils,
without shading. The beautiful waved and without shading. The beautiful waved and
fluted flowers are borne freely in threes and fours, well placed on long, stout stems........ $10 \mathrm{c} \quad 40 \mathrm{c} \quad 1.15 \quad 4.00$

234. Florence Morse. Light pink edged Coun-

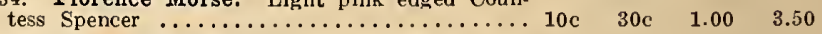

335. Florence Nightingale. The largest and finest pure lavender.................... $10 \mathrm{c}-30 \mathrm{c} \quad 1.00 \quad 3.50$

236. George Herbert. Beautiful, rich bright

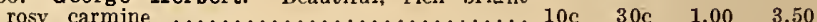

237. Helen Lewis Spencer. The wings orangerose; the standard is of an intense, rich crimsonorange. Blooms of a gigantic size........ 10 c

238. Illuminator, Rich glowing cerise salmon, with an indication of bright orange suffusion. $10 \mathrm{c}$

239. King Edward. Deep rich crimson; a strong and heautiful color. Does not fade or scorch $\ldots \ldots \ldots \ldots \ldots \ldots \ldots \ldots \ldots \ldots \ldots \ldots$. 10 c

240. King Manuel. Giant cbocolate maroon self, one of the largest and best of this color.. 10c

241. Loyalty. A fine large, waved, bright blue, flaked on wbite.................. 10 $30 \mathrm{c} \quad 1.00 \quad 3.50$

242. Margaret Atleo. Duplex salmon-pink. suffused on cream ground................. 10c $30 \mathrm{c} \quad 1.00 \quad 3.50$

243. Margaret Madison. Clear pale blue self. $10 \mathrm{c} \quad 30 \mathrm{c} \quad 1.00 \quad 3.50$

244. Marie Corelli Spencer. The large flowers are hrilliant rose carmine or red of the true are hrilliant rose carmine or red of the true
Spencer form. The wings are a pure rosc Spencer form. The wings are a pure rosc
crimson while the standard shows a tint of crimson while the standard shows a tint of $10 \mathrm{c}$

245. Maud Holmes, A large and bright rich crimson

246. Mrs. Hugh Dickson. One of the finest: beautiful salmon pink on a cream ground : $10 \mathrm{c}-30 \mathrm{c}-1.00-9.50$ 


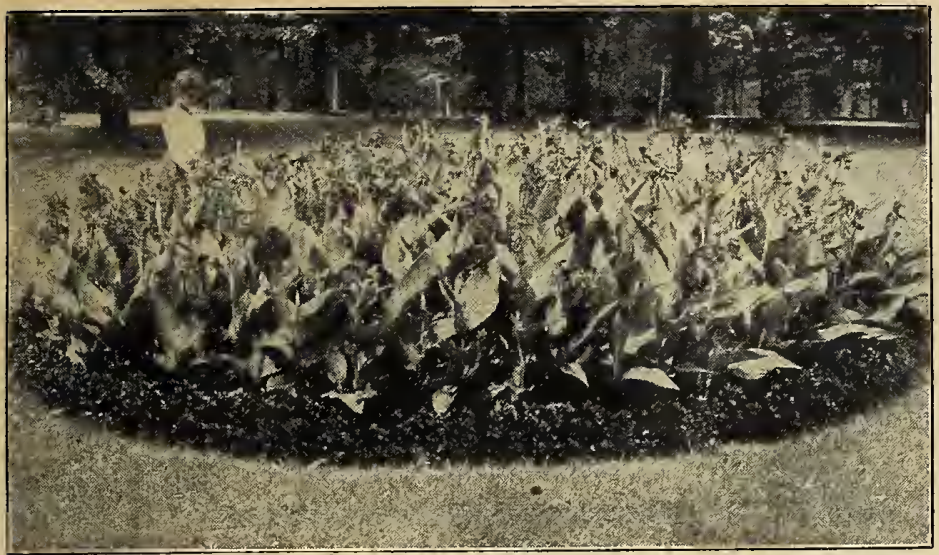

\section{Large Flowering Cannas}

Parcel Post Weight $1 \mathrm{Lb}$. per Root. Postage extra and must be incluaied

Culture. Cannas should be planted in good, rich garden soil, mixed with half of old rotten stable manure, by the end of May, when danger from frost is past. Water sparingly for first two weeks after planting. When growing freely, water liberally. Set the plants about 18 inches apart each way, and if mole than one kind is used, be careful to plant the taller growing kinds in the center and the dwarf ones along the edge. This applies to planting in berls.

A Beautiful Canna Bed

\section{Four New and Rare Varieties}

Apricot. Deep yellow buff petals, overlaid with salmon pink. More remarkable than its popular and pleasing color is the thickness and texture and consequent durability of the petals and hence of the flowers. Its flowers will stand up firmly against rain, wind and sun better than any other canna. It is of green foliage, average four feet high; a good producer and good keeper. 30c each. $\$ 3.25$ dozen.

\section{Other Choice and Rare Varieties}

Distinction (New). $5 \mathrm{ft}$. A very robust grower with large flowers of reddish chrome, widely bordered with pure yellow. $35 \mathrm{c}$ each. 3 for $\$ 1.00$.

Candelabra. $5 \mathrm{ft}$. A prodigy, producing 3 to 5 flower heads on each stalk. Color, fiery orange, scarlet. Price: $35 \mathrm{c}$ each. 3 for $\$ 1.00$.

Nokomis. $5 \mathrm{ft}$. The foliage is a combination of emeraldgreen and bronze, beautifully veined, making a lovely setting for the large, vivid crimson flowers. 15c each. $\$ 1.75$ dozen.

City of Portland. $3 \frac{1}{2} \mathrm{ft}$. Glowing Pink; profuse bloomer. Magnificent for bedding. $15 \mathrm{c}$ each. $\$ 1.75$ per doz.

King Humbert. $5 \mathrm{ft}$. In this grand canna we have a combination of the highest type of flowers with the finest bronze foliage. Its flowers measure 6 inches in diameter, produced in gigantic trusses, a brilliant orange scarlet with bright red markings; foliage broad and massivc, of a rich coppery-bronze. $10 \mathrm{c}$ each. $\$ 1.10$ per doz.

Morning Glow. $4 \mathrm{ft}$. A color contrast of more than usual picturesqueness; foliage an olive-green, striped and veined with bronze. Flowers exquisite, soft shell-pink with orangered center. 10c each. $\$ 1.10$ per doz.

The President. $4 \mathrm{ft}$. Nearly everyone had a chance to become acquainted with this canna marvel last summer, for this was the glorious red flower grown on the public grounds at Washington, D. C., and in the largest public parks in this country. Color is rich glowing scarlet, and the immense, firm flowers, 7 inches across when open, are produced 10 to 15 on a head, on strong, erect stalks. 15c each. $\$ 1.75$ per doz.

Wintzer's Colossal. $5 \mathrm{ft}$. The average fiower more than covers a man's hat. The color is a striking, vivid scarlet, that does not fade, but retains its brilliancy as long as the flower lasts. A splendid canna for large beds as it blooms continuously. 10c each. $\$ 1.10$ per doz.

Wyoming. $7 \mathrm{ft}$. Orange flowers, purple foliage. $8 \mathrm{c}$ each. $90 \mathrm{c} \mathrm{doz}$.

Yellow King Humbert. $5 \mathrm{ft}$. A rare beauty, grcen foliage, symmetrical plant, golden yellow flowers dotted red, strong habit, makes a splendid variety to bed with the bronze leaf King Humbert. 20c each. $\$ 2.20$ per doz.

\section{Calladium or Elephant Ears $\begin{gathered}\text { Postage extra and must bo } \\ \text { included with remittance. }\end{gathered}$}

Calladium or Elephant Ears. One of the most effective plants in cultivation for the flower border bed or for planting out on the lawn. They will grow in any garden soil, and is of the easiest culture. To obtain the best results they should be planted where they will obtain plenty of water and abundance of rich compost. Foliage light green. When full size they stand 6 feet high and bear immense leaves 3 to 4 feet long by $21 / 4$ feet wide.

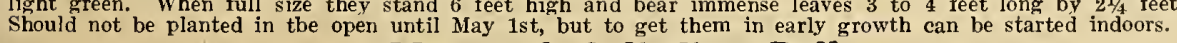

\section{Mammoth Calladium Bulbs}

These are particularly fine for center of beds, giving a beautiful effect where Cannas and Scarlet Sage are planted on the outside borders. They are only the choicest and most select bulbs, producing the most massive effect with their foliage.

Extra Large Bulbs. 12 inches in circumference, $25 \mathrm{c}$ each. $\$ 2.75 \mathrm{doz}$.

By mail add 10 c per bulb.

Large Bulbs. 9 to 11 inches in circumference, $15 \mathrm{c}$ each. $\$ 1.60 \mathrm{doz}$.

By mail add 5c per bulb.

Small Bulbs. 7 to 9 inches in circumference, 8c each. $85 \mathrm{c}$ doz.

\section{By mail add $5 c$ per bulb.}

\section{Bolgiano's Excelsior Double Pearl Tuberoses}

\section{Pastage extra and must be included with remittance.}

Mailing Weight $1 \mathrm{Lb}$. per Doz. 7 Lbs, per 100 Parcel Post Rates, see Page 2.

One of the most fragrant and most popular of the Summer flowering Bulbs. Easily recognized by its fragrance and beautiful flower spikes, which are borne on long stems, making it an admirable cut-flower for house
decorations, Plant in open ground after the first day of May. If started in pots and then transplanted to open ground can be had much earlier.

\section{MAMMOTH BULBS}

Bolgiano's Mammoth Excelsior Dwarf Pearl Tuberoses are a special selection which we have perfected after years of reselecting and improving. This Mammoth strain is positively the highest type of Tuberoses. The kind to grow if you desire prize blooms. Prices: 7c each. 75 c doz. $\$ 6.00$ per 100 .

Fìrst Size Bulbs. These a re choice, selected stock, free flowering, which are borne on long stout stems. They are the kind that are ordinarily sold for Mammoth bulbs. Prices: 4c each. $40 \mathrm{c}$ doz. $\$ 3.00$ per 100 .

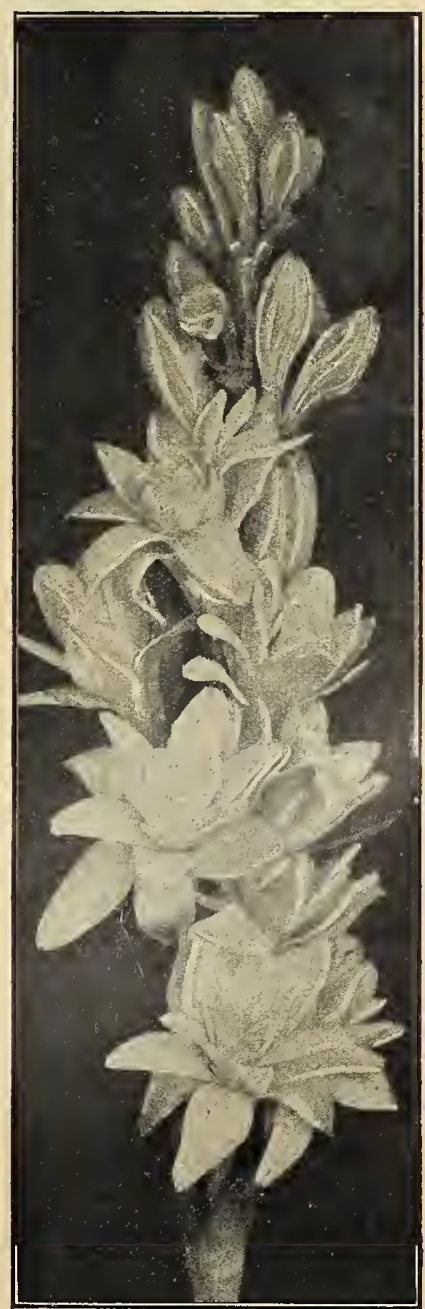

Fragrant Double Pearl Tuberoses 


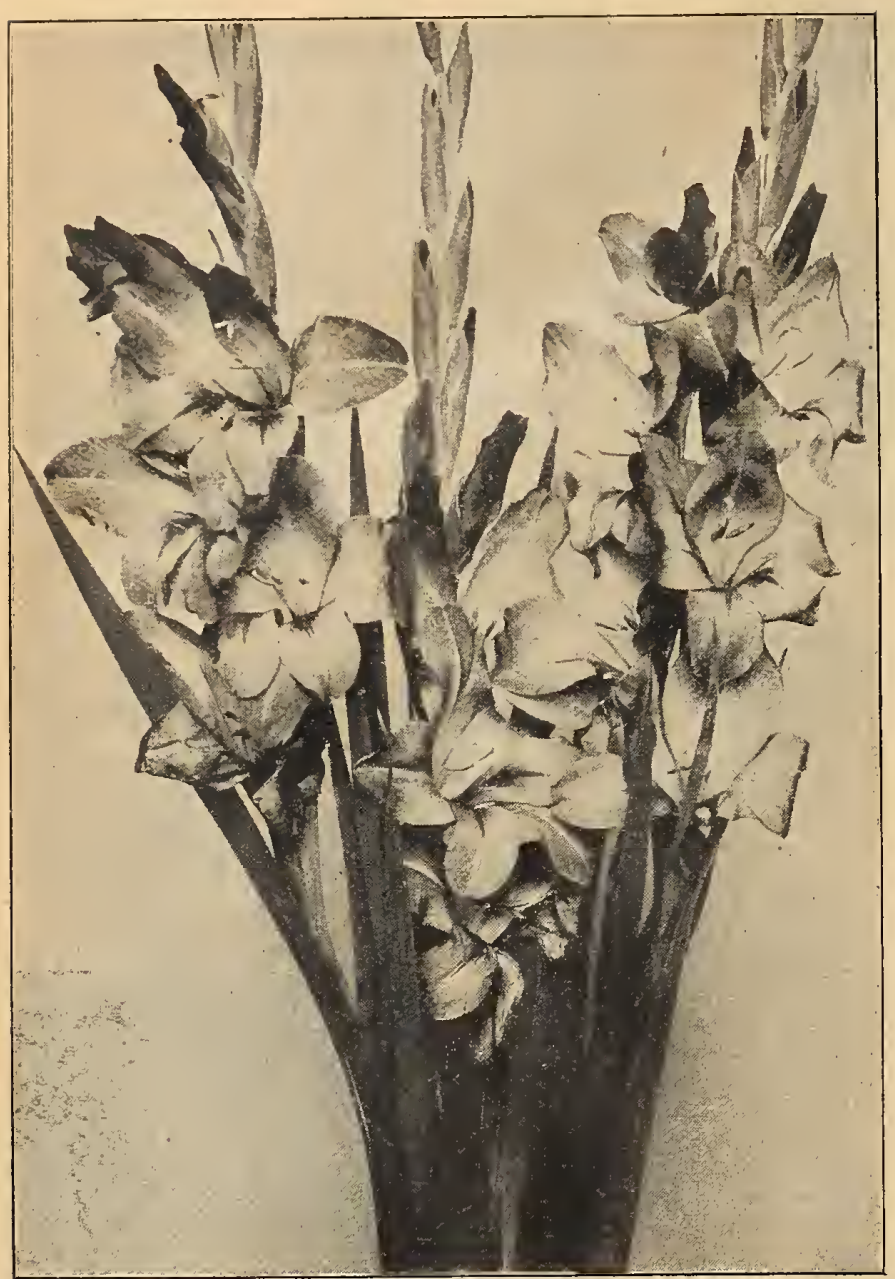

Bolgiano's Beautiful Gladiolus

Panama. Owing to its habit, color and form, it is sure to become the most popular Gladiolus in the near future. It has all the desirable features of the variety America, but in color is a rich rose-pink. Unquestionably one of tlie finest. The stalks are tall and very robust, many flowers appearing at one time. Mammoth Bulbs 8c each. 80c doz. $\$ 6.25$ per 100 .
Mailing Weight 1 Lb. Gladiolus Parcel Post Rates.
mer Doz.
ser Page

OUR LIST COMPRISES ONLY THE BEST BOTH IN MIXTURE AND NAMED SORTS

\section{All First Size Bulbs \\ Rare and Beautiful Varieties}

\section{The Most Popular Cut Flower of the Day Now Within the Reach of All}

This flower has made wonderful strides during recent years. Its popularity today is exceeded by few otliec flowers and it lias by no means reached its limit. Failure with this flower has never been known. They will grow in any open position and bloom well. They are not only slowy in the garden, but when cut with the first flower open will last for 10 days in the house. The newer colorings defy the choicest orchids. Plant bulbs 4 inches deep, 6 inches apart and stake when 2 feet high. Flowers appear from early July until late in the Fall. A succession of blooms may be had from July until October by making plantings from April to June about ten days apart.

\section{The Super Six Gladiolus}

America. A beautiful, soft, flesh-pink. The flowers are of the largest size. The petals are round, thick and strong, and will last at least 10 dass in the house after leing cut. By far the most vigorous and easily growii Gladiolus known. Stalks 2 to 3 feet long. Mammoth Bullss 5c each. 40 c doz. $\$ 3.00$ per 100 .

Augusta. A lovely and useful variety. A real gem of the garden. Beautiful flowers of pure white with blue anthers, which open all at one time. For massing in front of shrubbery or tall perennials, this variety is excellent, also for cut flowers. Mammoth Bulbs 6c each. 60c doz. $\$ 4.50$ per 100 .

Baron Jules Hulot. The finest blue Gladiolus yet seen. Rich deep color of an indigo shade. Mammoth Bulbs 10e each. $\$ 1.15$ doz. $\$ 9.00$ per 100 .

Princeps. Immense wide-open amaryllis-like flowers of a rich, dazzling scarlet, marked with white on the lower portion, which serwes to intensify the brilliancy of the scarlet. 9e each. 95e per doz; $\$ 7.25$ per 100.

Peace. A grand white with pale lilac featherings on interior petals; large flowers correctly placed on a heavy straiglit stalk 5 feet high. Peace is a wonderful variety, being a splendid keeper when cut. It flowers Midsummer and late when the best of otlier Gladiolus are gone. Mammoth Bulbs $7 \mathrm{c}$ each. $75 \mathrm{c}$ doz. $\$ 6.00$ per 100 .

TWO EACH OF ABOVE-12 BULBS FOR 70c.

\section{Other Rare Varieties}

Chicago White. Pure white. lightly marked with lavender; fine for cutting. 6e each, 65c per doz. $\$ 5.00$ per 100 .

Empress of India. Rich velvety dark red with deeper shadings. One of the richest colored varieties. Iminense flowers on strong stalks. Very decorative. Mammoth Bullss $7 \mathrm{c}$ each. $70 \mathrm{c}$ doz. $\$ 5.50$ per 100 .

Halley. Salınon-pink, sliaded yellow. Very large, wellexpanded flowers. The predominating color of the flower is a delicate pink, with a slight roseate tinge. The lower petals bear a creamy blotch with a bright red stripe through the center, producing a superb effect. Mammoth Bulbs 5e each. 50e doz. $\$ 3.75$ per 100 .

Kunderdi Glory. This attractive variety has large flower's and each petal is exquisitely ruffed and fluted. The color is a fine cream-pink with a neat crimson stripe. $9 \mathrm{c}$ each. $90 \mathrm{c} \mathrm{doz.}$ $\$ 7.00$ per 100.

Mrs. Francis King. A beautiful scarlet pink of recent ntroduction, which has everywhere created wide comment for startling heauty. Immense flowers on spikes growing 4 feet gh. The spikes are covered with a mass of blooms. A nder among Gladiolus. Mammoth Bulbs 5e each. 40e do\%. .00 per 100 .

Mrs. Frank Pendleton. Awarded Certificates of Merit by the Vasgachuetts Horticultural Society at Boston, August,
1909, and American Gladiolus Society of Baltimore, August, 1911. The flowers are very large and well-expanded, of a lovely flushed salmon-pink with brilliant carmine, or deep blood-red blotches in the throat, presenting a vivid contrast of orchidlike attractiveness. Nammoth Bulbs $9 \mathrm{c}$ each. 90e doz. $\$ 7.25$ per 100 .

Niagara. Immense flowers often $4 \frac{1}{2}$ inches across; color entirely new in Gladiolus. Soft primrose-yellow, slightly ringed rose-pink in throat, penciled with carmine on two lower petals. Mammoth Bulbs 7c each. 75c per doz. $\$ 6.00$ per 100.

Schwaben. Stalk produces about 20 very large flowers, 6 to 8 usually open at one time. The color is the best of clear canary yellow, shading to a soft sulphury yellow when opening. Nammoth Bulbs 9e each. 90e doz. $\$ 7.00$ per 100 .

Mrs. Watt. This is an unusual color among the Gladiolia elear wine-red shade. The flowers are large and bold. They are closely set on a short stocky spike. Sc each. $85 \mathrm{c}$ doz. $\$ 6.75$ per 100 .

\section{Bolgiano's Superb Mixture of Gladiolus}

A mixture of the largest number of the most magnificent varieties of any popular mixture yet introduced, contains best strains of each variety. Every bulb of this mixture has been selected with utmost care for coloring, size of flower and purity. $40 \mathrm{c}$ per doz. $\$ 3.00$ per 100 .

Bolgiano's Fine Mixture of Gladiolus

A mixture containing some of the choicest and best strains of the different named varieties. Second size. $35 \mathrm{c}$ doz $\$ 2.50$ per 100 . 
Mailing Weight, Dahlias Parcel Post Rates,
1 Lee Page 2 Containing All the Most Recent Introductions of Both Europe We will sell 6 at dozen rate.

\section{Six Grand Dahlias}

\section{Set of Six for $\$ 4.25$}

We here offer six of the best varieties in cultivation and especially elected for their value as cut flowers, vigorous growers and free bloomeis. Wonderful combinations and harmonious blendings of magnificent colors. We offer them with the utmost confidence that they will give the greatest satisfaction to dahlia lovers who want the very best in quality.

L. Kramer Peacock. (Decorative.) See illustration. The ideal white decorative dahlia for garden oi cutting. : The flowers are large, of perfect form and great substance, keeping a long time after being cut... $\$$
Mrs, F. F. Schock. (Decorative) Splendid form on long stiff stems. Color Picric Yellow at base of petals, blend to almost pomegranate purple at tips........... 1.00

Mrs. J. Harrison Dick, (Decorative.) Citron yellow at center, outer petals suffused and overlaid salmon pink. Long cane stiff stems................... 1.00

Patrick O'Mara. (Decorative.) The best Autumn Shade variety in existence. The color is an unusually soft variety in existence. The color is an unusually sot and pleasing shade of orange-buff and slightly tinged inches in diameter, and born on long stiff stems.

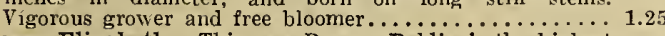

Queen Elizabeth. This new Paeony Dahlia is the highest type yet produced in this class. The color is a beautiful rosy mauve. The large flowers are facing on very long $2^{1 / 2}$ to 4 foot stems, slender, yet stiff, holding the able for cutting, exhibition and the garden...........

Sheba. (Decorative.) Vivid carmine red, tipped white.

Bright and effective. Form: fluffy, loose, artistic and Bright and effective. Form: fluffy, lose, artistic and
stylish. Size 5 to 6 inches. Blooms facing on perfect stem well above foliage................... 1.00

1000.00

\section{Superb New Cactus Dahlias} Set of 12 for $\$ 3.00$

Elsa. White, suffused yellow, overlaid pink and edged carmine rose. Very effective and pleasing..............
Faunus. Yellow shading to rosy scarlet, long pointed Faunus. Yellow shading to rosy scarlet, long pointed Francis white. A splendid new wbite cactus shading to sulphur at the center. An early and extremely profuse

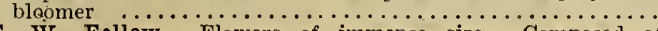
F. W. Fellow. Flowers of immense size. Composed of numerous long narrow petals of a lively orange scarlet...
Harlequin. Bright carmine, edged and tipped white...... Harlequin. Bright carmine, edged and tipped white.......
Lawine. A large white, lightly suffused pink. A strong vigorous grower, early and prof use blooiner.............. Libelle. Color a beautiful aster purple. Very effective...

Pink Pearl. Bright rose pink, tipped white; fine form, an early and profuse bloomer... Queen of Hearts. A beautiful pure white with yellow base of petals, making it a most lovely and effective flower. Reine Cayeux. Rich glowing cardinal red. An early and extremely profuse bloomer, with good stems. A grand gar-

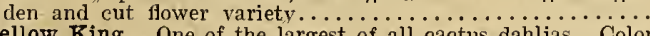

Yellow King. One of the largest of all cactus dahlias. Color light yellow, tinting to cream at the tips, giving it a most pleasing effect.

\section{New Decorative Dahlias}

One eoch of any twelve decorative dahlias for $\$ 2.8$.

Break O'Day. A delicate clear sulphur yellow, tinting to sulphur white at the típs. A strong vigorous grower and free bloomer with long erect sterns.$\ldots \ldots \ldots \ldots \ldots \ldots$. Harmony. Color mauve rose with golden suffusion, good form and habit of growth...................................

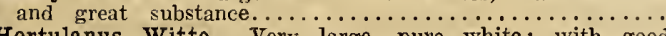
Hortulanus Witte. Very large, pure white; with good

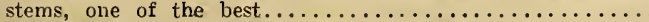
Jack Rose. Color a rich shade of crimson.............. Jumbo, Deep red, shaded maroon, very free............. Kitty De La Mare. Producing flowers of medium size of

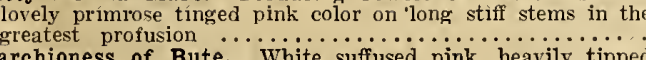

Marchioness of Bute. White suffused pink, heavily tipped Mrs. J. Gardner Cassett. Bright cerise pink, large flowers

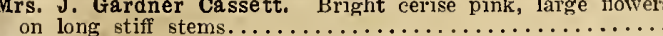
Nancy Alden. Light pink, suffused deep pink. The pink shades are clear and the flowers are held erect on lons stems. Free bloomer and very early ................... oregon Beauty. Very bright vermilion cardinal, rich an glistening. Flowers are large on long graceful stems......

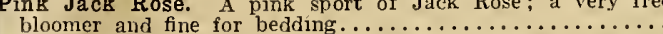
Queen Mary. The best pink dahlia for all purposes. The size is large to very large, full high center, even up to Novembe when killed by frost. Clear silvery cerise pink. Produce the giant flowers freely on long stiff stems......................
Doz.

10.00

12.00

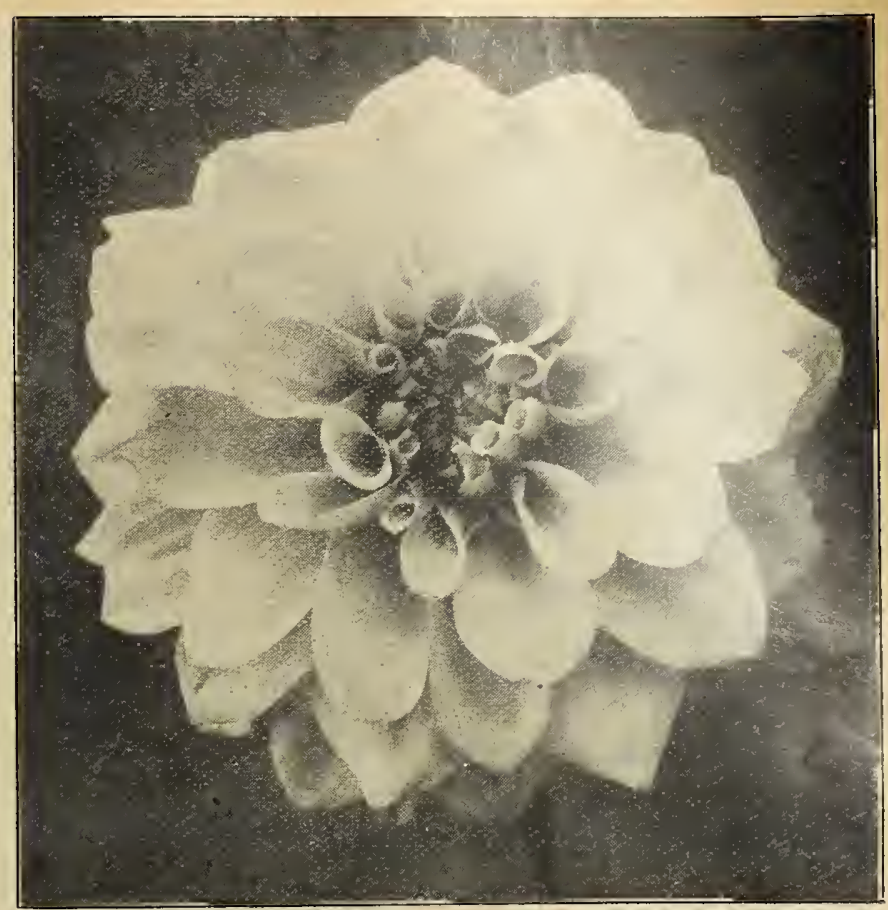

I. Kramer Peacock

\section{New Show or Ball Dahlias}

Each Doz.

$\$ 2.75$

2.75

23
Carol. A beautiful ball of small size, but beautiful round
full form, with quilled petals and clear pink color. Free bloomer on long stiff stems.......................... Pickford. Large, soft primrose, edgerl and

Mrs. Hartong. Soft bronzy buff, very effective bronze.

Mrs. Thos. Sharp. A rich golden orange of rather loose formation, but rery regular and alwars full to the center: medium to large size. An extremely profuse bloomer.

Queen Victoria. Rich golden yellow, quilled petals.

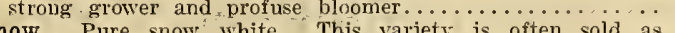

Snow. Pure snow white. This variety is often sold as

Stradella. Deep purple crimson, early and profuse.

Tansboro. Grimson shaded maroon, white suffured crimson at base of pefals, early and profuse.

White Swan. Pure white. The standard commercial white

ball dahlia. A strong grower and free blooner

\section{New Century Dahlias}

\section{3.) One each of any six of these dahlias for $\$ 1,10$}

Autumn Century. A fine bronzy variety; large fine form on long stems. Color buff yellow at base of petals shading through amber to red, with al ixidescent sheen......... size; rich bronzy vellow, produced profusely on long stiff stems

Do\%. Evelyn Century. Very bright and striking, white, outer half of petals a bright violet cerise making a beautiful white

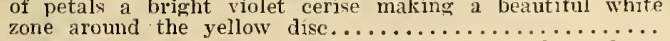

Geisha Century. Yellow and scarlet, very bright and $\ddot{\text { at- }}$

tractive. Strong grower with long stiff stens............
Gloria Century. Rich yellow, tipped and penciled vivid
red; flowers of great substarce, on long ligid stems. Very red; flower's of great

Mrs. Joseph Lucus Century. Immense size, beautiful form, produced profusely on good stiff stens. Yellow suffused

Rose Pink Century, The largest and best deep pink enol. mous flowers on long three foot stems ; a sure and con-
tinuous bloomer $\ldots \ldots \ldots \ldots \ldots \ldots \ldots \ldots \ldots \ldots \ldots$.

Yellow Century.

tiful form and a profuse bloomer on long stiff stent
New Paeony Dahlias

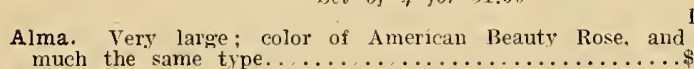

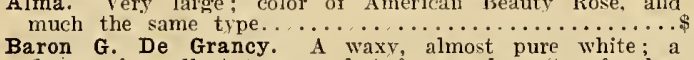
flower of excellent type, perfect form and purity of color. The blooms are borne profusely on long graceful stems...

Diemont von Bystein. Large white suffused ar:d shaded blue

lilac. Very fine form and a free bloomer

Thos. Walkins. Flowers are large, of beautiful form and coloring. White suffused cerise, heavily shaded and tipned 


\section{The Most Beautiful Lawns in America}

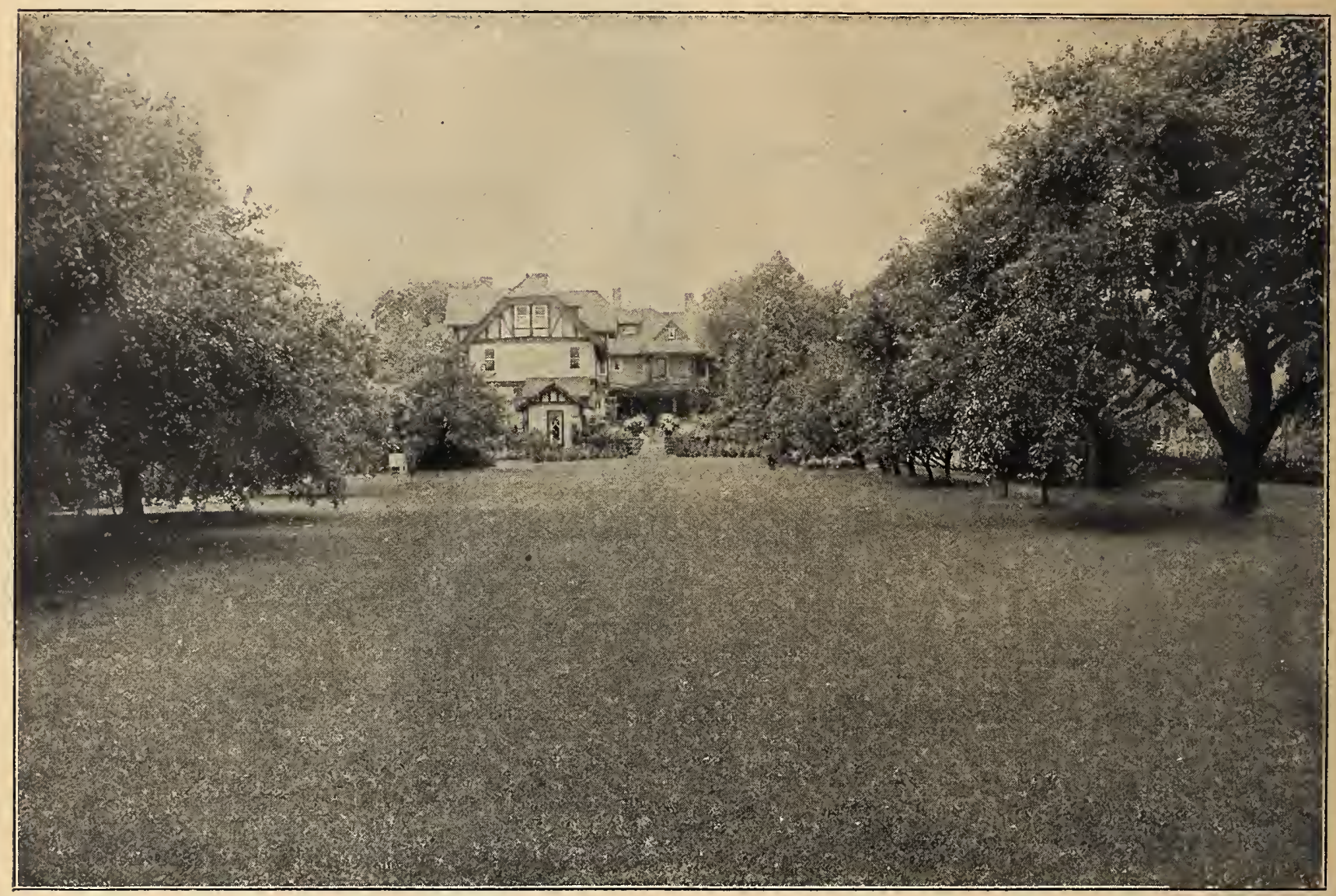

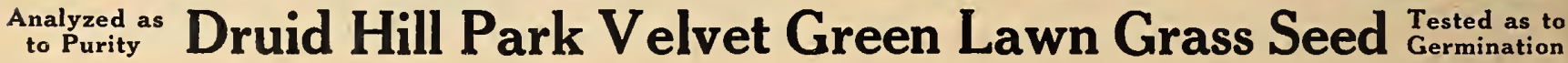

\section{Absolutely the best Lawn Seed Experience Can Suggest, or that Money Can Buy. Will Produce a Beautiful and Permanent Lawn in Four to Six Weeks}

Parcel Post Rates, see Page 2

The most important thing to consider in selecting seed for lawn grass, is to obtain a proper mixture of toveral varieties, for two reasons: First, each variety is at its best during a certain part of the season. By properly choosing early, medium and late grasses, a smooth, even, green lawn is assured from early Spring to late Autumn. Second, a given area can support only so many grass plants of one kind, for they all absorb the same food, but if several varieties are sown, the same area will support many more plants as different sorts live on various elements in the soil. This will give a much thicker and more luxuriant turf all over the lawn.

Bolgiano's Druid Hill Park Velvet Green Lawn Grass Seed, from yearly comparative trials, has proven to be unsurpassed for first-class and permanent results. This is due to the fact that we use only the very finest varieties of inost suitable grasses, tboroughly recleaned, free from all chaff and weed seeds.

Bolgiano's Druid Hill Park Velvet Green Lawn Grass Seed contains a well. balanced blend of various American and foreign fine bladed and deeply rooting grasses which has proved to produce the very best results under the varied conditions as to soil and climate met witb in America.

Bolgiano's Druid Hill Park Velvet Green Lawn Grass Seed will give a green, smooth, velvety sod with a thick bottom and free from such varieties of common grasses as produce clumps and knots on the lawn, which so frequently spoil the desired smooth and deep effect.

In the beautiful parks and cemeteries in and around Baltimore, where best results must be had in order to produce beautiful and enduring turf, Bolgiano's Druid Hill Park Velvet Green Lawn Grass Seed is used almost exclusively.

Not only is our Druid Hill Park Velvet Green Lawn Grass suitable for making of new lawns, but it will be found equally valuable for quickly renewing imperfect, old and worn-out areas. Always see that the soil is thoroughly prepared, carefully pulverized and enriched with Sheep Manure, Bone Fertilizer or Bolgiano's Hydrated Lime before sowing the seed. A mixture of $75 \mathrm{lbs}$. Pulverized Sheep Manure to $25 \mathrm{lbs}$. Bone Lawn Fertilizer prinkled over the lawn, once every month bcfore thc hot dry weather sets $n$, forms a mulch which protects it during the hot dry season. One pound will sow $20 \times 20$ fect, 10 pounds will sow $50 \times 150$ feet, 60 pounds will sow an acre, 30 pounds measures one bushel. 1/4 Lb. 15c. 1/2 Lb. 25c. Lb. $40 \mathrm{C}, 3 \mathrm{Lbs}, \$ 1.15,5$ Lbs, $\$ 1.80$, Bu. of 30 Lbs. $\$ 10.00$

\section{Bolgiano's Bone Lawn Fertilizer}

The very best fertilizer to use on lawns. It contains a large percentage of raw bone and when used on the lawn in early Spring will give a beautiful green lawn all during the entire Summer and Fall. Stable or chicken house manure should never be used as a top dressing on lawus, as it always contains large quantities of weeds. We bave therefore had prepared for us this special lawn fertilizer, whicb is clean of all weed seeds, free from disagreeable odors and is acknowledged by all that have used Bolgiano's Bone Lawn Fertilizer as being the very best for the lawns. It should be sown broadcast early in the Spring or late Fall, 25 pounds to 300 square feet or 2,000 pounds to the acre. When using less tban above described, two dressings should be given each year. Many of the best lawn makers prefer using the one dressing in early Spring. Pkt. 10c. 5 Lbs. 45c. 10 Lbs. $75 \mathrm{c}$. 25 Lbs. $\$ 1.75$ 50 Lbs. $\$ 225$. 100 Lbs. $\$ 3.75$. 500 Lbs. $\$ 17.00$. 1,000 Lbs. $\$ 32.50$. 2,000 Lbs. $\$ 65.00$.

\section{A Good Top Dressing for the Lawn}

can be made from the following compost Apply in September or October: Twelve ordinary garden wheelbarrows of garden loam, 25 pounds hydrated lime, 25 pounds fine ground bone, 50 pounds pulverized sheep nianure. Mix in a compost pile for one week, then apply. Tbis mixture will dress a section of 2,000 square feet of lawn.

\section{Bolgiano's Hydrated Lime}

After carefully testing all the different limes we find the Hydrated has given the very best results. It cures the acidity of the soil and produces strong, healthy, green sods. It is a sanitary and helpful fertilizer. Some of the finest lawns and grass plots have been produced by the judicious use of Hydrated Lime. If the ground is showing signs of a green cast or moss, use Hydrated Lime at once to save your lawn from the acidity or sour effect that will accumulate. It is a well-known fact that 100 per cent of the lawns need Hydrated Lime. lawns need Hydrated Lime. More than 50 per cent of grass seed sown is wasted on account of the sour condition of the soil. A generous application of Hydrated Lime being used two weeks before seeding tinie will prove very beneficial. It can be applied in early Spring or late Fall with the very best results. We advise when making new lawns, especially where top soil is being used, to apply very freely Hydrated Lime before seeding. Sow broadcast 25 pounds to 300 square feet or 2,000 pounds to the acre. Price per 50 Lbs, $\$ 1.00$. 500 Lbs, $\$ 6.25$. 1,000 Lbs. $\$ 11.50$ 


\section{Are Made With Bolgiano's Lawn Grass Seed}

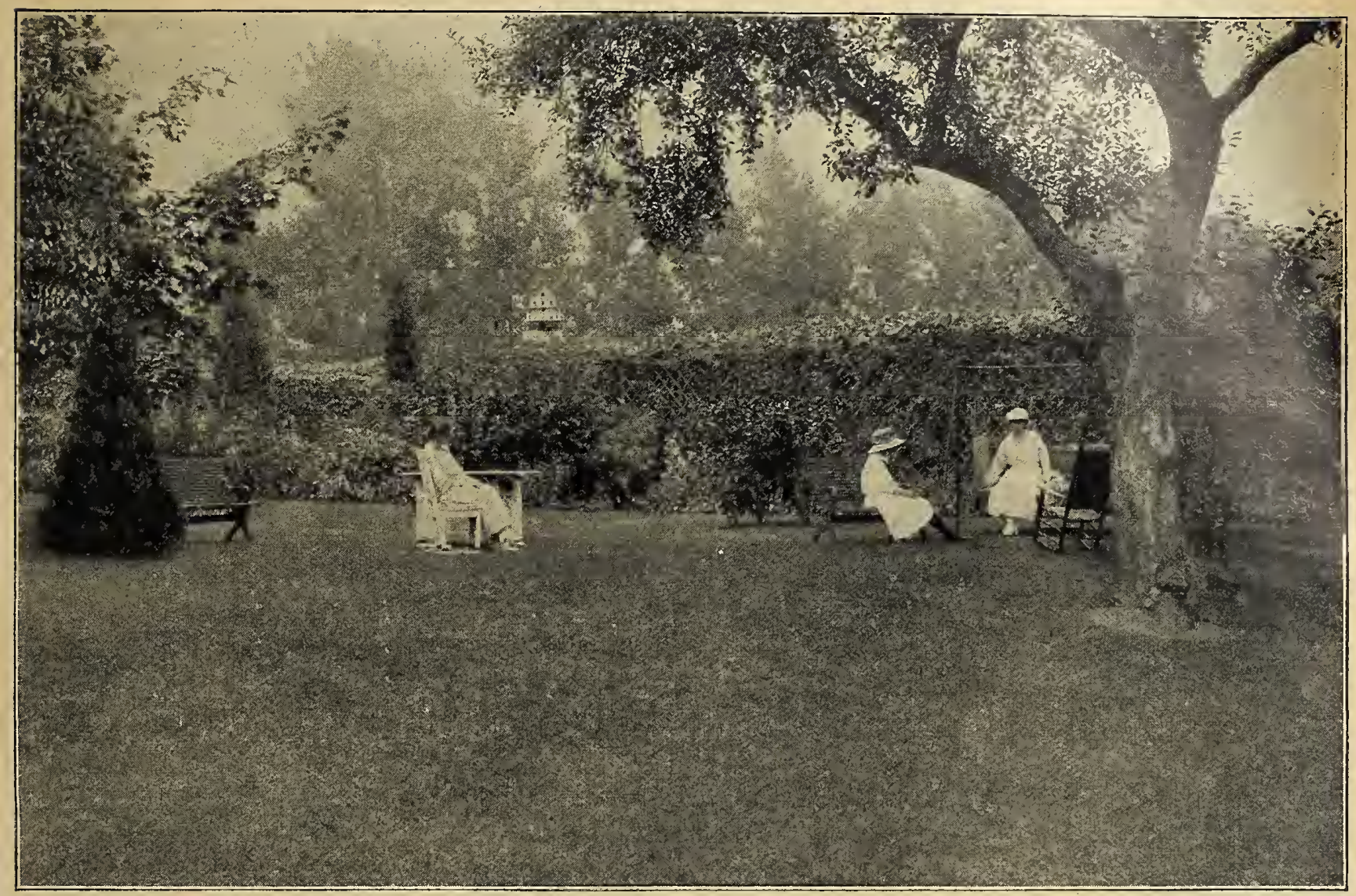

Shady Nook Lawn Grass Mixture

Usually it is quite difficult to obtain a satisfactory growth of grass under trees and in shady places. For sowing in such places we recoinmend tbe use of this special mixture. It will quickly produce an abundant and even growth of beautiful green grass. The grasses used in making this special mixture are only those that are well adapted for growing in shade, and as it blends well with our Druid Hill Park Velvet Green Lawn Grass Seed it may be used on those portions of the lawn which are shaded by trees, buildings, etc., thus covering the whole area with a rich green sward.
$1 / 4$ Lb. $15 \mathrm{c} .1 / 2 \mathrm{Lb}$. $25 \mathrm{c}$. Lb. $40 \mathrm{c}$. 3 Lbs. $\$ 1.15 .5$ Lbs. $\$ 1.80$. Bu. of 30 Lbs., $\$ 10.00$.

\section{Cloverless Lawn Grass Seed}

This excellent mixture contains all the valuable grasses composing ou: Druid Hill Park Velvet Green Lawn Grass Seed, but it contains absolutely no White Clover Seed. $1 / 1$ Lb. 15c. 1/2 Lb. 25c. Lb. 40c. 5 Lbs. $\$ 1.80$.

\section{White Dutch Clover} CROP VERY SHORT

This is the best Clover for lawns, as it forms a close herbage and remains green throughout the season. It is also a very valuable mixture with grass seed for pasture. Sown in the Spring at the rate of $6 \mathrm{lbs}$. per with grass seed for pasture sown in the
acre when sown alone; one-balf the quantity when sown with otber grass. acre when sown alone; $1 / 2$ ne-balf
$1 / 4$ Lb. 25 c. $1 / 2$ Lb. 40 c. Lb. $75 \mathrm{c}$.

\section{Pulverized Sheep Manure}

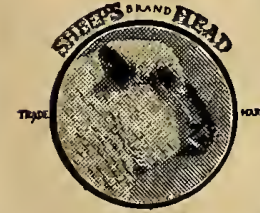

This is without exception the very best dressing for lawns The effect is inumediate and lasting. It is the only manure that is absolutely free from weed seeds. It contains no dirt, straw, leaves or bedding of any kind, being secured from the cemented floor of the Chicago stock yards. It is three times stronger tban cow manure. Contains nitrogen, phosphoric acid, ammonia and potash in liberal proportions. It is also unequaled as a fertilizer for the vegetable garden, flower garden, house plants, trees, hothouse, liquid to nourish all ketc. It is also dissolved in water and used as a

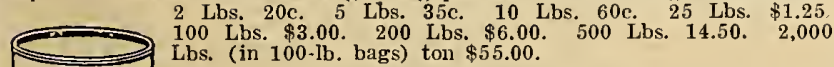

\section{Lawn Compound}

Kills weeds, but not the grass, and makes the sward creen and relvety. Destroys Moss, Dandelions, Chickweed Plantain. Crab Grass and all tbose weeds having broad, heavy leaves. It also acts as "Lawn Tonic," promoting a vigorous, healthy growth of the grass. 5 Lb. box $65 \mathrm{c}$.

\section{Special Golf Mixtures}

\section{For Putting Greens}

What is needed here is a close, low-growing grass that will stand a lot of tramping and will make a springy, tough turf. After thoroughly experi menting and scientifically testing, we have formulated a mixture that will give the desired results of an ideal putting green. This mixture will grow in most any soil. Please write for príces.

\section{For Fair Greens}

Over the course, where a very close growing sod is not necessary, but where a beautiful, velvety, green grass is wanted, we especially recommend our special mixture for Fair greens. By using this mixture in connection with our special mixture for putting greens you are assured an even, velvety.
green golf course equal to the best of lawns. This mixture will thrive well even on poor soll. Please write for prices.

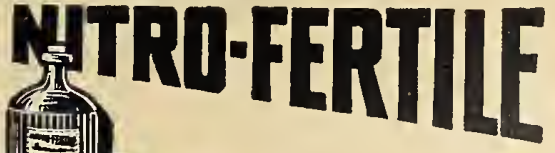

THE ODORLESS LIQUID FERTILIZER
Used by Florists and Professional

Growers

Specially Adapted for Use by the Home Gardener
A scientific combination in liquid form of the tbree essential elements in plant growth, Nitrogen, Phosphoric Acid and Potash. Nitro-Fertile being a liquid goes straight to the roots, showing results in from three to ten days. Flowers treated with Nitro-Fertile take on a healthier glow and develop to maximum size and quality. Shrubbery attains complete growth. Vegetables mature more fully and more quickly. Lawns scanty at the start, become thick and velvety. Mix two tablespoons of Nitro-Fertile with one gallon of water (one gallon to 120 gallons of water) and pour around the plants, soaking the soil thorougbly.

Lawns. Every three weeks during the late Spring and Summer sprinkle the lawn thoroughly with the mixture of water and Nitro-Fertile. During the dry season of July and August Nitro-Fertile will reduce the necessity for nightly watering with the hose.

Pt. 35c. Qt. 60 c. 1/2 Gal $\$ 1.00$. Gal. $\$ 1.75$. 


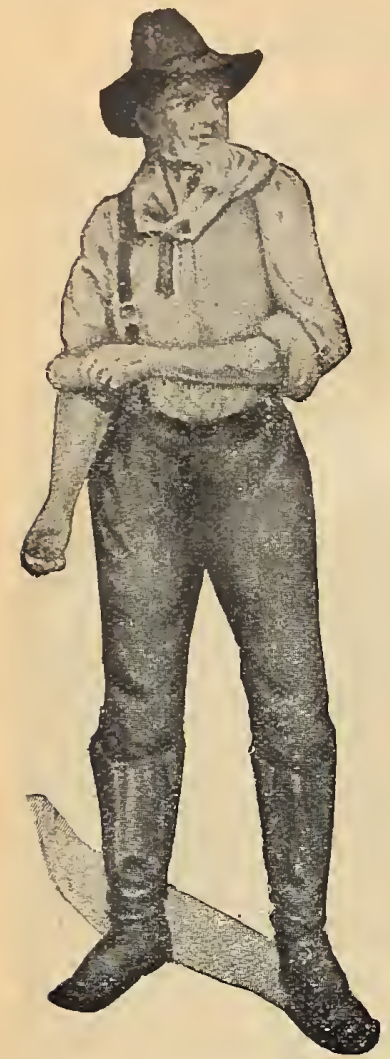

Blood Meal—for Roses

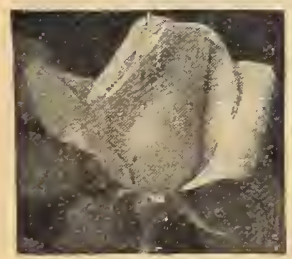

Seal to be the very best.

A tablespoonful to be sprinkled around the Rose Bush, about one inch away from the Bush, every two weeks. It is also very valuable as a top dressing in the vegetable garden, flower garden, around house plants, trees and in hot houses. 1 Lb. $10 \mathrm{c} .3 \mathrm{Lbs} .25 \mathrm{c}, 5 \mathrm{Lbs} .40 \mathrm{c}$.

\section{Fertilizers for the Farm, Garden and Lawn}

We present a list' of our brands of Fertilizers. You cannot judge the merits of a Fertilizer only by the analysis, hut you must have a knowlerlge of the basis from which it has been made.

It is a well-known fact that the animal waste products produced in the abattoirs give the purest and most available basis for Ammonia and Phosploric Acid. This is the basis of our goods. The company that manufactures our Fertilizers own and control a sufficient number of abattoirs, independent of the meat trust, to secure for our gocds this unexcelled source of our plant food. The expense is alnost as nuch working and reaping one-half a crop as it would he harvesting a full crop, which a good fertilizer would help to produce.

The four columns in the Analysis represent the following ingredients respectively: Ammonia, Phosploric Arid, Potash. Bone or Phos. of Lime.

\begin{tabular}{|c|c|c|c|c|c|c|c|}
\hline & Analysis & Ton & $1 / 2$ Ton & 500 Lbs. & $100 \mathrm{Lbs}$. & 50 Lbs. & 25 Lbs. \\
\hline 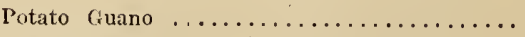 & $7-6-5$ & $\$ 6.5 .00$ & $\$ 32.50$ & $\$ 17.25$ & $\$ 3.70$ & $\$ 2.00$ & $\$ 1.15$ \\
\hline Higb-Grade Tiucker $\ldots \ldots \ldots \ldots \ldots \ldots \ldots$ & $5-8-5$ & 56.00 & 28.00 & 15.00 & 3.25 & 1.90 & 1.10 \\
\hline Early Truck and Vegetable Growar.......... & $4-8-5$ & 45.00 & 22.50 & 12.00 & 2.75 & 1.75 & 1.00 \\
\hline Bull Head Fertilizer.................. & $3-8-3$ & 38.00 & 19.00 & 10.50 & 2.25 & 1.50 & 1.00 \\
\hline Corn and Cereal special. ................. & $2-8-2$ & 31.00 & 15.50 & 8.75 & 2.00 & 1.25 & .75 \\
\hline Dissolved Organic Compound, . .......... & $1-9-3$ & 28.00 & 14.00 & 8.00 & 1.75 & 1.00 & .60 \\
\hline Sure Grower $\ldots \ldots \ldots \ldots \ldots \ldots \ldots \ldots \ldots \ldots$ & $1-8-1$ & 25.00 & 12.50 & 7.25 & 1.65 & .95 & .55 \\
\hline Crop Producer $\ldots \ldots \ldots \ldots \ldots \ldots \ldots \ldots$ & $1-10-0$ & 26.00 & 13.00 & 7.50 & 1.7 .5 & 1.00 & .75 \\
\hline Pure kaw Bone Meal.................. & $41 / 2-0-0-48$ & 63.00 & 31.50 & 17.50 & 3.75 & 2.25 & 1.2 .0 \\
\hline Pure Ground Bone................... & $3-0-0-50$ & 54.00 & 28.50 & $=16.35$ & 3.50 & 2.00 & 1.15 \\
\hline Acid Phosphate ...... & $0-14-0$ & 16.00 & 8.00 & 4.75 & 1.15 & .65 & .40 \\
\hline Acid Phosphate $\ldots \ldots \ldots \ldots \ldots \ldots \ldots \ldots$ & $0-16-0$ & 17.00 & 8.50 & 5.30 & 1.25 & .75 & .45 \\
\hline
\end{tabular}

Nitrate of soda market fluctuates, pleasc write for our lowest prices.

BEAUTIFUL FLOWERS, DELICIOUS VEGETABLES, LUXURIANT HOUSE PLANTS

All these Pleasures are Assured if You

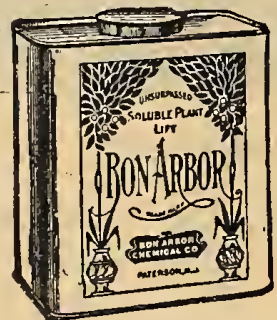
Use BON-ARBOR, the Ideal Food and Tonic for Household Plants and Home Flower and Vegetable Gardens-Clean, Safe, Odorless, Effective.

Bon-Arbor is immediately soluble in cole ties are available to plant life from the moment of application. It is quick in action, enabling you to see its effects in from 3 to 10 days on any quick growing plants; vegetables and lawns, an on slower growing plants in a proportionate time. It being complete food, containing Nitrogen. Potash and Phosphoric Acid in sufficient quanti. ties, will sustain grow th it makes.

BON-ARBOR Is Put Up As Follows:

$1 / 2$ Lb. package, making 15 gals., by mail postpaid............ 350 1 Lb. package, making 30 gals., by mail postpaid.................

\section{STIM-OP-PLANT \\ PLANT STMULANT TABLET}

Growers of fine flowers, shrubs and vegetables for the best markets and for exhibition, fertilize and stimulate them frequently, a little at a time. An excellent fertilizer for this purpose is Stim-U-planT, an odorless, highly concentrated plant-food,- in tablet form, with guaranted chemical analysis of 11 per cent nitrogen, 12 per cent phosphoric acid, 15 per cent potash. The proportions are accurate, there is no wasted filler, ant in this form you apply plant-fooil exactly when and where and as needed.

\section{Make Your Garden a Wonder Garden}

These tablets increase production, heighten color and imquality immediately. Many professional and amateur wice then extensively all the year round-from early pring until late fall outdoors, during the winter for pot plants, hot-honse benches, ete. They are as fine for evergreens and otliel trees as for all garden and potted plants.

\section{Easy to Use}

Simply insert tablets in soil near plants, or dissolve in water at the rate of four tablets to the gallon and apply as liquid manure. Complcte directions with every package.

Order Stim-U-planT tablets with your seed and plant order. Price, Trial size, 15c, small size, 25c, 100 tablets, $75 \mathrm{c}, 1,000$, $\$ 3.50$.

\section{Melons}

Kindly send us by mail another 5,000 Stim-U-planT tablets. We have used then with good results on our cantaloupes, hills yielding $\gamma$ to 9 weight 3 to $11 \frac{1}{2}$ lbs.

\section{Roses}

Upon recommendation of a friend who had used Stim-U.planT tablets. I placed tcn tablets in the ground surrounding a large bed of roses which during the previous season had done very poorly. The result was remarkable. during the previous season had done very poorly. The result was remarkable.
The foliage never looked so well nor the roses so large and beautiful. I will use Stim-U-planT very generally throughout the garden this spring. Mrs, R. W. Macdonald, Montclair, N. J.

\section{Window Boxes}

I have been using Stim.U-planT tablets in solution in my windou boxes afcording to instructions on your eircular, and must say that the effect has been astonishing. Although the plants were healthy and in good soil, $I$ have never seen blossoms in such quantity and quality. They are mostly petunias and are now over two feet high and a mass of color and bud. 


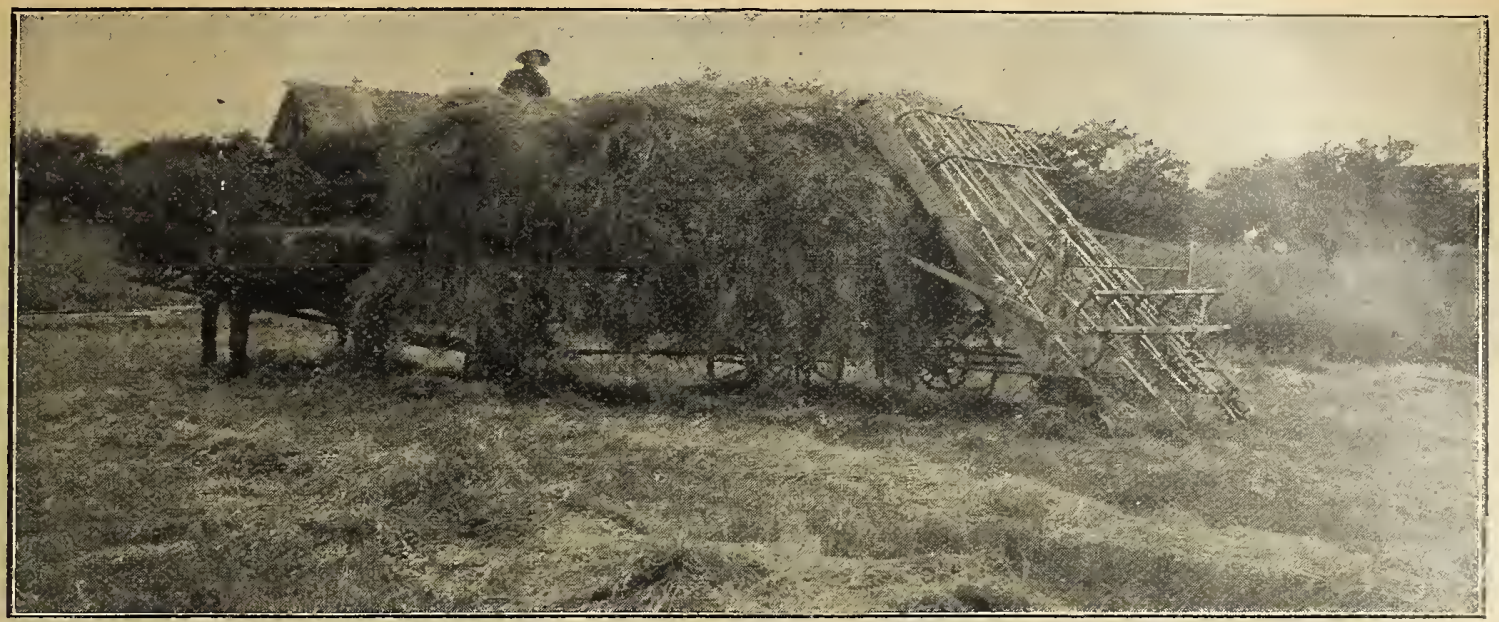

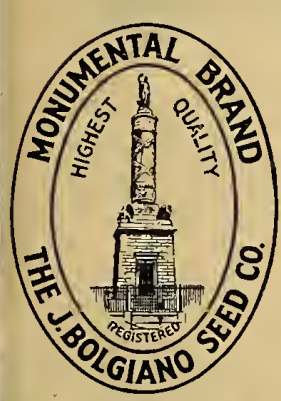

Enormous Crops of Hay are Produced from Bolgiano's “ Monumental BRAND FIELD SEEDS

"Brand Alfalfa Seeds

\section{Bolgiano's "Monumental" Brand Field Seeds}

\section{REPRESENTS THE BEST SEED OBTAINABLE BOTH AS RESPECTS PURITY AND GERMINATION. YOU ARE ALWAYS SAFE WHEN YOU ORDER "MONUMENTAL"}

\section{Mixtures for Permanent Pastures-But Can Be Mown}

$25 \mathrm{Lbs}$, or Over at $100 \mathrm{Lb}$. Rates

Mixture No. 1. For Light, Dry, Gravelly or Sandy Soils. Sow 30 to $35 \mathrm{lbs}$. to the acre. Lb. $25 \mathrm{e}$. $10 \mathrm{Lbs}$. at $23 \mathrm{c} 1 \mathrm{~b}$. $100 \mathrm{Lbs}$. at $20 \mathrm{c}$ per $\mathrm{lb}$. Mixture No, 2. For Good Loam Soil. Sow 30 to $35 \mathrm{lbs}$. to the acre. b. $25 \mathrm{c}$. $10 \mathrm{Lbs}$, at $23 \mathrm{c}$. $100 \mathrm{Lbs}$. at $20 \mathrm{c}$ per $\mathrm{lb}$.

Mixture No. 3. For Heavy Loam or Clay Soil. Sow 30 to $35 \mathrm{lbs}$. to the acre. Lb. $25 \mathrm{c}$. $10 \mathrm{Lbs}$. at $23 \mathrm{c} \mathrm{lb}$. $100 \mathrm{Lbs}$. at $20 \mathrm{c}$ per lb.

Mixture No. 4. For Moist Bottom Land. Sow 25 to $30 \mathrm{lbs}$. to the Lb. $25 \mathrm{c}$. $10 \mathrm{Lbs}$. at $23 \mathrm{c}$ lb. $100 \mathrm{Lbs}$. at 20 per lb.

Mixture No. 5. For Wet Bottom Land. Sow 25 to $30 \mathrm{lbs}$. per acre. Lb. 25c. 10 Lbs, at 23c. 100 Lbs, at $20 \mathrm{c}$ per lb.

\section{${ }_{1128}$ Alfalfa Seed}

Alfalfa Yields Splendidly Throughout the South, Yielding 4 to 6 Cuttings Per Year, Increasing Yield Each Successive Year

The requirements to obtain good stands and good crops is to sow in good, rich soil and give thorough preparation. A heavy application of lime is of decided benefit $-2,000$ to 5,000 lbs. per acje. Alfalfa is usually sown broadcast at the rate of 20 to $30 \mathrm{lbs}$. to the acre. March and April are the best months for seeding in the Spring, and the latter part of August and during September the best in the Fall. Our Alfalfa seed is the highest grade, strong germinating seed of the best and cleanest quality it is possible to procure

Price “Monumental " Brand Fancy Seed, Bu. of 60 lbs. $\$ 12.00$. "Silver" Choice Alfalfa Seed, Bu. of 60 lbs, at $\$ 11.70$. Prices fluctuate. Write us for market prices.

\section{Medium Red Clover}

For hay, it is particularly well adapted for sowing with Orchard and Tall Meadow Grass, as it ripens at the same time, and sowing these three grasses together will give larger yields and better quality hay than sowing either alone. It is also largely sown with other grasses, both for hay and pasturage

When sown by itself, sow 10 to 12 lbs, to the acre, either in the Spring or Fall or at the last working of Corn. Price: "Monumental " Brand Fancy Red Clover Seed, Bu. of 60 lbs. $\$ 13.80$. "Silver" Brand Choice Seed, Bu. of $60 \mathrm{lbs}$. $\$ 13.20$. Prices fiuctuate,

\section{Mammoth or Sapling Clover}

It is a good variety for thin soils or to seed with Timothy, Meadow Fescue, Herd's Grass or Red Top, as it matures about the same time as these
grasses. Sow 10 to 12 lbs. to the acre when sown alone. Wben sown with grasses. Sow 10 to $12 \mathrm{lbs}$. to the acre when sown alone. Wben sown with
Timothy use 6 lbs. Sapling Clover and 8 lbs. Timothy to the acre. Price: " Mlonumental" Brand Fancy Bu. of 60 lbs. \$14.40. "Silver" Brand Choice Seed, Bu. of 60 lbs. $\$ 13.80$.
Mixtures for Mowing for Hay-But Can Be Grazed

$25 \mathrm{Lbs}$. or Over at $100 \mathrm{Lb}$. Rates

Mixture No. 6. For Light. Dry, Gravelly or Sandy Soils. Sow 30 to 35 lbs. to the acre. Ib. $25 \mathrm{c}$. 10 Lbs, at $23 \mathrm{c} 1 \mathrm{~b}$. $100 \mathrm{Lbs}$. at $20 \mathrm{c}$ per $\mathrm{lb}$. Mixture No, 7. For Good Loam Soil. Sow 30 to $35 \mathrm{lbs}$. to the acre.

Mixture No, 8. For Heavy Loam or Clay Soil. Sow $30 \mathrm{lbs}$. to the acre. Lb. $25 \mathrm{c}$. 10 Lbs. at $23 \mathrm{c}$ lb. $100 \mathrm{Lbs}$. at $20 \mathrm{c}$ per lb. Mixture No, 9 . For Moist Bottom Lands. Sow 20 to $25 \mathrm{lbs}$. per
acre. Lb. $25 \mathrm{c}$. $10 \mathrm{Lbs}$. at $23 \mathrm{c}$. $100 \mathrm{Lbs}$ at $20 \mathrm{c}$ per lb.
Mixture No. 10 . Shady Nook Meadow Mixture. Like our Shady Nook Lawn Mixture, this mixture is specially prepared for good loamy soil in partially shady situations. A fine permanent pasture mixture, yields large crops of hay. Sow 30 to $35 \mathrm{lbs}$. to the acre. Lb. $25 \mathrm{c}$. $10 \mathrm{Lbs}$. at $23 \mathrm{c} \mathrm{lb}$. 100 Lbs. at $20 \mathrm{c}$ per $\mathrm{lb}$.

\section{Alsike Clover}

When sown with other grasses it forms a quick undergrowth and greatly increases the yield. It is well adapted for sowing with Red Clover. Timothy Herd's Grass, as it matures with tbese grasses, but flowering a little later "Silver" Choice seed, Bu. of $60 \mathrm{lbs}$. $\$ 12.60$.

\section{Crimson Clover Seed}

Hay be planted in the Spring, Summer or Fall. Splendid for reseeding Red Clover that has been Winter killed. Sow 15 lbs, to the acre. Price: "Monumental" Brand, Lb. 22c. Bu. of $60 \mathrm{lbs}$. $\$ 12.00$. Write for latest market prices.

\section{White Clover}

Sow in either Spring or Fall. When sown by itself, at the rate of 5 to 0 lbs. per acre. It is better, however, sown in mixture with other grasses. Price: "Monumental " Brand Fancr, 1/4 Lb. 25c. 1/2 Lb, 45c. Lb. $75 \mathrm{c}$.

\section{Japan Clover}

Sow at the rate of $10 \mathrm{lbs}$. per acre, in March or April. Write us for latest market prices.

1205 White Blossom Sweet Clover or Bokhora

(Hulled.) Melilotus Alba. Sweet Clover is especially valuable for worn-out soils and grows almost anwwhere except in acid soils. Sweet Clover is a legume, having the same bacteria on its roots that grow on Alfalfa. Sow 15 to 20 pounds per acre. "Mionumental "Brand, $15 \mathrm{c} \mathrm{Lb}$. Bu. 60 Lbs. $\$ 7.20$.

1268 White Blossom Sweet Clover or Bokhora (Unhulled.) Write for lowest prices.

\section{Hubam White Blossom Sweet Clover}

An annual variety of White Sweet Clover which has just recently come into prominence. Write us for lowest prices. 


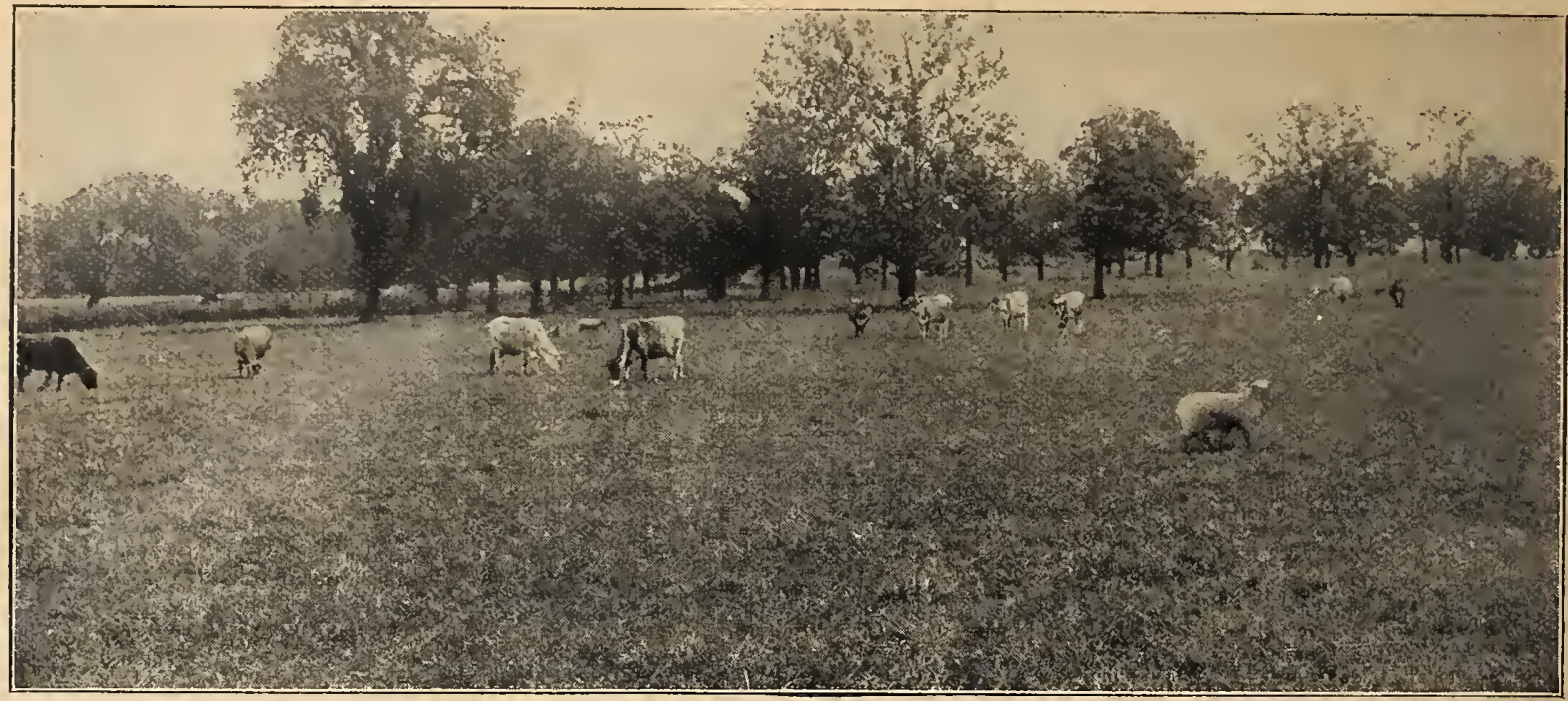

\section{Tall Meadow Oat Grass}

Sown alone use 2 to 3 bushels to the acre, either Spring or Fall. Sown in mixture, use 1 bushel (11 lbs.) Tall Meadow Oat Grass, 1 bushel (14,1bs.) Orchard Grass and $8 \mathrm{lbs}$. Red Clover. It gives the verv best results when sown with Clover. By adding 6 lbs. of Rer Top or Herd's Grass to the Brand Fancy, Lb. 30c. $\$ 3.30$ Bu. of $11 \mathrm{lb}$.

\section{Canada Blue Grass}

Canadian Blue Grass does not thrive when planted with Clover. Red Top and Orchard Grass are the best for mixing with it to grow on inferior soils. On good land it becomes tall enough for hay, and as it shrinks very little in drying the hay is heavy for its bulk. Grows from one to two feet high. Sow 30 lbs. of seed to the acre. Price: "Monumental" Brand Seed, Lb. 30c. Pk. $\$ 1.00$. Bu. of 14 lbs. $\$ 3.50$.

\section{Kentucky Blue Grass}

Blue Grass requires about two years to get well started and for that reason it is often sown in mixture with other Grasses. It will do well on almost any land, but does best on well drained clay land. Sow in the Fall or Spring at the rate of two or three bushels per acre. Price: " Monu-
mental " Brand Seed, Lb. 40c. Pk. $\$ 1.50$. Bu. of 14 lbs. $\$ 5.55$. "Silver" Choice $\$ 5.25$.

\section{Red Top or Herd's Grass}

Our Monumental Brand of the Fancy Cleaned Red Top is of extra finc quality, and carefully cleaned from impurities. We can also furnish the Choice and Prime Fancy Red Top as usually sold. It requires about 8 to 10 pounds to seed an acre of the Fancy Clean seed. When sowing with Timothy, sow 6 pounds of the Fancy Clean seed and 8 pounds Timothy per acre. It can be sown either in the Spring or Fall. "Price: "Monumental " or over at $25 \mathrm{c}$. $1 \mathrm{~b}$. Prices fluctuate ; latest prices quoted upon application.

\section{Meadow Fescue, Randall or English Blue Grass}

Sow either in the Spring or Fall at the rate of a bushels to the acre if sown by itself. When sown with Red Top or Timothy sow 1 bushel (14 lbs.) Meadow Fescue, 5 lbs. Fancy Clean Red Top and 6 lbs. Timothy per acre. Sown for grazing mixture with Orchard and Tall Meadow Oat Grass, add half a bushel each of these two Grasses. Write for lowest prices,

\section{Orchard Grass}

It makes excellent hay, and gives the rery best results mixed and grown with Tall Meadow Oat Grass and Red Clover. It should be cut when in blossom, as the hav is injured if the seed is allowed to ripen. It can be sown in the spring or Fall either with grain or alone. Sow two bushels per acre if sown alone, or with Red Clover, one and one-half bushels of Orchard Grass and cight pounds of Clover are the quantities usually sown. Price: Grass and cight pounds of Clover are the quantities usually sown. Price:
"Monumental" Fancy, Lb. 17c. Bu. of 14 lbs. $\$ 2.10$. "Silver" Choice "Monumental "
$\$ 1.75$ per Bu.

\section{Timothy}

Clovers grow well with Timothy and aid it by supplying nitrogen. Timothy alone a peck (11 lbs.) to the acre, or with Clover 10 lbs. Timothy and 6 lbs. Clover. A splendid mixture is 8 lbs. Timothy, 6 lbs. Clover (either Mammoth Clover or Alsike Clover preferred, as they mature at the same time as Timothy), 6 lbs. Fancy Red Top, $1 / 2$ bu. Meadow Fescue Together these will produce most excellent hay also nutritious and abundant
pasture in good loamy clay or low ground soils : 8 lbs. Timothy and 6 lbs. pasture in good loamy clay or low ground soils; 8 lbs. Timothy and 6 llss. $\$ 1.00$. Bu. of 45 lbs. $\$ 3.75$. "Silver" Choice $\$ 3.60$. Market fluctuates.

\section{Sudan Grass}

It is the universal opinion of those who have grown it that it is destined to make one of the very best ensilage crops known. It would be even better when grown with Soy Beans or Cow Peas, as this combination would make an enormous yield of ensilage that would be very palatable and well balanced. When seeded in rows 18 to 20 inches apart, drill 4 to 6 lbs. When sown $\$ 27.00$.

\section{Timothy and Alsike Clover Mixed}

For hay, the Alsike and Timothy Mixture is very valuable on soils too moist for Red Clover. Alsike is suitable for either hay or pasture. It i finer and more leafy than Mediun Red Clover and cattle prefer it. "Monu mental "Brand, $15 \mathrm{c}$ lb. 50 Lbs. or over at $13 \mathrm{c} \mathrm{lb}$.

\section{Millets}

1125 German or Golden Millet, Southern Grown

Makes a large yielding and most nutritious hay crop, quick growing and easily cured. Should be sown at any time between the middle of May until the end of June at the rate of 1 bushel per acre. It matures a crop in 6 to 8 weeks after seeding. Cow Peas sown with German Millet makes fine hay. Sown in this way, it should be sown with some quick maturing variety of Cow Peas and should be sown at the rate of three pecks of Millet and one bushel of Cow Peas to the acre. "Monumental "Brand Fancy Southern Millet. Write for prices.

\section{Hungarian Millet}

Hungarian Millet does not grow so coarse as some other varieties, but still yields quite heavily, from two to four tons of hay to the acre bein an ordinary crop. Hay is quite leafy, of very fine quality. Should be sown at any time between the middle of May, until the end of June at the rate

\section{Tennessee Cultivated Golden Millet}

This variety is extensively used tlroughout the United States, as they find it more nutritious in value for feeding. It is sown at the same time and at the same rate per acre as the common Millet. "Monumental" Brand,

\section{Japanese Millet}

$15 \mathrm{lbs}$, to acre broadcast. 10 to $12 \mathrm{lbs}$. in drills 12 inches apart. Cultiuntil 18 inches high when its rapid growth will smother all weeds. It
best on low moist ground. "Monumental "Brand, 10 Lbs. 70c. 100 1170 Pearl or Cattail Millet

\footnotetext{
Py dairvmen. It furnishes then oreen food throughout
}

tropical plant and grows to the best advantage in warm weatber. Sow 5 lbs. per 20 to 30 lbs. per acre. Lb. 15c. 100 Lbs. $13 \mathrm{c} \mathrm{Lb.}$

\section{Bolgiano's Rye Grasses for Spring Planting} 1121 English or Perennial Rye Grass

Produces an abundance of foliage, which remains bright and green during the season. The hay is relished by all kinds of stock. It will grow well on almost any land. When sown by itself sow $30 \mathrm{lbs}$. per acre either in the Spring or Fall. Price: Lb. 18c. 100 Lbs. $\$ 16.00$.

\section{Pacey's Short Seeded Perennial Rye}

Specially suitcd for fine lawn nixture, extensively used on the beautiful It makes a quick leafy growth of fine texture. $20 \mathrm{c} \mathrm{Lb}$. 100 Lbs. $\$ 18.00$

\section{Italian Rye Grass}

It is less wiry than Perennial Rye Gras sand is particularly wel adapted to the soils and climate of Florida, where it is sown very extensively in the Fall and Winter for lawn purposes. About $24 \mathrm{lbs}$ of seed to the acre Price: "Monumental" Brand, 18c Lb. 100 Lbs. $\$ 16.00$.

Sow Scarified Seed and lncrease Your Yield We will Scarify your Sweet Clover or Alfalfa for one cent per pound above our list price

Have your seed scarified and practically all of them will grow. The scarifying is donc by a machine specially built for the purpose of scarifying the hard outer coating of the seed, thereby allowing the moisture to penctrate quicker, producing a more rapid and complete germination. The extra cost quicker, producing a more rapid and complete germination. The extra cost 


\section{Cow Peas}

\section{Please Write For Latest Prices}

1175. Mixed Cow Peas, We strongly recommend sowing Mixed Cow Peas as soil improving erop. The upright growing varieties holding up the vining varieties; they will make a much better growth and give more satisfactory results.

1159. New Era. This new extra early Cow Pea is unquestionably one of the most valuable varieties in cultivation. It is quicker in growth than any other Cow Pea in cultivation; nakes a very large growth of vine and very prolific yield of Peas.

1162. Black Cow Peas. Seed medium sized and Black. Vines trailing. eed matures early.

1163. Clay Peas. Secds medium sized and cream colored. Vines grow tall and erect., Seed matures medium late.

1164. Whip-Poor-Will. Vines erect. Seed large and mottled red and white nd matures early. Good to grow between Cox'n.

1166. Wonderful or Unknown Pea, Seed medium sized and buff. Vines rect if planted late, trailing if planted early. Seed matures late.

1208. Shinney Pea. Very popular, sced large, mottled white and red, early aturing, erect vines.

1168. Black Eye. Vines erect. Seeds medium sized and white, matures medium late.

1190. Red Rippers. Red seeded, resembles Black Cow Peas in growth of es, but 10 days earlier and more prolinic.

1241. Gray Crowders, Vine trailing, seed large and mottled oray and blue. Matures medium late.

1271. Groit. A fine, new, early maturing Cow Pea, somewhat resemhline New Era in appearance and size of seed. but makes a larger growth. Very highly recommended as an early maturing, large-yielding variety.

1305. Brabham Peas. This is a cross between the Whip-Poor-Will and Iron varieties. It is especially valuable in that it partakes of the good characters of both parents.

\section{Soja Beans}

PLEASE WRITE US FOR LOWEST PRICES

1242. Mammoth Yellow, The largest growing and most popular Soja Bean for forage purposes, although a little later in maturing than other varieties.

1243. Tar-Heel or Mammoth Black. Slightly earlier than Man oth Yellow and produces about same amount of forage.

1244. Mammoth Brown. Matures slightly earlier than Mammotl Yellow and produces about one-third more forage.

1246. Wilson Black, Very small seed, matures in about ninety days, $n$ be grown in the Northern States where an early variety is desired.

1306. Virginia, About 20 days earlier than the Mammoth Yellow. The vines make a fine growth, are filled with pods, stand about 3 fcet high, are easy to cut and easy to cure.

\section{Seed Oats}

PLEASE WRITE US FOR LOWEST PRICES

1156. Burt or 90-Day Oats. The earliest, most prolific and surest cropping of Spring Oats; far superior to an ordinary Spring or rust-proof Oats for Spring seeding. Wherever tbis Oat is grown it comes into great

1161. Virginia Gray Winter or Turf Oats. When sown early, before the Middle of March, these Oats will far outyield tbe ordinary Spring Oats, making a larger crop and heavier grain

1157. White Spring Oats. Tbis is the variety most generally sown throughout the North and West, and is also so largely grown in this section, although the newest varieties offered hy us are decidedly preferable, both as to yield and reliability of cropping.

1272. Appler Oats. The Appler Oat is equally adapted for sowing both in the Spring and in the Fall, hut when sown in the Spring should be sown before the middle of March. It is a strong, quick growing Oat, bunchy head and heavy grain. One of the best and most reliable Rust.Proof Oats for the South

1274. Montana or Swedish Oat. These Oats originally imported from Sweden are very large, white, plunip and heavy grained and yield enormous crops. The straw is coarse and is noted for its stiffness and power to withstand lodging and is a great drought resister.

\section{Dwarf Essex Rape}

It is a pasture plant which must be eaten off by any kind of live stock, but it is pre-eminently fitted to furnish pasture for sheep. cattle and swine. Under favorable conditions Rape is ready for pasturing sheep or cattle within 6 weeks from the time of sowing, and on an average one acre will carry from 12 to 15 sheep six weeks to two months.

For continued hog pasture sow Rape early and at successive intervals. It may well follow any grain crop and is always splendid to plow under for green manure. Sow 5 lbs. per acre broadcast. 2 to 3 lbs. per acre in drills. green manure. Sow 5 lbs, per acre broac
$10 \mathrm{cb}$. 10 , at $9 \mathrm{c}$. $100 \mathrm{Lbs} \$ 8.00$.

\section{Flax}

1194. Flax. When grown for seed, sow one bushel to acre : if fibre is wanted, 2 to 3 busbels. Prices fluctuate. Please write for lowest prices.

\section{Canada Field Peas}

1165. Here is a crop which is not only profitable but will return to the land the much needed nitrogen. Peas are second only to Clover in their soil enriching properties and can be grown under almost any condition of soil or climate. There is always a ready market for Peas, or chev can be profitable ground and fed to the stock. The vines make rich, nutritious hay. If fed to milch cows, when in a green state, pods, vines and all, the flow of milk will be almost doubled

Sown in January, February or early March. Pk. \$1.50. Bu. \$5.50.

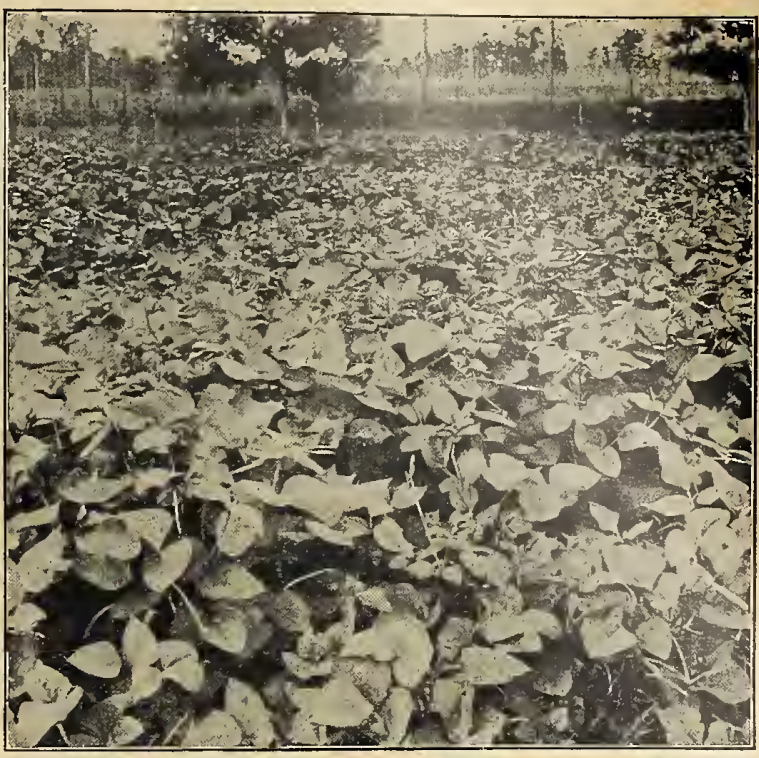

New Era Cow Peas-43 Days After Planting

\section{Buckwheat}

1160. Japanese Buckwheat. It has the advantage of remaining for some time in bloom and produces seed earlier. 1t resists drought and bligh very well. As much as 40 bushels to the acre have been harvested, making it very profitable to raise. Sow 1 bushel per acre. Pk. 50c. Bu. \$1.50. Pleas

1178. Silver Hull Buckwheat. A prolific and favorite sort, making wheat, which it has almost entirely superseded. Please write us for latest wheat,
prices.

\section{Spring Rye}

Produces 30 to 40 bushels of grain per acre. As it does not stool like Winter Rye, not less than two bushels to the acre should be sown. Please write for prices.

\section{Long Yellow Cow-Horn Turnip}

They can he fed to the stock as they are needed and the rest allowed to remain in the ground and rot, having a valuable fertilizing property. They grow nearly half out of the ground and are carrot-like in form. Sow two pounds of seed to tlie acre, broadcast. Pkt. $5 \mathrm{c}$. Oz. 10c. 1/4 Lb. 20c. Lb. $50 \mathrm{c} .5 \mathrm{Lbs}$. at $45 \mathrm{c}$.

\section{Mammoth Russian Sunflower}

1211. Sunflower las proved to be the best paying crop of anything that has been planted during the last two years. Sow in March to July, 5 to 10 lbs. per acre. Plant with Corn drills in rows 3 to $3 \frac{1 / 2}{2}$ feet apart and thin to 1 plant every 18 to 22 inches, cover very lightly, not over 2 to $2 \frac{1}{2}$ inches, the less tbe better. Write for prices.

\section{Beardless Spring Barley}

It makes a quick growing orop of most excellent and nutritive oreen feed and is growing in popularity wherever it is used, and will also make a good grain crop, although its principal value is as an early nutritious forage crop, either to feed green or cure as hay. Sow $1 \frac{1 / 2}{2}$ to 2 bushels per acre. Please write us for market prices.

\section{Hairy Vetch (Vicia villosa)}

Not only does it produce an enormous anount of very valuable feed, but it at the same time restores to the soil a great amount of fertility, which inental "Brand, Lb. 30c. 10 Lbs, at 25c Lb. 100 Los. at $23 \mathrm{c} \mathrm{Lb.} \mathrm{Write}$ us for latest market prices.

\section{Spring Vetches or Tares}

1150. Closely associated with Peas in character. Used for the same purpose as Hairy Vetch, but must be planted in the Spring wherever the valuable for severe, as this variety manuring. Sow alone 70 to 90 pounds per acre, and if with Oats 60 pounds of Vetch and 40 pounds of Oats. Sow in Spring while the ground is cool and moist or in early Autumn. "Monumental "Brand, Lh. 10c. 10 Lbs. at 9c. 50 Lbs. at $8 \mathrm{c}$. $100 \mathrm{Lbs}$. at $7 \mathrm{c}$. Write us for latest market prices.

\section{Oregon Vetch}

1275. Same as Spring Vetcb, but owing to its hardiness is known as Oregon or Winter Vetch. It can be planted in the Fall in all of tbe Southern States as well as in the Spring with results about the same as Hairy Vetch. Sown alone, sow 70 to 90 pounds per acre. Sown with Oats, sow 60 pounds Vetch and 40 pounds Oats. "Monumental "Brand, Lb. 10c. 10 Lbs. at 9c. 50 Lbs. at $8 \mathrm{c}$. $100 \mathrm{Lbs}$. at $7 \mathrm{c}$. 


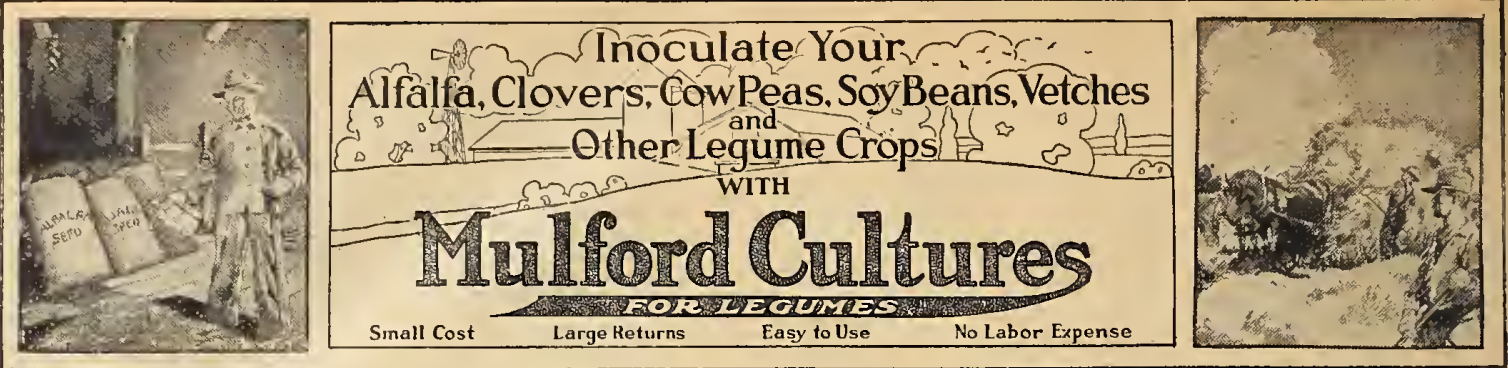
or soil.

Mulford Cultures contain pure, tested strains of active, vigorous nitrogen-fixing bacteria, for inoculating seeds of legumes

Mulford Cultures are scientifically prepared and tested with the utmost care and skill. Enormous numbers of these very valuable and desirable bacteria are thus available to you in every package of Mulford Culture and may readily be applied to rour seed. The sealed bottle insures purity.

Legumes offer the best known means of maintaining soil fertility and rejuvenating over-cropped and worn-out fields. They ard both humus and nitrogen to your soil and thus increase your yield of wheat, cotton, corn and other non-legume crops.
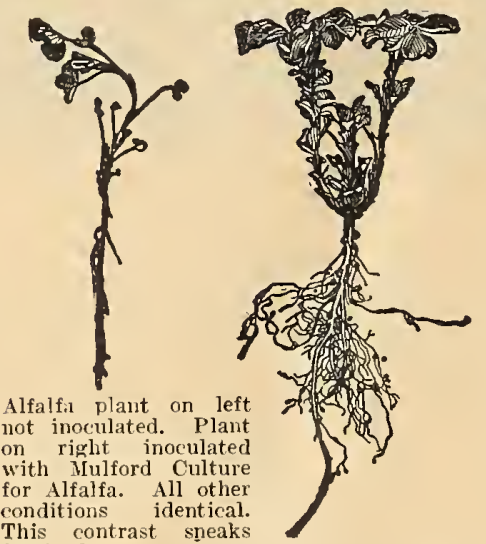

Alfalf: plant on left not inoculated. Plant on right inoculated with Mulford Culture for Alfalfa. All othe conditions identical.
This contrast sneaks for itself.
The U. S. Department of Agriculture and many State Agricultural Experiment Stations recommend inoculation of legumes with nitrogen-fixing bacteria to induce a prompt "catch" and increase your yield.

Mulford Cultures are prepared for:

$\begin{array}{llll}\text { ALFALFA } & \text { ALSIKE CLOVER } & \text { VETCH } & \text { LIMA BEANS } \\ \text { CRIMSON CLOVER } & \text { BURR CLOVER } & \text { VELVET BEANS } & \text { LESPEDEZA } \\ \text { SWEET CLOVER } & \text { COW PEAS } & \text { SWEET PEAS } & \text { BEGGAR WEED } \\ \text { RED CLOVER } & \text { SOY BEANS } & \text { GARDEN PEAS } & \text { and OtherS } \\ & \text { PEANUTS } & \text { GARDEN BEANS } & \end{array}$

Always specify on your order what crop you want to inoculate, as there is a different strain of bacteria for each legume.

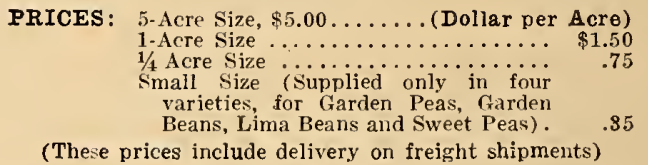

FREE DESCRIPTIVE FOLDER SENT UPON REQUEST

\section{A SEED AND SOIL
INOCULANT
That Increases Crop Production and Greatly \\ Improves the Soil}

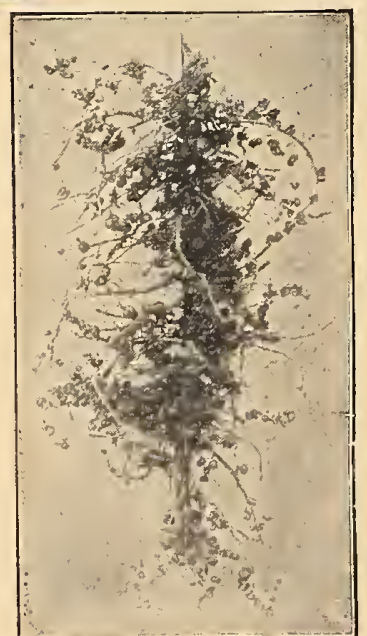

Roots like this mean bigger
Soil and crop experts agree that for best growth, and to put atmospheric nitrogen in the soil, it will pay all farmers to inoculate all legumes, even where they are at present successfully grown. The cost is trivial when compared with the profit it will bring you. Legumes are clovers, peas and beans, alfalfa, soy beans, retches, and other plants that grow their seeds in a pod. Their roots are the lome of bacteria that draw fertility-building nitrogen from the air and store it in swellings on the roots, called nodules. These nodules not only feed nitrogen to the crop they are on, but rot away in the ground and supply valuable nitrogen to the soil for future bumper crops of corn, wheat, cotton, oats, fruits, etc.

\section{ECONOMICAL-EASY TO USE}

The 1-A size bottle will inoculate: Clovers $15 \mathrm{lbs}$ alfalfa $20 \mathrm{lbs}$. Canada field peas 100 lbs., vetch $60 \mathrm{lbs.}$, soy beans $75 \mathrm{lbs}$.; other sizes in relative proportion. Place seed in a pile, fill bottle with water, add a little sugar, shake and moisten seeds; when dry, plant in usual way. This is infinitely easier, safer and better than the old laborious soil transfer method.

We have a special composite culture for garden peas, beans and sweet peas: ask for No. 5 , $50 \mathrm{c}$, and you will insure large, luscjous peas and beans, and abundant sweet pea blossoms of wonderful coloring. 
Seed Corn Weight by Parcel Post. Pts. 1 Lb., Qts. 2 Lbs., 4 Qts. 6 Lbs.

Pk. 11 Lbs.

Seed Corn

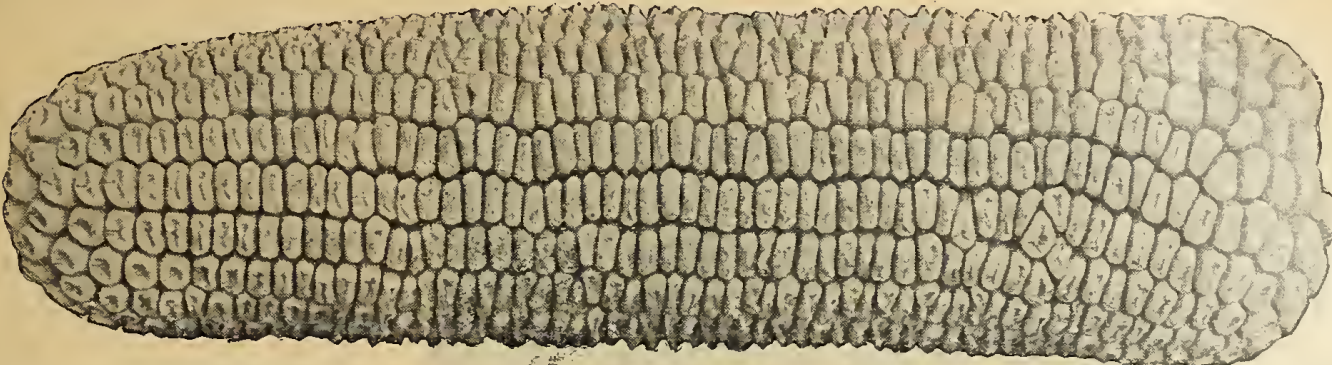

Parcel Post Charges Extra and

Must $\mathrm{Be}$ Included with Remittance Parcel Post Table See Page 2

\title{
${ }^{1141}$ Bolgiano's Wonderful Prosperity Yellow Dent Corn
}

\author{
Has Yielded of Shelled Corn 160 Bushels Per Acre Average Yield \\ 10 Years on About 100 Acres 125 Bushels Per Acre
}

If you really want to grow a bunper crop of bejutiful Yellow Dent Corn this year, just take our advice and plant Bolriano s s " Prosperity" Corn. Large kernels, well developed over tip and butt. It is a laxiriant grower, from 12 to 15 feet ligh, and if planted during the first half of Mays will mature before the 20tb of September. For more than a score of years "Prosperity Corn" has been under the most watchful breeding and selection; the magnificent results more than pay for every effort put forth. Tbe yield has been miraculous, 160 bushels or more of shelled Corn per acre, and it has even averaged on a number of acres planted the sanie year 133 bushels shelled Corn per acre. During a continuous test of 10 years on about 100 acres it has averaged 125 bushels shelled Corn per acre. Is it any wonder we have called such a wonderful Corn "Prosperity"? "Prosperity" is undoubtedly the most attractive, the largest, the finest, the greatest yielding Yellow Dent Corn ever produced. Pk. \$1.00. Bu. $\$ 3.50$.

1138. Long's Prolific. The climax of 25 years of Corn breeding and selection by Mr. I. S. Long. Pk. 8jc. Bu. $\$ 2.75$.
1140. Reid's Yellow Dent. This is a splendid Yellow Dent variety with 18 to 24 rows of kernels on an ear. The cob is small and red and the grains are very close together, so there is scarcely any room between the rows. Reid's Yellow Dent has been awarded more prizes at Corn show than any other variety except "Prosperity" The ears average 8 to
inches long. The stalk is very heary and is not easily blown down. It matures in 100 days and is a heavy yielder in the Middle and southern matures in 100 days and is
States. Pk. 85 c. Bu. $\$ 2.75$.

1143. Improved Leaming Corn. Its extreme earliness and fine quality has made it very popular with the farmers, and especially witl those in the localities where the seasons are short. It produces from 65 to 90 bushels to the acre, in accordance with the quality of the soil. The ears and grains are of inedium size. Pk. $85 \mathrm{c}$. Bu. $\$ 2$,

1139. Mammoth Golden Beauty Corn. Has the largest ears of any 100-day Corn. It outyields many other Corns. The increased yields repay the seeds many times over. Growers should make sure of getting the largest vield and most handsone grain to meet competition and secure the highest prices. Ears usually averaging from 9 to 12 inclies long. Pk. $85 \mathrm{c}$. Bu. $\$ 2,75$.

\section{White Varieties of Seed Corn}

1299. Eureka Ensilage Corn. The very best Silo Corn on the market. For many years we have used great care in the selection of our seed, which will give a large amount of fodder, 3 or 4 long, slender ears of Corn to the stalk. Grows to a height of 15 feet. Can be sown in hills or planted in checked rows. It is a very rapid grower and can b? grown throughout the United States with wonderful success. Growers should not miss planting this special variety of ours for their Silo Corn. Pk. 85. . Bu. \$2.75.

1145. "Hickory King" White Corn. So large are the grains and o small the cob that on an ear broken in balf a single grain will almost cover the cob section. Of a strong growth, the stalks take a firm hold in the ground and stand upright, resisting severe storms. It yields splendid crops on light soils, and is undoubtedly the best and most productive White Field Corn for the South. Pk. 85c. Bu. $\$ 2.75$.

1148. Bolgiano's Cuban Giant Ensilage Corn. We have thoroughly tested the Cuban Giant beside all large white grain ensilage varieties. Grains are pure white, very large, broad and long. Of stronger vitality than any other variety. It is the best milk producer of all ensilage Corns, being as sweet as Sugar Corn. Outyields the Red Cob Ensilage and is 10 to 12 days earlier. Pk. $85 \mathrm{c}$. Bu. $\$ 2.75$.

1214. Evergreen Broom Corn. Improved. An excellent variety ; is good length, fine, straight and bas a green appearance when ripe, and sells at the highest market price. Sow in drills three feet apart and thin out to three inches. Sow 5 pounds per acre. Lb. $15 \mathrm{c}$.
1215. Collier's Excelsior White Corn. We believe this to be the best all around White Com in existence. It is a lieary rielrer; has large ears, deep crain, snall cob and produces good-sized fodder, free from barren stalks. Matures in 110 to 115 days. Pk. $85 \mathrm{c}$. Bu. $\$ 2.75$.

1054. Red Cob 90-Day Corn. This Corn meets a long felt want because it can be used as a roasting ear Corn and when fully natured makes a first.class Crop Corn for feeding stock. The ear is large, handsome, suit for an early crop or for a late crop, because it matures in 90 days. This makes it always a safe and profitable crop. Pk. $85 \mathrm{c}$. Bu. \$2.75.

1142. Maryland White Corn. This very handsome Corn is the farorite of old farmers who like a big grain on a small cob. The grain is pure white, with good-sized ear, having ten rows to the cob. Used for gieneral crop. Pk. $85 \mathrm{c}$. Bu. $\$ 2.75$.

1257. Boone County White. Ears well filled out at both ends, cylin lrical, 9 to 11 inches long, averaging 20 rows, some 18 and 22. Grain ver deep, a little rough. Cobs wbite, of medium

1069. Connecticut Field or Large Yellow Pumpkin. Excellent for growing in Corn. Lb. $40 \mathrm{c}$.

1058\%. Kentucky Field Pumpkin. extensively and profitably in cornfield. Lb. 35

\section{Kaffir Corn-The Great Forage Plant}

1169. Red Kaffr Corn. Fon-saccharine. The plant is low, stalky, perfectly erect-the stalk as well as the blades; cures into excellent fodder, and in all stages it is available for green food. Lb. 6c. Pk. 50c. Bu. \$1.50. Special price in quantity.

1276. Red and White Milo Maize. These are popular varieties of sorghum, somewhat similar to the Kaffir Corm, valuable for both forage and grain. Cultivation is same as for Kaffir Corn. Lb. 6c. Pk. 50c. Bu. of 50 lbs. $\$ 1.50$.

1158. Early Orange Sorghum. This variety is rapidly growing in favor wherever it is grown. Similar in growth to Early Amber, but it is claimed that it produces a heavier crop. Please write for lowest prices.
1146. Early Amber Sorghum. Furnishes a large vield of most nutritious forage, wbich can be fed either green or cured, and will yield 2 or 3 cuttings a vear, stooling out thicker each time it is cut. It grows 10 to 12 feet high. Sow broadcast for forage at the rate of 1 to $13 / 4$ bushels per acre. When sown in drills, sow at the rate of 1 peck per acre in drills $3 \frac{1}{2}$ to 4 feet apart. Please write for prices.

1117. White Kaffir Corn. Makes nutritious food for stock and poultry. For a forage crop when sown by itself Kaffir Corn should be sown broadcast at the rate of from $3 / 4$ to 1 bushel per acre. When sown for a forage crop, either by itself or with Cow Peas, the crop should be cut before it is headed out. Lb. 6c. $\mathrm{Pk}, 50 \mathrm{c}$. Bu, $\$ 1.50$. Writc for latest prices. 


\section{SELF-WATERING FLOWER BOXES Made Entirly of Metal and}

They Do Away With all the Objectionable Features of the Old-Style Wooden Window Box

All Prices Subject to Change Without Notice

All Prices on This Page F. O. B. Baltimore, Md. Parcel Post Table, See Page 2

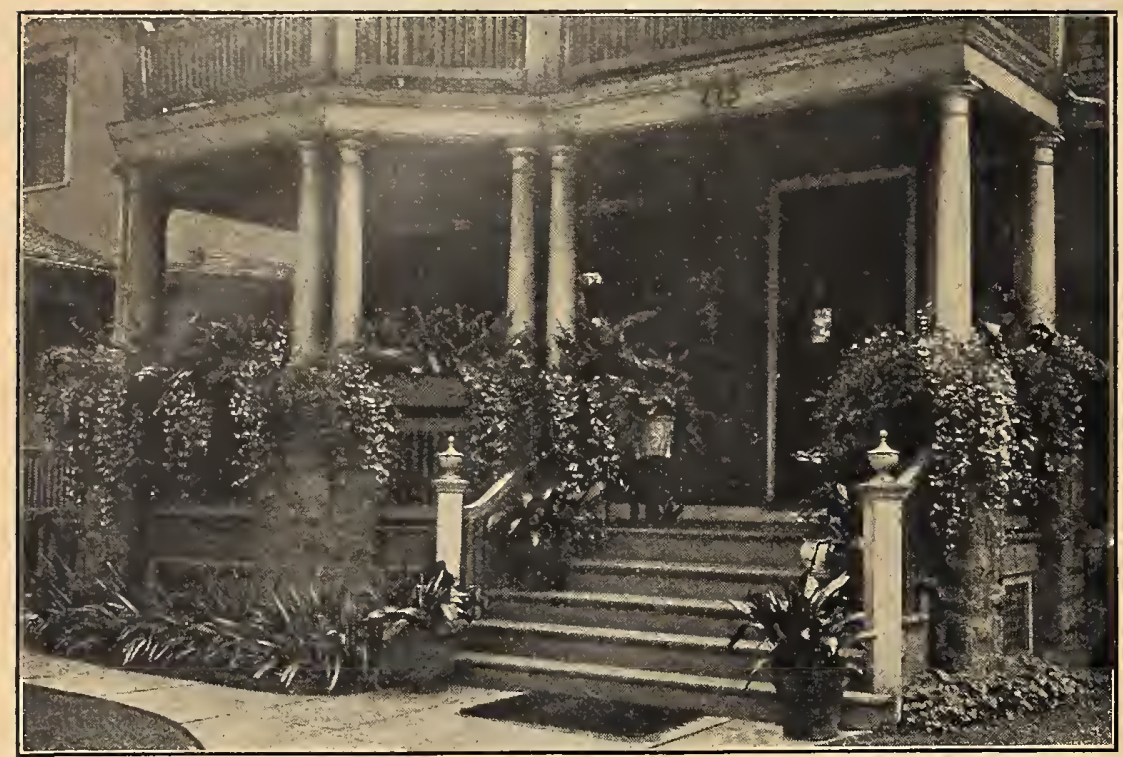
ADD DISTINCTION TO YOUR HOME-ATTRACT MOST FAVORABLE ATTENTION TO
YOUR PLACE OE BUSINESS

Savo All-Year-Round Flower and Plant Box

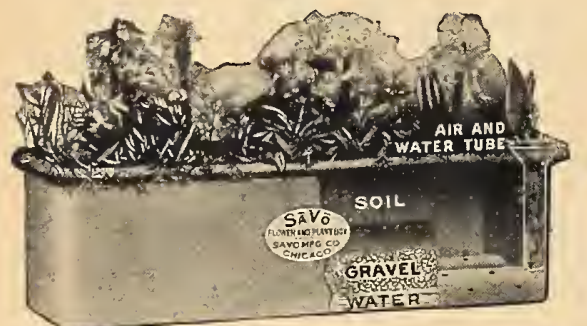

Self-Watering and Self-Irrigating, for Windows, Porches, Posts and Sun Parlors

The Savo Flower and Plant Boxes are made of the best grade of galvanized steel, with neat round corners and a full roll rim, the watering is easy, the drainage ample, the air circulation perfect. The enamel finish, both inside and out prevents rust or leakage and will last in constan use many years.

Directions for Using: First, place coarse gravel, pebbles, broken flower pots, charcoal or moss about an inch deep over the top of the moss about an inch deep over the top of the good, rich, black dirt, fill the reservoir with good, rich, black dirt, fill the reservoir with ree them grow.

Standard Stock Sizes and Price List

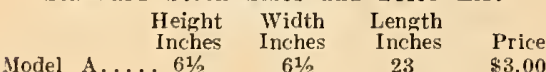
$\begin{array}{lllr}\text { Model } \text { B.... } 8 & 91 / 2 & 23 & \$ 3.00 \\ \text { H. } & & 49 & 4.00\end{array}$

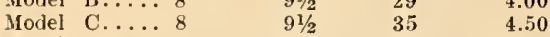
Model D....8 $\quad 91 / 2 \quad 41 \quad 5.00$ By freigbt or express only

These are outside measurements, including the Beautifully finished in aluminum or dark green.

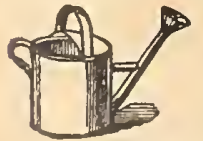

\section{Galvanized Iron} Water Pots

4 qts. $\$$.f 5510 qts.\$ $\$ .95$ 6 ats. $.70 \quad 12$ ats. 1.10 Mailing weight

16 gts. 1.30

\section{Cedar Tree Tubs}

Made of seasoned selected white cedar. bound with electric welded wire hoops (galvanized).

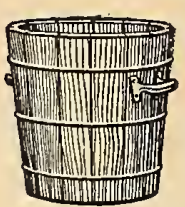
\begin{tabular}{ccccc} 
& Top & Bot. & Depth \\
No: & In. & In. & In. & Price \\
5 & 10 & $71 / 2$ & 9 & $\$ .80$ \\
7 & 12 & 9 & 11 & 1.15 \\
9 & 14 & 11 & 13 & 1.70 \\
11 & 16 & $121 / 2$ & 15 & 2.10 \\
\multicolumn{7}{r}{ Mailing } & weight, No. 5, 4 lbs.
\end{tabular} No. 7,6 lbs, No. 9,8 Ibs. No. 11, $11 \mathrm{lbs}$.

Handles extra at $30 \mathrm{c}$ per tub.

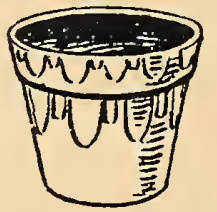

\section{Earthen Flower} Pots

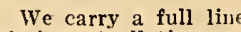
of sizes at all times.

Size Each Doz.

$31 / 4$ in.... 4c $\$ .35$

4 in ..... $5 \mathrm{c} \quad .45$

6 in $\ldots \ldots 7$. $7 \mathrm{c}$ c $\quad .75$

6 in $\ldots \ldots .11 \mathrm{c} \quad 1.20$

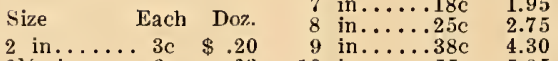

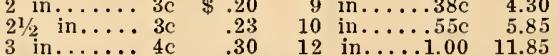

Earthenware cannot be packed for shipment by Parcel Post.

Packing charges extra on Earthen Flower Pots, Earthenware Saucers, Earthern Fern or Bulb Pans. Minimum charge 25c. 50c ner 100 up to size 6 -inch. $\$ 1.00$ per 100 size 6 -incb and up.

\section{Earthenware Saucers}

Size Each Doz. Size Each Doz. 4 in...... 4c $\$ .35 \quad 8$ in.....11c $\$ 1.25$

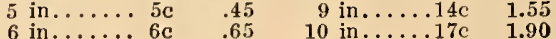

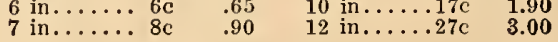

\section{Earthen Fern or Bulb Pans}

Size Each Doz. Size Each Doz. 5 in $\ldots \ldots .7 c \quad \$ .75 \quad 8$ in $\ldots \ldots .25 c \quad \$ 2.75$ 4 qt. 2 lbs. 6 at. 3 lbs. 8 at. 4 lbs.

\section{The Illinois Self-Watering Flower Boxes}

The Illinois Self-Watering System absolutely assures success with plants, bulbs and ferns in the home. This system is based on the principle of subterranean irrigation, a principle which is accepted by agricultural authorities as most conducive to the healthful growtb of plants. In our window boxes and hanging baskets this method is ingeniously adapted through the use of sponges and a false bottom (see diagram below). The correct quantity of water is assured to thi delicate root fibers of the plants at all times. the water being drawn up slowly by means of capil lary attraction. Rapid and luxuriant growth results.

\section{WE GUARANTEE}

Every Box, Pot or Basket WILL NOT LEAK. Blooms will be larger and foliage heavier tbal in any surface-watered device. We will replace any box that leaks or wears out in any part within FIVE YEARS of date of purchase. We will refund the purchase price of any box or pot not giving satisfaction if returned witbin 60 days.

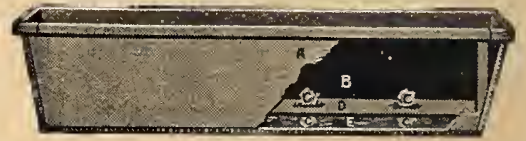

Illinois' Self-Watering Window Boxes

\begin{tabular}{|c|c|c|c|c|c|}
\hline & Height & Width & Length & \multicolumn{2}{|l|}{ Water } \\
\hline No. & Inches & Inches & Inches & Cap. Qts. & Price \\
\hline $0 \ldots \ldots$. & - 6 & 6 & 16 & 1 & $\$ 2.25$ \\
\hline & 8 & $91 / 2$ & 23 & $21 / 2$ & 2.85 \\
\hline $2 \ldots$ & 8 & $91 / 2$ & 25 & 3 & 3.0 .5 \\
\hline 3 . & 8 & $91 / 2$ & 27 & $31 / 2$ & 3.30 \\
\hline 4. & 8 & $91 / 2$ & 29 & 4 & 3.50 \\
\hline 5. & 8 & $91 / 2$ & 31 & $41 / 2$ & 3.75 \\
\hline $6 \ldots \ldots$ & 8 & $91 / 2$ & 33 & 5 & 3.95 \\
\hline $7 \ldots \ldots$ & 8 & $91 / 2$ & 35 & $51 / 2$ & 4.20 \\
\hline $8 \ldots \ldots$ & 8 & $9^{1 / 2}$ & 37 & 6 & 4.40 \\
\hline $9 \ldots \ldots \ldots$ & 8 & $91 / 2$ & 39 & $6 \frac{1}{2}$ & 4.60 \\
\hline $0 \ldots \ldots$ & - 8 & $9^{1 / 2}$ & 41 & 7 & \\
\hline
\end{tabular}

By freight or express only

Illinois Self-Watering Porch Boxes

Special sizes made to order at prices proportionate to the above.

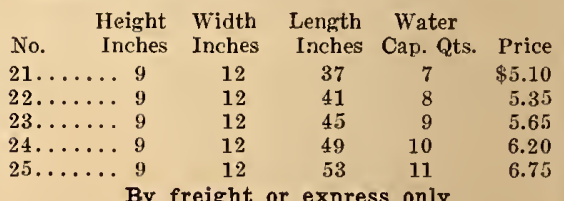

By freight or express only

Red Rubber Plant Sprinklers

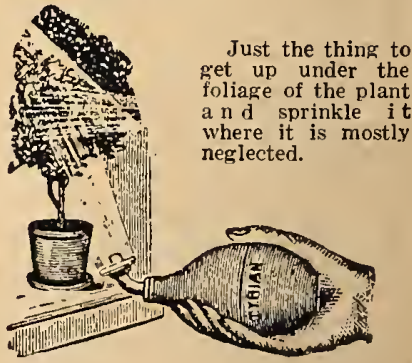

10 ounce bent ........................ 1.00 each 
Unglazed Hot Bed Sash

$3 \mathrm{ft} .2 \mathrm{in.} \times 6 \mathrm{ft}$. To hold 28 lights.

$\$ 2.25$ each. Please write for prices in quantity.

Hot Bed Glass

$8 \times 10$ in., 90 lights in box. Price....... $\$ 3.50$

Burlap Hot Bed Mats

Made of strong Burlap, interlined with wool.
ize $40 \times 76$ in. Single Sash........... Size $40 \times 76$ in. Single
Mailing weight $10 \mathrm{lbs}$.

Size $76 \times 76$ in, Double Sash.......... $\$ 2.90$ Hailing weight, $20 \mathrm{lbs}$.

\section{Mastica}

For glazing greenhouse or sash, new or old. It is elastic, adhesive and easily appl
affected by dampness. Gal. $\$ 2.25$.

Mailing weight 8 lbs. per Gal.

\section{Glazola}

An ever elastic material for glazing and repair work. Will always remain in a rubber like condition. 1 Gal. $\$ 1.70$. 5 Gal. cans $\$ 1.65$ per gal. 20 Gal. drum at $\$ 1.55$ gal. 40 Gal. drum at $\$ 1.50$ gal.

$\$ 1.50$ gal. each barrel or $1 / 2$ barrel of Glazola.

railing weight 8 lbs. per Gal.

\section{Grafting Wax}

$1 / 2 \mathrm{Lb} . . .20 \mathrm{c} \quad 1 \mathrm{Lb} . . .38 \mathrm{c}$

\section{Peerless Glazing Points}

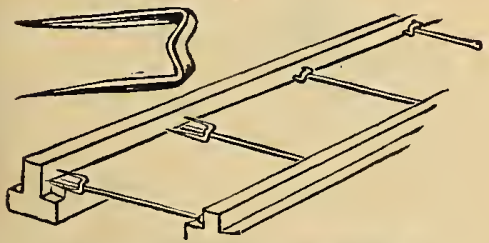

Will stop your glass from sliding.

priailing weight 2 lbs. per 1,000

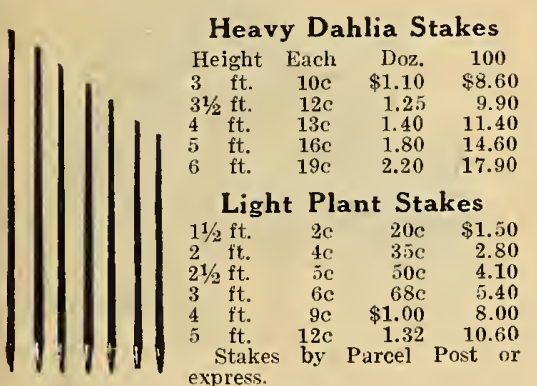

Hyacinth Stakes

Use for staking Hyacinths, Tulips and slender plants

\begin{tabular}{|c|c|c|c|}
\hline 18 in.. & 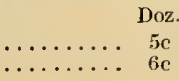 & $\begin{array}{l}100 \\
25 \mathrm{c} \\
35 \mathrm{c}\end{array}$ & $\begin{array}{r}7,000 \\
\$ 1.95 \\
2.90\end{array}$ \\
\hline \multicolumn{4}{|c|}{ Pot Labels } \\
\hline & 100 & 500 & 1,000 \\
\hline 4 in., plain & $\ldots \$ .15$ & $\$ .65$ & $\$ 1.1 \overline{5}$ \\
\hline 5 in., plain & $\begin{array}{ll}\ldots . .10 \\
\ldots .\end{array}$ & .80 & $\begin{array}{l}1.500 \\
1.50\end{array}$ \\
\hline 6 in., plain & …... .22 & 1.00 & 1.90 \\
\hline 8 in., plain & $\ldots \ldots \ldots, \quad .60$ & 2.70 & 5.20 \\
\hline 12 in., plain & $\ldots \ldots \ldots \quad .95$ & 4.55 & \\
\hline
\end{tabular}

Tree Labels

$\begin{array}{lll}100 & 500 \quad 1,000\end{array}$ $3 \frac{112}{111 .,}$ plain, copper wired.. $25 \mathrm{c} \quad \$ .95 \quad \$ 1.80$

\section{Hedge Shears}

6-inch....\$1.00 9-inch....\$1.65 8 .inch.... 1.50 10-inch.... 1.80 With notch, $25 \mathrm{c}$ cxtra.

12-inch with notch only...\$2.65 Mailing weight, $6 \mathrm{lbs}$. each.
Parcel Post Rates, see Page 2

All Prices Subject to Change without Notice

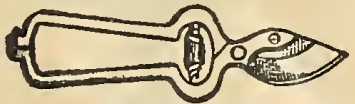

Pexto Pruning Shears

No. 50. 8.in., Pexto.............. \$ .70

No. R.50. 9-in., Pexto $\ldots . ., \ldots \ldots \ldots, \quad .90$

No. $60,9 \cdot$ in Pexto

No. R-60, 9.in Pexto

No. 65. 9-in., Pexto, fuil polished......... 1.25

No. R.70. 9 -in., Pexto. ..............

No. R-85. 9-in., Pexto, full polisher

No. 14. 6-in., Ladies' Nickeled.

No. 140. 6-in., Ladies' not polished

Mailing weight, 2 lbs. each.

\section{Long Handle Pruning Shears}

No. V-20. 26 inches long............. 1.90

No. V-30. Long. Handle Pruning shear, with

lock nut, 26 inches
Mailing weight, 4 lbs.

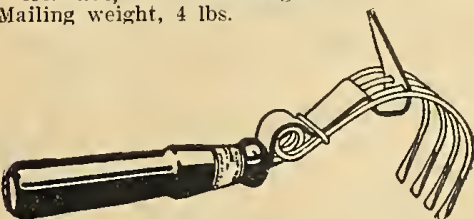

Combination Spring Tooth Magic Weeder Hoes

The Magic Weeder Hoe is a dandy, and in very rreat demand, far exceeding our expectation. Made especially for the trade.

\begin{tabular}{|c|c|c|c|c|c|c|}
\hline$\stackrel{u}{N}$ & $\begin{array}{c}\text { Length } \\
\text { of } \\
\text { Handle }\end{array}$ & $\begin{array}{l}\text { Length } \\
\text { Over } \\
\text { All }\end{array}$ & $\begin{array}{l}\text { Diame- } \\
\text { ter of } \\
\text { Tines }\end{array}$ & $\frac{5}{3}$ & Biade & $\stackrel{\breve{g}}{\mathscr{E}}$ \\
\hline $\begin{array}{l}\mathrm{G} \\
\mathrm{K}\end{array}$ & $\begin{array}{l}48^{\prime \prime} \\
48^{\prime \prime}\end{array}$ & $\begin{array}{l}57^{\prime \prime} \\
56^{\prime \prime}\end{array}$ & $\begin{array}{l}8-32^{\prime \prime} \\
7-32^{\prime \prime}\end{array}$ & $\begin{array}{l}5^{\prime \prime} \\
4^{\prime \prime}\end{array}$ & $\begin{array}{l}\text { No blade } \\
\text { "V" blade }\end{array}$ & $\begin{array}{l}300 \\
400\end{array}$ \\
\hline
\end{tabular}

\section{Village Blacksmith} Sickles

No. 3. Forged from bar tool steel. Thoroughly tempered and ground sharp, ready for use. Hangs perfectly without mnuscular effort. Natural hamner ninish; upper side full polished. Turned maple handle. Price $55 \mathrm{c}$.

No. 3ิ3. Same style as No. 3. Made of heavier material. Price 65.

No. 4. Cutlery steel. Corrugated blade- round wide, thin and sharp. Temper finished blade. Securely riveterl hard wood handle. t5e each. Blue Ribbon Sickle. Idcal or light ork 50c.

Clark's Solid Black Sickle, 50c each.

Austrian Sickle, $50 \mathrm{c}$ each.

Sickles Mailing Weight 2 lbs. each.

\section{Gardeners' Trowels}

No. 1. 6-inch steel-one piece..... 10c

No. 2. 6-inch riveted shank.......

Riveted shank-6.inch bladee...

Riveted shank--6.inch blade...
100 . Florist's Trowel. Extra heavy. Cold-rolled steel. One

D. s. T. High grade English steel. Socket Towe Mailing Weight $i$ ib. each.

Transplanting Trowels

No. 15. Cold-rolled steel $51 / 2$-inch b i a d e. Finest transplanting trowel on the market.

Mailing weight, $1 \mathrm{lb}$.

\section{Garden Barrows}

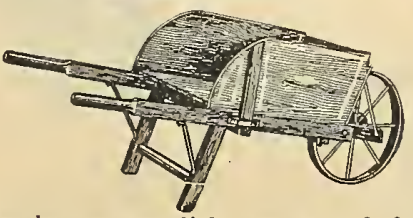

These barrows are light, strong and durable. painted and varnisherl.

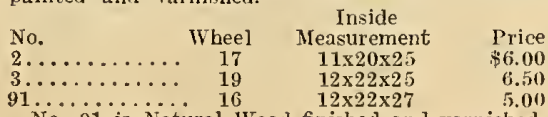
$91 \ldots .93$ No. 16
No. 91 is Natural Woorl finisherl and varnished.

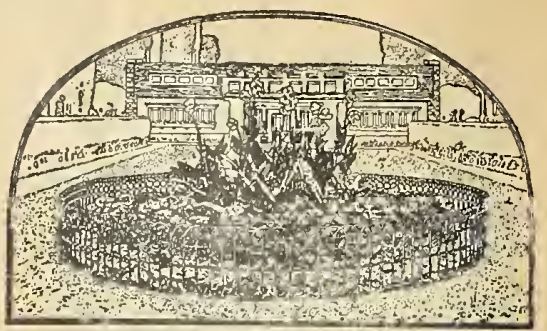

Perfection Flower Guard

It is just as easily applied to any 10rm or s1ze of flower bed. No posts are required. the picket ends are left projecting for insertion in the ground. Not expensive and can be taken up trom year to year. It is cut off to the length requires and the ends hook together when set. Thi border not only protects, but adds to the bcauty
of every flower hed.

12 in. high, per running font

18 in. high, per running foot

$25 \mathrm{ft}$. lengths and over $1 \mathrm{c}$ per $\mathrm{ft}$. less. Trellis Wire

Excellent for training
vines of all kinds up porches, rerandas, pegolas, etc. Easy to put up. will galvanized and well made, gakt a litetion

Our Special
Price per ft.

No. 107.

No. 107 .

Single
No. 108

Double

Doubl 24 in. wide

$25 \mathrm{ft}$ lengths and

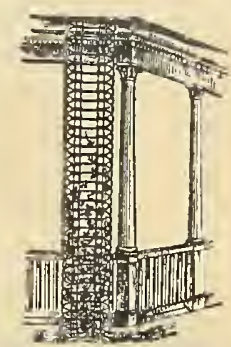

"Norcross" Cultivator Hoes and

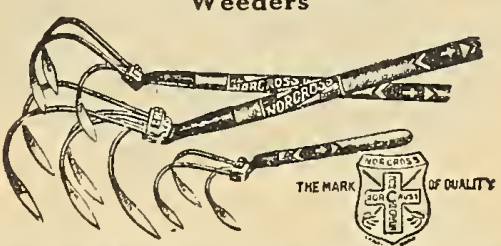

Will cultivate closer to plants without injuring then than any other type of implement known, leaving the soil level, loose and untrampled. The sharp, tapering shovels enter the ground easily and are so arranged, one with another, as to literally tear up every inch of the soil, from one to five inches deep, as required. Detachable steel prongs, malleable head, cxtra high orade handles. finely finished throughout. Three sizes, suited to both men and women, and the average cost is only that of a common hoe. Three Sizes and Prices

prong, $4 \mathrm{ft}$. handle; weight $3 \mathrm{lbs}$

prong, $4 \mathrm{ft}$. handle, weight $2 \mathrm{lb}$

.75

\section{The Little Giant Mole Trap}

No Mole Can Pass!

\section{SIMPLEST -}

\section{SUREST-}

SAFEST -

it is made of all steel and heavily tinned, which makes it durable trap. The spears are made of spring-steel and are therefore smaller than those made of soft steel, piercing a mole of soft steel, pie
more easily. $70 \mathrm{c}$.

Mailing weight, $3 \mathrm{lbs}$

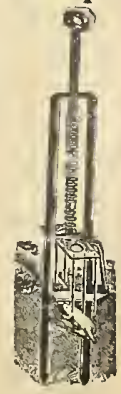

Troweed

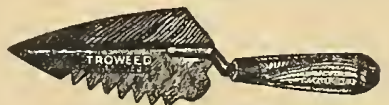

A boon to gardeners, forists, greenhousemen. A combination garden tool; has many advantage over the ordinary trowel weeder. Price $50 \mathrm{c}$ each. Mailing weight $1 \mathrm{lb}$. 
The J. Bolgiano Seed Co., Baltimore, Md.

\section{ALL PRICES SUBJECT TO CHANGE WITHOUT NOTICE}

Bolgiano's High Grade Lawn Mowers Our Lawn Mowers are guaranteed in every respect; no pains or expense have been spared to produce the best nover thit mechanical skill

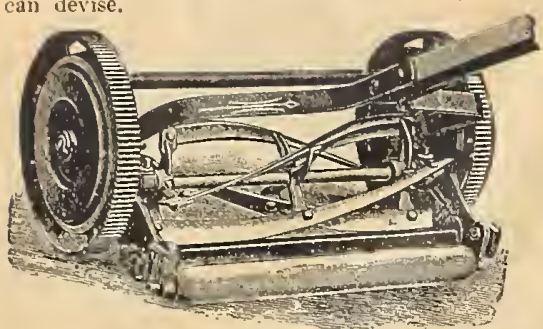

Druid Hill Park Special

Blade lind Wheel Price

12 in. Druid Hill Park special....8 in. $\$ 6.00$

14 in. Druid Hill Park Spectal...8 in. 6.50

Bolgiano's Ball Bearing Lawn Mowers

For thowe who now their. lawns frequently tie advise the Ball Bearing Machines.

Blade Find

12 in. Bolgiano's Leader

14 in. Bolgiano's Leader

16 in. Bolgiano's Leader

18 in. Bolgiano's Leader

$14 \mathrm{in.} \mathrm{Bolgiano's} \mathrm{Crackerjack}$

16 in. Bolgiano's Crackerjack

Wheel Price

.8 in. $\$ 7.50$

8 ill. $\quad 8.00$

8 in. 8.25
8 in. 8.75

9 in. $\quad 9.2$

9 in. 10.00

Bolgiano's Flyer

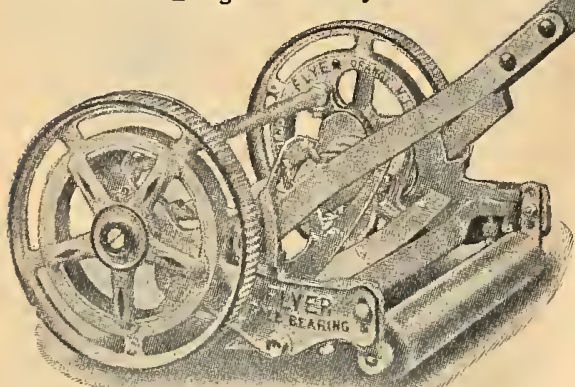

Bolgiano's Flyer, Here is the strongest, lightest ruming, most beautiful designed an finished mower in the world. Fully guaranteed. Blades made of crucible steel, oil tempered. double Pawl ratchet design placed in the pinion. Blade Kind Wheel Price

14 in. Bolgiano's Flyer $\ldots \ldots \ldots .9$ in. $\$ 10.25$

16 in. Bolgiano's Flyer $\ldots \ldots \ldots \ldots 9$ in. 11.25

18 in. Bolgiano's Flyer $\ldots \ldots \ldots \ldots .9$ in. 12.25

Bolgiano's New Matchless

Bolgiano's New Matchless
kind

$14 \mathrm{in.}$ New Matchless $\ldots \ldots \ldots \ldots \ldots \ldots \$ 13.75$

16 in. New Matchless $\ldots \ldots \ldots \ldots \ldots \ldots \ldots 15.00$

$20 \mathrm{in.}$. New ylatchless $\ldots \ldots \ldots \ldots \ldots \ldots .616 .50$

Bolgiano's New Orange Kind

14 in. New Orange

16 in. New Orange

20 inl. New Orange

Price

$\$ 13.75$

15.00
16.50

18.00

Horse and Power Lawn Mowers

Please write us for luwest prices.

Grass Catchers

No. 1. Metal Bottom Catchers. 16 inches leelt, mide of heavy duck; leavy galvanized wir frane; adljustable steel hoops, will fit any nower, nowers, 12 to 16 inches wide, 85 .

No. 2. Metal Bottom Catcher.

but for mowers 16 to 20 irehes wide, $95 \mathrm{c}$

\section{Grass Shears}

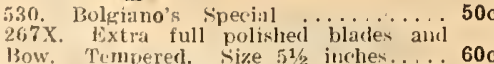

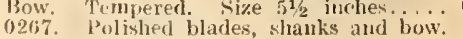

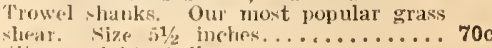

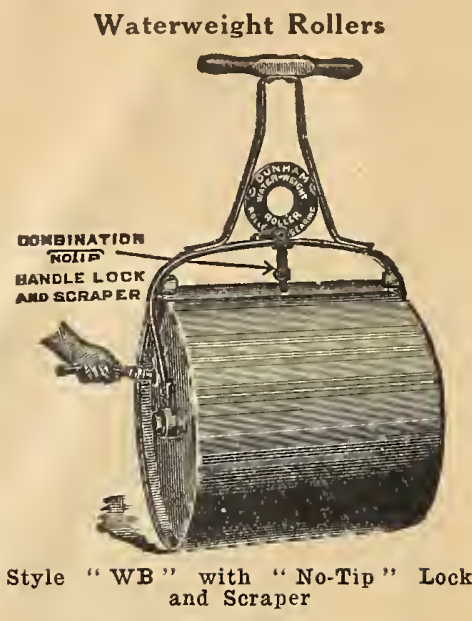

Diam. Length Sec- Weight Filled with
No. ins. ins. tions empty Water Price W. B. $3 \quad 14 \quad 20 \quad 160 \mathrm{lbs}, 160 \mathrm{lbs}, \$ 15.00$ W. B. $5 \quad 18 \quad 24 \quad 1$ 8.j lbs. 300 lbs. 18.00

This roller has a steel clrum into which water can be poured until the roller is just the weight for the work at hand. For soft lawns it will not need so much water, while for firm turf, teuni court or drives it can be made as heavy as desired. When through rolling, all water is emptied out and the roller is light enough to be easily handled and put in the basement or garage. The drum is narke of heavy steel plates. carefully welderl to form a solid. one-piece container for the water.

The freezing and thawing of Winter heave and crack the turf away from the subsoil, leaving loots exposerl to the air. These roots dry ou and die. In Summer, wind and sun dry out, bake and rack the soil about the roots. This will happen even in clinates where there are no heavy frosts.

Rolling the lawn just as soon as the frost is out preves the heaved turf back against the subsoil and settles the earth firmly around the grass roots. Rolling throughout the Summer im. mediately after rains keeps the surface even for the mower to run over and discourages worms ants, moles, etc.

\section{Machine Oil}

The best refinet oil to be used on your lawn mowers or any of your delicate machinery. Price. $1 / 4$ pint $15 \mathrm{c}$.

\section{Clover Lawn Mower Sharpening Compound}

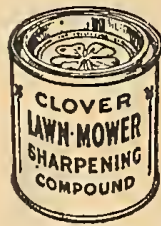
ing Compound is a rrindin conpound, and when applied to the cutting edges of a mower, after these edges have been properly adjusted, it will grind them together in place sharp, and make a perfect job of it. so simple is the whole operation, that any boy, girl, man or wounan who can push a mower can sharpen lo a better job than can id trained mechanic. Buy a 50 rent can of Clover Mower sharpening Compound and sharpen it every time you use it. You will hever know the delight of cutting grass until your to. Price $50 \mathrm{c}$ ner cals.

Goodwin Grass Shears

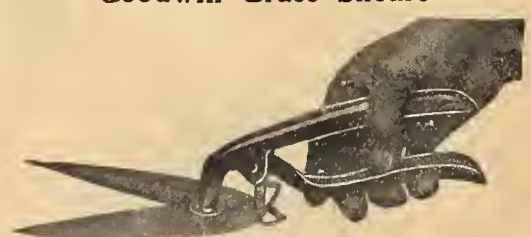

A shear that allows the hand to be held in the easiest and most natural position possible. It docsult tire the lrand, or raise a crop of blisters. you car operate it much faster, the blades can int sip apart, it's woudlerfully easy even for a woman to we and it cuts like a razor. Price $\$ 1.50$ ench.
Bolgiano's "Square-Deal " Moulded Hose

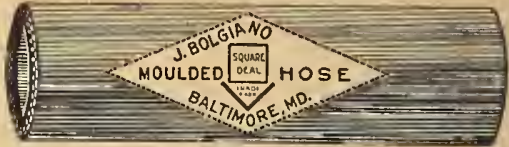

Bolgiano's “Square-Deal" Moulded Hose is made of the very best inaterial and fills a long felt want for a high-grade hose at popular price. $16 c^{\prime}$ per foot

Heavy High-Grade 3 -Inch Hose in Continuous Lengths, Add 20c for Couplings

Per running foot

"Square-Deal," $8 / 4$ inch............ $16 \mathrm{c}$

Mars, 3/4 inch................... 17c High Pressure Hose for Spraying Purposes Prices on application.

Hose Nozzles

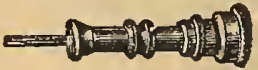

Plain, 6 in.... 50c Mystic Spray .. 60c Mailing weight, $1 \mathrm{lh}$

\section{Hose Sundries}

Hose Menders, Sure Grip............ Each 10 Hose Couplings ................." 200

Hose Bands ................." $5 c$

Hose Washers ................. Dozen 10 Mailing weight, $1 \mathrm{ll}$.

The Newest Member of the Fountain "Family"

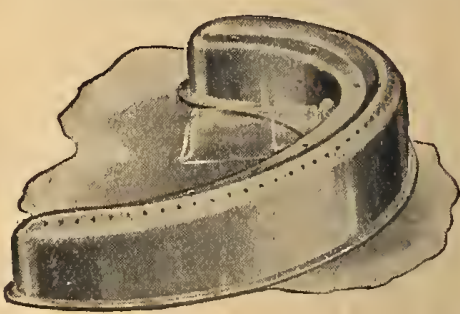

The Half Fountain Lawn Sprinkler

Has the "Mist-Like" SprayCovers but half of the full circleSprinkles the lawn--keeps the walks dryUser moves it without getting wetStays upright-Price $60 \mathrm{c}$. Mailing weight, $1 \mathrm{lb}$.

The "Original" Fountain

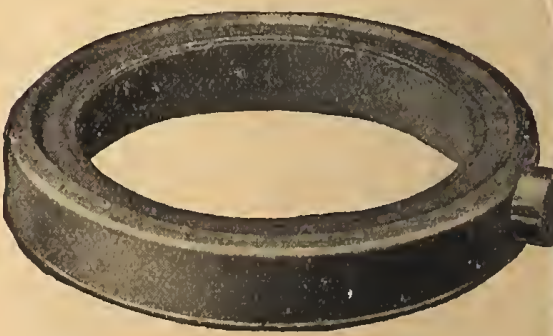

No moving parts. Sprinkles in a full cirele Very popular. 70c. Mailing weight, 1 ll.

\section{B. Sprinkler}

Solid brass, with anchor to keep from tipping. One of the best sprinklers macle. $45 \mathrm{c}$. Mailing weirht, $1 \mathrm{lb}$. 
Rainbow Brass Lawn Sprinkler

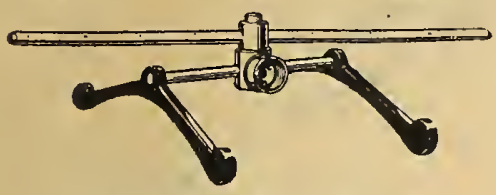

World's Best Rain Insurance

Does Not Stick or Rust. The water descend in smail particles like mist and rain combined over inl area of 40 to 50 feet, watering every inch of ground.

Instantly Set in Motion with Low Water Pressure. The Rainbow Sprinkler is supported on a brass sled, which may be easily drawn over the lawn. The sprinkler may also be connected to a stand pipe.

The Rainbow Lawn Sprinkler works perfectly from artesian well or tank pressure. Strong in construction. Attractive in appearance.

Mailing weight, 4. Lbs. Price, $\$ 2.00$ each. Guaruntee attached to each sprinkler.

\section{Revolving Lawn Sprinklers}

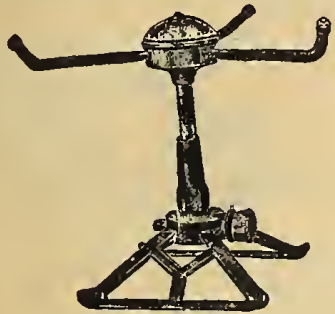

Universal Sprinkler

Universal. Black frame, with full nickel top and spreading arms. Sprinkles from both top anci arms. $\$ 2,15$.

Preston. Black frame, with brass spreading arms. Not as tall as Universal, and sprinkles rom arms only. $\$ 1.60$

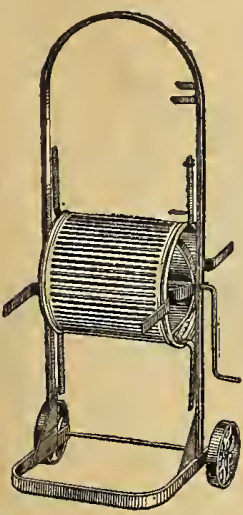

\section{Wirt \& Knox Hose Reels}

Wirt \& Knox No. 2 All metal, best tubular teel frame, heavy corrugated galvanized steel drum ....\$2.75

No. 10. Absolutely all metal, tubular steel rims and $\mathrm{f} r$ a $\mathrm{mes}$. diameter of rim 21 inches $\ldots \ldots \ldots \$ 3.50$

No. 20. Same as No. 10 only diameter of rim 24 inches ..... $\$ 4.00$

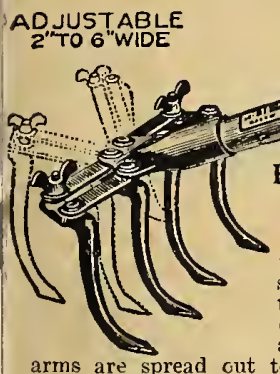

arms are spread cut a garden tool. When the the cultivator is like a rake.

Fer narrow rows the outer ends of the arm can be closed to any width down to 7 inches Hand Cultivator, 9-tooth, long hondle.... \$ \$1.10 Pull-Easy, Jr., short handle, 4-tooth..... 35c Pull. Fasy Jr long handle 4.tooth ...... 55c -Prong Adjustable Pull- Easy. Center tooth easily removable. 4 -foot straight grain ell handle. Mailing weight $2 \frac{3}{4}$ hhs... $85 \mathrm{c}$ Pull- Fasy Weeder $\ldots$

\section{Steel Hoes}

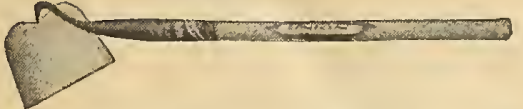

Malleable Iron Socket, steel blade, S. R. $7 \ldots 40 c$ Sockets, Y. S. G. $61 / 2$

Faultless, F. S. 7 ......

Warren. W. 7 .

Wurren, $W, 7 \frac{1}{2}$

snrouting Hoe, H. G. 6-0.

Mailing wejght, 3 lbs

Spades

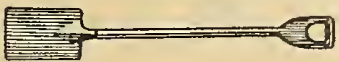

D Handle, No, 2, plain.............. \$1.10 D Handle, No. 2, polished.............. 1.25 D Handle, Post or Ditching Sparle, No. 3. . 1.50
No. 452. Long Handle Spade.......... 1.00

Hailing weight, $8 \mathrm{lbs}$

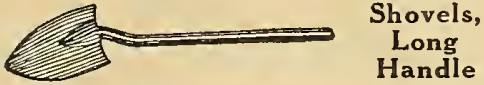

Long Handle Shovel, No. 2, polished.....\$1.25 I Handle, No. 3, polished, round print.... 1.40 Hollow Back scoop shovel, No. 2 ......... 1.25 Mailing weight, $8 \mathrm{lb}$.

Square Point Dirt or Coal Shovel

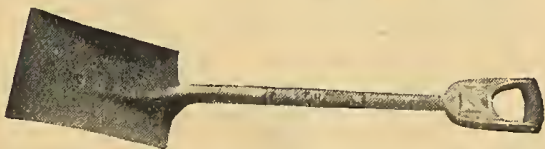

Price, $\$ 1.00$ each. Mailing weight, \& llss.

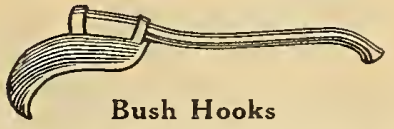

Assolutely the best steel Busl Hook made. fully guaranteerl. Price $\$ 1,50$. Mailing weight 6 lbs.

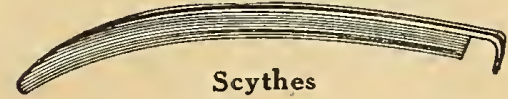

Englsh Steel WaIdron Grass, 34 inch..... \$2.50 Silver Steel Waldron Grass, 30,32 and 34 in. 1.60 Cloverleaf Grass Scythe, 30, 32 and 34 inch.

$$
\text { light, yet strong and durable... }
$$

light, yet strong and durable....

1.25

Copper King Weed Scythe, 24 and 28 inch. . 1.50

railing weight, 5 lbs.

\section{Snaths}

Scythe Handles with Loof Bolts.

Scythe Handles, with Rings.

Mailing weight, 3 lbs.

\section{Carborundum Scythe Stones}

Carborundum, No. 190. 101/4 in. long, 1 in. 30 Carborundun, No. $191,121 / 4$ in. long, $11 / 1$ in wailing weight, 2 ibs.

Mattocks, Heavy Steel

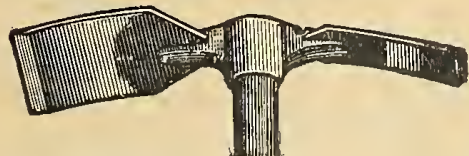

Mattock, No. 424, L. C.

Hindles, extra
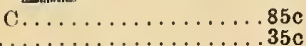

. H. 3, Nattock Hoe, light, complate.......70c Mailing weight, 6 lbs.

\section{Double Prong Weeding Hoes for Weeding and Cultivating}

No. 2, "P. W." ....... 35c teme, A. w. (like cut) .......90 P. S. W. . . . . . . .

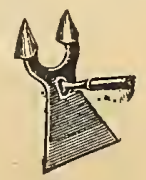

Potato Hooks

All steel, 4 B. 0. L................. 85 Mailing weight, 2 ihs.

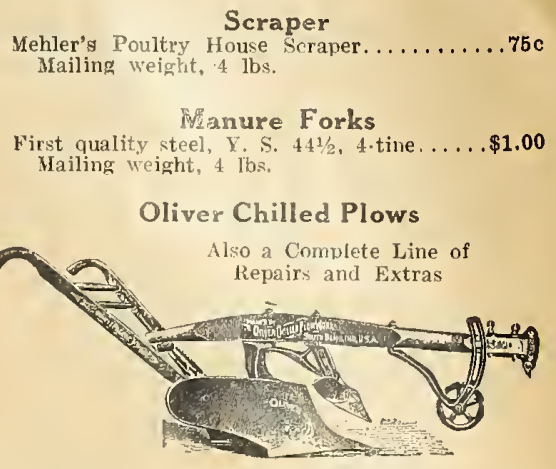

Wood or Steel Beams

No. A-1. Right-hand only, light one-horse. $\$ 8.75$ No. B. N. Right-hand only, medium an horse. Price

10.00

\section{Right and Left Hand}

No, 10. N. Full one-horse.

No. 20. N. Medium two-horse steel Beam 17.50 No. 20. N. Nedium 2-horse Wood Beam. 16,00 No. 40. N. \& $40 \mathrm{X} . \mathrm{N}$. Two or three-horse 20.00 No. 40. N. \& $40 \mathrm{X}$. N. Two or three-horse Wood Beam ............................. 170

\section{Whecls}

Brace Standard, two-borse, complete. Straight standard, one-horse, complete. Jointers, complete, two or three-horse.

3.50

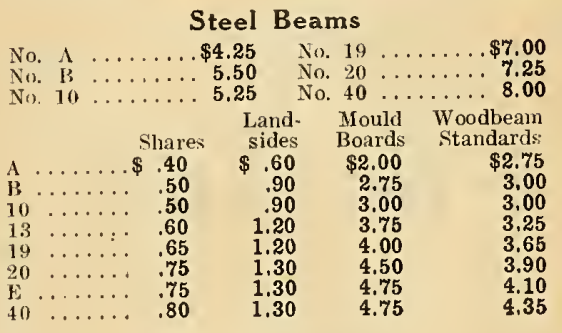

Turf or Edging Knife

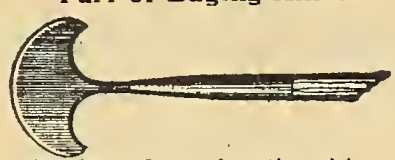

For trimming edges of paths, drises, flower beds and border:

Kohler's Half- Mloon Shape, T- $\mathbf{E}$. ......... 90 failing weight, ; lbs.

No. 2 Planet Jr. Edger

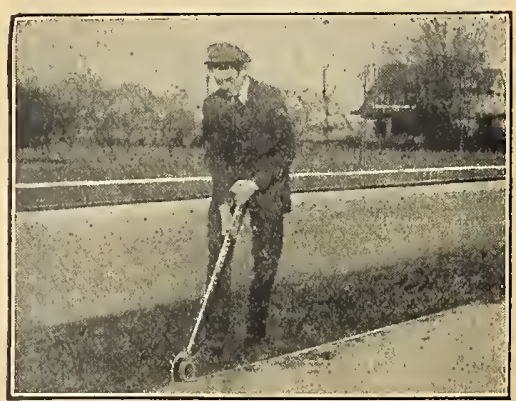

Neatness is the great secret of attractiveness in grounds surrounding a house, and to have this neatness the grass bordering walks must be frequently edged or trimmed. With the No, 2 Planet Jr. Edger you can edge either straight or curved walks of cement, stone or brick, rapidly and easily.

The edging dise is made of high-grade steel and will last for years. The tool is extremely simple and easy to operate, and there is nothing to get out of order. It is always ready for use, and should be the constant rompanion of the lawn mower. Price, $\$ 1,75$ earh. Mailing weioht, 4 lhs 
The J. Bolgiano Seed Co., Baltimore, Md.

\section{Lawn \\ and \\ Garden \\ Rakes \\ The Ole Olsen Lawn Rake \\ The teeth are so constructed tlat \\ when driven into the load they \\ will never shrink from place and \\ "tnnot fall out. Prise 80c. Mail-}

Iron and Steel Garden Rakes

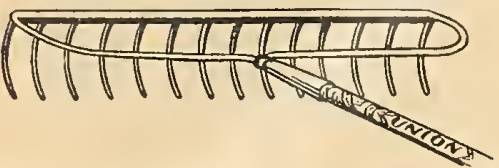

Malleable Rakes, M. S. 12,............ 45 Malleable Rakes, M. S. $14 \ldots \ldots \ldots \ldots \ldots \ldots .50 \mathrm{c}$ Steel Rake, high grade, bent tooth, B. 12...990 steel Rake, high grade, bent tooth, B. 14... 95c teel Bow Rakes, F. B. 14........... 75c

Ifailing weight, $5 \mathrm{lbs}$

\section{Lawn Queen Rake}

\section{nonananganang IIIIIIItimi}

Made of heary, tinned, steel wire. These are excellent for lawn or walk work. The rake is reversible and will answer sever side. Price $50 \mathrm{c}$ $24-$ tooth one side, 12 to the
Ilailing weight, 5 lbs.

\section{Floral Sets}

Sliovel, Hoe and Rake, 3 F. S... $\$ 1.50$

Mailing weight, $10 \mathrm{lbs}$.

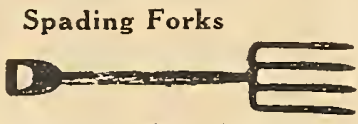

Union No. B. A. D. Boys, 4-prong....... 80c Union "D" Handle, 4-prong, Z. S. A. L. D. 90c Union "D" Handle, 4-prong, Y. S. A. L. D. $\$ 1.15$ Union "D" Handle, 5-prong, 5 A. D..... 1.85 Yailing weight, $6 \mathrm{lbs}$

\section{THE"OUT-U-KUM" WEED PULLER}

An Entirely New Principle

A slight Push and Pull thoroughly loosens the surrounding soil and re. moves not only the weed, but the entire root.

When pushed into the ground the two points guide the BRIDGE down alongside the weed, loosening the soil from that side. It then crosses under the root disengaging the latter. As the tobl is withdrawn the BRIDGE slips up the opposite side of the weed, loosening the ground from that side and engages the head of the weed above the ground. The now thoroug iy loosened weed is readily roth loosened weed is readily witharawn clinging soil.
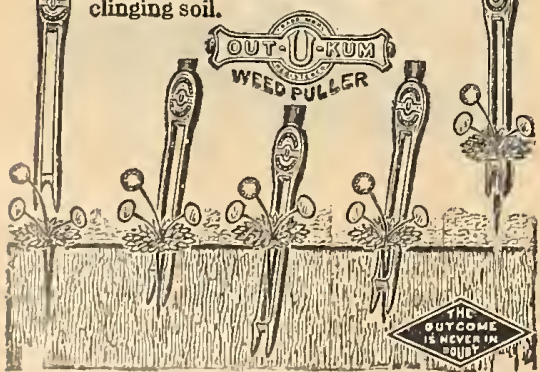

Price, 75 c each.

Viriling weisht, 211
"Iron Age" No. 12 Wheel Plow and Cultivator

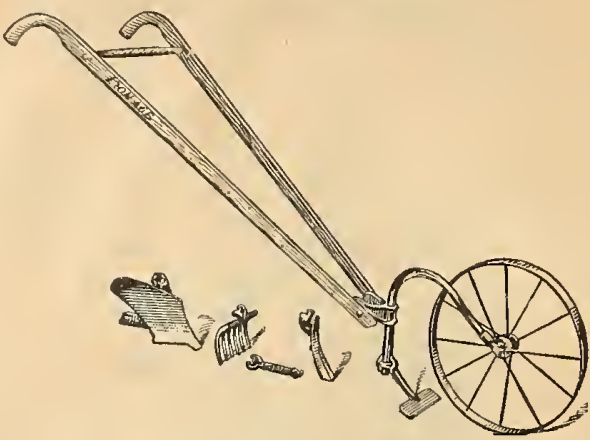

This simple, light-weight machine will be found of great service in simplifying the work in the small regetable or flower garden. The average weight of this machine with one working tool is but 8 pounds. Price $\$ 5.00$.

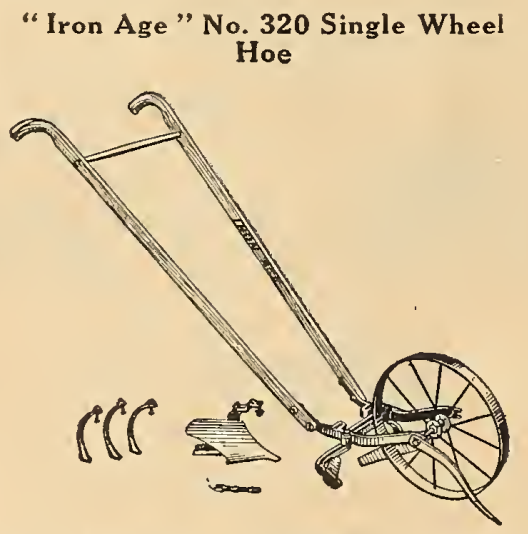

A strongly constructed implement for the ama tour or market gardener. It is light in weight and of simple construction. The attachments are a pair of side hoes, tbree cultivator teetl, a vine lifter and a plow. Price $\$ 6.75$.

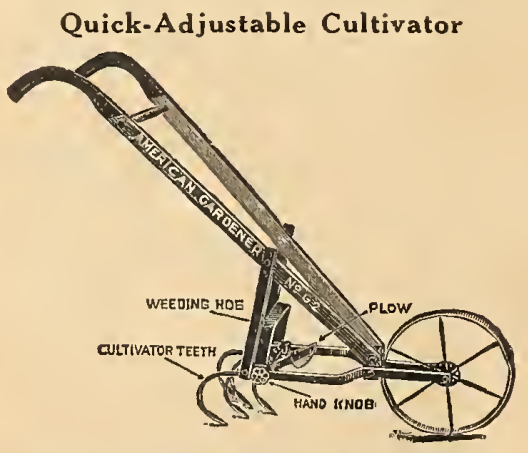

The True Temper Geneva, No. G2, is recognized everywhere as the only real quick-adjustable cultivator on the narket.

It has a Weeding Hoe, a Plow and five Cultiator Teeth, all permanently attached to a revolving steel plate.

Any of these tools nuay he securely locked into working position by a few turns of the Hand Wheel-a time and labor saver.

Macline has steel forged tools, well selecter oak handles, with comfortable handle grips. It las 14 -inch steel wheel and is finished in colors. then varnished. Weight 20 lbs. Price $\$ 5.50$.

The large Turning Plow with landside, which is sold as extras, may be easily attached in place. of Drill Plow. Price \$1.50.

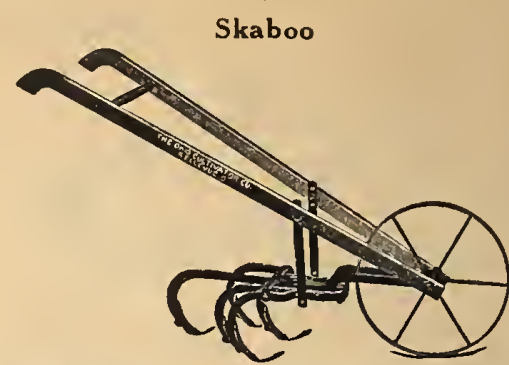

A complete five-shovel cultivator with detachable double-point reversible shovels. Adjustabl from 10 to 14 inches in cutting width. A gardel tool that will please the most exacting. Price $\$ 4.00$. Weight, 21 lbs.

\section{Fire-Fly Garden Plow}

Packed weight, 14 pounds

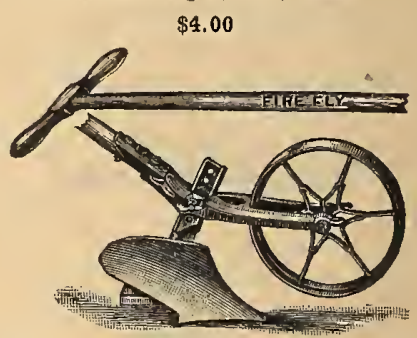

This tool is exceedingly useful to owners of small gardens. It will throw a furrow of 4 to 6 inches wide and 1 to 3 inches deep, and deeper by going a second time in each furrow. It opers furrows for nanure or seeds and covers them. and opens up rows for all kinds of plant setting. Chicken raisers find it of great advantage in Chicken raisers find it of great
plowing up their scratching vards.

\section{No. 119 Planet Jr. Garden Plow and Cultivator} $\$ 5.00$

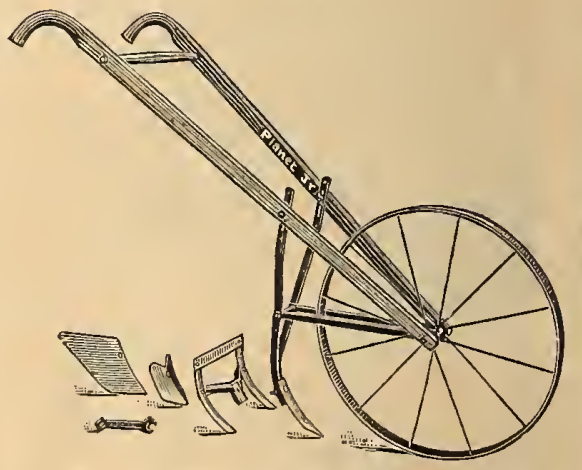

This new member of the "Planet Jr." family will appeal to all those who prefer a high wheel tool for their garden work. Where the soil has uot been so thoroughly and carefully prepared. the high wheel undoubtedly makes an easy running tool. The wheel is 24 inches in diameter with a rim $1 \frac{1}{2}$ inches wide, insuring easy running in the lightest soil.

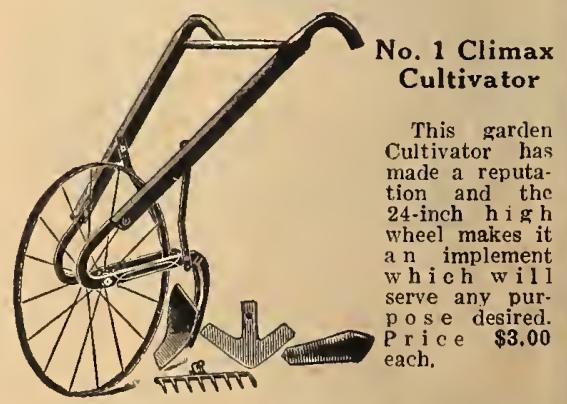

No. 2. Same as No. 1, only handles run straight to axles without overhang. Price $\$ \mathbf{3 , 0 0}$. 


\section{Planet Jr. Garden Tools}

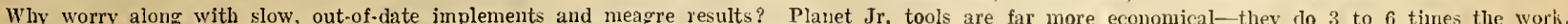

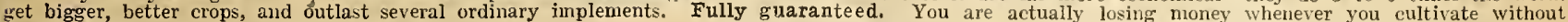
thenr.

No. 4 Planet Jr. Combined Hill and Drill Seeder, Wheel Hoe, Cultivator and Plow

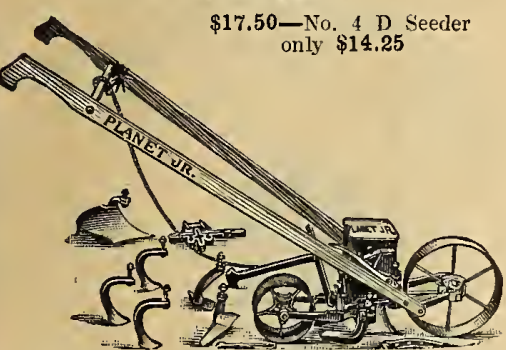

Soon pays for itself in the family garden as well as in the larger acreage. Sows all garden seeds (in drills or in hills). plows, opens furrows and covers them, hoes and cultivates quickly and easily.

No. 17 Planet Jr. Single Wheel Hoe

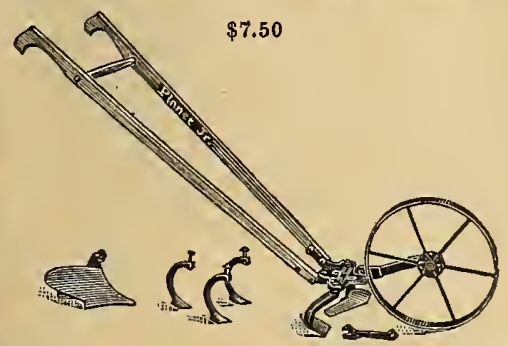

The highest type of Single Wheel Hoe made. light, but stroing, and can be used by man. woman or boy. Will do all the cultivation in your garden in the easiest, quickest and best way.

No. 35 Planet Jr. Seeder Attachment $\$ 5.75$

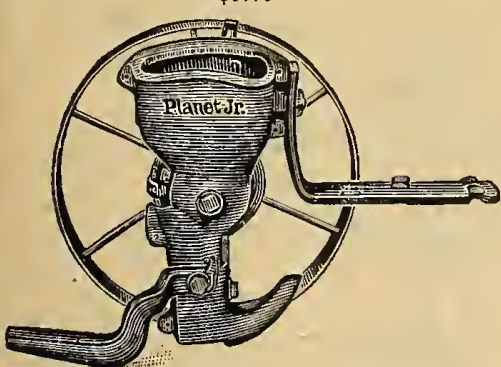

This small seeder can be attached to any Planet Jr. Single or Double Wheel Hoes or Garden Plows, and will be found particularly uitable for the small kitchen garden. It will plant practically all seeds in a straight contiuuous row, at a uniform depth in a fraction of the time required by hand and infinitely better. The hopper holds one pint of seed and it ce!ll be used for planting even a small packet of seed. Also has a bracket to which a handle can be attached and used independently of the wheel hoe.

Everyone having a small kitchen gardes should have this liandy seeder.

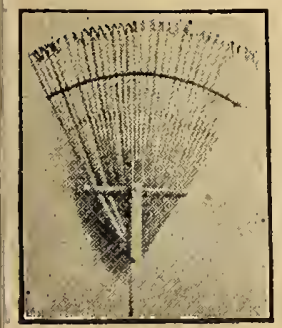

YAMADE

Nature's Wonder Rake

Works like the hu man hand, is flexible. djustable, invincible Saves time, energy and labor. Removes worm and worm casts from Putting Greens. Highly recommended for clear ing lawns, gravel walk and driveways of crab grass, leaves, etc. Price $\$ 1.50$.
No. 25 Planet Jr. Hill and Drill Seeder, Double and Single Wheel Hoe

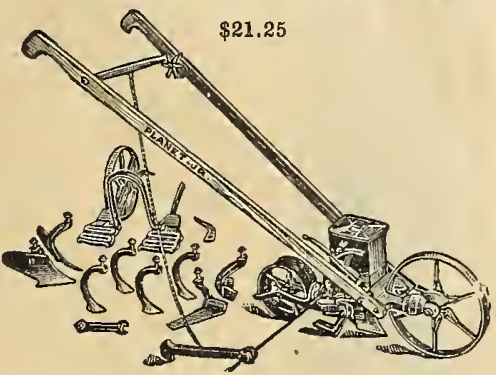

A splendid combination for the family arden, onion grower, or large gardener. It is a nerfect seeder, and combined double and single wheel hoe.

No. 12 Planet Jr. Double and Single

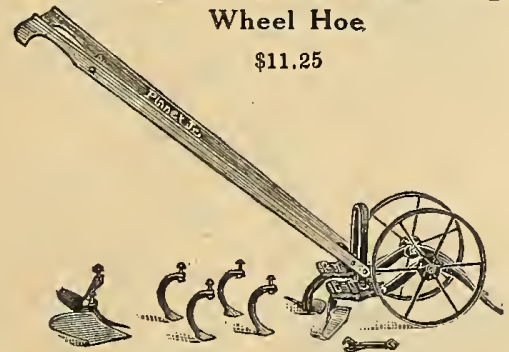

A single and double wheel hoe in one. Stradiles crops till 20 inches bigh, then works between. Has steel frames and 14. inch steel wheels. The greatest hand.cultivating tool in the world.
No. 31 Planet Jr. Combined Drill Seeder and Single Wheel Hoe

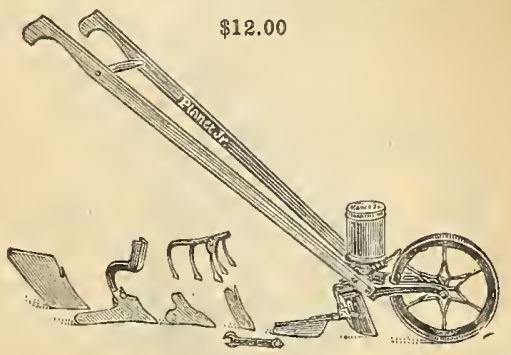

It will sow even a small packet of garden seed with great precision. Quickly changed to splendid wheel hoe. A special machine for the
s?lull gardener. No. 31.D (Seeder only.) $\$ 9.75$.

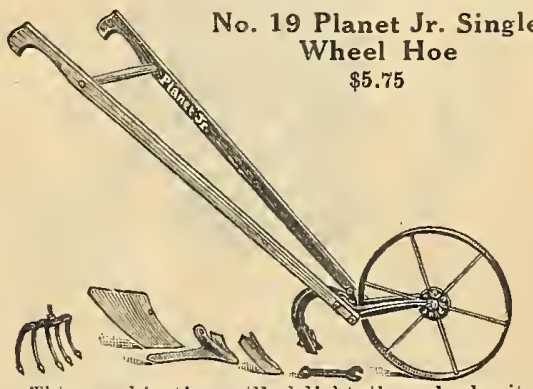

This combination will delight the suburbanite. the growing boy, woman, younger or older, who save them hard work and help nuch to supply the table with fine vegetables.

\section{The "Iron Age" Plows, Cultivators, Hoes,}

Rakes and Drill Seeders Catalog on Request

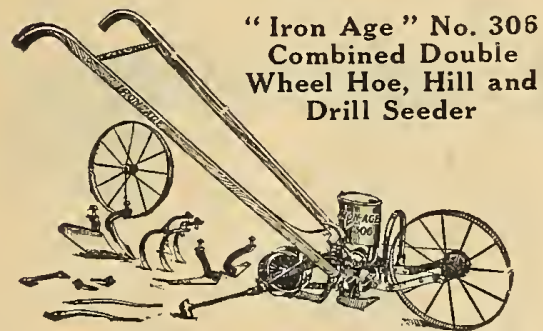

practical tool for the market gardener: will sow all kinds of seed from Celery to Beans witl the greatest regularity. Can be changed instantly trom Irill to bill-dropper, which will drop seed $4,6,8$. 12 or 24 inches apart. Complete with cultivators, boes, plows. Price $\$ 16.75$

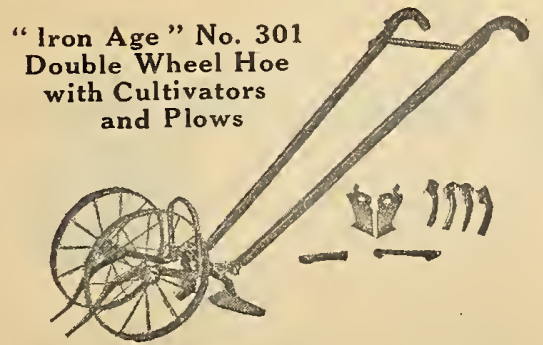

An indispensable machine to the market yardener or anyone cultivating a rarden. This machine complete with all attachments. Price $\$ 8.75$.

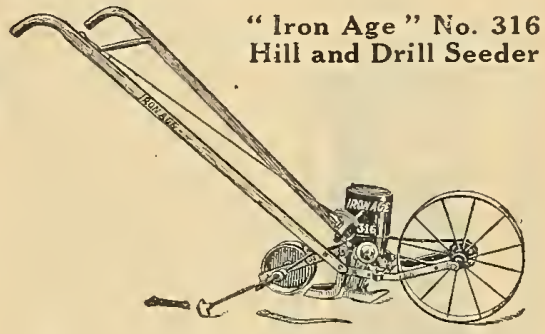

Here is an important tool built especially for those who do not care for a combined tool luut dosire separate machines for cach purpose. Thr No. 316 will sow either in continuous rowy or deeply in hills $4,6,8,12$ or 24 inches apart. The change from hill to drill seeder takes only a moment. We strongly recomnend it to all "1

The No. 19-C "Iron

Age" Wheel Plow

and Cultivator

Consists of plow

rake, scutile hoe, 2 cul.

tivator" teeth.

nlow is use d

round, opening

furrow, and eu!

tivating. The

ing, raking and cultivating the cultive are small : the are small: the

brcaking the soil, which may become hard from rain baking or stamping: the two cultivator teeth for making small furrows, deep cultivating, etc. Price $\$ 4.25$. 
The J. Bolgiano Seed Co., Baltimore, Md.

\section{Do You Buy Satisfaction or Just Sprayers?}

\section{Parcel Post Rates, see Page 2}

"Perfection"

Sprayer

Highest Priced Sprayer in the Worldand Worth It

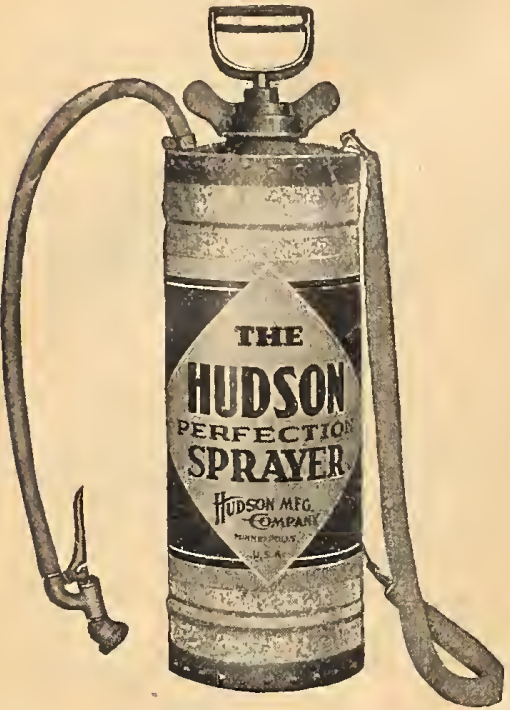

For spraying, disinfecting or whitewashing on plants, bushes, vines etc.

Made of heavier metal, with fewer parts stronger in construction, more powerful in action. Tank $71 / 2$ in. $\times 20$ in., lock seated with 24 rivets. Hose attached with clanps. All furnished with automatic shut-off nozzles. Hade of galvanizes t6.25 Pr solid brass. $\$ 9.50$. Perfection Nozzle, \$6.25. Price, brass, $\$ 9.50$. Perfection Nozzle, tension Rod, $40 \mathrm{c}$.

\section{Hudson Junior Sprayer}

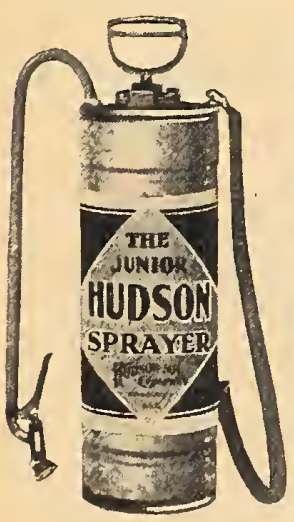

The Hudson Junior pressecl air sprayer. It is designed especially for the Farmer and Gardener, or any one having a few fruit shrubs, rose bushes, or a vegretable garden which requires spraying. It will do the as any larger power outfit, as it has all the necessary features to produce the best reIt is equipped with special spray hose built to withstand high pressures, and our " Perfection " automatic shut sion may be used with it if desired.

Capacity about $2 \frac{1}{2}$ gallons. Shipping weight pounds. No. 140-G. Junior with galvanized tank. Price each, $\$ 4.75$.

Hayes Power Sprayers

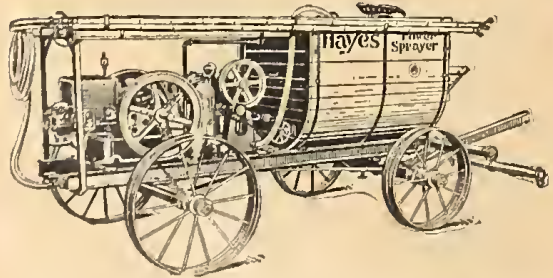

Ideal for th Orchardist. Writc for Special

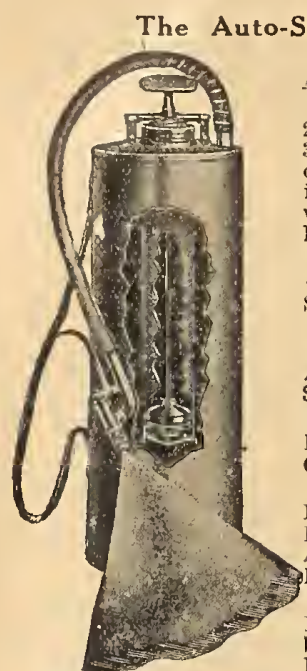

A Self-Operating or utomatic sprayer.

Length of Cylinder, 21 in.; weighrt, loaded 39 pounds; diameter of cylindler, 7 in.: caicleity, about 4 gallons Extension pipes extra.

Auto.Spray No, 1 C Galvanized Reservoi Stop Cock. Price $\$ 6.00$ Auto-Spray No. 1D. Galvanized Reservoir. $\$ 6,50$.

Auto-Spray No. 1A. Brass Reservoir. Stop Cock. Price $\$ 8.75$.

Auto-Spray No. 1B.

Brass Reservoir. Auto-

Pop Nozzle. Price $\$ 9.25$. Auto-Pop Nozzle, with Extension Pipe, $2 \mathrm{ft}$. Brass, 50c. Brass Elbow Extension, $35 \mathrm{c}$. ment solid brass 1 nozzle $\$ 1.50$, Brass Strainer, $\$ 1,20$. Mailing weight, 17 lbs.

\section{"Iron Age" Horizontal Barrel} Sprayers

No. 190. This Sprayer will not tip over on hillsides, where many orchards are set. Note how barrel and pump are mounted and the barrel held in place by adjustable hoops. It holds 50 gallons. Can be used in any wagon, cart or sled. One horse can pull it. No corrosion, solution touches brass parts onlv, all parts easy to get at, and decent to handle The pump is single-acting-always reliable and Price $\$ 30.00$

Little Wonder Special Hand Spray

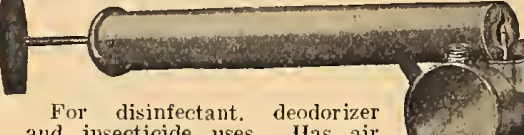
and insecticide uses. Ilas air barrel large enough to throw as much spray as any hand sprayer. as liquid tube carefully located and protected. Has a drip cup with finished edges, Ilas lock seams and tank tested by 20-pound air pressure. Capacity $1 \mathrm{Pt}$. Mailing weight, $3 \mathrm{lbs}$. Price 40c.

No. 4512 Misty Sprayer The best quart size Splay'er made, and one that is a unithe very bost. Price $45 \mathrm{c}$.

Auto Compressed Air Sprayer No. 25

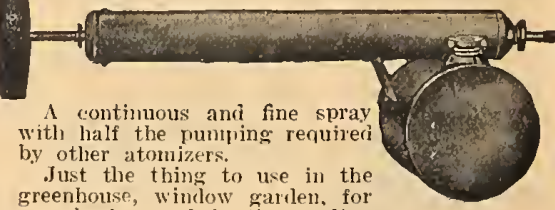
greenhouse, window garden, for rose buslies and in the poultry insecticicles and disinfectants. Matle througliout of stout material. Copper syphon tube, bronze ball valve plunger, rod 1 -inch copper' plated steel. The solution does not come in contact with the pump cylinder. The spray may be adjusted by a slioht turn of The spray may be adjusted by a slight turn of nozzle cap. Tin Pump and brass tank. Price

\author{
Hayes Hand Barrel Spray Pump \\ without Barrel
}

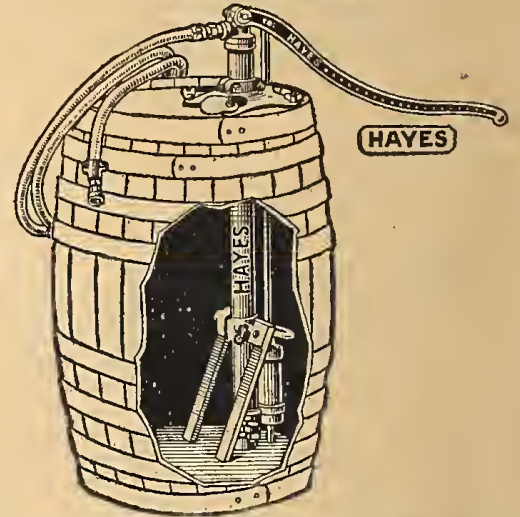

This punip represents all that is best in hand suray pump construction. Designed with powerul leverage it is easy working and capable of pumping All working parts including cylinder valves, valve seats, apriug expander and struine ralves, valve seats, spring expander and strainer

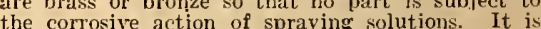
built for continuous service, year after year, with the minimun of attention and repair.

It has a universal plate which allows it to be mounted on eitler the closed end or side if barrel

Ni. Description Whipping

1821 Pump No. 182, 2-inch

cylinder, $2 \frac{1}{1}$-ineh air 38 bs, $\$ 13,50$

182 chamber $\ldots \ldots \ldots \ldots 38$ Lbs. $\quad \$ 13.50$

Equipment on 182i. $12 \mathrm{i} / 2 \mathrm{ft}$. $1 / 2$-inch 5-ply spray hose, couplings, clamps and Hayes Dise Nozzle

With barrel add $\$ 7.25$, with 8 -font extension add $80 \mathrm{c}$, with pressure guage add $\$ 4.25$.

Prices on larger size Hayes Barrel and Power Sprayers on request.

Hayes Hand Bucket Sprayer, No. 231

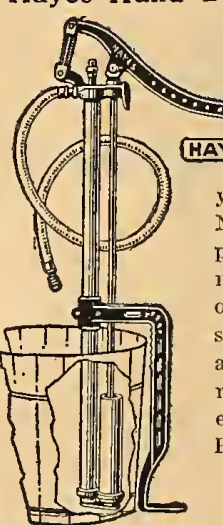

Hayes Hand Bucket Sprayer No, 211

Indispensable for furm, lonte and garden use. Sprays trees, ardets, fower...mashes window, (1) ol' "hes, buggies-disinfects, whitew'shes, All bronze workin parts, This pump is identical with 231, only all operation is on the down stroke which temd to steady and hold the pum down. The air chamber is extr. lurce, giving a continuous spray. large, ging a continuous spray A large capacity pumip and
popular type. Price $\$ 3,50$.

you grow any. consists of pump com. mp of the bucket type. ce $\$ 5.75$

Shipping weight, 9 lbs.

\section{Auto Spray No. 26}

so designed that excessive pressure generated on the down stroke alfows it to generate a c'ontinuous mist-like spray so that spraying can be done more rapidly with less exertion. Âll brass, price each, $\$ 1.25$.

Mailing weight, 3 lbs 


\section{T}

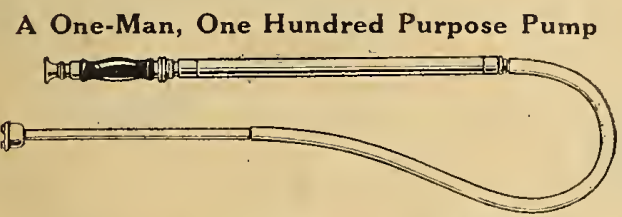

As Supplied for Spraying from Bucket

The Armstrong Standard Spray Pmmp is simply a very carefully designed and accurately marle "squirt-giu " pro vided with a proper outfit of nozzles. Its simplicity largely accounts for its unusual power.

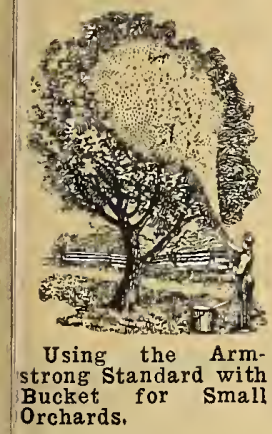

Its plan of operation is so simple and so different from other types of spraying apparatus. This permits the use of the hose on the suction end instead of on the discharge end. That is why it is possible to use the Armstrong Standarcl either with a bucket, barrel or knapsack, depending upon the number of trees or the kind of spraying to be done. The work of spraying is always done from the ground. No ladder, long ax tension or raised platform is needed. A large tree can be completely sprayed with ten or a dozen strokes of the pump.

\section{Armstrong Standard Pump with Knapsack and Short Extension Attachments}

For spraying young or scattered trees or truck crops such as potatoes, tobacco and the like, the knapsack and short curverl extension are used with the pump. With this equipment, the Armstrong Standard will spray potatoes one row at a time at the rate of an acre an hour or better.

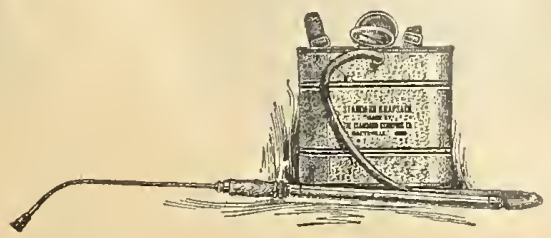

$B_{y}$ different alrumgements of the several nozzles regularly supplied, sprays of varyng fineness-from a mist to a straight itream that earries sixty feet-are produced.

The Armstrong Standard spray Pump is ideal for spraying liquid inmecticides of all kinds, for whitewashing poultry houses and cattle barns, for spraying disinfectants in building. or on animals and poultry, for fire protection, for veterinary use, for washing windows, for washing antos-there is almosi a daily use for the Armstrong Standard about the home, farm, garden and orchard.

The Armstrong Standard is made entirely of brass. No leather packings are lised and no metal subject to rust or decay Every Armstrong standarl is warranted for five years. This nakes it the most economical spraying device on the market.

\section{PRICE LIST:}

The Armstrong Standard Punp, with short hose and all three spraying nozzles (for bucket use) ....... each $\$ 4.50$ Knapsack attachment, galvanized iron, five gallons capacity, ready for attaching to puinp..........each

3.25 ('urved Extension, 19 inches long............each .75

Veterinary nozales, hard rubber, 6 in. long........ench

lixtra halfinch lose, per foot............. each
No. 1721 F. Hayes Wheelbarrow Sprayer

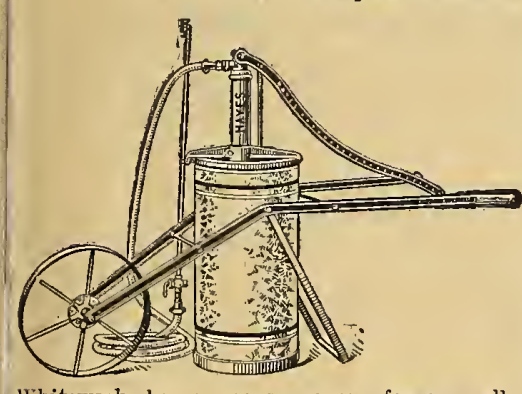

This handy portable outfit is especially designed for small orclards, truck gar. dens. greenhouses. estates. dens, greenhouses, estates public parks and general
farm. home and garden farm. home and garden
work. Goes anvwliere like a wheelbarrow, through nar row openings and between narrow row crops.

Most powerful and easiest working hand pump made. 1.50 to $2.50 \mathrm{lbs}$. pressure witl
little effort. Just look at the number of things you can do. Spray orchard irees, bushes, vines. Spray potatoes, garden crops. Whitewash barns, pens, coops, fences, cellars, trees. Disinfect stables,
heds, yards and poultry house. Its many uses plant it well at the top of profitable farm equipment.

\section{SPECIFICATIONS}

Cart. All steel, strongly cross braced. Steel wheel 16-inch, 2-inch tire. Folding brace steadies pump.

Tank. 121/2 gals. heavy galvanized steel banded.

Pump. Cylinder 2-incli, 21/4-inch air chamber.

Equipment. 121/2-foot section Hayes 5-ply $1 / 2$-inch sprav hows, with fittings ; 8-foot steel extension with leakless stop cock, one Hayes Vermorel Nozzle, Shipping weight, $75 \frac{1 / 2}{2} \mathrm{lbs}$. Price $\$ 22.00$.

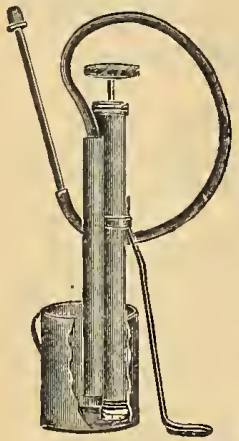

\section{No. 28 Whitewash Sprayer and Force Pump}

No. 28. Whitewash Sprayer and Force Pump ts designed for uxe in pail or bucket, and will fit any size. The pump is made of galvanized iron. The top and hottom are made of brass. It is regularly equipped with 3 feet of best hose. 1-foot brass extension rod and a brass nozzle, which will give two different sizes of sprays. It has ball valves and steel foot rest. The pump is provided with an over flow, which carries all the liquid which might get above the plunger back into the pail. The plunger is easily removed and easy to operate, due to double action. Made with large air chamber. The pressure being held in the air chamber and on the nozzle euables the operator to throw a continuous spray, which is not affected by the movement of the plunger.

Huch more work can be done with this pump in a day than can be done with a brusl. The force with which the material is applied causes it to penetrate the small crevices, making a preffect job. Price $\$ 2.75$.

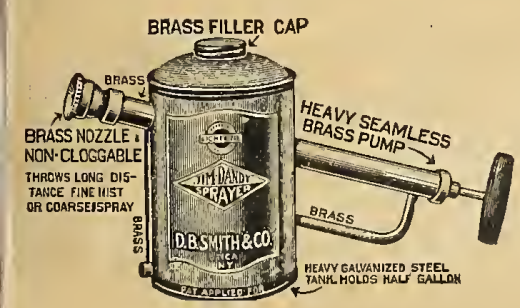

\section{J I M - D A N DY SPRA YER}

Something Novel-Something New

Adapted for spraying Gauden and Farm Vegetables of every description, Fruit Trees, etc. Will spray Disinfectants in Poultry Houses and Stables; Fly spray on cattle; Whitewash, Carbola, Cold Water Paints, etc. To

To

The reservoir is made of heavy galvanized iron, capacity two quarts; all other parts are entirely of brass, including ball check valves and nozzle. The Golden spray Nozzle furnished is adjustable for large fine mist spray or long distance coarse spray, as desired.

The JIM-DANDY is a sturdy, well made sprayer, of the best material and workmanship-made for hard work and long service. "Quiek as Lightning",

When empty it weighs 2 pounds, and when loaded ready for work the weiglit is 6 pounds. 
Cahoon's Broadcast Seeder

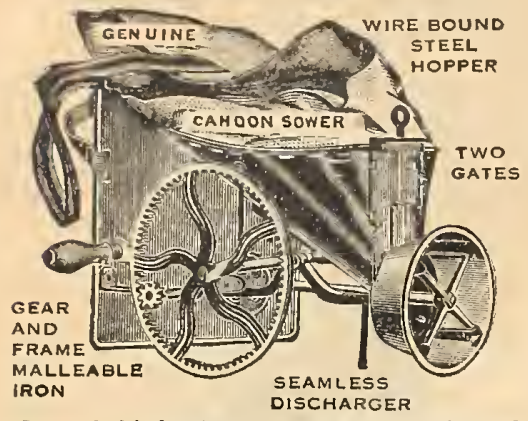

Sows all kinds of elover. grass and grain seeds. and throws heary seeds; it will throw forty feet iron frame, steel lopper and gate, brass discharger. Price $\$ 4.00$.

The "Little Giant" Seed Sower

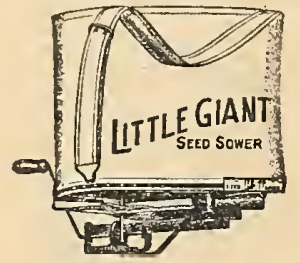

The Little (riant (geared), known as No. 3. needs no introduction. It has been sold for more than twenty five years. It is well known and has a good reputation.

Construction: This sower has a steel frame with heavy bearings and strong cog wheels. Has a rigid distributing wheel. with steel spindle and ferrule. Is equipped with a stirrer to keep the seed from clogging. a body shield and a conveniently placed carrying handle. Is made from good materials and is nicely finished. Sack holds
one-half bushel. Will sow all linds of farn seeds, lawn grass, etc. Shipping weight, $4 \mathrm{lbc}$. Price $\$ 1.75$,
The "Cyclone" Seed Sower

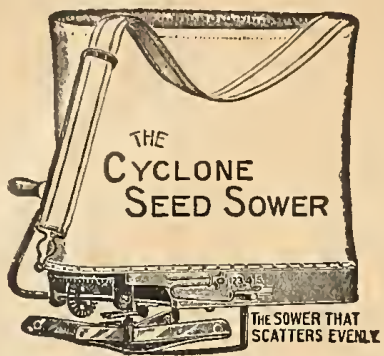

Has won for itself first place among all kinds of Hand Seed Sowers. It has proven in thousands of instances that it is the most accurate, most convenient to operate and most cconomical machine for sowing Clover, Timoths, Ilfalfa, and all other farm seeds that can be sown broadcast. It runs easily and will distribute any desired quantity of seed per acre.

The "Cyclonc" Seed sower is constructed on correct up-to-date principles. Price $\$ 1.75$.

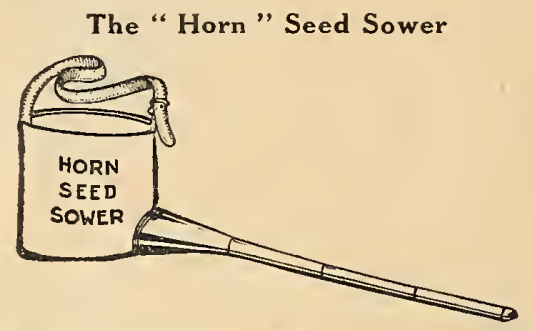

A light, accurate Seeder that will broadeast all varieties of clean farm seed, lawn grass, etc. It is made to telescope in three sections and has a feed gauge to regulate the flow of different kinds of seed. The sack is made from a good grade of duck. Shipping weight, $1 \mathrm{lb}$. Price $75 \mathrm{c}$ each.

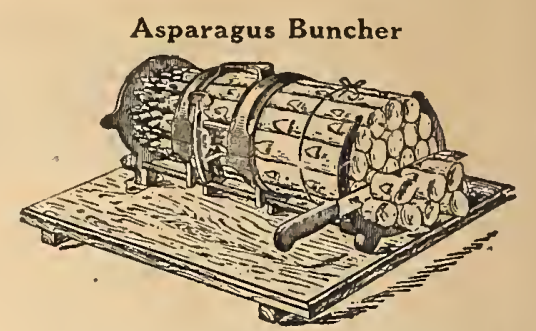

Price $\ldots \ldots \ldots \ldots \ldots \ldots$

$\$ 3.00$

Iailing weight,

Asparagus Knives Made of Solid Steel Nu. 260. Concave Straight Edge........35c No 399. Concave Fish Tail............40c Yailing weight, $1 \mathrm{lb}$.

\section{The Feeny Model B Duster-The Best Duster Made}

The Model B is always ready to pick up and use-so clean that you may do your dusting with your good clothes on. Your Carden, Flowers, Fruit, Bushes, etc., will not suffer from insect pests if you have a Hodel B Duster handy-it does not have to be cleaned after use. You simply use it, lay it aside and pick it up all ready for use the next time. It is so easy, clean and conrenient that it is really fascinating to use the Model B Duster. Price 90c.

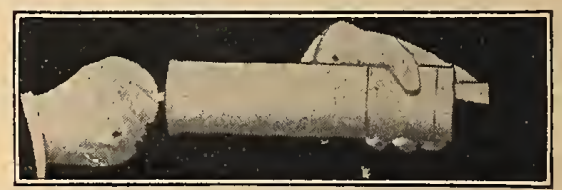

Here It Is

\section{Orchard Brand Insecticides}

\section{"Orchard Brand" Lime Sulphur Solution \\ For Use in the Dormant Period}

This naterial combines the great fungicidal properties of Sulphur with the scale remedy and is especially recommended for Peach and Plum trees, which need the combined treatment in the Fall and Spring. In spraying this material care should be exercised to aroil getting it in the eves, and gloves should protect the hands.

Add 10 parts cold water to one part of Lime Sulphur solution and stir thoroughly: Apply with spray pump.

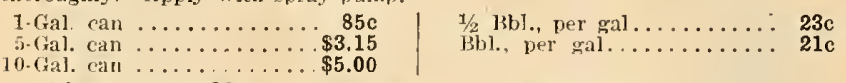

Bbls. extra at $\$ 2.00$ each and returnable at same mice F. O. B. shippers station before August 1st. 1993, if returned in good condition.

\section{Orchard Brand Bordeaux Mixture Powder}

Recommended for liust. Scab and all kinds of Rot and other funcous diseases. This is a distinctive product, possessing a peculiarly fine phrsical structure, manufactured according to a special process with a view to insuring good adhesive properties. It contains not less than 33.49 per cent mpler hydroxide, equivalent to 21.82 ver cent metallic conper. As it is in a Iry form, it is preferable to the paste because it is more stable, easier to haudle. may be more accurately weighed out, is less wasteful and conse. quently is morc economical in general use. Directions: $3 \frac{1}{2}$ to 6 lbs. to 50 gals. of wuter according to strength desired.

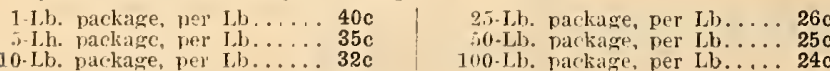

\section{Dry Powder Arsenate of Lead}

One pound of Dry Arscrate of Lead equals three pounds of any paste Arsenate of Lead. It mixes with water more readily th:m any other Arenate of Lead. Stays in suspension better. colers more thoroughly and sticks on the foljage longer; no lumps, no sediment, no waste; simpler, cleaner and better in every particular. Easily prepared fo the spray tank.

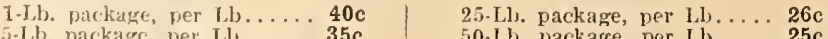

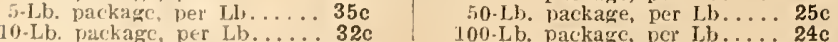

\section{Orchard Brand Bordeaux Arsenate Lead Powder}

A combined Fungicide and Insecticide. This is a combination of our Bordeaux mixture and arsenate of lead in dry form. It contains not les. than 24.1 per cent copper hydroxide, equivalent to 15.7 per cent metallic copper and not less than 30 per cent lead arsenate. It is preferable to the paste form because it is more stable, easier to handle, may be more easily weighed out and is generally more convenient and economical to handle. Directions: 5 to $81 / \mathrm{lbs}$. to 50 gals. of water according to strength desired. 1.Lb, package, per Lb. . . $42 \mathrm{c}$ 5-Lb. package, per Lb..... 39c 10-Lb. packige, per Lb..... 37c

25. Lb. parkage, per Lh.... 30 50 -Lb. package, per Lb..... $28 \mathrm{c}$ 100-Lb. package, per Lb..... 27c

\section{Arsenate of Zinc, Powder}

This is a dry powcler containing not less than 30 per cent metallic arsenic, equivalent to 40 per cent arsenious oxide. It is convenient to handle, economical to use and equally as effective when used in dry or liquid applications. Owing to its quick killing properties, adhesiveness and freedom from injurious effects, it is recognized as the best material for killing potato bugs, asparagus beetle and sone other insect pests on truck crops.

1. L. wackage, per Lb..... $42 \mathrm{c}$ 10. Lb. packagc, per Lb...... 37c
2.5. L. b. package, per Lh.... 30 c 50-Lb. package, per $\mathrm{Lb} \ldots \ldots 28 \mathrm{c}$ 100. Lb, package, per Lh..... 27c 


\section{Orchard Brand Insecticides-Continued \\ ALL PRICES SUBJECT TO CHANGE WITHOUT NOTICE}

\section{B. T. S.}

This is a dry barium sulphur compound in a granular crystalline form, readily soluble in cold water.

It can be used for dormant spraying of all fruit trees and in the growing period may be used on apple trees the same as lime-sulphur solution. Like the solution it should not be used in the growing period on peach or other stone fruits.

A $100-\mathrm{Lb}$. keg of B. T. S. is equivalent to a 50 -gallon barrel of lime-sulphur solution weighing about $600 \mathrm{lbs}$.

The advantage in having a dry product like B. T. S., which reduces the bulk and weight of material to be handled and dispenses with leakage, will be appreciated by all fruit growers. Price: 1 Lb. 24c. 5 Lbs. 21c Lb. 10 Lbs. 19c Lb. 25 Lbs. $14 \mathrm{c}$ Lb. 50 Lbs. 12c Lb. 100 Libs. 11c Lb.

\section{Commercial Flour Sulphur $99 \frac{1}{2}$ Per Cent Pure}

Price: 1 Lb. 5c. 25 Lbs. 4c Lb. $150-\mathrm{Lb}$ bag $\$ 4.00$. 260-Lb. Bbl, at $\$ 3.15$ per 100 Lbs.

\section{Arsenate of Calcium, Powder}

This is a fine, white powder similar to powdered arsenate of lead. The arsenic is combined with lime instead of lead, thus making a cheaper product. It contains nearly one-third more arsenic oxide than that contained in powdered arsenate of lead. It is recommended for use as a substitute for arsenate of lead on shade trees, grape vines, and the more resistant varieties of apples. It is also valuable for general spraying on vegetables. It is specially recommended for dusting cotton. It should not be used on peaches or other stone fruits.

1 Lb. 33c. 5 Lbs. $30 \mathrm{c} \mathrm{Lb.} 10 \mathrm{Lbs}$. 28c Lb. $25 \mathrm{Lbs}$. 20c Lb. 50 Lbs. 19c Lb. 100 Lbs. 18 c Lb.

\section{Blue Stone}

Crystal Copper Sulphate 99 Per Cent Pure

Price: 1 Lb. 12c. 25 Lbs. 11c Lb. 50 Lbs. 10c Lb.

100

\section{Pure Para-Dichlorobenzene for Peach Borer}

One of the most troublesome and destructive pests with which the peach grower must annually contend is the peach borer. This insect is found generally throughout the Uniterl States wherever peaches are grown, east of the Rocky Mountains.

Unless they are destroyed or removed they will frequently so completely girdle the tree as to destroy the flow of sap and thus cause the tree to die through lack of nourishment.

For the control of the borer PARA-DICHLOROBENZENE has proved to be safe and most effective.

\section{Dosage}

On peach trees six years old and over, use from 1 to $1 \frac{1 / 2}{2}$ ounces per tree. On peach trees from four to five years old, use $1 / 2$ to $3 / 4$ ounces per tree. It is not advisable to treat trees under

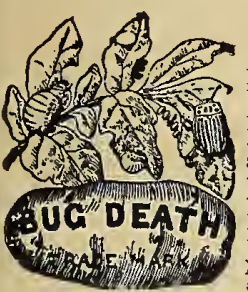

Bug Death

Bug Death kills Potato, Squash and Cucumber Bug Death kills Potato, Squash and Cucums and Bugs ; Currant and Tomato Worms, and all Bugs and Worms that chew the leaves of the plants; nonpoisonous. Directions for applying dry: For Potato and other vines which require a top application, apply dry with a shaker or sifter, or powder spray at the rate of 15 to 25 pounds per acre to an application, according to size and condition of the vines. Directions for using in water: Add 15 to 20 pounds to 80 gallons of water and mix thoroughly. 1-Lb. package 15c. 3-Lb. package 38c. 5-Lb. package

Slug Shot (Hammond's)

A light, non-poisonous composite fine powder for killing Potato Bugs, Currant and Cabbage Worms, Chicken Lice, Sow Bugs, Green and Black Fly, Beetles and Caterpillars. Not injurious or dangerous to persons and Caterpillars. Not njurious or dangerous to persons or animals. Easily distributed by duster bellows, or in
water by spraying. Ten to 40 pounds sufficient for an acre. 1-Lb. package 15c, 5-Lb. package $45 \mathrm{c}$.

\section{Paris Green}

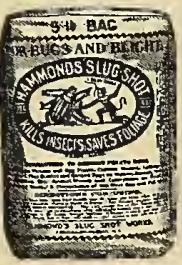

The chief merit of this article is the destruction of the Potato Bug. It may be used in liquid form, 1 pound in 50 gallons of water, or with Land Plaster at the rate of 1 pounds Paris Green to 100 pounds Land Plaster.

owing to the uncertainty of the market we are unable to quote ositive prices, but will furnish prices on application.

\section{Lemon Oil Company's "Standard" Insecticide}

Perfectly safe and harmless to the tenderest foliage and roots. It effectually destroys Mealy Bugs by syringing or dipping. It also destroy Scales, Thrip, Red Spider, Black and Green Fly, Caterpillar, American Blight, Mildew, etc. Dilute with $50 \mathrm{p}$
Qt. $\$ 1.00$. 1/2 Gal. $\$ 1.75$, Gal. $\$ 3.00$.

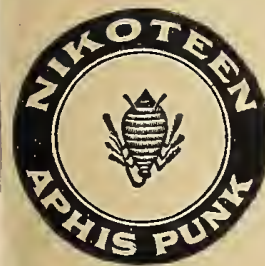

\section{Nikoteen}

Roses, flowers, shrubs and plants of every kind when sprayed with a prepared bath of NIKOTEEN will brighten at once. The beneficial effect can hardly be exaggerated. If the NIKo TEEN is used at all carefully, IF PROPERLY DILUTED, most of the life-sucking plant lice are killed; spraying should be done early in the year and while the insects and the plants are young. Delay means a multiple of the original few and a harder fight ahead. four years of age with para-dichlorobenzene. After four or five weeks, it is desirable to scrape away the mounds, removing any remaining crystals away from the tree.

\section{Time of Application}

Where only one treatment is given the application of paradichlorobenzene should be made from September 1st to October 10th; the earlier date applying in the northern latitudes and the later date in the southern sections of the country.

Some growers prefer to make two applications, in which event the first should be made during the month of June.

Para-dichlorobenzene should not be used on apple trees.

1. Lb. 34c. 5 Lbs. 31c Lb. 10 Lbs. 29c Lb. 25 Lbs. $27 \mathrm{c} \mathrm{Lb.}$ $50 \mathrm{Lbs} .26 \mathrm{c} \mathrm{Lb} .100 \mathrm{Lbs}$. 25c Lb. $150-\mathrm{Lb}$. Keg 24c Lb.

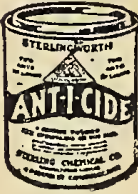

\section{Ant-i-cide}

For Use Against Ants in Lawns

They are a persistent pest. It is impossible to harbor them and have a rood Jawn. Either cive up the lawn or the them and have a good lawn. Either give up the lawn or the
ants. If you prefer the lawn, try Ant-i-cide. It is a powder ants. If you prefer the lawn, try Ant-i-cide. It is a powder
to be sprinkled on the ground. One pound covers about 200 square feet. Guaranteed to give satisfaction or money refunded. Price: 1-Lb. box $25 \mathrm{c}$.

\section{Aphis Punk, For Fumigating}

Specially prepared for Greenhouses and Conservatories. It vaporizes the Nicotine economically and evenly, Nothing keeps a house free from Aphis, Thrip and other plant parasites so thoroughly and cheaply.

Price: 1 doz. sheets in airtight package, $80 \mathrm{c}$.

\section{Powdered Tobacco}

For Green and Black Aphis, Fleas, Beetles, etc. Splendid fertilizer and preventative for insects in the oround and fertilizer and preventative for insects in the ground and duster or bellows. For Worms or Grubs in the soil, apply duster or bellows. For Worms or Grubs in the soll, apply
liberally to the surface and rake in or strew thickly in the liberally to the surface and rake in
drills before planting. Per Lb. $20 \mathrm{c}$.

\section{Tobacco Stems}

Indispensable for fumigating greenhouses and conservatories for the destruction of Green and Black Aphis and other insects. Dampen thoroughly a few hours before using, place about a half pound over a handful of shavings in a fumi-
gator and light. Also for covering lawns during Winter. It not only acts as a protector, but imparts large quantities

\section{Powdered White Hellebore}

Less poisonous than Paris Green and safer to use when fruit or vegetables are nearly ripe. $1 / 4 \mathrm{Lb}$. 12c. $1 / 2 \mathrm{Lb}$. 20c. $1 \mathrm{Lb} .35 \mathrm{c}$.

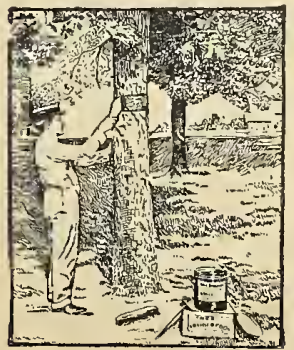

Tree Tanglefoot

For protecting trees against climbing insect pests in a simple, economical and effective way. Tree Tanglefoot, a sticky substance applied directly to the bark of the tree. One application remains sticky on the trees three months fully exposed to weather. Easily applied with small wooden paddle. One pound will spread 8 feet long by 5 inches wide, 1-16 inch thick. 1-Lb. can 45c. 5-Lb. can $\$ 2.00,10-\mathrm{Lb}$. can $\$ 3.85$. 


\section{"SAFETY FIRST"}

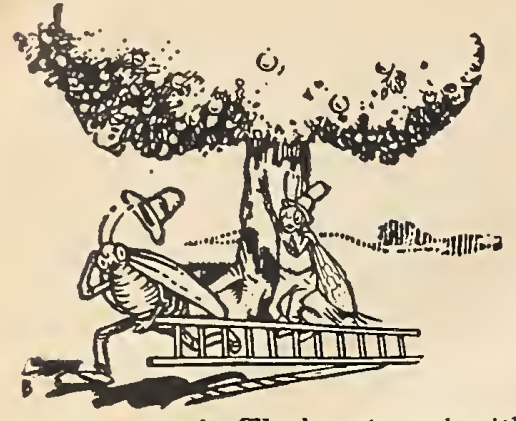

"Il's no usel They're sprayed with Pyrox."

You haven't

Pyrox is first and last for th

Pyrox is all ready to use by sinply mixing with cold water. It is
can be sprayed as fine as fog. It goes farther ond does better work.
It sticks like paint. It stays on for weeks. Respraying is necessa ben insects and disease do their deadliest work

Prices: 1 Lb. $45 \mathrm{c}, 5$ Lbs. $\$ 1.65,10$ Lbs. $\$ 3.00,25$ Lbs. $\$ 6.00,50$ Lbs. $\$ 11.00,100$ Lbs. $\$ 18.50 .300$ Lbs. $\$ 51.00$.

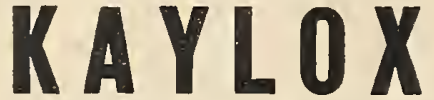

Insecticide and Fungicide

(Two Sprayings at One Operation)

Can Be Used for Dusting as Well as Spraying

KAYLOX is a Powder Not a Paste

One Pound of Powder Equals Two Pounds of Paste Apples, for Potato Beetles, most Caterpillars and naany Leaf-eating Insects Cauliflower and many other plants.

A preventive of many blights and certain fungous diseases.

Used as a general spray-1 pound to 10 gallons or 5 pounds to 50

For Potatoes, Bitter Rot and Blotch on Apple.

gallons or $6 \%$ to 7 pounds to 50 gallons of water.

Not to be used for late Spring or early Summer application on Apples $1 \mathrm{Lb} .55 \mathrm{c}$. $5 \mathrm{Lb}$.
100 Lbs. $\$ 35.00$.

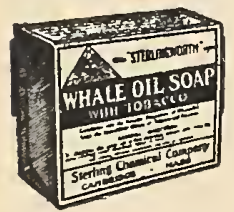

Whale Oil and Tobacco Soap

Makes an elegant wash for trees and plants where insect and eggs affect the bark. For plant lice, oyster shell and San Jose Scale. For April or May spraying for scale or when buds are spray wben in bloom. $1 \mathrm{Lb} .30 \mathrm{c}$.

\section{Cutworm Killer}

coarse powder for sprinkling in proximity to the regetation be protected. $1 \mathrm{Lb}$. box $25 \mathrm{c}$.

Why Raise Roses to Feed Bugs

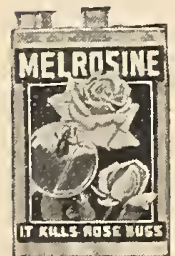

Melrosine-the only remedy-endorsed by leading authorities. The GENERAL CONTACT INSECTICIDE that KILLS ROSEBUGS and other insects. Used with any good spray-punp, diluted with from 20 to 25 parts of water. spray-punp, diluted with from 20 to 25 parts of water. useri according to direction on can. Gal. $\$ 6.00$. 1/2 Gal. $\$ s ́ .25$. Qt. $\$ 1.75$. Pt. $\$ 1.00$. Trial Size, 50c. By inail or express at customer's expense. Descriptive booklet on Melrosine-It Kills Rosebugs
KAYLOX is adapted for spraying for late broods of Codling Moth on on fruits and other trees, Tomatoes, Grapes, Currents, Celery, Cabbage, gallons of water.

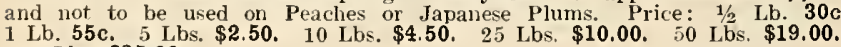

\section{"Black Leaf 40 "}

Black Leaf 40 " is Truly a "Contact" Insecticide

The "sucking" insects feed by inserting their sharp, slender beaks into the interior of the leaf, blossoms, etc. They cannot eat plant tissue, and, therefore, cannot eat poisons, hence nust be destroyed with a preparation which kills by coming in contact with their bodies-in other words, by a " contact" insecticide. The most conmon sucking insects, with soft bodies, are the aphids (plant lice), thrips and leaf hoppers. They may be effectively are the aphids (plant lice), thrips and leaf hoppers. They may be effectively sulphate guaranteed to contain 40 per cent of nicotine by weight. $10 z .25 \mathrm{c}$ $1 / 2$ Lb. $\$ 1.25$. 2 Lbs. $\$ 3.75,10$ Lbs. $\$ 15.50$.

\section{Target Brand Weed Killer}

Destroys Weeds, Grass, Pnison Ivy, Sumac and all kinds of undesirable veretation. An application of this will keep drives, walks and tennis court absolutely free from regetable growths. Target Brand Weed $\mathrm{K}$ iller is liquid which is to be dituted in water. It can be applied with an ordinary sprinkler or watering pot. Mix one part to 49 parts of water. 1-Qt. can 70c. 1 Gal. $\$ 1.75$. 5 Gals. $\$ 7,00$. Bbl., 50 gals., $\$ 47,50$.

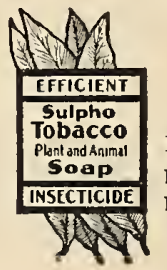

\section{Sulpho Tobacco Soap}

An excellent article for the person with a few plants. Especially good for destroying scale on palms and other plants. Soluble in warm water. Per 3-oz. package 7c; postage 2c. 15c per 8-oz. package; postage $4 \mathrm{c}$.

\section{Dethol}

Insecticide-Moth Preventive-Disinfectant-Deodorant

Dethol is an efficient insecticide that quickly kills and rids prenises of such pests as flies, mosquitoes, roaches, bed bugs, ants and water bugs. Spray Dethol around windors and keep out flies and mosquitoes. Wben bothered with roaches, ants and other bugs, Dethol sprayed on infested places will quickly draw out these pests and a few more applications will kill them instantly. Spray Dethol thoroughly and frequently everywhere in the bed room and on the bed if troubled with bed bugs. As a moth preventive, Dethol can be freely sprayed on clothing, rugs, draperies, etc. as it will not stain even the most delicate fabrics

spray it on refuse cans, in outhouses and in damp cellars where foul odors are likely to arise, and it will quickly neutralize and do away with all such offensive odors.

Do not spray Dethol on or near growing plants. Price: Pt. 50c. Qt. 90c. Gal. \$2.75.

\section{So-Bos-So Kilfy}

Keeps the Flies Away from the Cow Increases Milk Production Over 20 Per Cent

Don't let your cows suffer from the torture when their energy is used to switch the from their backs they cannot give the maxi-
anount of milk. It makes them irritated run down.
and KILFLY the cow twice a day with SO-BOS-So while milking or while in the pasture. Not injur-
ious to skin. Will not gum the hair. Positive Is the most effective preventive againe

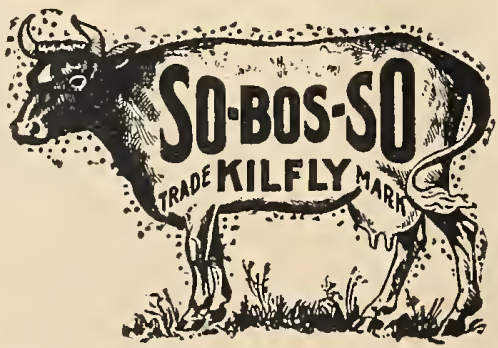

MANY USES FOR SO-BOS-SO KILFLY

1. Spraying cows, horses and other stock in flytime.

2. Used in pig pens, poultry houses, etcgets rid of lice and vermin.

3. A thorough disinfectant.

Economical because when thoroughly sprayed into crevices it lasts several months.

4. Sprayed in the barn and yard, it kills breeding flies and mosquito larvae. Kills the stench of rotting vegetable matter and manure. 


\section{"Square-Deal " Ornamental Gates}

Our "Square-Deal " Ornamental Gates are made to match our "Square-Deal " Ornamental Lawn Fence. The frames are made of best grade 11/8-inch o. D. tubular steel. All "Square-Deal" Ornamental Gates are equipped with scroll top and spring latch. The fabric in all "Square-Deal" Ornamental Gates are made especially to fit the frame of the gate. There are no sharp ends projecting, and each filler is a complete piece of fabrie in itself.

Price of Ornamental walk Gates

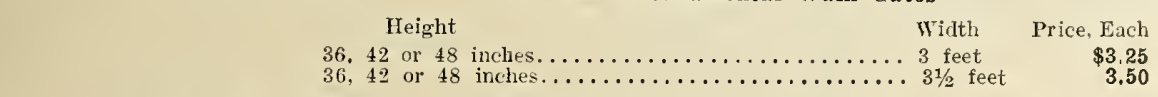

\section{"Square-Deal " Ornamental Lawn Fence Style 600 Fabric \\ Specifications}

Upright or picket wires are No. 9 heavily galvanized, spaced $27 \%$ inches apart at top, with an additional No. 9 galvanized picket interworen, so as to give an extra close spacing of $13 / 8$ inches at the bottom.

Cabled line wires are No. 121/2, spaced 6 inches apart, except the two top cables, which are spaced $23 \%$ inches apart.
Height of fabric........ 36 inches' 42 inches 48 inches
$\begin{array}{lccc}\text { Number of cables............ } & 7 & 8 & 9 \\ \text { Price per lineal foot....... } & 13 \mathrm{c} & 14 \mathrm{c} & 16 \mathrm{c}\end{array}$

Price per lineal foot........ 13c $14 \mathrm{c}$.
Put up in 20-rod rolls. Full rolls 10 per cent discount.
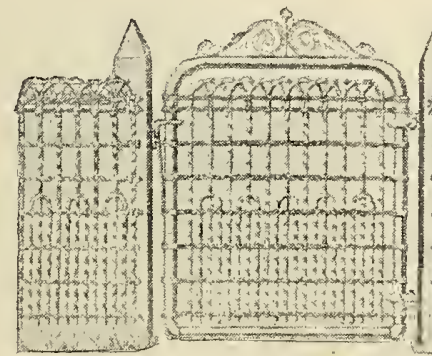

The extra pickets at bottom of fabric engage the lower eables as follows: 36 -inch and 42-inch, four eables; 48 -inch, five cables.

\section{National Poultry and Garden Fence}

Stay Wire Six Inches Apart

Furnished in Ten Rod Rolls. Prices F. O. B. Baltimore, Md.

Top or botton boards are not required with this Poultry Fence. The heavy top and bottom wires and the close spacing make the fence rigid and easy to stretch.

The illustrated cut at the right show's the National Poultry and Garden Fence, giving the inches of spacing, the number of bars and the heights. We carry in stock the three most popular heights, as listed below. The National Poultry and Garden Fence makes an ideal fence against poultry and all small animals. The spacing (as per illustration) is graduated from $11 / 2$ inches at the bottom to 5 inches at the top. The distances between the stay wires is 6 inches.

Furnished in rolls of 10 rods each, or 165 lineal feet, at 10 per cent discount from prices listed below.

$\begin{array}{ccccccc}\text { Distance } & \begin{array}{c}\text { Dight, } \\ \text { Between } \\ \text { Stays }\end{array} & \begin{array}{c}\text { Height, } \\ \text { Inches }\end{array} & \begin{array}{c}\text { Number } \\ \text { of Bars }\end{array} & \begin{array}{c}\text { Approximate } \\ \text { Weight } \\ \text { per Rod }\end{array} & \begin{array}{c}\text { List Price } \\ \text { per Rod }\end{array} & \begin{array}{c}\text { Our Price } \\ \text { per Rod }\end{array} \\ 2158 & 6 & 58 & 21 & 10.5 & .71 .37 & \$ .75 \\ 1948 & 6 & 48 & 19 & 9.7 & \mathbf{1 . 2 2} & .65 \\ 1635 & 6 & 35 & 16 & 8.0 & 1.01 & .55\end{array}$

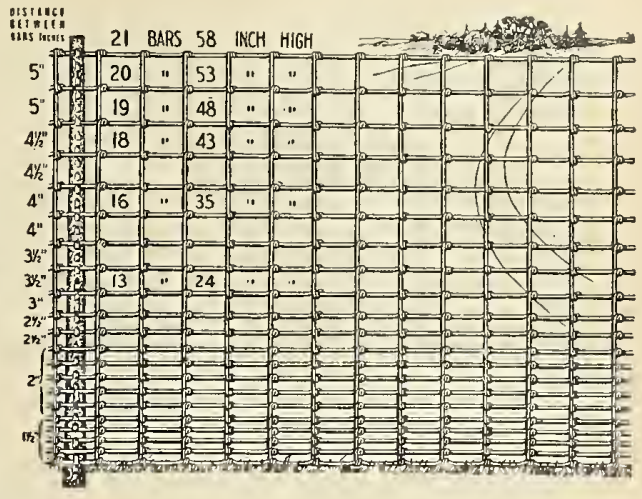

isrunce 35 BARS 58 INCH HIGH —

\begin{tabular}{|c|c|c|c|c|c|c|}
\hline \\
\hline 6 & 14 BARS & 52 INCH & $"$ & & & \\
\hline a & 13 BARS & 46 INCH & " & & & \\
\hline 6 & 12BARS & 40 INCH & $"$ & & & \\
\hline 6 & 11 BARS & 34 INCH & $"$ & & & \\
\hline 1 & 10BARS & $28 \mathrm{INCH}$ & $"$ & & & \\
\hline d & 9 BARS & 24 INCH & $"$ & & & \\
\hline 1 & BAARS & $201 \mathrm{NCH}$ & 11 & & & \\
\hline 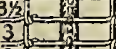 & & & & & & \\
\hline & $p=$ & 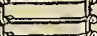 & $=$ & 6 & & \\
\hline 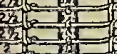 & $=$ & & & $=$ & & \\
\hline & $p=$ & & 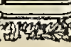 & & & \\
\hline
\end{tabular}

\section{National Close Mesh Hog and Cattle Fence}

Made Especially for the Southern Trade. Stay Wires are 12 Inches Apart Furnished in 20-Rod Rolls, at 10 Per Cent Discount from Prices Listed Below

The illustrated cut at the left shows the National Close Mesh Hog and Cattle Fence, giving the inches of spacing, the number of bars and the heights. Wc carry in stock the two most popular heights, as listed belcw. The spacing is graduated from 2 inches at the bottom to 6 inches at the top, as shown in the illustration. All prices on Wire F. O. B. Baltimore, Md., and subject to change without notice.

$\begin{array}{ccccrr}\text { Style No. } & \begin{array}{c}\text { Number of } \\ \text { Horizontal } \\ \text { Wires }\end{array} & \begin{array}{c}\text { Height } \\ \text { in Inches }\end{array} & \begin{array}{c}\text { Approximate } \\ \text { Weight } \\ \text { per Rod }\end{array} & \begin{array}{c}\text { List Price } \\ \text { per Rod }\end{array} & \begin{array}{c}\text { Our Price } \\ \text { per Rod }\end{array} \\ 1346 & 13 & 46 & 9.3 & \$ 1.07 & 50 \mathrm{c} \\ 1134 & 11 & 3.4 & 7.8 & .90 & 45 \mathrm{c}\end{array}$

National Hog and Cattle Barbed Wire

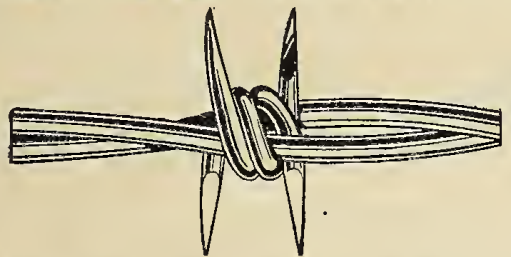

There is always a heavy demand for a good Barbed wire. We carry in tock the Four-Point only.

Four-Point Hog Barbed Wire................. $5 \mathrm{c}$ per $1 \mathrm{~b}$. Four-Point Cattle Barbed Wire....................

\section{Hardware Cloth}

For lining corn cribs, to circle around brooders for newly hatched chicks. Put up in rolls of 100 feet

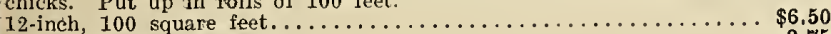

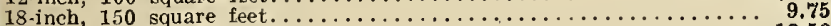

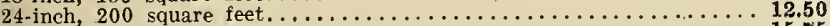

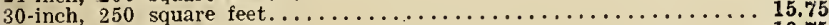

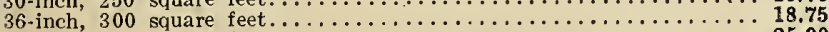

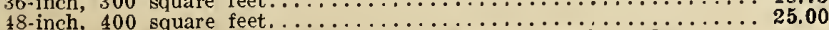
10 per cent discount from prices listed above on full rolls.
The Lott Stretcher

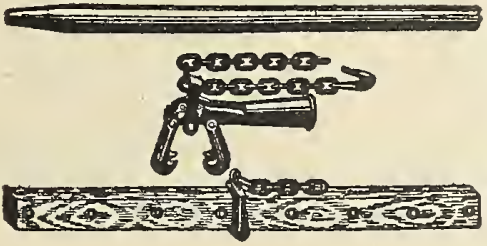

This Stretcher is operated by long lever, and can be used singly, pulling from center of , in pairs, pullins from top and bottom. All stretching chains are 8 feet in length. We do not furnish Our Special Price, \$3.50.

\section{Mann's Superior Juniata}

First quality welded steel handled ax. Painted red, full polished cutter.

Handled

Weight, $3 \frac{1}{2}$ to $6 \mathrm{lbs}$.

$\$ 1.75$ each

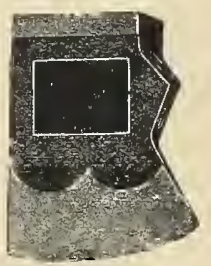




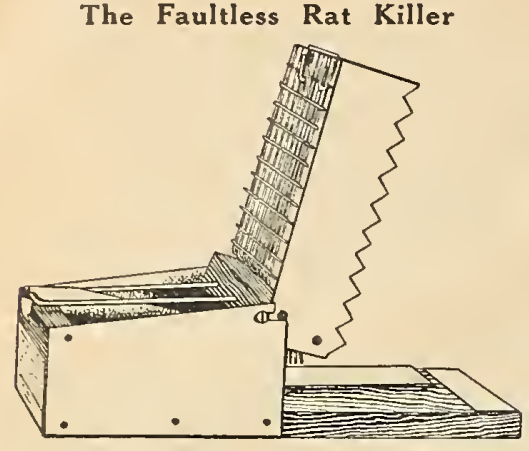

Deceives the most cumning and wary animal by holding baits out in the most deceiving and tempting manner. Kills instantly without a squeal to warn or attract its mates, enabling vou to repeat the performance every few minutes. A child can work it. This is the best trap we have ever hanoiled. Every sale is followed with a repeat order. Price 50c each. Mailing weight, 2 lbs.

\section{Victor Mice and Rat Traps}

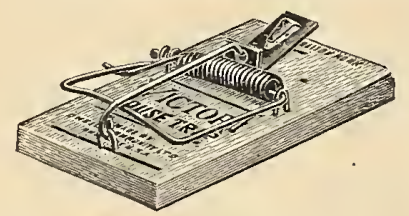

For Mice, three for 10c. Rats, 10c each, three for 25c. Mailing weight, $1 \mathrm{lb}$.

\section{Barium Carbonate}

A surc rat exterminator. The poison that hias rid Baltimore and other large cities of rats. $25 \mathrm{c}$ per box, \$2.75 doz. Postpaid

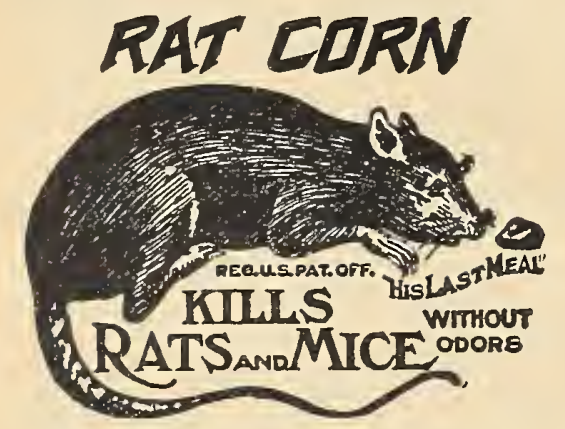

Small trial size package........25c. Postpaid Medium size package..........50c. Postpaid

"Delphos" Improved Sheet Iron Corn Popper

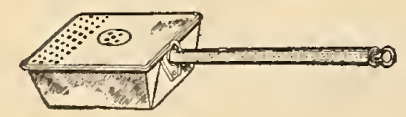

Why Better Than Others

First-Has all nerits of other poppers.

Second-Patent "Delphos" tinned wire rod perating cover device, running through sheet metal handle, opens and closes cover, preventing Third-Improved sunken butter drainer in Fourth-Perforated cover for shaking out un Fifth-Handsome embossed cove general construction.
Parcel Post Table, See Page 2

\section{Red Cross Cider Mills}

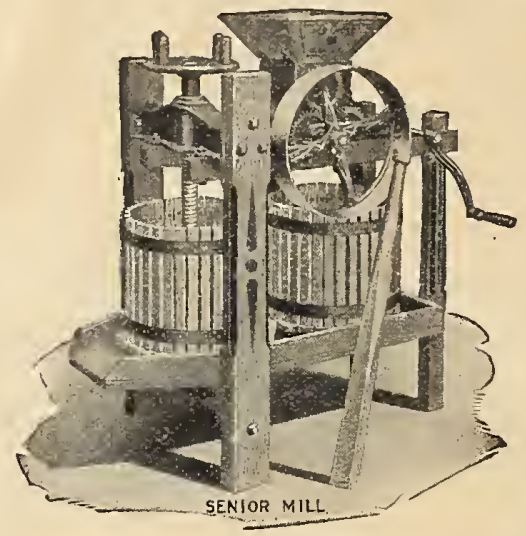

The Junior and Medium

These mills have no superior at any price, in design ease of operation or appearance. The frame is made of niaple and finished in natural wood color. The nressscrew is of steel, with accurately cut threads, an operates through a heavy cast.iron crosshead.

The Junior and the Medium are similar in construc tion, the Medium heing a larger and heavier mill. Eacl is fitted with a heavy pulley, 16 inches in diameter, and this may be driven with a $2 \frac{1}{2}$-inch helt from a small gasoline engine. These sizes are usually operated hy hand, and the pulley, which weighs 20 pounds. serves as a very effective halance wheel.

The Junior weighs 180 pounds and has a capacity of 2 to 4 barrels of cider per day. Price $\$ 27.25$.

The Medium weighs 235 pounds and has a capacity of 3 to 6 barrels of cider per day. Price $\$ 31,25$.

\section{The Senior}

The Senior is of the same general design as the Junior and Jedium, but is larger and is operated by power or by two cranks, which are furnished with the

The Senior has a capacity of 6 to 12 barrels of cider per day, and weighs 341 pounds. Price $\$ 44.75$.

The Force Feed Cider Mill

This mill should not be confused with other single-tub mills of the Hutchinson type, which will only grind apples that have been halved or quartered. We guarantee this machine to handle all sizes of apples without clogging or being forced. $\$ 19.00$.

The Bearings

An exclusive feature of our mills is the type of bearings used. These are eccentric and selp. aligning. The distance between the rollers is varied by revolving the eccentric boxes. The hole through this hox is bored off center in the direction of the pointer. If it is desired to move the rollers closer together, these lugs, or pointers, are turned toward each other.

A great advantage is gained over the old eccentric holt by using our self-aligning feature, by means of which the box is free to turn in any direction. The old style will bind unless the shafts are absolutely parallel and at right angles to the hearings. Our hoxes do not hind in any position.

The hearing box has a large cavity in the center surrounding the shaft and this cavity is packed with a good grade of grease before the mills leave the factory. This makes it unnecessary to oil the bearings during the first season. No Other Cider Mill Has These Features

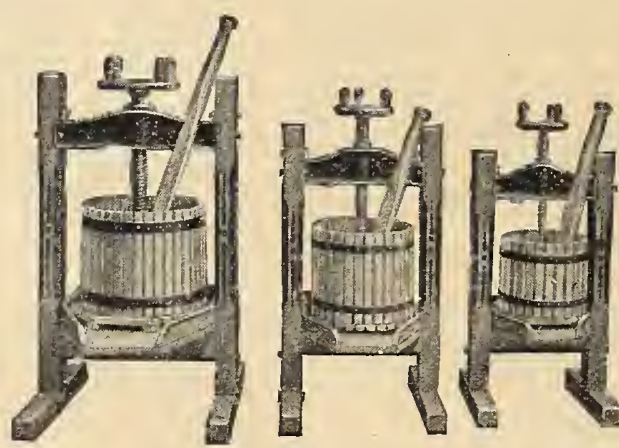

\section{RED CROSS Fruit Presses}

Red Cross Fruit Presses have heavy iron cross-heads. The press screws are heavy cold rolled steel with accurately cut threads. The follower and handwheel are iron. Frames are heavy and strongly bolted together. Troughs are wide and deep. Tuhs are capacious. Capahle of withstanding great pressure, Red Cross Presses enable the user to get all the juice from the fruit.

Red Cross Presses are numbcred 1,2 and 3 merely to differentiate the sizes. They are made of Junior, Medium and Senior parts respectively and should not he confused with other and lighter macbines of the same numbers.

No. 1 PRESS-Height of legs, $36 \mathrm{in.}$ Tub, $10 \mathrm{in.} \mathrm{high,} 12 \mathrm{in.} \mathrm{diam.}$ Press screw $1 \frac{1 / 8}{8} 18 \frac{1}{4}$ in. Weight each, 72 lbs. Price $\$ 13.50$. No. 2 PRESS-Height of legs, 40 in. Tub 12 in. high, 14 in. diam. Press screw, $1 \frac{1 / 2}{x} 20$ in. Weight each, $100 \mathrm{lbs}$. Price $\$ 16.75$. No. 3 PRESS-Height of legs, 46 in. Tub 14 in. high, 17 in. diam. Press serew $2 \times 231 / 2$ in. Weight each, 168 lbs. Price $\$ 22.00$.

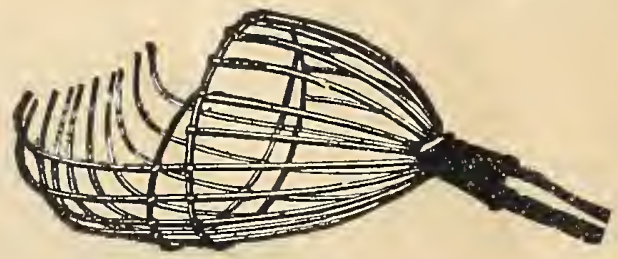

Pennsylvania Fruit Picker

More Pennsylvania Fruit Pickers are used than all other makes combined. A reliable Fruit Picker whicb can be sold at a low price.

As a Fruit Picker it has no superior. Made of Heary Galvanized Wire, and easily adjusted to a pole.

It will gather Apples, Peaches, Pcars, etc. each. $\$ 4,00$ Doz.

\section{"HOLDZEM"}

An Adhesive Especially Prepared for Catching Rats and Mice.

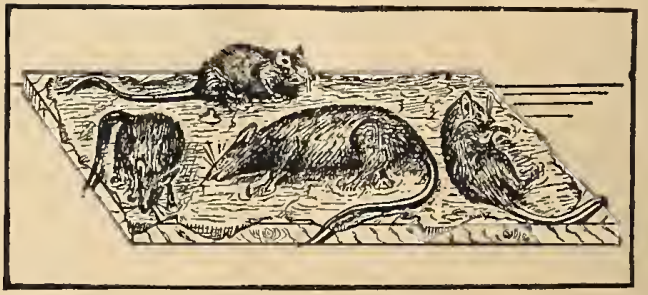

\section{Price}

1 ih. $\ldots \ldots \$ 2.25$

2 lbs. $\ldots 4.50$

5 lbs. $\ldots .10 .00$

Preferable to Poisons or Metal Traps. SAFE-Non-Poisonous-Non-Inflammable. EFFECTIVE-For use inside or outside of buildings. EASY-Just spread it on a board. 


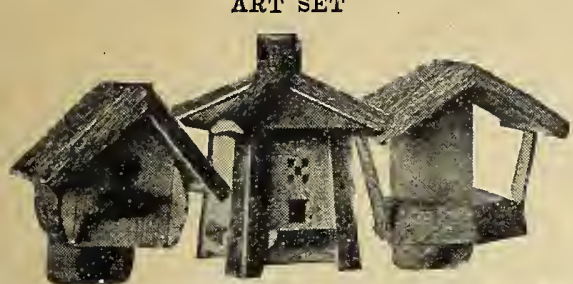

Bluebird No, 62 Wren No, 61 Robin No, 60 $\$ 1.65$ Each. The Three for $\$ 4.75$ Weight 9 pounds

\title{
Bolgiano's Bird Houses
}

\author{
KEEP YOUR BIRDS AT HOME
}

Great enthusiasm is now being shown in the protection of our native song birds; fewer birds migrate because the many bird friends are doing all in their power to keep the birds at home by placing feeding boxes and shelters conspicuously on Winter storms. birds when it is impossible for them to find food from natural sources.

You understand birds are great insect destroyers; it is reported by the United States Department of Agriculture that Blue Birds, Robins, Black Capped Chickadee, House Wren, Brown Thrasher, Cat Birds, Barn Swallows, Towhee, Song Spar rows, Field Sparrows, Purple Grockle, Baltimore Oriole, Mieadow Lark, Red Winged Blackbird, Bobolink, Blue Jay, Phoebe, Flickers, Red Headed Woodpeckers and Yellow Billed Cuckoo are all great insect destroyers. The Government has gone very extensively in their investigation, and on examining the stomach of the birds they have found the larger percentage of its contents to be insects, and many of these insects are giving the fruit growers the most trouble; had our birds been protected years ago, spraying birds feed on weed seed, and this is of great benefit to the American farmer, as it reduces the crop of weeds that oftentimes prove a destruction to crops in wet seasons.

Why should we neglect something so important and something that means so much to our welfare? Let us impress you to start now and use your best efforts to protect your birds and keep thein at home.

Put up feeding boxes and feeding shelters. Keep plenty of feed in them. We can supply you with the many different varieties. Wild seeds make a good feed for the birds. If you want birds to have their home in the grove near your home, take advantage of the opportunity now and put up bird nest boxes. They will build their nests there in the Spring, thus making your home a source of pleasure with their morning songs. What is more beautiful than having all the trees filled with birds warbling their songs? Don't delay in putting up the bird box nest, as they locate their nest building early.

We wish we could make our words strong enough for you to understand that it is just as mucb profit for you to feed and care for the birds as it is to feed and look after your poultry. Write to the Department of Agriculture for Farmers' Bulletin No. 630. This will give you knowledge that will cause you to study the bird proposition and you will get busy in doing all you should to make your location a place for birds to dwell.

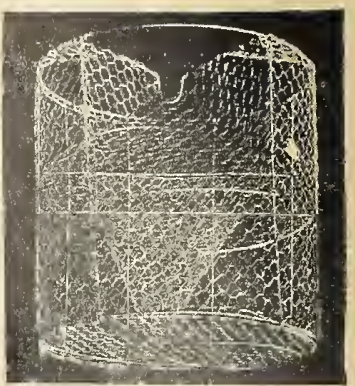

Crescent Sparrow Trap

Sparrows the Bolsheviki Among Birds

Some of their evil traits: Greedy in matter of food; mostly grain eaters. The few insects
they eat do not balance their damage to grain and all sorts of garden crops. Never

chatter is annoying.

They are certainly "Free Lovers," breaking up family life of Wrens and other small birds, even at times attacking Robins. By parcel post, size $18 \times 18$ $\$ 5.00$ and post charges.

\section{Prices Bolgiano's Rustic Bird Houses}

WREN HOUSES-5 STYLES

Log Cabin, No. 11 ; Tepee, No. 12 ; Shack, No. 13 ; Bungalow, No. 61 and Slab, No. 23. \$1.65 each; any three for $\$ 4.75$. Add postage.

Weight 4 pounds each.

BLUE BIRD HOUSES-2 STYLES

No. 21 and No. 62 . \$1.65 each. Add postage. Weight 4 pounds each. WOODPECKER HOUSES

No. 25. \$1.65. Weight 4 pounds. Postage extra.

ROBIN HOUSE, No, 60

\$1.65. Weight 4 pounds, Postage extra.
COMBINATION WREN AND ROBIN HOUSE

No. 63. Wren with Robin pulpit. \$2.00. Weight 5 pounds. Postage extra. BRACKET WREN HOUSE, NO, 17

“Jennie's Choice." Weight 3 pounds. \$1,50. Postage extra.

HANGING BARREI WREN HOUSE, No. 50

English Sparrows do not trouble this swinging house. Price $\$ 1.50$. Weight 3 pounds. Postage extra.

SWINGING HOUSE, No, 14

Suitable, for either Wren or Blue Bird. Interchangeable. Price $\$ 2,00$, Weight 4 pounds. Postage extra.

\section{Valuable Books on the Farm and Garden}

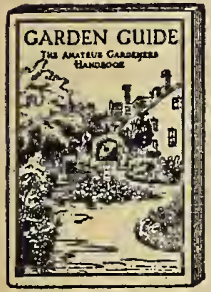

\section{CARE OF PLANTS, Etc.}

GARDEN GUIDE

\section{THE AMATEUR GARDENER'S HANDBOOK}

Tells how to plan, plant and maintain the home grounds, the suburban garden, the city lot; how to grow good vegetables and fruit; how to care for roses and other favorite flowers, hardy plants, trees, shrubs, lawns, porch plants and window boxes. Chapters on garden furniture and accessories, with useful rules and receipts, selected lists of plants, etc.

\section{THE GARDEN GUIDE}

Covers all of the above subjects fully; tells what to do and how to do it, from plowing up the ground to storing or canning the harvest. Written by gardening experts to meet the wants of the home gardener, who will find in it an answer to the 1001 questions that crop up season after season. in it an answer to the 1001 questions that crop up season after season.
Tbe GARDEN GUIDE is the most practical book of its kind published. GARDEN GUIDE is the most practical book of its kind published.
Handsome four-color cover. 384 pages. 15 Planting Plans. 275 teaching illustrations. Price: Paper bound, $\$ 1.00$ ( $\$ 1.10$ postpaid). Cloth bound, $\$ 1.50$ ( $\$ 1.65$ postpaid).

\section{HOME FRUIT GROWER}

A practical guide to the growing of fruit for home use It covers the entire subject of growth. cultivation, pruning and grafting. Illustrated with teaching nictures. Beautiful cover in four colors. Very valuable. Paper bound, $\$ 1.00$ ( $\$ 1.10$ postpaid). Cloth bound, $\$ 1.50$ (\$1.65 postpaid).

\section{MILADY'S HOUSE PLANTS}

To all women taking pleasure in the companionship of plants in the home and wishing to be made acquainted with the conditions essential to their well being, this instructive book, concisely written and easily understood, will make a strong appeal. 100 illustrations. 4 color cover. The is gone into minutely and this one chapter alone is worth many times the price asked for the book. Paper bound, $75 \mathrm{c}$ ( $80 \mathrm{c}$ postpaid.) Cloth bound, $\$ 1.00$ ( $\$ 1.10$ postpaid).

\section{PLANT PROPAGATION}

Second Edition Revised and Greatly Enlarged

This book is written to instruct the florist and gardener in knowing just how to propagate the plants he expects to grow without the necessity of consulting more voluminous or expensive works. Copiously illustrated with instructions readily understood. It makes clearer a thousand little points which the old edition touched upon. Cloth bound, 2.00 (postpaid $\$ 2.15)$

\section{IANDSCAPE GARDENING, PRACTICAL}

A work containing practical and detailed information on subjects pertaining to the general landscape development of residential properties. Essential points illustrated by numerous sketches, plans and pbotographs. 266 pages. Cloth bound, $\$ 2.50$ (\$2.65 postpaid)

\section{A IITTLE BOOK OF ANNUALS}

\section{By ALFRED C. HotTES}

This Little Book of Annuals has been written for the increasing throng of amateurs who grow flowers for the love of them. It is a reliable guide through the season of annual bloom. A handsome, carefully written, thoroughly edited, freely illustrated, accurately indexed book of 128 pages.

Paper cover, $\$ 1.00$, postpaid, $\$ 1.10$; cloth binding, $\$ 1.25$; postpaid, $\$ 1.35$.

\section{A LITTLE BOOK OF PERENNIAIS}


If You Are Interested in Hotel, Factory or Community Steam Pressure Canning Outfits, We Will Be Pleased to Furnish Prices

"National" Junior No. 1 Canner

For Canning Vegetables, Fruit, Meat, Fish, Etc.

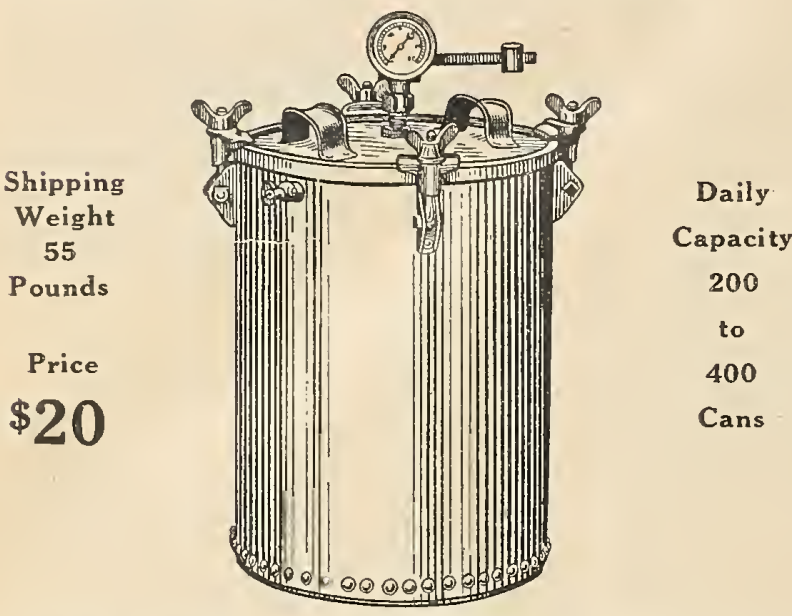

Consists of one $12 \times 18$ inch steel retort, with cover, packing, etc., steam gauge, one perforated galvanized crate, one safety valve, one petcock. one triangle and one thumb nut wrench.

In order to be prepared to can all varieties of fruit, vegetables, meats, fish, etc.," it is absolutely necessar"y to have a "Steam Pressure Canner," as this is the only way you can be assured of perfect sterilization. A great many vegetables and all meats requirc a pressure of 250 degrees Fahrenheit for perfect sterilization, and the only way this can be attained is with
steam under pressure. Our "National" Junior No, 1, which is jllussteam under pressure. Our " National Junior No, 1, which is illusfor use by Government demonstrators. It will hold ten quart jars o fifteen pints at one loading. Tin cans may also be used. With one of our supply the table for the entire year at a great saving.

\section{A Few Reasons for Canning in Sanitary Tin Cans With The Burpee Home Can Sealer}

Marketable.

When canning

is done in the

regular market

able size tin cans, much fruit and vege. tables that now go to waste can be anned and sold.

Simple and Easy to Operate. The machine is simple, inexpensive, easy to operate and can be clamped to any table. one machine can be used to seal the No. 2 (pint) and No. 3 (quart) size cans. A separate machine is used for sealing gallon cans.

book of reliable receipt or camning fruit, vegetables, soups, meat d fish is supplied with each machine Costs Less. The cost of tin cans is much less than glass jars and there is absolutely no danger of breakage.

No Loss. When properly sterilized, or ooked, there is no danger of spoiling, as

cans always seal airtight.

Flavor Retained. The delicious flavor of the fresh fruits and vegetables is not lost when canning in tin cans, because the cans are seale

Reduces Labor and Fuel. By piling the cans one on top of another hen being cooked, twice the amount can be cooked in the same time. Sealer Without Opener and Can Saving Features

No. 2. Burpee Home Can Sealer, for sealing No. 2 (pint)

No. 3. Burpee Home Can Sealer, for sealing No. Nan $_{3}$ (quart)

No, 23. Burpee Home Can Sealer, for sealing both No. 2 . urpee Home Can Sealer, for sealing both No. 2 and 19.00 Sealer With Opener and Can Saving Features

Nos. 2 or 3 . With opener and reflanger

16.50 16.50

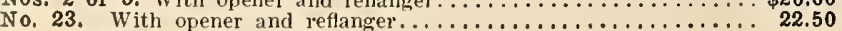

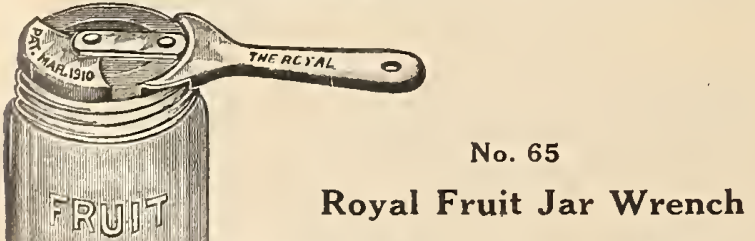

Make your jars absolutely airtight. Save your hands and eliminate waste.

Price 10c each

\section{"National" Aluminum Pressure Cooker}

The high cost of living can be reduced materially. by the use of our Aluminum Pressure Cooker and mum Pressure cooker and be saved by the louserife erery day in the rear. erely day in the year. every detail and should be a part of the equipment of every kitchen. It is made of lighly polished aluminum and the fitting: are all of high-grade brass, which also adds greatly to the appearance of the cooker. The cooker may also be used for canning in small quantities.

The steam gauge registers the number of pounds pressure in the cooker at all times and is absolutely reliable, The petcock to create free circulation of steam and should be left entisy apen suld then until all the cold air is forced out commences to pass off, when it should be partly when it should be partly
closed. The special safety valve, which is made specially for use with the "National" Pressure

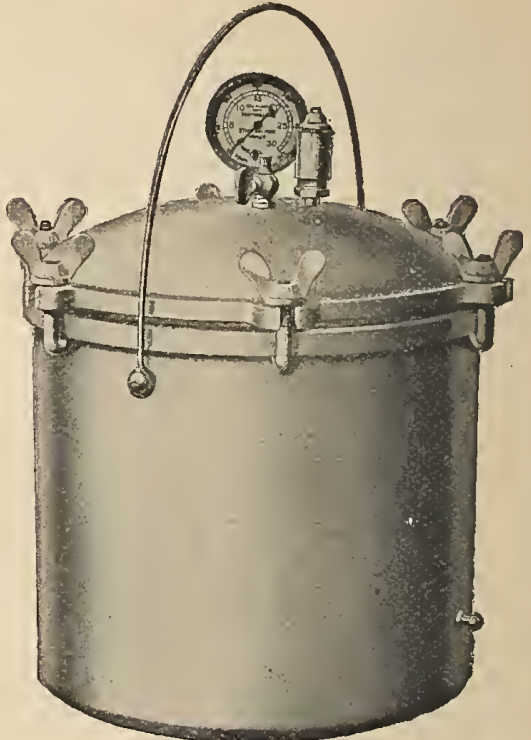

that it can be set at any desired point and will automatically blow off the excess steam so as to maintain the desired pressure for the necessary length of time. This is one of the features of the "National "which will not be found in any other style of pressure cooker. There is absolutely no danger comected with the operation of it, and a complete receipt book, together with instructions for operating, are furnished with each outfit.

10 Quart Size (liquid capacity). Inside diameter, 9 ins, Height, $81 / 4$ ins. Net Weight, $9^{1 / 2}$ lbs. Shipping weight, 12 lbs. Price, $\$ 29.00$

17 Quart Size (liquid capacity). Inside diameter, 111/2 ins. Height, $10 \frac{1}{2}$ ins. Net weight, 18 lbs. Shipping weight, 25 lbs. Price, $\$ 37.00$.

25 Quart Size (liquid capacity). Inside diameter, $12 \frac{1}{2}$ ins. Height, $11 \frac{1}{2}$ ins. Net weight, 23 lbs. Shipping weight, 30 lbs. Price, $\$ 44.00$

\section{"Thrift" Way}

\section{"Thrift" Seals Them Tight and Keeps Them Right}

How many of the jars of vegetables and fruits that you "put up" last year spoiled? Canning experts state that for every dozen jars packed, processed and sealed the ordinary way, two are lost. But not the Thrift Way-because foods canned the Thrift Way can't spoil. They are mechanically and hermetically sealed before cooking; sealed just as the big packers seal their jars for marketwith all the flavor and juices in the jar. The Thrift Way is easier and quicker, too. Fo uncertain tops or rubber rings to bother with: no hot jar's to handle. It isn't the number

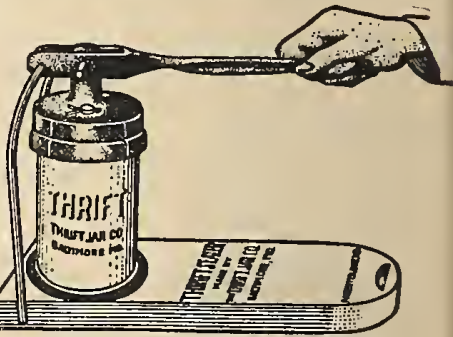

THE THRIFT SEALER of jars you "put up" its the jars

that keep that count. That is why so many women who can foods for home or market are using the Thrift Way.

\section{"Thrift" Way Jars Are Extra Strong}

Thrift jars are made of the finest clear flint glass. They will stand unusual extrenles of lieat and cold; and constant use for many years. Made in two sizes, quart and pint and a quarter with wide mouths making them easy to fill and clean.

\section{The "Thrift" Sealer}

A filled jar (filled only to within one-half inch of the top) is placed in sealer, with patent cap on mouth of jar. Lowering handle of sealer presses head of sealer over cap and mechanically "crimps" cap on mouth of jar ; sealing it airtight-hermetically. As an extra precaution lift handle, give jar.a slight turn and again press down handle, giving the jar an extra sealing. No strength or skill is required to seal the Thrift Way; a child can do it perfectly:

11/4 Pint Thrift Jars and Caps $\$ 1.15$ per dozen

1 Quart Thrift Jars and Caps $\$ 1.40$ per dozen.

Extra Thrift Caps per box of 6 doz. $\$ 2.15$.

Thrift Sealer $\$ 2.50$ 


\section{Beekeepers}

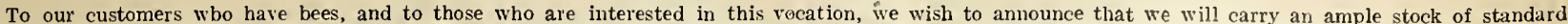

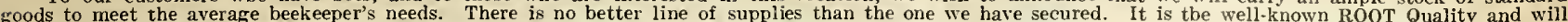

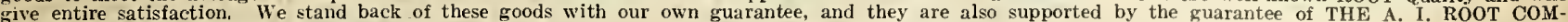
cive ef

We will only illustrate and describe a few of the hives and supplies whicb we will have to offer.

We will issue a special catalog for beekeepers. Please write for a copy.

One-Story Standard Hive, With Metal Cover

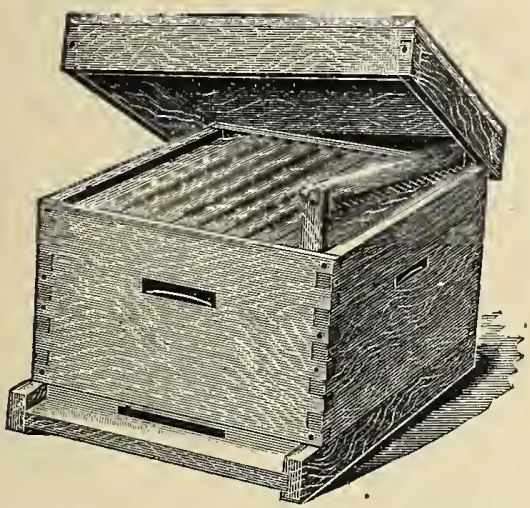

This hive is the one most universally used by the largest honeyproducers on account of its light weight and the ease with which it may be moved from one location to another. It is of highest quality throughout, being made of best selected white pine, perfectly milled and fitted together.

While made either in eight-frame or ten-frame size, we recommend the ten-frame hive. It consists of a bottom-board, double telescoping cover witb metal cap and body or brood-chamber, with Hoffman frames. Nails and tin rabbets are included with all hives.

\section{Comb Foundation}

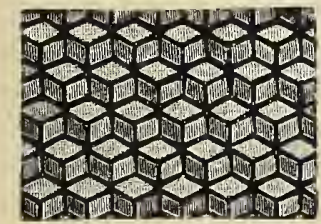

Medium Brood

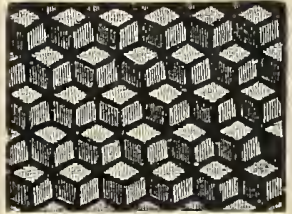

Thin Super
We carry fresh comb foundation, without which it is quite difficult to secure straight, perfect worker comb in the brood nest or straight marketable sections of comb honey in sections.

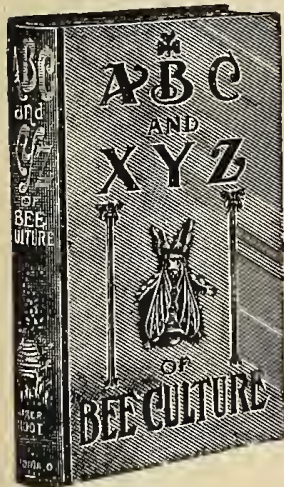

This edition of the $\mathrm{A} B \mathrm{C}$ and $\mathrm{X} \quad \mathrm{Y} \mathrm{Z}$ of Bee Culture contains 850 pages of real information on bees. It is arranged alphabetically, making it a fine reference book in time of doult.

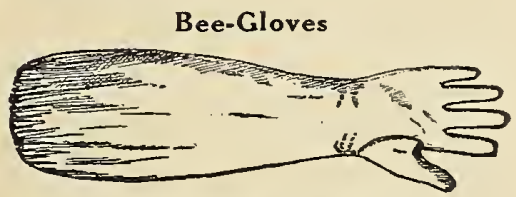

Bee-Gloves are furnished

in three sizes:' Small,

Medium and Large.

\section{Root Smokers}

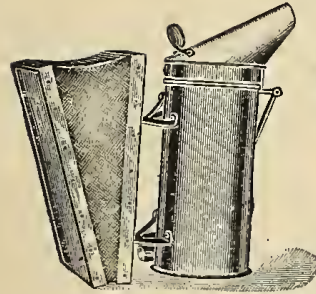

Standard

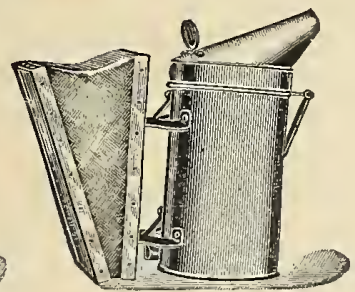

Jumbo
Root Smokers are so well known that they need no introduction. We carry both Standard and Jumbo sizes, in copper and tin.
$44 \times 41 \times 17$ Beeway Section Super for Comb Honey in
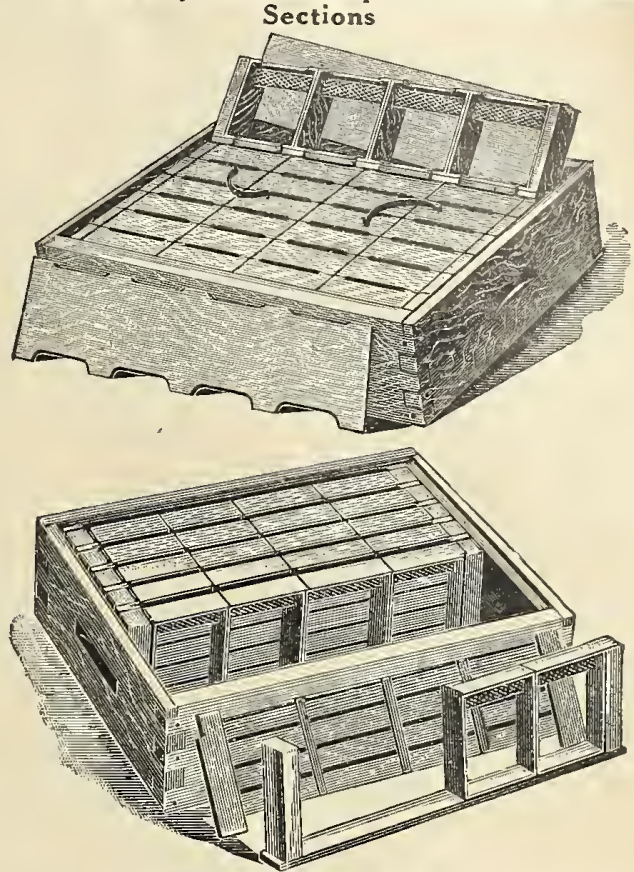

$4 \times 5 \times 13$ Plain Section Super

We show two of the most practical supers for comb honey. These two have stood the test of use and are today more generally used than any other. We can heartily urge you to use either, especially the $4 \times 5 \times 13$ which produces that tall, well-filled section that sells so easily.

\section{Section Honey-Boxes}

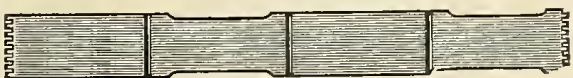

$4 \frac{1}{4} \times 4_{4}^{1} \times 17$ Inches Wide with Two Beeways

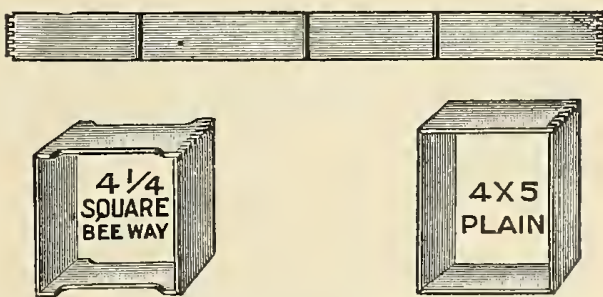

$4 \times 5 \times 13$ Plain Section, no Beeways

These sections are made of clear white basswood and fold witbout breaking.

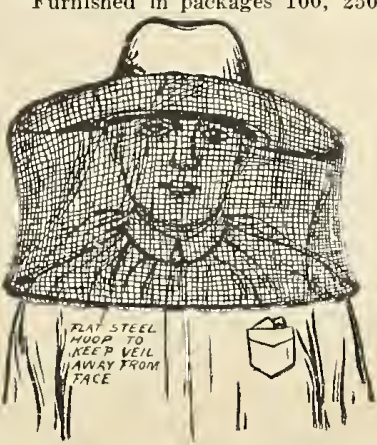

Root Bee-Veils

For those who need protection a Root Veil will prove quite adequate It is light, durable and built on right principles.

Write for Special Catalogue on Beekeeper's Supplies and Prices 
ANne Arundel Co., Mid,

March 1, 192:2.

The J. Bolgiano Seed Co.,

Baltimore, Md.

GeNTLEMEN: It is with great pleaswre that I am woriting to you to tell you of the wonderful success I hare had since feeding your "Square Deal" Buttermilk Starting Feed.

Our first hatch came off February 14 and our second hatch one week later. The chicks at this writing are three weeks and two weeks old respectively, and of course have been confined to their brooder since they were hatched on account of the weather. So far we have had absolutely no mortality and the rate of growth and development of these chicks has been very gratifying to me to say the least.

I heartily recommend your Starting Feed unreservedly to anyone raising chicks, especially in large numbers.

Thanking you for past favors, I beg to remain,

Yours respectfully,

L. M. SCHNEIDER.

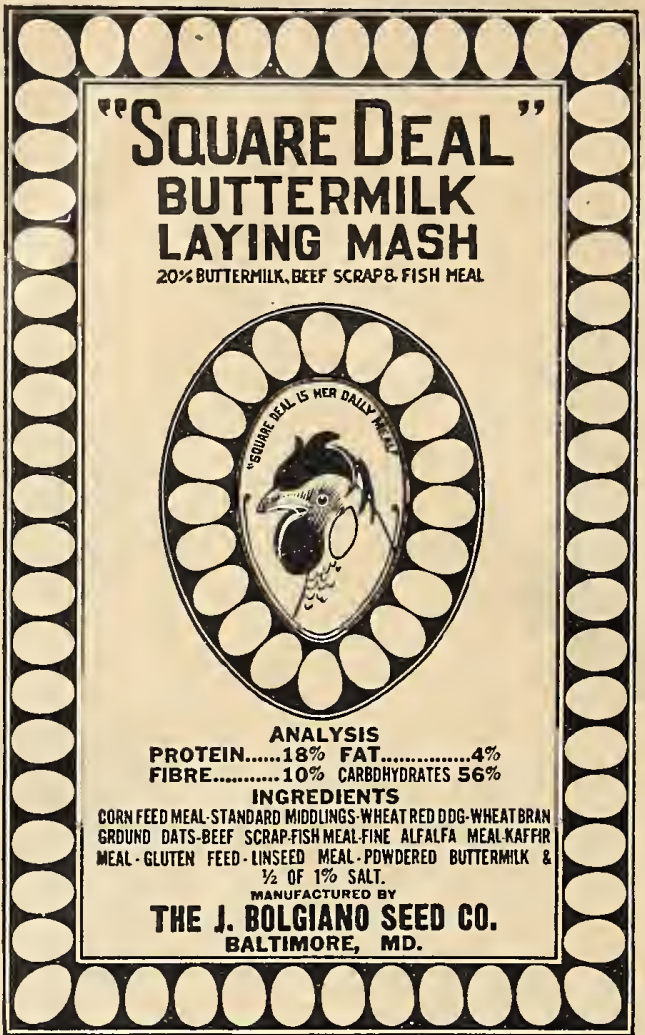

Frankiln County, Pa., February 4, 1922.

The J. Bolgiano Seed Co., Baltimore, $M d$.

Gentlemen: Maving used your "Square Deal" Chick Starter last season with success, I should like to feed it again this year.

If you are still making it, please quote price. Respectfully,

J. W. BERGER.

Cumberland County, Pa., July $10,1922$.

The J. Bolgiano Seed Co.,

Baltimore, $M d$.

Gentlemen: I received my last order $0 . K$. and am well pleased with the fine beef scrap you sent me, and will order several hundred more in the near future.

$I$ also appreciate the thirty cents rebate you sent me, not that the thirty cents is so much to me, but now $I$ can send you a check with my orders with the assurance that I will get back what I send over the price of the goods. Scars Roebuck \& Co. is the only other house I have dealt with that sends back what is over the amount.

If you can quote prices on poultry feed this fall that I can buy it as cheap from you after paying the freight, I cxpect o buy screral tons for the winter. I would appreciate it very much if you will advise me when you could give me the lowest Gluten Feed by the ton.

Wishing you a successful scason, I remain, Yours truly, G. C. $\Pi A K I N G$.
Baltimore County, Mo. September 25, 1922.

The J. Bolgiano Seed Co.,

Baltimore, $M I d$.

GENTLEMEN: I received the feed ordered several days ago and am very much pleased with it. I really do ap. preciate your kindness and service. and $I$ will always endeavor to recom mend, and try to have those whom I come in contact with, to patronize your Company, as Baltimore firms such as yours should be reeognized.

Thanking you and hoping you will ship the enclosed order out promptly. I remain,

Yours truly,

J. FITZGERALD.

Prince Georges Co., Mo., June 17, 1922.

The J. Bolgiano Seed Co.,

Baltimore, Md.

Gentlemen: Allow me to eongrat ulate you on the quality of feed and seeds you sell. I have been in the poultry business now for six years, and $I$ have never been able to get the quality of feed anywhere that I am now getting from you.

I have also planted your garden and field seeds and have received good crops in return, and every time I send. you an order I know I am getting quality and saving money.

Any time you wish to use my name as a reference or refer any one to me in regard to the quality of goods you sell, it will be a pleasure to me to have you do so.

Thanking you for past favors, I am,

Very truly yours,

L. B. SEDWICK.

\section{A New "Square Deal" Feed}

Last Spring, after several successful and practical experiments, we offered to our trade "SQUARE DEAL" BUTTELMILK STARTING FEED.

This fecd is a creation of our own, and the public demand for it the first season surpassed all expectations. This in itself should be ample evidence of its value as a primary feed for baby chicks.

The marvelous rate of growth and development attained by chicks fed on "SQUARE DEAL" BUTTERMILK STARTING" FEED, is explained by the fact that there is present in the mixture in the most palatable and assimilable form, the proper proportion of the essential nutrients necessary for the proper development of bone, tissue, and muscle. It is only natural. therefore, that chicks raised on this feed, have strong, finely developed bodies.

Another striking feature of "SQUARE DEAL" BUTTER MILK STARTING FEED is its tendency to prevent white diarrhœa. We have recently talked with several commercial poultrymen who used this feed exclusively last season, and they all tell us that they did not have a single case of this dreaded disease.

"SOUARE DEAL" BUTTERMILK STARTING FEFD is the ideal feed for baby chicks. When you seriously consider how invaluable this feed is, the cost becomes a negligible factor. A chick given the proper start means a profitable layer in the Fall. 


\section{Bolgiano's "Square Deal" Poultry and Pigeon Foods} SOLD WITH AN ABSOLUTELY "SQUARE-DEAL" GUARANTEE

\section{"Square-Deal " Baby Chick Feed}

A Primary Grain Feed for Baby Chicks Up to Three Weeks Old This is a primary grain feed for Baby Chicks; contains only the best selected, recleaned, sound, sweet, cracked grains and seeds in proper proportions essential to quick and healthy growth. This feed should be fed in litter to induce exercise. 10 Lbs. 40c. 25 Lbs. 90c. 100 Lbs. $\$ 3.10$.

\section{"Square-Deal " Chick Developer \\ Quickly Develops Growing Chicks}

This is a carefully selected high-grade mixture of recleaned, sound, sweet, cracked grains and seeds, and is an intermediate feed for growing chicks too small to eat our "Square-Deal" Scratch Feed. Make them work for it; exercise promotes health and aids digestion. $10 \mathrm{Lbs} .40 \mathrm{c} .25 \mathrm{Lbs} .90 \mathrm{c} .100 \mathrm{Lbs}$ \$3.05.

\section{"Square-Deal " Scratch Feed} (All Grain)

A Scratch Feed of the Highest Grade-Contains Sunfiower Seed
This is a combination of carefully selected, recleaned, sound, sweet grains-the feed that keeps the fowls vigorous and healthy; when fed in deep litter, keeps the fowls active. The busy lien is always profitable. 10 Lbs. 40c. 25 Lbs. 85c. 100 Lbs. \$2.85.

\section{"Square-Deal" Pigeon Feed-}

Without wheat, corn, grit or shell. It Without wheat, corn, grit or shell. It
is composed of carefully selected, appropriate, recleaned, sound, sweet grain and seed, especially adapted to flying pigeons. 10 Lbs. 50c. 25 Lbs. $\$ 1.20$. 100 Lbs. $\$ 4.20$.

"Square-Deal" Pigeon FeedNo. 3

Without corn, grit or shell, but contains some wheat. It is composed of carefully selected, appropriate, recleaned, sound, sweet grains and seeds. 10 Lb.
50 c. 25 Lbs. $\$ 1.15$. 100 Lbs. $\$ 4.00$. "Square-Deal" Pigeon FeedNo. 4

This pigeon feed does not contain any cracked corn, wheat, grit or shell, but is composed of flint corn and carefully selected, appropriate, recleaned, sound, sweet grains and seeds, especially adapted to fancy pions, 10 Lbs, 50c. 25 Lbs. $\$ 1.15$. 100 Lbs. $\$ 4.00$. Powdered Buttermilk
Bolgiano's "Square-Deal" Blood Meal

\section{"Square-Deal " Buttermilk Starting Feed}

This is the ideal starting feed for your baby chicks. It contains a minimum of fiber, and produces rapid growth and development, besides preventing white diarrhoea. Full feeding directions are furnished with each package. 5 Lbs. 30c. 10 Lbs. 55c. 100 Lbs. $\$ 4.50$.

\section{"Square-Deal "Buttermilk Growing Mash}

Our Growing Mash is a mixture of first quality ground grains, beef scrap, powdered buttermilk, and fancy bone meal, propcrly proportioned and scientifically balanced so as to insure quickest possible growth and development. Feed dry and you will be surprised at the results. Let the chickens have free access to "Square-Deal " Growing Mash all the time, they will not gorge themselves. When four months of age mix one-half Laying Mash with the Growing Mash and watch results. 10 Lbs. 45c. 25 Lbs. 95c. 100 Lbs. $\$ 3.35$.

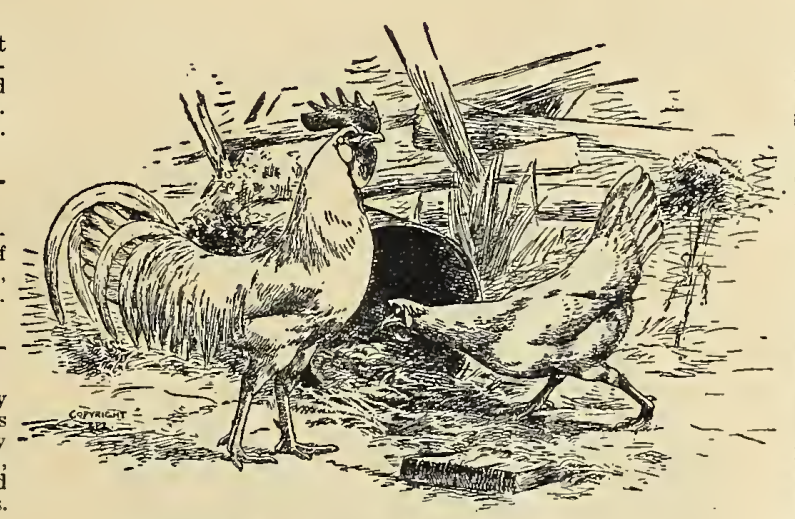

Single Comb White Leghorns
"Square-Deal " Buttermilk Laying Mash Makes Hens Lay

It is a complete scientifically balanced mash composed of carefully selected mixture of recleaned, sound, sweet ground grain and green food, Beef Scraps, Buttertains proper proportions essential It con\begin{tabular}{l} 
ducing big egr yield. 10 Lbs. $45 \mathrm{c}$. \\
\hline
\end{tabular} Lbs. 95c. 100 Lbs. $\$ 3.35$.

Bolgiano's "Square-Deal " Crushed Oyster Shells. The best poultry authorities recommend the "Grit-Box" system. Our fresh ground shell supplies Carbonate of Lime to increase the production of eggrs. Poultry, pigeon and chick sizes.
$\$ 1.00$ per 100 Lbs.

Bolgiano's "Square-Deal" B e f Scrap 55 to 65 per cent protein. For success with poultry it is absolutely neces sary to give them plenty of animal food.
For this purpose "Square-Deal" Beef Scrap is the best food that can be used. 10 Lbs. 60c. 25 Lbs. \$1.45, 100 Lbs. $\$ 5.35$.

\section{Poultry and Pigeon Supplies}

We can supply the following selected ingredients in large or small quantities at the lowest possible prices, quality considered.

Corn and Corn Products

No. 2 Yellow Corn

Small Yellow Corn

Argentine Flint Corn

Coarse Cracked Corn

Nedium Cracked Corn

Fine Cracked Corn

Corn Chop

Corn Feed Meal

Corn Gluten Feed

Wheat and Wheat Products

Fancy Feeding Wheat

Cracked Wheat for Baby Clicks

Wheat Screenings

Wheat Bran

Standard Middlings

Red Dog Flour

\section{Oats and Oat Products}

No. 2 White Oats Special

No. 34 Clipped Oats

No. 34 Clipped Oats Ground

Fancy Hulled Oats

Fancy Steel Cut or Pinlead Oats

Fancy Rolled Oats

Oat Flour
Milo Maize and Kaffir Corn

No. 2 Red Milo, Recleaned

No. 2 Red Kaffir, Recleaned

No. 2 White Kaffir, Recleaned

No. 2 Mixed Milo and Kaffir

Cracked Milo and Kaffir for Baby Chicks

\section{Miscellaneous Feed Grain}

Faucy Broken Rice

Fancy Barley

Fancy Buckwheat

\section{Miscellaneous Seeds for Feeding}

Large Red Millet

Large Kellow Millet

Recleaned Hemp Seed

Recleaned Canary Seed

Bird Rape

Large Vetch

Striped Sunflower Seed

Canada Field Peas

\section{Concentrates}

Cottonseed Meal

O. P. Oil Meal

Linseed Oil Meal

Tobacco Products

Tobacco Dust

Tobacco Stems

Poultry and Pigeon Grit

"Square Deal" Crystalline Grit Cockeysville Egg Shell Grit

Standard Egg Shell Maker Grit

Hen-E-Ta Grit

Foust's Healtlı Grit

Red Cross Health Grit

\section{Miscellaneous}

Curtiss Cut Clover

Choice Fine Ground Alfalfa Meal

Fancy Dustless Charcoal (all sizes)

Fancy Poultry Bone (all sizes)

"Square Deal "Crushed Oyster Shell 


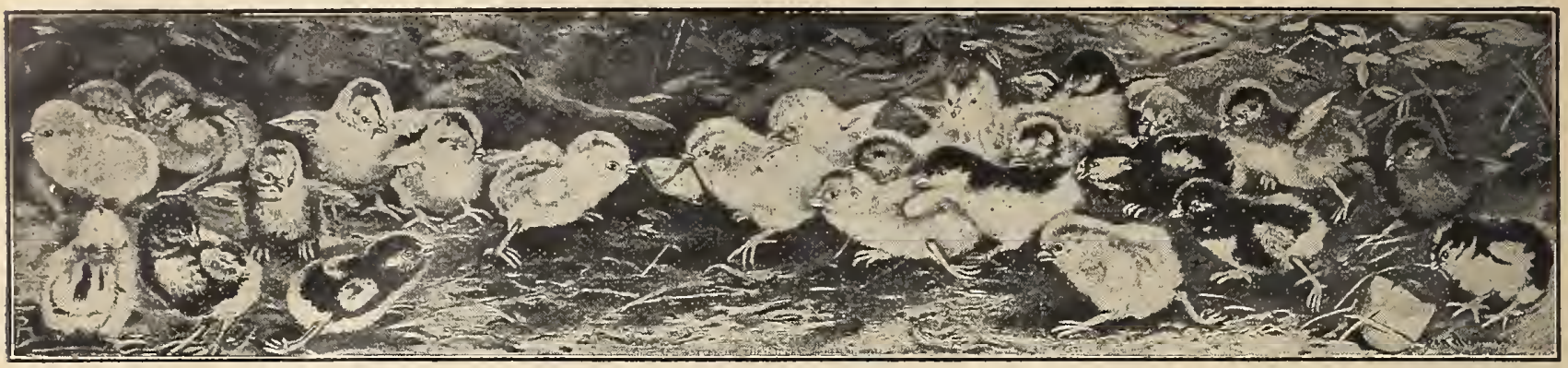

\section{Bolgiano's "Vital Hatch" Baby Chicks are Bred for Constitutional Vigor and Heavy Egg Production}

Hatching Season March 1 st to June 1st

\begin{tabular}{|c|c|c|c|}
\hline VARIETY & $\begin{array}{c}25 \\
\text { Chicks }\end{array}$ & $\begin{array}{c}50 \\
\text { Chicks }\end{array}$ & $\begin{array}{l}100 \\
\text { Chicks }\end{array}$ \\
\hline Single Comb White Leghorns. . . . . . . . . . . . . & $\$ 6.00$ & $\$ 11.00$ & $\$ 20.00$ \\
\hline Single Comb Brown Leghorns................. & 6.00 & 11.00 & 20.00 \\
\hline Single Comb Anconas............ & 6.50 & 12.00 & 22.00 \\
\hline Single Comb Rhode Island Reds....... & 6.50 & 12.00 & 22.00 \\
\hline White Wyandottes .............. & 6.50 & 12.00 & 22.00 \\
\hline Barred Plymouth Rocks............... & 6.50 & 12.00 & 22.00 \\
\hline White Plymouth Rocks............. & $\gamma .00$ & 13.00 & 24.00 \\
\hline Single Comb Black Minorcas......... & $\% .00$ & 13.00 & 24.00 \\
\hline Single Comb White Orpingtons....... & 1.00 & 13.00 & $2 \pm .00$ \\
\hline
\end{tabular}

$\begin{array}{cc}\begin{array}{c}\mathbf{5 0 0} \\ \text { Chicks }\end{array} & \begin{array}{c}\mathbf{1 0 0 0} \\ \text { Chicks }\end{array} \\ \$ 95.00 & \$ 180.00 \\ 95.00 & 180.00 \\ & \\ 105.00 & 200.00 \\ 105.00 & 200.00 \\ 105.00 & 200.00 \\ 115.00 & 220.00\end{array}$

PRICES SUBJECT TO CHANGE WITHOUT NOTICE

\section{READ CAREFULLY- IMPORTANT!}

Weather conditions permitting. we will place the first eggs in our ineubators early in February. We manage large flocks of brecders, and are in a position to fill orders for Vital Hateh Baby Chicks early and in large numbers.

Records of all eggs placed in the incubators and of the tests made thereafter are kept to aseertain the percentage of fertility and the probable pereentage of hatch to be expected.

We are, therefore, in a position to wite you when you may expect shipment of your order. As we are continually booking orders agaiust our Hatching records it will be to you advantage to plaee your order with us inmediately, and we will give you the earliest shipping date possible. All orders for Vital-Hatch Baby Chieks are filled in rotation, as re

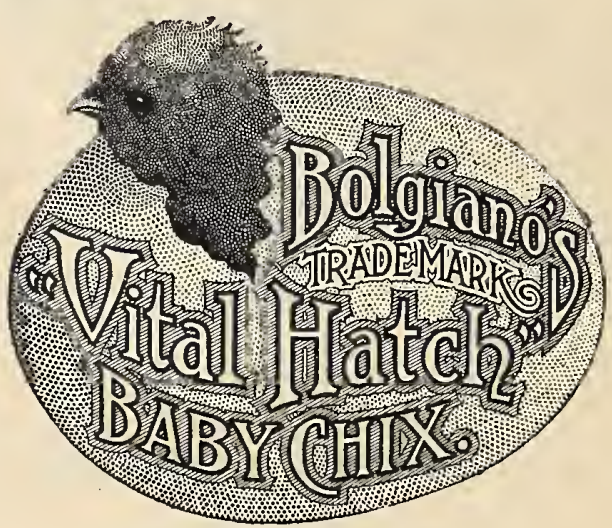

CHICKS WITH “VITALITY"

Comparison of prices should not be the deciding factor in placing your order for chicks. Weak, sickly, poorly hatched chicks are dear at any price. Why buy such when you can get VITALITY as well as QUALITY at a reasonable price? ONE HUNDRED of this kind are worth ONE THOUSAND poorly hatched mongrels. ceived, as near to the date desired as possible.

All prices are subject to change without notice.

We accept all orders for Baby Chicks subject to delays incident to Hatching oftentimes effected by weather collditions.

\section{HOW TO ORDER BABY CHICKS}

Be sure and give full name of your postoffice. (Write full name plainly.) State plainly the number and variety of chicks foll want and when wanted. All orders are acknowledged same day received with approximate date of shipment given.

If you have a second choice, please name the variety when ordering, and in that way delays will be avoided many times.
If you wisl to book your order early and it is not convenient for you to pay for them at the time, send one-quarter, or twenty-five per eent, of the full amount of the order.

A card will be mailed you, showing balance due on your order which must reach us 10 days beforc shipping date. We cannot ship C. 0 . D. by Express or Parcel Post.

\section{OUR GUARANTEE TO YOU}

If Prices are redueed at the time of slipping, the purchaser will be proportionately credited with the annount or enough additional chicks shipped to make up the difference.

Wc guarantee 97 per cent of the Baby Chicks to reach you in good condition.

Do not sign for damaged goodsunless marked damaged by the Agent -on the receipt which you sign.

EXAMINE THE SHIPMENTS

On arrival, open box; if any chieks are dead, liave postmall mark number on the back of the receipt and return the receipt to us. If this number exeeeds 3 per ecnt we will lefund your money for them or replace them, free of charge.

We have sueeessully shipped baby chicks 1,500 miles and ean guarautee safe arrival.

All CLAIMS must be made within TWENTY-FOUR HOURS, together with a statement from your postmaster, showing the CHICKS were received in POOR CONDITION.

DON'T give BABY CHICKS COLD WATER TO DRINK. DON'T OVERFEED CHICKS. EITHER of the ABOVE will START BOWEL TROUBLES. FEED liberally, so long as they keep ACTIVE. Keep their BACKS WARM.

Have the brooder warmed up and ready to receive and care for the chicks properly. 


\section{About Shipping \\ WE SHIP ALL CHICKS BY PARCEL POST}

All of the prices quoted on Baby Chicks are Postpaid to your Postoffice.

The purchaser assumes all risks when chicks are ordered shipped by express.

\section{About Ordering}

We are usually in a position to ship Day Old Chicks within a week from the date your order is received. We, however, advise you to allow us to book your order carly, thereby avoiding all delays and the many disappointments that are bound to occur in the busiest part of the season. Our First Floor will be alive with Baby Chicks this Spring. Come and see them.

\section{BABY CHICK BOOKLET SENT ON REQUEST}

\section{Well Pleased-Will Order Again}

May 12tlı, 1922, Miss Clara Dashiell, Wicomico County, MId, wrote: "I received my Baby Chicks $O$. K. on the tenth. they are fine, very much pleased with them. I think I shall order some Anconas. Thanks."

\section{1,000 Miles-Arrived in Fine Shape}

March 10th, 1922, Mr. Albert Shavos, of Dade County, Fla., wrote: "The White Wyandotte day-old chicks that I ordered of you came alright, in fine shape and hungry. Only two dead. Thank you for the fine way you ship them."

\section{Eggs for Hatching from Thoroughbred Poultry}

Eggs for hatching may be sent by parcel post. One setting, ready for shipment, will weigh about four pounds; two settings, seven pounds. To ascertain the cost, refer to the table on page 2 of this Catalogue. Forward us that amount in addition to the prices quoted on this page and we will ship the eggs to you by mail prepaid. In many cases, eggs will go cheaper this way than by express.

\section{F. P. C. Chick Manna}

The Original Special Prepared, First TenDay Food for Baby Chicks

Standard First Food Since 1884

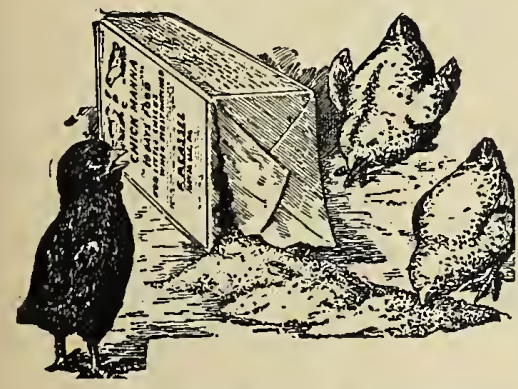

Prepared with great care for little chicks just hatched. Peculiarly adapted to the promotion and health, quickening of growth and developing strong chicks in winter and early spring. Put up in packages-1 Lb., 15c ; 3 l.bs., 40c; 5 l.bs., 60c; 15 Lbs., $\$ 1.65$.

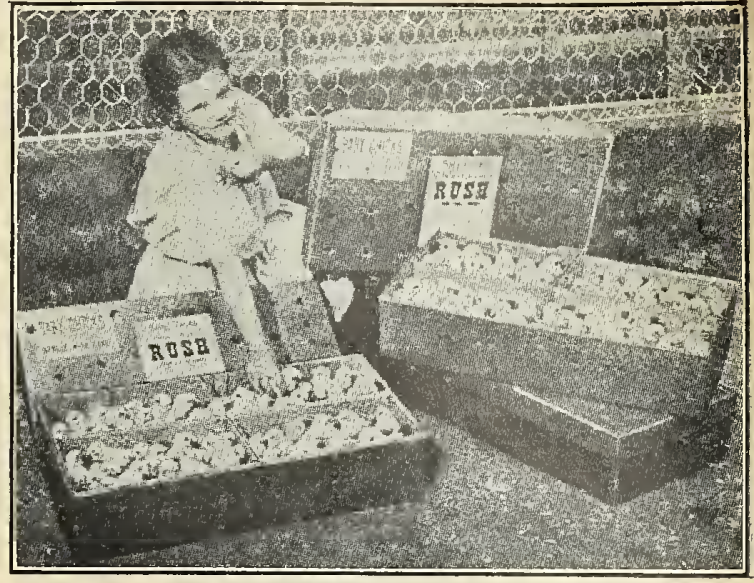

Looked As If They Had Just Come From Under The "Biddy"

March 31st, 1922, Mrs. L. O. Forbush, of Northumberland, Va., wrote: "The Baby Chicks (Barred Rocks) reached me tonight. I ordered 50 and there were 50 live ones and one dead one. I consider this remarkable indeed and they are every one lively and look as if they liad just come from under the "Biddy," but instead they liave traveled 150 miles-taking two days for the journey. Thanks."

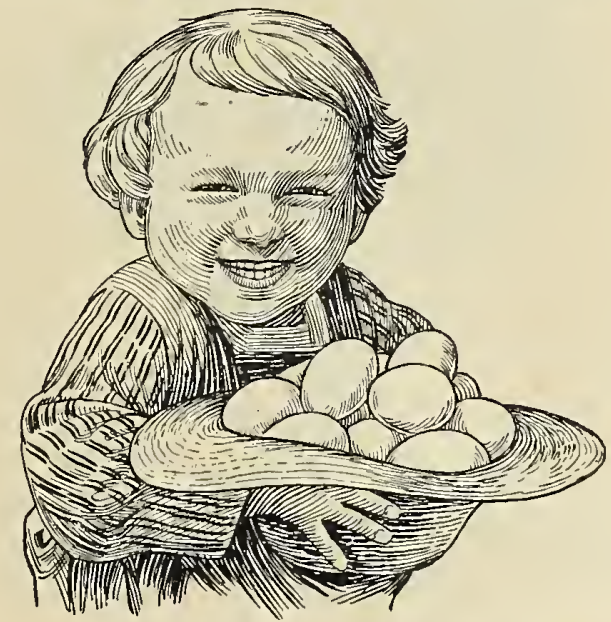

\section{About Ordering}

We are usually in a position to ship eggs for hatching and Day Old Chicks within a week from the date your order is received. IV c, howerer, advise you to allow us to book your order early, thereby aroiding all delays and the many disappointments that are bound to occur in the busiest part of the season.

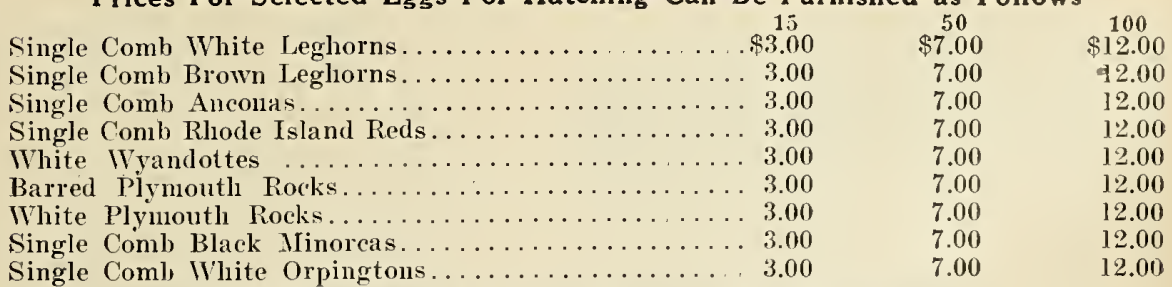

Directions For Feeding Baby Chicks First 8 Weeks

Give the chicks fresl water and fine grit from the start but no feed until they are 48 hours old. The yolk, absorbed into the system just before hateling out, is Nature's nourishment at this period and is all the chick requires. The fasting period gives the chick a cliance to assimilate the yolk, and removes the cause of many chick losses. through feeding too soon.

$\mathrm{By}$ fecding the chicks grit at the start the gizzard will be ready to perform its proper functions when the food is finally given to the chick. After the 48 lours have elapsed give tlie chicks Bolgiano's Buttermilk Starting Feed $d r y$ just as it comes from the bag but allow then very little the first few feeds. When 72 hours old give the chicks their first feed of Bolgiano's Square Deal Click Starter, scattering it five times per day in a clean litter of cut clover or alfalfa.

After six days place food in small feeding loppers to prevent waste, keeping it before them all the time. 
The J. Bolgiano Seed Co., Baltimore, Md.

\section{Our Live Stock Department}

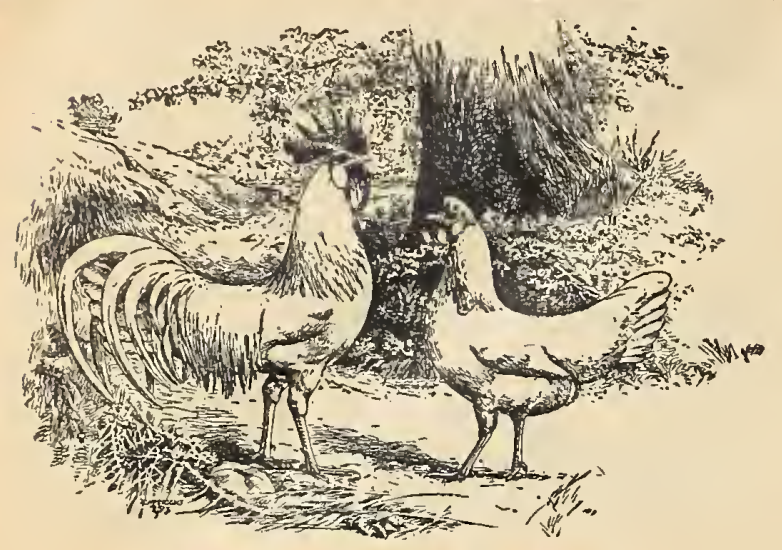

SINGLE-COMB WHITE LEGHORNS

The past few years we have been supplying the most popular standard varieties of poultry, both for breeding and commercial purposes. We have established our own Vital Strain of Thoroughbred Standard Varieties. Our first aim is for constitutional vigor, quick growth and good egg production within the breed.

We have produced a strain noted for heavy egg production during the fall and winter months, which months bring to the poultryman the very highest prices.

The factors necessary for best results, and especially during the natural period of low production, are as follows: Pullets hatched from good, thoroughbred stock, properly housed, ample floor space, cleanliness, pure food and water. Sunlight and fresh air, avoid draughts. Scratching in deep litter for the greater part of their food. Dry mash, oyster shells, grit, charcoal and fresh water before them at all times. Always feed plenty of green food in some form. This is important. Green food is a liealth preserver, an egg producer and cheapens the cost of production.

\section{Single Comb White Leghorns}

The Single Comb IVhite Leghorns are acknowledged to be the greatest producers of large white eggs. They are bred in large numbers on all extensive EGG FARMS, from Maine to California, and are bringing big money where properly cared for. Considering the amount of feed consumed, no breed ean show such good returns. The young male birds make excellent plump broilers, and they have rich yellow skin and shanks, making a fine appearance when shipped to the markets.

We are in a position to furnish single birds or pens of this breed.

We furnish each year about 100,000 Single-Comb White Leghorn baby chicks to satisfied customers.

Il will be to your advantage to order now and avoid disappointment later.

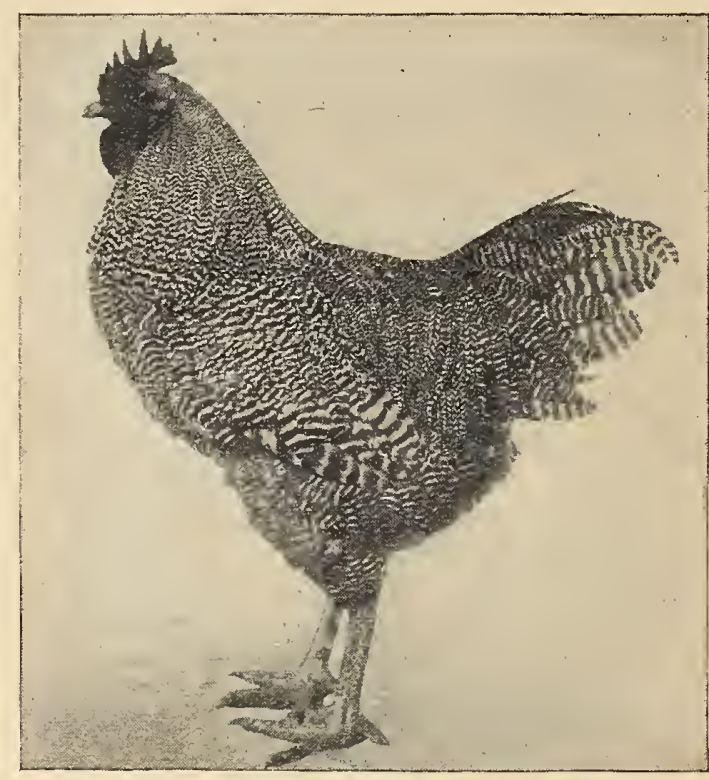

SINGLE-COMB BARRED ROCKS

\section{Barred Plymouth Rocks}

The Barred Plymouth Rock is most widely known as a general purpose fowl, a breed which has proven its value as a market fowl and an egg producer. They are extremely profitable and popular farm flock.

We are in a position to furnish single birds or pens of this breed from some of the best strains in the country at reasonable prices, qua lit y considered. DAY-OLD CHICKS and EGGS for HATCHING, in season, at popular prices.

\section{Rhode Island Reds}

As a "business hen" for eggs and meat they are hard to beat. They lay a well-shaped, good-sized brown egg, and mostly uniform in shape, size and color.

We lave fine Reds, good, quick, hardy growers, and good egg producers. ITe are in a position to furnish single birds or pens of this breed. We have planned to hatch approximately 75,000 Vital Hatch Rlode Island Red chicks this season,

\section{Just A Word in Regard to Prices}

Quality of stock cuts a big figure and the wants of buyers are many. Me can and will supply you with good utility breeders at the lowest prices possible-quality at all times considered.

If you want a male bird, a pair of birds or a pen of birds of any variety, for show purposes or for breeding show birds, lat us serve you. IVrite to us telling us what you want and what you can afford to pay. Our poultryman can and will gladly tell vol what quality and how many birds you can get for the amount named.

In serving our customers squarely and faithfully, we are serving ourselves.

We keep the old customer and we want the new. Then we tell you that 90 per cent of our orders the past year have been from customers of long standing, you can rest assured that you get a square-deal."

We strongly recommend the following varieties for Egg production-White Leghorns, Minorcas and Anconas, all of which are heavy layers of white shelled eggs.

For a general purpose fowl the Plymouth Rocks, Wyandottes, Rhode Island Reds and Orpingtons are in high favor.

Our prices are always reasonable, quality of stock considered.

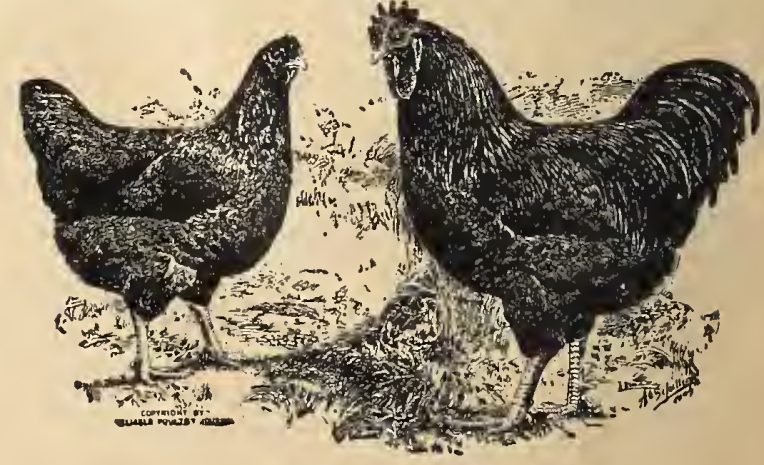




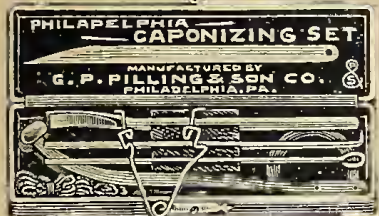

Philadelphia

Complete with Instructions, in Velvet-lined Case, as per Engraving...........\$2.75 Postpaid

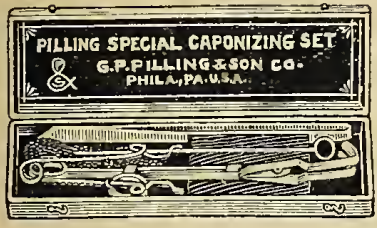

Pilling Special

It is just the same as other Caponizing Sets, except that the Testicle Remover cuts like a pair of scissors the cord of the testicle clean and clear as a whistle. The Instruments in this set are put up in Oak Case, sent postpaid with full, easy-to-use directions, on receipt of $\$ 4.00$.

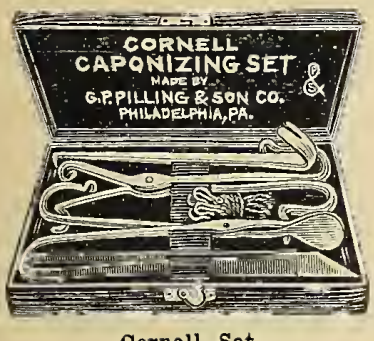

Cornell Set

Experiments in the use of various caponizing instruments recently carried on hy E. W. Benjamin, Instructor of the Department of Poultry Husbandry at Cornell University, have resulted in the manufacture by is of the Cornell Caponizing Set. This set-two testicle removers, Pill ing-Farmer twisting scoop and Pilling-Yiles re mover-sells for the reasonable price of $\$ 5.00$. Postpaid

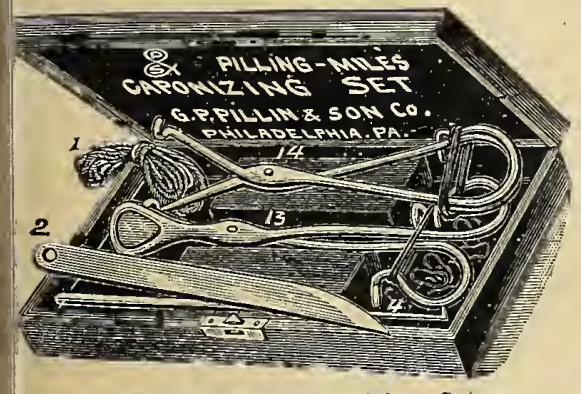

Pilling-Miles Caponizing Set

This set has many admirers, as it does away with horse hair. It consists of a innife for making the incision; the Spreader Forceps for holding the sides open; sharp book for catching the skin; the Loop Forceps for catching and removing. Cords with hooks are for holding the bird. They are very fine instruments, made of the finest steel and of the best workmanship. The above set, with instructions, in a fine velvetlined case, sent by prepaid mail on receipt. Price, $\$ 5.00$ each.

\section{What are Capons?}

A capon is a male bird (cockerel or rooster) from which the testicles bave been removed. As in other animals-bull, horse, boar; etc.-this operation changes bis nature entirely. He has only one function in life-to. get fat. The growtb is more rapid, the comb and wattles cease to grow, the bird is lazy, his plumage is heavy and very beautiful, the spurs do not develop, neither hen nor rooster lias any further use for him, and he seeks the company of the little chickens, brooding over them at night and leading them about during the day. He makes quick meat, tender meat, and much of it, and. best of all, he makes the highest-priced meat in the market. The uncaponized rooster runs his flesh off; he is always in trouble. Caponize good-for-nothing fowl-áll legs and appetiteand. presto! he is changed into the quiet Capon. IIis mission in life is now to convert his owner's food into the delicious and highly profitable meat. Properly killed and dressed, he attracts the attention of the best buyers-people to whom money is no object if they can get what they want.

\section{Best Time to Caponize}

Fowl hatched any time of the year make fine capons; no ill-results follow the operation at any time in the year. The bird should be from two to three months old (not over six months), and weigh not less than a pound and a half. The size is equally as important as the are. April, Nay, June, July, August, September and October are the months generally taken for caponizing, for the reason that spring chickens arrive at proper age and weight during these months; also because cockerels caponized then arrive at the proper age and weight for market during the months of November, December, January, Feb ruary, March, April and May, at which time there is the greatest demand for them in the cities and highest prices secured.

\section{Feeding Capons}

The ouestion is often askcd, "How are capons to be fed?" The answer is easily given. After caponizing, give the bird all he will eat of soft feed, and let him have plenty of water. Caponized fowl begin to eat almost immediately after the operation is performed, and no one would think for a moment that a radical change had been made in their nature.

\section{Points for the Learner}

The first question asked by the learner is, "How long does it take to caponize a bird?" We would say; "Make haste slowly." The first operation may take from fifteen to twenty minutes, but take your time; go slowly, but act quickly; note every point, keeping your thoughts intently on the work. The firs operation is your instructor; the second find: you master of the situation. After a little practice a bird can be caponized in tw minutes with the Pilling Sets,

\section{Killing and Dressing Capons for Market}

The capon should be allowed to grow unti at least one year old. By this time they are a beautiful bird, and will have attained an imposing size. Some keep them even longer than a year While this is optional with the raiser, we would not advocate killing them under one year old if they are being raised for market.

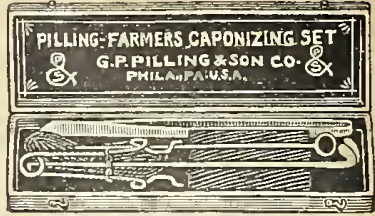

The Farnuer's Caponizing Set differs somewhat from the Philadelphia Caponizing Set, inasmuch that a twisting and tearing scoop is used instead of the Canula for removing the testicles.

Price, complete set of instruments in velvet-lined case, $\$ 3.00$ per Set, Prepaid.

\section{Lansdowne Capon Set}

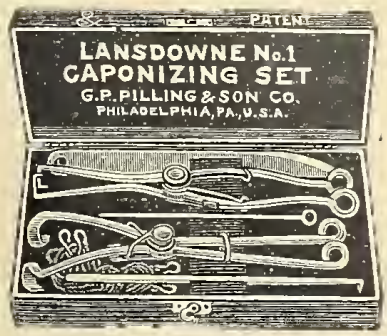

Lansdowne No. 1. Price $\$ 3,50$ Postpaid

Lansdowne Automatic Testicle Remover in Sets No. 1 and No. 2 (Pilling Patent) is, as its name implies, automatic-quick, easy to use and just the remover for the beginner.

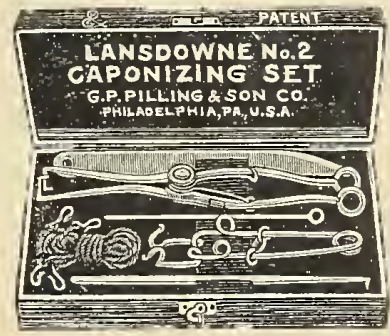

Lansdowne Set No, $2-\$ 3,00$ Postpaid

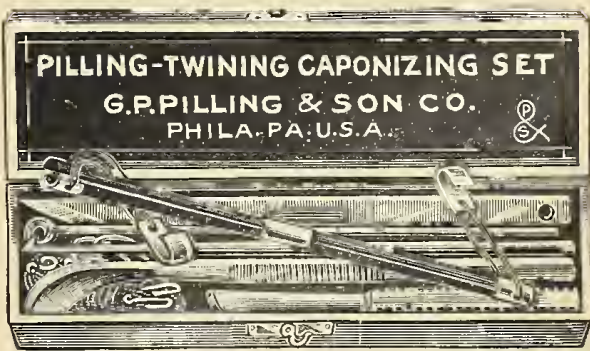

Pilling-Twining Caponizing Set

The Pilling-Twining Caponizing Set is the sane as the Philadelphia Set, except the Pilling.Twining Testical Remover takes the place of the im proved caponizing canula.

The instruments in this set are put up in Oak Case, sent postpaid, with full, easy-to-use directions, on receipt of $\$ \mathbf{4 . 0 0}$. 


\section{Pilling French Poultry Killing Knife}

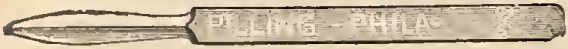

Every poultry raiser should have one of our Killing knives. They are made of a finely tem. pered instrument steel, with nickeled handle: will last a lifetime. Don't wait! Send for one now! Sent securely packed by mail, postpaid, on receipt of $60 \mathrm{c}$.

\section{Safe Edge Killing Knife}

FRENCH SAFE-EDGE KILLINE KNIFE \& $8 \times$

Exactly same as French Killer, except cut on one side only, Prepaid on receipt of $60 \mathrm{c}$.

\section{Russell's Killing Knife}

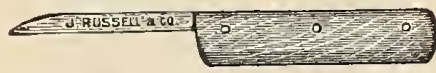

50c each. Postpaid 55c.
Parcel Pcst Table, See Page 2

Lansdowne Poultry Marker

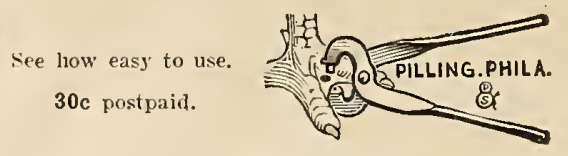

Perfect Poultry Marker

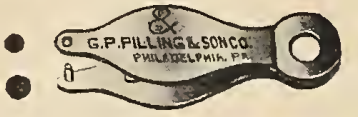

The best little chick marker ever made. Small and convenient to carry in the pocket. $30 \mathrm{c}$ postpaid.

Philadelphia Gape Worm Extractor

Postpaid, 30c each

\section{The Aluminized Metal Egg Crates}

solve the problem of shipping eggs, butter and other farm products by Parcel Post. Tbey are made for continued use, being strongly constructed but light in weight.

All crates are provided with built-in shock absorbers to give a cushion for the eggs. Fillers to hold the eggs are made for long life.

Netal Egg Crates do not require outside wrapping for mailing. A short string only is needed for tying "pin" which holds lid securely closed.

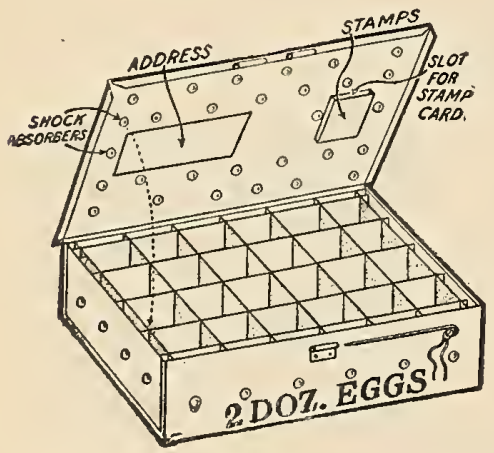

Metal Crates showing compartment for the "ggs, shock absorbers that prevent breaking. stamp card-reversible.

\section{Four Sizes}

Metal Egg Crates are made to hold two, three, four and six dozen eggs each; also combinationcrates to hold eggs and butter of different crates to

\section{High Cost of City Products}

The cost of living ean be oreatly reduced by buying eggs. butter and other costly produce direct from the farmer, shipped in the Combination Crates.

Reversible address card to be placed over eggs, address visible through opening in lid. Names of shipper and receiver are placed on each side of this card.

\section{Prices-Eggs only}

Two dozen size-all eggs. ... $\$ 1,00$ Three dozen size-all eggs... 1.25

Four dozen size all eggs.... 1.50 Six dozen size-all eggs.... 1.75 Combination butter and eggs.

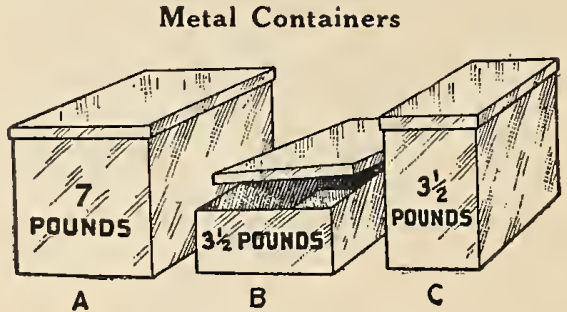

Combination Crates

Any size Combination Crate desired can be upplied to carry egg 3 with Metal Containers to lold butter, lard, sausage, honey, cut-up chicken, country sliced ham, etc. Any of these Combination Crates will be found surprisingly satisfactory. Butter, lard and other soft products will not melt or run in warmest weather.

\section{Combination Crates-Butter and Eggs} No. 1-A container-2 doz. eggs......... \$1.75 No. 2-B container -1 doz. eggs......... 1.50 No. $3-\mathrm{C}$ container -2 doz. eggs $\ldots \ldots \ldots \ldots \ldots$
No. $4-\mathrm{B}$ container-3 doz. eggs. $\ldots \ldots \ldots \ldots$
1.85

\section{Butter Only}

No. 5-Two A containers............. $\$ 2.50$

No. 6 - Two B containers................

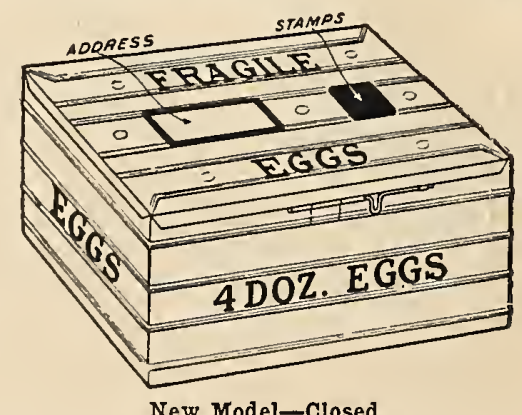

New Model-Closed
Roup Syringe

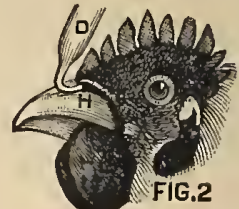

This is one of the cures for roup and similar diseases to which poultry are so liable. Can be nsed either internally or externally. 15c each. Postpaid.

Nickel-Plated Rabbit Spreaders Price ...............30c each. Postpaid

Imported Telescopic Judges Sticks

The best judges' stick on the market. Neat. strong, durable and compact. Made of brass tubing. with Japamed handle, and easily carried in the pocket. When closed, all sizes measure 9 inches long.

Small size, 16 inches opened.......... \$.90 Mediun size, 23 inches opened.......... 1.25

Large size, 29 inches opened......... 1.75 Mailing weight, $1 \mathrm{lb}$. each.

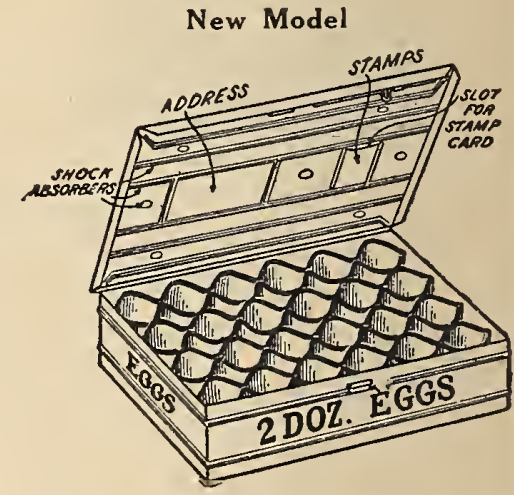

This is the New Yodel with the metal edged filler and it is a wonder. Solves every problem of shipping egos and butter and other soft products by mail. Built for continued use; practically indestructible; lasts for years. No wrapping is required. A permanent lock pin that does not lose, holds the lid rigidly closed.

\section{Reversible Address Cards}

Reversible address cards are. placed over eggs. address visible through opening in lid. Names o shipper and receiver are placed on each side of this card.

\section{Metal Edge Filler}

This is a wonder-so strongly made that it will not require replacements. Every user praises the New Model, with the Metal Edge Filler. Nothing better can be made to stand the jar and shocks in transit.

$$
\text { Prices-Eggs Only }
$$

Two dozen size - all egms . . . \$1.50

Three dozen size-all eggs.... 1.75

Four dozen size-all eggs.... 2.00

Six dozen size-all eggs..... 2.50
Postage Empty Filled $7 \mathrm{c} 9 \mathrm{c}$ $7 \mathrm{c} \quad 10 \mathrm{c}$ $8 \mathrm{c} \quad 12 \mathrm{c}$ $9 \mathrm{c} \quad 15 \mathrm{c}$ 


\section{Anderson Egg Box}
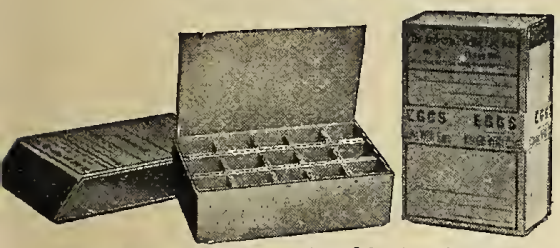

A strong collapsible box for shipping fancy eggs.

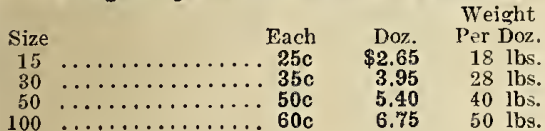

Master Breeders Chick Box

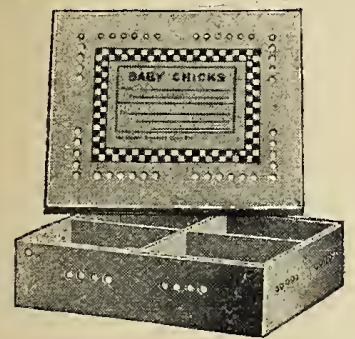

"It is important to have baby chicks arrive in a healthy condition. Baby chicks cannot be safely. nor humanely shipped when jamined in "like sardines," nor-on the oth

The "Master" package is designed for coinfort and safety of contents. It is protective. roomy, handsome-a safe, suitable "Pullman Car " for the fluffy youngsters within. The construction is exceptionally strong, light in weight and well ventilated through holes cut in both the body and

Anderson "Master" breeder Chick Boxes are made correct to the sizes and specifications which liare beell approved by the International Baby Chick Association."

Size Each Per Doz. Per Doz. 25 Chicks, $11 \times 9 \times 51 / 2 \ldots 20 \mathrm{c} \quad \$ 1.60 \quad 12 \mathrm{lbs}$. 50 Chicks, $18 \times 11 \times 51 / 2 \ldots 25 \mathrm{c} \quad 2.25 \quad 16 \mathrm{lbs}$. 100 Chicks, $22 \times 18 \times 51 / 2 \ldots 30 \mathrm{c} \quad \mathbf{3 . 0 0} 30 \mathrm{lbs}$

\section{Andrews' Efficiency Baby Chick Carriers}

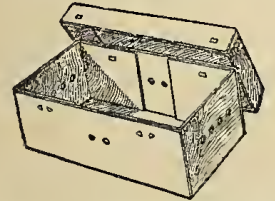

Makes "Safe-chick-delivery guarantee" a safe thing for then and also pleases their customer when they see lively, healthy chicks arrive 0 . K. Isn't that exactly what you're after? "Ask the Judges."

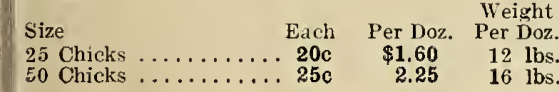
trouble for the seller. They knock down in a very

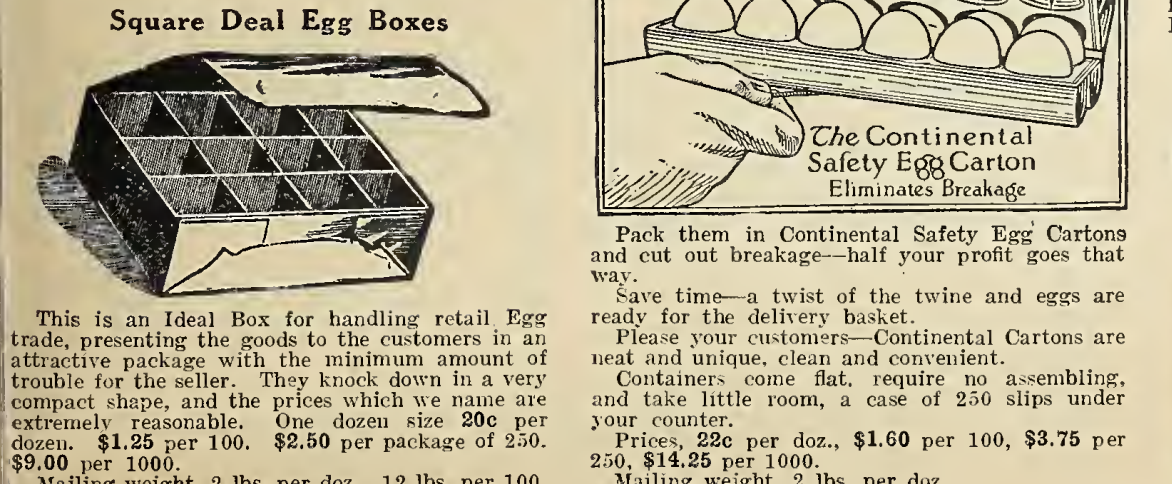

Parcel Post Table, See Page 2

Corrugated Parcel Post Egg Bores

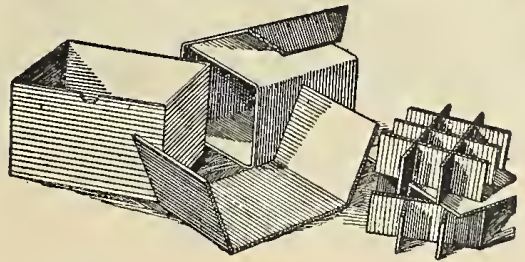

Weight

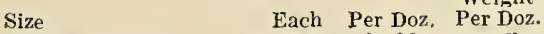

1 dozen .......... 8c $8.90 \quad 8$ lbs.

2 dozen $\ldots \ldots \ldots \ldots \ldots \ldots$ 11c $1.20 \quad 12 \mathrm{lbs}$

3 dozen $\ldots \ldots \ldots \ldots \ldots \ldots$ 13c $\quad 1.40 \quad 16 \mathrm{lbs}$

4 dozen $\ldots \ldots \ldots \ldots \ldots .19 \mathrm{c} \quad 2.20 \quad 21 \mathrm{lbs}$

5 dozen .........22c $2.40 \quad 24 \mathrm{lbs}$

6 dozen ......... 31c $\quad 3.40 \quad 28 \mathrm{lbs}$

10 dozen $\ldots \ldots \ldots \ldots \ldots .3 \%$ 37c $\quad 3.70 \quad 40 \mathrm{lbs}$

HOW ABOUT THAT SHOW?

You'll Need a Shipping Coop Eyrie Shipping Coop

Made of corrugated pasteboard, will carry any distance, saves expressage and always delivers the contents in good shape. Shipped knocked do w 11 and takes up very little space in stockroom.

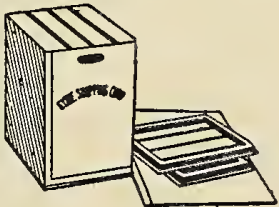
Eyrie Shipping Coops

Too large for mailing.

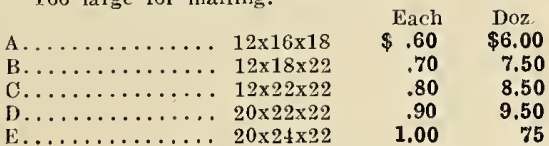

Andrews' Koop De Luxe

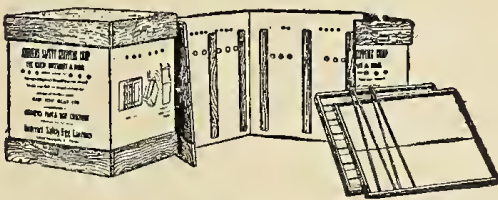

Too large for mailing.

This is a specially constructed Koop fool-proof and extra strong, for shipping high-grade birds.

$\begin{array}{lll}\text { Siingle size } \ldots \ldots \ldots \ldots \ldots \ldots \ldots & 22 \times 13 \times 24 & \begin{array}{r}\text { Each } \\ \$ 1.00\end{array} \\ \text { Double size } \ldots \ldots \ldots \ldots \ldots \ldots & 22 \times 19 \times 24 \\ \text { Pen size } \ldots \ldots \ldots \ldots \ldots \ldots & 22 \times 23 \times 24 & \begin{array}{r}1.25 \\ 1.50\end{array}\end{array}$

Safety First

How to Make More Money Out of Eggs

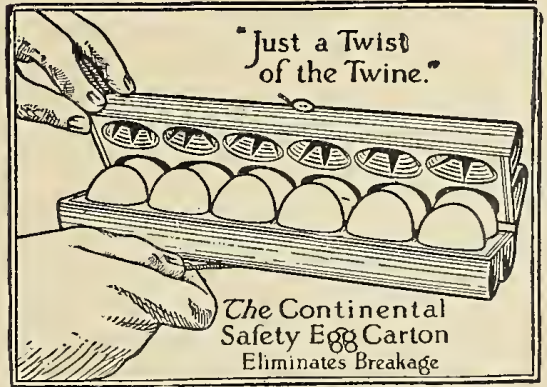

Humpty Dumpty Folding Egg Crate

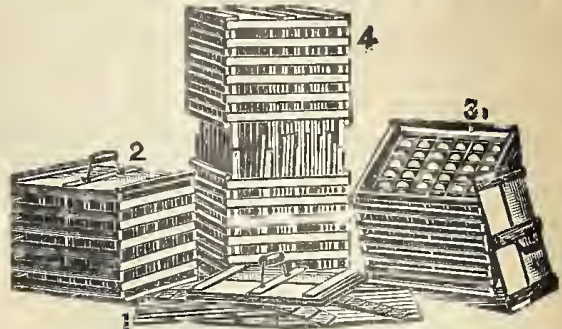

Fig. 1, folded flat; Fig. 2, set up closed ; Fig. 3 set up open; Fig. 4 shows half dozen complete ready for shipment. A very light, strong and convenient egg erate and carrier. Made of hard wood slats securely fastened. The lid, with handle, springs into position when crate is filled.

Capacity

14 Eggs

Each Per Doz

Egg Case Fillers

Cardboard fillers for the ordinary 30 dozen market case come packed in cases of 15 sets per case (150 fillers, 120 flats) for $\$ 2.25$ per case; less than case, 25c per dozen.

Mailing weight, 4 lbs, per set.

\section{H. and D. Egg Boxes}

Size
$30 \mathrm{egg}$ Each Doz.
$10 \mathrm{c}$
$\$ 1.00$

Weight

15 lbs.

\section{Fire-Fly Tester}

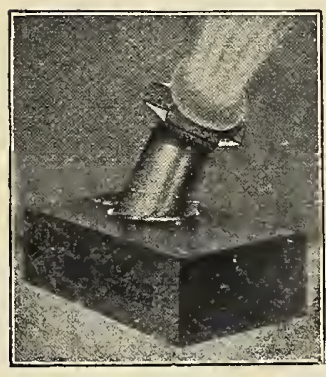

It's Electric Equipped with the Latest Im. proved Tungsten

Battery

Shows condition of egg at a glanceno heat generated to injure the egg no danger of fire or smoke.

Will Test Fifteen to Twenty Thousand Eggs Without Renewal of Battery. All you have to do is to place tbe egg in egg and the light is gone.

Price Complete, $\$ 5.00$

Mailing weight, 5 lbs.

\section{Egg Tester}

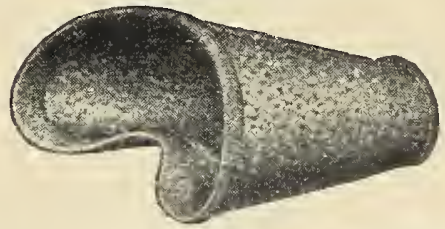

An egg tester is a liandy article to have. By its use the progress of the hatching chicks can be observed, and eggs that are infertile may be removed from the machine.

Our Buckove Ego Tester is a simple device that our ing made of heavy steel, it cannot wear out or get out of order. Price, $50 \mathrm{c}$ each. Mailing weight, $1 \mathrm{lb}$

Egg Testers-All Tin, 35c Each.
This is an Ideal Box for handling retail Egg trade, presenting the goods to the customers in an attractive package with the minimum amount of compact shape, and the prices which we name are extremely reasonable. One dozen size $20 \mathrm{c}$ per dozen. $\$ 1.25$ per 100 . $\$ 2.50$ per package of 250 $\$ 9.00$ per 1000

Mailing weight, 2 lbs. per doz. 12 lbs. per 100

Pack them in Continental Safety Egr Cartons and cut out breakage--half your profit goes that and

Save time-a twist of the twine and eggs are ready for the delivery basket.

Please your customers-Continental Cartons are neat and unique, clean and conrenient.

Container come flat. require no assembling, and take little room, a case of 250 slips under your counter.

Prices, 22c per doz., $\$ 1.60$ per $100, \$ 3.75$ per $250, \$ 14.25$ per 1000

Mailing weight, 2 lbs. per doz.

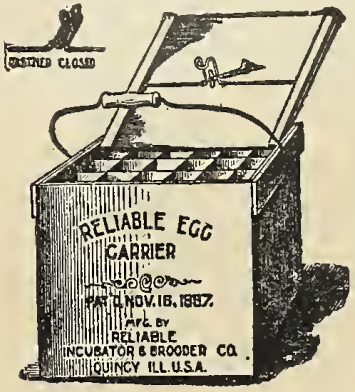

Reliable

Egg

Carriers

12 dozen size, with patent fastener, cover lift and bale.

Price, each, $90 \mathrm{c}$ 


\section{THE BUCKEYE HAS NO SUPERIOR}

\section{THE INCUBATOR OF UNFAILING RESULTS}

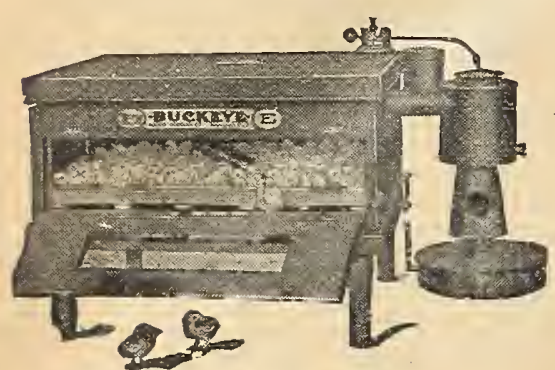

No. 14

Style E

Weigbt, crated for shipment, 56 lbs.

Weigbt, crated for shipment, 56 .

No. 14 is especially adapted for use by the small raiser. It has all the important features of the larger machines, such as visible thermometer, and the Buckeye heating and ventilating system. The temperature is easily regulated and the consumption of oil is low.

the 16 . Style E Capacity 110 eqrs; weight. No. 16, style E. Capacity 110 Price, weight, (a) This machine is the same as No. 14, except that it has a greater egg capacity and long leg.

instead of short ones. Capacity 210 eggs; weight, crated for shipment, 132 pounds. Price, $\$ 36.75$. Same as No. 16, except that it has greater egg capacity.

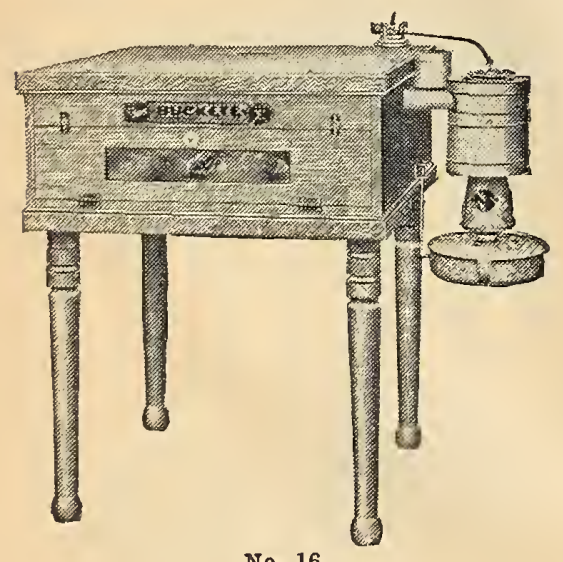

No. 16

Style $\mathbf{E}$

110 Eggs

Price $\$ 27.50$ All stvle $\mathrm{E}$ incubators have ingle walls and
are equípped with galvanized rust-resisting heaters.

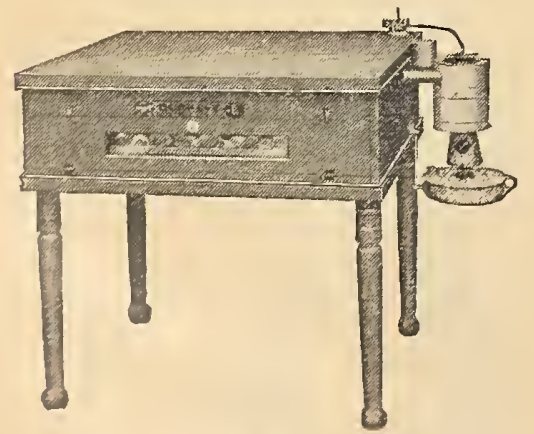

No. 17

210 Eggs

Price $\$ 36.75$
For thirty years it has been producing increasingly greater hatches for large and small poultry raisers, until today there are OVER HALF A MILLION Buckeyes in operation.

\section{A Proven Producer}

The superiority of the Buckeye has been PROVEN TIME AND TIME AGAIN by experiments and comparisons with ALL other incubators. Agricultural Colleges, Experiment Stations, ten thousand dealers and half a million users - MEN WHO KNOW-liave unqualifiedly conceded its leadership.

\section{Quality Built Throughout}

The Buckeye is built to last. Fibre board (paste board) and other impractical materials do not enter into its construction. The genuine redwood cabinet stands up under any atmospheric change. The Buckeye double lock-seamed, circulating lot water system is conceded by every authority to be the BEST METHOD OF INCUBATOR HEATING. The galvanized iron oil lamp and boiler is fire-proof and fool-proof, and is capable of bringing the temperature of the egg chamber up to 103 degrees within an hour. The patented Buckeye Thermostat keeps an even moist temperature in the egg chamber at all times-these are the things that have given the BUCKEYE a reputation for unfailing results and have made it the LEADER IN THE INCUBATOR FIELD. In every phase of construction, and in day-in-and-out service, the BUCKEYE MUST PERFORM BETTER. An ironclad guarantee assures this.

\section{A Binding Guarantee}

Besides being guaranteed to hatch more chicks out of a given number of hatchable eggs than any other incubator, the Buckeye is guaranteed to operate satisfactorily in any temperature down to freezing; to require no artificial moisture; to demand no attention to the regulator from the time the hatch is started until it is finished and to be perfect in construction. SOLD ON 40 DAYS' APPROVAL. ANY BUCKEYE INCUBATOR THAT FAILS IN ANY WAY WILL BE REPLACED without question.

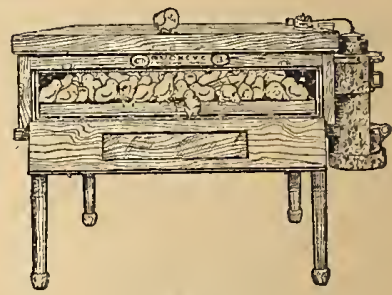

No. 1

Standard

110 Eggs

Príce $\$ 37.50$

No. 1 Standard has a capacity of 110 hen eggs, or 85 duck egos. It is complete in every detail, and is ready for immediate use. The weight crated for slijpment, is 104 pounds. This incubator is insurable, and bears the Underwriters' label. An improved feature of all Standard incubators is the enclosed lamp. Equipped with oil bators is the

or gas heater.
No. 2 Standard has a capacity of 175 hen eggs or 140 duck eggs, is equipped with oil or ga heater, and is complete and ready for usc. Weight crated for shipment, 129 pounds. This machine is insurable, and bears the Underwriters' label. Príce, $\$ 44.50$.

No. 3 Standard has a capacity of 250 hen eggs or 200 duck egrs, is equipped with oil or leater, and is complete and ready for use. Weight, heater, and is complete and ready for use. Weight is insurable, and bears the Underwriters' label. Price, $\$ 57.75$.

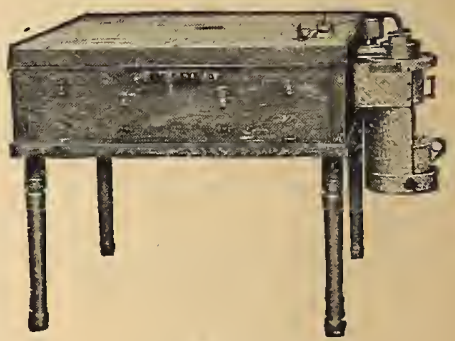

No. 3

Standard

250 Eggs

Price $\$ 57.75$

No, 4 Standard has a capacity of 350 hen eggs or 280 duck eggs. Equipped with oil or ga heater. and is ready for use. Weight, crated for shipment, 206 pounds. Insurable, and bear Underwriters' label. This machine is very convenient for the commercial raiser Price, $\$ 68.00$ No. 5 Standard (Mammoth Standard). CapaNo. 5 Standard (Mammoth standard). Capadimensions, 54 inches square, 36 inches high Equipped with four egg trays, holding 150 egg Equipped with four egg trays, holding 150 eggs each Double doors on front and back; oil or
gas heater. Complete and ready for use. Bears Underwriters' label. Weight, crated for shipment, Underwriters' label. Weight,
314 pounds. Price, $\$ 107.00$.

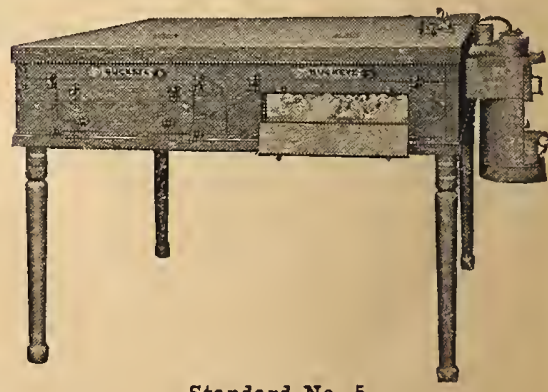

Standard No. 5

$600 \mathrm{Eggs}$

Price $\$ 107.00$ 


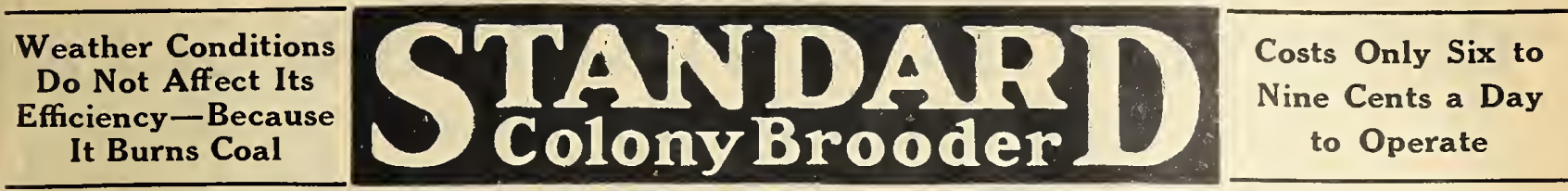

\section{THE BROODER THAT BROODS ALL THE TIME}

The Standard Colony Brooder is on the job all the time-not twenty-three out of twenty-four, but every single hour of the day all night. The Standard Colony Brooder burns coal-the fuel that is conceded to be the best for any purpose.

\section{INEXPENSIVE-AUTOMATICALLY REGULATED}

The self-regulating coal-burning stove of a Standard Brooder provides adequate heat under any and every conceivable weather condition. It is inexpensive to operate. It burns only six to nine cents' worth of coal a day and requires filling only once in every twenty-four hours. The patented buckeye thermostat automatically regulates the heat according to changing

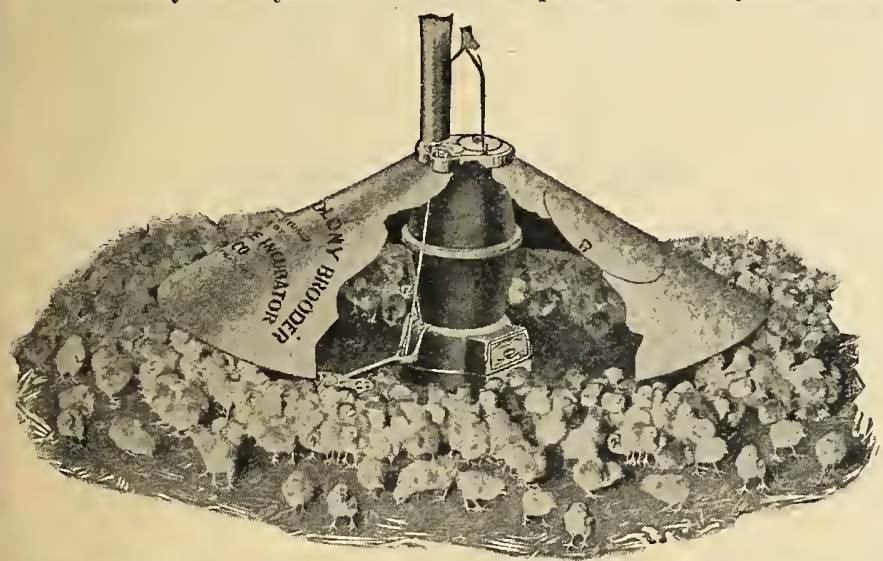

Showing a Buckeye Colony Brooder in Operation with 1000 Chicks weather conditions. There are no curtains or wooden walls to harbor vermin or disease; no corners where chicks may be crowded or killed; no fume-laden air to poison the chicks; ABSOLUTELY NOTHING TO PREVENT THE FREE CIRCULATION OF FRESH, WARM, HEALTHFUL ATR. By its steady, dependable performance, the Standard has won the endorsement of Agricultural Colleges and Experiment Stations throughout the country. Decide today to put your chicks under a Standard Colony Brooder and stop the profit-killing loss of healthy chicks.

\section{WRITE YOUR OWN GUARANTEE FOR THIS BETTER BROODER}

Write down all the things that you demand of a brooderand we will sign it. If it does not meet all your require ments and our claims, we will return your money without argument.

\begin{tabular}{|c|c|c|c|c|c|c|c|}
\hline No. & $\begin{array}{l}\text { Diameter } \\
\text { of Canopy }\end{array}$ & Capacity & $\begin{array}{l}\text { Height of } \\
\text { Stove }\end{array}$ & $\begin{array}{l}\text { Diameter } \\
\text { of Base }\end{array}$ & $\begin{array}{l}\text { Diameter } \\
\text { of Grate }\end{array}$ & $\begin{array}{l}\text { Shipping } \\
\text { Weight } \\
\text { Complete }\end{array}$ & Price \\
\hline 18 & 42 inch. & 500 Chicks & 20 inch. & 11 inch. & $81 / 4$ inch. & 75 Lbs. & $\$ 21.50$ \\
\hline 19 & 52 inch. & 1000 Chicks & $211 / 2$ inch. & 12 inch. & 9 inch. & $95 \mathrm{Lbs}$. & 26.50 \\
\hline 25 & 56 inch. & 1200 Chicks & 24 inch. & 14 inch. & 10 inch. & 109 Lbs. & 30.00 \\
\hline
\end{tabular}

\section{BUCKEYE PORTABLE BROODERS}

\section{Self-Feeding}

\section{Self-Regulating}

Everlasting

Cuts the Cost of Equipment and Operation to Less Than Half-Reduces the Time and Labor to Less Than a Fourth. Nothing to Break. Nothing to Wear Out. The Simplest, Safest and Most Economical Brooder Ever Invented.

BUCKEYE BROODER STOVES will do anything any other brooder will do-regardless of price-and do it better. It matters not whether you have ten or ten hundred chicks under a Standard Colony Brooder, the results are the same. You can remove part of the chicks or increase the number at any time.

Air Always Pure and Fresh_-No dampers or valves of any kind between the smoke pipe and the fire, the draft being controlled automatically, an exclusive feature of the Standard Colony Brooder and the only coal-burning Brooder that is absolutely free from gases under the Hover.

operated Anywhere-No room is too large or too small for a Standard Colony Brooder. Whether it is operated in the largest barn or the smallest colony house, the results will be the same.

Burns any Fuel-Hard or soft coal, charcoal, coke, briquettes or gas. Hard coal is best simply becausc it is cleaner. All fuel should be nut size.

Regulator-Two double dise thermostats-tandem litehed-supported on substantial casting that is bolted solidly to stove. Lower arm movable and attached to check valve by substantial iron rod. Chick-proof, accurate and positive.

Standard Colony Brooder is fire-proof, simple and requires little attention; has but one adjusting nut which you need never touch more than once in a season. Requires absolutely no nore attention than filling with coal once a day, shaking down the ashes into the pan twice.

The first cost is the only cost. Nothing to wear out. Nothing to break, being made of cast iron just like a kitclien range, and the Hover is of galvanized steel built to last a lifetime.

No. 20

Diam., 19 Inches Capacity,

$\$ 11.75$
No. 21

Diam., 22 Inches Capacity, 100 Chicks.

$\$ 15.50$
No. 22

Diam., 30 Inches Capacity, 150 Chicks

$\$ 19.00$

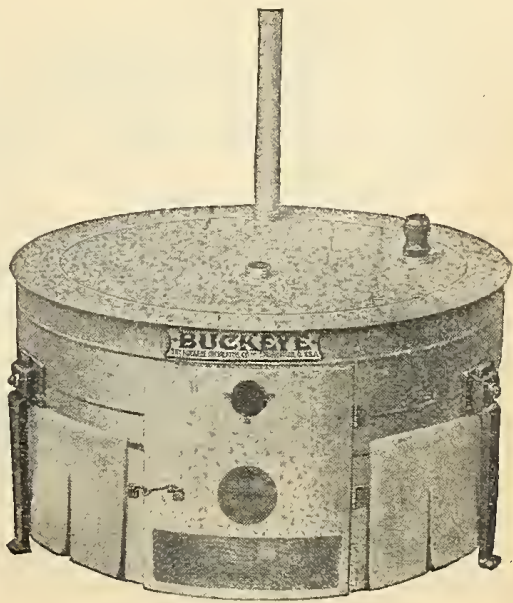




\section{“IMPROVED" BLUE-FLAME BROODERS REGULATED WITH A WICK!}

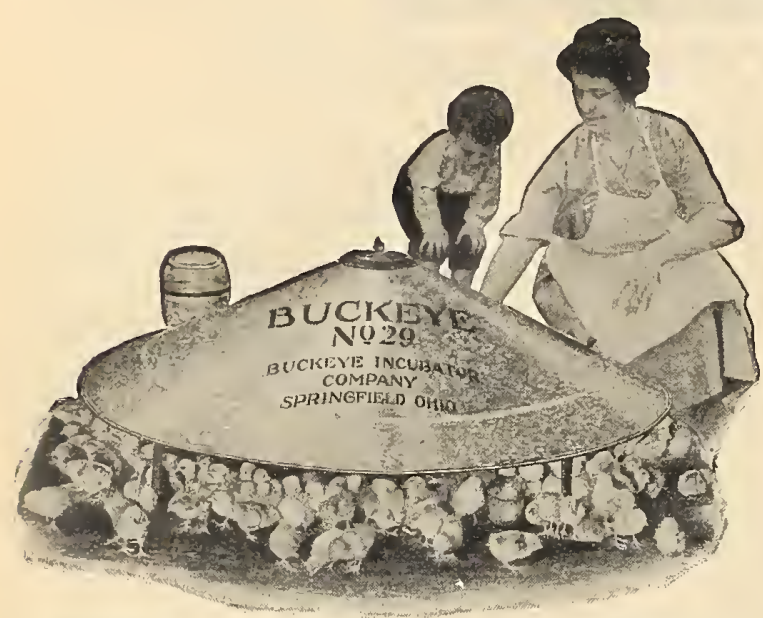

Showing Brooder in operation. A convenient door enables the operator to reach the burner without removing the canopy.

In the construction of this new brooder valves of erery character have been entirely eliminated. Two years' experience proved beyond question that valves of any type were both dangerous and impractical.

We show below an illustration of the burner that we are placing on all "Improved" Blue-Flame Brooders. This burner operates on exactly the same principle as the wickless burners which we have used in the past, but instead of depending on the level of the oil, or the feeding of the oil throngh a valve, the oil is fed to the burner by an old-fashioned wick such as everybody understands. It is a new development of an old principle and was discovered by one of the most efficient oilgas engineers in the United States.

\section{EASY TO OPERATE}

This "Improved" Buckeye burner requires no priming whatsoever. To start the burner, it is only necessary to raise the drum, apply a match to the wick and drop the drum in place again. The lighting process is exactly like lighting an ordinary house lamp and the size of the flame is controlled in precisely the same manner. To secure more heat the wick is turned up and to reduce the heat it is turned down. The application of this principle of regulation to a Blue-Flame Brooder will be welcomed with enthusiasm, as it is not only positive in its operation, but more important than that-it requires no special education to operate it.

\section{ECONOMY IN OIL CONSUMPTION}

The simplicity of the "Improved" Buckeye Blue-Flame Brooder is almost mubelievable. 'The oil is fed by gravity in the usual way direct to the burner and the amount of oil necessary to generate the required amount of heat is controlled entirely by the height to which the wick is turned. The position of the wick is controlled by the same type of lever that is found on the ordinary house lamp. The efficiency of the "Tmproved" Buckeye Blue-Flame Brooder is eminently superior to anything we have previously used. It not only produces a greater rolume of heat, but it does it with a smaller consumption of oil. This new "Buckeye" burner will not consume more than a gallon of oil in twenty-four hours under the most severe conditions and when used with the smaller hovers two quarts of oil will suffice in mild weather. This remarkable economy in oil consumption is made possible by mixing a larger proportion of air with the oil-gas than has heretofore been possible in other types of burners.

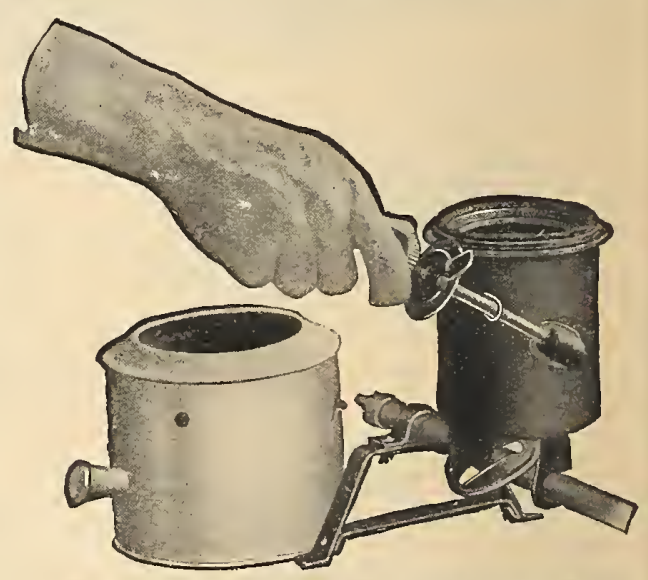

Showing the new burner with drum removed to expose the wick and the very simple method of turning it up or down.

\section{FILLS EVERY REQUIREMENT}

The "Improved" Buckeye Blue-Flame Brooder is positively insured against the clogging of oil or flushing the lurner. The large free chanmels guard against all chance of stopping the oil supply and a continuous supply of heat is therefore assured during every minute of the day and night. Just so long as any oil remains in the reservoir, it will be fed to the burner with absolute certainty, so with an assnred supply of oil to the burner and a system of

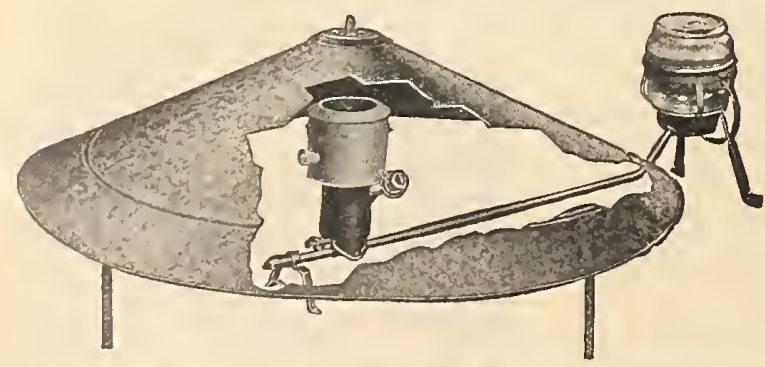

Showing an "Improved" Buckeye Blue Flame Brooder with a portion of the canopy cut away to show the general appearance of the new burner. regulation that camnot go wrong we have a brooder that should fill every requirement and satisfy every user.

\section{MADE IN THREE SIZES}

\begin{tabular}{llllr} 
No. & \multicolumn{2}{c}{ Capacity } & Diameter & Price \\
27 & $\ldots \ldots \ldots \ldots$ & 200 Chicks & 34 in. & $\$ 17.50$ \\
28 & $\ldots \ldots \ldots \ldots$ & 350 Chicks & 42 in. & 20.00 \\
29 & $\ldots \ldots \ldots \ldots$ & 500 Chicks & 52 in. & 22.50
\end{tabular}




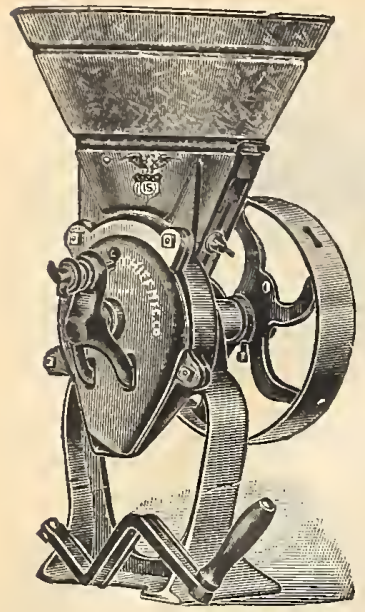

Power Mill No. 15

\section{"Red Chief" Corn Sheller}

This is our Famous No. 20 Grinding Mill with Sheller and Meal Attachment.

One man with a two-horse engine can shell and grind twelve bushels or more of feed per hour, and while grinding feed save all the Table Meal he can use.

A Hand Crank with every Sheller enables the operator to shell Seed Corn by detaching sprocket chain and reversing spout.

These devices can be attached to any No. 20 Mill now in use by any farmer. You can buy any or all of these attacliments, each being detachable.

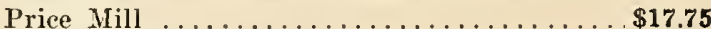

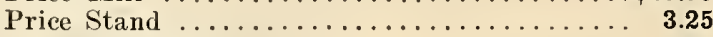

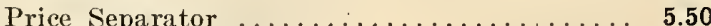

Price Power Sheller................ 8.00

Total ................. \$34.50

\section{The "Red Chief" Power Mill No. 15} PRICE \$12.75

For Engine Three-Quarter Horse Power and Over

The best Power Mill on the market.

It has best Bronze Poxes, Steel Axles-in fact, all of the good features of the No. 20 , except that it has no loose pulley and the capacity is not so great.

It can be run easily with a crank when engine is not running Capacity, 6 to 8 Bushels Feed per Hour

\section{The "Red Chief" Power Mill No. 20} PRICE \$17.75

For Grinding Corn Meal, Graham Flour, Stock Feed, etc.

With a speed of 300 to 450 revolutions per minute will grind 10 to 20 bushels feed per hour. Power required, $1 \frac{1}{2}$ to 2 horse power engine. Hand crank for use when engine is not running. A child can grind a bushel of chicken feed by hand in 10 minutes. Patent tension for regulating size of ground material, making change of Burrs unnecessary. Tight and loose pulley, 10 inches in diameter, $21 / 4$-inch face. Reversible belt shift, Feed Regulator. All bearings Bronze Bearing Metal. Weight, erated, 100 pounds. Painted red and blue with bronze trimmings.

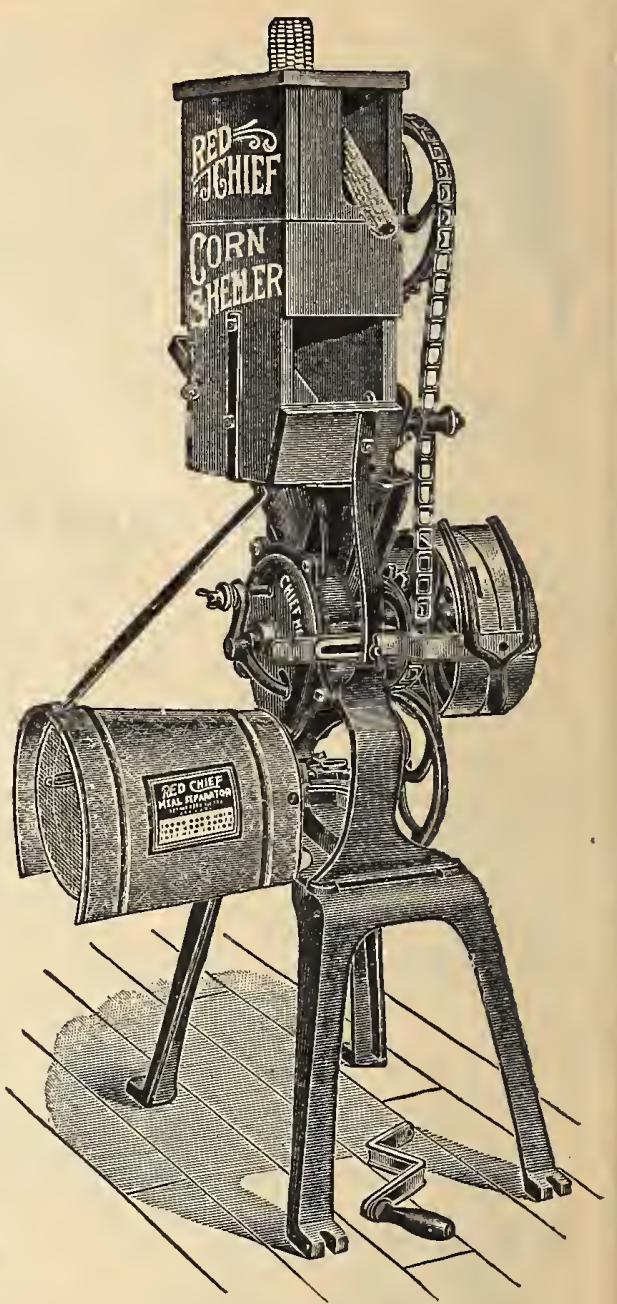

Fed Chief Corn Sheller

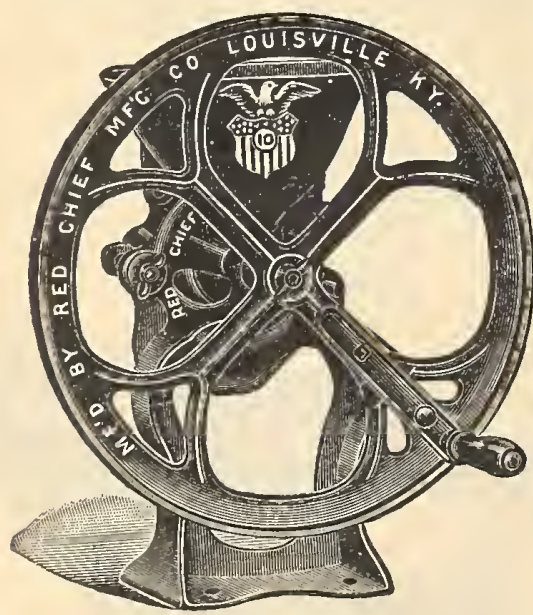

\section{The "Red Chief" Rapid Grinding Feed and Grist Mill No. 5}

A Perfect Hand Power Crinding Mill PRICE $\$ 6.25$

The flywheel makes the Mill run steady and with the least possible power to turn it. With the erank extended there is no Mill that will run as easy.

\section{The "Red Chief" Mill No. 10}

\section{No. 10-PRICE $\$ 7.75$}

Capacity, 2 to 4 Bushels per Hour

Equipped with extra-hardened burrs. Burrs are self-sharpening; they eut-do not

Grinds Coffee, Chicken Feed, and cracks Peas, ete. Will make good Corn Meal and Graham Flour. Can be cleaned and adjusted in a moment's time without the use of a wrench

It has beautiful outlines, and makes an excellent Coffee and Spice Mill for grocers' or family use, as well as being a very rapid grinder of Chicken Feed or Meal; also Oystei Shells and Dry Bone.

Feed Gauge in Hopper

New Fine Grinding Burrs

The only line of Mills that can be taken apart, eleaned and put together in a few minutes witlout wrench or screwdriver. 
The J. Bolgiano Seed Co., Baltimore, Md.

\section{The Norwich Automatic Feeders}

Parcel Post Table, See Page 2

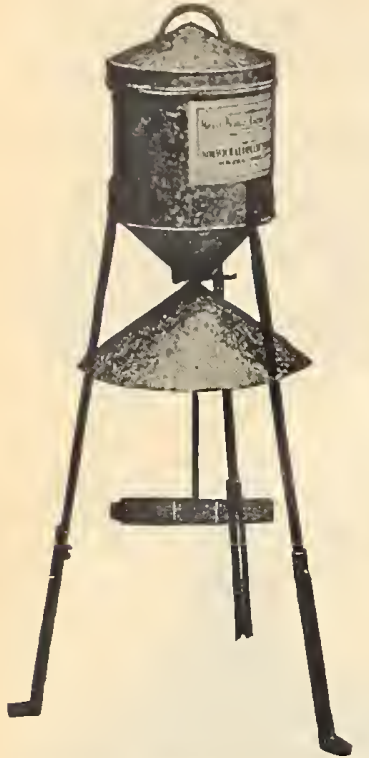

Norwich Automatic Feeder
THE TORWLH AUTOMLTIC E.TE ClFE AND FEEDER is as near perfection as human intelligence, coupled to a long experience in poultry raising, can produce it. Every detail from the operation and construction of the Bait Bar to the form and construction of the cover of the Hopper las had our undivided attention, and the whole machine may be relied upon as fulfilling every requirement of the much-rlesired derice for the automatic feeding of poultry.

The machine consists of a Hopper sufficiently large to carry a given quantity of grain feed, in the bottom of which is fitted an adjusting valve, which is set to allow such quantitics of feed to escape from the Hopper as may be desired. Directly under the valve is located the Deflector and the feed, passing from the Hopper through the valve, falls at once to the Deflector and by it is scattered on the ground or floor in a wide even circle.

The Bait Bar (which is the cross piece under the Deflector resembling an ear of coril) is connected by adjustable rod with a swall agitating disk which performs the double duty of acting as a stop to the valse, and stirring up the feed about to be valse, and stirring up
be ubserved, is mounted delivered. The machine, as will be observed, is mounted on three adjustable iron legs, so it will stand in any yard, whether level or located on a hillside, and may bc the adult fowl by simply lengthening or shortening the legs as desired.

The Norwich Chick Feeder

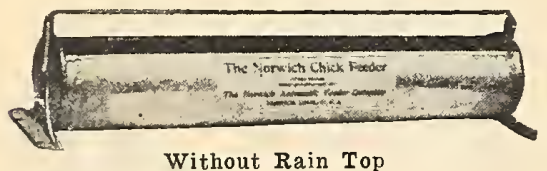

Convex in shape, it is impossible for the chicks to put. out and scatter the feed and its saving feature is, therefore, at once apparent. Fitted with a remorabie guard rod it is a physical impossibility for the chichs to get into the feed and the rod is too small to permit their standing or roosting on it-hence we have a device in which pollution is absolutely aroided and in which therc is 110 waste of feed.

The body of the Norwich Chick Feeder is of galvanized cel with ends riveted and burred to malleable iron sockets. It is the strongest and best Chick Feeder on the market. Made in one size only, 20 inche

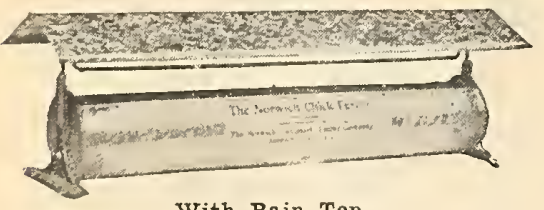

With Rain Top

For outside use the Fecder is made with a removale rain top which not only protects the feerl from showers followed by a hot sun that ruiclily sours the mash and is responsible for but also prevents the older fowls from iating the chicks feed.

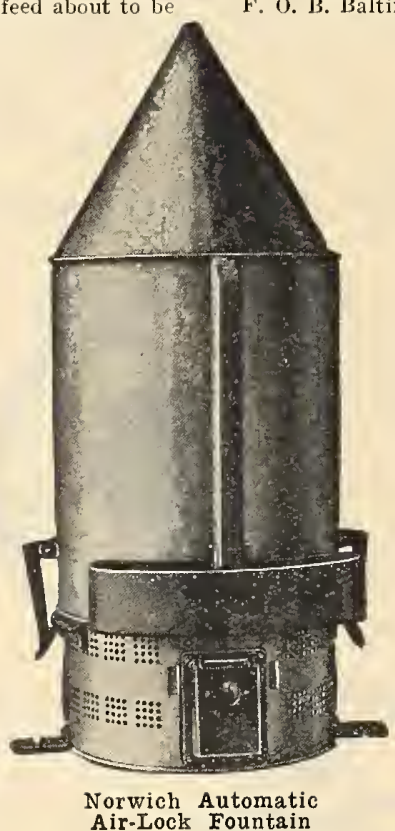
Norwich Automatic
PRICE LIST

Norwich Automatic Exerciser and Feeder F. O. B. Baltimore

No. 1-8.Quart Hopper, actual shipping weight 13 lbs.........\$5.00

o. 2-14.Quart Hopper, actual shipping weight $1.5 \mathrm{lbs} \ldots \ldots \ldots \ldots \ldots .50$

No. 3-20-Quart Hopper, actual shipping weight $20 \mathrm{lb} \ldots \ldots \ldots \ldots \ldots .6 .50$ No. 4-32-Quart Hopper, actual shipping weight 27 lls.......... 7.50

\section{Apaco Poultry Feeder}

which in general design is built on the sane lines as our well-known and justly famous Nor. wich Automatic Exerciser and Feeder, but is a hanging machine rather than arranged with adjustable standard.

Constructed of 28-gauge Galranized, Tight Coated Sheeting, malleable and gray iron cast ings for the Valves, Agitators, Collars, etc., and the workmanship of the highest possible character, we unhesitatingly guarantee our APACO FEEDER as the best machine ever placed on the market at its price, and offer the same guar. antee that covers all our goods.

\section{PRICE}

Made in one size only, 9 quarts capacity ... \$2.00 F. O. B. Baltimore. Shipping weight, 5 Lbs.

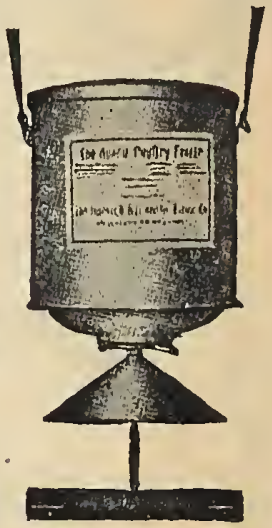

Apaco Feeder
The Norwich Automatic Air-Lock Fountain

How to supply water to the poultry house during the winter montlis has been one of the problems whic! has confrouted the poultrynien for years, for there is perhaps notling more discouraging thill to fill the drinking vessels, witl all the accompanying discomforts of carrying water in cold weatler, dnd then have the fountains freeze almost before we finish the task, and it has been the experience of many poultrymen that their birds have been without water for most of the day in consequence.

One of the many features of THE NORWICH AUTOMATIC AIR-LOCK FOUNTAIN is the freedom irom constant care and cleaning. The water witlin the reservoir is always fresh until used, exactly the samc as it would be were it in a corked bottle or pneumatic tamk, and to clean the slime accumulation which is always present where water is stored it is but necessary, perhaps but once a month, to put a solution of caustic soda and water into the reservoir, rinse it, anl the inside of the ressel will be found perfectly clean and bright, thus obviating the necessity of constant clealling, which is the case in almost every type of fountain on the market today.

\section{PRICE}

Made in one size only. 'j gallons capacity.

Shipning weight, 14 Lbs.

Complete with Burner Base...............\$6.00

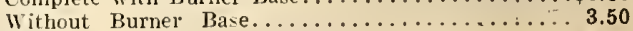

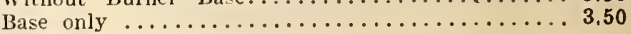

F. o, B. Baltimore.
Peerless Fountain and Heater

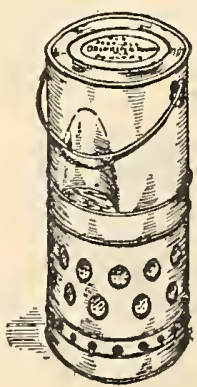

The Pecrless Combination Fountiain and Heater is very popular for winter use. It requires a very small quantity of oil to keep the drinking water warm at all times. It is made in two sizes.

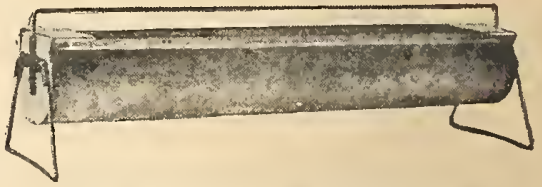

It is really surprising the number of users of Norwich Chick Feeders that have suggested to us that we make a feesler on the lines of that prachine onty larger for the growing chick. In nachine onty larger for the growing chick, m response to this denand we have designed the Norwich Vibro Feeder which we offer as a conl-
plete solution of feeding mash or growing feerls plete solution of feeding miash or growing feerk Vibrator and Follow Rods, wc have conquered the element of waste to a point where the only waste encountered is the crain which falls from the birds' bills as they withdraw their heads from the feeder, and there is no going berond that point unless we the teach chicks to ure napkin. it is made in one size only, 27 inches long.

$$
\text { PRICE LIST }
$$

Without rain top, weight $5 \mathrm{lbs}$ 
Bolgiano's Poultry Supplies, Baltimore, Md.

\section{Non-Freezable Fountain and Heater}

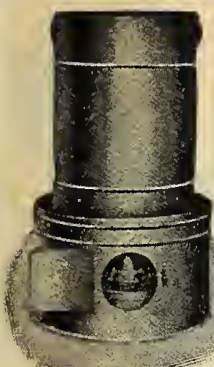

This fountain can be used in the mid winter with no danger of the water freezing, and also is a good heater to keep your poultry house warm, your poultry house warm, to increase egg produc-
tion. It is equipped with an oil lamp with our special burner that needs no chimney; large lamp fount furnishes oil 48 hours. It can be used in summer as well by putting summer as weil by putting not light it. They are not light it. They are on sizc and 8-gallon size. The 8-gallon size is large enough for 80 to 100 fowls. The 4-gallon size is large enough for 40 to 50 fowls. There is no danger of fire. No dirt or litter can be scratched in fount. They are positively sanitary and clean.

$\begin{array}{ccr}\text { Size } & \text { Weight Crated } & \text { Price } \\ \pm \text { galion } & 12 \mathrm{lbs} . & \$ 5.50 \\ 8 \text { gallon } & 18 \mathrm{lbs} . & 6.50\end{array}$

\section{1-2-3 Poultry Feeder}

1-2-3 Feeder is used for dry mash, scraps, shells, grit, charcoal or any poultry feed.

When used for one kind of feed only, take out separator; two kinds, put separator in one end. When used for three kinds, say scraps, shells and grit, put separator in middle and you have three separate feedcrs.

No, 1 , small size...................85c

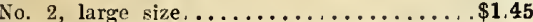
Mailing weights, No. 1,3 Lbs.; No. 2, 5 Lbs.

Moe Shell and Grit Box No. 9

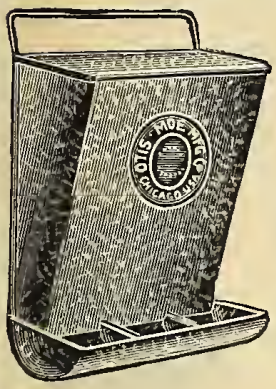

Grit, shell and charcoal bave now become a recognized essential part of the diet insuring healthy fowls. They cannot be more economically supplied than in one of our inexpensive compartment boxes. Can also be used as a feed hopper for little chicks. Made of heavy galvanized iron.

Nailing weight, 4 Lbs. Price ........90c

\section{Grit and Charcoal Box for Baby Chicks}

Yo. 45-Two compartment, square bottom grit and charcoal box for baby chicks.

Mailing weight, 2 lbs. Price, 40c each.

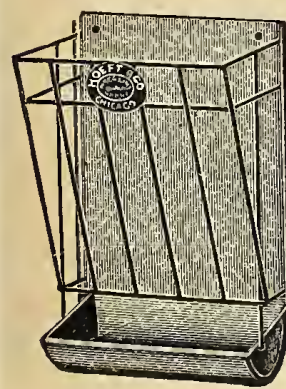

Parcel Post Table, See Page 2

The Improved Handy Hopper

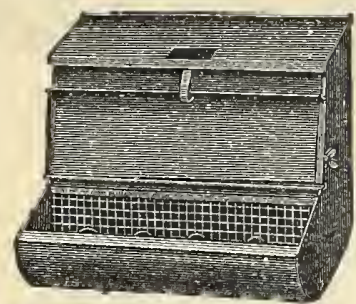

The Improved Handy Hopper is made of galvanized iron throughout. All parts are spot welded together. It is provided with hinged lid over both hopper and trough, making it rat and mouse proof, as well as dirt proof.

It is provided with a swinging front, adjustable to suit any kind of dry mash and which eliminates any possibility of clogging.

Hopper is 15 inches in height and $4 \frac{1}{2}$ inches in width and made in four lengths.

No. 1,12 in. in length.............\$1.65

No. 2,18 in. in length.............. 2.10

No, 3, 24 in. in length............. 2.25

No, 4, 36 in, in length.

3.50

Mailing weights, 6, 8, 12 and 16 Lbs.

\section{Sexton Dry Feed Hopper}

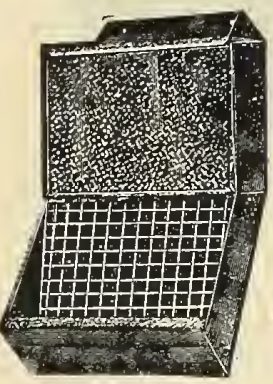

Open

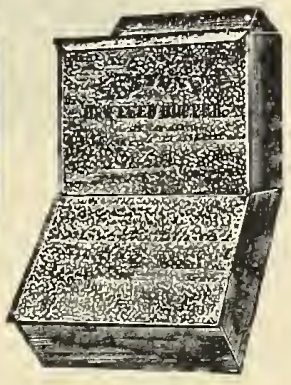

Closed
No waste, no dirt and Rat Proof. Food is always before fowls.

Each Wailing

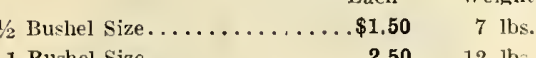

1 Bushel Size............2.50 12 lb.

Wall Chick Feeders

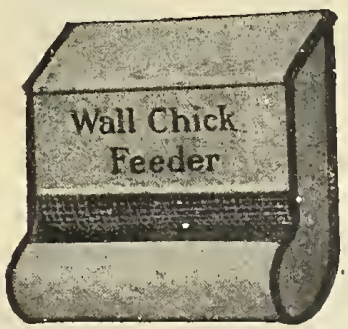

These are made in two sizes, ten inches long and twenty incles long. The sloping top prevents the chicks from roosting on it and a wire screen prevents chicks from wasting the food This is an entirely new invention and has proven its worth and efficiency among the largest chick raisers in the world. $10 \mathrm{in.,} \$ 1.15 ; 20 \mathrm{in}, \$ 1.45$

Iailing weights, 3 and 5 Lbs.
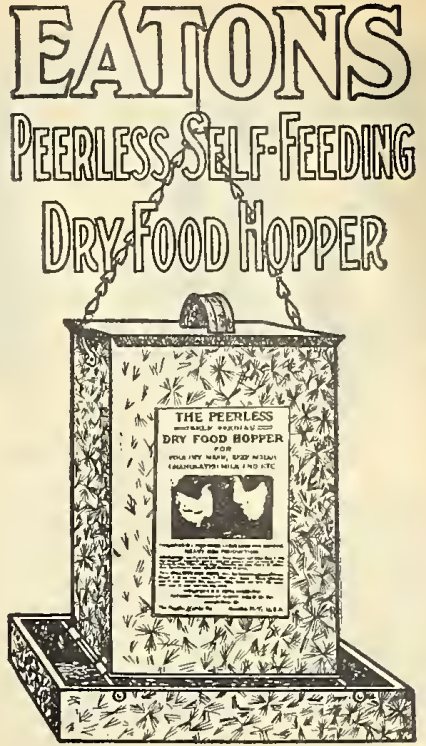

It is the only hopper that is absolutely rat proof all the time, day and night, which needs no attention except refilling when empt

It is the only hopper that will feed grains, dry mash, beef scrap, etc., with equal facility as it has an unobstructed feed outlet.

With this hopper the fowls positively cannot waste the feed, as they have to exercise for every mouthful they get, though the food is freely before them all the time.

it occupies neither wall space nor floor space, and is never in the way of the fowls, though always convenient to tliem.

The design of this hopper makes it impossible for fowls to roost on it.

Your fowls are kept ever active and healthy. which ensures heavy egg production. They are obliged to work for their food, and it's a well known fact that the working hen is the laying hen. This hopper makes them work even when cooped up in winter, and consequently assures you of a steady supply of eggs when prices are high.

An automatic pulley is supplied with every Peerless Hopper, which "can be easily attached to any style of roof. This pulley grips the cord and holds the hopper at any desired height.

Fill the hopper with dry mash or mrain and hang it well above the floor or pen, high enough to compel the birds to arch their necks in order to reach the feed.

\section{Sizes and Prices}

Small, 8 gt. size for 10 to 15 birds.

Nedium, 16 qt. size for 15 to 30 bircs.

Large, 32 qt. size for 35 to 50 birds.

Mailing weights, 4,6 and 8 Lbs

$\$ 1,75$

\section{Chick Feed Troughs}

These troughs are very convenient for feeding flocks of growing chicks.

The trough is made on a half circle, so that every bit of feed can be easily eaten out of it.

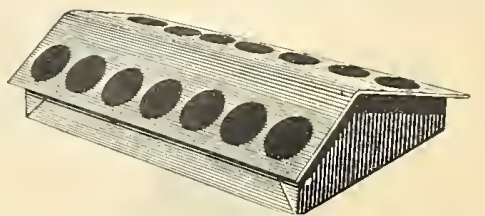

Made in two sizes, 10-inch, 14 holes, and 20 -inch, 26 holes.

10 -inch trough with grate.

Shipping wcight, 11/2 Lbs.

20 -inch trough with grate

Shipping tweight, 2 Lbs. 
The J. Bolgiano Seed Co., Baltimore, Md.

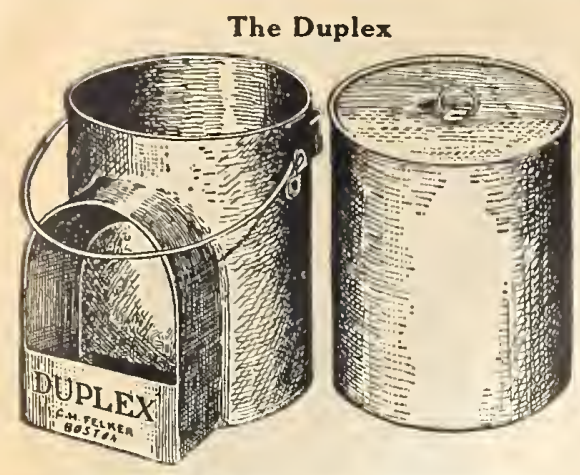

Parcel Post Tahle, See Page 2 holes, each, $25 \mathrm{c}$.

Price, 1-qt. size, 45c; 2-qt. size, 65c; 4-qt. size, $90 \mathrm{c} ; 8$ qt. size, $\$ 1.25$.

Mailing weights, $1,2,3$ and 4 Lbs.

\section{Sexton Heavy Wall Fount}

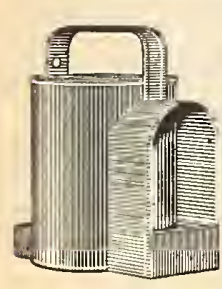

These are niade of No, 28 gauge steel and are much better and stronger than most other fountains of this style now on the market. A hood over the trough prevents dirt from getting into water. 2 qt., $55 \mathrm{c} ; 4$ gt., $70 \mathrm{c} ; 8$ qt., $90 \mathrm{c}$.

Mailing weights 2, 3 and

Moe's Feed and Water Cup

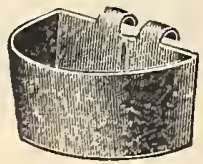

For Exhihition Cages or Futches

Made of galvanized iron. Easily hung on the side of the Hutch or Exhibition Cage.

No. 61-Mailing weight, 1 I.b. Price, 15c.
Moe's Star Jar Fountain and Feeder

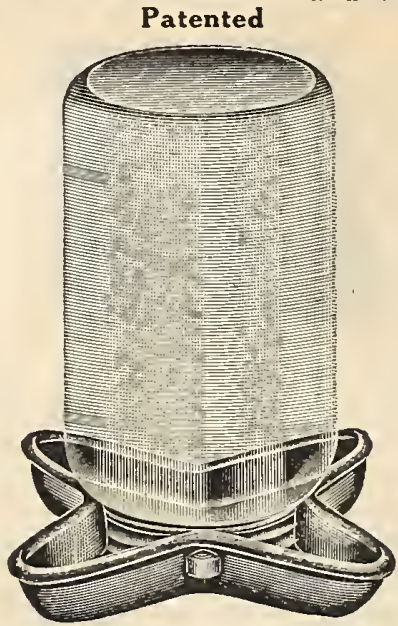

The most simple, practical and durable Mason jar fount on the market.

No. $32,10 \mathrm{c}$ each, without the jar (two) postpaid, $25 \mathrm{c}$.

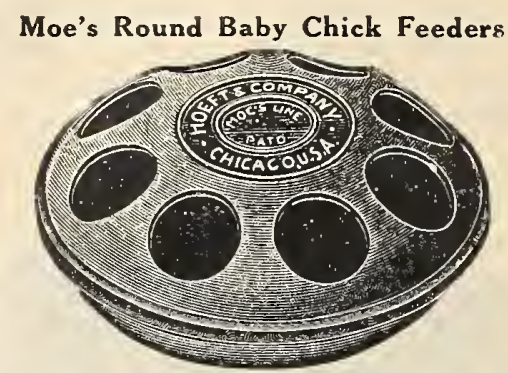

Pure food for the hahy chicks. A great feed saver, as the little chicks cannot get into it and contaminate the feed. Cannot be upset. Can also he used for water or milk. This is a prac. tical, well-made feeding device that will last for years. Manufactured in two sizes.

No. $11-6$ inches in diameter, 8 feeding holes, each, $15 \mathrm{c}$.

No. $12-8 \%$ inches in diameter, 12 feeding

Postage, 7c extra.

\section{Moe's Feed and Water Dish}

Automatic Fountain and Chicken Feeder

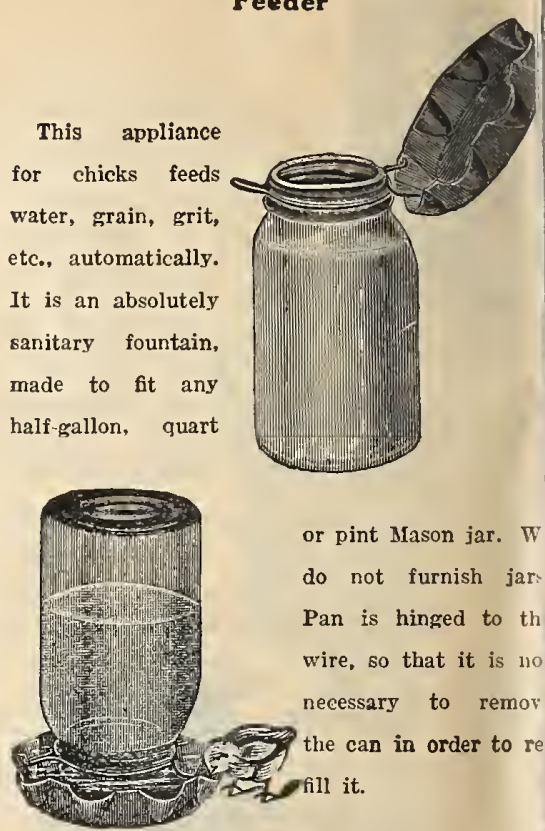

Price, 10c each.

Mailing weight, $1 \mathrm{lh}$.

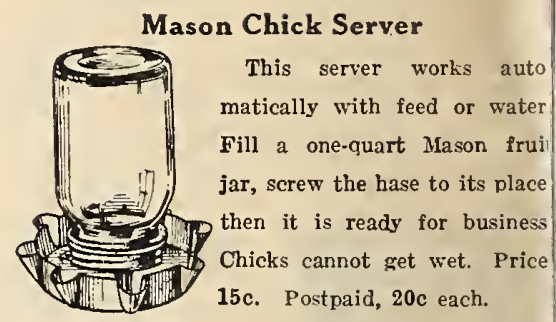

\section{Nesco Chick or \\ Brooder Fountain}

Quickly filled and the chicks cannot get wet. Price, 20c each. Postage $5 c$ extra.
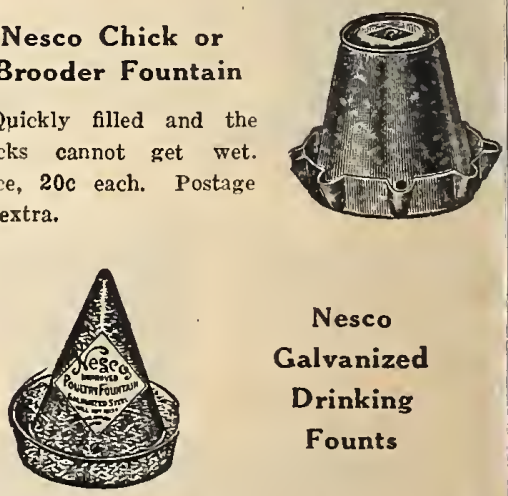

Made of galvanized iron. Rolled-in top pre. vents wasting. Dish held to the floor of Rabbit Hutch by a simple locking derice and easy to remove for cleaning. Impossible for stock to tip over.

No. 46-Mailing weight, 2 Llss. Price, $20 \mathrm{c}$.

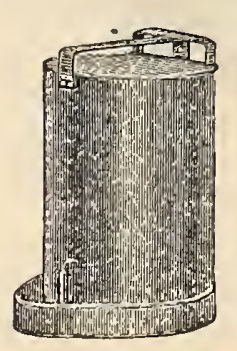

Improved Drop Bot. tom Fountains Single Wall

The pan, which forms the trough, is hinged at the hack and fastened by a catch in front. The flat back allows the fountain to be firmly placed against the wall and the drop bottom enables the fount to be thoroughly cleaned and kept in a sani. tary condition. $2 \mathrm{Qt}$. size tary condition. $2 \mathrm{Qt}$.
Improved, 1 qt., 30c; 2 gts., 35c; 4 qts., $45 \mathrm{c}$ Mailing weights, Improved, 1, 2 and 3 Lbs.

\section{Moe's Hutch Scraper and Cleaner}

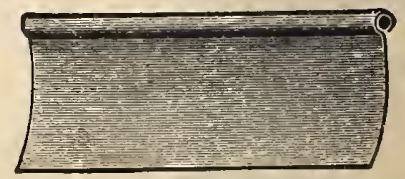

Made of one-piece galvanized iron. Just the thing to get into the corners when cleaning. 10 in. long.

No. 47-Mailing weight, 2 Lbs. Price, 20c. 


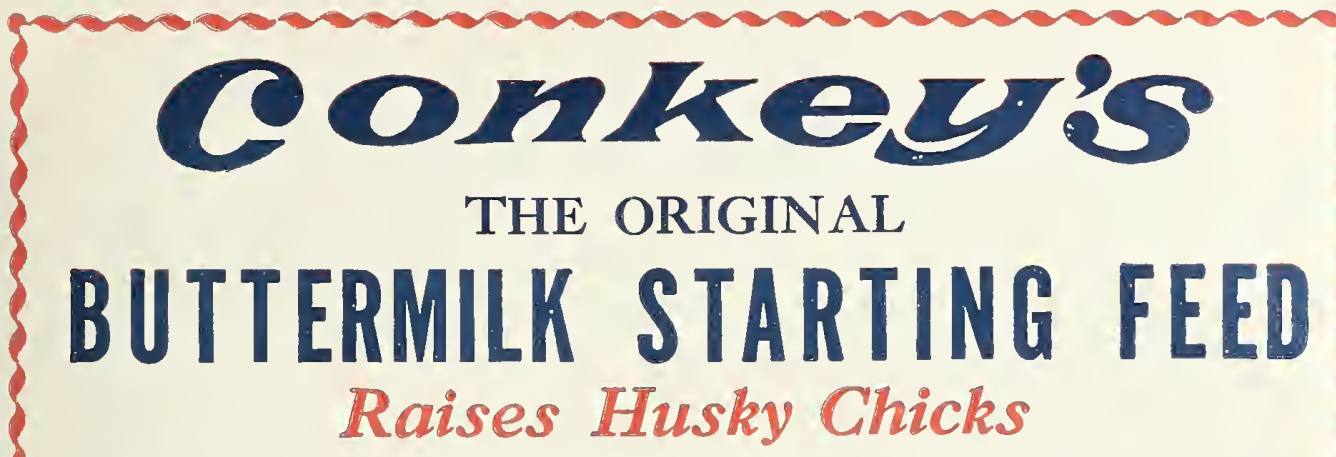

A Ready Prepared Mash for baby chicks and all self-feeding young fowls. This remarkw able feed-originated by Conkey and prepared through processes controlled and used exclusively by Conkey is a complete ration-containing all the elements needed for safely starting baby chicks, ducklings, goslings, poults, guineas, pheasants, etc.

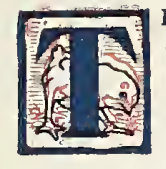

HIS superior chick mash was the first commercial poultry feed containing buttermilk - that is why we call it the only ORIGINAL buttermilk starting feed.

Conkey's did not "just happen" -it is a scient ifically-balanced feed as clean and wholesome and as conscientiously-prepared as inlant food." Selected, plump grains, ground t proper fineness, are combined with other ingre dients so as to make the feed readily digestible, palatable and nutritious. TASTE it,
that's the way to judge a chick feed.

Conkey's carries buttermilk in just the right proportion as an aid in prevention of bowel troubles, White Diarrhea, leg weakness, etc. with the other ingredients by the ORIGINAL with tile other ingredients by the tizing, tonic, and other properties of the newlychurned product.

The moisture in the buttermilk is drawn off by the exclusive Conkey process in such a way as not to subject it to the terrific heat usually required in "drying" buttermilk.

Lactic acid in buttermilk is described as an "Intestinal broom" which sweeps away unfriendly bacteria and disease germs in the delicate digestive tract. Buttermilk is also rich in one of the vitamines necessary to growing birds. It is a wonderful appetizer, aid to dis gestion and flesh builder.

However, it is not the buttermilk nor the other Ingredients alcne that causes people to declare ingredients alcne that causes people to declare
that their chicks grow twice as fast on Conkey's.

GUARANTEED ANALYSIS
Crude Protein, $12 \% ;$ Crude Fibre,
$4 \% ;$ Crude Fat $3 \% ;$ Nitrogen Free
Extract, $56 \% ;$ Carbohydrates, $60 \%$.
Ingredients
Semi-Solid Buttermilk, pinhead
oatmeal, a special wheat middlings
whole corn meal, corn feed meal
and granulated bone.

It is not the buttermilk alone that protects the chicks from disease during the first critical eight weeks. The secret is in the combination of these materials by the Conkey method-the balancing of the ration, as Conkey alone knows how.

Don't be influenced by "cheaper" imitations labeled "buttermilk" - that word may be used to deceive unwary buyers - to cover up a multitude of "sinful" grains, mill sweepings, poisonous weed seeds, musty screenings, worthless by-products, or other poor material having litule or no nutritive value.

Conkey's is so palatable that one poultrymen said it ought to be used for "breakfast fool." One woman wrote: "My chicks just love Conkey'。 It is so tasty, and $m y$, how they do grow! 3 ey'o It is so tasty, ard my, how they do grow still, we didn't have a single loss in the present hatch,

\section{FEED IT FIRST 8 WEEKS}

Conkey's is all the chicks need the first eight weeks except greens, charcoal, grit. clean water and some fine scratch grains in the litter for exercise. Give grit and water from the start. During the second week add green stuff and in the fourth week fincly cracked chick grains, like Con-

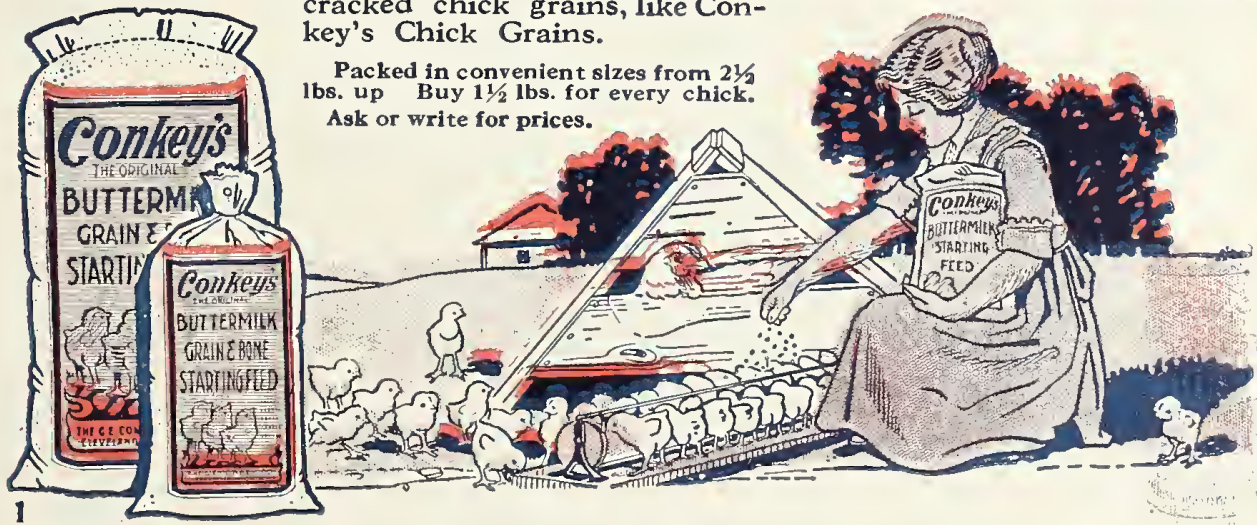
Packed in convenient slzes from $21 / 2$
bs. up Buy $11 / 2$ lbs. for every chick. Ask or write for prices. 
THE J. BOLGIANO SEED COMPANY, Baltimore, Md.

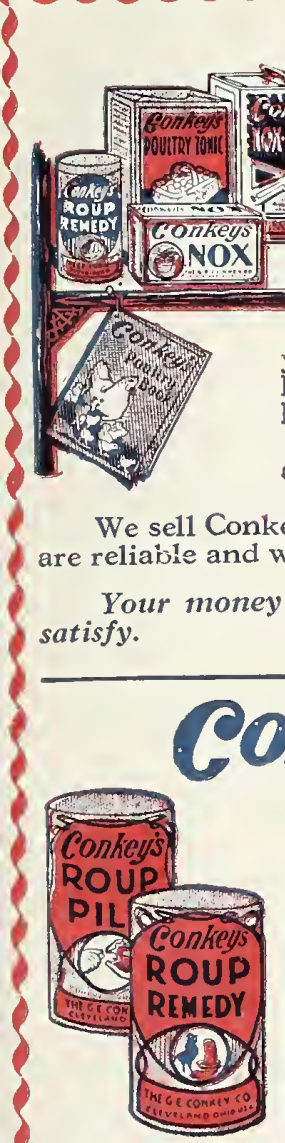
drinking water. Sick birds doctor themand disappointment.
When Roup breaks out there's no time to experiment-start treatment at once-the disease is very contagious. Cold, rainy weather and changeable conditions intensify froth in eyes, or run at Sick birds doctor themRoup. When birds sneeze,

\section{Have a Conkey} Corner in Your Poultry House

Raising poultry is pleasant and profitable when "good luck" is with you. Good luck, however, is not merely a matter of chance, but of BEING PREPARED. For more than twenty-five years Conkey has been THE POULTRY DOCTOR. Take his advice. Install a Conkey Corner of remedies in your poultry house as insurance against disease, trouble, loss

We sell Conkey's Poultry and Stock Remedies because we know they

Your money refunded cheerfully if any Conkey remedy does not

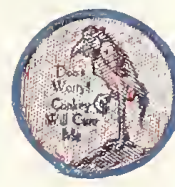

selves and others are protected from catching the disease. Better still, always at the first sign of "roupy weather," place Conkey's Roup Remedy in fountains-it's a great preventive.

Packages 25c,50c, $\$ 1.00$; breeder size (5-lb. can) Packages 25c, 50,
\$5.75. All postpaid.

\section{Conkeys Roup Pills}

For treating individual cases and for use at shows when birds develop colds. These pills have saved many a valuable bird.

Packages 30c, COc. $\$ 1.20$, cll postpaid; breeder size (1000 pills) $\$ 3.00, \$ 3.10$ postpaid.

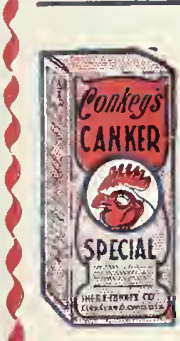

\section{Conkeys' Canker and Bronchitis Remedy}

This splendid remedy checks cankerous growths and sores and soon restores the bird to normal. This remedy is Conkey's Specific for bronchitis. Also desirable in treating individual cases of Roup and for use at shows for colds.

Package 50c Postpaid.

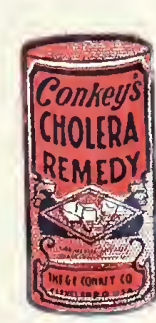

Conkeys

\section{Cholera Remedy}

So-called Cholera, bowel troubles, indigestion, diarrhea and kindred ailments often kill a whole flock in a few days. Diarrhea, a drowsy, 1istless appearance and great thirst-these are the signals to put Conkey's Cholera Remedy in the drinking water.

Packages 25c, 50 c, 81.00 , all postpaid; breeder size 5 lbs., $\$ 2.50 ; \$ 2.65$ postpaid.

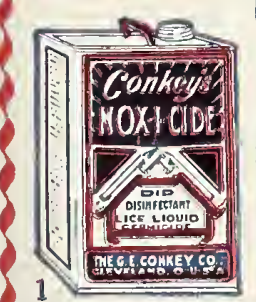

\section{Conkeys NOX-I-CIDE}

\section{Mite Liquid, Dip, Disinfectant}

Every poultry yard, ranch, home, factory, stable, store, office building-in fact, every place where sanitation is necessary to health-needs Conkey's Nox-i-cide every day in the year.

For poultrymen, Nox-i-cide is indispensable as a red mite destroyer-paint it on the roosts and spray it into cracks. Spray premises daily when disease is present and once a week as a preventive of red mites, present and once a week as a preventive of

As a veterinary wash in treating swine, sheep. stock, etc. Nox-i-cide is widely used. Sheep raisers, swineherds, cattlemen and others praise it highly as a dip.

Try it for household use-for assisting in driving out ants, destroying odors, routing out bedbugs and cockroaches, for making sinks, cess-pools, garbage containers, etc., sanitary and safe.

Cans, Pint 45c: Quart 70c; $\frac{1}{2}$ Gallon \$1.15; Gallon \$1.80; 5 Gallon \$8.75; 10 Gallon \$17.00. Parcel post, express or freight charges ext ra.

Ask for Prices on Sprayers 


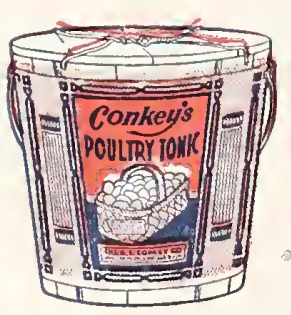

Conkeys POULTRY TONIC

Every bird from chick to maturity will be more productive, healthier and more profitable if given a good tonic and regulator. Conkey's Poultry Tonic helps birds to get more out of their feed; they produce more eggs and better flesh on LESS FEED, by better digestion and assimilation.

Conkey's Tonic is all medicine-free from filler, "red pepper, and "hot stuff" to overstimulate the birds and break down their health. Conkey's builds on a natural, healthy tasis, inducing steady and persistent laying. Kceps the young chicks growing, makes molting easy, strengthens the bird for bad weather and generally maintains a high health average.

Buy it by the pxil. Packases, $25 c, 50 c$, $\$ 1.00 ;$ pails, 12-lb. $\$ 1.60 ; 25-1 b$. \$3.00: hags, 50-1b. \$5.00; 100-lb. \$9.50. Parcel post, express or freight charges extra.

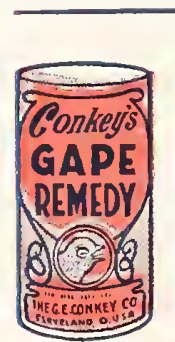

\section{Conkeys \\ Gape Remedy}

Don't try to extract gapes with a wire or feather when you can get such an effective remedy as Conkey offers. This remedy comprises two powdersboth in same box for one price-one siftcd over chicks causes them to dislodge the worms in wind-ipe by coughing, the other is a tonic powder which is mixed in the fced-to help the bird build up its resisting powers.

Packeges, 25c, 50c; 30c, 55c postpaid.

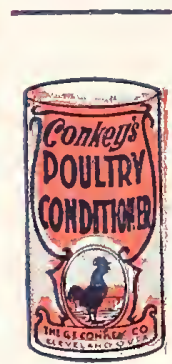

\section{Conkeys \\ Poultry Conditioner}

Highly concentrated fowl-regulator, blood-purifier and nerve food, to build up birds in a rundown condition or for fowls recovering from disease. Splencid for putting birds in condition for shows, and sustaining them during exhibition.

Packages, 25c, Ecc; 30c, 55c postpaid

\section{Conkeys}

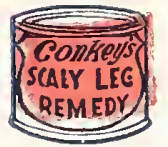

\section{Scaly Leg Remedy}

This ointment applied to birds' legs in a few treatments will kill the parasites responsible for the trouble and heal up the legs with a healthy lustre.

Package, 25c Postpcid.

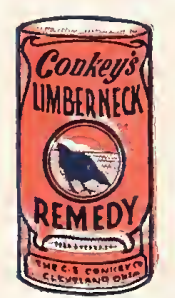

\section{Conkeys}

\section{Limberneck Remedy}

For limberneck (or ptomaine poisoning) this remedy should be on hand in your Conkey Corner at all times as Limberneck must be treated promptly.

Packages, 50c; 55c postpaid.

\section{Conkeys' Fly Knocker}

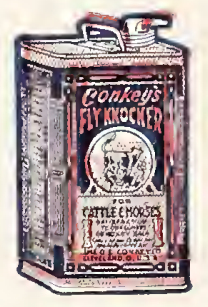

Dairymen, horsemen, cattlemen, and sheep raisers declare this to be the best investment they make-animals free from insects do better in milk and insects do better in milk and butter fat production, while fattens faster when relieved from disease-spreading insects.

Cans-at. 60c; 1/2 gal. 90c; gal. $\$ 1.50 ; 5$ gal. $\$ 7.25 ; 10$ gal. \$14.00. Parcel post, express or freight extra.

\section{Conkeys's Stock Tonic}

$A$ general conditioner of real merit for live stock.

Packages, 25c, 50c: pails, $12 \mathrm{lb}$. $\$ 2.10 ; 2.5 \mathrm{lbs}$. \$3.45: bags, 50 lb. $\$ 5.25$; $100 \mathrm{lb}$. $\$ 10.00$. Parcel post, express or freight charges extra.

\section{COHKeys, LICE POWDER}

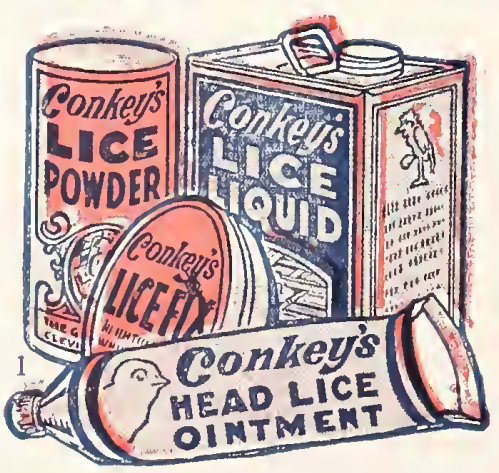

For dusting hens, nests, growing chicks-wherever body lice must be overcome.

Packages, 10c, 25c, 50c; pails 12-lb. $\$ 1.40 ; 25-l b$. \$2.75. Parcel post, express or freight extra.

\section{Conkeys Lice Liquid}

For painting roosts, fittings, inside of house, nest boxes and wnerever mites congregate.

Cans-qt. 60c, 2-qt. 90c; gal. \$1.50; 5-gal. \$7.00. Parcel post, express or freight extra.

\section{Conkeys's Head Lice Ointment}

For overcoming and preventing murderous head louse which "eats u?" baby chicks.

Packages, $10 \mathrm{c}, 25 \mathrm{c}$, postpaid.

\section{Conkeys' Lice Fix}

A preparation in ointment form for fighting body lice. One application lasts a month. 


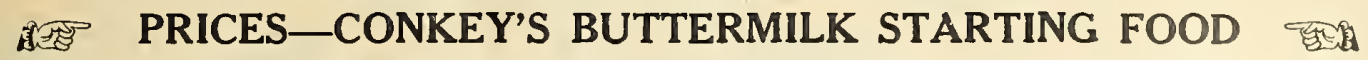

$\begin{array}{ll}21 / 2 & \text { Lbs. } 25 c \\ 5 & \text { Lbs. } 45 c\end{array}$

100 Lbs. $\$ 5.50$
10 Lbs. $75 c$

25 Lbs. $\$ 1.65$
F. O. B. BALTIMORE, MD.

\section{Bolgiano's}

\section{Square Deal Water Glass}

\section{Saves Money and Helps Keep Down the High Cost of Living}

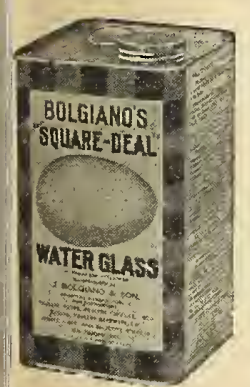

Put your eggs down in the spring and summer when they are cheap and keep them fresh for ten months. One gallon makes sufficient solution for 50 dozen. "Square Deal" Water Glass has been thoroughly tested. Do not trust eggs to a water glass of inferior strength. It inust be pure an.l strong to safely protect eggs.

Stone or earthenware crocks, wooden kegs, glass jars, tin or iron vessels, or galvanized iron cans may be used; practically any convenient water-tight vessel that can be kept covered. Have about two inches of the preserving solution clear above the eggs. If necessary to add more solution because of evaporation, make up a fresh quantity of 11 parts water to 1 of solution and pour in. Do not simply fill up with water.

Prices: 1 quart, 30c; 2 quarts, 55c; 4 quarts, $\$ 1.00$.

\section{Bolgiano's "Square-Deal" Poultry Remedies}

Bolgiano's Square Deal Roup Remedy

Roup is one of the most common, most contagious and most fatal diseases which affict poultry. It frequently starts with a simple cold, and if unchecked quickly spreads through the entire flock. The symptoms are odorous discharges at the mouth and nostrils, followed by a swelling of the head and quick breathing. If it is used in the drink, the fowls take their own medicine.

Prices: Box to make 25 gallons, 25c, postpaid; box to make 75 gallons, $50 \mathrm{c}$, postpaid.

\section{Bolgiano's Square Deal Cholera Remedy}

Cbolera is a contagious and fatal disease and must be treated promptly pon appearance to save the flock infected. Unless stamped out it will annihilate the whole flock. For quick relief we can recommend this powder Price: $25 \mathrm{c}$ and $50 \mathrm{c}$, postpaid.

Bolgiano's Square Deal Liquid Lice and Mite Killer For Destroying Certain Lice, Insects and Mites on Fowls and Stock We believe the strongest and most satisfactory liquid lice and mite killer manufactured. If you don't feel that way after using it, get your money back.

It requires an entirely different method of treatment to rid poultry houses of mites than to kill lice on fowls. Fou must " get after " these terrible blood-sucking pests with a fluid, and it is necessary to depend upon a gaseous por to penetrate their hiding places.

Square Deal Liquid Lice and Mite Killer has a double value. It kills by contact and the vapor thrown off by it kills most vermin.

Prices: 2-qt. cans, $75 \mathrm{c}$, mailing weight, 7 lbs, ; 1 -gallon cans, $\$ 1.25$, mailing weight, $11 \mathrm{lbs}$.

Bolgiano's Square Deal Disinfectant and Deodorizer For Disinfecting Poultry Houses, Stables, Kennels, Toilets, Sink-drains, Cesspools, and to destroy most foul odors. Use two tablespoonfuls in one

Valuable for washing out Incubator Cellars, Incubators, Brooders, Brood Coops and Drinking Utensils.

For General Use. One quart of Square Deal Disinfectant, makes fifty quarts of Disinfectant. No household, farm, stable or factory should be without it. Full directions on each package.

Prices: 2-qt. can, 75c, mailing weight, 7 lbs.; 1-gal. can, $\$ 1.25$, mailing weight, $11 \mathrm{lbs}$.

\section{American Turkey Powder}

One of the best Turkey Powders on the market. Guaranteed to give satisfaction or money refunded. If you raise turkeys and are troubled with sickness or disease try a package of the powder in your feed, also in the water, and you will see what a difference and how soon your birds will be back in condition again. Will prevent Black Head, a disease dreaded by turkey raisers. Price, per package, 35c; by mail, 10c extra.
PRICES SUBJECT TO CHANGE WITHOUT NOTICE

Bolgiano's Square Deal Lice and Scaly Leg Ointment An Ointment for External Use

For Scaly Leg. Grease surface thoroughly. Let renain two days, wash off with warm water and soap and then make new application.

For Head Lice. At night apply a small quantity to top of bead and ub in well.

Price: 25c, postpaid.

\section{Bolgiano's Square Deal Salt Cat}

Square Deal Salt Cat is a scientific combination of those aromatic and tonic properties that are recognized by pigeon keepers as aiding digestion, promoting goo health and egg production in pigeon and game fowls.

These ingredients are cast in a brick form of sufficient consistency to hold the component parts in a solic mass, yet soft enough to be easily pecked apart. Each brick is encased in a box. Every pigeon fancier should feed Square Deal Salt Cat.

Price: Per brick, 20c; mailing weight 2 lbs.

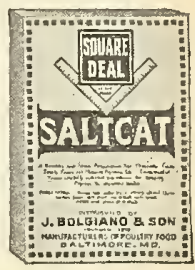

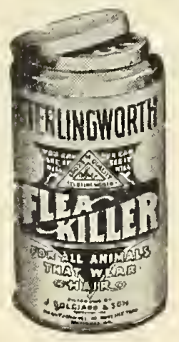

\section{Sterling worth Flea Killer}

When your dog gives you the "scratching sign" remember bow miserable a few mosquitoes make you and "get busy" with flea relief measures. Don't keep a pet unless you are willing to do the "right thing" by it, and leaving your eat or dog to fight fleas when you can relievc him with a $25 \mathrm{c}$ box of Sterlingworth Flea Killer is NOT doing the "right tbing."

We know of no otber powder like it in results. stand the animal on a slieet of paper and work Sterlingworth Flea Killer to the skin on the bead then into the hair on the rest of the body, and you vill see the fleas drop dead from the animal. Price: 2 oz. sprinkler box, $25 \mathrm{c}$, postpaid.

\section{Sterlingworth Egg Tablets}

More Eggs or Your Money Back

The fellow who tells you tbat egg tonics are useless and should not be fed to hens is the fellow you meet most frequently in the drug store buying spring tonics, cascara, quinine or liver pills, careful inquiry will generaly "helping out" the ben he takes a different stand.

We want every poultryman in the United States who wants more eggs than he is now getting to try Sterlingworth Egg Tablets, with the distinct understanding that, if after using one-half the contents he does not believe that they have helped him, he may return to us tbe unused balf and we will return to him the purchase price.

These tablets contain more real concentrated egg-stimu-

These tablets contain more real concentrated egg-stimu-

lating tonic value than is contained in a pound of many filler egg foods. They are used by dissolving in water or crushed into powder, and may be given either in the fowl's drink or by moistening food with the
water in which the tablets are dissolved or mixed dry with mash foods. The best way is to feed in the food. Full directions on every package.

Prices: Trial size ( 25 tablets, sufficient to medicate $130 \mathrm{lbs}$. of feed), 25c, postpaid, Large size, 75 tablets, 50c, postpaid.

\section{Sterlingworth Sulphur Candle}

Irills Many Insect Pests and Certain Disease Germs

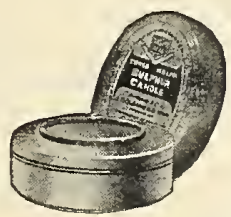

Sterlingworth Sulphur (tbree bours) Candles produce a large quantity of vapor. "The wick is easy to light and when "lit" stays "lit." hours. This is more sulphur than many candles contain that are sold for a higher price. They are excellent for ridding poultry bouses, dog, kennels, cellars, outhouses, etc., of certain insect pests and cellars, outhouses, etc., of certain insect pests and
many disease germs. The vapor from them penetrates crevices which cannot be reached by powders or liquids. Sulphur fumes are recommended by many Boards of Health and physicians for destroying Typloid, Diphtheria, Small-pox and many other disease germs.

Price: 10c each ; mailing weight, 1 pound.

\section{Sterlingworth Going Light Tablets for Pigeons}

When used as per dircctions will cure the dreaded disease known to Pigeon Keepers as " going ligbt," except in cases where the bird has reached an incurable stage of the disease. These tablets contain powerful remedial properties, and should not be fed to young birds. Directions with every package. Price, 25c, postpaid. 
The J. Bolgiano Seed Co., Baltimore, Md.

Parcel Post Table, See Page 2

\title{
Dr. HESS
}

\section{Poultry and Stock Preparations}

\author{
Prescriptions of Dr. Hess (M. D., D. V. S.)
}

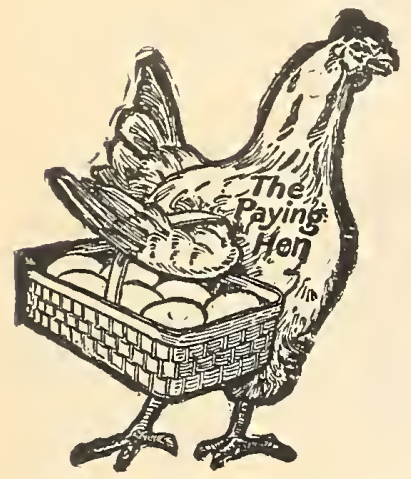

\author{
Dr. Hess \\ Poultry Pan-a-ce-a
}

makes poultry healthy; makes hens lay; not a stimulant, but a tonic that tones up the dormant egg organs, brings back the seratch and cackle and compels cach hen to put her share of eggs in the market basket.

It also contains internal antisepties that counteract disease; insures a healthy, singing poultry floek. Cost but a trifle-a penny's wortl enough for 30 hens per day. 11/2 lbs., 25c; 5 lbs., 75c; 12 lbs., $\$ 1.50$; 25-1b. pail, $\$ 3.00$. Guaranteed. Postage extra.

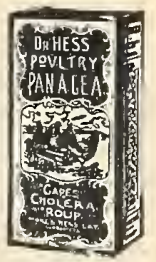

\section{Dr. Hess Stock Tonic}

Formula printed on every paekage

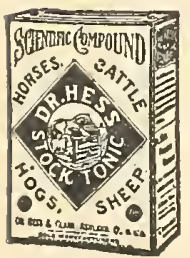

Every ingredient indorsed by the U. S. Dispensatory and other high medical authorities. It aids digestion, makes stock healthy and expels worms. Helps stock convert more ration into milk, flesh, blood and muscle. Every pound backed by the Dr. Hess \& Clark unqualified guarantee.

Prices. 2-1b. package, 25c; 41/2-1b, package, $50 \mathrm{c} ; 10$-1b. package, $\$ 1.00 ; 25-1 \mathrm{~b}$. pail, $\$ 2.25$. Postage extra.

\section{Dr. Hess Healing Powder}

The modern gall cure. Cures galls, cuts, wounds, ulcers, grease heel. Antiseptie and soothing. Heals everything it touches by forming a coating, cleaning and closing up wounds. Comes in sifting-top cans. Price, 4 ozs., 25c; 10 ozs., 50c. Guaranteed. Postage extra.

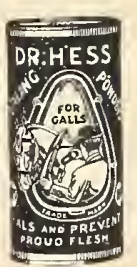

\section{Dr. Hess Roup Remedy}

For Roup, Diphtheria, Chicken-pox and all catarrhal diseases. It las these distinctive features: it is antiseptic, slightly astringent, non-irritating and healing. 4-oz. cans, 25c; $10.0 z$. cans, 50c. Guaranteed. Postage extra.

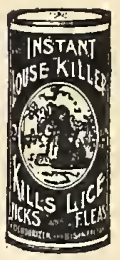

\section{Instant Louse Killer}

Kills lice on poultry, horses, eattle; sheep ticks; bugs on cucumber, squash and melon vines; cabbage worms; slugs on rose bushes, etc. Sold in sifting-top cans-look for the word "Instant" before buying. Price, 1 lb., 25c; $2 \frac{1}{2}$ lbs., 50c. Guaranteed. Postage extra.

\section{Dr. Hess Dip and Disinfectant}

Non-poisonous and non-irritating and guaranteed to be absolutely uniform in strength at all times. One gallon of Dip makes from 70 to 100 gallons effective solution. Spray it on roosts. Sprinkle it over the runs and in all cracks and crevices. Spray it on cattle and lıorses. Makes a splendid dip for logs and sheep. It's a sure parasite and disease germ

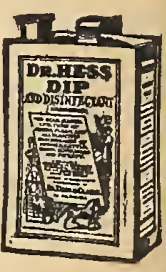
destroyer. Purifies stables, troughs, sinks, drains. Guaranteed.

Keeps the premises pure and healthful. Good alike for home and stable. Price, Pt., 40c. Qt., 60c. 1/2 Gal., \$1.00. Gal., \$1.75. Postage extra.

\section{Dr. Hess Fly Chaser}

Drives flies away. One application lasts six hours. Prevents milk slump. Keeps eattle and horses contented during the fly season. Most humane idea of the age. Its use during summer months will insure good profits. Guaranteed.

Drives away flies. Prerents milk slump. Price $1 / 2$ Gal., 90c. Gal., \$1.50. Postage extra.

\section{Dr. Hess White Diarrhoea Remedy for Chicks and All Poultry Effected with Diarrhoea}

Can be given either way, mixed with the feed or adjed to the drinking water. $25 \mathrm{c}$ and $50 \mathrm{c}$ sizes. Postpaid.

\section{LEE'S POULTRY REMEDIES}

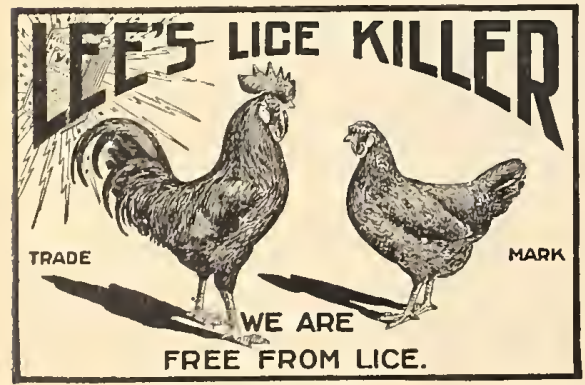

\section{LEE'S GERMOZONE FOR POULTRY}

Cures Roup, Colds, Canker, Chicken.Pox Sore Head, Swelled Head, Cholera, Bowel Trouble

Germozone is peculiarly adapted to all of these troubles because it unay be administered eithe externally or internally for poultry according as the case may require. The Germozone is antiseptic and healing and has the important property of counteracting, in the chicken's crop, much or all of the musty or poisonous matter which will eause trouble later. It also has a regulating effect upon the bowels.

This is the reason why we recommend the giving of Germozone in the drinking water of chickens, young or old, two or three times a week with regularity. Many follow the plan of giving chickens, young or old, two or three times a week with regularity. Many follow the plan of giving it every day in the last drink at night,
given in all drinking water all the time.

Germozone comes in liquid or tablet form with full directions in each package.

Liquid, 40c and 75c. Tablets $25 \mathrm{c}$ and $75 \mathrm{c}$.

Lee's Liquid Lice Killer. 1 Qt. 60c. 2 Qts. 90c. 4 Qts. $\$ 1.50$.

Lee's Louse Powder. 1 Lb. package. 25c. 


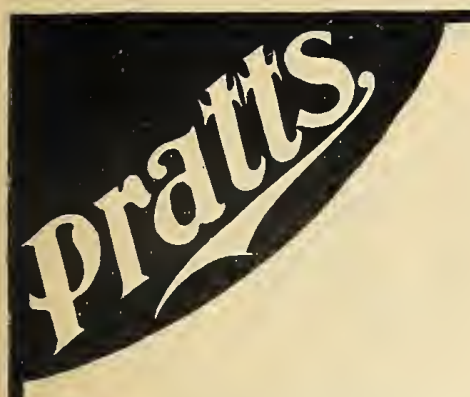

\section{ANIMAL AND POULTRY REGULATORS AND REMEDIES Buttermilk Baby Chick Food}

\section{SATISFACTION GUARANTEED OR MONEY BACK}

Parcel Post Table, See Page 2

\section{Postage Extra and Must Be Included When Remitting}

Healthy stock and lots of eggs, the two big things in poultry raising, are made certain by giving.

\section{Pratt's Poultry Regulator}

Packages, 25c, 50c and \$1.10. $12 \mathrm{lb}$. pail, \$1.65. 25 lb. pail, $\$ 3.00$.

It builds up vitality, insures sound digestion, sharpens appetite and prevents disease, th u s putting birds in condition for heavy egg lay. ing or winning blue ribbons.

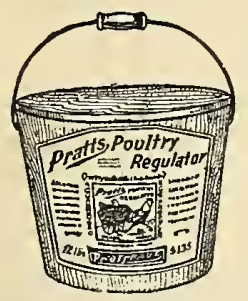

Pratt's White Diarrhoea Remedy

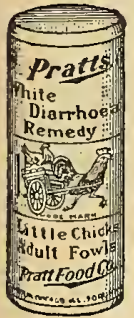

To protect your chicks from white diarrhoea, the most de structive of all chick diseases, it is only necessary to give Pratt's White Diarrhoea Remedy in the drinking water from the first drink. This remedy has saved many dollars' worth of chicks for poultry raisers. You can depend on it. $25 \mathrm{c}$ and $50 \mathrm{c}$.

Pratt's Roup Remedy

Don't let ROUP cut your profits. The sure and easy " ounce of pre. rention " against this dangerously contagious disease is

Pratt's Roup Remedy Tablets or Powder, 25c, 50c Quickly absorbed by the blood, purifies the system, reduces fever, allays inflammation. The safe remedy for roup, colds, catarrh and all bad weather diseases.

\section{A Guaranteed Pratt Remedy} For Practically Every

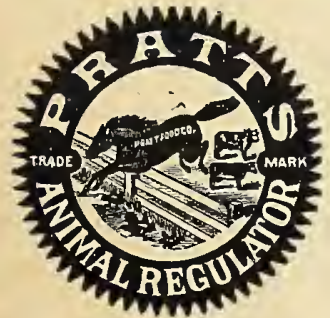

Stock and Poultry Ailment

\section{Pratt's Powdered Lice Killer}

Get rid of lice on your poultry, in nests, dustbaths, incubators and elsewhere in a day's time by using

\section{Pratt's Powdered Lice Killer}

Effective, non-poisonous, nonirritating. May be used wherever a powder is suitable. $\Lambda$ splendid deodorizer. Will kil

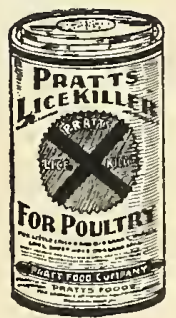
lice on horses, cattle, dogs, cats and plants. Price, $12 \mathrm{c}, 25 \mathrm{c}$ and $50 \mathrm{c}$

\section{Pratt's Condition Tablets}
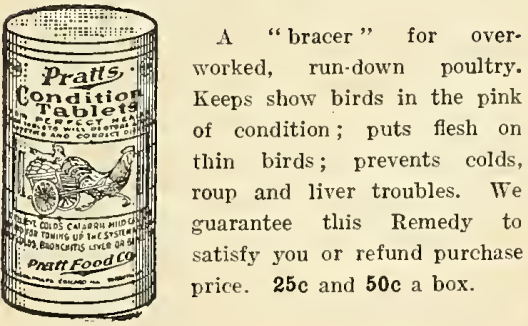

Pratt's Gape Remedy

An unfailing guaranteed remedy for Gapes. If used in the drinking water from the start until the chicks are four weeks old, gapes will be practically unknown.

Prices, 25c and 50c.

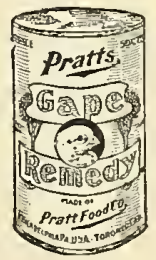

\section{Horse and Cattle Remedies}

Pratt's Conditioner, 60c. 12 Ib. bags, $\$ 1.00$. $25 \mathrm{lb}$. bags, $\$ 1.90$.

Pratt's Distemper and Pink Eye, 70c.

Pratt's Healing Ointment, $30 \mathrm{c}$ and $60 \mathrm{c}$.

Pratt's Healing Powder, 30c.

Pratt's Worm Powder, 50c.

Pratt's Liniment, $35 \mathrm{c}$ and $70 \mathrm{c}$

Pratt's Heave, Cold and Cough Cure, 50c. Pratt's Liquid Lice, 1 qt. $50 \mathrm{c}, 2$ qts. $85 \mathrm{c}$, 4 qts. $\$ 1.35$.

Pratt's Bronchitis Remedy, 25c and 50c. Pratt's Head Lice Ointment, 30c. Pratt's Scaly Leg Remedy, 30c and 60c.

Pratt's Germothol Botties, $30 \mathrm{c}$ and 60c.
Just Watch Them Eat It-and Grow Pratt's Buttermilk Baby Chick Food

The first three weeks is the critical time of a chick's life. They are tender babies and n eed Pratt's, the original " baby food for baby chicks." It is the right food because it contains only the sweetest and best of wholesome est aning food elements that will meet every need of a baby chick.

Dried Buttermilk, cook. ed wheat, bone-building

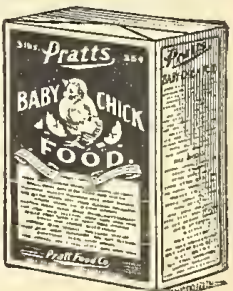
phosphates, these and

host of other splendid ingredients go to make up Pratt's Buttermilk Baby Chick Food. Best be cause it gives results; cheapest because it raises more and better chicks. Always uniform, sweet, appetizing and satisfying. Used for years by thousands of the most successful poultrymen the world orer. Packages $25 \mathrm{c}$ and $50 \mathrm{c}$. $14 \mathrm{lb}$. bags $\$ 1.10$.

Write for prices on larger quantities.

\section{Pratt's Poultry Disinfectant}

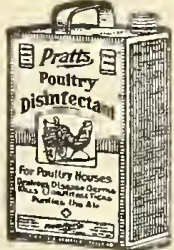
Gives comfort and health by destroying lice, mites and other vermill, and the germs eases by freely and regularly using

\section{Pratt's}

Poultry Disinfectant

Three times as powerful as carbolic acid. Doesn't burn or irritate; safe to handle
lowest in price. Besides its use in the poultry adnirable household antiseptic and deodorant. 1 qt., 55c. 2 qts., 90c. 1 gal., $\$ 1.50$

Pratt's Animal Regulator

More work out of your horses. More milk from your cows, fatter hogsthese are a few of the using

\section{Pratt's}

Animal Regulator

Always sold on a guarantee that it will satisfy you or money back.

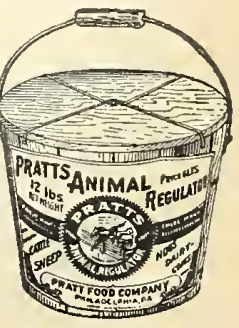

12 lb. pails, \$2.15. 25 lb. pails, $\$ 3.40$, are popular with our customers. Packages at $25 \mathrm{c}$, $50 \mathrm{c}$ and $\$ 1.00$. $50 \mathrm{lb}$. drums, $\$ 5.85 .100 \mathrm{lb}$. drums, $\$ 11.40$. 


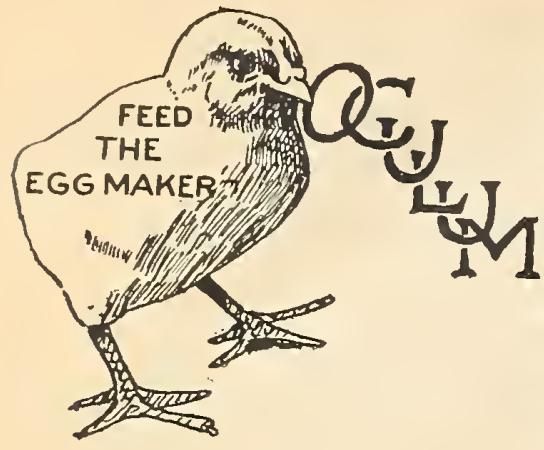

Oculum

"OCULUM" is not a stimulant, but is a SCIENTIFIC GERMICIDE. It destroys disease germs in the bowel and keeps fowls healthy.

"OCULUII" increase eight from $1 / 2 \mathrm{lb}$, to lbs., according to breed.

Prices: $10 \mathrm{c}, 50 \mathrm{c}$ and $\$ 1.00$ Bottles.

Postage extra.
Macnair's Chicken Powder Get More Eggs

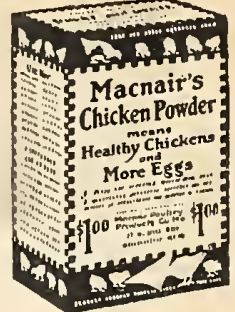

By using Macnair's Chicken Powder. Used for more than ten years by hundreds of successful poultry raisers. It will assist nature to keep your hens in normal, healthy condition, causing them to lay more eggs. Used successfully in the treatment of poultry eggs. Used successfully in the treatment of pou
discases. Price, 50c and $\$ 1.00$. Postage extra.

Macnair's Barnyard Protector

Destroys Hawks, Crows and All Barnyard Pests Save Your Chicks and Turkeys

Mix one tablespoonful with half pint of feed and feed the chickens or turkeys just before the usual time the hawk makes his visit, or three times a day in order for the lawk to get the full effect of the medicine. The drug that destroys the pest is contained in the craw of the chicken or fowl and this being a part of the anatomy that is never used on the table there is no danger to you. This being a stomach poison it will not effect your birds. Price, $50 \mathrm{c}$ and $\$ 1.00$. Postage extra.

Price, $50 \mathrm{c}$ and $\$ 1.00$. Postage
Insist always on the original.

\section{Don't Feed Green Food!} Do away with the bother by using

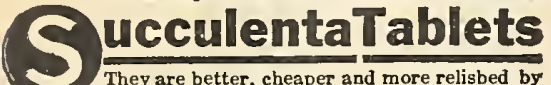

They are better, cheaper and more relisbed by of drinking water. Succulenta Tablets ar not a drug nor a remedy. but a food-wholesome and harmless. They make chicks grow. A FULL EGG BASKET IS ASSURED 100 large tablets by mail, $\$ 0.50$ Yrour Money 250 ": "ै

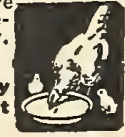

\section{Feed Succulenta to the Home Flock}

The U.S. Government is urging everyone who has a backyard to heep a few hens to supply the home table. Such a flock costs little to keep, as it can be fed to a considerable extent upon table scraps. The backyard poultry keeper will find Succulenta a great boon, as it takes the place of green feed which is oftên so difficult to secure.

\section{Dog Foods}

\section{"SPRATT'S" MEAT “FIBRINE" VEGETABLE DOG CAKES ARE THE BEST} AND CHEAPEST

The standard dog food. They will keep a dog in show form and working condition. Used at the leading kennels and dog shows throughout the world. A staple and constant food for all breeds of dogs.

\section{Convincing Proof of Merit}

At three shows recently over three thousand $(3,000)$ prizes were won lig dogs fed regularly and exclusively on Spratt's Dog Foods.

Prices: $100 \mathrm{lbs} ., \$ 13.00$. $50 \mathrm{lbs} ., \$ 7.00$. $25 \mathrm{lbs} ., \$ 3.50$. Cartons, $15 \mathrm{c}$ and $30 \mathrm{c}$.

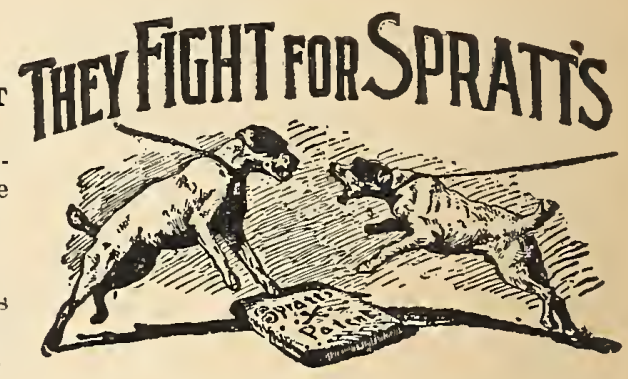

\section{PUPPY FOODS}

\section{SPRATT'S" PUPPY BISCUITS. The Standard Puppy Food}

Are the best and cheapest for puppies of all breeds, toys or small dogs that gets very little exercise. They are refined and dainty.

A perfect and whole food for puppies of all breeds.

Puppies should be started on these biscuits when about one month old and they slould be continued until such time as their teeth become sound and strong, usually when they are about six months old. Follow directions on each package.

Prices: Cartons, $15 \mathrm{c}$ and $35 \mathrm{c}$.
"SPRATT'S" TURKEY FOOD (fine for chicks or poults, coarse for old birds) is an absolute necessity for the successful rearing of turkeys. It prevents disease and rears strong, vigorous birds. Prices: Cartons, 40c.

\section{"SPRATT'S" PHEASANT MEAL}

The ideal food for young pheasants. Prices: Cartons, $40 \mathrm{c}$.

\section{SPRATT'S AQUARIUM FISH FOOD}

is the result of years of careful experimenting on all kinds of fish in aquariums. It contains the precise combination of vegetable and animal matter for the maintenance in health of aquarium fish, tadpoles, etc.

Price per tin 15c, by mail $20 \mathrm{c}$.

\section{SPRATT'S DOG REMEDIES}

Spratt's Alterative Cooling Tablets. For heated blood, etc........ $\$ 0.60$

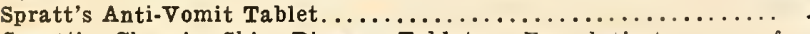
Spratt's Chronic Skin Disease Tablets. For obstinate cases of .60 Spratt's Cough Tablets. Generally effect a quick cure................60 Spratt's Constipation Tablets. A gentle and effective laxative..... . .60 Spratt's Digestive Tablets. For severe cases of indigestion....... .60 Spratt's Diarrhoea Tablets. To reljeve Diarrhoea, which usually

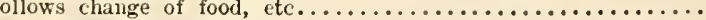
Spratt's Distemper Tablets. May be used as a preventive.......... Spratt's Ear Canker Ointment. For both internal and external

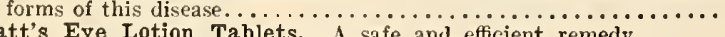

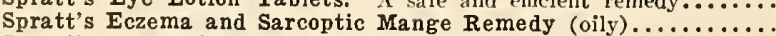

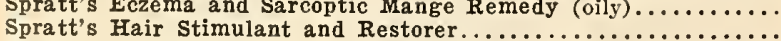
Spratt's Kidney Tablets. For Cystitis or lnflammation of the

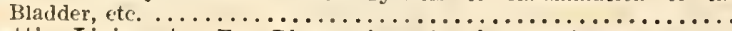
Spratt's Liniment. For Rheunlatism, Sprains, Bruises, Lameness, etc, and may be used for human treatment as well...

Spratt's Liver Tablets. A safe and reliable remedy................
Spratt's Locurium Ointment. For Wounds and Cuts, Bruises, pte Good for man as well as beast.
Spratt's Mange Remedy ...................... $\$ 0.60$ Spratt's Purgative Tablets. Perfectly safe and effective............60 Spratt's worm Capsules. An expedient of Round, Maw and Tape Spratt's Worm Capsules for Puppies. Jiay be given with perfect afety to puppies from six weeks old to six months............. Spratt's Tonic and Condition Tablets for Toy Dogs and Puppies. Spratt's Pneumonia Tablets. A safe and reliable remedy.......... Spratt's White Dog Soap. For fleas, lice, etc.; per cake............... Spratt's Patent Antiseptic Soap (Black) for veterinary use, etc.... SPRATT'S AQUARIUM FISH FOOD. The only aquarium fish food that does not foul the water.

SPRATT'S BIRD TONIC (Henning's). For the prevention and cure of all diseases which cage birds are subject to.

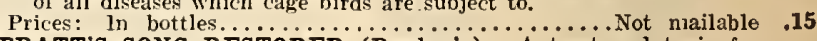
SPRATT'S SONG RESTORER (Dunlap's). A treat and tonic for Canaries, Linnets and all seed-eating birds.

Prices: By mail, 30c............................ Spratt's Tonic and Condition Tablets for Cats............... Spratt's Distemper Tablets for Toy Dogs and Puppies.......... Spratt's Distemper Tablets for Cats.

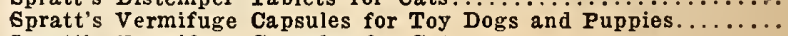

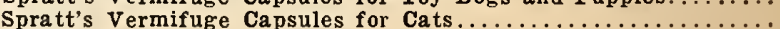

\section{0} 60 


\section{Collins Sectional Fireless Oat Sprouter}

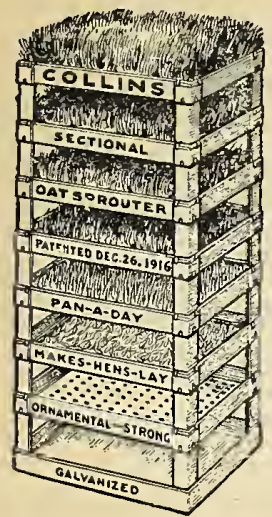

Made in three sizes at the following popular prices :

Five pans, $11 x 15 \ldots \ldots \ldots \ldots \ldots \ldots \ldots \ldots \ldots \ldots \ldots \ldots \ldots \ldots \ldots \ldots$ Eight pans, $11 \times 15 \ldots \ldots \ldots \ldots \ldots \ldots \ldots \ldots .4 .00$ Eight pans, $11 \times 32 \ldots \ldots \ldots \ldots \ldots \ldots .8 .00$ Shipping weights, 10 Lbs.. 1 t L.bs., 29 Lbs.

Quality Always

Reliable Grain and Oats Sprouter

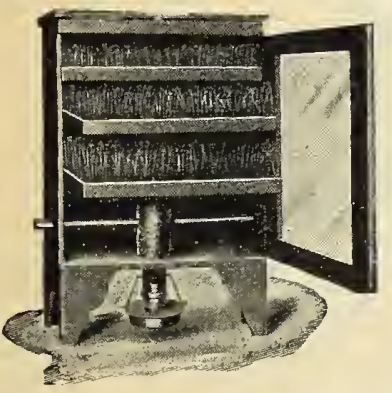

Sprouted oats will make hens lay. The Reliable Sprouter will sprout oats in three days. They have galvanized-iron panels, large glass doors, so light can enter.

3 tras, 50 chicks................ $\$ 11.50$
The "Successful" Grain Sprouter

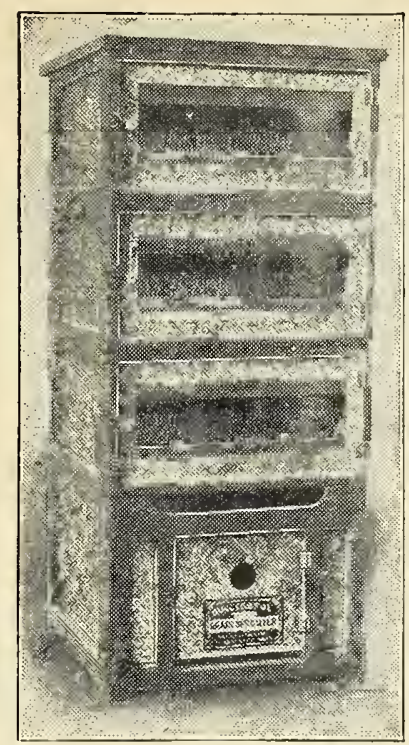

The only grain sprouter with double steel walls made in sections.

$50 \%$ to $80 \%$ more fall and winter eggs.

$30 \%$ to $40 \%$ lower production cost.

Better fertility in winter eggs.

Quick growth promoting green feed for early chicks.

\section{Indispensable,
Indestructible.}

Prices and Capacities

No. 2. Base and 2 Sections. 4 trays, holds 16 to $20 \mathrm{Qts}$ dry grain................ $\$ 15.00$ (For flocks from 75 to 100 hens.)

No. 3. Base and 3 Sections, 6 trays, holds 24 (For flocks from 130 to 200 hens.)

Fo 5 Base and 5 Sections, 10 trays, holds 40 to 50 Qts. dry grain................. \$25.00 (For tlocks from 400 to 600 hens.)

\section{Clay Pigeon Nest}

Made of very high grade and valuable clay. Each, 25c. $\$ 2.50$ per doz.

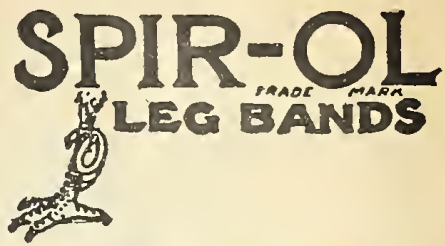

All Poultry and Pigeon Bands Postpaid "Spir-ol Leg Bands." Made of celluloid. in ten colors. Goes on and off like key ring. Five sizes-Baby Chicks or Pigeons. Price, doz., 10c ; $25,20 \mathrm{c} ; 50,35 \mathrm{c} ; 100$ for $50 \mathrm{c}$. Mediterranean. American and Asiatic Classes. Price doz, 15c: $25,30 \mathrm{c} ; 50,50 \mathrm{c} ; 100$ for $75 \mathrm{c} ; 1000$ for $\$ 6.50$.

Leg Bands for Poultry and Pigeons Size Used for Different Breed. (Order by riumber.)

No. 1 for Bantams and small Mediterraneal females, etc. No. 2 for Ordinary Mediterraneal and Pit Game females, etc. No. 3 for Medi. terranean males, American females, Pit Game males and French females. No. 4 for medium ordinary large Asiatic and Tom Turks, etc.

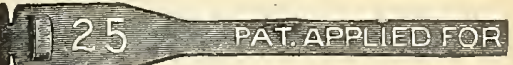

Champion Adjustable. 12 for 15c. 25 for 25c. 50 for $45 \mathrm{c}$. 100 for $75 \mathrm{c}$.

\section{Double Clinch Leg Band}

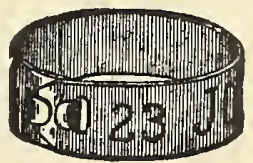

This is one of the best and most popular band on the market. A favorite among Poultry account of its security. 12 for $15 \mathrm{c} .25$ for $25 \mathrm{c}$ 50 for $45 c$. 100 for $80 c$ Postpaid.

Double Clinch Pigeon Bands, 12 for $15 \mathrm{c}, 2$ for $25 \mathrm{c}$. 50 for $45 \mathrm{c}$. 100 for $80 \mathrm{c}$

Open Pigeon Bands for Marking Day old chicks, etc. 12 for $15 \mathrm{c}, 25$ for $30 \mathrm{c} .50$ for $45 \mathrm{c} .100$ for $65 \mathrm{c}$.

\section{Seamless $\mathbf{P}$ i g e o}

(6i) Bands. 12 for $25 \mathrm{c}$. 25 for $45 \mathrm{c}$.

\section{Pigeon Baths}

Made of heavy galvanized iron, 19 inches square, 4 inches deep; capacity, 5 gallons.

Made of galvanized iron, with heavy wire and riveted corners; it is durable and convenient. Each, $\$ 1.50$. Medium, round, $\$ 1.25$. Small, round, $75 \mathrm{c}$.

Mailing weights, 5 lbs., 3 lbs., and 2 lbs.

\section{The Little Putnam Stove}

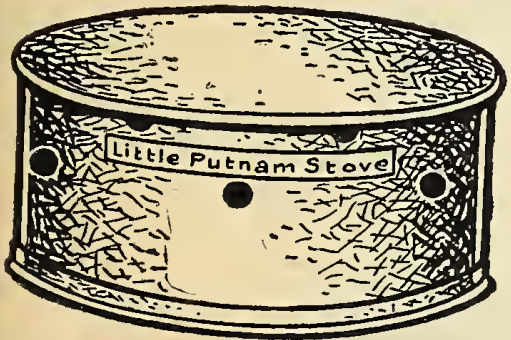

Price, $\$ 2.00$ Each. Postpaid

\section{Uses of the}

\section{Little Putnam Stove}

Used under the drinking vessels of the poultry house to keep the water from freezing in the coldest winter weather.

Used as the heat element for a Putnam homemade oat sprouter.

\section{Description of the Little Putnam Stove}

A Little Putnam Stove is nine inches in diameter and four inches high; made of galvanized iron and equipped with a burner which embodies an entirely new principle in oil combustion. Combustion is complete and perfect, doubling the heat value of the oil. The oil tank holds three pints of oil and burns three to four weeks without refilling or any other attention. The stove with any hind of fair nsage will last a life-time.

\section{Advantages of the Little Putnam Stove}

The advantages which the Little Putnam Stove has over all other devices for keeping water from freezing are:

First-The stove may be used with the same water server used in summer - can, crock or fountain.

Second-The stove has to be filled but a few times during the entire winter and never requires trimming. This will be appreciated by those who have used heaters that need trimming or filling almost every day.

Third-The cost of running the stove the entire winter is but from 20 to 30 cents. The expense for oil to run otìer heaters runs from 75 cents to $\$ 2.00$ per season.

Fourth-The Little Putnam Stove does not furnish hot water to the fowls, but water at that tonic temperature which is best relished by them, and which increases the amount of food digested and assimilated, thus promoting growth and increasing the egg supply.

Fifth-It is absolutely essential that a constant supply of unfrozen water be accessible to the fowls at all times if they are to be kept at the top notch of health and productiveness.

Sixth-This stove is absolutely fire-proof and non-explosive. If it is tipped over it will go out. If it becomes buried in the litter it will go out.

The Gilt Edge Egg Scale

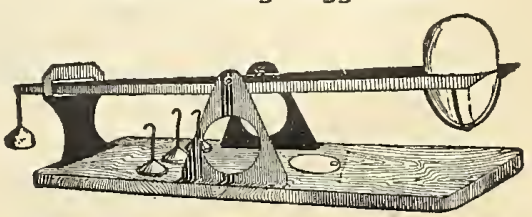

IS ONE OF THE MANY WAYS Price, 50c Each. Postpaid 
The J. Bolgiano Seed Co., Baltimore, Md.

NO. 8-BOLGIANO'S "SQUARE.DEAL" COMBINED LAYING AND SCRATCHING HOUSE Capacity, 12 Birds

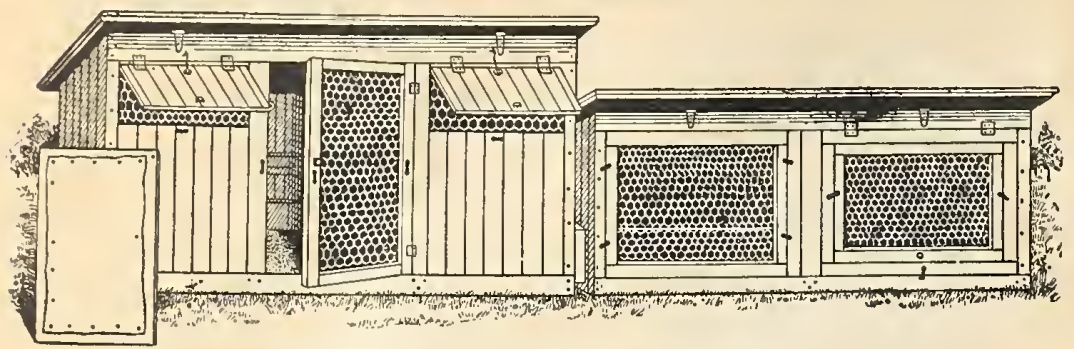

The Delphos Superior Galvanized Brooder Coop

Price Complete, $\$ 30.00$, F. O. B. Baltimore, Md. Weight, Crated for Shipment, 325 Lbs.

This house is 68 inches long, 35 inches wide, 44 inches higlı in front and 32 inches high in back. Scratching house same size, only 8 inches lower-both together making a house nearly 12 feet long. Roof is hinged, so you can care for your birds from front or back. With a louse of this kind the scratch house can he altered from one end to the other. These houses are shippet knocked down; easily put together. This house is equipped with patent back witl dropping board and roost for cleaning and air.ing.

\section{NO. 6-BOLGIANO'S "SQUARE-DEAL" COMBINA- TION OPEN AND CLOSED POULTRY HOUSE}

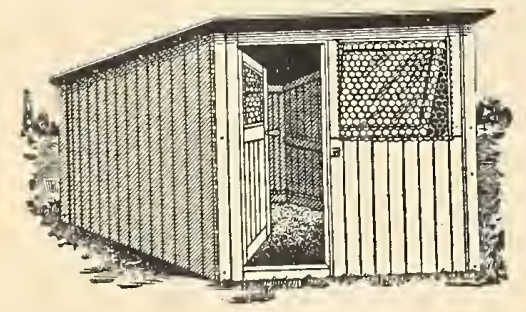

Six (6) Feet Wide, Eight (8) Feet Deep and $6 \frac{1}{2}$ Feet High Front. Price, F. 0. B. Baltimore, Md, $\$ 43,00$.

An Extra Charge of One Dollar Will Be Made for All Local Deliveries.

This house has for years been our largest seller. It is an ideal house for the man with thousands of birds as well as the man with a small flock.

We had these houses especially built for us. They are made of $\frac{7}{8}$-incl lumber, planed on both sides, tongued and grooved. We supply the best grade of thrce-ply roofing paper for covering the roof. The honse is complete with two roosts, dropping board and four nests.

This house is six feet wide, eight feet deep, six and one-half feet high in front and four and one-half feet in back. Roof has a 3-inch overhang. The front is boarded up three feet, thereby avoiding any direct wind or storm striking the birds, the upper half being wire and a linged frame to cover with oiled waterproof slieeting, which can be closed on cold nights and stormy weather. This gives the open-front feature witl plenty of fresh air, at the same time keeping the birds protected from the weather. These houses are shipped knocked down, and they are easily put together in an hour's time. Shipping weight, $575 \mathrm{lbs}$.

\section{"The Amhurst," Our Latest Model}

$8 \mathrm{ft}$. $x 8 \mathrm{ft}$. open front, $\$ 54.50$. $8 \mathrm{ft}$. $\times 8 \mathrm{ft}$. closed front with 1 glass window and ventilator, $\$ 59.75, F$. O. B. Baltimore, Md. rigid.

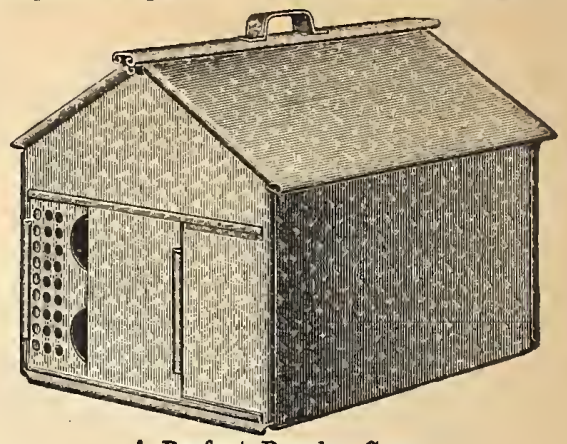

A Perfect Brooder Coop

Packed flat and can be put together without any tools. The bottom can be removed in an instant to be cleansed.

All Parts slide together in a bead and coop is perfectly

Can be taken apart and packed away flat, occupying very little space when not in use.

Rat and rermin proof.

A perfect slielter for hen and young chicks. Price

Size 18 inches wide, 22 inches long, and 18 inches high.

NO. 15-BOLGIANO'S “SQUARE-DEAL” BROOD COOP AND YARD

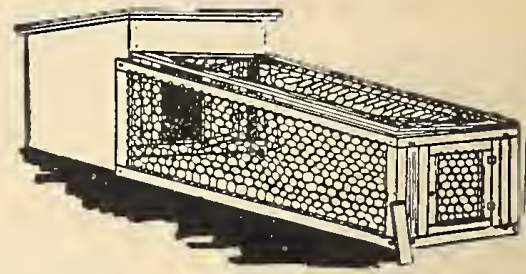

Price Complete, $\$ 5.75, F$. O. B. Baltimore, Md.

Shipping Weight, Knocked Down, 45 Lbs.

This coop is marle of $\frac{3}{4}$-inch pine lumber, planed and tongued and grooved. It is 21 inches wide, 22 inches from front to back, 22 inches ligh in front, 14 inches in back. The roof is hinged and covered with high-grade roofing paper. The wire run is 38 inches long by 21 inches wide and 16 inches high, and is covered with a hinged wired frame. There is a door in both the coop and the run, so arranged that you can let the chickens out and keep in the hen. The coop and run together is five feet long.

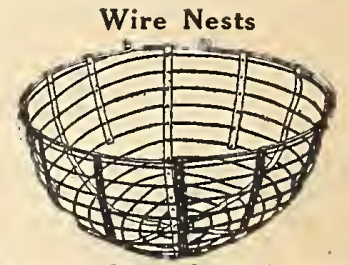

These nests are strongly made of Copper wire and strongly braced and will not get out of shape like other nests on the market. Price $25 \mathrm{c}$ each. $\$ 2.50$ per doz.

Mailing weight, $1 \mathrm{lb}$. each.

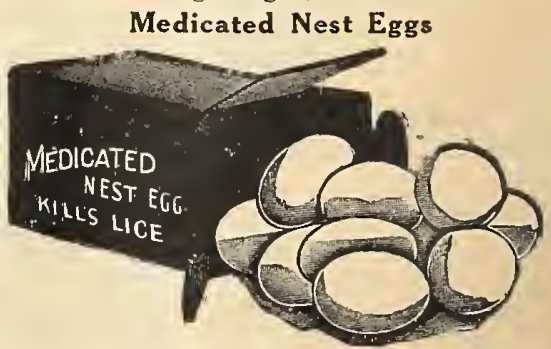

They contain a powerful disinfectant, which is guaranteed to drive out all lice and rerinin. Each, 6c. Doz., 60c. Not postpaid. Mailing weight, 2 llos. doz.

Opal or China Nest Eggs

White flint, will last a lifetime, 4c each. 2 for $7 c .12$ for 35c. Mailing weight, $1 \mathrm{lb}$. doz.

\section{Chalk Nest Eggs}

$15 \mathrm{c}$ dozen. Mailing weiglit, 2 lbs. 
Silver Finish Poultry and Pigeon Wire

Galvanized after weaving. TVorth 50 per cent more to the customer than galvanized before weaving.

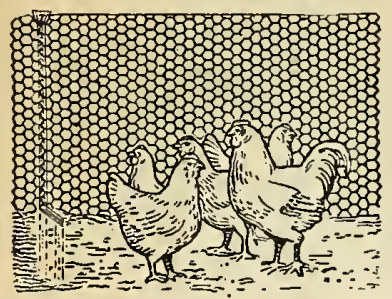

Hard steel wire. Put up in rolls of 150 feet. Galranized after weaving. Two-inch mesh.

12 inch, 150 square feet.

$\$ 1.30$

24 inch, 300 square feet

2.35

36 inch, 450 square feet

3.20

48 inch, 600 square feet.

4.25

60 inch, 750 square feet

5.30

72 inch, 900 square feet

6.35

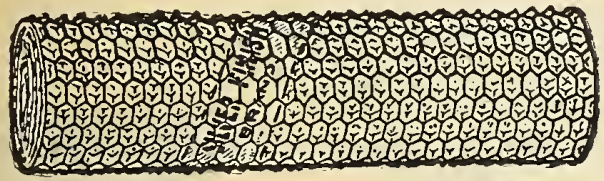

Pigeon Wire

Galvanized after weaving. One-inch mesh.

12 incl, 150 square feet

$\$ 2.95$

24 inch, 300 square feet.

5.40

36 inch, 450 square feet

7.35

48 inch, 600 square feet

9.85

60 inch, 750 square feet.

.12 .30

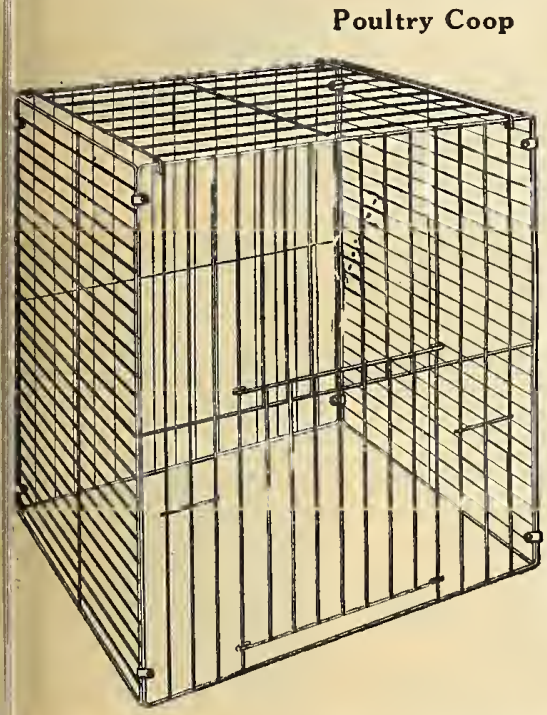

Made in single compartment, consequently easy to
handle and to store dway. on the front and back sections the wires run vertically, and on the side sections horizontally.

The wires on the side sections are spaced to make a narrow mesh, and are so arranged that and are so arranged that when the coops are set
side by side the wires on the adjoining partitions alternate, making a. mesh of one-fourth inch, thus rendering it impossible for the birds to peck or fight each ther between the coops.

The use of this design for cooping slows is very effective, as it permits a show from any part of the room.

Standard, $24 \times 24 \times 27$ ins. high. Price $\$ 1.75$.

Wood bottom, 60c.

\section{Poultry Pen Coop}

The construction of the Pen Coop is like the single coops heretofore cribed.

Has two doors making it especially convenient to secure the birds ide, and which also retains the coop uniformity of the show room.

It can be used as a two-compartment coop by inserting our removable artition. These partitions can be put in or taken out at will.

Made in one size

$48 \times 24 \times 27$ inches high. Price........................... $\$ 3.00$

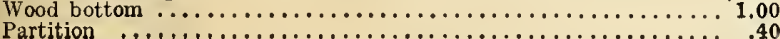

\section{Medicated Salt Spools}

For keeping rabbits in a good healthy condition. 10c each, $\$ 1.00$ per doz.

Water-Proof Sheeting-or Oiled Muslin

For keeping drafts and dampness out of poultry houses. $25 c$ per yard. 1 yard wide.

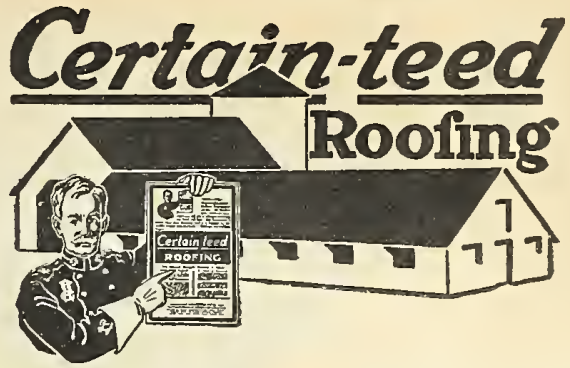

\section{See That Your Roofs Are in Good Repair to Stand the Winter Storms}

\section{"Certainteed" Asphalt Roofing}

Fully guaranteed 5, 10 and 15 years. Put up in rolls of 108 square feet. Nails and cement included.

1 ply, weight about 35 lbs. Price.....................\$1.65

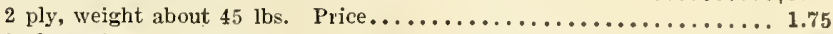

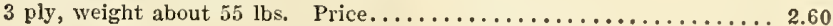

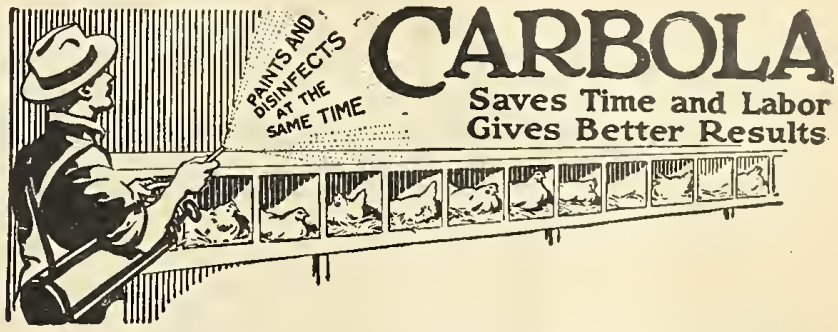

Casbola will make your buildings lighter and sweet-smelling-put them in the cleanly, sanitary shape they must be if you expect the best production from your stock.

\section{Use lt Instead of Whitewash and Disinfectants}

in poultry houses, stables, cellars, hog pens, factory and outbuildings. Carbola is used and endorsed by thousands of poultry, dairy and breeding farms in all parts of the country, and by many experiment stations and agricultural schools.

Carbola is a combined disinfectant and paint, or whitewash, that has been thoroughly tested by time under all conditions of climate and temperature. It has gained unqualified endorsement and is used by agricultural colleges, experiment stations and by many of the largest and most carefully conducted poultry, dairy and breeding farms.

Carbola kills lice, mites, fly eggs, etc., and is a preventive of many contagious diseases that affect poultry and live stock-such as roup, white diarrhoea, scaly leg, glanders, cholera, contagious abortion, etc. These diseases are of germ origin, and if once started in a flock or herd, spread rapidly and cause severe money loss.

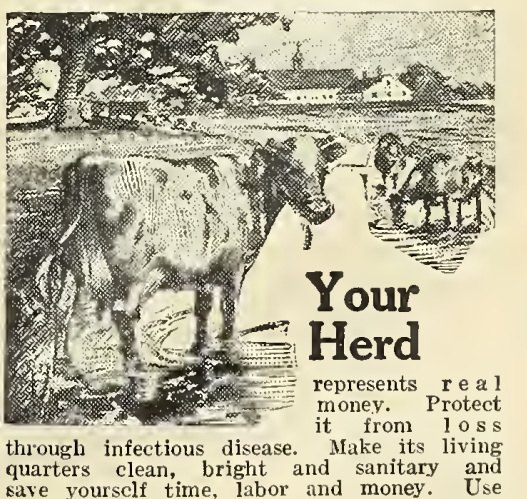

Carbola comes in powder form, packed in convenient-sized packages, and is ready to use just as cold or hot water.

It can be applied with brush or a spray pump. and positively will not clog the sprayer. One with one gallon of water has a germicidal strength about 3 times stronger than a 5 per cent solution of pure carbolic acid. which is the standard for generaI disinfecting vurposes, but is neither poi sonous nor caustic. One gallon will cover approxigallon will cover approxisurface.

\section{Prices}

ARBDLA

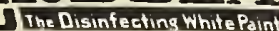

2 lbs. Trial pkg...\$.30 10 lbs. (10 grals.). 1.25 50 lbs. (50 gals.). 5.00 


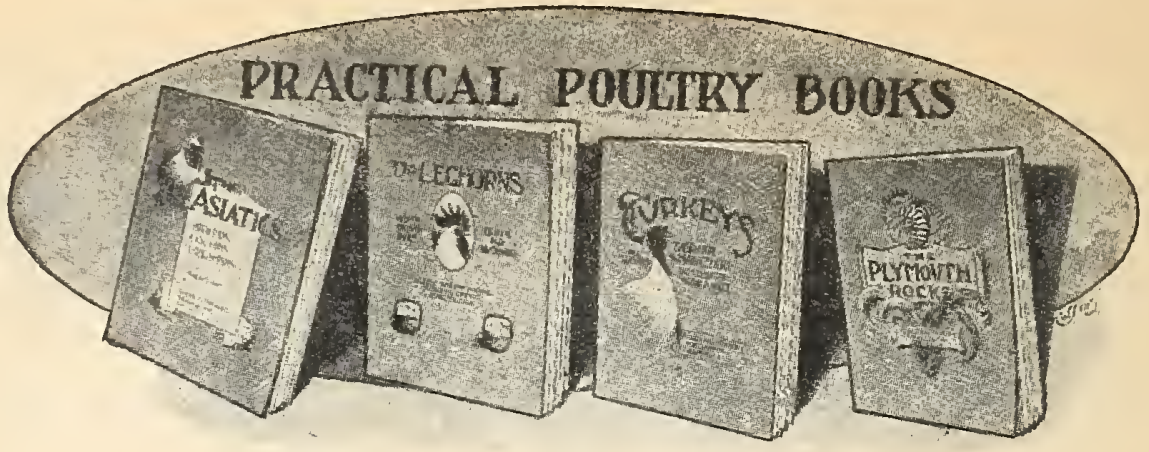

Postage Paid to Second Zone on All Books

Artificial Incubating and Brooding

Chick Book, Their Care and Rearing

$\$ 1.00$

Ducks and Geese (all varieties)... .

Leghorns (all varieties)

Orpingtons (all varieties)

Plymouth Rocks (all varieties)

Poultry Houses and Fixtures.

\section{"Feeding Poultry For Any Purpose With Profit" Br John 11 . Robinson}

Size of book $9 \times 12$ inches; 112 pages and cover, profusely illustrated. Price, \$1.25.

\section{"Profitable Culling and Selective Flock Breeding"}

Size of book, $9 \times 12$ inches; 120 pages with attractive art cover. Compiled and edited by Homer IV. Jackson and Grant M. Curtis. Price, $\$ 1.50$.

"The Mating and Breeding of Poultry"

Written and compiled by Mr. Harry Lamon and Mr. R. R. Slocum, both of the Department of Agriculture at Washington, D. C. The book bound in cloth and the price $\$ 2.00$.

\section{"Use of Artificial Illumination to Increase Winter Egg Production"}

Size of book, $9 \times 12$ inches, consisting of 120 pages and art cover. Price, $\$ 1.50$.

\section{HIGH EGG PRODUCTION}

By Individual Hens, Pens and Flocks

By Homer W. Jackson and Grant M. Curtis

A complete guide to profitable production of market eggs. How to breed for increased productive capacity and how to feed and handle fowls in order to secure highest practicable egg yields. Fully illustrated. Price, $\$ 2.00$ each.

\section{"Practical Poultry Production"}

Written and compiled by Mr. Harry Lamon, Head Poultryman, and Mr. Kinghorne, both of the Department of Agriculture at Washington, D. C. This new book contains four hundred pages of valuable information and three hundred illustrations. It is bound in cloth and the price will be $\$ 2.25$.

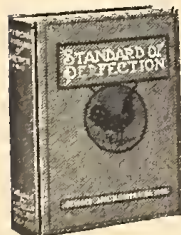

In seventy-five chapters this useful book gives complete and reliable directions for the best cultivation of vegetables, fruit and flowers, the management of poultry and pets, the proper care of the lawn, vines and shade trees, and discusses everything pertaining to the outdoors of the home throughout the year. A book that will be treasured by every person who possesses a garden, large- or small, in the city or the country. Price, \$1.25.

Selected List of Books on Rabbits, Cavies and Pet Stock Cavies for Pleasure \& Profit, by Diecke............ \$1.00

Rabbit Culture and Standard, by Roth........... .50

The Cavy; by Wagner..................... .50

Cavies, How to Feed, Breed \& Condition Them, by Young . . $\quad .50$

The Grey Parrot, by Greene..................... .65

A. to Z. on Pigeons....................... .75
Rhode Island Rerls (all varieties) . . . . . . . . . . .75

Reliable Poultry Remedies...... 25

Successful Poultry Keeping................. 1.00

Turkeys, Their Care and Management.............. .75

Wyandottes (all varieties) . . . . . . . . . . . . . 1.00

Egg Record and Egg Account Book .............. .40

\section{SUCCESS WITH HENS}

\section{By ROBERT JOOS}

This is a reliable guide to poultry. raising that thoroughly covers the subject by an expert. It is clear, practical and up-to-date. The fiftyfive chapters give full directions for the hatching and brooding of chickens, incubation, feeding and housing, increasing the egg supply, cure of diseases, the marketing of eggs and fowls and everything pertaining to the care of hens. Price, $\$ 1.25$.

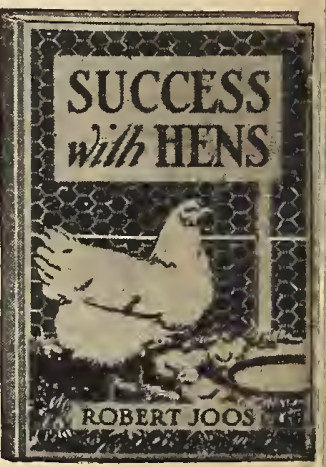

Making the Farm Pay, by C. C. Bowsfield, has been received with more enthusiasm than any book published this year on any subject. The critics and farm experts have been unanimous in endorsing the book. Price, $\$ 1.25$.

\section{Plymouth Rock Breed Standard Just published \\ Bound in Cloth, $\$ 3.00$}

Valuable Standard Poultry Books The Call of the Hen "Hogan." Price, \$2.25.

Successful Backyard Poultry Keeping by Robinson. Price, $\$ 1.00$.

\section{Success With Hogs \\ By Charles Dawson}

In this important book everything con nected with the raising of hogs is thoroughly treated in a clear, practical and reliable manner by an authority of long and wide experience. It gires the latest and best methods for the feeding, breeding and care of swine. Every hog raiser needs this book to help him take advantage of the present great demand for pork products. Price, $\$ 1.25$ net.

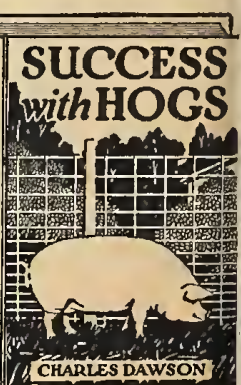




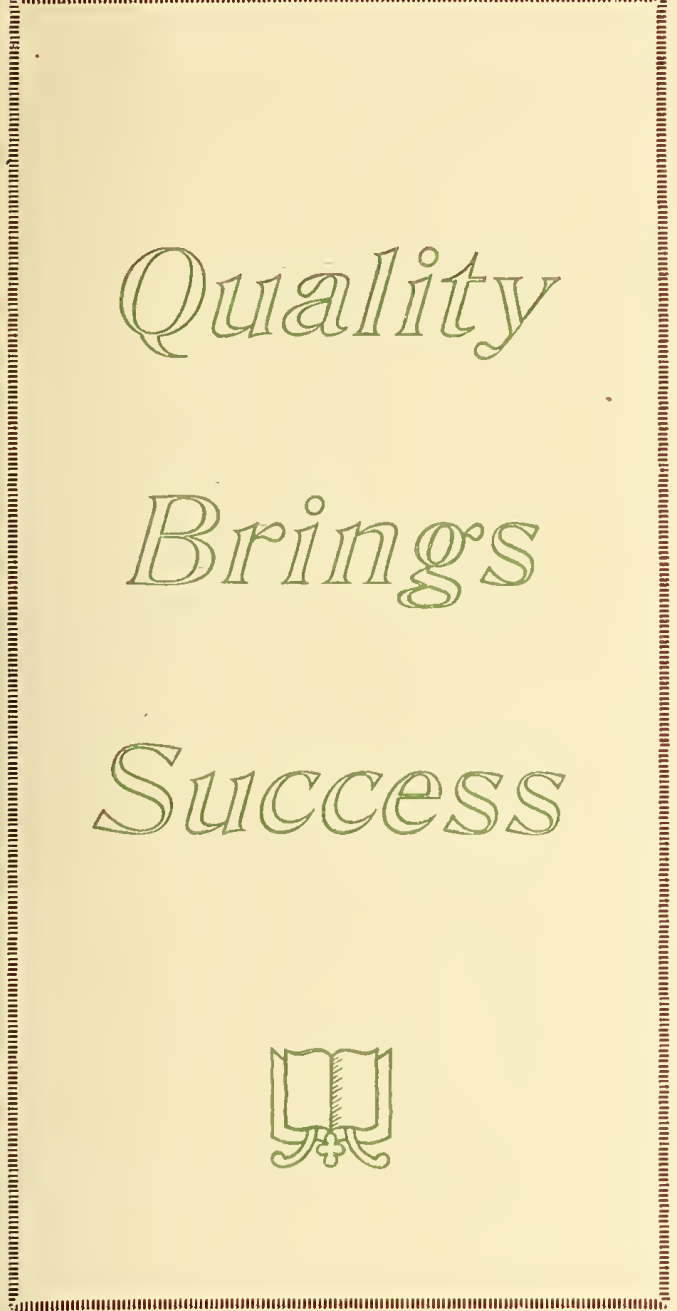




\section{t Voluntary Testimonials}

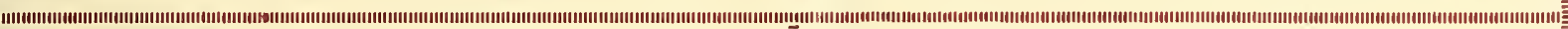

On March 5th, 1923, Harry T. Swope, Lovettsville, Va, wrote: "I have used your seerls many years, and always fonnd them satisfactory and cheaper than other firms. but high in quality."

On March 5th, 1923, Theodne Julia, Alex. 3ay. N. Y., wrote: "Having had gool luck with your seeds last year. will give you another order this vear."

On March 3rd. 1923. P. H. Hailey. Proffit, Tirginia. wrote: "The Fordhook Bush Limas 1 ordered of you last year were the nicest I ever saw. The weather was dry, but they bore just the same. I sold $\$ 13.00$ worth, besides eating some, from two pounds of sech, and about half of the blooms dropled off. from dry weather. I am sending an order for more."

On March Tth, 1923, A. J. Sowers, Camp Creek, Va.. wrote: "The onion sets which I've ordered from zou are the finest I've ever' grown. Everyone around are wanting your seed book."

On March 12th, 1923, Kilio R. Gibert, Henderson, Md., wrote: "I take pleasure in recommending your seeds to all gardeners ant truckers. I had splendid success with all secds purchased from you last season."
On Tebruary 28th, 1929, Mrs, H. C. Tucker. Midlletown. $\mathrm{N}$. Y., wrote: "I just want to say we have been using your tomato seed for 15 vears now, and think there is no other as mood."

()n March 7th, 1928. I. I. Peed. Newland, Va.. wrote: "I have tried Garden Seed from several firns. hut lave had more success with Bolgiano's than any I have tried. Have foumt them true to name. of strong germination and vigorous growers, and ran recommend them to anyone wanting the best in seeds. I have been especially successtul with your Farly Fortuns cucumbers and California $1 V^{2}$ as Beans."

On March 9th. 1923, The Drake Plant Co. Norfolk, Va., wrote: "VVe were very murll pleased with the last seed from you."

On March 7th, 1923, Fred M. Dietz. Warren, Mich., wrote: "I recommend your seeds whelever I can. as I always found them very goo] (ver since I started to use them in Maryland in 1914."

On March jth. 192:. Wallace C. Ougheltree, Dover. Del.. wrote: "Am pleased to state that I had wonderful success last season with Polgiano's Greater Baltimore Tomato Seed, and raised 300 baskets per acre using this variety. Please send me only Greater Baltinure Seel." 


\section{The J, Bolgiano Seed Co,} Everything for the Farm, Garden, Lawn and Poultry Farm

\section{Baltimore, Maryland}




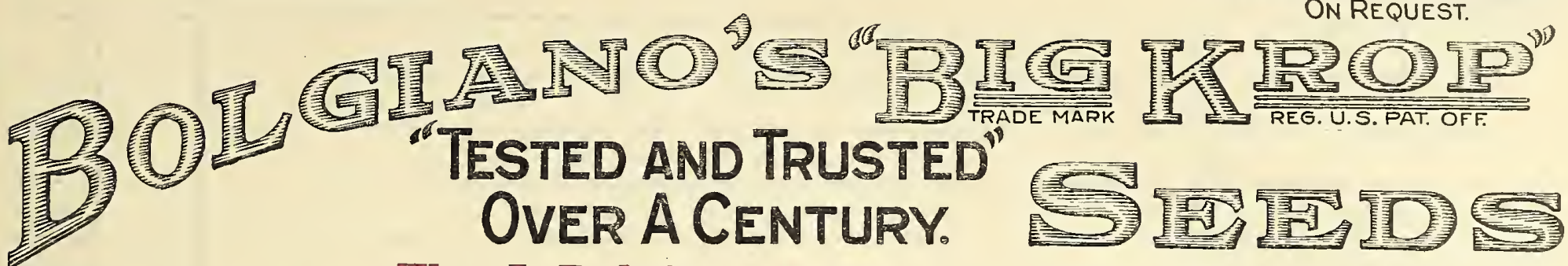

The J. Bolgiano,Seed Co., successor

STORES AND

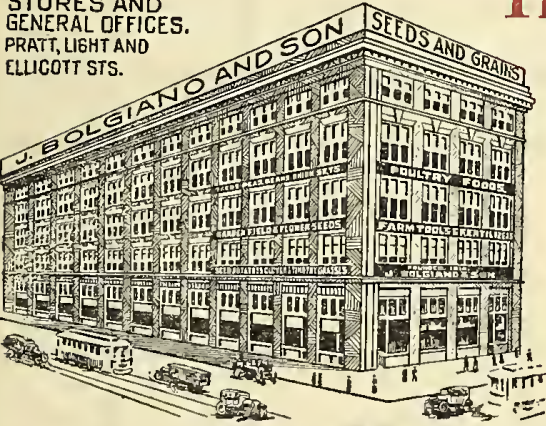

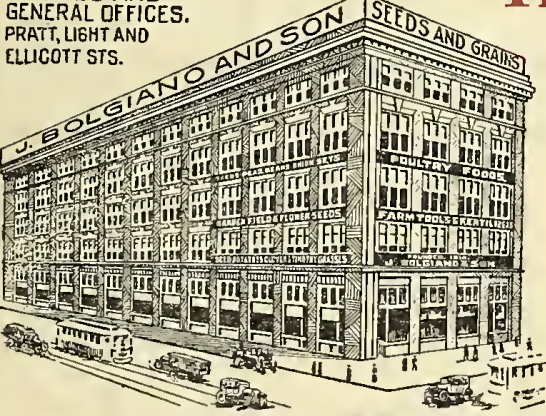

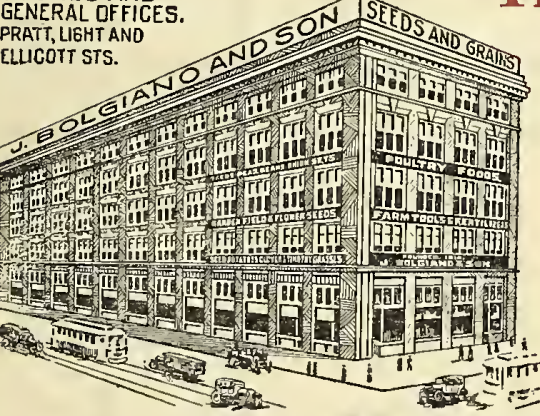

ming

雪要要

i

BOLGIANO'S PIER

SEEDS AND GRAINS

\section{KEY HIGHWAY AND \\ THE HARBOR. \\ J.BOLGIANO \& SON}

DATE

19

\section{BALTIMORE,MD.}

Please forward the Following order for WhICH FIND ENClosed:

NAME

Post OfFICE

STREET P. O. BOX

R.F. D.No

EXPRESS OFFICE

SHIPPING POINT

COUNTY

State

Name Whe. Steamboat Line or R.R.

IN COMMON WITH. OTHER RESPONSIELE SEED HOUSES. WE SELL OUR GOOOS SUIEJET TO THE FOLLOWING TERMS, IT BEING TMAT ADOPTED BY THE AMERICAN SEED TRADE ASGOCIATION

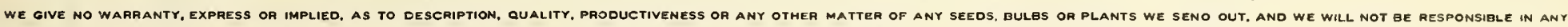

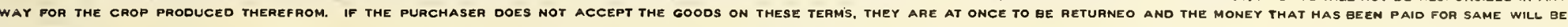
REFUNDER

KINDLY USE THIS SHEET FOR YOUR ORDER ONLY

FOR CORRESPONDENCE OA INQUIRIES USE SEPARATE SHEET INCLOSED-TMIS WILL ALLOW US TO GIVE BOTH YOUR ORDERS ANO INQUIRIES IMMEOIATE ATTENTION.

\begin{tabular}{c|c|c|}
\hline $\begin{array}{c}\text { CATALOG } \\
\text { NO. }\end{array}$ & QUANTITY & \\
\hline & & \\
\hline & & \\
\hline & & \\
\hline & & \\
\hline
\end{tabular}

SEEDS, ETC., WANTED
PLEASE DONOT WRITE IN ABOVE SPACE

P. O. ORdER \$

EXPRESS M. O. \$

DRAFT \$

CASH

Postage Stamps $\$$

FORWARD BY

IF OUT OF VARIETY ORDERED HAVE WE YOUR PERMISSION TO SUBSTITUTE EQUAL OR BETTER. ANSWER YES OR NO. 


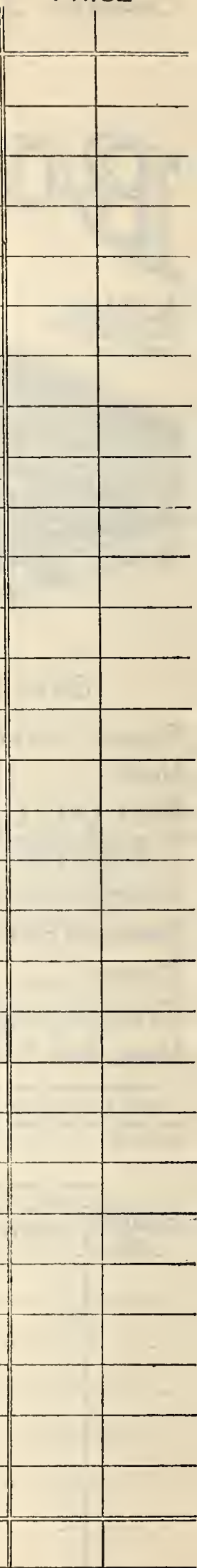

CUSTOMER - PLEASE DO NOT WRITE IN SPACE BELOW

DATE FILLED

FILLED BY

CHECKED BY

PRICED BY
PACKED BY

SHIPPED BY

POSTAGE 


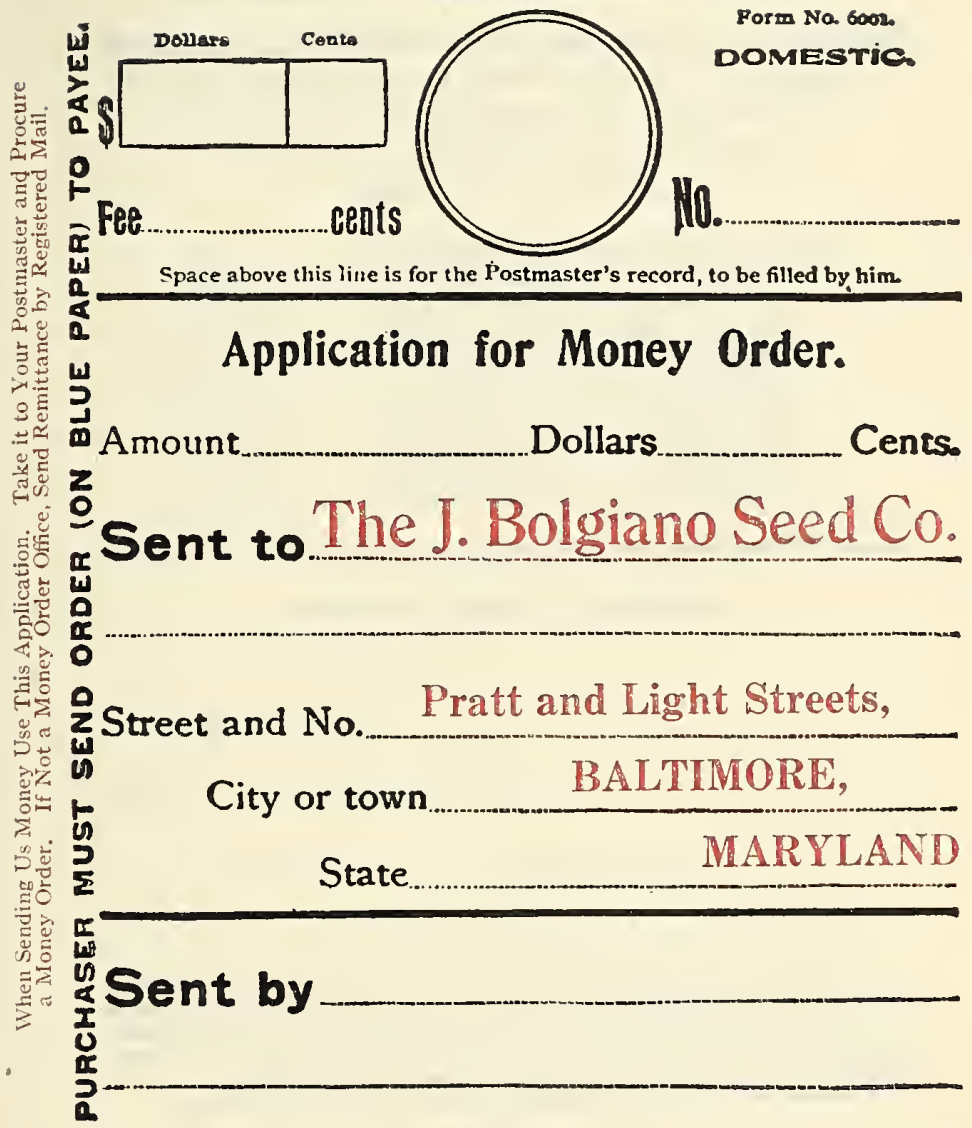

Address of sender: No. 


\section{Fees for Money Orders.}

Payable in the United States (which includes Guam, Hawail, Porto Rico and Tutuila, Samoa); also for Orders payable in Canada, Cuba, Newfoundland, the United States

Postal Agency at Shanghai (China), and the Philippine Islands.

For Orders for sums not exceeding $\$ 2.50\} \quad \ldots . . .3$ cents.

Over $\$ 250$ and not excceding $\$ 5.00$ l....5 ccnts.

Over $\$ 5.00$ and not exceeding $\$ 10.00 \quad 1 . . . .8$ cents.

Over $\$ 10.00$ and not excecding $\$ 20.00 \quad \ldots . .10$ ccnts.

Over $\$ 20.00$ and not exceeding $\$ 3000 \quad$......12 cents.

Over $\$ 30.00$ and not exceeding $\$ 40.00 \quad \ldots . .15$ cents.

Over $\$ 40.00$ and not exceeding $\$ 50.00 \quad \ldots . .18$ cents.

Over $\$ 50.00$ and not exceeding $\$ 60.00 \quad$ !.....20 cents.

Over $\$ 00.00$ and not exceeding $\$ 75: 00 \quad$ i....25 cents.

Over $\$ 75.00$ and not exceeding $\$ 100.00 \quad$ l......30 cents.

\section{Memoranda of Issuing Postmaster:}

Nore.-Tbe maximum amonnt for which a single Stoney Order may be istued is 8100 . Whes - larger gum is $t 2$ be sent additional Orders must be obtained. A g rumber of Orders maj be Arawn on any Money Order office; but, if Orders are drawn la excess of $\$ 200$ on any one der apon an office of the 4tb class, notjce of tbe fact by letter (or Form 6037) is to be promptig aent ay Department by the issuing Postmister so tbat provision mas be made for payment.

Applicstions must be proserved at the ofice of Issne for four years from date of lares 


\section{HINDLY USE THIS SHEET}

\section{FOR CORRESPONDENCE OR INQUIRIES}

\section{Use Order Sheets for Orders Only}

This will permit our giving both your order and your inquiry immediate attention THE J. BOLGIANO SEID CQ. Successor J. Bolgiano de Són CAREFUL SEED GROWERS FOR 100 YEARS

BALTIMORE, MD.

Your Name

$$
\text { Very Plain }
$$

Post OfficeP. O. Box, R. F. D. or Street Address

County

Gentlemen:
State

Date 
We shall esteem it a great favor if you will give us in the spaces below the names and addresses of Market Gardeners, Truck Farmers or any persons interested in seed among your acquaintances, we wish to send them our Seed Catalog. For your kindness, we will inclose some seed which you do not order, Free of Charge.

NAME

POST OFFICE

STATE

If you have been particularly successful with any of our seeds, tell us about it. It will assist us to help others to be successful.

J. BOLGIANO \& SON 


\section{SPECIAL $15 \%$}

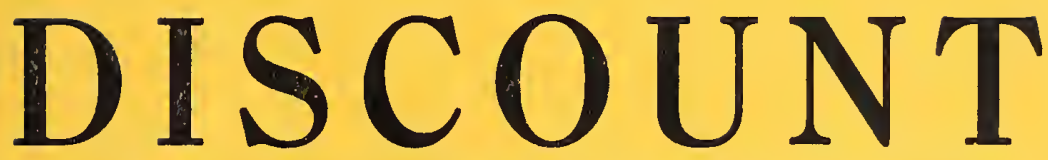

Market Gardeners and Truckers may deduct $15 \%$ from the prices printed in this cata$\log$ on all orders amounting to $\$ 3.00$ and over for Garden Seed excepting ONION SETS and POTATOES This Special DISCOUNT Applies to Garden Seed Only

And

Does Not Include Any Other Items

The hearty response which our offer of this Special Discount met with last year indicates it is appreciated by our customers and prompts us to repeat it this year. Send us your orders early as some items are short and will be unobtainable, we believe, early in the season.

\section{The J. Bolgiano Seed Co. Baltimore, Md. (Only)} WE HAVE NO BRANCHES 


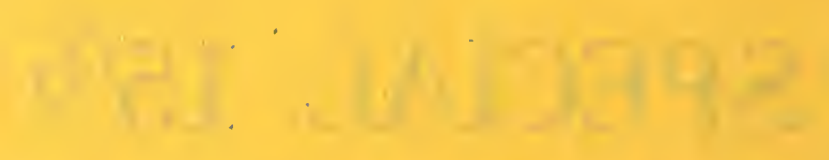

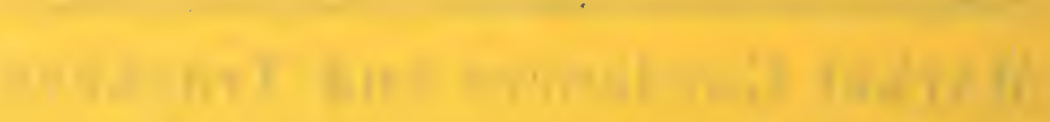

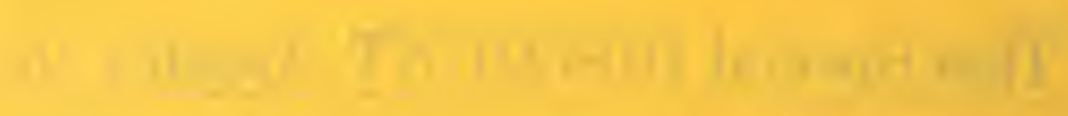

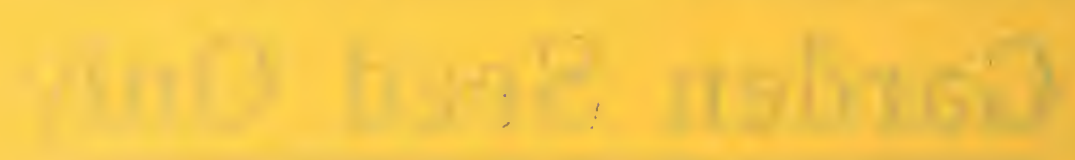

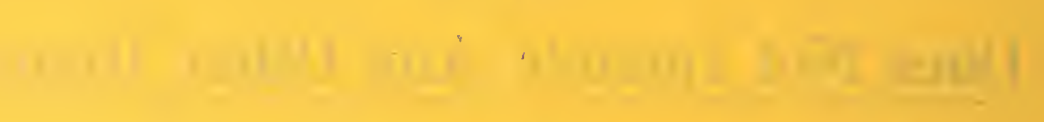

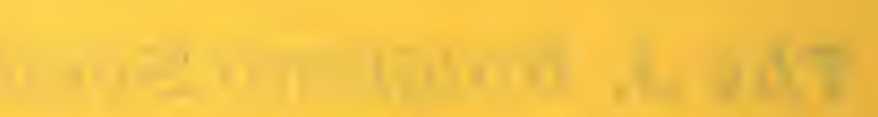

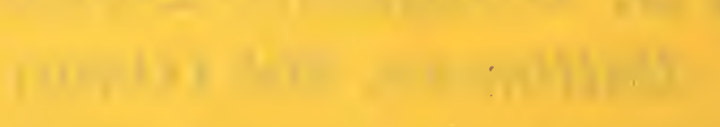

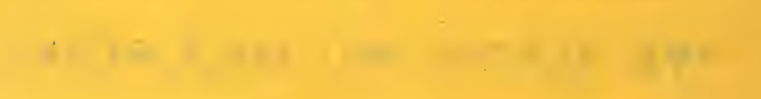




\section{BOLGIANOS "BOUNTIFUL"}

Vegetable Gourden Collection

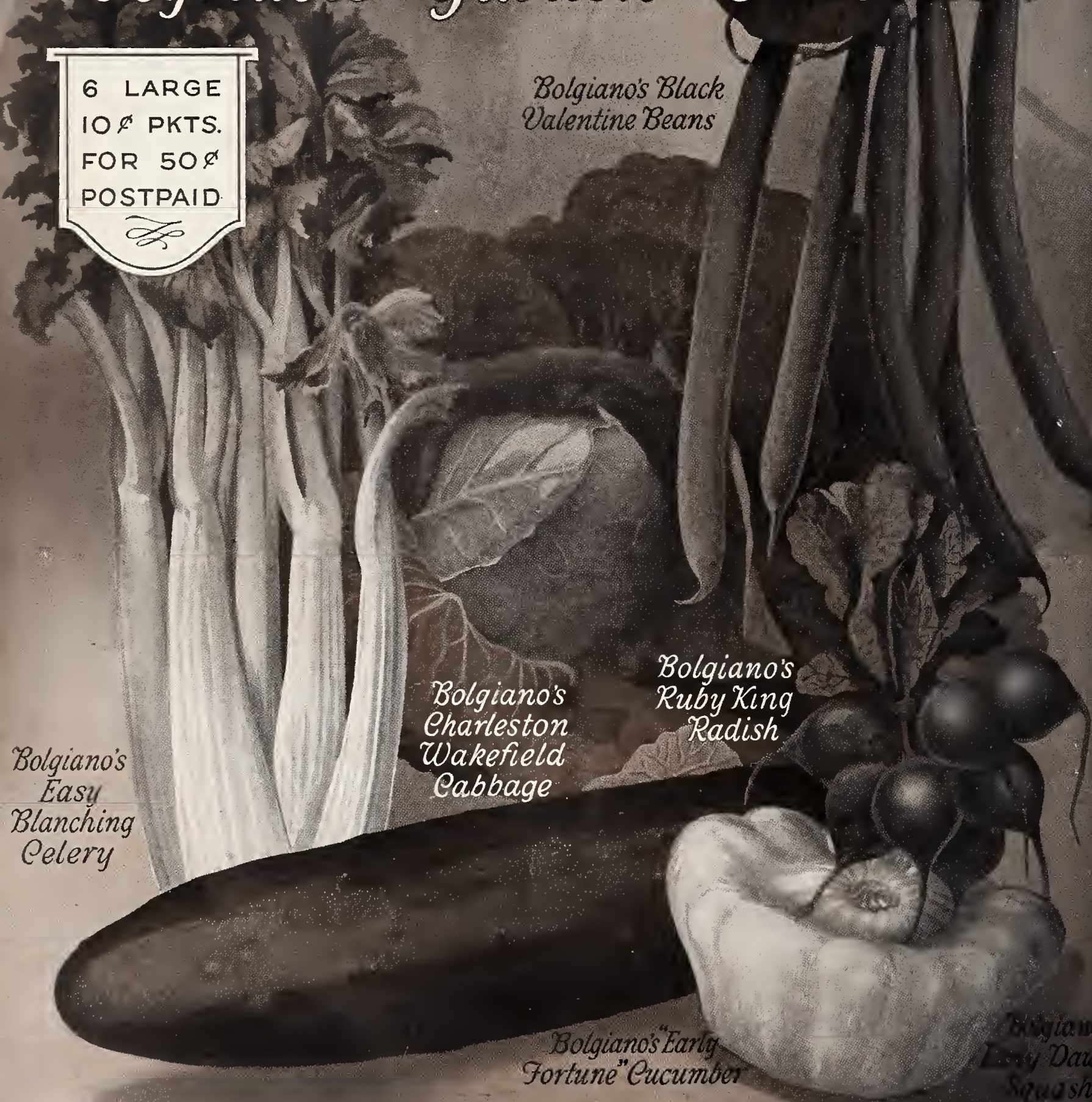

Bolgiano's Easy Blanching Pelery 